Luciana Borges Patroclo

\title{
AS MÃES DE FAMÍLIAS FUTURAS: A REVISTA O TICO-TICO NA FORMAÇÃO DAS MENINAS BRASILEIRAS (1905-1921)
}

Tese de Doutorado

Tese apresentada como requisito parcial para obtenção do grau de Doutor pelo Programa de PósGraduação em Educação do Departamento de Educação da PUC-Rio.

Orientadora: Prof ${ }^{\mathrm{a}}$. Ana Waleska Pollo Campos Mendonça 
Luciana Borges Patroclo

\section{AS MÃES DE FAMÍLIAS FUTURAS: A REVISTA O TICO-TICO NA FORMAÇÃO DAS MENINAS BRASILEIRAS (1905-1921)}

Tese de Doutorado

Tese apresentada como requisito parcial para obtenção do grau de Doutor pelo Programa de PósGraduação em Educação do Departamento de Educação da PUC-Rio. Aprovada pela Comissão Examinadora abaixo assinada.

Prof ${ }^{a}$. Ana Waleska Pollo Campos Mendonça

Orientadora

Departamento de Educação - PUC-Rio

Prof ${ }^{2}$. Patrícia Coelho da Costa Departamento de Educação - PUC-Rio

Profa. Ana Maria Bandeira de Mello Magaldi Universidade do Estado do Rio de Janeiro- UERJ

Profo. André de Lemos Freixo Universidade Federal de Ouro Preto - UFOP

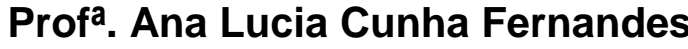
Universidade Federal do Rio de Janeiro - UFRJ

Profa. Denise Berruezo Portinari Coordenadora Setorial do Centro de Teologia e Ciências Humanas

Rio de Janeiro, 29 de maio de 2015 
Todos os direitos reservados. É proibida a reprodução total ou parcial do trabalho sem autorização da universidade, da autora e do orientador.

\section{Luciana Borges Patroclo}

Graduou-se em Bacharelado em Comunicação Social pela Pontifícia Universidade Católica do Rio de Janeiro (PUCRio) em 2004. Graduou-se em Bacharelado e Licenciatura em História pela Universidade Gama Filho (UGF) em 2011. Concluiu o Mestrado em Educação em 2010 pela Universidade Federal do Estado do Rio de Janeiro. (UNIRIO).

Ficha Catalográfica

Patroclo, Luciana Borges

As mães de famílias futuras: a revista o ticotico na formação das meninas brasileiras (1905-1921) / Luciana Borges Patroclo; orientadora: Ana Waleska Pollo Campos Mendonça. - 2015.

300 f.: il. (color.); $30 \mathrm{~cm}$

Tese (doutorado )- Pontifícia Universidade Católica do Rio de Janeiro, Departamento de Educação, 2015.

Inclui bibliografia

1. Educação - Teses. 2. O tico-tico. 3. Impresso infantil. 4. Relações de gênero. 5. Formação feminina. I. Mendonça, Ana Waleska Pollo Campos. II. Pontifícia Universidade Católica do Rio de Janeiro. Departamento de Educação. III. Título. 
Dedico esta tese de Doutorado a meu amado irmão Marcos Aurélio, leitor e colecionador de revistas em quadrinhos. 


\section{Agradecimentos}

A Deus, pela força nos momentos de dificuldade.

Aos meus pais, Aurélio e Célia, pelo carinho e apoio nos momentos de dúvidas e incertezas.

Aos meus irmãos Cristiane e Marcos Aurélio, pelo amor e por pela confiança em meu potencial.

À minha madrinha Vera Lúcia e à minha Tia Eliane, por estarem sempre ao meu lado e prontas a me ajudar em todos os momentos.

À minha orientadora Prof ${ }^{\mathrm{a}}$. Dr ${ }^{\mathrm{a}}$. Ana Waleska Pollo Campos Mendonça, pela generosidade, delicadeza, cuidado e atenção ao longo destes quatro anos de convívio.

Aos amigos Cíntia Nascimento, Fernando Santos, Ivone Goulart, Luciana Lacerda, Regina Cravo, Venina Aparecida e Luciana Pascoal por tornarem esta trajetória mais alegre e divertida.

Aos colegas do grupo de pesquisa História da Profissão Docente (Histprof) pela troca de experiências no âmbito acadêmico.

À Prof ${ }^{a}$. Dr ${ }^{a}$. Guaracira Gouvêa, pela orientação no Mestrado em Educação da Universidade Federal do Estado do Rio de Janeiro (UNIRIO). Construção das bases de conhecimento necessárias ao ingresso no Doutorado.

À Prof. ${ }^{a}$ Dr. ${ }^{a}$ Ana Maria Bandeira de Mello Magaldi e à Prof. ${ }^{a}$ Dr. ${ }^{a}$ Patrícia Coelho da Costa, pelas importantes contribuições na Qualificação I e II. 
À Banca examinadora por ter aceito o convite de avaliar minha tese: Prof $^{a}$. Dr ${ }^{a}$. Ana Lucia Cunha Fernandes, Prof. ${ }^{a}$ Dr $^{\mathrm{a}}$. Ana Maria Bandeira de Mello Magaldi, Prof $^{\mathrm{o}}$. Dr ${ }^{\circ}$. André de Lemos Freixo, Prof. ${ }^{\mathrm{a}}$ Dr $^{\mathrm{a}}$. Patrícia Coelho da Costa, Prof ${ }^{\mathrm{o}}$. Dr $^{\circ}$. Jefferson da Costa Soares e Prof. ${ }^{a}$ Dr $^{\mathrm{a}}$. Tania Dauster Magalhães e Silva.

Aos professores do Programa de Pós-Graduação em Educação da Pontifícia Universidade Católica do Rio de Janeiro (PUC-Rio), pelos ensinamentos que se fazem presente nesta tese.

Aos funcionários do Departamento de Educação da Pontifícia Universidade Católica do Rio de Janeiro (PUC-Rio), pelo auxílio e ajuda para com minhas dúvidas e solicitações.

Ao Departamento de Educação da PUC-Rio, pelos auxílios concedidos que possibilitaram minha participação em eventos e congressos.

À Coordenação de Aperfeiçoamento de Pessoal de Nível (CAPES) e ao Conselho Nacional de Desenvolvimento Científico e Tecnológico (CNPq) pela oportunidade de me dedicar de forma exclusiva ao Doutorado em Educação.

À Fundação Biblioteca Nacional, pela iniciativa de disponibilizar via Hemeroteca Digital Brasileira o acervo de O Tico-Tico.

À Fundação Casa de Rui Barbosa, por ter digitalizado o acervo de $O$ Malho e permitir um amplo acesso aos exemplares da revista.

Aos intelectuais Cardoso Júnior, Luiz Bartolomeu de Souza e Silva, Manoel Bomfim e Renato de Castro, pela iniciativa de criar O Tico-Tico. 


\section{Resumo}

Patroclo, Luciana Borges; Mendonça, Ana Waleska Pollo Campos. As mães de famílias futuras: a revista $O$ Tico-Tico na formação das meninas brasileiras (1905-1921). Rio de Janeiro, 2015.300p. Tese de Doutorado Departamento de Educação, Pontifícia Universidade Católica do Rio de Janeiro.

A presente pesquisa tem o propósito de analisar os conteúdos femininos presentes em O Tico-Tico. O recorte temporal, de 1905 a 1921, compreende a data de lançamento do impresso e o último ano de registro da Seção para meninas, espaço fixo destinado à promoção da educação doméstica. O Tico-Tico é considerada a primeira revista ilustrada infantil brasileira e a pioneira na publicação de histórias em quadrinhos dedicadas a este público específico. A sua criação está inserida no contexto de legitimação da nova ordem sociocultural republicana, no início do século XX. Os intelectuais-fundadores - Cardoso Júnior, Luis Bartolomeu de Souza e Silva, Manoel Bomfim e Renato de Castro creditavam à imprensa infantil a capacidade de conformar comportamentos. Em consonância ao pensamento conservador, O Tico-Tico defendia que meninos e meninas, embora igualmente crianças, possuíam papéis sociais distintos. As meninas eram preparadas, desde a infância, para o casamento e à maternidade. E os meninos, dotados dos conhecimentos necessários para liderar a nação. O arcabouço teórico desta pesquisa engloba os conceitos de gênero e representação, caracterizados como construções sociais marcadas por relações de disputa de poder. A metodologia se constitui na análise documental de mais de 800 exemplares da revista $O$ Tico-Tico, cujo acervo digitalizado pertencente à Hemeroteca Digital Brasileira da Fundação Biblioteca Nacional.

\section{Palavras-chave}

O Tico-Tico; Impresso infantil; Relações de gênero; Formação feminina 


\section{Abstract}

Patroclo, Luciana Borges; Mendonça, Ana Waleska Pollo Campos. (advisor). The mothers of future families: the magazine $O$ Tico-Tico in the formation of brazilian girls (1905-1921). Rio de Janeiro, 2015,300p. Doctorate Thesis - Departamento de Educação, Pontifícia Universidade Católica do Rio de Janeiro.

The objective of the present research is to analyze the magazine $O$ Tico-Tico in order to identify its female content. Its time frame, from 1905 to 1921, covers the launch of magazine and the ending of Seção para meninas, a section to promote housewifely formation. O Tico-Tico is the first brazilian illustrated children`s magazine and the first of all to publish comic books dedicated to this specific audience. It was engaged in the project of consolidation and legitimation of a new social and cultural republican order. For this reason, its intellectual's founders - Cardoso Júnior, Luis Bartolomeu de Souza e Silva, Manoel Bomfim e Renato de Castro - advocated that children`s magazine should promote standards of behaviors. In agreement with conservative thoughts, $O$ Tico-Tico justified that boys and girls, although equally children, had different social roles. The girls should be early prepared form marriage and motherhood. The boys had the role to lead the nation. The methodology used was the document analysis of over 800 copies from $O$ Tico-Tico, whose digitized collection belongs to Hemeroteca Digital Brasileira of Fundação Biblioteca Nacional.

\section{Keywords}

O Tico-Tico; Children's magazine; Gender relations; Female formation 


\section{Sumário}

1.Introdução

2.O Tico-Tico: um impresso para meninas e meninos 19

2.1.A revista infantil e seus intelectuais-fundadores 27

2.2.Leitores e personagens ilustrados 42

2.3.As ilustradas primeiras décadas republicanas 62

2.4. Os amiguinhos de Chiquinho: a criança republicana 77

2.5.As gentis leitoras de O Tico-Tico 93

3.O Tico-Tico e o Bello Sexo: uma questão de gênero 102

3.1.Paginas em defesa da futura mãe e esposa 107

3.2.A educação feminina: ler, escrever e cuidar 128

3.3.O trabalho feminino: mais lar e menos rua $\quad 142$

3.4.A formação tradicional versus a mulher em transformação 156

3.4.1.O exemplo de Faustina 164

4.Seções dedicadas às meninas e às mulheres 191

4.1.Seç̧ão para meninas: uma formação para o lar 195

4.2.Leitoras na moda: meninas e mulheres elegantes 213

4.3.O corpo feminino: meninas e mulheres esbeltas 228

4.4.A perfeição feminina: a boa mãe e bela mulher 250

4.4.1.A boa mãe 251

4.4.2.A bela mulher 259

$\begin{array}{ll}\text { 5.Considerações finais } & 271\end{array}$

$\begin{array}{ll}\text { 6.Bibliografia } & 274\end{array}$ 
Foi uma notícia lida dos jornais que me levou à infância; criatura sem saudades, nem por isso deixo de relembrar pedacinhos da minha vida - menina, tão alegre e tão sadia. Quando aprendi a ler, aos cinco anos de idade, - o que não é de se espantar, pois minha mãe, muito mocinha quando nasci, era professôra pública-, entre maravilhosos livros e deliciosas intimidades tornei-me amiga de Chiquinho, Faustina e Zé Macaco, tôda aquela familia ingênua. (...) Depois, mais tarde, quando vim para o colégio interno, deixei nas estantes arrumados, empilhados, todos os números de "O Tico-Tico". Lembro que pedi muito e muito à mamãe que não deixasse um exemplar sequer ser retirado daquele lugar, não consentisse que sôbre êles caissem as mãos destruidoras de meus irmãos. (Meus irmãos: uma a morte levou, os outros dois andam tão longe de mim, mas tão amados sempre pelo meu coração). Quando voltei do colégio, mamãe cumprira meus desejos. Saira menina, voltava mocinha: "O Tico-Tico" tornara-se passado na minha vida que começava.

Eneida de Moraes, Um cinqüentenário

De modo que a coleção do "Tico-Tico" é, hoje, material precioso para aquêles que se dedicam ao estudo sociológico e antropológico da história do Brasil: o Brasil destes últimos cinqüenta anos. Não é só através do adulto que se estuda a história do povo: também através do menino. Da vida, do vestuário, dos brinquedos, dos jogos, das leituras, dos desenhos, das garatujas dos meninos. E no "Tico-Tico" se encontra muita expressão significativa das tendências e preferências da infância durante fase interessantíssima da formação nacional. (...) A coleção do "Tico-Tico", estendeu-se por meio século da vida brasileira, presta-se a mais um estudo de natureza sociológica. Sociológica e psicológica. Só estudando-se o material que essa coleção reúne, pode-se entender bem o que sobre o mesmo período sugerem as caricaturas e os comentários de "O Malho", de "Fon-Fon" e de "Careta". 


\section{Introdução}

Por ventura de atividade realizada durante minha graduação em História tive a oportunidade de conhecer a revista $O$ Tico-Tico ${ }^{l}$. Em 2009, cursei a disciplina Oficina III, cujo propósito era estimular o contato dos alunos com a pluralidade das fontes de pesquisa. No tocante à escolha do corpus documental, para a realização de um seminário, optei por me dedicar ao estudo dos impressos. Influência da minha primeira graduação em Comunicação Social ${ }^{2}$, das pesquisas no Mestrado em Educação e do estágio docência na disciplina Imagem $e$ Educação do curso de graduação em Pedagogia da UNIRIO ${ }^{3}$.

A referência bibliográfica indicada foi História dos, nos e por meio dos periódicos, pertencente ao livro Fontes históricas, organizado por Carla Bassanezi Pinsky (2008). Escrito por Tania Regina de Luca, o capítulo faz uma análise do processo que resultou na consolidação da imprensa como objeto de estudos históricos.

Na década de 1970, poucos pesquisadores legitimavam o uso de jornais e revistas como fontes primárias. Os impressos serviam apenas para corroborar dados e informações presentes em outros documentos. "Reconhecia-se a importância de tais impressos e não era nova a preocupação de se escrever a História da imprensa, mas relutava-se em mobilizá-los para a escrita da História por meio da imprensa" (p.111). Os críticos apontavam a falta de objetividade e a subordinação aos interesses econômicos das elites como elementos limitadores do ofício do historiador. Em um contexto marcado por dúvidas e reflexões começaram a ser publicados, principalmente por acadêmicos paulistas, trabalhos questionando estas supostas limitações. Destaque para Arnaldo Contier, Maria Helena Capelato, Maria Ligia Prado e Vavy Pacheco Borges.

No item Imprensa, gênero e família, são apresentados estudos sobre impressos femininos e infantis. Luca aponta a emergência das pesquisas de gênero voltadas às análises de estereótipos, construções sociais e representações do ser mulher, em circulação na imprensa desde o século XIX à atualidade. Sobressaem-

\footnotetext{
${ }^{1}$ Bacharelado e Licenciatura em História pela Universidade Gama Filho.

${ }^{2}$ Bacharelado em Comunicação Social pela Pontifícia Universidade Católica do Rio de Janeiro (PUC-RIO).

${ }^{3}$ Mestrado em Educação pela Universidade Federal do Estado do Rio de Janeiro (UNIRIO).
} 
se as produções historiográficas de Dulcília Buitoni, Carla Bassanezi Pinsky, Joana Maria Pedro e Alessandra El Far.

No tocante às publicações infantis, é feita alusão à pesquisa $O$ Tico-Tico: meio século de ação recreativa e pedagógica de Zita de Paula Rosa (2002). No decorrer deste estudo foram analisados mais de 2000 exemplares da revista e abordadas temáticas referentes à criança, à educação entre outros assuntos. Também é mencionado o livro A Guerra dos Gibis: a formação do mercado editorial brasileiro e a censura aos quadrinhos - 1933-1964 de Gonçalo Júnior (2004). A publicação se refere ao período no qual as publicações em quadrinhos, mesmo populares entre o público infanto-juvenil, foram acusadas por grupos de intelectuais, como a Associação Brasileira de Educação (ABE), de prejudicarem a formação intelectual das crianças e as afastar nobres atividades como a leitura de um livro. Gilberto Freyre foi um dos principais defensores das narrativas em quadrinhos. Propôs que a Constituição de 1946 fosse publicada neste formato, pois “(...) as revistinhas serviam como 'ponte para a leitura' de livros (...) E aconselhou os pais a parar de defender a censura e a demonstrar interesse pelo que liam seus filhos (p.157). A leitura do texto de Tania Regina Luca, despertou-me a curiosidade em conhecer mais o universo dos impressos para crianças.

Consegui ter acesso à edição inaugural de $O$ Tico-Tico por meio do facsímile anexo ao livro $O$ Tico-Tico: centenário da primeira revista em quadrinhos do Brasil organizado por Waldomiro Vergueiro e Roberto Elísio dos Santos (2005). A capa do exemplar publicado em 11 de outubro de 1905 traz a história Manda quem póde ${ }^{4}$ (Fig.1):

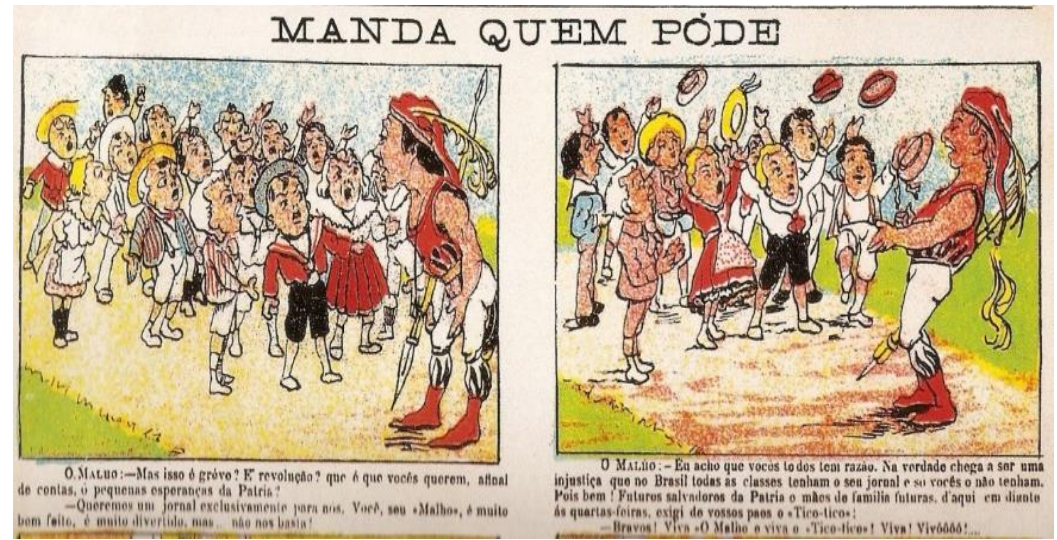

Figura 1- O Tico-Tico - 11/05/1905-p.1

\footnotetext{
${ }^{4}$ Manda quem póde é constituída por duas narrativas sobre histórias sobre o lançamento de $O$ Tico-Tico.
} 
Composta por apenas dois quadrinhos, a primeira narrativa descreve uma versão fantasiosa sobre a criação de $O$ Tico-Tico. Um grupo de crianças protesta junto à redação da revista $O$ Malho, localizada à rua do Ouvidor no Rio de Janeiro. Com o punho em riste, meninos e meninas se dirigem a personagem $O$ Malho, símbolo da gráfica e de revista de mesmo nome, para fazer uma série de cobranças. Assustado, $O$ Malho indaga aos pequenos manifestantes se tal movimento é uma revolução: “- que é que querem, afinal de contas, ó pequenas esperanças da Pátria?”. Ouviu como resposta: “- Queremos um jornal exclusivamente para nós. Você, seu Malho, é muito bem feito, é muito divertido, mas...não nos basta! O segundo quadrinho mostra as crianças lançando os chapéus ao alto. Qual seria o motivo para tal mudança de humor? O Malho concordou em satisfazer o anseio das crianças: “- Futuros salvadores da Pátria e mães de família futuras, d'aqui em diante ás quartas-feiras, exigi de vossos Paes o Tico-Tico".

O uso das expressões pequenas esperanças da Pátria, Futuros salvadores da Pátria e mães de família futuras, despertou-me questões: Como as crianças eram percebidas pela sociedade brasileira do início do século XX? Qual o tipo de conteúdos cívicos era produzido para crianças? Como se davam as relações de gênero no início do período republicano?

As primeiras inquietações sobre o tema resultaram na elaboração do trabalho de conclusão da Licenciatura em História: $O$ Ensino de História e a Primeira República: um estudo da Identidade Nacional através dos quadrinhos e calendários cívicos da revista O Tico-Tico (2010). Entre as obras de referências: Vergueiro e Santos (2008; Op.cit.), Hansen (2007; 2008) e Rosa (Op.cit.).

Na seleção do Doutorado PUC-Rio - 2011, apresentei o anteprojeto $A$ Primeira Republica e a questão da Identidade Nacional: o uso da revista O TicoTico como um instrumento de formação moral e educacional da criança brasileira. Depois, o anteprojeto foi modificado para Ensinar e divertir: um estudo sobre o uso pedagógico de O Tico-Tico na formação moral, intelectual e cívica da criança brasileira entre 1905 e 1930.

Sob a orientação da Prof. ${ }^{a}$ Dr. ${ }^{a}$ Ana Waleska Pollo Campos Mendonça, de 2011 a 2015, e os apontamentos da Prof. ${ }^{a}$ Dr$^{\mathrm{a}}$. Ana Maria Bandeira de Mello Magaldi e da Prof. ${ }^{a}$ Dr. ${ }^{a}$ Patrícia Coelho da Costa, nas Qualificações I e II, a pesquisa sofreu novas modificações. Entre as alterações estava a centralização em uma temática ou a uma seção específica do impresso. O Tico-Tico é uma revista 
ilustrada composta por uma ampla gama de conteúdos: contos, histórias em quadrinhos, seções informativas e de aconselhamento, concursos e publicidade. Desta forma, retomei minhas questões iniciais e optei por desenvolver um estudo sobre a temática de gênero.

Denominada As mães de famílias futuras: a revista $O$ Tico-Tico na formação das meninas brasileiras (1905-1921), este tese de Doutorado está inserida no campo da História da Educação com ênfase na linha de pesquisa História das Ideias e das Instituições Educacionais do Programa de PósGraduação em Educação da PUC - Rio.

O Tico-Tico é considerada a primeira revista ilustrada infantil e a pioneira na publicação de histórias em quadrinhos destinadas às crianças brasileiras. Lançado em 11 de outubro de 1905 pelos intelectuais - Cardoso Júnior, Luiz Bartolomeu de Souza e Silva, Manoel Bomfim e Renato de Castro - tornou-se peça importante na formação de leitores até fevereiro de 1962, quando foi extinta. Pertencente à Sociedade Anonyma $O$ Malho, estava imersa ao processo de modernização e de estruturação da imprensa de caráter empresarial e segmentada (HANSEN, Op.cit; VELLOSO, 2006). Projeto editorial desenvolvido em consonância ao processo de consolidação de uma literatura infantil nacional:

\begin{abstract}
Esta, por assim dizer, prontidão e maturidade da sociedade brasileira para absorção de produtos culturais mais modernos e especificamente dirigidos para uma ou outra faixa de consumidores expressa-se exemplarmente no surgimento, em 1905, da revista infantil O Tico-Tico. O sucesso do lançamento, a longa permanência da revista no cenário editorial, a importância de suas personagens na construção do imaginário infantil nacional, a colaboração recebida de grandes artistas tudo isso referenda que o Brasil do começo do século, nos centros maiores, já se habilitava ao consumo de produtos da hoje chamada indústria cultural (LAJOLO; ZILBERMAM ,2007, p.23).
\end{abstract}

No tocante à consolidação deste gênero literário, observa-se que as obras em circulação, nos anos finais do século XIX e no início do século XX, tinham os meninos como leitores privilegiados. Os conteúdos se propunham a exaltar a pátria brasileira. Diante deste contexto, instituiu-se a perspectiva de que $O$ TicoTico também considerava somente as crianças do sexo masculino como seu público primordial. O fato da publicação, inicialmente, ter somente Chiquinho como personagem principal e anúncios com frases e expressões direcionadas aos garotos reforçou tal representação: 
As páginas D’O TICO-TICO não se descuidarão também do lado util e moral, procurando no meio de suas historias de fadas e desenhos travessos, fortalecer e orientar o espírito desses que serão amanhã os nossos grandes homens. (O MALHO, 16/09/1905, p.40).

O Tico-Tico mantinha seções como Lições do Vôvô, na qual os leitores são chamados de meus netinhos. Em A arte de formar brasileiros, a personagem Tio José aconselha os sobrinhos sobre a importância de se tornarem homens honrados e ciente de seus deveres para com a nação. Espaços destinados apenas aos meninos.

No entanto, a leitura e a análise dos exemplares de $O$ Tico-Tico permitem identificar a existência de espaços de leitura destinados apenas ao sexo feminino: Secções para meninas, Figurinos para nossas leitoras, Para nossas leitoras. As páginas da revista são constituídas por histórias protagonizadas por meninas e mulheres. A personagem Faustina se tornou uma das figuras mais populares do impresso infantil. Para além disto, entre as publicações infantis estrangeiras que inspiraram a criação de $O$ Tico-Tico está o semanário feminino francês: $L a$ Semaine de Suzette.

Rosa (Op.cit.) e Vergueiro (Op.cit.) são autores que fazem referência à temática do gênero em $O$ Tico-Tico. Compartilham a perspectiva de que os responsáveis pela revista também se preocupavam com a formação das Mães de família futuras. Desta forma, torna-se imperativo identificar qual representação ou quais representações femininas circularam nas páginas do impresso infantil. A tese defende a hipótese de que tais representações estão calcadas em um modelo de bases conservadoras no qual as meninas devem ser preparadas, desde a infância, para o casamento e a maternidade.

A análise dos exemplares de $O$ Tico-Tico abrange o recorte temporal de 1905 a 1921. O período corresponde ao ano de lançamento do impresso e o último registro da Secção para meninas, primeiro espaço feminino de caráter fixo presente na revista. Em 1921, a Secção para meninas se desmembrou em espaços como Prendas domésticas e Secção de meninas. Por tal razão, foram analisados os exemplares até a edição n. 831, publicada no mês de setembro. O corpus documental é constituído por mais de 800 edições de $O$ Tico-Tico pertencentes ao 
acervo Hemeroteca Digital Brasileira da Fundação Biblioteca Nacional ${ }^{5}$. Desde 2012, o material se encontra digitalizado e disponível para consulta ${ }^{6}$.

A proposta de realizar um estudo sobre a contribuição de $O$ Tico-Tico na formação de suas leitoras encontra consonância na perspectiva de Perrot (1989), na qual a produção historiográfica relegou a trajetória feminina a condição de "sombras tênues" (p.9). Para compreender como as relações entre o feminino e o masculino se fazem presentes em $O$ Tico-Tico, o desenvolvimento da tese se faz por meio do conceito gênero.

Priore (2014) Burke (2008), Perrot, (2005, Op.cit) e Soihet (1997) relacionam o movimento feminista ao processo de abertura do campo historiográfico às pesquisas sobre mulheres e suas trajetórias históricas. Propunhase a superação dos parâmetros de dominação presentes na sociedade.

Para Scott (2012), tais narrativas estavam centradas na perspectiva de jogar luz sobre a biografia de mulheres que pudessem se encaixar na categoria de heroínas. Uma ação de caráter político, alvo de resistências e questionamentos. Contestava-se a existência de uma categoria universal de mulher. Na prática são múltiplas identidades: social, étnica, cultural, sexual, religiosa entre tantas outras categorias. A temática da diferença ganhou força.

Essa questão da diferença estava centrada na comparação com aquilo que era considerado universal, o padrão da coletividade. Por isso reivindicar a importância das mulheres significava uma modificação no padrão de história que existia no período, passando a priorizar os grupos locais. Inicialmente "parte da história da mulher buscava demonstrar a similaridade da atuação das mulheres e dos homens, e parte enfatizava a diferença das mulheres; ambas as abordagens consideravam as "mulheres" como uma categoria social fixa, mas cuja categoria essencial como mulher não se alterava (p.84).

Neste contexto, a categoria gênero passa a delinear os estudos sobre as relações entre homens e mulheres. Os aspectos físico e biológico são sobrepujados por via da construção social. Bassanezi (2014) ressalta que as construções de gênero se caracterizam pela complementaridade, por isso quaisquer mudanças no status da mulher se refletem no gênero masculino.

\footnotetext{
${ }^{5}$ HEMEROTECA DIGITAL BRASILEIRA. www.hemerotecadigital.gov.br

${ }^{6} \mathrm{O}$ referido acervo é constituído por alguns silêncios, pois o mesmo não se encontra completo. Em referência a 1905, ano de lançamento de $O$ Tico-Tico, só existe um exemplar do mês de novembro. Entre ausências mais significativas estão os exemplares publicados em 1908.
} 
Quando falamos em gênero, estamos falando da construção cultural do que é percebido e pensado como diferença sexual, ou seja, das maneiras como as sociedades entendem, por exemplo, o que é "ser homem" e "ser mulher", e o que é "masculino" e "feminino". Assim, podemos tratar essas noções como conceitos históricos. Nessa, perspectiva, as ideias sobre "masculino" e "feminilidade", as oposições do tipo "santa"/"puta", "moça de família"/"leviana", e os papéis e identidades tais como "esposa ideal", "boa mãe", "pai de familia", "homossexual", são encarados como concepções produzidas, reproduzidas, mas também transformadas ao longo do tempo, que podem variar em cada contexto social (p.1)

Almeida (2007) aponta que tais relações não se caracterizam pela imparcialidade, pois elas são flexíveis e imersas a disputas de poder. Por tal razão, nesta pesquisa a categoria gênero torna-se complementar ao conceito de representação.

As representações sociais se caracterizam como formas de ver o mundo. Não surgem aleatoriamente, são construídas a partir de uma determinada finalidade ou propósito. Segundo Chartier $(2010 ; 2006 ; 2004 ; 1991 ; 1990)$ para investigá-las e analisá-las é preciso compreender que elas não se caracterizam pela neutralidade e estão imersas a um contexto de luta e competitividade. Estabelecese a perspectiva de que diferentes grupos entram em disputa com o propósito de consolidar, junto ao meio social, uma determinada visão de mundo. Anderson (2008) afirma que representações são os principais elementos que permitem a existência das uma nação. Configuram-se em geradoras de práticas sociais e permitem que os indivíduos possam partilhar de uma determinada perspectiva sobre o meio social em que vivem. Assim, institui-se a necessidade de se traduzir estas representações em algo papável e que faça sentido a seus membros.

Chartier (Op.cit.) e Darnton (2010) identificam o livro como meio de circularidade dessas representações. Anderson (2008) aponta a imprensa como um dos principais meios para a dinamização dessas ideias. As narrativas escritas e imagéticas presentes nestes meios de comunicação se tornam o meio eficaz para a circulação, por exemplo, de modelos comportamentais femininos.

O segundo capítulo, intitulado O Tico-Tico: uma revista de meninos $e$ meninas, aborda o contexto de criação do impresso e a vinculação ao processo de mudanças políticas e socioculturais provenientes do advento da República. Como também, a emergência de uma literatura infantil brasileira. É descrito como a 
intelectualidade se imbuiu da missão de regenerar a pátria. As revistas ilustradas, símbolos da imprensa moderna, tornam-se arautos dos discursos calcados na necessidade da construção de uma sociedade civilizada. Neste contexto, as crianças foram vislumbradas como importantes atores sociais, pois caberia as mesmas garantir a continuidade deste projeto de nação. Por meio de uma formação intelectual e moral sólidas, as gerações futuras estariam inseridas no modelo de cidadão idealizado pelas elites brasileiras. Os conteúdos de $O$ TicoTico - concursos, histórias, personagens e seções - tinham o propósito de conformar os comportamentos de meninos e meninas dentro destes padrões sociais. Reforçando-se a perspectiva de que os fundadores da publicação se preocupavam com a formação dos futuros líderes da nação e das mães de famílias futuras.

No terceiro capítulo, O Tico-Tico e o Bello sexo: uma questão de gênero, faz-se referência ao modelo feminino em voga na revista: mulher-mãe-esposa. A formação educacional das meninas deveria priorizar os conhecimentos voltados a torná-las eficientes no desempenho de tais funções. O trabalho, para além do lar, seria aceito apenas em caso de necessidade e se fosse condizente à natureza da mulher, por exemplo, o magistério. A publicação fazia uso de personagens, como Faustina, para criticar certas mudanças no comportamento feminino e as demandas do movimento feminista.

Nomeado O Tico-Tico em páginas para meninas e mulheres, o quarto capitulo analisa as representações presentes em seções, espaços informativos e anúncios publicitários destinados às leitoras. O impresso infantil reproduz o formato e as estratégias da imprensa feminina em vigência desde o século XIX. Assuntos ligados a moda, a beleza, ao cuidado com o corpo e aos trabalhos manuais ganhavam destaque. Salienta-se que tais espaços eram destinados às meninas, mas também às moças e às senhoras. Por tal razão, os anúncios publicitários se destinavam a reforçar as representações da boa mãe e da bela mulher. 


\section{1.}

\section{O Tico-Tico: um impresso para meninas e meninos}

Todos amam as crianças; não há poeta que não celebre a sua innocencia e a sua belleza... Entretanto, caso singular! nada se faz em favor dellas, para divertil-as, para distrahir e encantar a sua existência. Não organisamos festas alegres, em que elas possam folgar e rir em liberdade e não lhes damos uma literatura especial, simples, ingênua ao alcance de sua intelligencia. Ao contrario disso, as festas que crianças figuram são destinadas a divertir... os marmanjos; marchando ao sol em batalhões, obrigadas a uma disciplina e a uma tenue que as fadiga e aborrece, ou representando comedias e dizendo monologos que não comprehendem, ellas vão a essas festas como a um sacrifício e a um castigo. Este jornalzinho (para empregar uma chapa inevitável) vem preencher uma lacuna. E'um jornal que se destina exclusivamente ao uso, á leitura, ao prazer, á distração das crianças. Não queremos a attenção nem o applauso da gente grande: os pequeninos, os innocentes, os simples formarão o nosso publico. E' para elles que escrevemos, - e si conseguirmos agradar-lhes, teremos obtido o único triumpho que ambicionamos. Contos, poesias, problemas, concursos, contribuirão nas paginas do Tico-Tico, para, ao mesmo tempo, instruir e deliciar as crianças; e, de hoje e deante, ellas poderão dizer, com orgulho: "Os marmanjos têm os seus jornaes? Pois nós também temos nosso jornal, que é feito para nós, exclusivamente para nós!" E não somente os pequeninos nos hão de agradecer! Todas as mãis, todos os que verdadeiramente amam as crianças hão de comprehender que a nossa iniciativa é digna de apoio.

Esta longa citação foi publicada, em 11 de outubro de 1905, no editorial da primeira edição de $O$ Tico-Tico. O conteúdo ressalta o pioneirismo do impresso, tendo em vista a preferência pela criança como público. Afirma que a revista foi criada com o objetivo de suprir uma lacuna na imprensa nacional, insistente em não produzir publicações que privilegiassem os anseios e as necessidades da infância. Critica veementemente a comercialização de livros classificados como infantis, mas que, na prática, continham histórias destinadas ao deleite dos adultos. As narrativas eram simploriamente adaptadas, sem cuidados específicos quanto à linguagem e a qualidade das ilustrações. Embora afirme não se preocupar com o aplauso de gente grande, o texto tem a clara intenção de convencer aos pais, principalmente às mães, de que $O$ Tico-Tico se constituiria no meio ideal de instrução e diversão para seus filhos.

A enfática defesa da infância nacional não deve ser entendida como um discurso aleatório, pois a mesma estava inserida no contexto de consolidação, 
junto à sociedade brasileira, de uma nova concepção do ser criança. Como observa Velloso (1996), os editoriais se constituem em uma espécie de "manifesto ou artigo fundador" por meio dos quais, jornais e revistas são apresentados aos leitores. É neste espaço que os responsáveis pela publicação expõem suas ideias com o propósito de obter a "simpatia imediata" do público (p.57).

O lançamento de $O$ Tico-Tico coincide com o período de consolidação da literatura infantil escrita por autores nacionais e especialmente direcionada à criança brasileira. Segundo Arroyo (1968), Bastos (2004), Hallewell (2005), Lajolo e Zilberman (2007), Gouvêa (2007; 2000), Silva (2010), Hansen (2012; 2012a, 2012b, 2011; 2011a; 2009; 2009a; 2008; 2007) foi entre as últimas décadas do século XIX e o início do século XX que a intelectualidade se imbuiu de tal missão.

Em seus primórdios no Brasil, este gênero literário estava vinculado à literatura escolar, "simplesmente destinados a fornecer leituras aos meninos nas escolas" (ARROYO, Op.cit., p.120). Não havia qualquer tipo de adequação dos conteúdos à idade dos leitores:

Daí tanto menino e tanta menina sofrer, desde tenra idade, mal saídos da perfeita articulação de vogais e consoantes, ao ter que ler, por exemplo, cantos inteiros de Os Lusíadas, ou decorá-los mesmos (...) (Loc.cit.).

Lajolo e Zilberman (Op.cit.) ressaltam que a aproximação entre a literatura infantil e a escola ocorreu porque é em sala da aula que meninos e meninas adquirem as habilidades e os códigos necessários para desenvolver a leitura. Por esta razão, Hansen (Op.cit.) defende que os textos destinados às crianças devem ser analisados por meio do diálogo entre a história da infância e a história da educação.

Ao longo do século XIX, a literatura infantil presente no país era, em sua maioria, constituída por traduções de livros estrangeiros destinados ao público em geral. Por exemplo: Contos seletos das Mil e uma Noites (1882), Robison Crusoé (1885), As viagens de Gulliver (1888) e o As Aventuras do Barão de Münchhausen (1891). Observa-se que muitas destas obras chegavam ao Brasil sem a classificação etária adequada e, por este motivo, os editores optavam por vendê-las como sendo direcionadas às crianças (SILVA, Op.cit.)

Neste mesmo período, houve registros de autores nacionais que se detiveram a escrever livros infantis. No entanto, os textos eram marcados por uma 
matriz estrangeira. O escritor Alberto Figueiredo Pimentel ${ }^{7}$, por exemplo, publicou Contos da Carochinha (1894) e Histórias da Avozinha (1896). As obras pertenciam à coleção de 10 volumes denominada Biblioteca Infantil lançada pela Livraria Pedro Quaresma ${ }^{8}$. Constituíam-se em compilações de narrativas clássicas europeias com o intuito de ajudar na formação moral das crianças:

As crianças brasileiras às quais dedicamos está série de livros populares, encontrarão nas Histórias da Avozinha um agradável passatempo, aliado a lições de moralidade, porque tais contos encerram sempre um fundo moral e piedoso (PIMENTEL, 1896, p.1).

Apesar dos livros terem obtido muito sucesso, inclusive por várias décadas, eles não abordavam assuntos relacionados à história e a identidade nacional brasileira. Neste contexto, a Proclamação da República (1889) se instituiu como um marco da literatura infantil brasileira (HANSEN, Op.cit.).

A consolidação do gênero literário infantil ocorreu em consonância à valorização da família nuclear burguesa e à legitimação da escola como espaço formador da criança. Os livros adquiriram um caráter educacional e pedagógico, visto que tinham a função de suprir a falta de materiais didáticos nas instituições de ensino republicanas.

A disciplina e os valores pedagógicos conformaram o gênero de maneira tão vigorosa que mesmo na modernidade, a literatura não conseguiu desatrelar-se totalmente de uma feição educativa e moralizante (SILVA, Op.cit, p.50).

(...) a literatura destinada à criança é socialmente mediada pela família e pela escola, definindo-se por um sentido pedagógico de sua produção (sentido também presente na literatura destinada ao público adulto) (GOUVÊA, Op.cit., p.29).

Na obra Educação Nacional, José Veríssimo (1906) tece uma série de críticas sobre a ausência de publicações infantis voltadas ao cultivo do sentimento pátrio. Identifica a escassez de produções didáticas nacionais referentes às disciplinas de história e geografia. Considera inconcebível o fato de alunos terem

7 Alberto Figueiredo Pimentel (1869-1914) nasceu em Macaé, no Estado do Rio de Janeiro.
Iniciou a carreira de jornalista, aos 17 anos. Era o responsável pela coluna social Binóculo,
publicada no jornal Gazeta de Notícias. É considerado o autor da expressão O Rio civiliza-se,
intitulação que se tornou famosa, na primeira década do século XX, em razão das reformas
urbanas na área central do Rio de Janeiro. Disponível em:
http://www.unicamp.br/iel/memoria/Ensaios/LiteraturaInfantil/figueire.htm. Acesso em: 30.mar.2015.

${ }^{8} \mathrm{Cf} .:$ EL FAR, Alessandra.. Páginas de Sensação: literatura popular e pornográfica no Rio de Janeiro (1870-1924). São Paulo: Companhia das Letras, 2004 
de aprender sobre o próprio país por meio de compêndios franceses 9 . "É preciso que o livro de leitura entre nós se reforme completamente e que sobre tudo fale do Brazil e de suas cousas" (p.133). Enfatiza ser imperativo que os autores brasileiros se dediquem à escrita deste tipo de material escolar.

Veríssimo cita como exemplo a ser seguido, o livro Cuore (1886) do autor italiano Edmondo de Amicis. Intitulado Coração e lançado no Brasil em 1891, pela Livraria e Editora Francisco Alves, foi traduzido pelo professor e historiador João Ribeiro. O texto se destaca pelo caráter cívico e o fato do protagonista ser o garoto Henrique. A narrativa indicada para meninos de 9 a 13 anos tem o processo de Unificação da Itália (1861) como pano de fundo. Além da exaltação dos valores nacionais e do progresso trazido pela consolidação da República italiana:

(...) é, contada em primeira pessoa, em forma de diário, escrito ao longo de um ano letivo escolar. Em suas páginas sucedem-se tanto episódios de sua vida cotidiana doméstica e escolar, como textos e histórias lidas e ouvidas pelo protagonista narrador. Aderindo ao modelo confessional de um diário, o primeiro texto do livro se reporta a outubro, ao "Primeiro dia de escola", encerrando no julho subseqüente, com "Ultimo exame" e "Adeus” (LAJOLO; ZILBERMAN, Op.cit., p.31).

Bastos (Op.cit.) faz referência aos elogios de José Veríssimo à Coração no artigo Educação Nacional (a propósito de um livro italiano) publicado na Revista Pedagógica de fevereiro de 1892. O livro é descrito como um "tão acabado manual de educação moral e cívica" cujo conteúdo "ensinará a moral mais elevada e simpática” (VERÍSSIMO, 1892 apud Ibidem, p.5). No entanto, lamenta o fato de não existirem obras nacionais que permitissem às crianças admirarem e aprenderem sobre os grandes feitos de sua própria pátria.

\footnotetext{
${ }^{9}$ Durante o Império, a falta de publicações nacionais de história e de geografia também se fazia presente. Na introdução do compêndio Lições de História do Brazil (1861), o escritor e professor do Colégio de Pedro II, Joaquim Manuel de Macedo (1820-1872) defende ser dever do professor suprir esta lacuna. "Professando desde alguns annos a Historia do Brazil no Imperial Collegio de Pedro II, reconhecemos no fim de breve experiencia que e fazia sentir a falta de um compendio dessa materia que fosse escripto e metbodizado de harmonia com o systema de estudos adoptado naquelle importante estabelecimento, e tambem comprehendemos que á nós como professor da cadeira respectiva, cumpria mais que á outro qualquer procurar satisfazer uma tal necessidade". (p.7). MACEDO. J.M.. Lições de História do Brazil. Rio de Janeiro: TYP Imparcial, 1861.
} 
A intelectualidade nacional se inspirou, neste tipo de publicação estrangeira para desenvolver as bases inicias da literatura infantil do Brasil ${ }^{10}$. Hansen (Op.cit.; Ibidem.) indica que os primeiros livros efetivamente direcionados à infância nacional primavam pelo caráter cívicopedagógico $^{11}$. Arroyo (Op.cit.) classifica este período de Reação Nacional (p.163) em razão da emergência do gênero literário estar em consonância a um intenso combate, principalmente, aos livros infantis provenientes de Portugal. Alegava-se que tais exemplares chegavam ao Brasil sem à adequação necessária aos pequenos leitores brasileiros.

Podem ser classificadas como parte desta primeira geração de obras infantis brasileiras: Contos infantis (1886) de Julia Lopes de Almeida e Adelina Lopes Vieira, Pátria (1889) de João Vieira de Almeida, América (1897) de Coelho Neto, O livro das crianças (1897) de Zalina Rolim, A terra fluminense (1898) de Olavo Bilac e Coelho Neto, Por que me ufano do meu país (1900) do Conde de Affonso Celso, Contos Pátrios (1904) de Coelho Neto e Olavo Bilac, Histórias de nossa terra (1907), Os nossos brinquedos (1909) de Alexina de Magalhães Pinto, Através do Brasil (1910) de Olavo Bilac e Manoel Bomfim e Alma: Educação feminina (1910) de Coelho Neto.

As publicações partilham de representações sobre a criança estabelecidas a partir de parâmetros dos próprios autores, podendo ou não corresponder à realidade.

\footnotetext{
${ }^{10}$ O livro francês Le Tour de La France par Deux Enfants (1877) de G. Bruno, pseudônimo da autora Augustine Fouillé (1833-1923), também é identificado como obra de referência para os escritores brasileiros. Segundo Lajolo e Zilberman, na história narrada em terceira pessoa, os meninos órfãos André e Julien percorrem a França com o intuito de encontrar um tio. Ao longo da viagem, os garotos aprendem sobre as riquezas do país e a importância do cultivo do sentimento pátrio. Embora não tenha sido publicado no Brasil, estudiosos identificam que Através do Brasil (1910), de Olavo Bilac e Manoel Bomfim, foi diretamente influenciado pela obra francesa. A narrativa brasileira versa sobre as andanças dos irmãos, Carlos e Alfredo, em busca do pai. Após saberem de sua morte, prosseguem a busca, desta vez, para encontrar os parentes. "Cruzando o Brasil de norte a sul, os irmãos percorrem as diferentes paisagens físicas e econômicas da terra, interagindo com as diferentes populações e vivenciando os diferentes costumes, desde o Nordeste até os pampas sulinos” (p.33). LAJOLO, Marisa; ZILBERMAN, Regina.. Literatura infantil brasileira: história e histórias. 7. ed. São Paulo: Ática, 2007.p.31-33.

${ }^{11}$ Patrícia Hansen define que, a primeira fase da literatura infantil brasileira, estende-se de 1889 a 1921. O término é condicionado à publicação de Narizinho Arrebitado (1921) de Monteiro Lobato (1882-1948). O livro instituiu um novo paradigma literário, por não vincular o conteúdo à temática cívica. HANSEN, P. S.. Brasil, um país novo: literatura cívico-pedagógica e a construção de um ideal de infância brasileira na Primeira República, 2007. 253 f. Tese (Doutorado em História) Faculdade de Filosofia, Letras e Ciências Humanas, Universidade de São Paulo, São Paulo, 2007. p.15.
} 
No caso da produção literária, os signos constituem-se como representações. A literatura, entendida como prática simbólica, configura-se como a formulação de uma outra realidade que embora tenha como referente constante o real no qual o autor e o leitor se inserem, guarda com a realidade uma relação não de transparência, mas de opacidade própria da reconstrução. O conceito de representação significa considerar que o autor não produz o real, mas o reconstrói, tendo como matéria-prima os signos. No momento da produção do texto, traz para a escrita a sua compreensão do real, bem como o projeto de realidade pretendida. Ele representa, portanto, a realidade, tendo a linguagem literária como signo (GOUVÊA, Op.cit., p.23).

Ressalta-se que tais representações não eram homogenias, refletiam as disputas entre os diferentes grupos republicanos e seus respectivos projetos de nação $^{12}$. Lajolo e Zilberman (Op.cit.) identificam como uma de suas vertentes, a literatura de caráter ufanista. Por que me ufano do meu país, escrito por Conde de Affonso Celso ${ }^{13}$, é um dos exemplos mais representativos. Publicado em 1900, durante os festejos do quarto centenário do Brasil, tinha o objetivo de despertar nas crianças o amor pelo país e por suas riquezas naturais: ${ }^{14}$

Consiste em minha primordial ambição em vos dar exemplos e conselhos que vos façam úteis à vossa família, à vossa nação e à vossa espécie, tornando-vos fortes, bons, felizes. Se de meus ensinamentos colherdes algum fruto, descançarei satisfeito de ter cumprido minha missão. Entre esses ensinamentos, avulta o do patriotismo. Quero que consagreis sempre ilimitado amor à região onde nascestes, servindo-a com dedicação absoluta, destinando-lhe o melhor de sua inteligência, os primores de vosso sentimento, o mais fecundo da vossa atividade dispostos a quaisquer sacrifícios por ela, inclusive o da vida. (...) Ousa afirmar muita gente que ser brasileiro importa condição de inferioridade. Ignorância ou má fé! Ser brasileiro significa distinção e vantagem. Assisti-vos o direito de

\footnotetext{
${ }^{12} \mathrm{O}$ movimento republicano brasileiro não era homogêneo. Havia de três grandes projetos em disputa: o liberalismo norte-americano e os modelos franceses: o jacobinismo e o positivismo. Apesar das fortes influências da França no campo sociocultural, no âmbito político-administrativo, os Estados Unidos foram a principal referência à adoção do federalismo e da autonomia dos estados previstas na Constituição de 1891. CARVALHO, J.M.. Formação das Almas: o imaginário da República no Brasil. São Paulo: Companhia das Letras, 2009. p.17-18.

13 Affonso Celso de Assis Figueiredo Júnior (1860-1938) era mineiro da cidade de Ouro Preto. Dedicou-se à política, ao jornalismo e ao magistério. Nomeado, o primeiro Visconde do Ouro Preto, foi colaborador dos periódicos Correio da Manhã e Jornal do Brasil. Foi membro do Instituto Histórico Geográfico Brasileiro (IHGB), além de membro fundador da Academia Brasileira de Letras (ABL). Disponível em: http://www.dec.ufcg.edu.br/biografias/ABLACAFJ.html. Acesso em 29.mar.2015.

14 A narrativa é dividida em 11 motivos para se orgulhar do Brasil: a grandeza territorial, as belezas naturais, a sua riqueza, a variedade e a amenidade do seu clima, a ausência de calamidades; a excelência de tipos que entraram na formação do tipo nacional, os nobres predicados do caráter nacional, nunca ter sofrido humilhações, nunca ter sido foi vencido, o seu procedimento cavalheiroso e digno para com os outros povos, as glórias a colher nele e a sua história. CELSO, Conde de Affonso.. Por que me ufano do meu país. [S.1]: ebooksBrasil, 2002.
} 
proclamar o desvanecimento, a nossa origem, sem receio de confrontar o Brasil com os primeiros países do mundo. Vários existem mais prósperos, mais poderosos, mais brilhantes que o nosso. Nenhum mais digno, mais rico de fundadas promessas, mais invejável. (...) Que vossa geração exceda a minha e as precedentes, senão em semelhante amor, ao menos nas ocasiões de o comprovar. Quando disserdes: "Somos brasileiros!" levantai a cabeça, transbordantes de grande ufania. Convenceivos de que deveis agradecer quotidianamente a Deus o haver Ele vos outorgado por berço o Brasil (CELSO, 2002, p.8-10).

A obra, escrita em homenagem aos três filhos, destaca a importância do patriotismo na formação das crianças. A linguagem sentimental e o tom exacerbado são utilizados como recursos para despertar, desde a meninice, o sentimento de comprometimento para com a nação.

Hansen (Op.cit.) identifica os meninos como público preferencial da literatura infantil cívico-pedagógica. No entanto, ressalta a existência de obras destinadas à formação moral e intelectual das meninas. O livro História de nossa terra (1896) de Julia Lopes de Almeida ${ }^{15}$ constitui-se em

(...) uma reunião de contos, cartas e anotações fictícias de crianças, meninos e meninas, é uma exceção por não segmentar o público por gênero (entre os livros publicados antes de 1920 é o único que não induz a esta distinção considerando a pretensão de identificação dos leitores com os personagens) e reforça ainda a representação das meninas com fotografias de escolas femininas (...) (p.27).

A narrativa apresenta papéis femininos em destaque. A razão de a autora ter salientado a importância destas personagens estava na luta pela ampliação do acesso feminino à educação.

Coelho Neto ${ }^{16}$ dedica Alma: Educação Feminina às filhas Marieta, Dina e Violeta. O livro composto por 34 pequenas narrativas, separadas em duas partes com 17 textos, destinava-se a dois fins: "á literatura e á dicção” (p.1). O autor

15 Julia Valentim da Silveira Lopes de Almeida (1862-1934) foi importante intelectual e abolicionista. Publicou Traços e Iluminuras, aos 24 anos de idade. Era casada com o poeta português, Felinto de Almeida (1857-1945), e mãe de três filhos. É autora de diversos livros e dos popularíssimos manuais femininos: Livro das Noivas (1896), Livro das Donas e Donzelas (1906) e Maternidade (1924). MAGALDI, Ana Maria Bandeira de Mello.. Lições de Casa: discursos pedagógicos destinados à família no Brasil: FAPERJ; Belo Horizonte: Argumentum, 2007.

${ }^{16}$ Henrique Maximiano Coelho Neto (1864-1934) nasceu em de Caxias, no estado do Maranhão. Foi aluno do Colégio de Pedro II e se graduou em Direito, na Faculdade de Direito do Recife. Atuou como jornalista, escritor e político. Tornou-se um dos primeiros membros da Academia Brasileira de Letras (ABL). É considerado o autor do principal codinome da cidade do Rio de Janeiro: Cidade Maravilhosa. A expressão foi publicada, pela primeira vez, em artigo publicado no impresso A Notícia de 29 de novembro de 1908. Disponível em: www.academia.org.br/publicacoes/coelho-neto. Acesso: 29.mar.2015. 
enfatiza que os escritos, também poderiam ser usados no ambiente escolar. Os conteúdos descritos, em tom de aconselhamento e abordagem cívica, versavam sobre: amizade e honra, leitura, trabalho, ambição, escrúpulo, ordem e outros assuntos. Estas características podem ser observadas no trecho extraído do texto Pátria:

Não penses que o patriotismo consiste apenas no sacrifício de sangue feito pelo soldado...a guerra é o lance extremo. O patriotismo funda-se na dedicação, no respeito, no amor, em summa, de quantos interessam-se pela prosperidade do paiz nativo. E a mulher, minha filha, o ser fraco, cabe a responsabilidade maior nesse trabalho, porque, como o Senhor, no dizer dos livros, criou a alma do Homem infundindo-lhe no corpo e seu halito divino, a mulher mãe deve inspirar o coração do filho o bom exemplo, que é o gérmen da perfeição (NETO, 1928, p.141).

O escrito faz referência à condição feminina de um ser fraco, porém Coelho Neto condiciona e este, mesmo ao sexo feminino, a responsabilidade pela função mais importante do projeto republicano brasileiro: a formação moral dos futuros líderes da nação. Em consonância à perspectiva de que a mulher deve apenas se dedicar à maternidade, ao casamento e à administração do lar.

Observa-se que a consolidação da literatura brasileira para crianças não ficou restrita ao suporte livro, também encontrou na imprensa escolar infantil um importante nicho de desenvolvimento:

(...) a formação das coordenadas da literatura infantil brasileira, a criação de um campo propício à sua evolução - sem nunca esquecer aqui a importância fundamental do desenvolvimento da educação e do ensino - para a sua base, se assim nos podemos exprimir, foi a imprensa para crianças e jovens, impressa não só na forma de jornal, como na forma de revistas (ARROYO, Op.cit., p.131).

No contexto paulista destaca-se Álbum das meninas: revista literária dedicada às jovens brasileiras. Criado pela educadora Anália Franco ${ }^{17}$, em 1898, era inicialmente vendido ou adquirido via assinatura. Posteriormente, foi distribuído gratuitamente nas escolas públicas paulistas até o fim da publicação na

\footnotetext{
${ }^{17}$ Anália Franco Bastos (1856-1919) era natural de Resende, no estado do Rio de Janeiro. Formouse normalista e exerceu o magistério em São Paulo, cidade para a qual se mudou com a família quando pequena. Dedicou-se a criação de instituições educacionais e filantrópicas como as Escolas Maternais, as Escolas Elementares e os Asilos para Órfãs. Fundou o Liceu para formação de professoras. Publicou uma série de livros e impressos como A voz maternal (1903). Disponível em: www.histedbr.fe.unicamp.br/navegando/.../verb_b_analia franco.htm. Acesso. 27.mar.2015.
} 
década de 1920. O impresso traz textos sobre educação e religião, contos, poemas e poesias. Na edição inaugural, Anália Franco publicou o editorial As mães e educadores no qual ressalta sua preocupação com os rumos da instrução de feminina:

A nossa missão é, pois evangelisar a rasão, e levantar bem alto o estandarte da virtude e do bello, inoculando no coração da mocidade confiada ás nossas mãos, as grandes qualidades que nos vão faltando: - a ordem, o trabalho, a noção exacta do dever, o verdadeiro amor da pátria, a comprehensão da vida humana com um destino elevado e serio e sobre tudo fazer-lhe conceber o bem absoluto, a eterna justiça, o Espirito Supremo que anima e vivifica toda a natureza. E' porém fora de duvida que a educação e instrucção elementares só poderiam tornar-se verdadeiramente profícuas, se os alumnos ao voltarem de escola encontrassem no lar, os meios de continuarem a instruir-se, e um dos mais efficazes recursos para consegruil-o consiste em facilitar- lhes a leitura dos bons livros. Todos sabem entretanto que os livros não se acham ao alcance de todos. O jornal é que percorre por toda á parte e penetra tanto no tecto do abastado como no albergue do pobre, é o livro das famílias e a fonte perenne d'onde todos recebem a verdade e o ensino sem presumirem em tal $(30 / 04 / 1898$, p.2).

O conteúdo ressalta o papel imperativo da educação como elemento conformador da sociedade. Menciona à função materna de acompanhar a feitura das lições e o processo de aprendizagem dos filhos. Sobressaem-se as referências acerca do desempenho da imprensa como veículo formador dos cidadãos. Entre os aspectos apontados, o preço mais acessível dos periódicos ante os livros.

Coincidentemente, em 1898 foi lançado o primeiro periódico não escolar destinado à criança brasileira: o Jornal da Infância. A publicação contou com apenas 20 edições cuja circulação deu-se entre os meses de fevereiro a junho do referido ano. As oito páginas eram preenchidas por poesias, passatempos e histórias europeias traduzidas para o português (VERGUEIRO; SANTOS, 2005; ROSA, 2002). Embora de curta duração, a breve iniciativa rendeu frutos. Após sete anos, entrou em circulação: $O$ Tico-Tico.

\subsection{A revista infantil e seus intelectuais-fundadores}

\section{Segundo Arroyo (Op.cit.), O Tico-Tico}

(...) galvanizando tôda a necessidade de leitura das crianças brasileiras se impunha pioneiramente como publicação tècnicamente concebida. Fôra a revista organizada em bases racionais, com motivos e temas de interesse nacional (...) (132). 
O projeto de criação deste impresso infantil envolveu a atuação de intelectuais que apostaram na imprensa não escolar como meio de difusão de conhecimentos voltados à formação das crianças brasileiras: Cardoso Júnior, Luis Bartolomeu de Souza e Silva, Manoel Bomfim e Renato de Castro.

$\mathrm{O}$ uso da categoria intelectual vincula-se às categorias elaboradas por Sirinelli (2003) sobre os Intelectuais criadores e mediadores culturais. Neste grupo estão presentes: jornalistas, escritores e professores secundários. Caracterizam-se por usufruírem da imprensa como instância de sociabilidade. As redações e os conselhos editoriais das revistas constituem-se em locais para o compartilhamento de visões de mundo. "Em suma, uma revista é antes de tudo um lugar de fermentação intelectual e de relação afetiva, ao mesmo tempo viveiro e espaço de sociabilidade (...)" (p.249).

Gomes (2009) descreve os intelectuais brasileiros do final do século XIX e início do século XX como “"profissionais” de produção de bens simbólicos, essenciais à legitimação de regimes políticos modernos” (p.26). Sevcenko (2003) afirma que a intelectualidade encontrou na imprensa, com destaque para as revistas ilustradas, seu principal meio de atuação. Velloso (2006) ressalta:

Percebendo o lugar estratégico da revista como espaço de vinculação de suas idéias, possibilitando a articulação de projetos político-culturais, parte e expressiva da intelectualidade envolveu-se na dinâmica do mercado editorial. Freqüentemente os intelectuais tornaram-se proprietários das revistas ou passam a ocupar postos influentes em sua direção editorial (p.313-314).

Diante do contexto apresentado, Rosa (Op.cit.) identifica - o médico, escritor, jornalista, professor, sociólogo e "pensador da história"18 - Manoel Bomfim como o intelectual que vislumbrou a criação de um periódico como $O$ Tico-Tico. Autor de livros - A América Latina (1905), Através do Brasil (1910) e a trilogia O Brasil na América (1929), O Brasil na História (1930) e O Brasil Nação (1931) - exalta o potencial transformador da educação junto à sociedade brasileira.

\footnotetext{
${ }^{18}$ Roberta Gontijo utiliza a categoria pensador da história, pois Manoel Bomfim, embora autor de uma série de trabalhos dedicados à análise histórica, não gozava das prerrogativas que conferiam à intelectuais, como Capistrano de Abreu e João Ribeiro, o título de historiador. O primeiro possuía "[...] experiência no trato com fontes documentais em arquivos o que era fundamental num momento em que se almejava conferir cientificidade à história" e o segundo o obtinha "através de sua atividade docente" (p.13). GONTIJO, Rebeca.. Manoel Bomfim: "pensador da história" na Primeira República. Rev. Bras. Hist., São Paulo, v. 23, n. 45, p. 129-154, julho 2003.
} 
Em entrevista à edição do jornal $A$ Noite, de 11 de outubro de 1955, o ilustrador Vasco Lima ${ }^{19}$ atribui a Manoel Bomfim a responsabilidade por revisar os conteúdos publicados e dar-lhes “(...) um sentido eminentemente educativo, visando, sobretudo, formar o caráter das crianças” (p.1). Bomfim permaneceu pouco tempo à frente de $O$ Tico-Tico. Os motivos seriam as intensas atividades na vida pública, a escrita de livros e os cargos ligados à instrução pública. No entanto, não se afastou completamente da carreira jornalística, pois continuou a publicar artigos nas revistas O Malho e Leitura para Todos (ROSA, Op.cit.).

Gontijo (2010), Ventura e Sussekind (1984), apontam que Manoel Bomfim se diferia de outros intelectuais de seu tempo, como Nina Rodrigues ${ }^{20}$, por não creditar à miscigenação racial as marcas do atraso presentes na sociedade brasileira. Para ele, as desigualdades nacionais estariam calcadas no processo histórico de exploração, por exemplo, entre a metrópole portuguesa e a colônia brasileira. Discorda da excessiva imparcialidade, dos discursos e das teorias sobre uma suposta superioridade dos brancos frente aos negros. "Criticado por não se ater a 'objetividade científica', é no questionamento dessa imparcialidade que se constrói o discurso de Manoel Bomfim. Oscilando entre a ciência e o afeto" (Ibidem., p.26). Creditava à educação o poder de reverter as mazelas brasileiras:

Sofremos, nesse momento, uma inferioridade, é verdade, relativamente aos outros povos cultos. É a ignorância, é a falta de preparo e de educação para o progresso - eis a inferioridade efetiva; mas ela é curável, facilmente curável. O remédio está indicado: a necessidade imprescindível de atender-se à instrução popular (BOMFIM, 1897 apud GONTIJO, Op.cit., p.11.).

${ }^{19}$ Vasco Lima (? - 19-) foi jornalista e ilustrador de O Tico-Tico. Ocupou o cargo de diretorgerente do jornal A Noite e foi fundador das revistas Carioca e Vamos Ler. É creditado a Vasco Lima, a criação do cargo de Rei Momo no carnaval carioca. “(...) o fato passou-se anos atrás, precisamente em 18 de fevereiro de 1933. 'A Noite' rodava duas, três, às vezes, até cinco, seis, ou sete edições por dia. Seu diretor-gerente, Vasco Lima teve então a idéia maluca, ou melhor, retumbante: para alegrar mais ainda o carnaval carioca, que já era o mais famoso do mundo, engendrou uma personagem, o Rei Momo, que reinaria na cidade por três" (p.10). QUE SAUDADES do Rei Momo. Revista da Semana, Rio de Janeiro, p.9-10, 11.fev.1950.

${ }^{20}$ Raimundo Nina Rodrigues (1862-1906) era maranhense e se formou médico pela Faculdade de Medicina do Rio de Janeiro). Atou como professor das cadeiras, Clínica Médica e Medicina Legal, na Faculdade de Medicina da Bahia. Foi pioneiro no desenvolvimento da Medicina Legal no país. Desenvolveu estudos com o propósito de demonstrar, cientificamente, a superioridade racial dos brancos. Entre suas produções literárias estão: As raças humanas e a responsabilidade penal no Brasil (1894), O animismo fetichista dos negros da Bahia (1900) e Os africanos no Brasil (1932). CORRÊA, Mariza.. Raimundo Nina Rodrigues e "a garantia da ordem social”. Revista USP, São Paulo, n.68, p. 130-139, dezembro/fevereiro 2005-2006. 
Nascido na cidade de Aracaju - Sergipe em 1868, Manoel Bonfim faleceu no Rio de Janeiro no ano de 1932. Aos 17 anos, mudou-se para Salvador com o intuito de cursar a Faculdade de Medicina da Bahia. No entanto, pediu transferência para a Faculdade de Medicina do Rio de Janeiro pela qual se graduou em 1890. Embora médico, obteve destaque e prestígio por sua atuação no magistério e na administração da instrução pública. De 1898 a 1902 ministrou as disciplinas moral e cívica, português e pedagogia na Escola Normal da Capital Federal. Situação consonante à atuação como diretor do Pedagogium ${ }^{21}$, cargo exercido ao longo de 17 anos divididos em dois períodos distintos: 1896 a 1905 e 1911 a 1919 quando foi decretado o fim da instituição (CAMARA E COCKELL, 2011). Também desempenhou funções no Conselho Superior de Instrução Pública do Distrito Federal e na Diretoria de Instrução Pública do Distrito Federal, de 1899 a 1907 (GONTIJO, Op.cit.).

Segundo Rosa (Op.cit.) e Cardoso (2008), durante viagem de estudos à Paris, de 1902 a 1903, com o intuito de aprender sobre a Pedagogia experimental $^{22}$, Manoel Bomfim teve contato com revistas ilustradas infantis francesas: Le Jeudi de La jeunesse (1902), La Jeunesse Illustrée (1903) e Les Belles Images (1903). Deste modo teria surgido a inspiração para se criar O TicoTico. Após o retorno ao país, Bomfim teria apresentado o projeto a Cardoso Júnior e a Renato de Castro. O acesso aos exemplares de Le Petit Journal Illustré de La Jeunesse (1904) e La Semaine de Suzette (1905) ocorreu por meio do recebimento de exemplares provenientes da França. As publicações citadas

${ }^{21}$ O Pedagogium foi criado pela iniciativa do General e Ministro e Secretário de Estado dos Negócios da Instrução Pública, Correios e Telégrafos, Benjamin Constant. (1836-1891). Em 16 de agosto de 1890, o Generalíssimo Marechal Deodoro da Fonseca assinou o Decreto Lei nº 667 , permitindo o seu funcionamento. Constituía-se em um museu pedagógico que visava promover a modernidade escolar republicana, por meio da realização de cursos, de exposições permanentes sobre métodos e materiais escolares e a publicação da Revista Pedagógica. KUHLMANN JÚNIOR, Moysés. O Pedagogium: sua criação e finalidades. In: MIGNOT, A. C. V.. Pedagogium: símbolo da modernidade educacional republicana. Rio de Janeiro: Quartet; FAPERJ, 2013.p.2542.

${ }^{22}$ A Pedagogia experimental se desenvolveu a partir da segunda metade do século XIX, em decorrência ao afastamento do pensamento pedagógico da Filosofia. Por sua vez, houve a aproximação da Pedagogia com a Sociologia, a Antropologia e a Psicologia, consideradas ciências positivas e dedicadas ao estudo do homem. Os partidários da Pedagogia experimental realizam estudos sobre os paradigmas científicos da indução e da experimentação, ou seja, calcados na observação dos fatos. Caracterizou-se pelo desenvolvimento de ações voltadas à educação das crianças via a elaboração de métodos de avaliação da aprendizagem e da medição das aptidões específicas da inteligência infantil. CAMBI, Franco. História da pedagogia. São Paulo: EDUSP, 1999.p. 498-502. 
influenciaram diretamente no formato e nos conteúdos de O Tico-Tico. (Fig.2) (Fig.3) Fig.4).

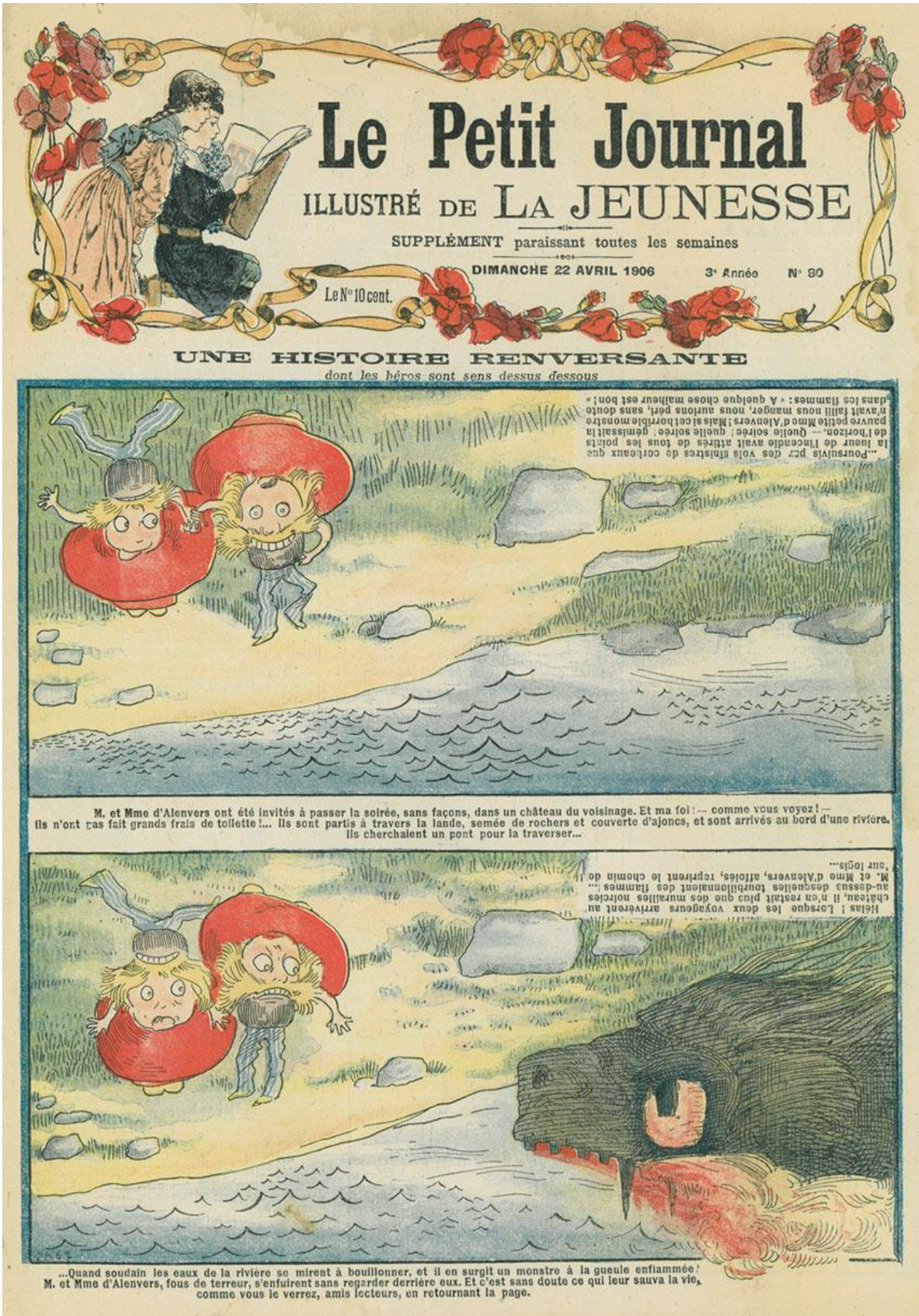

Figura 2- Le Petit Journal Illustré de La Jeunesse-22/04/1906 - p.1 


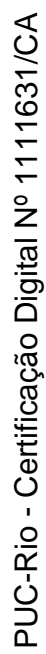

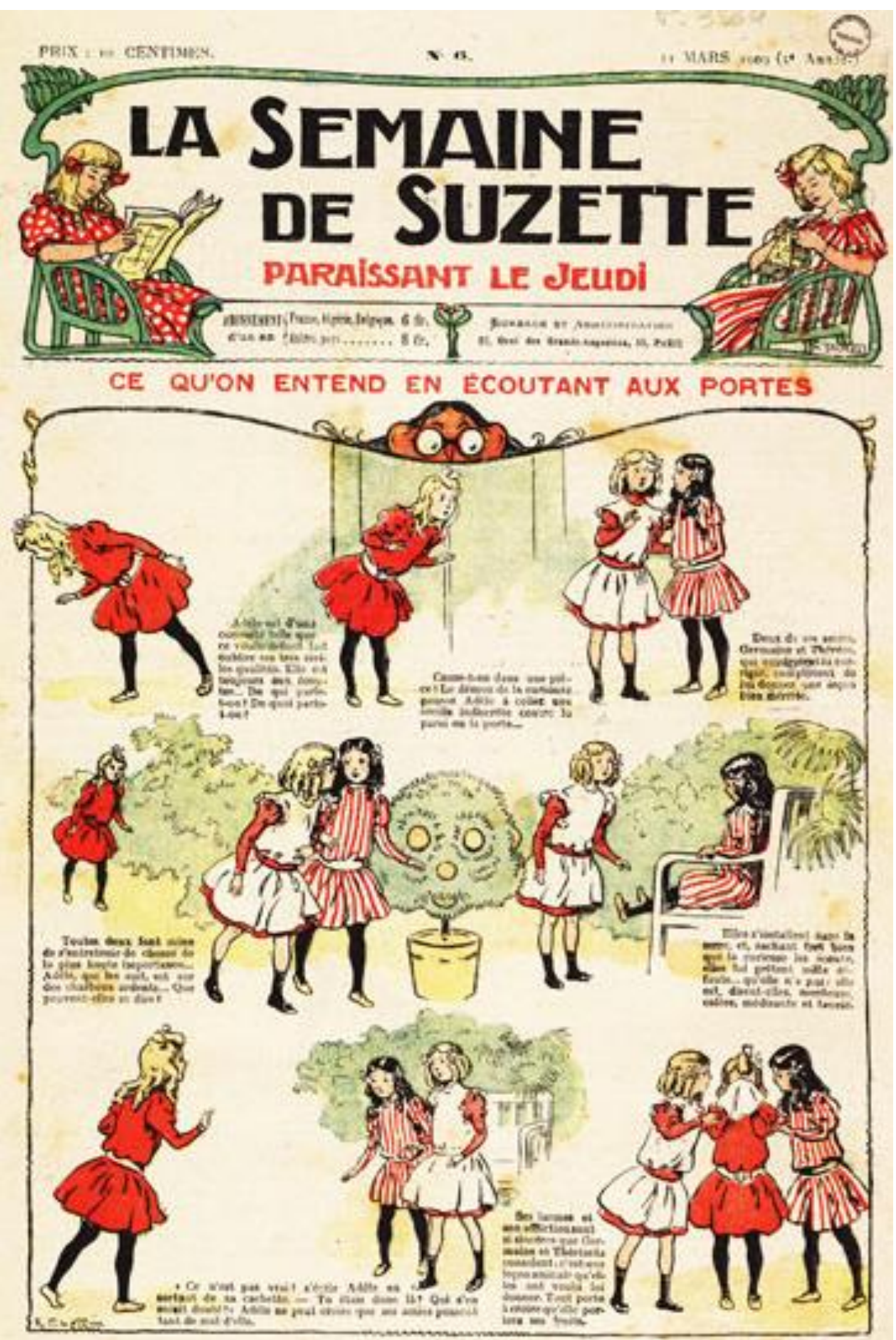

Figura 3 - La Semaine de La Suzette - 11/03/1909 - p.1 


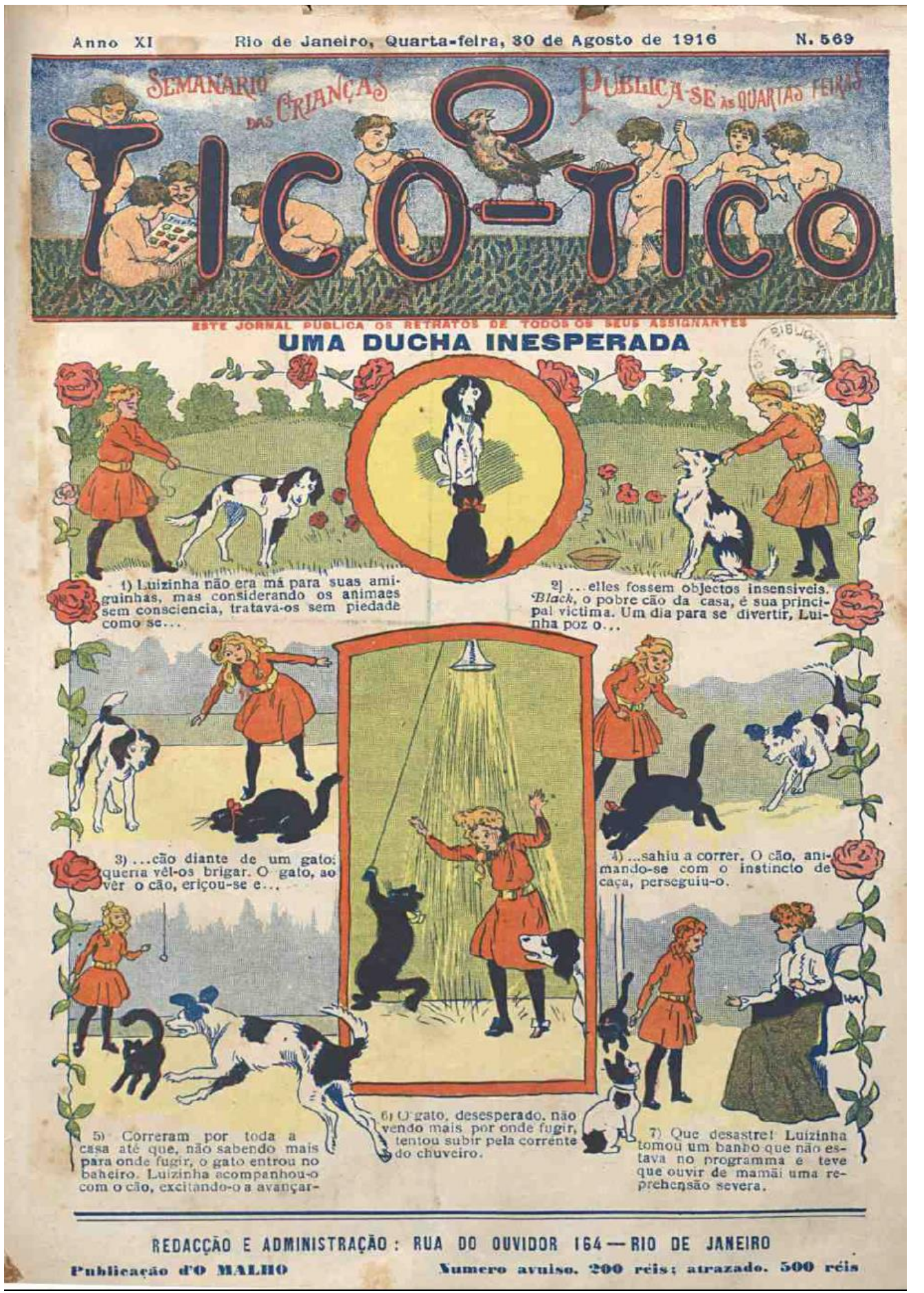

Figura 4 - O Tico-Tico-30/08/1916-p.1 
Ao longo da pesquisa, não foram encontradas vastas informação sobre Cardoso Júnior. No livro O Rio de Janeiro do meu tempo, Luís Edmundo (2003) o descreve como bom amigo, poeta, jornalista e frequentador do Café Paris, um acanhado estabelecimento localizado no centro do Rio de Janeiro:

Já à porta surge a figura entroncada de Cardoso Júnior, Le bongéant com os seus eternos jornais, os seus infalíveis folhetos de propaganda e sua pasta-de-ovo, marrom enorme, debaixo do braço. É um tipo esplêndido e viril, a porejar saúde. E bom humor. Usa uma barbicha rala, em ponta, a lhe fugir do queixo, um queixo anglo-saxão, amplo, duro, e bem marcado. Chega falando alto, do meio da rua, que para todos ouçam. (...) Cardoso Júnior não acredita também na maldade dos homens. É, por isso, feliz (p.360).

No decorrer de sua carreira jornalística, fundou o impresso Avenida e a Revista Contemporânea, esta última permaneceu em circulação de 1899 a 1901. Trabalhou como redator do periódico Correio da Manhã. No tocante à revista $O$ Tico-Tico, Cardoso era o responsável por responder às colaborações dos leitores (ROSA, Op.cit.). Na edição de 9 de outubro de 1918 foi publicado um um artigo em sua homenagem, mas sem dados específicos sobre sua vida pessoal.

Quem foi o fundador d'este lindo jornal de creanças?

Não há dúvida nenhuma que elle se deve aos esforças da empreza de outro grande semanario: $O$ Malho; mas teve como aula creadora o inesquecível Cardoso Junior, poeta e jornalista de grande talento e coração, e que era também um adorável chefe de família ( LIÇÕES DO VÔVÔ, s/p).

Renato de Castro nasceu em 1878 e faleceu aos 64 anos no ano de 1942. Estudou no Ginásio de São Bento e na Escola de Belas Artes, instituição na qual se dedicou ao estudo do desenho, da escultura e da gravação de medalhões. Iniciou o curso de Medicina, mas optou por se dedicar ao jornalismo. Iniciou a carreira na imprensa como secretário de redação da Gazeta de Notícias, periódico no qual conviveu com José do Patrocínio e Olavo Bilac. Trabalhou como ilustrador e caricaturista nos jornais Dom Quixote de Angelo Agostini ${ }^{23}$, Tribuna, O Malho e Ilustração Brasileira. Exerceu o cargo de diretor-secretário da

${ }^{23}$ Angelo Agostini (1843-1910) foi um caricaturista de origem italiana. Chegou ao Brasil no ano de 1859 e, posteriormente, naturalizou-se brasileiro. É considerado o precursor das histórias em quadrinhos no país pela publicação, em 1869, no jornal A Vida Fluminense, de As Aventuras de Nhô Quim ou Impressões de uma Viagem à Corte. Em 1876 fundou a Revista Ilustrada, impresso considerado um dos baluartes na defesa pela Abolição e pela República. É o autor do cabeçalho com anjinhos de $O$ Tico-Tico e pela seção $A$ arte de formar brasileiros. MAGNO, L..História da Caricatura Brasileira: os precursores e a consolidação da caricatura no Brasil. v.1.Rio de Janeiro: Gala Edições de Arte,2012. p.196-217. 
Companhia Editora Americana, pertencente à Revista da Semana. Nesta instituição, participou da fundação da Eu sei tudo e A Cena Muda. Para além da profissão de jornalista, atuou como taquígrafo do Senado Federal e professor das disciplinas de português e história na Escola Amaro Cavalcanti (REVISTA DA SEMANA, 9/05/1942, p.33). Entre os fundadores de O Tico-Tico, Renato de Castro foi o único a permanecer à frente da revista até o final da década de 1910, período no qual foi diretor artístico e trabalhou para “(...) solicitar e encomendar aos ilustradores e redatores o tipo de material a ser publicado, promover a sua seleção e se dirigir aos leitores em nome da empresa” (ROSA, Op.cit., p.61).

Cardoso Júnior e Renato de Castro foram colaboradores da revista $O$ Malho. Sucesso de vendas desde o lançamento em 20 de setembro de $1902^{24}$, pertencia à Sociedade Anonyma $\mathrm{O}$ Malho cujo proprietário e diretor era o jornalista e político Luis Bartolomeu de Sousa e Silva.

Descrito por Arroyo (Op.cit.,p.153), como um homem "de uma vasta experiência jornalística”, Luis Bartolomeu de Souza e Silva nasceu em 1868 na cidade mineira de Rio Preto. Filho do Major Luiz José de Souza e Silva e de D. Anna de Souza e Silva, foi aluno do conceituado Colégio Caraça. Transferiu-se para São Paulo com o propósito de concluir o ensino secundário. Depois, seguiu ao Rio de Janeiro com o intuito de cursar a Escola Militar da Praia Vermelha, um dos epicentros do movimento republicano. Por ocasião da Proclamação da República tinha a patente de Oficial do Exercito, mas preferiu abandonar as Forças Armadas e se mudou para o Paraná. No retorno à Capital Federal, consolidou a carreira de jornalista em cargos de chefia dos impressos $O$ Tempo, $A$ República e A Tribuna. Após o lançamento de O Tico-Tico, fundou as revistas Leitura para todos e Ilustração Brasileira. Abandonou o jornalismo após ser eleito Deputado Federal pelo estado do Paraná. Desta forma, a Sociedade Anonyma O Malho passou a ser dirigida por seus familiares. Faleceu em 1932 (ARROYO, Op.cit.; ILLUSTRAÇÃO BRASILEIRA, 22/12/1922, p. 35).

Rodrigues (2013) e Cardoso (Op.cit.) apontam que a ausência de registros pessoais e de informações sobre as atividades realizadas por seus intelectuais-

\footnotetext{
${ }^{24}$ A revista $O$ Malho: semanário humorístico, artístico e literário circulou, ininterruptamente, de 1902 a 1930. Após a Revolução de 1930, a redação do impresso foi incendiada, pois a publicação combateu o movimento Aliança Liberal que apoiou a chegada de Getulio Vargas à Presidência da República. O impresso voltou a ser publicado, em 1935, sob censura. No ano de 1954, foi impressa sua derradeira edição. SODRÉ, Nelson Werneck. História da Imprensa no Brasil.4.ed. Rio de Janeiro: MAUAD, 1999.p.301.
} 
fundadores demonstra a existência de silêncios sobre o processo de criação de $O$ Tico-Tico. Esta tese partilha da perspectiva de Rosa (Op.cit.), na qual a iniciativa de fundação do impresso infantil foi, inicialmente, calcada nos estudos de Manoel Bomfim sobre a educação e a criança. Como o seu afastamento da publicação, outras diretrizes foram sendo estabelecidas.

Na obra Lições de Pedagogia (1920), Bomfim almeja que educadores estejam atentos ao ambiente social no qual vivem seus alunos. "Só deste modo saberá elle como deve completar a educação natural, no que tiver que ser completado, e como poderá corrigir o que nella houver de falho ou defeituoso". (p.24). Critica o ensino enfadonho proporcionado às crianças. Desta forma, a escola não poderia competir com "usos costumes, leis, tradições, ações correntes, gestos e discursos (...) influindo sobre os seus juizos e sentimentos (...)" (Loc.cit.). Considera o estimulo à curiosidade e ao progresso, de meninos e meninas, como algo primordial nas ações educativas. Outro aspecto ressaltado pelo intelectual é a formação da personalidade, definida como:

(...) energias essenciaes ou tendencias e qualidades especificas que a criança traz ao nascer, como herança de sangue; e das influencias que sobre ella se desenvolverem durante o período de organização psychica (p.16).

A formação psíquica é influenciada pelo meio social no qual o indivíduo está inserido. Manuel Bomfim afirma que os valores morais adquiridos no âmbito doméstico são de extrema importância. Por meio das relações com os pais e os familiares, a criança estabelece seus primeiros parâmetros comportamentais. No entanto, salienta que tais valores familiares são baseados em impulsos e não em práticas racionais e científicas:

Os paes são educadores por instinto. Absorvidos pelo cuidado com a prole, eles são conduzidos pelo afeto por isso tão profundos e intensos são taes impulsos, que a consciencia se offusca, e a intelligencia não busca a compreensão clara e racional dos verdadeiros interesses da creança, das possibilidades de exito, e das formas efficazes de intervenção educativa. Na vida domestica, a educação conserva o caracter de actividade, systematizada pela rotina (p.18).

As instituições escolares não devem questionar estes valores, somente apenas quando os mesmos fossem prejudicar o desenvolvimento da criança ou expô-la a um ambiente de degradação. Afirma ser função imperativa da escola prover os meios necessários para que os alunos pudessem adquirir a consciência e a capacidade intelectual de julgar os chamados atos de moralidade. O educador 
define que a finalidade da educação é a promoção da formação moral do indivíduo. “(...) para a educação ou formação moral do indivíduo se devem orientar todos os recursos e processos da intervenção educativa" (p.330). Para Bomfim, a moral é a combinação entre os instintos sociais e a inteligência.

A visão de Bomfim sobre o processo educacional encontra consonância nos princípios do método intuitivo. Também denominado Lições de coisas ou Ensino pelos aspectos, despontou na Alemanha do século XVIII e difundido pelo restante da Europa no século XIX. No Brasil, este ideário se fez presente desde a década de 1870. O livro Lições de Coisas: manual de ensino elementar para uso de paes e professores do autor norte-americano Norman. A. Calkins, e traduzido por Rui Barbosa, constituiu-se em um dos principais meios de divulgação deste ideário pedagógico no país.

Segundo Valdemarin (2004; 2000) e Souza (2011), o método intuitivo era centrado no atendimento das necessidades educacionais das crianças. Valendo-se de preceitos científicos, difundiu a aprendizagem direcionada a privilegiar o conhecimento concreto. Posteriormente, seriam trabalhadas tais questões pela via abstrata. Além disso, os conteúdos tinham que ser ensinados de forma concêntrica, ou seja, partindo-se dos elementos mais fáceis para depois abordar os temas mais difíceis, respeitando-se os critérios de idade e de desenvolvimento intelectual de meninos e meninas. Os materiais didáticos à disposição de professores e alunos deveriam incluir: mapas, esferas, lousas e outros recursos educativos. Pretendia-se instituir uma educação de caráter prático que se diferenciasse do ensino livresco vinculado à instrução modelar do período imperial $^{25}$, estabelecendo a criança como protagonista do processo de aprendizagem. Este modelo educacional se aproximava dos propósitos republicanos de conceder à infância um papel de destaque junto à sociedade brasileira.

\footnotetext{
${ }^{25} \mathrm{Na}$ atualidade, a historiografia da educação questiona a visão pessimista sobre a educação brasileira no período imperial. Cf.: GONDRA, José Gonçalves; SCHUELER, Alessandra. Educação, poder e sociedade no império brasileiro. São Paulo: Cortez, 2008.
} 
As leituras de exemplares de O Tico-Tico publicados de 1905 a 1921 demonstram que a revista tinha como uma de suas principais diretrizes: a formação moral dos petizes. ${ }^{26}$ Em entrevista, desta vez, ao jornal Correio da Manhã, Vasco Lima salientou: "Embora recreativa a revista tinha por finalidade básica a formação moral da meninice e da juventude" (p.3). Neste sentido

Assim como o fenômeno educacional não se limita à escola, mas se encontra disseminado na sociedade, consideramos como dotados de um viés educativo, também outros tipos de impressos que, ainda que não se dirigissem a um público escolar ou abordassem diretamente matérias relativas ao campo da educação, contribuíram para a modelação de sujeitos na sociedade brasileira, a partir da segunda metade do século XIX e ao longo de todo o século. Nesse quadro, são valorizados, para além das ações situadas na transmissão de conhecimentos formais, dispositivos diversos voltados para a conformação de hábitos, valores e comportamentos (MAGALDI; XAVIER, 2008, p.9).

Os conteúdos publicados em $O$ Tico-Tico têm o propósito de estimular as boas ações e as virtudes morais infantis. As narrativas Pão Secco (Fig.5) e A curiosidade castigada (Fig.6) traduzem a vertente formativa da publicação. A primeira narrativa apresenta duas irmãs generosas que decidem ajudar um menino pobre. A segunda história retrata a importância de as crianças respeitarem e obedecerem aos mais velhos. A desobediência e a avareza podem resultar em consequências negativas e punições dolorosas às personagens. Por tal razão, os bons sentimentos devem ser sempre estimulados e difundidos.

\footnotetext{
${ }^{26}$ É preciso ressaltar que existia uma grande satisfação, por parte dos responsáveis de O Tico-Tico, quando professores e alunos faziam uso da revista em sala de aula. A edição, de 25 de abril de 1906, traz o seguinte texto: "O 'Tico-Tico' nas escolas" no qual eram feitos elogios a dois alunos que terem utilizado contos publicados no impresso para realizarem suas atividades escolares. "O nosso agente na Fortaleza, Ceará, Sr. Luiz Teixeira, teve a gentileza de nos enviar duas provas escriptas de alumnos do collegio Instituto de Humanidades, daquella capital, onde os contos illustrados d'O Tico-Tico servem de modelo para as escriptas. Num dos últimos exames cada alumno com o n.4 d'O Tico-Tico em sua frente, fez na banca, em presença da comissão examinadora, a sua prova escripta, falando sobre o nosso jornal e desenvolvendo o texto das historias alli publicadas. Alcançaram o $1^{\circ}$ e o $2^{\circ}$ logares os alumnos Antonio Bezerra de Menezes e Adriano de Castro Martins, ambos do curso secundario, $2^{\circ}$ anno. São os autores das duas provas que gentilmente nos foram enviadas e que, com palavras lisongeiras que muito nos sensibilisam, começam por fazer um pouco da historia do nosso aparecimento e acabam descrevendo e explicando o conto illustrado Meninos endiabrados até com batatas, sahido naquelle numero. Os alumnos Antonio Bezerra e Adriano Castro Martins revelam nessas provas grande facilidade de redacção e clareza de espirito. Mostram-se, enfim, dignos filhos da terra da luz onde, por toda a parte vai $O$ Tico-Tico obtendo o acolhimento que deste caso se deprehende" $(\mathrm{s} / \mathrm{p})$.
} 


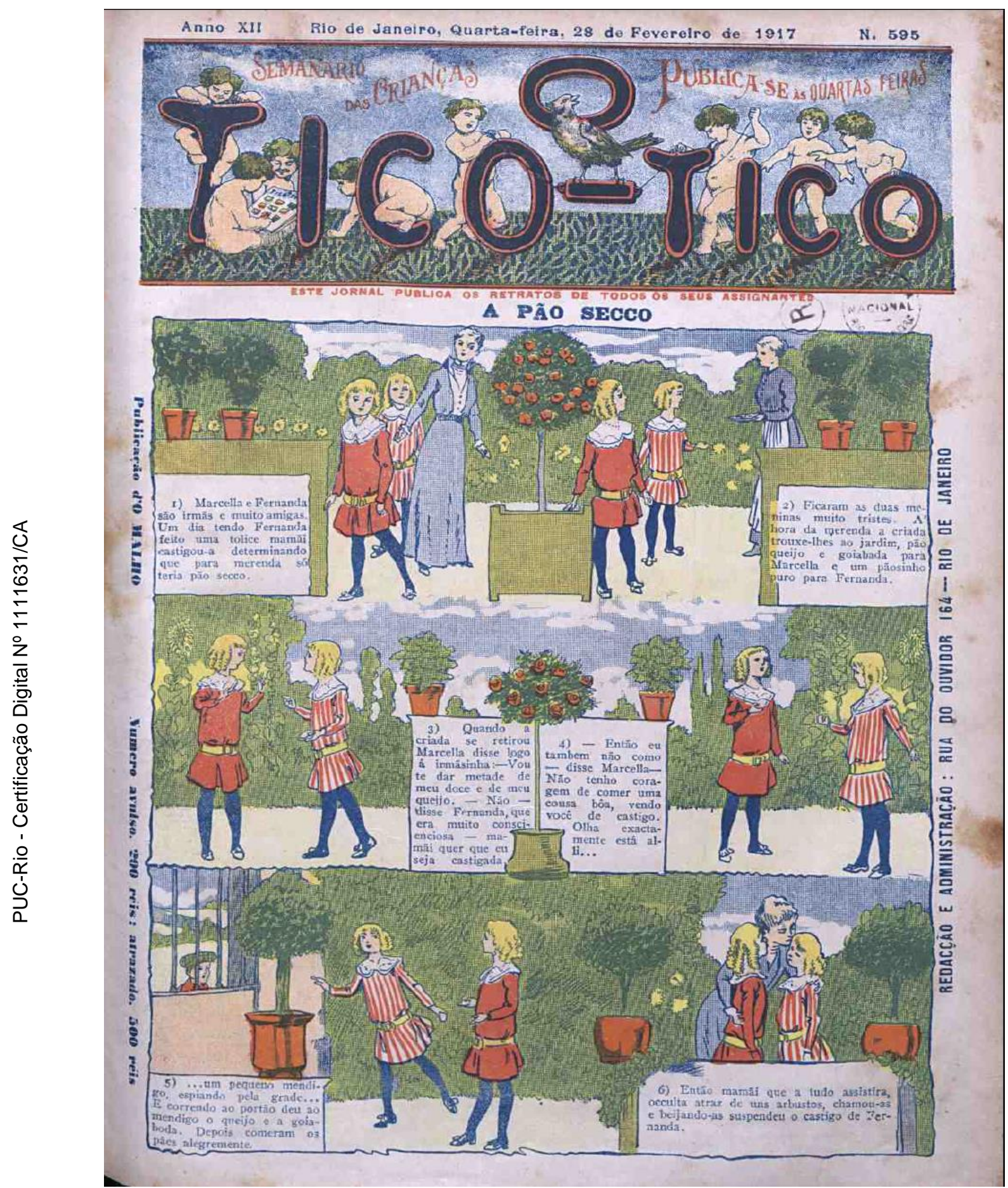

Figura 5 - O Tico-Tico-28/02/1917-p.1 


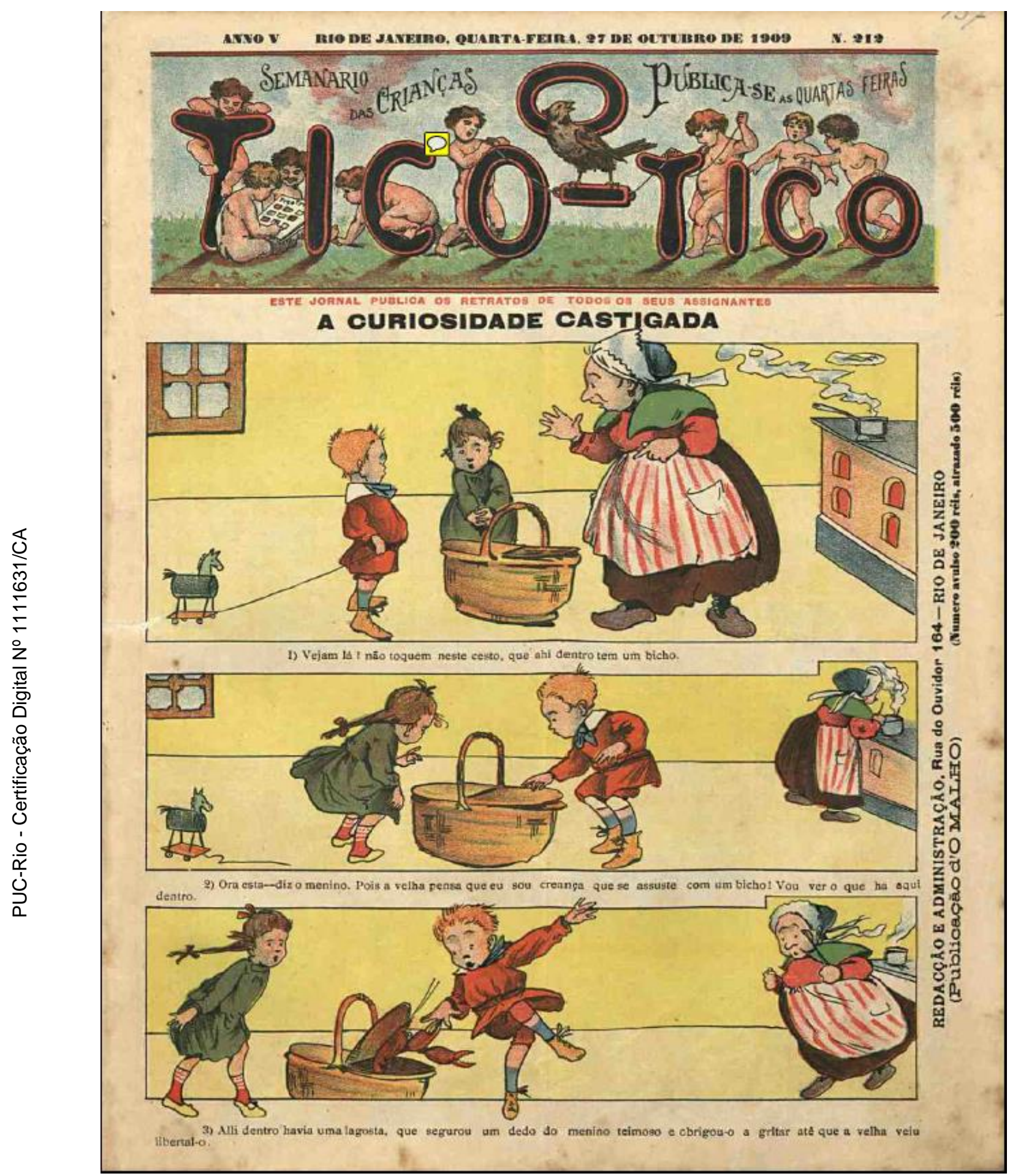

Figura 6 - O Tico-Tico - 27/10/1909-p.1 
Embora se identifique o quão importante foi a participação de Manoel Bomfim para o lançamento de $O$ Tico-Tico, salienta-se que a memória ${ }^{27}$ sobre a criação da revista, vinculada em suas próprias páginas, não lhe confere tal status. Os textos alusivos ao aniversário do impresso costumam fazer referências a sua fundação. Luis Bartolomeu de Souza e Silva é apontado como o principal articulador do projeto. No exemplar de 11 de outubro de 1933 é relatado que a concepção da revista teve como inspiração as atividades propostas pela preceptora inglesa de seus filhos:

Luiz Bartholomeu, um combatente intemerato das lides da imprensa, director da Sociedade Anonyma O MALHO, tinha filhos crianças, cuja professora, ilustre dama ingleza, costumava recrear a imaginação de seus discipulos com exemplares de revistas infantis escriptas em inglez. A Luiz Bartholomeu, alma boníssima de pae, coração que andava sempre a vibrar pelo amor da família e pelo amor da Patria, não passava despercebido o gesto da dama ingleza que entregava jornaes inglezes á leitura dos discípulos queridos. E Luiz Bartholomeu imaginou um jornal para creanças. A' hora do jantar, entre os filhos e a esposa queria, falou da Idea que tivera. $O$ contentamento dos filhos, manifestado immediatamente, foi um incentivo á realização do projeto (LIÇÕES DO VÔVÔ, p.5).

A mesma questão ocorre em 12 de outubro de 1938 no texto intitulado $O$ dia d' O Tico-Tico:

No dia 11 de Outubro de 1905, ha trinta e tres anos portanto, apareceu o primeiro numero d'O Tico-Tico, todo colorido, contendo uma porção de contos e bonecos que encheram de mais da mais viva alegria o mundo das crianças do Brasil.E dessa data em diante, todas as semanas, sem qualquer interrupção, vem $\mathrm{O}$ Tico-Tico ampliando mais e mais o seu programa de recrear e educar a infancia, mantendo uma tarefa de grande finalidade educacional sobejamente provada. E' para a criança que O TICO-TICO tem vivido, é para ela que se vive e viverá, sob a bandeira bonita da formação do espírito, sadio e culto dos brasileiros de amanhã. Nem ha de faltar, para isso, aos atuais dirigentes d'O Tico-Tico o mesmo entusiasmo patriótico que animou àqueles que vieram, numa tarefa esplendida de patriotismo, dirigindo a vida desta revista e cujos nomes numa homenagem sincera, declinamos com emoção - Luiz

\footnotetext{
${ }^{27}$ Jaques Le Goff define a memória como a "propriedade de conservar certas informações (...) graças às quais o homem pode atualizar impressões ou informações passadas, ou que ele representa como passadas". (p.419). No tocante à memória coletiva, objeto de atenção do Estado, pode ter sido vivenciada, de forma direta ou não pelos indivíduos. Por esta razão, é alvo das "lutas sociais de poder". (p.422). A memória coletiva é entendida como algo passível de manipulação e "os esquecimentos e os silêncios da história são reveladores desse mecanismo". (Loc.cit.). LE GOFF, Jacques. História e Memória. 5.ed. Campinas-SP: Unicamp, 2003.p.419-476.
} 
Bartholomeu, Cardoso, Renato de Castro, Eurycles de Mattos, José Lopes dos Reis, Oswaldo de Souza e Silva (p.3).

Este discurso construído sobre $O$ Tico-Tico também se faz presente nos em livros sobre o tema. A própria a Sociedade Anonyma O Malho em 1956, publicou Cinqüentenário de O Tico-Tico, no qual o texto de abertura referencia o papel de fundador de Luis Bartolomeu:

Foi seu fundador o jornalista Luiz Bartolomeu de Souza e Silva, que era diretor da Sociedade Anônima "O Malho", tendo esta revista, muito popular em todo o Brasil, feito a propaganda do lançamento no novo jornalzinho. A época do aparecimento de "O Tico-Tico" não havia, no Brasil, uma única revista para as crianças, fato que impressionou aquêle jornalista, homem empreendedor e idealista, levando-o a tomar aquela iniciativa (p.7).

Em História da Caricatura no Brasil, Herman Lima (1963) descreve que o impresso infantil foi fruto de conversas entre Cardoso Júnior e Luis Bartolomeu de Sousa e Silva. Arroyo (Op.cit.) também compartilha da visão de protagonismo do empresário. Pesquisas recentes - Rosa (Op.cit) Vergueiro e Santos (Op.cit.) e Hansen (Op.cit.) - ressaltam a contribuição de Manoel Bomfim. Pode-se estabelecer que tal perspectiva sobre Luis Bartolomeu está vinculada ao fato de que foi por meio da estrutura de sua gráfica que o $O$ Tico-Tico pôde efetivamente ganhar vida ${ }^{28}$. Instituindo-se um viés no qual mundo prático se sobrepôs ao mundo das ideias.

\subsection{Leitores e personagens ilustrados}

Segundo Rosa (Op.cit.), para que o lançamento de O Tico-Tico fosse concretizado, realizaram-se uma série de encontros com o propósito de convencer Luis Bartolomeu de Souza e Silva de participar de tal empreitada:

A idéia da publicação de revistas para criança era vista com simpatia mas, simultaneamente, com reservas, pois a ausência de um público leitor expressivo desestimulava a assunção de um empreendimento complexo e de incógnita lucratividade. (p.60).

\footnotetext{
${ }^{28}$ A presença de Luis Bartolomeu de Souza e Silva é sempre reforçada enquanto a memória sobre a participação dos outros intelectuais-fundadores é fluída. No artigo publicado em $O$ Malho, de setembro de 1952, o poeta Eustorgio Wanderley (1882-1962) aponta o poeta Luiz Pistarini (18771918) como um dos fundadores de $O$ Tico-Tico: "Possuidor de admirável tino administrativo, lembrou-se de lançar, com Renato de Castro e o poeta Luiz Pistarini, uma revista para crianças. E surgiu O TICO-TICO" (p.35). WANDERLEY, Eustorgio.. O "83" de Luiz Batholomeu. O Malho, Rio de Janeiro, p. 35-36, set.1952.
} 
Como forma de testar a receptividade dos conteúdos infantis junto aos leitores, a revista $O$ Malho publicou, entre 1903 a 1904, a tradução de contos europeus e as narrativas dos escritores brasileiros Décio da Ponte e Chrysanthème, este último o pseudônimo de Cecília Bandeira de Melo. Nas edições de 15 e 22 de outubro de 1904 foi apresentada a narrativa Por causa de um cachorro. A história em quadrinhos, ilustradas por Angelo Agostini, é protagonizada pelos meninos: Oswaldo e Zezinho. Descreve as confusões causadas pelo ataque que sofreram de um cachorro feroz (p.38). No ano de 1905 são encontrados registros de atividades destinadas às crianças até outubro, mês de lançamento de $O$ Tico-Tico. A edição de 2 de setembro traz a seção Página para criança cujo conteúdo versa sobre construções rápidas em papel (p.38).

As respostas positivas sobre a iniciativa incentivaram a publicação do impresso infantil, como destaca o anúncio publicado na edição de $O$ Malho de 23 de setembro de 1905:

O TICO-TICO

jornal com que a empreza d' $O$ Malho pretende completar o numero de suas publicações.

\section{O TICO-TICO}

sahirá em breve, às quartas-feiras. Imaginem-se as vantagens que, sobre todos os brincos para crianças, terá

\section{O TICO-TICO}

o qual, ao mesmo tempo que a divertirá, lhes será um vehiculo suave e alegre de instrucção.

\section{O TICO-TICO}

será do mesmo formato d'O Malho, terá desenhos coloridos, e os seus desenhos e o seu texto estão confiados pela nossa empreza a artistas que adoram a especialidade: escrever e desenhar para crianças, fazer rir esses pequenos entes, buliçosos e irrequietos, que são o encanto da vida.

\section{O TICO-TICO}

terá todo o sabor, todas as atrações para os seus pequenos leitores, que naturalmente vão ser todos os nossos pequenos patrícios. As páginas

\section{D'O TICO-TICO}

tornar-se-ão, sem duvida, todas as quartas-feiras, o brinquedo indispensável, o desejo ardente de todas as crianças, que pedirão aos pais com o mesmo fervor com que lhes pedem os classicos brinquedos - a boneca, o carrinho, etc. E como

\section{O TICO-TICO}

será um brinquedo que, sobre todas as outras vantagens, terá a de custar apenas 200 réis, é claro que todos os pais às quartasfeiras o levarão a seus filhos.

\section{O TICO-TICO}

será não só o jornal que seu título deixa prever: um jornal leve, saltitante, delicado, jovial, traquinas, um diabrete de asas, em 
summa, como o exige a idade dos leitores a que se destina. As páginas do

\section{O TICO-TICO}

não se descurarão tambem do lado util e moral, procurando, no meio das suas historias de fadas e desenhos travessos, fortalecer e orientar o espirito desses que serão amanhã os grandes homens. De accordo com essa feição

\section{O TICO-TICO}

Começará logo publicando uma história do Brasil com os principais fatos representados por imagens coloridas, abrirá os mais variados concursos interessantes. Nelles haverá o intento prático. Serão concursos de beleza, de robustez, de crescimento, concursos literários, concursos de desenhos, concursos arithmeticos e outros. $\mathrm{Na}$ idade em que o estimulo mais aproveita muito servirão para desenvolver a intelligencia e o espirito de nossos pequenos patricios e de nossas compatriciasinhas esses torneios abertos no

\section{O TICO-TICO}

Conforme o prometido, em 11 de outubro de 1905 O Tico-Tico começou a ser vendida nas ruas ${ }^{29}$ do Rio de Janeiro, sempre às quartas-feiras ${ }^{30}$, ao preço de 200 reis $^{31}$. A escolha do título do impresso infantil é alvo de diferentes versões.

A filha de Luis Bartolomeu de Souza e Silva, e a própria publicação, difundiram que tal denominação era inspirada em um tico-tico que havia pousado no viveiro de pássaros da família localizado no jardim de sua residência. (VERGUEIRO, 2005; AZEVEDO, 2005). “A escolha do nome 'O TicoTico' foi uma homenagem à avezinha do mesmo nome, popularissima entre as crianças, trêfega, alegre, movimentada e sempre simpática" (O TICO-TICO, 10/1949, p.13). Também se considera a possibilidade de $O$ Tico-Tico fazer referência às Escolas de Tico-Tico, instituições de primeiras letras:

Chama-se, pelo tempo, colégio Tico-Tico, ao que só ensina a ler, escrever e contar. Colégio do muito pobre, do que só aprende o que é estritamente necessário para poder vencer na vida, ler e contar até as quatro operações. Nada mais (COSTA, Op.cit., p.129).

\footnotetext{
${ }^{29} \mathrm{~A}$ revista também podia ser adquirida via assinatura no Brasil e no exterior. Os leitores brasileiros que viviam em outros países costumavam enviar fotografias para serem publicadas em O Tico-Tico. SOBRAL, José. O Tico-Tico de Além Mar. In: VERGUEIRO, Waldomiro; SANTOS, Roberto Elísio dos. O Tico-Tico: centenário da primeira revista em quadrinhos do Brasil. São Paulo: Opera Graphica Editora, 2005. p.69 -71. A edição de $O$ Malho, publicada em 26 de maio de 1906, traz a fotografia do menino Flavio Goulart, de apenas 7 anos, e o identifica como o primeiro assinante de O Tico-Tico. OS HEROES D` O TICO-TICO. O Malho, Rio de Janeiro, p.25, 26.mai.1906.

${ }^{30} \mathrm{~A}$ partir da edição de agosto de 1941, a publicação passou a ser publicada mensalmente.

${ }^{31}$ Uma moeda de 200 réis era o que se costumava pagar aos meninos por pequenos serviços como o de entregador. ROSA, Zita de Paula. O Tico-Tico: meio século de ação recreativa de pedagógica. Bragança Paulista: EDUSF,2002. p.25-26.
} 
De acordo com Vasco Lima (Op.cit.), Manoel Bomfim escolheu o título do impresso em virtude da existência deste tipo de instituição escolar.

Desde a concepção de $O$ Tico-Tico, as crianças são identificadas como seus leitores principais. No entanto, a leitura dos exemplares demonstra que seu público também era constituído por jovens e adultos. A revista recebia colaborações e mensagens de cumprimento vindas de adolescentes de até 16 anos (ROSA, Op.cit., p.69). Encontram-se registros de uma gama colaboradores das mais diferentes idades. Em 21 de outubro de 1914 foi publicado o artigo Nosso Anniversario no qual o impresso agradecia as mensagens recebidas por crianças e adolescentes:

Somos immensamente gratos a nossos leitores que saudaram, com carinho, verdadeiramente emocionante, a data do anniversario d'O Tico-Tico. Recebemos de todo o Brazil, mesmos dos Estados mais distantes d'esta capital, saudações effusivas, que nos causaram o mais vivo prazer e que consideramos generosa recompensa a nossos esforços de instruir todas as crianças e adolescentes de nossa terra (p.3).

Também havia mensagens direcionadas aos adultos, em muitos casos, por terem participado, indevidamente, dos concursos promovidos pela publicação. $\mathrm{Na}$ data de 4 de julho de 1906 é publicada na seção Gaiola D`O Tico-Tico uma resposta, pouco cordial, a um leitor que reclama ostensivamente por não ter tido seu texto publicado:

Hans Esel (Rio Grande do Sul) - Em primeiro logar devemoslhe recordar que $O$ Tico-Tico é um jornal especialmente dedicado ás crianças e nessas condições preferimos publicar versos e contos dos nossos pequeninos leitores para acostumalos a escrever. Trabalhos de adultos só quando forem de especial interesse. Francamente, o trabalho de que se trata não é seu, dissel-o. O senhor zangou-se paciência. Quanto a dizer que a nossa edição se vende toda aqui na capital, graças a Deus, tambem não é verdade, temos assignantes e leitores até em Manáos e Goiaz, como se o quiser, poderá verificar em nosso ecriptorio (p.6).

No artigo Cinquentenário de O Tico-Tico, Josué Montello descreve Rui Barbosa, como um leitor assíduo da revista infantil:

Quando seus olhos míopes, cansados de interpretar os grandes tratados de sabedoria universal, buscam um remanso, que pudesse restituir ao homem de gênio a infância distante, lá iam elles pelas páginas de "O Tico-Tico", ao encontro de excellente Chiquinho. E o grave Conselheiro, que tudo sabia e tudo guardava na cabeça assombrosa, desmanchava a gravidade e 
sorria, vivamente interessado nas primeiras histórias em quadrinhos que se fizeram no Rio de Janeiro para a infância de todo o Brasil (1956, p.56).

No decorrer dos mais de 50 anos de circulação, $O$ Tico-Tico instituiu espaços direcionados também aos adultos. Na seção Clínica Médica d'O TicoTico os pais podiam sanar dúvidas sobre doenças infantis. A senhoras podiam saber as novidades da moda em Figurinos para nossas leitoras, Para nossas leitoras entre outros espaços femininos. Os anúncios publicitários também eram direcionados, principalmente, às mães.

No tocante ao formato, o impresso fazia uso, inicialmente, do subtítulo Jornal das Crianças ${ }^{32}$. No entanto, O Tico-Tico se constitui em uma revista ilustrada. Suas páginas são compostas por histórias em quadrinhos, ilustrações coloridas e uma gama de conteúdos divididos múltiplas seções. De 1905 a 1921, identifica-se como suas atrações mais populares:

\section{Tabela 1}

\begin{tabular}{|c|c|}
\hline Seções & Conteúdo \\
\hline A Página do Sr. X & $\begin{array}{l}\text { Espaço destinado a demonstrações de inventos, jogos e } \\
\text { brincadeiras a serem feitos pelos leitores. }\end{array}$ \\
\hline Brinquedos para os dias de chuva & $\begin{array}{l}\text { Os leitores eram apresentados a modelos de brinquedos } \\
\text { de armar e jogos direcionados às meninas e aos } \\
\text { meninos. }\end{array}$ \\
\hline Clínica Médica d'O Tico-Tico & $\begin{array}{l}\text { Tinha o objetivo de solucionar as dúvidas dos adultos } \\
\text { sobre doenças e cuidados médicos. }\end{array}$ \\
\hline Concursos d' O Tico-Tico & $\begin{array}{l}\text { Os leitores eram instigados a responder desafios. Os } \\
\text { vencedores ganhavam prêmios em dinheiro e tinham } \\
\text { seus nomes publicados na revista. }\end{array}$ \\
\hline Contos d'O Tico-Tico & Histórias de cunho moral. \\
\hline Doutor SabeTudo & $\begin{array}{l}\text { A personagem responde aos questionamentos dos } \\
\text { leitores, sobre quaisquer assuntos. O Dr. SabeTudo } \\
\text { publica análises grafológicas das cartas recebidas. } \\
\text { Determinava a personalidade de cada criança. }\end{array}$ \\
\hline Gaiola d'O Tico-Tico & $\begin{array}{l}\text { Publicação de cartas e de colaborações enviadas pelos } \\
\text { leitores. }\end{array}$ \\
\hline Galeria dos Homens Célebres & $\begin{array}{l}\text { Biografias de personagens históricos considerados } \\
\text { importantes no Brasil e no mundo. }\end{array}$ \\
\hline
\end{tabular}

\footnotetext{
${ }^{32}$ Em seguida, a revista adotou o subtítulo Semanário das Crianças. Posteriormente, abandonou o uso deste tipo de recurso e passou a se intitular apenas $O$ Tico-Tico.
} 


\begin{tabular}{|l|l|}
\hline Historia do Brasil em Figuras & $\begin{array}{l}\text { História brasileira no formato de narrativas em } \\
\text { quadrinhos. }\end{array}$ \\
\hline Lições do Vôvô & $\begin{array}{l}\text { Tinha o objetivo de aconselhar e instruir, } \\
\text { principalmente os meninos, sobre temas cívicos, } \\
\text { virtudes morais e conteúdos ligados a geografia, a } \\
\text { história, a matemática e a física. A personagem título } \\
\text { costumava chamar os leitores de meus netinhos. }\end{array}$ \\
\hline Páginas de Armar & $\begin{array}{l}\text { Brinquedos de papel para serem montados pelas } \\
\text { crianças. Os desenhos também podiam ser feitos pelos } \\
\text { leitores e enviados à redação da revista. Caso fossem } \\
\text { aprovados, eram publicados. }\end{array}$ \\
\hline O Tico-Tico Mundano & $\begin{array}{l}\text { Caracterizava-se pela publicação de notícias sobre } \\
\text { batizados, nascimentos, aniversários e outras } \\
\text { amenidade. }\end{array}$ \\
\hline Secção para Meninas & $\begin{array}{l}\text { Dedicada a ensinar as leitoras sobre a importância das } \\
\text { prendas domésticas. }\end{array}$ \\
\hline Sports d'O Tico-Tico & $\begin{array}{l}\text { Publicação dos resultados de competições esportivas } \\
\text { destinadas às crianças. }\end{array}$ \\
\hline
\end{tabular}

Fonte: MERLO, Maria Cristina. O Tico-Tico: A brincadeira por meio da imaginação, conhecimento e entretenimento. In: VERGUEIRO, Waldomiro; SANTOS, Roberto Elísio dos.. O Tico-Tico: centenário da primeira revista em quadrinhos do Brasil. São Paulo: Opera Graphica, 2005.p.81-87.

Além de distribuir os conteúdos por seções, O Tico-Tico também utiliza, como estratégia de diálogo e transmissão de conteúdos (CERTEAU, 1994; CARVALHO, 2005), a presença de personagens divertidos com a função de contribuir para a formação das crianças brasileiras. Incialmente, esta missão foi designada ao menino Chiquinho. Adorado pelas crianças, era uma imagem decalcada do protagonista da história em quadrinhos norte-americana: Buster Brown. A narrativa criada por Richard Felton Outcault, foi publicada pela primeira vez no jornal New York Herald em 4 de maio de $1902^{33}$. Abordava as aventuras e as confusões protagonizadas pelo “(...) garoto branco, loiro, limpo e bem vestido; filho de família burguesa, mas que aprontava poucas (muitas) e boas. Quando punido se arrependia, mas só até a próxima traquinagem" (MORETTI, 2005, p.52).

Nos quadrinhos a seguir é possível observar as semelhanças entre Buster Brown e Chiquinho. O primeiro pertence à narrativa Great Bargain Sale de 1904.

${ }^{33}$ Richard Felton Outcault já era reconhecido pela criação de Mickey Dugan, o Yellow Kid, personagem cujas tirinhas foram publicadas, em 1896 no periódico sensacionalista New York Jornal. As histórias ganharam destaque pelos balões de diálogo que, até a atualidade, ainda se constituem nos principais elementos da linguagem narrativa dos quadrinhos. No ano de 1901, Outcualt lançou, no New York Herald, o título Pore L'ilMose. As histórias são sobre menino negro Mose e sua vida em Nova Iorque. MORETTI, Fernando. Cem anos de Buster Brown... No Brasil: Chiquinho. In: VERGUEIRO, Waldomiro; SANTOS, Roberto Elísio dos. (Org.). Op.cit.,p.52. 
O segundo faz parte de Um dia em apuros publicada em três episódios: 8, 22 e 29 de março de 1911. As narrativas são iguais. A cor das roupas foi alterada, os balões de diálogo foram suprimidos e o formato passou do horizontal para o vertical (Fig. 7) (Fig. 8).

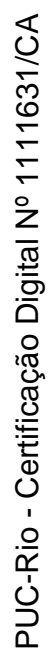
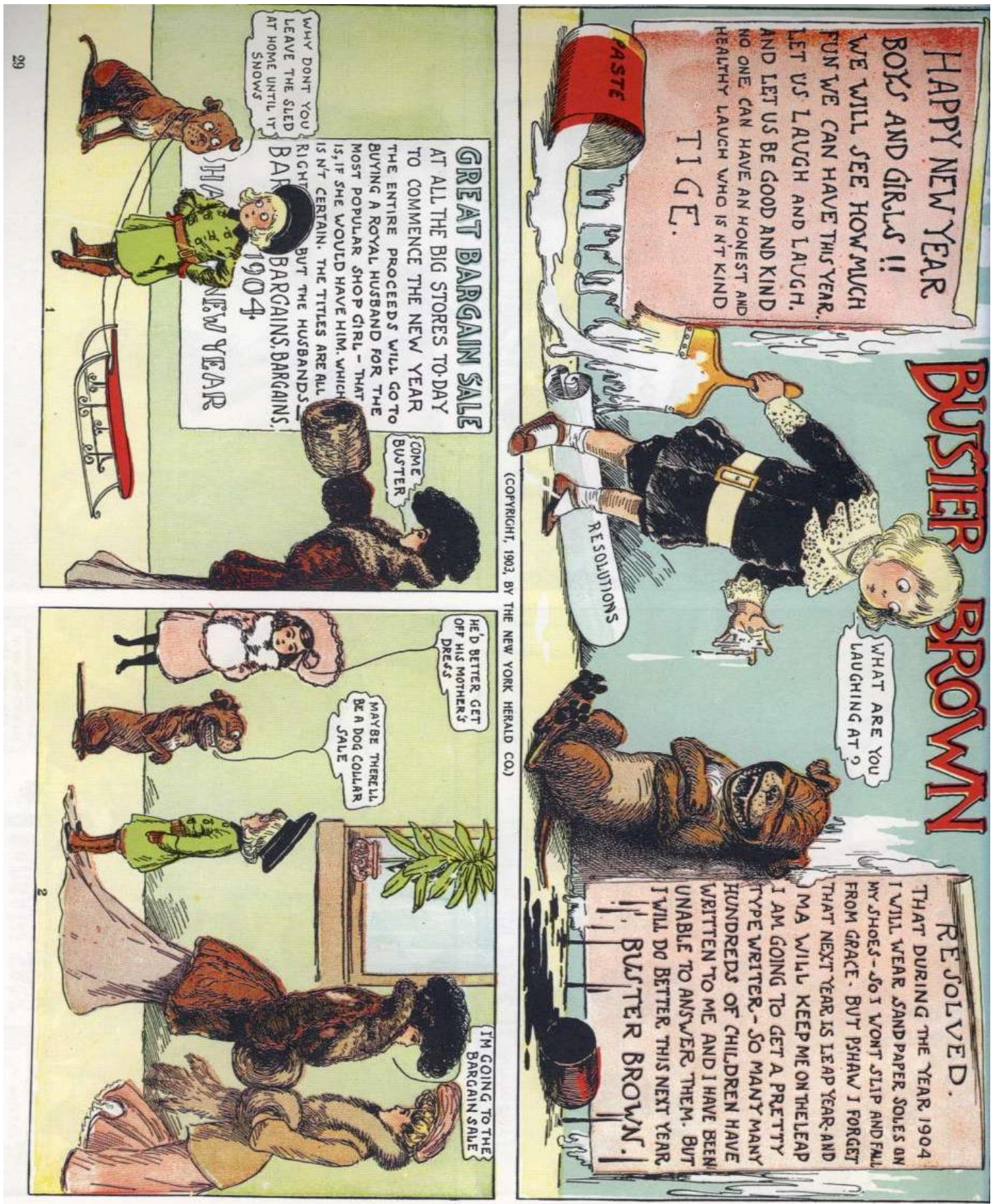

Figura 7 - Buster Brown - 1904 


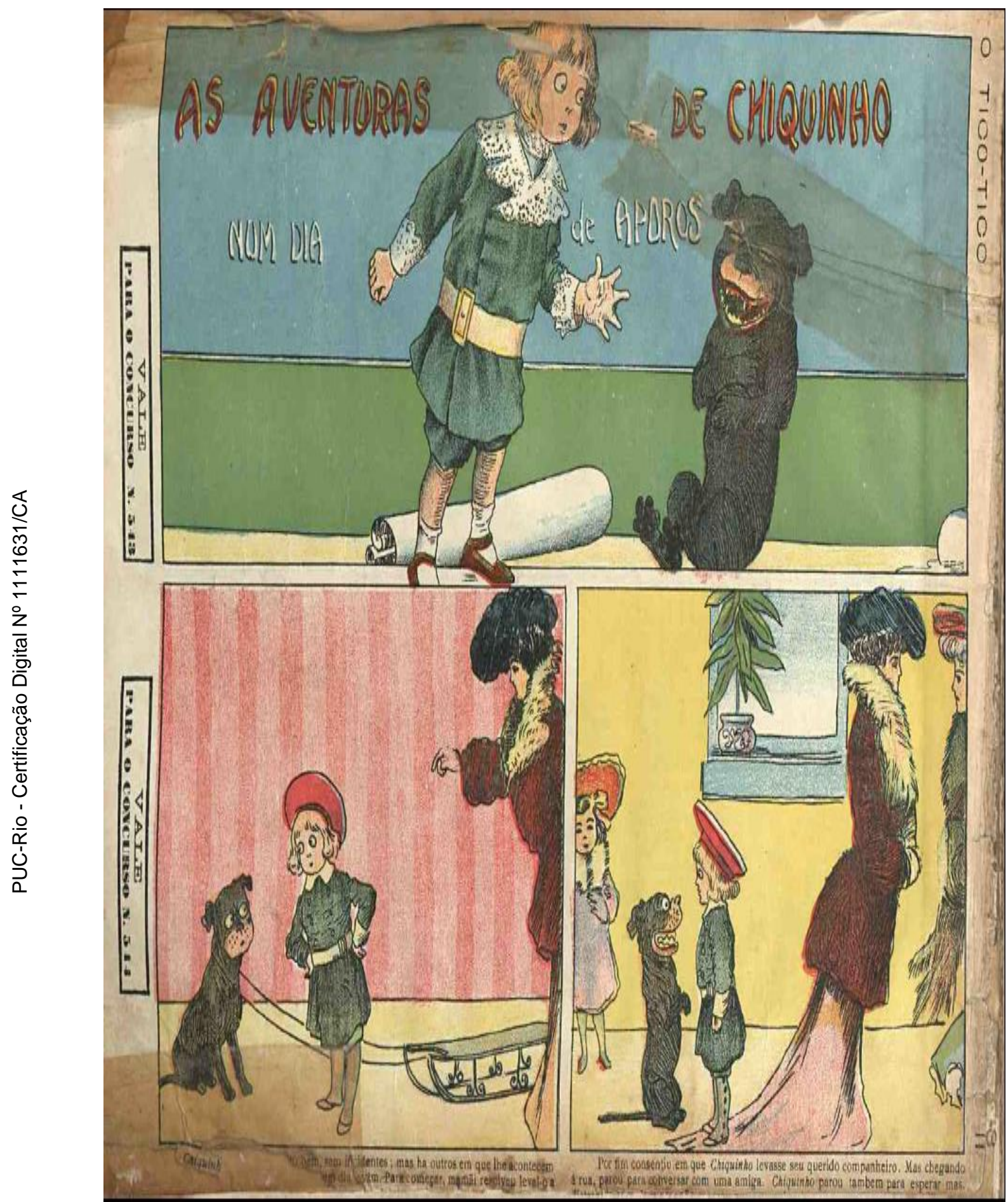

Figura 8 - O Tico-Tico-08/03/1911-p.9 
As características físicas e sociais da personagem estavam em consonância com o discurso defendido por setores das elites brasileiras. Buster Brown foi transformado Chiquinho: um menino branco pertencente a uma família da burguesia carioca do início do século XX. Gilberto Freyre (1956) descreveu seu descontentamento com a escolha de um menino branco para heroi da publicação:

Protestei uma vez contra o fato de Chiquinho - herói maximo
da revista ser um menino louro em vez de brasileiramente
moreno. Mas essa deficiência não impediu nunca "O Tico-
Tico" ser neste vasto Brasil de muitos morenos e de alguns
louros e outros tantos pardos e pretos, bom companheiro dos
meninos de todas as cores, classes e regiões cujos pais fossem
capazes de comprar a revista e no fim do ano seu festivo
almanaque. Vem assim "O Tico-Tico" agindo como elemento
de unificação nacional (p.51).

Em 1915, a personagem Benjamin ganhou as páginas de O Tico-Tico. Criado pelo ilustrador Luis Gomes Loureiro, o garoto negro é um agregado da família de Chiquinho. Torna-se “(...) aliado de Chiquinho, em algumas ocasiões vítima de suas brincadeiras em outras, e até chega a aprontar traquinagens para cima do protagonista" (SANTOS, 2005, p. 92). Nas suas primeiras participações ele não está calçado. Posteriormente passou a ser desenhado com sapatos. Benjamin se tornou popular entre os leitores do impresso infantil.

No tocante ao discurso de Manoel Bomfim, contrário às teorias raciais da superioridade branca, certas narrativas presentes em $O$ Tico-Tico primam pela intolerância. A história Travessuras de Nhônhô, publicada em 10 de novembro de 1909, apresenta esta questão de modo contundente. O casal João e Maria, empregado em uma casa de família, pede licença para visitar o zoológico. Maldosamente, Nhônhô prega nas costas de ambos cartazes chamando-os de macacos. O casal foi alvo de pilherias e humilhações. O menino levou uma surra da mãe quando a mesma soube o acontecido.

Não apenas Chiquinho foi inspirado nos traços das personagens de Outcault. O cachorro Jagunço é idêntico ao buldogue Tige. A ilustração da mãe do protagonista brasileiro é igual à figura materna do garoto norte-americano. A prima Lili é um decalque de Mary Jane, irmã de Buster Brown. Segundo Cagnin (2005), esta era uma prática relativamente comum. O fato da revista ser semanal instituía a necessidade da elaboração de farta quantidade de conteúdos. Para fazer as ilustrações, utilizava-se a técnica da litogravura na qual os moldes dos desenhos eram feitos em pedra. Em virtude da dificuldade de se importar estas matrizes 
litográficas, preferia-se comprar exemplares das publicações estrangeiras e decalcar suas páginas.

Esta situação se modificou após o início da Primeira Guerra Mundial (1914-1918). Com a interrupção da importação deste material, as ilustrações sobre temas nacionais, como o Carnaval e a Festa Junina, ganharam destaque nas em $O$ Tico-Tico. Outro aspecto primordial foi o término da publicação de Buster Brown, na década de 1920. Em virtude deste novo panorama, Chiquinho ganhou histórias inéditas. Luís Gomes Loureiro, responsável pelos decalques de Chiquinho, foi o primeiro a lhe conferir vestimentas mais condizentes à realidade nacional (LUYTEN, 2005). Os outros membros de sua família também tiveram seus traços e vestimentas modificados. No decorrer deste período O Tico-Tico ganhou novas personagens (Fig.9) (Fig.10) (Fig.11) (Fig.12):

\section{Tabela 2}

\begin{tabular}{|c|c|c|c|}
\hline Personagens & Características & Criadores/ilustradores & $\begin{array}{c}\text { Primeiro } \\
\text { registro }\end{array}$ \\
\hline Chiquinho & $\begin{array}{l}\text { Menino travesso } \\
\text { pertencente a classes } \\
\text { mais abastadas da } \\
\text { sociedade carioca. }\end{array}$ & $\begin{array}{c}\text { Luís Gomes Loureiro, } \\
\text { Augusto Rocha, Paulo } \\
\text { Affonso, Alfredo Storni, } \\
\text { Oswaldo Storni e Miguel } \\
\text { Hochmann. }\end{array}$ & 1905 \\
\hline Lili & $\begin{array}{l}\text { Prima de Chiquinho. } \\
\text { Também participava de } \\
\text { suas brincadeiras e } \\
\text { armações. Estava sempre } \\
\text { bem vestida e penteada. }\end{array}$ & $\begin{array}{c}\text { Luís Gomes Loureiro, } \\
\text { Augusto Rocha, Paulo } \\
\text { Affonso, Alfredo Storni, } \\
\text { Oswaldo Storni e Miguel } \\
\text { Hochmann. }\end{array}$ & 1905 \\
\hline Mamãi e Papae & $\begin{array}{l}\text { Pais de Chiquinho e um } \\
\text { casal típico da burguesia } \\
\text { carioca. Sempre } \\
\text { elegantes e bem vestidos, } \\
\text { costumavam perder a } \\
\text { cabeça com as } \\
\text { traquinagens do filho. }\end{array}$ & $\begin{array}{c}\text { Luís Gomes Loureiro, } \\
\text { Augusto Rocha, Paulo } \\
\text { Affonso, Alfredo Storni, } \\
\text { Oswaldo Storni e Miguel } \\
\text { Hochmann. }\end{array}$ & 1905 \\
\hline Benjamin & $\begin{array}{l}\text { Uma das personagens } \\
\text { mais famosas da revista. } \\
\text { Era um garoto negro e } \\
\text { sempre acompanhava } \\
\text { Chiquinho em suas } \\
\text { brincadeiras, mas } \\
\text { também era vítima das } \\
\text { mesmas traquinagens. }\end{array}$ & Luís Gomes Loureiro & 1915 \\
\hline
\end{tabular}




\begin{tabular}{|c|c|c|c|}
\hline Jagunço & $\begin{array}{l}\text { Cachorro de estimação } \\
\text { de Chiquinho. } \\
\text { Costumava participar das } \\
\text { aventuras de seu dono. }\end{array}$ & $\begin{array}{l}\text { Luís Gomes Loureiro, } \\
\text { Augusto Rocha, Paulo } \\
\text { Affonso, Alfredo Storni, } \\
\text { Oswaldo Storni e Miguel } \\
\text { Hochmann. }\end{array}$ & 1905 \\
\hline $\begin{array}{l}\text { Família Zé } \\
\text { Macaco } \\
\text { Zé Macaco, } \\
\text { Faustina, } \\
\text { Baratinha, } \\
\text { Chocolate e } \\
\text { Serrote }\end{array}$ & $\begin{array}{l}\text { Família desastrada que } \\
\text { ambicionava pertencer à } \\
\text { burguesia carioca. Zé } \\
\text { Macaco e Faustina eram } \\
\text { casados. O filho do casal } \\
\text { se chamava Baratinha. } \\
\text { Além disso, vivia com a } \\
\text { família o garoto negro } \\
\text { Chocolate. Tinham como } \\
\text { animal de estimação o } \\
\text { cachorro Serrote. }\end{array}$ & Alfredo Storni & $\begin{array}{c}\text { A } \\
\text { personagem } \\
\text { Zé Macaco } \\
\text { foi criada em } \\
\text { 1908. O } \\
\text { restante de } \\
\text { sua família } \\
\text { passou a ser } \\
\text { parte da } \\
\text { revista a } \\
\text { partir de } \\
1910 .\end{array}$ \\
\hline $\begin{array}{c}\text { Carrapicho e } \\
\text { Jujuba }\end{array}$ & Dupla de pai e filho. & $\begin{array}{c}\text { J. Carlos } \\
\text { (José Carlos de Brito e } \\
\text { Cunha) }\end{array}$ & 1919 \\
\hline Lamparina & $\begin{array}{l}\text { Menina negra e travessa. } \\
\text { Inicialmente apareceu na } \\
\text { série o Grande vôo do } \\
\text { Bhau como figurante. } \\
\text { Apenas na década de } \\
1920 \text { passou a ter uma } \\
\text { história própria. }\end{array}$ & $\begin{array}{c}\text { J. Carlos } \\
\text { (José Carlos de Brito e } \\
\text { Cunha) }\end{array}$ & 1928 \\
\hline Juquinha & Primo de Chiquinho & $\begin{array}{c}\text { J. Carlos } \\
\text { (José Carlos de Brito e } \\
\text { Cunha) }\end{array}$ & 1906 \\
\hline $\begin{array}{l}\text { Kaximbown e } \\
\quad \text { Pipoca }\end{array}$ & $\begin{array}{l}\text { Kaximbown era um grã- } \\
\text { fino que gostava de se } \\
\text { aventurar pelo mundo. } \\
\text { Usava sempre um } \\
\text { cachimbo. Estava sempre } \\
\text { acompanhado de seu } \\
\text { criado Pipoca. }\end{array}$ & Max Yantok & 1911 \\
\hline $\begin{array}{l}\text { Reco-Reco, Bolão } \\
\text { e Azeitona }\end{array}$ & $\begin{array}{l}\text { O menino Bolão pensa } \\
\text { que tem dons artísticos, } \\
\text { mas é alvo de gozações } \\
\text { por parte de seus amigos, } \\
\text { especialmente Azeitona. } \\
\text { As personagens Bolão e } \\
\text { Reco-Reco eram brancos } \\
\text { e Azeitona era negro. }\end{array}$ & $\begin{array}{l}\text { Luiz Sá } \\
\text { I. Galvão de Queiroz Neto }\end{array}$ & 1931 \\
\hline João Garnizé & $\begin{array}{l}\text { Personagem com uma } \\
\text { perna de pau e muito } \\
\text { atrapalhado. }\end{array}$ & $\begin{array}{c}\text { A.Rocha } \\
\text { (Augusto Rocha) }\end{array}$ & 1914 \\
\hline $\begin{array}{c}\text { Tinoco, o caçador } \\
\text { de feras }\end{array}$ & $\begin{array}{l}\text { Personagem mentiroso, } \\
\text { mas de bom coração. }\end{array}$ & $\begin{array}{c}\text { Théo } \\
\text { (Djalma Pires Ferreira) }\end{array}$ & $\begin{array}{c}\text { Década de } \\
1930 \\
\end{array}$ \\
\hline
\end{tabular}

Fonte: SANTOS, Roberto Elísio dos. Artistas e personagens de destaque da revista O Tico-Tico. In: VERGUEIRO, Waldomiro; O Tico-Tico: Centenário da primeira revista em quadrinhos do Brasil. São Paulo: Opera Graphica, 2005.p.89-95. 


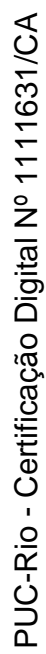

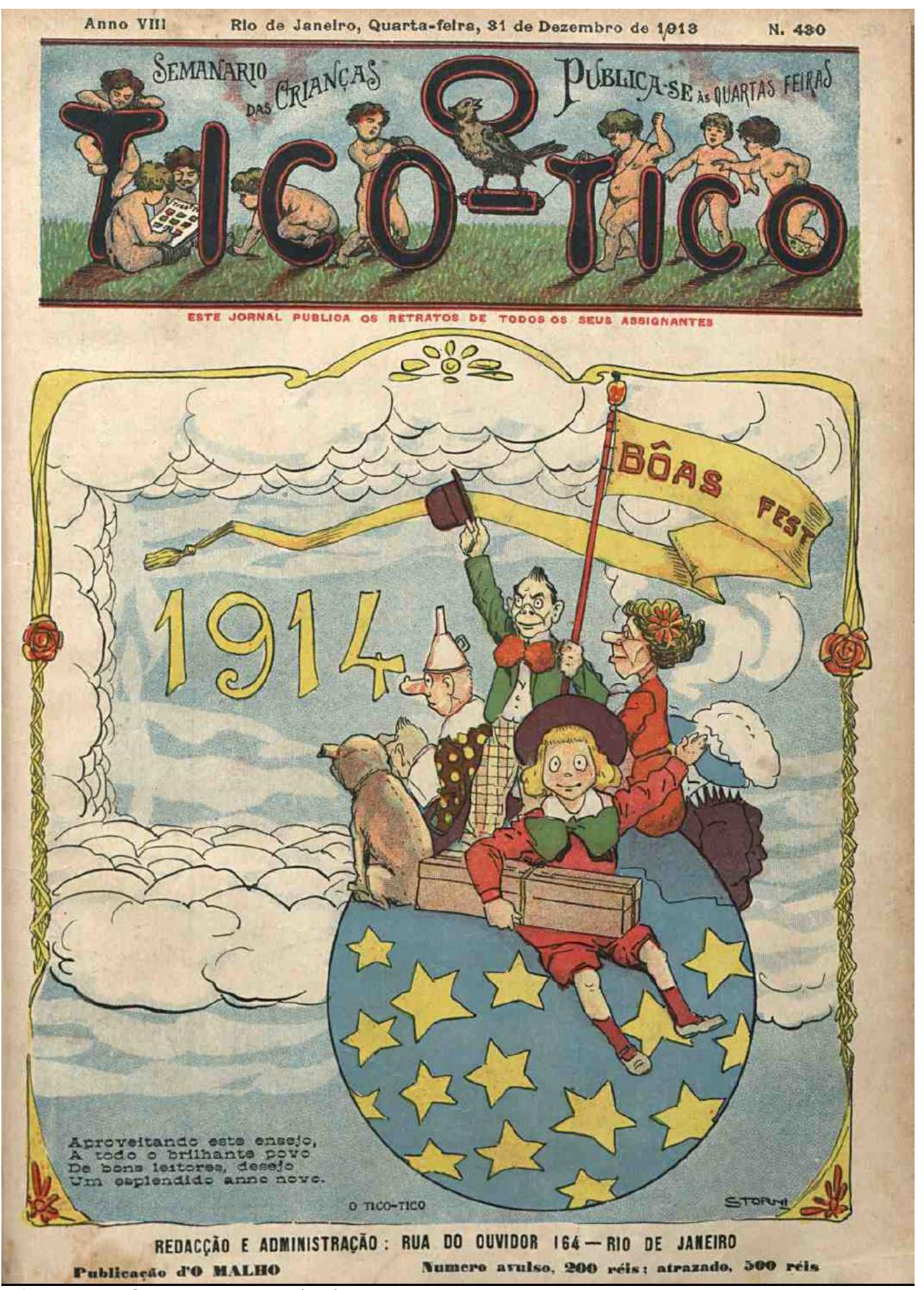

Figura 9 - O Tico-Tico - 31/12/1913-p.1 
FISTOEIA DO EIRASII EMI IIGUIAS

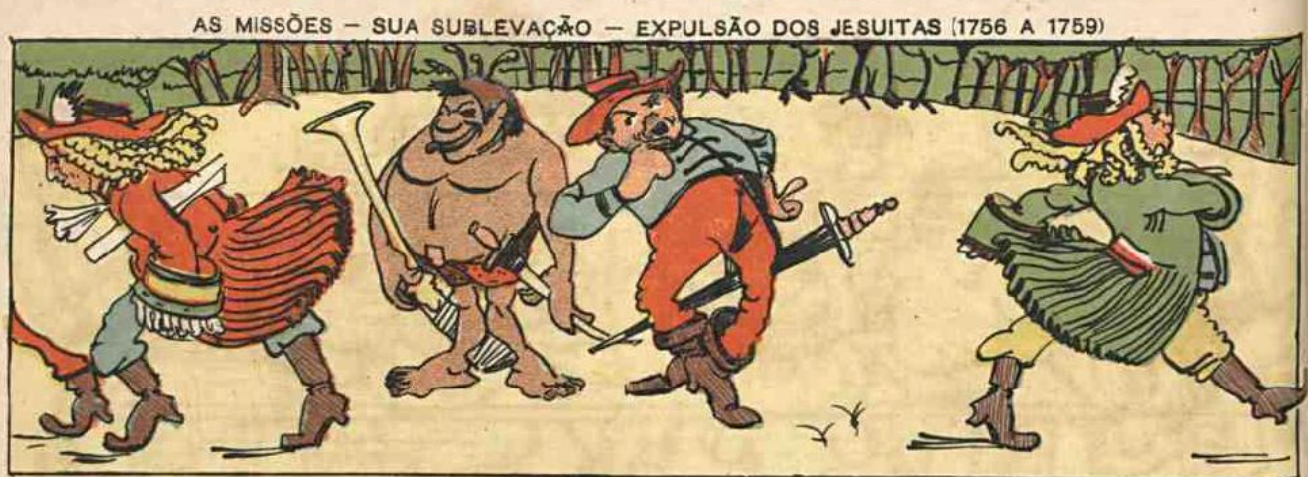

O Conde de Bobadella e o de Valdelirios vendo claramente que os indios falavam grosso porque por detraz da cortina estavam os jesuitas, acharam mais acertado celebrar um armisticio com o alferes Sépe, que se mostrava ameaçador, so sacudindo o espadagao. dante de ordens, um indio, bonito mesmo de tao feio, ficaram escarnecendo dos dois e como que dizendo :-Vao pela sombra, seus araras seus con des de meia tijella 1 E se quizerem voltem, seus bocós ?

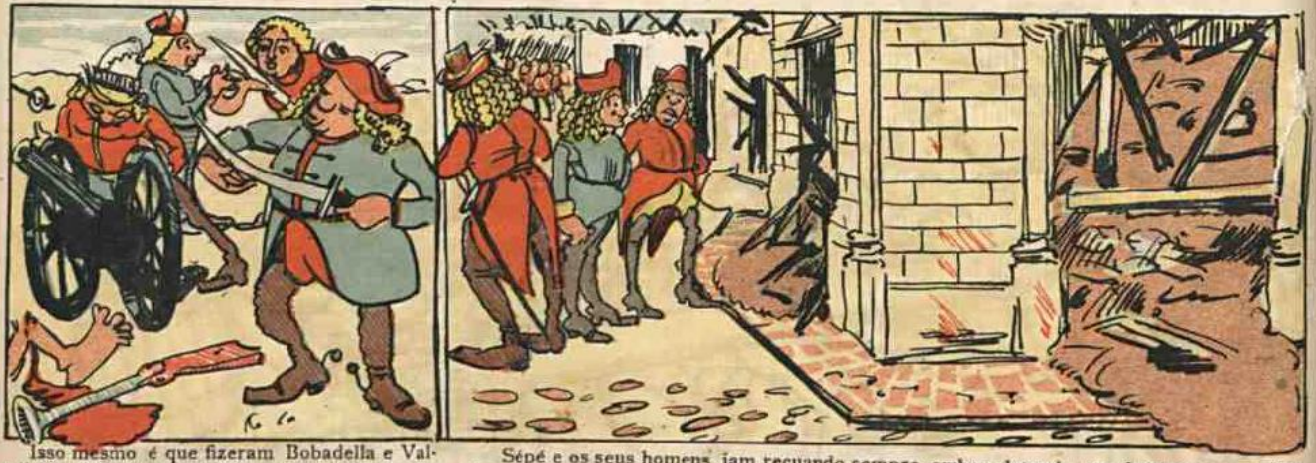

Isso mestho ef que fizeram Bobadella e Val.

Sépé e os seus homens, iam recuando sempre, embora lutando com delirios, logo que receberam um reforço de tro. do no dia I6 de Maio as tropas portuguezas e hespanholas entraram na povoacao de Suan. Mi e venceram-nos, $\mathrm{em}$ a batalhas e varios comba. annexos tinham sido incendiados pelos espectaculo que viam. A igreja e todos os edificios tes. Mas os indios deram bem que fazer e entre que nao podiam conservar as Missóes, haviam.se raspados quaes, convencendo-se afinal de os seus despojos Bobadella e Valdelirios encon. outra margem do rio Uruguay, depois de reduzirem a cinzas todas as obras haveres para que provava estarem elles armedos comocas;

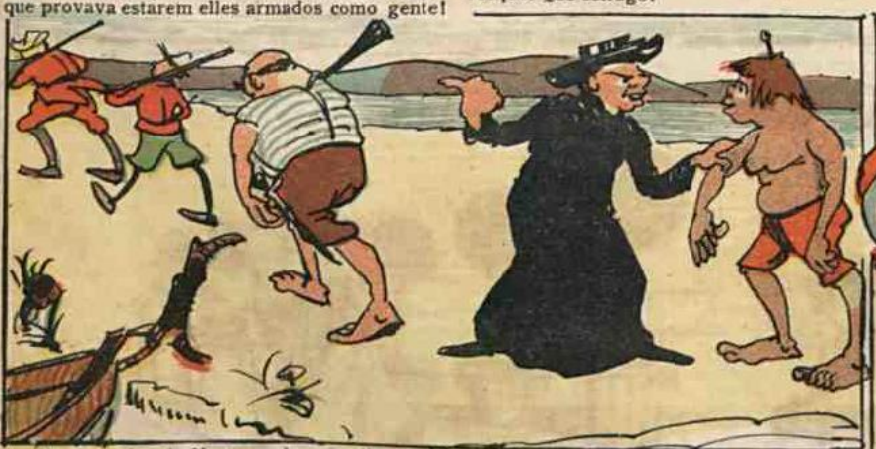

Na fronteira do Norte, onde procedia á demarcaço de limites o capitao general do Maranhao e Para Francisco Xavier de Mendonça Furtado, nio foi menos tenaz a resistencia vam impedil 0 , ora sublevando os indios dos ingares visinhos, ora instigando os remadores. es guias das canous de Mendonça Furtado a resistirem. - Nao sejam tolos, diziam elles aos pobres indios. Em nos $f$ Por ali $E$ o caminho

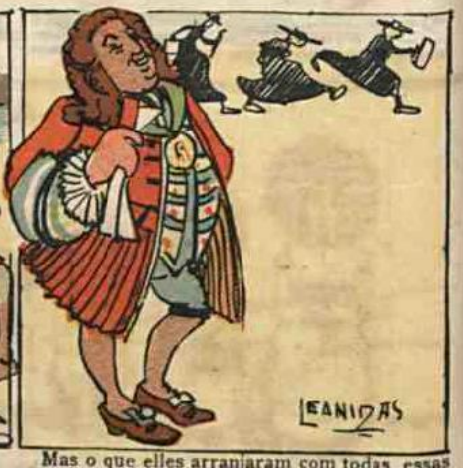

Mas o que elles arranjaram com todas essas 1759, em que el-rei D. Jose mandou que todos os jesuitas fossem puxando a trouxa p'ra fóra de Prazeral e dos seus dominios. 1950 com grande vrar esse decreto e so descancou quando viü os uhimos jesuitas pelas costas !

Figura $10-O$ Tico-Tico $-16 / 05 / 1906-\mathrm{s} / \mathrm{p}$. 


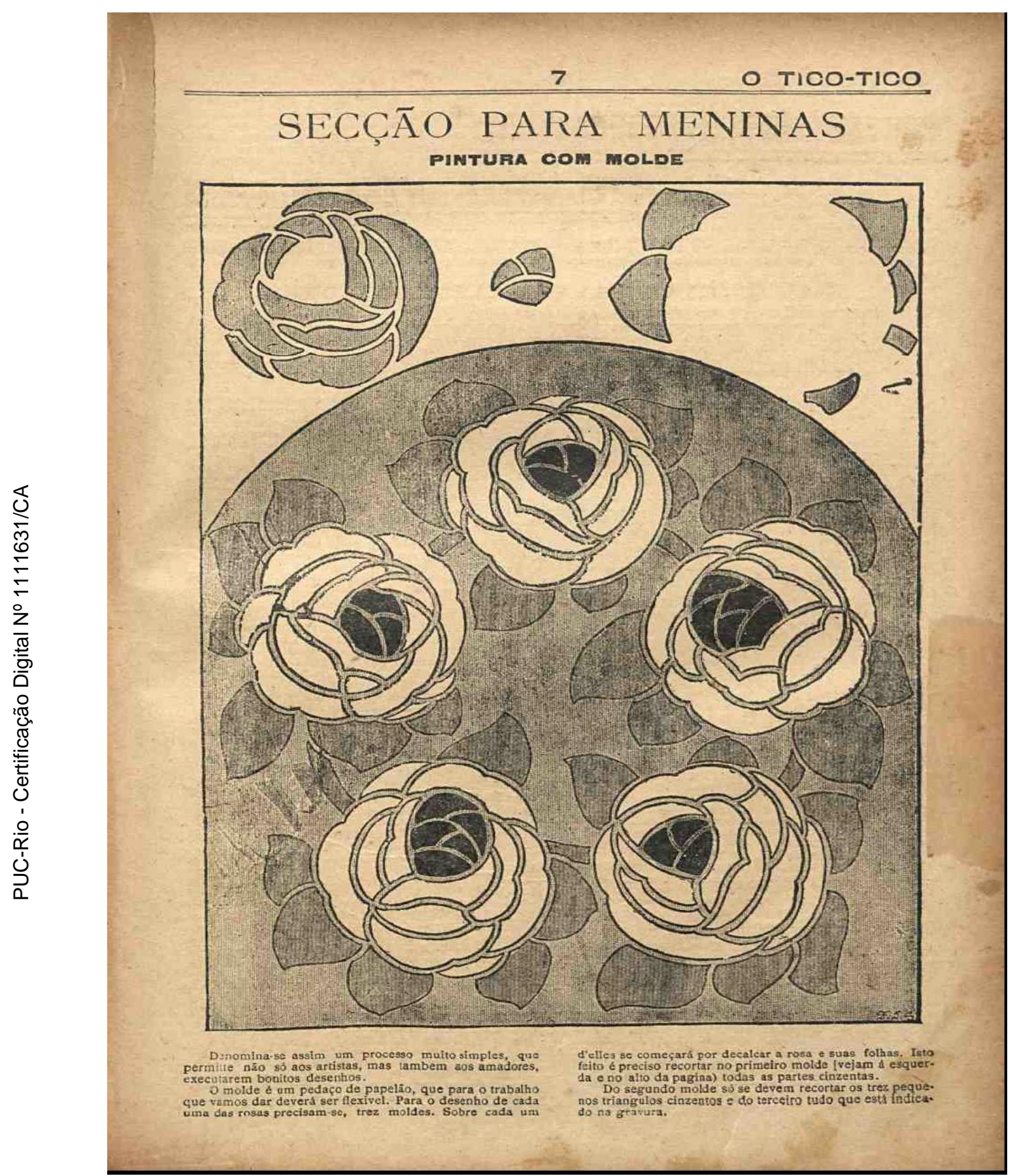

Figura 11 - O Tico-Tico-27/03/1912 - p6. 


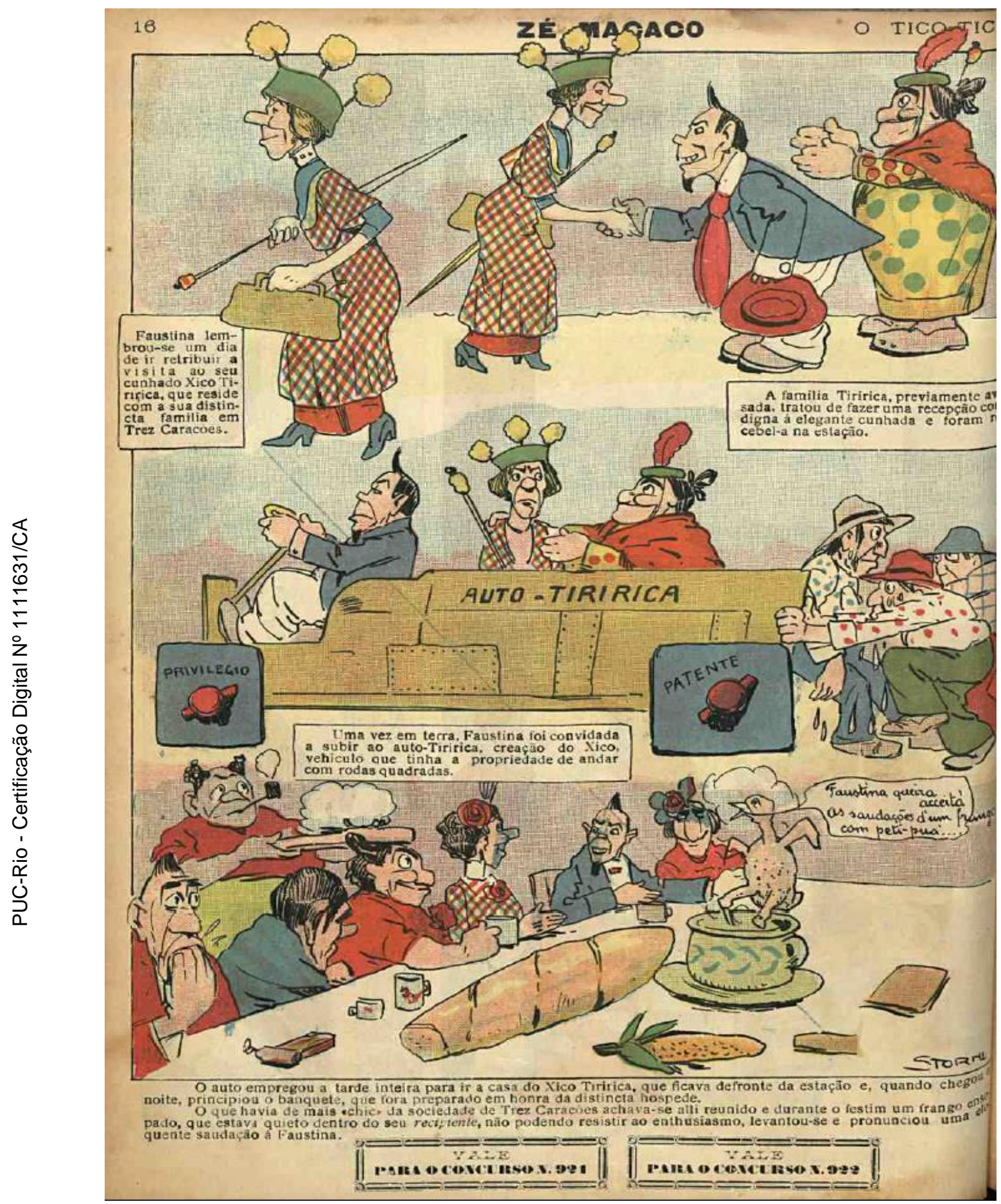

Figura 12- O Tico-Tico - 22/10/1914-p.18 
É preciso observar que a revista ilustrada, modelo jornalístico no qual $O$ Tico-Tico estava inserido, foi alçada à categoria de meio difusor dos ideais de republicanos de modernidade: "idéias de liberdade, progresso, ciência, democracia, termos que apontavam, todos, para um futuro desejado" (MELLO, 2009, p.16). A imprensa se caracterizou como o principal meio de circulação do discurso de regeneração social defendido pelas elites brasileiras entre os anos finais do século XIX e início do século XX (BARBOSA, 2011).

A prática republicana de utilizar impressos para a circulação de determinado ideário de nação e sociedade não foi pioneira. O Império fez uso da literatura e dos jornais para legitimar a concepção de oficial de identidade nacional. Os escritores românticos - José de Alencar, Domingos Gonçalves de Magalhães e Gonçalves Dias - foram alguns dos autores que ajudaram a consolidar narrativas e figuras históricas durante a Monarquia ${ }^{34}$.

O folhetim se destaca como um dos principais espaços de atuação dos homens de letras do Império (SODRÉ, 1999). Na Europa, este tipo de leitura se propagou a partir da década de 1830 no âmbito das transformações ocasionadas pela Revolução Industrial. ${ }^{35}$ No Brasil, tornou-se efetivamente popular anos 1850 com a publicação de obras como $O$ Guarani (1857) de José Alencar, um dos grandes sucessos da época ${ }^{36}$. Sodré (Ibidem) e Oliveira (2011) afirmam que o folhetim se caracteriza como uma literatura feminina ${ }^{37}$. Esta modalidade de impresso estabeleceu novas práticas de leitura ao instituir a narrativa fragmentada, dividida em capítulos, e capaz de despertar em seus leitores a sensação do suspense e a curiosidade sobre o que estará por vir. (MARTIN-BARBERO, 2003). No século XIX, também já existiam publicações ilustradas: O Fígaro: folha illustrada, a Revista Illustrada e a Semana Illustrada. Esta última se destacou por ter instituído, no século XIX, o formato padrão para tal modelo de

${ }^{34}$ Cf.: BOSI, Alfredo. Cultura. In: CARVALHO, J.M..; et.al.(Coord.). A construção nacional: 1830-1889. Rio de Janeiro: Objetiva, 2012. p.225-279.

${ }^{35}$ Grandes cidades como Londres e Paris passaram a ser ocupadas pelo trabalho do proletariado. O trabalho nas fábricas instituiu uma nova concepção de tempo, vinculada, simbolicamente, ao relógio e à linha de produção. MARTÍN-BARBERO, Jesús.. Dos meios as mediações: comunicação, cultura e hegemonia. 2. ed. Rio de Janeiro: Editora UFRJ, 2003.p.192-193.

${ }^{36}$ Incialmente, o folhetim remetia parte inferior das páginas do jornal. Era um espaço destinado a publicação de notícias consideradas mais amenas como críticas literárias, resenhas de peças, receitas culinárias e resultados das corridas de cavalos. Ibidem., p.183.

${ }^{37} \mathrm{O}$ primeiro registro de um folhetim, na imprensa brasileira, foi no impresso O Beija-Flor: Annaes brasileiros de sciencia, politica, litteratura..,etc... COSTA, Carlos.. A Revista no Brasil do século XIX: a história da formação das publicações, do leitor e da identidade do brasileiro. São Paulo: Alameda, 2012.p.127-134. 
publicação “(...) as páginas 1, 4,5 e 8 são ilustradas com litografia e as 2-3 e 6-7 são de texto impresso em tipografia" (COSTA, 2012., p.167). Suas páginas continham desenhos, caricaturas e histórias em quadrinhos. No entanto, eram produzidas em modo artesanal e não tinham acesso a páginas colorias e a inserção de fotografias.

No início do século $\mathrm{XX}$, a revista ilustrada se constituiu no veículo jornalístico alinhado a um novo modelo de imprensa. Tornou-se o símbolo do novo jornalismo brasileiro caracterizado por novas técnicas de edição e impressão que possibilitaram o barateamento e a ampliação da produção de jornais e revistas (SEVCENKO, Op.cit.).

O acabamento mais apurado e o tratamento literário simples da matéria tendem a tornar obrigatório o seu consumo cotidiano pelas camadas alfabetizadas da cidade. Esse "novo jornalismo", de par com as revistas mundanas, intensamente ilustradas e que são o seu produto mais refinado, tornam-se mesmo a coqueluche da nova burguesia urbana, significando o seu consumo, sob todas as formas, um sinal de bom-tom sob a atmosfera da Regeneração. Cria-se assim uma "opinião pública urbana, sequiosa do juízo e da orientação dos homens de letras que preenchiam as redações (p.119).

As identidades forjadas nas obras dos escritores românticos foram paulatinamente substituídas pelos textos jornalísticos publicados nas revistas ilustradas.

Segundo Sodré (Op.cit.) e Luca (2008), os impressos produzidos em pequenas tipografias perderam espaço para as empresas jornalísticas. A inserção das "Máquinas modernas de composição mecânica, clichês de zinco, rotativas cada vez mais velozes" permitiram às publicações utilizarem ilustrações coloridas e fotografias. Além de aumentar e tornar mais rápida a impressão dos exemplares (Ibidem., p.1). Para Martins (2008) e Chartier (1998), a profissionalização gerou demanda por funções especializadas: redatores, ilustradores, editores, revisores. Como também criou novos modelos de distribuição e de gerenciamento. Instituiu uma espécie de cadeia produtiva para a publicação de livros, jornais e revistas (p.77). O Tico-Tico tinha uma estrutura jornalística formada por redatores, ilustradores e colaboradores: Alfredo Storni, Angelo Agostini, A. Rocha, J. Carlos, Carlos Manhães, Cícero Valadares, Euricles de Mattos, Eustorgio Wanderley, Leônidas, Lobão, Luis Gomes Loureiro, Luis Sá, Max Yantok, Miguel Hochman, Vasco Lima e outros. 
As revistas eram consumidas pelas camadas alfabetizadas da população, um grupo restrito e pertencente, em sua maioria, às elites brasileiras. Retratam as mudanças socioculturais voltadas à "homogeneização das consciências pelo padrão burguês universal da Belle Époque (...)" (SEVCENKO, Op.cit., p.123). Como observam Diogo (2005) e Velloso (2010), é através de suas páginas que os leitores conheceram novas linguagens e vivenciaram o ritmo da modernidade:

Como veículos de informação, as revistas intervinham no cotidiano da cidade, atuando como porta-voz da atualidade ao mesmo tempo em que criavam elos indenitários com os leitores. Podemos pensar que as revistas cariocas da virada dos séculos XIX para o século XX constituíam, em seus textos, um peculiar arquivo da cidade do Rio de Janeiro, auxiliando na projeção das imagens que vão compor uma cidade ideal a ser projetada para os leitores (DIOGO, Op.cit. p.464).

Capas atraentes, imagens inusitadas, diagramação elegante e moderna, cores, qualidade do papel, enfim, todos esses fatores acabaram se constituindo em poderosos atrativos que cativaram definitivamente os leitores. Inaugurando uma nova linguagem jornalística, as revistas apresentam uma estética moderna, apoiada no recorte, na colagem, no fragmento, justapondo fotografias a poemas, crônicas e comentários na apresentação da modernidade carioca. Numa conjuntura em que se impunha, inicialmente, a valorização de "ser moderno", seguida da "ser brasileiro", as revistas souberam cativar, conquistar o leitor, fazendo-o sentir-se identificado com esse universo de valores simbólicos (OLIVEIRA; VELLOSO; LINS, 2010, p.42).

De acordo com Velloso (Op.cit.), as revistas ilustradas se tornaram populares por atuar junto aos cinco sentidos dos seus leitores:

De forma vibrante e divertida, as revistas comunicam o que é ser moderno: como proceder, reagir, pensar e sentir situando os leitores na correnteza viva dos acontecimentos e na vida mental da cidade (p.81)

Como o calendário (LE GOFF, 2003), estes impressos instituíram uma concepção de tempo socialmente construída e convertida em ferramenta de poder (DIOGO, Op.cit.).

Com formato tabloide, $23 \times 32,5 \mathrm{~cm}$ (CARDOSO, Op.cit.), a tiragem inaugural de $O$ Tico-Tico alcançou os 10 mil exemplares. Em razão do sucesso de vendas, a Sociedade Anonyma Malho imprimiu uma segunda leva de 30 mil revistas (AZEVEDO, 2005). Em comunicado publicado na revista $O$ Malho de 25 de novembro de 1905 é feita referência ao processo de reimpressão do exemplar inaugural do impresso infantil: 


\section{"O TICO-TICO"}

Acha-se prompto e á venda em nosso escriptorio, á rua do Ouvidor, n.132, o primeiro numero d' $O$ Tico-Tico que mandamos reeditar. Por não tinham sido guardados nem os desenhos, nem as pedras lithographicas, essa reedição foi demorada e nos ficou muitissimo cara, visto que, para não perturbar os nossos outros serviços, toda ella teve que ser feita durante a noite. Por esse motivo só podemos vender essa reedição do primeiro número d $O$ Tico-Tico a $1 \$ 000$ o exemplar (p.5).

O aprimoramento técnico permitiu à revista, inicialmente com 16 páginas, alcançar a quantidade de 32 folhas. Como também a fotografia ${ }^{38}$ permitiu outro tipo de aproximação com os leitores. Na edição de 2 de janeiro de 1907 a novidade foi apresentada aos leitores:

Uma Grande Novidade!

Os retratos dos nossos leitores

O TICO-TICO COM PHOTOGRAVURAS

Communicamos aos gentis amiguinhos que, á vista do êxito obtido pelo Almanach d'O Tico-Tico, especialmente com relação a retratos, resolvemos fazer neste jornal um importante melhoramento. Como se vê por este numero e pelo ultimo publicado, foi tal a quantidade de retratos recebidos por esta redacção, apesar do curto espaço de tempo concedido, que não conseguimos publical-os todos no Almanach d'O Tico-Tico e assim vimo-nos forçados a incluir neste numero um supplemento especial, conforme fizemos numero passado. E', pois evidente que agradou muito a idéa da publicação de retratos. Desde que isso agrade, é nosso dever satisfazer as preferencias dos leitores, e como é pouco para isso o Almanach, que só sai no fim do anno, resolvemos publicar tambem retratos n'O Tico-Tico. Para isso é preciso que $O$ Tico-Tico tenha uma seção de photogravura: porém, um jornal como o nosso, não conhece difficuldades quando se trata de executar os desejos de seus leitores. Daremos, portanto, este anno, constantes supplementos de photogravura que nelles publicar retratos. Assim, fiquem sabendo os nossos amigos que, de ora em deante, $O$ Tico-Tico. Publicará os retratos de todos os seus assignantes (s/p).

A revista passou a estampar em sua capa a seguinte mensagem: Este jornal publica os retratos de todos os seus assignantes. Depois, a frase foi modificada:

${ }^{38}$ A Revista da Semana foi pioneira no uso da fotografia. A publicação criada por Álvaro de Tefé entrou em circulação, em 20 de maio de 1900, como suplemento ilustrado do Jornal do Brasil. Todo o equipamento fotográfico foi trazido da França. Em 1915, o impresso foi vendido e passou a ser vendido individualmente até a década de 1950, quando saiu de circulação. SODRÈ, Op.cit., p.274 - 297. 
Este jornal publica retratos de todos os seus amiguinhos ${ }^{39}$ (Fig.13). Foram criados espaços específicos para a divulgação das fotos de leitores e leitoras. A imagem fotográfica também pode ser entendida como outro meio de circulação dos princípios republicanos de civilidade.

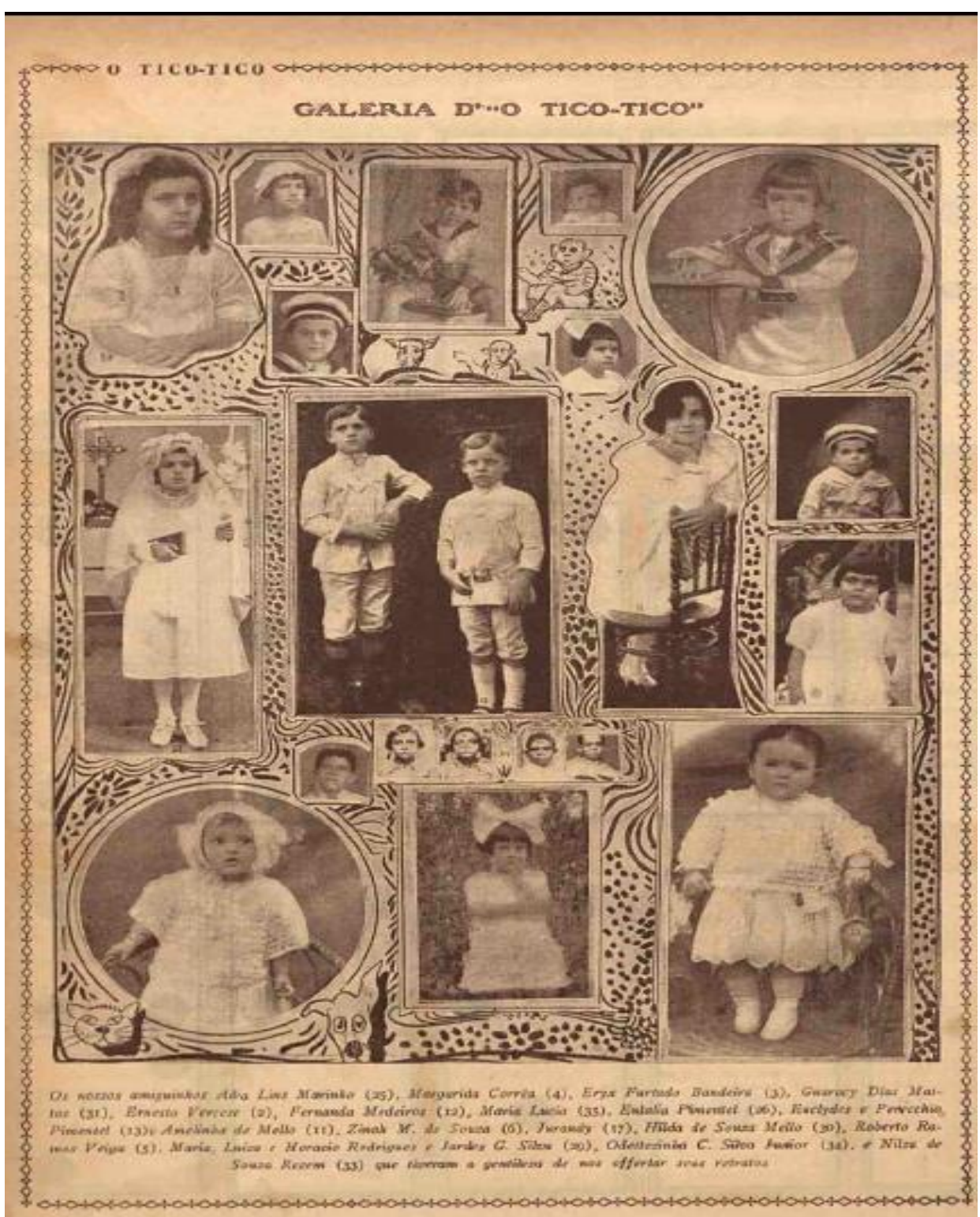

Figura 13 - O Tico-Tico - 31/03/1920 - s/p

${ }^{39}$ A fotografia como recurso jornalístico foi tema da seção $\mathrm{Sr}$. X e a sua página. Denominada Como se illustra um jornal pela photographia, explica aos pequenos leitores sobre como são inseridos, os materiais fotográficos nas páginas do impresso infantil. O Tico-Tico - 18/09/1912. p.17-18. 
No início do século $\mathrm{XX}$ as fotografias eram consideradas registros verídicos da realidade. Embora na prática os estatutos das imagens fotográficas a definam, na atualidade, como um fragmento da realidade, um instante construído. Naquele período não se faziam reflexões sobre os contextos ou os elementos não presentes na imagem. Eram considerados válidos, apenas, os momentos aprendidos pela máquina. Ao mesmo tempo, as fotografias passam a ser caracterizadas como elementos constitutivos da memória (KOSSOY, 2001).

Os retratos publicados em $O$ Tico-Tico mostram crianças em trajes de festa e em poses delicadas. As legendas exaltam a representação ideal de infância. As pequenas e os pequenos leitores são elogiados por sua beleza, inteligência e meiguice. Registra-se que as crianças são não retratadas sorrindo. Suas feições são sérias, mesmo quando estão ao lado de um brinquedo ou dos amigos. Evidenciase uma forma moderna de se instruir e construir uma memória sobre o público da revista. A modernidade dos impressos ilustrados coincidia com uma nova concepção de cidadão. As imagens das elegantes senhoras passeando junto aos filhos, também bem vestidos, constituíam-se em ferramentas de ensino e aprendizagem. O mesmo ocorria em O Tico-Tico.

Percebe-se que a publicação infantil estava em consonância com um panorama marcado por mudanças no âmbito da imprensa, mas também de transformações políticas e socioculturais.

\subsection{As ilustradas primeiras décadas republicanas ilustradas}

Os anos finais do século XIX e do início do século XX, coincidentes ao período lançamento da revista $O$ Tico-Tico, constituíram-se em um período marcado pela ocorrência de eventos como a Abolição da Escravatura (1888) e a Proclamação da República (1889) cujas consequências tiveram reflexos expressivos na sociedade brasileira.

Camara (2010) salienta que o advento do novo regime político inseriu junto às elites econômica e intelectual discursos e ações voltadas à instituição de uma nova ordem social. Compartilhavam da representação de que o Império foi um tempo marcado pelo atraso socioeconômico, exclusão política e analfabetismo. De forma contrária, o 15 de novembro foi inicialmente descrito 
como um marco da inserção do país no caminho da ordem e do progresso. A República significava uma ruptura com o passado:

(...) a correção necessária dos vícios do poder: os abusos do Poder Pessoal, vitaliciedade do Senado, centralização excessiva, fraude eleitoral que possibilitava ao governo vencer sempre as eleições, etc (COSTA, 1999, p.323).

Constata-se tal perspectiva em trecho de artigo publicado na Revista Ilustrada para festejar a mudança de regime político e a esperança em uma nova nação:

A monarchia em vez de se encorporar á marcha triumphal de um povo quis detel-a, e confiou a homens audazes a missão de nos fazer retroceder aos tempos idos da escravidão das almas e dos supplicios dos corpos. Uma grande maré de civismo avolumou-se do seio das classes mais patrioticas, rodeou o velho throno e, de onda em onda, de crista em crista, cuspiu-o nas plagas da Europa, d'onde nos viera, libertando a America da única testa coroada, que servia de dique á realisação de sua unidade republicana. [...] Hoje, os Estados Unidos do Brazil, teem no seu pavilhão as 21 estrellas, representando os seus Estados, que, todos, se mostram contentes e orgulhosos do que se fez, desassombrando o nosso futuro e abrindo ao povo o caminho de todas as conquistas do progresso (REVISTA ILLUSTRADA, 07/12/1889, p.2).

Embora grupos distintos disputassem a primazia do projeto republicano brasileiro, eles tinham em comum a busca pelo novo. Configurou-se um processo de construção de uma nova memória nacional. A figura envelhecida de D. Pedro II, amplamente difundida nas páginas da mesma publicação, foi substituída por símbolos nacionais como a bandeira, o hino, os heróis e as datas cívicas (Fig.13). Oliveira (1989) faz referência ao Decreto 155-B, de 14 de janeiro de 1890, que instituiu as datas comemorativas da República. Entre os exemplos estavam a decretação do dia de Tiradentes, em 21 de abril, e o fato de o 13 de maio não fazer menção à figura da Princesa Isabel. Como descreve Carvalho (2009) "A luta pelo mito de origem, pela figura do herói, pela alegoria feminina, era parte importante da legitimação do novo regime (...)" (p.109). Compreendia-se que a aceitação da República não estava circunscrita a uma nova Constituição (1891), era preciso promover a "formação das almas" dos brasileiros (Ibidem).

Anderson (2008, p.12) descreve a nação como uma "comunidade politica imaginada" em virtude de seus habitantes, mesmo não partilhando de relações cotidianas ou de quaisquer contatos interpessoais, identificarem-se por meio de 
uma identidade nacional em comum. Por esta razão, os republicanos buscavam conceber uma nova identidade nacional que estivesse em consonância à visão de nação calcada no discurso da modernidade e da civilização.

É plausível assegurar, então, que a identidade nacional configurou-se como elemento essencial na costura que se estabeleceu entre a ideia de um destino comum a ser comungado por todos os indivíduos, identificados com ele, e a visão perspectivada de um futuro a ser construído. Entre o passado com suas tradições, rituais, valores e normas, e o futuro glorioso e moderno, construíram-se os sentidos para as identidades ideais (CAMARA, Op.cit.,p.121).

O conceito de moderno é polissêmico e controverso. Segundo Velloso (Op.cit.), ele pode ser definido como "um processo que começa a ser gestado na sociedade brasileira na virada do século XIX para o século XX” (p.32). Vinculado ao avanço técnico-científico, ao processo de industrialização e ao crescimento urbano, também engloba questões para além da materialidade, por exemplo: as relações espaço-tempo. Tinha-se uma sensação de aceleração temporal, na qual as locomotivas diminuíam as distâncias, o telégrafo aproximava as comunicações e o cinema criava a narrativa em movimento ${ }^{40}$.

${ }^{40}$ A primeira apresentação de imagens em movimento no Rio de Janeiro ocorreu, em 8 de julho de 1896, pouco mais de um ano após os irmãos franceses, Auguste e Louis Lumière, terem projetado, na data de 22 de março de 1895, o filme A Saída da Fábrica Lumière à Lyon. SEVCENKO, Nicolau. In: (Org.). História da Vida privada no Brasil - República: da Belle Époque à Era do Rádio. v.3. São Paulo: Companhia das Letras, 2006.p.518. 


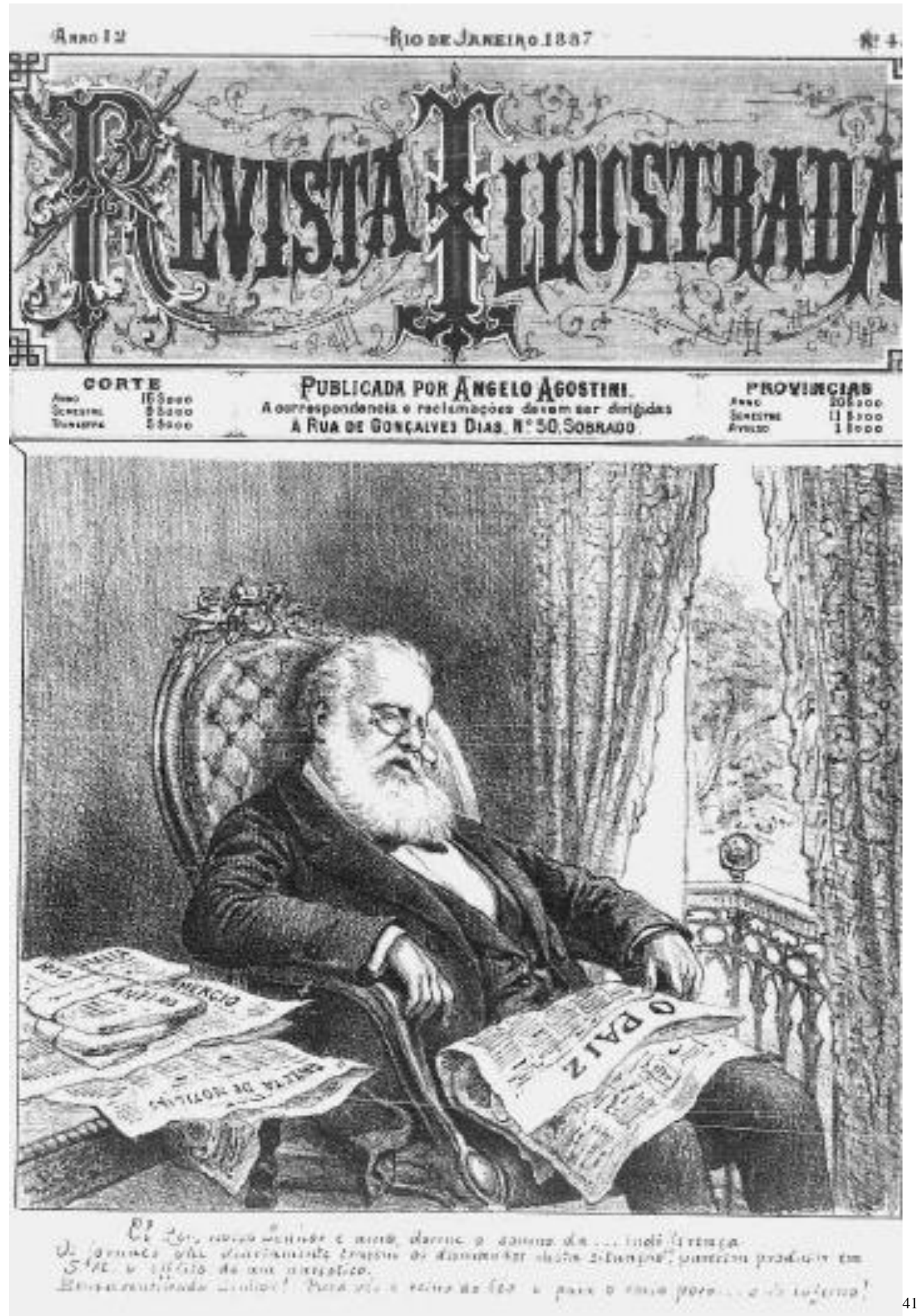

Figura 14 - Revista llustrada - 05/02/1887- p.1

\footnotetext{
${ }^{41}$ Legenda: El Rey, nosso senhor e amo, dorme o sonnoda...indifferença. Os jornaes, que diariamente trazem os desmandos desta situação, parecem produzir em S.M. o efeito de um narcotico. Bem aventurado senhor! Para vós o reino do céo e para o nosso povo... o do inferno!
} 
No Brasil, a área central do Rio de Janeiro passava por importantes mudanças. Apelidada de Bota-Abaixo, a reforma liderada pelo Prefeito Pereira Passos (1902-1906) inebriou a Capital da República com um ar cosmopolita. As ruas estreitas e a arquitetura colonial deram lugar a edifícios e a vias largas e arborizadas como a Avenida Central (1904). As pessoas passaram a circular de bonde elétrico. A cultura erudita ganhou um espaço de excelência com a inauguração do Teatro Municipal (1909). A cidade festejava sua modernidade na Exposição Nacional (1908) em homenagem ao centenário da Abertura dos Portos. O Rio civiliza-se e relegava ao passado as memórias da Cidade Febril (CHALHOUB, 1996) com seus cortiços e as epidemias de febre amarela ${ }^{42}$.

O símbolo máximo da Regeneração, porém, ficou sendo o eixo fundamental do projeto de reurbanização, a avenida Central. Inspirada no planejamento dos bulevares parisienses, conforme o projeto dos amplos corredores comerciais do barão de Haussman, prefeito plenipotenciário de Paris sob o Império de Napoleão III, A Avenida introduziria na capital a atmosfera cosmopolita ansiada pela nova sociedade republicana. Não só os produtos à venda nas vitrines de cristal eram via de regra franceses, assim também eram as roupas e os modos dos consumidores, tanto quanto os bandos de pardais encomendados pelo prefeito Pereira Passos, por serem típicos de Paris. O caráter suntuoso da Avenida era acentuado pelas fachadas em arquitetura eclética, oferecendo um cenário para o desfile ostensivo da nova sociedade e instigando a animação do consumo conspícuo (SEVCENKO, 2006, p.545).

Cumpria-se a promessa feita pelo Presidente Rodrigues Alves (1902-

1906) durante o seu discurso de posse:

A capital da Republica não póde continuar a ser apontada como séde de vida difícil, quando tem fartos elementos para constituir o mais notavel centro de attracção de braços, de atividades e de capitaes neste parte do mundo. Os serviços de melhoramento do porto desta cidade devem ser considerados como elementos da maior ponderação para esse emprehendimento grandioso. Quando se consummarem, poder-se-há dizer que a capital da Republica libertou-se da maior difficuldade para o seu completo saneamento e o operário bemdirá o trabalho que lhe for proporcionado para fim de tanta utilidade (ALVES, 1902, p.12).

\footnotetext{
${ }^{42}$ As estimativas apontam que a incidência de febre amarela, durante a epidemia ocorrida no verão de 1849-1850, atingiu cerca de 1/3 dos 266 mil habitantes do Rio de Janeiro, então Município Neutro da Corte. De acordo com os dados oficiais, 4.160 pessoas morreram da doença. Chalhoub. S. Cidade Febril: cortiços e epidemias na Corte imperial. São Paulo: Companhia das Letras: 1996 p.61.
} 
Embora houvesse certo encantamento com os ares franceses do Rio de Janeiro da Belle Époque, torna-se imperativo ressaltar que a maior parte da população não vivenciou este sonho republicano. Neves (2008) aponta a sensação da existência de tempo acelerado, não igualmente compartilhado, entre os que viviam nos centros urbanos e aqueles que residiam no interior do país. Esta diferenciação pode ser evidenciada em $O$ Tico-Tico de 23 de novembro de1913, por meio da história Chico das Aguas Quentes de A. Rocha (Fig.15). Transportando-se seu conteúdo para o contexto da Capital Federal, é possível observar que os indivíduos mais pobres não foram diretamente beneficiados pela modernização da cidade. Os moradores dos cortiços, alijados das áreas mais nobres, mudaram-se para as favelas que começam a se expandir pelos morros da cidade.

Espaço da ordem, do tempo cronológico, da racionalidade, a cidade convivia também com o mundo da vida, da desordem e do ócio. (...) Facetas de uma mesma moeda, a ordem e a desordem revelavam-se como espectro de uma cidade que corrompida, insegura, degenerada, revigorava-se pelas iniciativas da modernização e civilização formuladas pelos poderes públicos (CAMARA, 2008, p.146).

A Revolta da Vacina (1904) acabou por se consolidar como uma espécie de símbolo da "República que não foi" (CARVALHO, 2009). Os distúrbios sociais, ocorridos entre 10 e 16 de novembro, ultrapassaram o debate sobre a vacinação obrigatória contra a varíola proposta pelo médico sanitarista Oswaldo Cruz, ou os rumores de que "os médicos do governo visitariam as famílias para aplicá-la nas coxas, ou mesmo nas nádegas, das mulheres e filhas dos operários" (Id.,2002, p.75). Os manifestantes, muitas vezes descritos como desordeiros, externavam seu descontentamento com as ações do Estado. Nas edições de $O$ Tico-Tico, referentes aos meses de janeiro e fevereiro de 1909, foram publicados os capítulos da história no qual Zé Macaco, personagem símbolo do atraso a ser superado pela sociedade, passa por apuros durante protestos no centro do Rio de Janeiro em virtude do aumento no preço das passagens do bonde (Fig.16) (Fig.17) (Fig.18) (Fig.19) 
2 O CHICO DAS AGUAS QUENTES por म. ROCHA O TICO-TICO

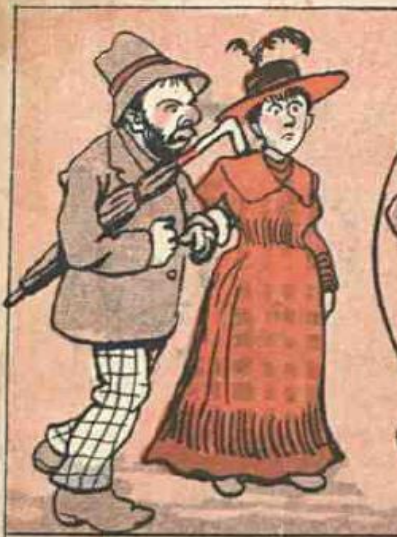

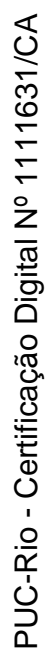

1)-O Ghico das Aguas Quentes, convidou a Dorothea, sua mulher,

hóa estado em 1870 .

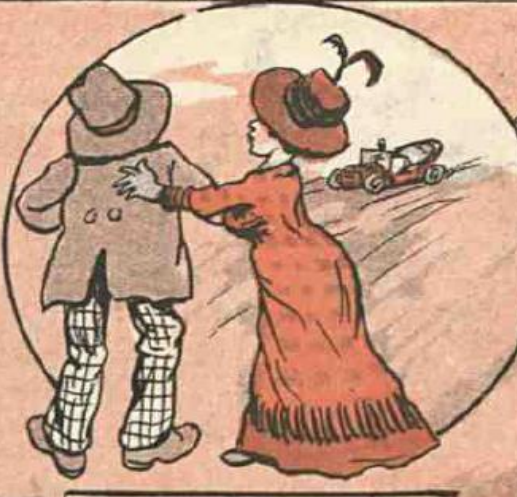

2) Veiu, porém, muito prevenido contra os terriveis automo veis Desembarcou na Central c cm caminto para o hotel viu, parafá.

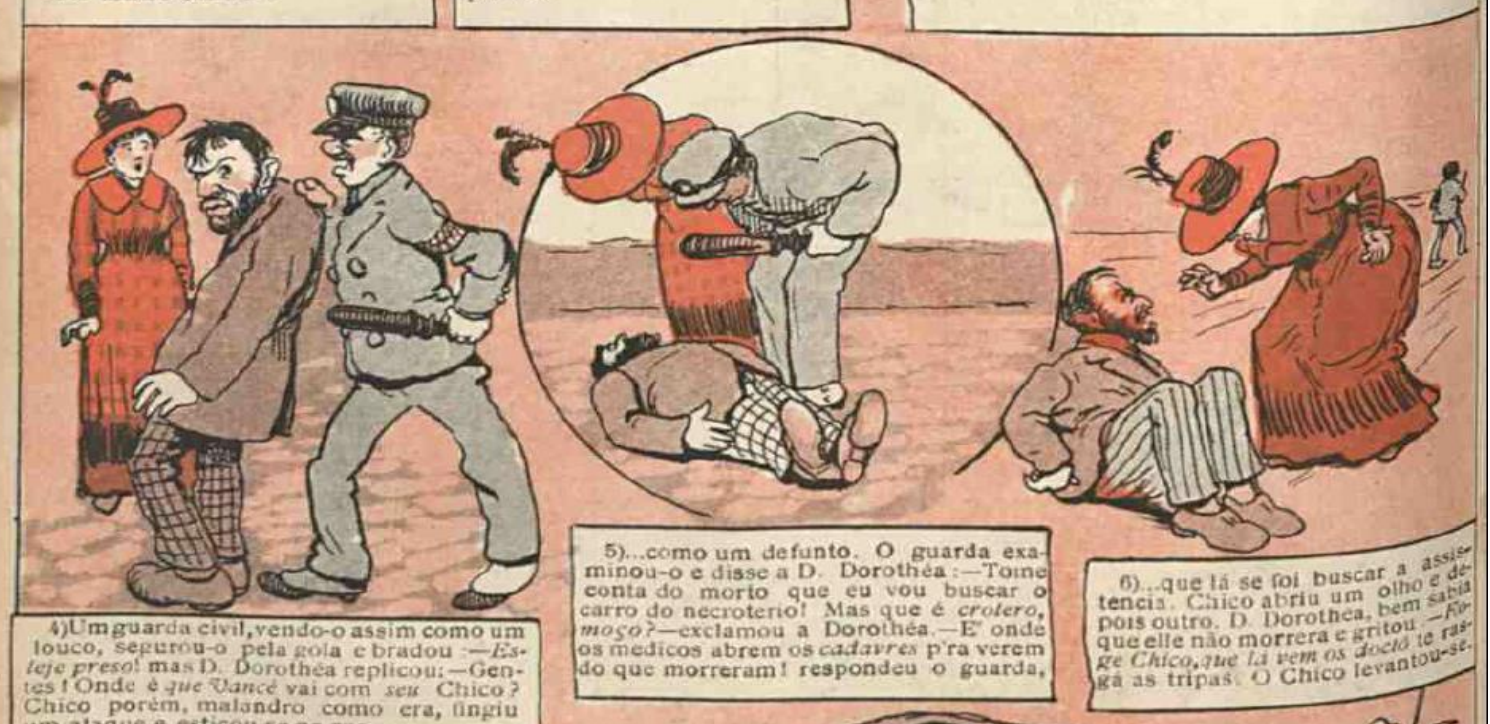

Chico

Chico porsm, halandro como era, lingi
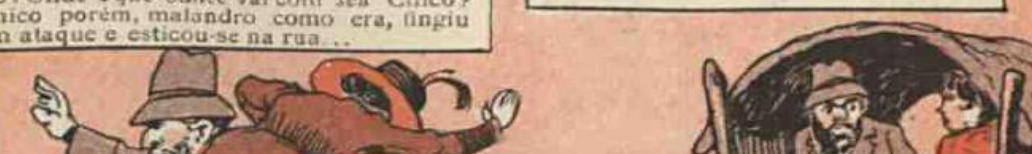
o morrera cigr (5) (3)
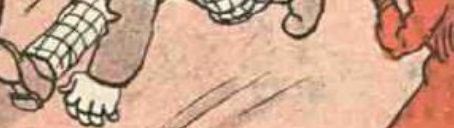


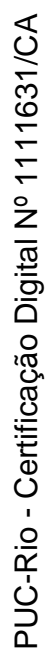

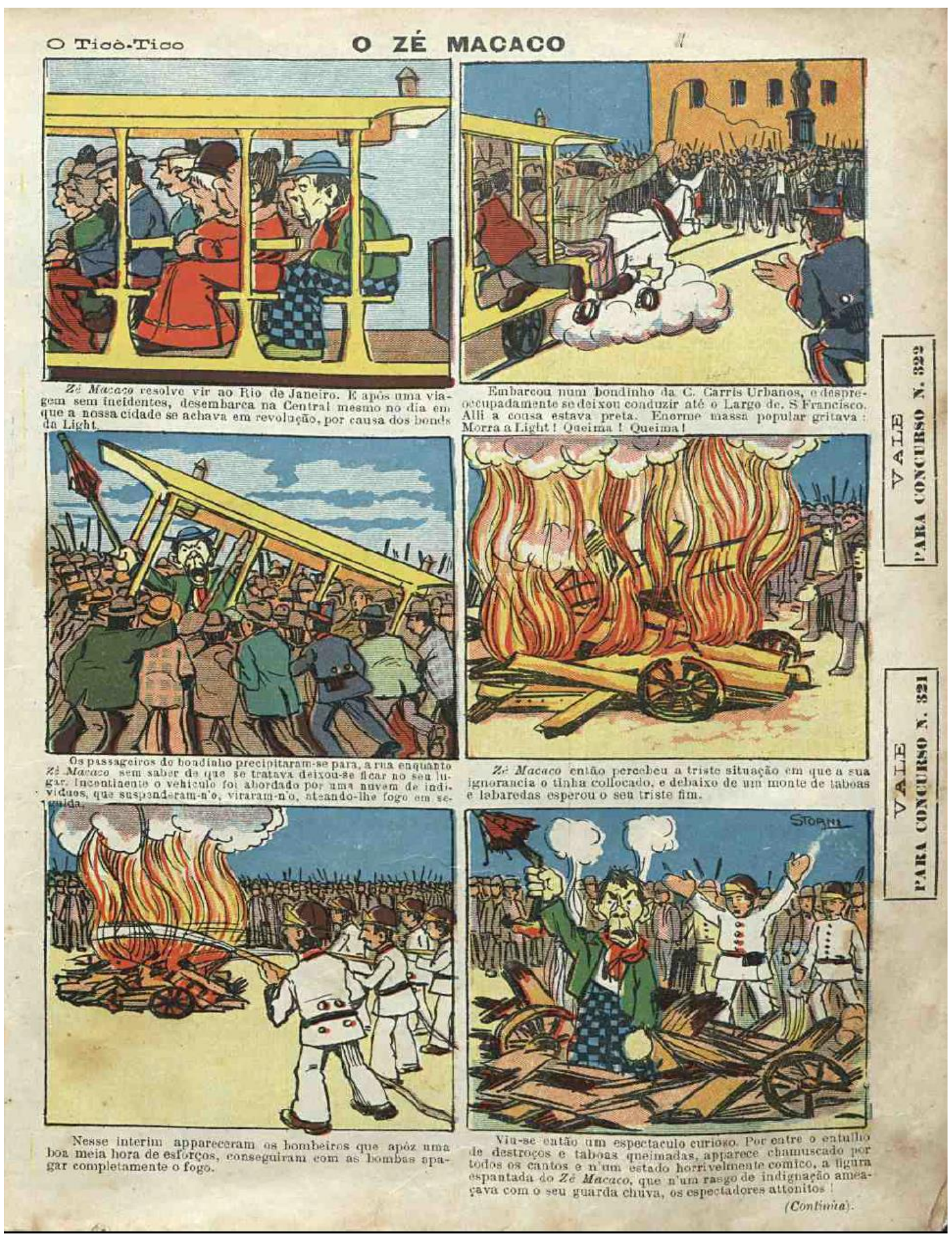

Figura 16 - O Tico-Tico-20/01/1909-s/p 


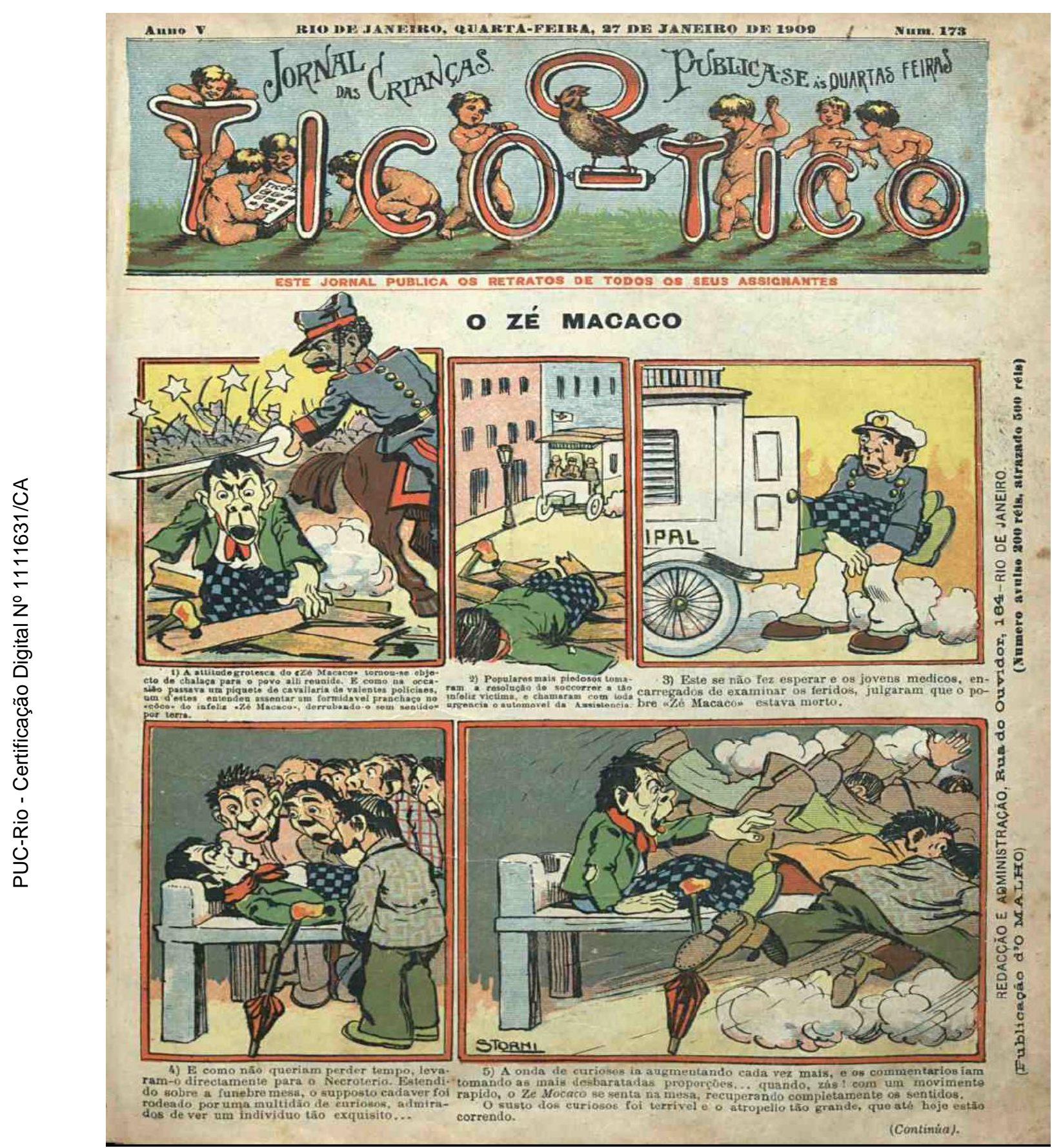

Figura 17 - O Tico-Tico-27/01/1909-p.1 


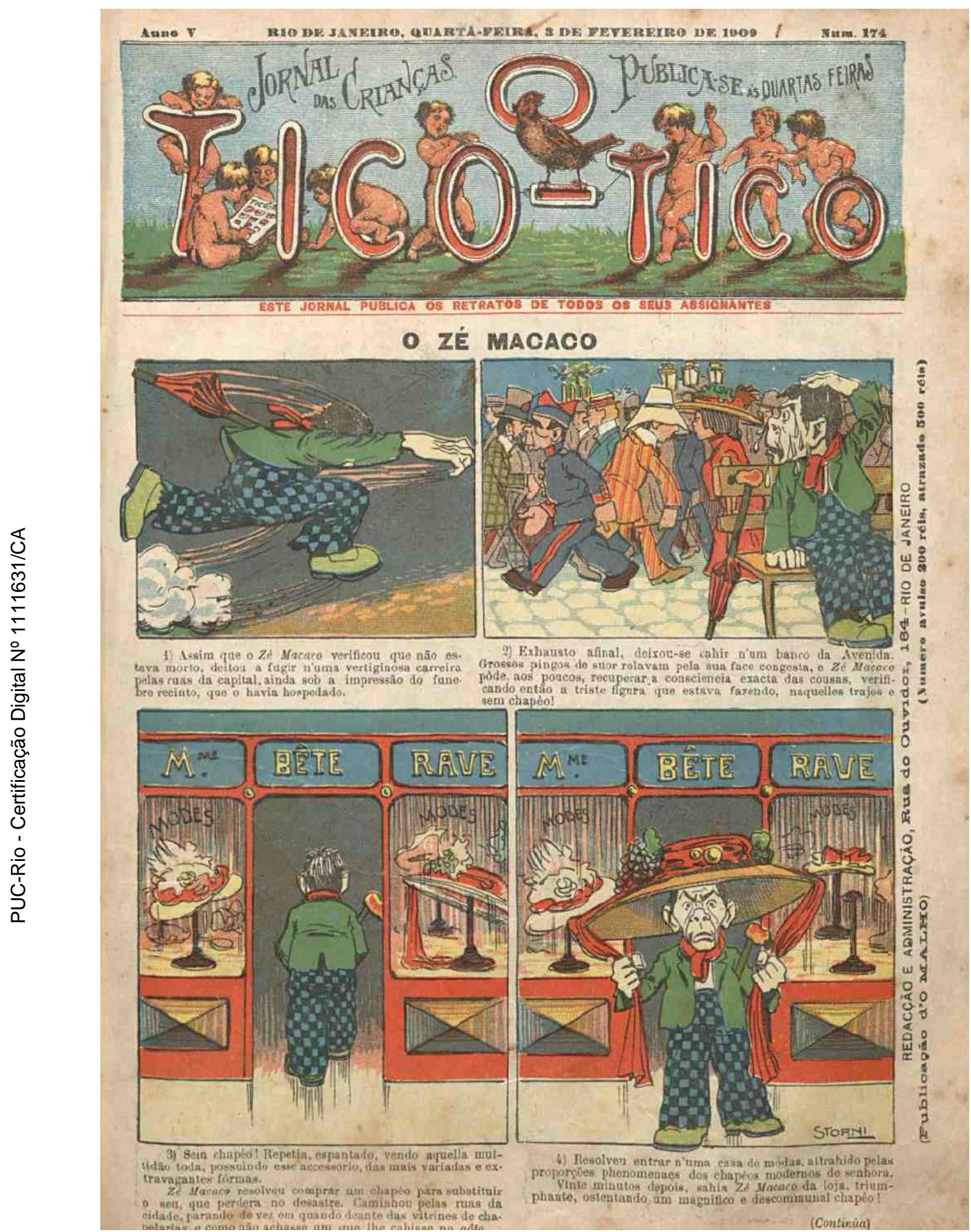

Figura 18 - O Tico-Tico -03/02/1909-p.1 


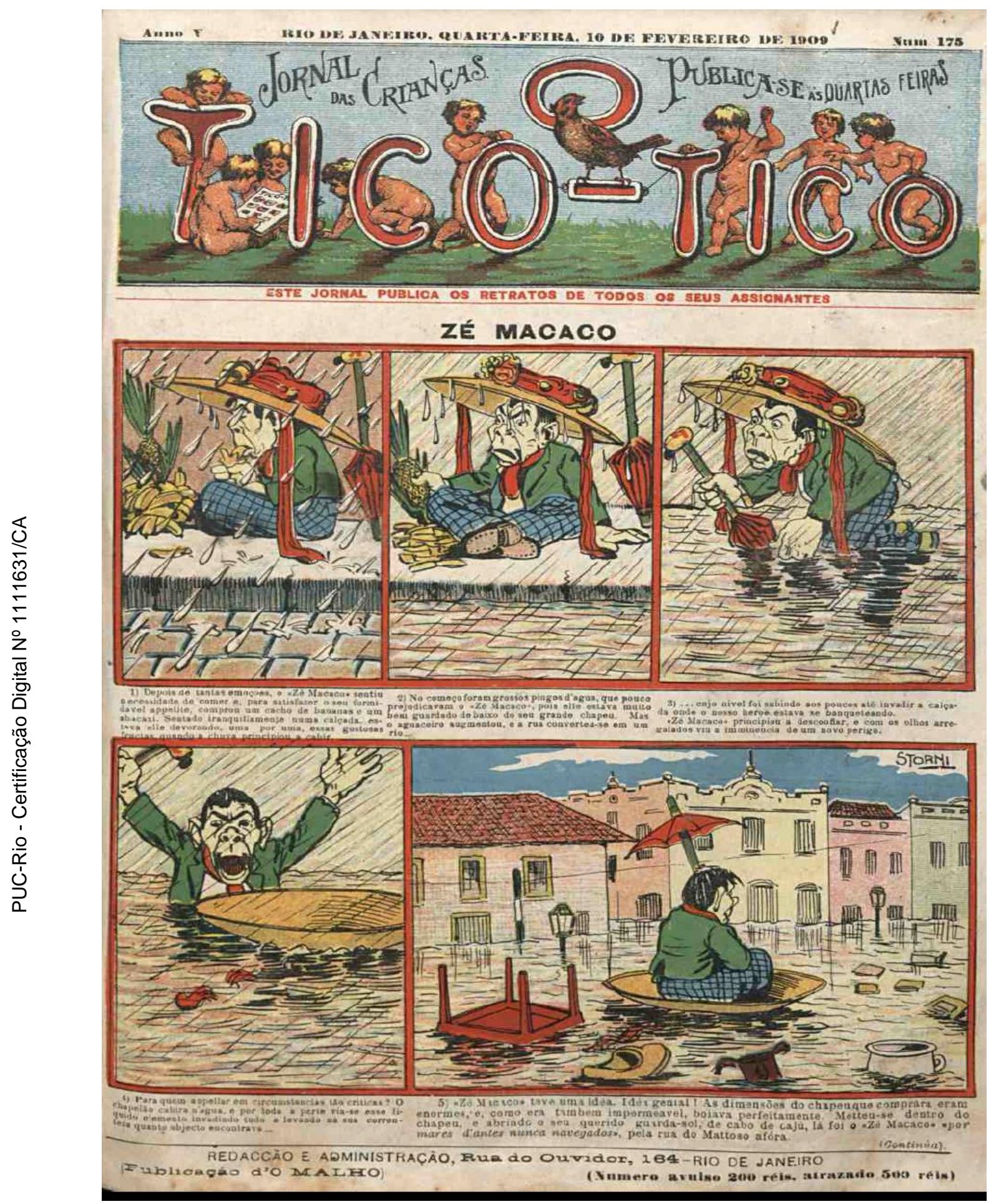

Figura 19 - O Tico-Tico - 10/02/1909 - p.1 
Apesar da mudança de regime político, constatava-se a permanência de antigos vícios, como a troca de favores e a corrupção. Monarquistas de carteirinha se transformaram em republicanos de primeira hora, situação descrita por Machado de Assis no capítulo Troca de Opiniões, do livro Esaú e Jacó. O texto faz referência à trajetória final dos irmãos Pedro e Paulo. O primeiro inicialmente um defensor ardoroso da Monarquia e o segundo identificado como um partidário dos ideais republicanos.

Paulo entrou a fazer oposição ao governo, ao passo que Pedro moderava o tom e o sentido, e acabava aceitando, o regímen republicano, objeto de tantas desavenças. A aceitação por parte deste não foi rápida nem total; era, porém, bastante para sentir que não havia entre ele e o novo governo um abismo. (...) A oposição de Paulo não era ao princípio, mas à execução. Não é esta a república dos meus sonhos, dizia ele; e dispunha-se a reformá-la em três tempos, com a fina-flor das instituições humanas, não presentes nem passadas, mas futuras. Quando falava delas, via-se-lhe a convicção nos lábios e nos olhos, estes alongados, como alma de profeta (1997, p.222).

A ampla participação política, com a qual sonharam os republicanos, foi impedida pelo poderio das oligarquias e pela manutenção da Lei Saraiva (1881), reforma eleitoral na qual mulheres e analfabetos eram impedidos de exercerem o direito ao voto. Segundo Carvalho (Op.cit.), tais restrições resultaram na exclusão de $80 \%$ da população da cidade do Rio de Janeiro do processo eleitoral (p.91). Para que o cenário de cartão de postal não fosse ofuscado pela desilusão com os rumos da realidade republicana, as elites intelectuais se apropriaram do discurso civilizatório voltado a um projeto de regeneração da sociedade brasileira. Propunha-se a consolidação uma nova perspectiva de cidadão calcada nos valores burgueses de moralidade e modos de comportamento. O Decreto Lei ${ }^{\circ} 847$, de 11 de outubro de 1890, transformou a vadiagem e a embriaguez em práticas punidas com prisão. Os vícios da preguiça e da malandragem deveriam ceder lugar às boas condutas. Como descreve o refrão do samba enredo da Escola de samba Portela (2014): 


\author{
Oi, bota abaixo, sinhô \\ Oi, bota abaixo, sinhá \\ Lá vem o Rio de terno de linho \\ E chapéu panamá.
}

Segundo Sevcenko (Op.cit.), os novos modos eram justificados pelo fato da Capital da República ter se transformado no "eixo de irradiação e caixa ressonância das grandes transformações do mundo" (p.522), o local no qual as novidades eram cunhadas e, posteriormente, divulgadas para o restante do país. Papel que a cidade já havia desempenhado, com as devidas diferenças, durante o Império. O centro do Rio de Janeiro, por exemplo, passou a ser identificado como o lugar ideal para ver e ser visto. Constituiu-se no palco de encenações de uma sociedade que almejava ser civilizada. A revista Careta criou a seção Instantaneos para publicar fotografias das damas e dos cavalheiros durante suas andanças pelas largas e movimentadas avenidas cariocas (Fig.20).

As mulheres passeavam pela Avenida Central trajando roupas fechadas, luvas e grandes chapéus. Vestuário mais adequado às temperaturas amenas da Europa do que ao clima carioca. As reformas urbanas ampliaram os espaços de circulação das mulheres das elites. Elas podiam flanar elegantemente pelas ruas centrais da cidade. Deve se observar que na maior parte das fotos de Instantaneos elas estavam acompanhadas de outras mulheres ou seus maridos e filhos. A razão para tal fato estava na perspectiva de que as mulheres desacompanhadas podiam ficar mal faladas. 


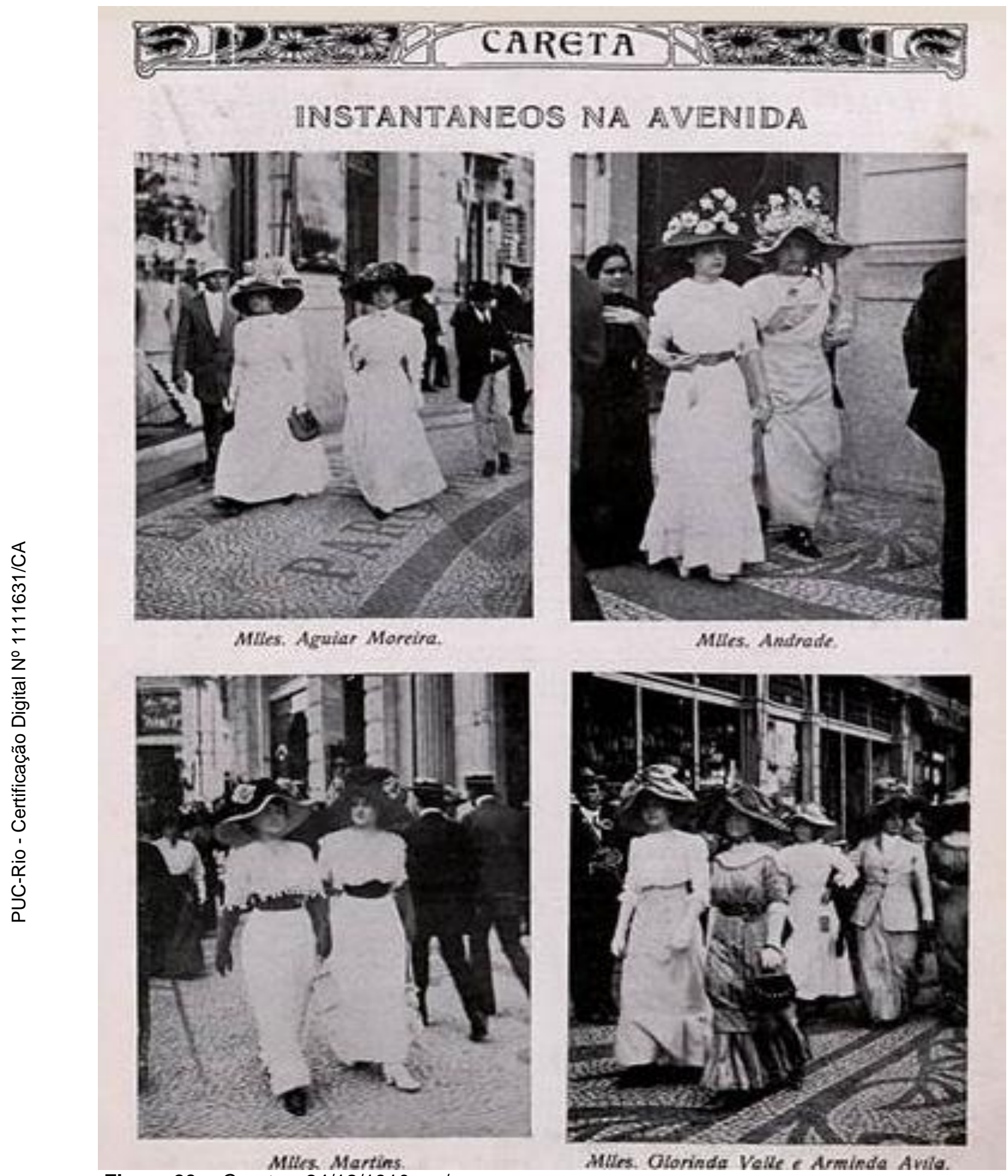

Figura 20 - Careta - 24/12/1910 - s/p. 
Os bons cidadãos republicanos eram aqueles que aderissem a esta concepção de civilidade compartilhada pelas elites. Jacques Revel (2009) identifica as normas de civilidade como uma linguagem que deve ser compartilhada e reconhecida pelo outro. A adoção destes comportamentos institui contrato social destinado a garantir à manutenção da disciplina coletiva. A publicação de fotografias dos cidadãos modelos da República durante seus passeios conformava como os manuais de comportamento da sociedade moderna. Elias (1994) descreve que

O conceito de civilisationé inicialmente (...), um instrumento dos círculos de classe média - acima de tudo - da intelligentsia de classe média no conflito social interno. Com a ascensão da burguesia, ele veio, também, a sintetizar a nação, a expressar a auto-imagem da nação (p.64).

O modelo de civilização partilhado, por exemplo, pela burguesia francesa após a Revolução Francesa (1789) era semelhante ao instituído pela aristocracia. Estabeleceu-se uma ruptura com a estrutura administrativa do Estado Absolutista, mas os costumes não se alteraram de forma rápida e sistemática. $\mathrm{O}$ processo civilizatório se caracteriza pela longa duração. Neste sentido, não se poderia esperar que o simples advento da República pudesse modificar os comportamentos sociais em ritmo acelerado. A sociedade havia sido forjada mediante ao contexto sociocultural imperial.

Para que as reformas na ordem social brasileira não adquirissem caráter pontual, as elites intelectuais visavam estabelecer meios para garantir o seu o futuro. O regime republicano ainda estava em processo de consolidação, mas já se tornava necessário garantir que as gerações futuras estivessem imersas nos parâmetros de civilidade e homogeneização propagados pelas elites. Assim, tornava-se imperativo investir na formação da infância brasileira. Como salienta Camara (Op.cit.), nada mais natural que um regime, que ainda engatinhava, escolhesse a criança como principal alvo de ações voltadas à conformação de nova uma sociedade civil brasileira. 


\subsection{Os amiguinhos de Chiquinho: a criança republicana}

A pintura A Pátria (1919) de Pedro Bruno pode ser compreendida como uma imagem-símbolo do projeto de formação de uma infância republicana (Fig.21).

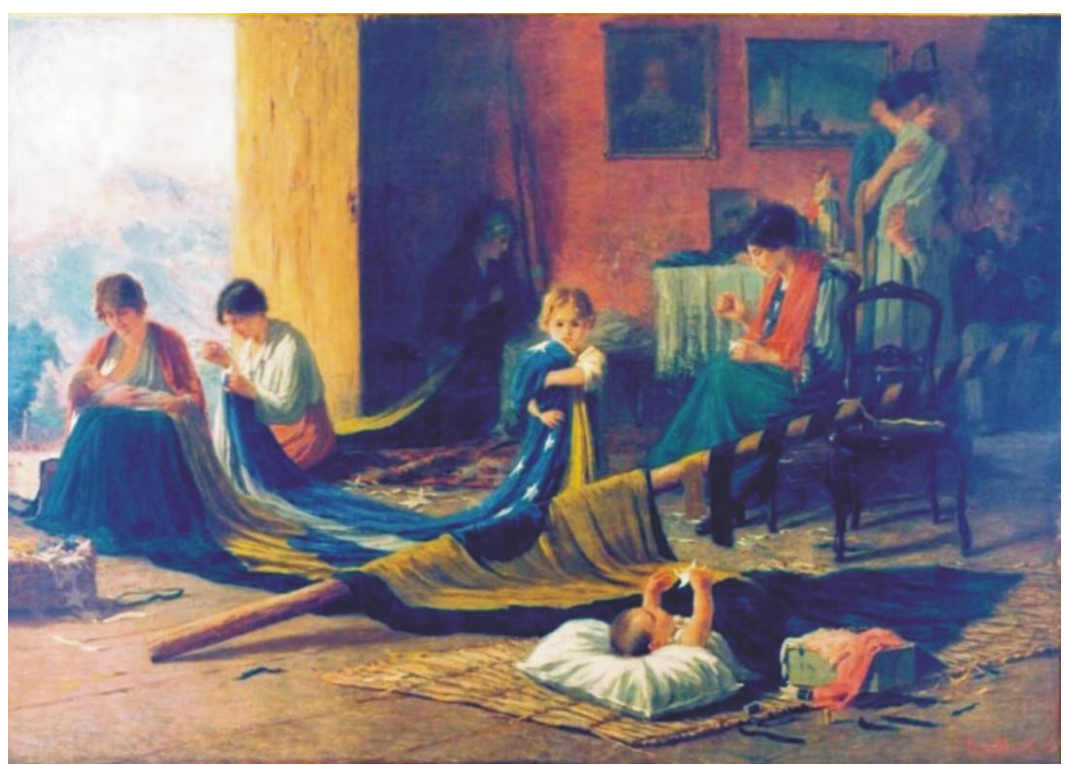

Figura 21 - $A$ Pátria (1919)

Em primeiro plano, uma criança branca e loira, não se pode definir o sexo, olha fixamente a sua frente e abraça a bandeira do Brasil. Ao lado, um bebê brinca com uma das estrelas que simbolizam os estados da nação. Duas mulheres acalentam os filhos enquanto as outras costuram e bordam o novo pavilhão nacional $^{43}$. A representação do nascimento de um dos principais símbolos do novo regime é uma síntese do papel social que as elites defendiam como ideal para o sexo feminino: a maternidade.

Segundo Hansen (Op.cit.), a partir das décadas finais do século XIX, emergiu na sociedade brasileira "um tipo de sensibilidade que colocava a criança no centro das atenções, tanto no âmbito da vida privada como na esfera pública" (p.29). Compartilhava-se a perspectiva dos petizes como guardiães do futuro da nação.

\footnotetext{
${ }^{43}$ A bandeira da republicana foi confeccionada na casa de Benjamin Constant, um dos principais articuladores da proclamação do novo regime. Faziam parte do grupo de colaboradoras estavam a esposa Maria Joaquina da Costa e a filha Bernardina Botelho de Magalhães. MAGALHÃES, Bernardina Botelho de. In: CASTRO, C.; LEMOS, R. (Org.). O Diário de Bernardina: da Monarquia à República, pela filha de Benjamin Constant. Rio de Janeiro: Jorge Zahar,2009. p.97112.
} 
O modelo ideal da infância republicana possui um caráter excludente. Constituído pela criança branca, proveniente de família nuclear estruturada e pertencente às classes urbanas mais abastadas (ROSA, Op.cit.). Características presentes, por exemplo, na personagem Chiquinho.

Esta representação encontra ressonância no conceito de infância burguesa, em voga na Europa do século $\mathrm{XIX}^{44}$. O período, descrito por Ariés (2006) como $o$ século das crianças, concretou as bases da construção de uma visão científica sobre o desenvolvimento infantil: a Puericultura e a Psicanálise. Os avanços da medicina diminuíram os índices de mortalidade infantil.

(...) graças ao progresso da higiene e da saúde pública, mudou a relação de mães e filhos, tanto no que diz respeito aos cuidados com a alimentação quanto às manifestações de afeto (PRIORE, 2013, p.129).

Evidencia-se que as crianças são indivíduos distintos dos adultos. "Para tudo e contra tudo, a infância se torna a idade fundadora, a criança vira uma pessoa" (PERROT, 2009, p.148).

Para Lajolo e Zilberman (Op.cit.), no final do século XVIII e no decorrer do século XIX, a burguesia se impões como classe social e suas bases de poder fortalecidas: a família, a escola e a criança. A estrutura familiar passa a se configurar em um espaço legitimado de preservação da infância. Como forma de normatização das práticas familiares determinou-se que a mãe tinha a responsabilidade de cuidar do lar e o pai de prover o sustento da família.

Segundo Perrot (Op.cit.) e Vincent (2009), a nova estrutura familiar concedeu aos filhos: o status de figuras centrais do lar. Tornam-se objeto de investimento, pois cabia aos pais garantir a eles um crescimento sadio. A concepção temporal linear, calcada na perspectiva de futuro, introduziu a representação dos filhos como herdeiros, aqueles que teriam a responsabilidade de garantir a sobrevivência do patrimônio e do sobrenome da família:

\footnotetext{
44 Embora o conceito burguês de infância tenha adquirido um caráter modelar, ressalta-se a existência, naquele período, de outras infâncias como a proletária. A migração para os centros urbanos não garantiu a melhoria das condições de vida para, significativa parte, das famílias que abandonaram o campo em busca de um novo oficio. A pobreza acarretou na presença de crianças trabalhando nas fábricas, por mais de 10 horas diárias, em troca de baixos salários. Cumpriam a função social de ajudar no sustento da família. CHALMEL, Loic. Imagens de crianças e crianças nas imagens: representações da infância na iconografia pedagógica nos séculos XVII e XVIII. Educ. Soc., Campinas, v. 25, n. 86, p. 57-74, abril. 2004.
} 
No final do século XIX, a criança passou a ser valorizada; tornou-se o "reizinho da casa", no lugar do pai. A família acompanhava a gravidez, preparava-se o enxoval, e era imprescindível que a mãe costurasse, bordasse ou tricotasse uma peça para o pequeno, símbolo do amor materno. A escolha de nome era determinada pela tradição familiar. O pai agora acompanhava o parto do lado de fora - cedera lugar ao médico, coisa rara até então. A perda de um filho era considerada um golpe irreparável (PRIORE, Op.cit. p.132).

No contexto brasileiro, a centralidade social da criança acarretou em certo afrouxamento dos laços que consolidavam a família patriarcal na qual seus membros se reuniam "em torno de um chefe, pai e senhor forte e temido, que impunha sua lei e ordem nos domínios que lhe pertenciam” (Ibidem, p.12).

A capa da primeira de O Tico-Tico traz o título Manda quem Póde, composto por duas narrativas em quadrinhos. A primeira foi descrita na Introdução. A segunda apresenta um pai cujos filhos queriam exemplares do impresso infantil (Fig.22). Embora as crianças tenham feito pirraça, ele justifica a compra da publicação por ter observado que nas ruas do Rio de Janeiro: "Só se vêem pequenos por todos os cantos a lerem O Tico-Tico" (1905, p.1). A narrativa institui questionamentos sobre o caráter dúbio na escolha deste título. Quem realmente manda? As crianças ou os adultos? Os meninos e as meninas conseguiram ganhar seus exemplares, no entanto dependeram da vontade dos adultos em satisfazê-las. O mesmo ocorre em Como se provoca e como se acaba com uma revolução, publicada em 31 de janeiro de 1906 (Fig.23). O pai comunica aos três filhos não ter comprado $O$ Tico-Tico. Diante do desespero das crianças, ele revela ter feito uma brincadeira. Para a alegria dos pequenos leitores, cada um ganhou uma edição da revista. 


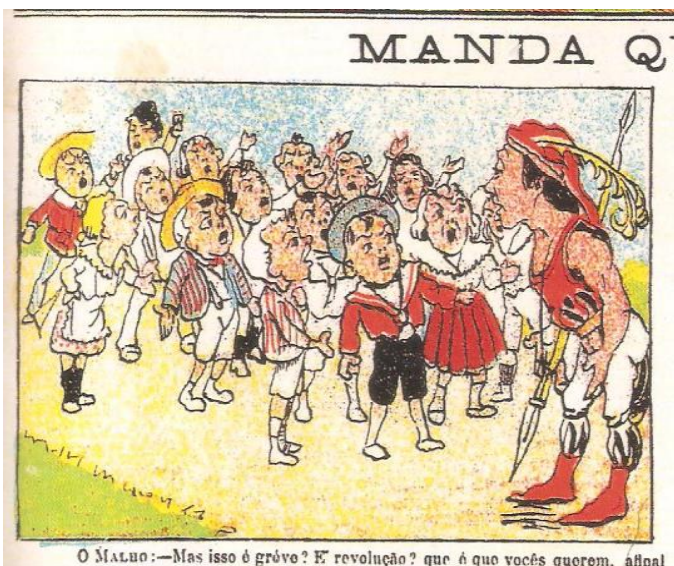

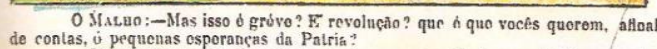

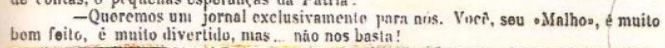

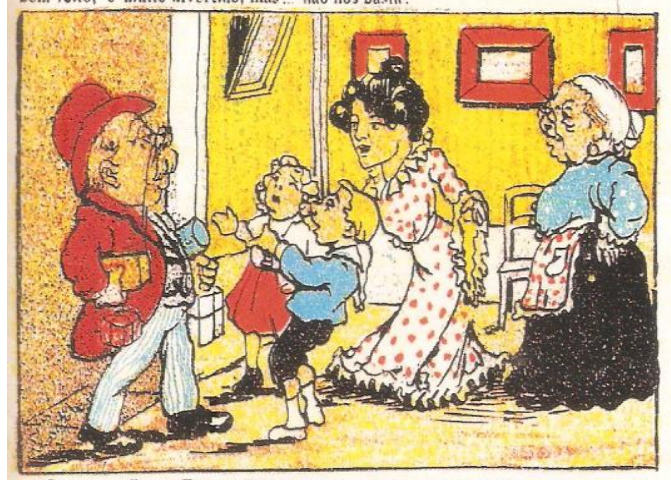

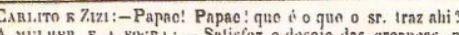

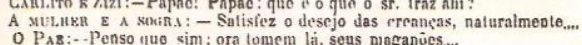

Qẫo gostosissimos oslos biscoilos:

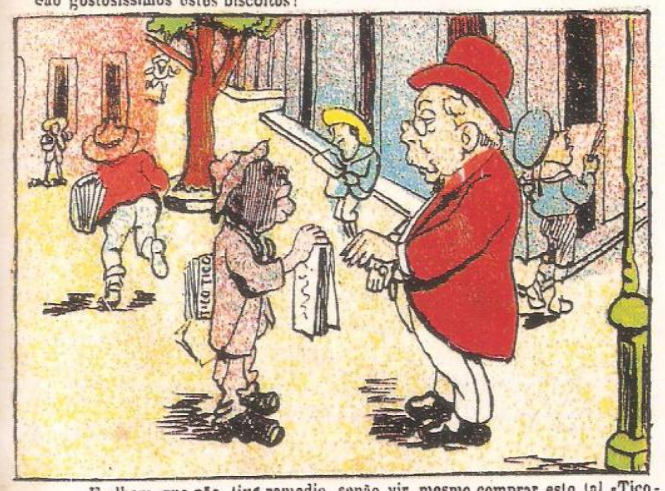

-E olhom que năo live reniodio semío vir mosmo comprar esto lal aTiro

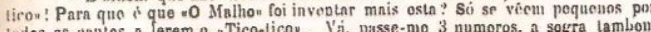

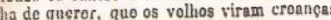

REDACC̄̃O E ADMINISTRACÃO Rua do Ouvidor, 138

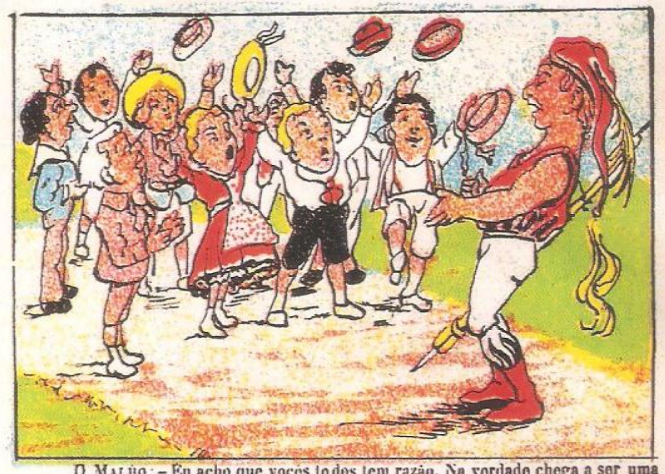
injustica que no Brasil todas as classes Lenham o sen joraal e so tocess o mato teaham.
Pois bem? Fuluos sol

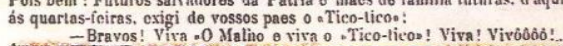

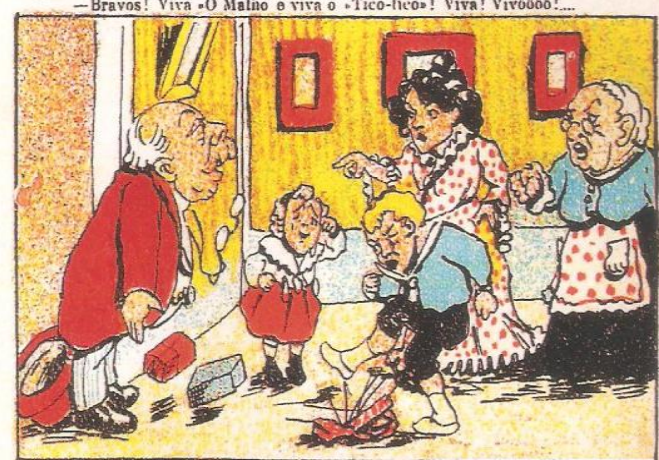

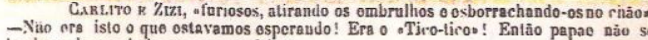
ine que hoje era quarta-foiro

A surLHF: - Tambem rocè não trazer uma coisa que as craançes estavam

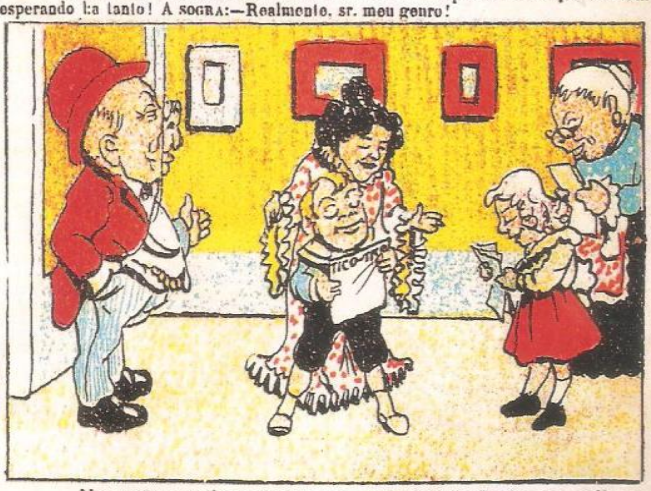

-Mas ontá os sonhoras ostao nas suas sete quintas! $\mathbb{E}$ ato a sogra! Eu Dho

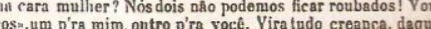
ronaprar mais dois stico-ticos

(Publicagão d'O MAIFO)

RIO DE JANEIRO

Numero avulso 200 réls

Figura 22 - O Tico-Tico - 11/10/1905 - p.1 


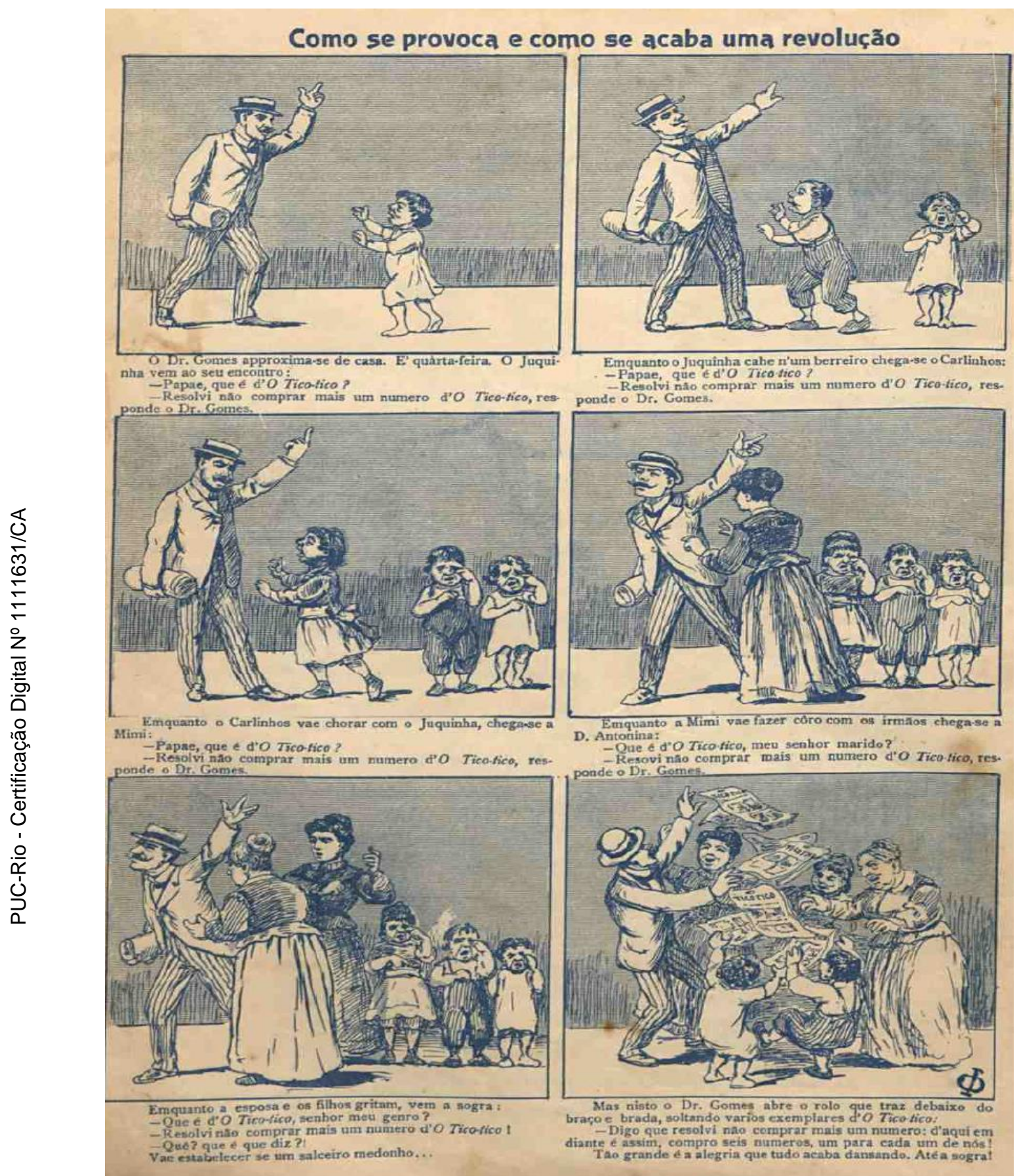

Figura 23- O Tico-Tico - 31/01/1906 - p.8. 
Identificadas como importantes atores sociais, as crianças não eram consideradas indivíduos plenos e, por tal razão, precisavam ser guiadas pelos pais. Grupos de intelectuais brasileiros entendiam ser preciso cuidar da formação do caráter das crianças burguesas e desenvolver estratégias para que as meninas e os meninos pobres pudessem estar a salvo de ambientes considerados nefastos. Estes perigos foram descritos no conto Os que começam...de João do Rio:

Há no Rio um número considerável de pobrezinhos sacrificados, petizes que andam a guiar senhoras falsamente cegas, punguistas sem proteção, paralíticos, amputados, escrofulosos, gatunos de sacola, apanhadores de pontas de cigarros, crias de famílias necessitadas, simples vagabundos à espera de complacências escabrosas, um mundo vário, o olhar de crime, o broto das árvores que irão obumbrar as galerias da detenção, todo um exército de desbriados e de bandidos, de prostitutas futuras, galopando pela cidade à cata do pão para os exploradores. Interrogados, mentem a princípio, negando; depois exageram as falcatruas e acabam a chorar, contando que são o sustento de uma súcia de criminosos que a polícia não persegue (2013, p.81).

$\mathrm{O}$ combate à vadiagem, à mendicância e à preguiça eram assuntos presentes em $O$ Tico-Tico. O jogo e o alcoolismo eram apontados como capazes de degenerar o futuro, principalmente dos meninos. O fato das crianças terem familiares e parentes com vícios era um sinal de possível comprometimento de seu futuro. Ao invés de bons cidadãos, a sociedade ficaria à mercê de desajustados. O impresso infantil publica conteúdos voltados a alertar os pequenos sobre tais males:

\section{Jogar}

Eis ahi outro vicio que os meninos devem evitar. E' claro que não nos referimos aos jogos próprios da idade, como sejam: pião, o foot-ball, a carniça, os quatro cantos, a malha, a amarella, e muitos outros - jogos estes que usando com certa moderação, até são uteis para o desenvolvimento do corpo. Mas isso são jogos e nos queremos falar do jogo, dessas combinações inventadas para distrahir o espírito ou matar o tempo, mas que foram transformadas num meio de se ganhar e perder dinheiro. Nós nos referimos á roleta, ao sete e meio, á vermelhinha, ao cunho e corôa e a tantos outros meios de perversão a que temos visto entregues muitas crianças, arriscando o pouco ou muito dinheiro que trazem no bolso e que lhes poderia servir para comprar qualquer cousa ou dar-lhes o goso de um passeio ou de um espectaculo. Mesmo entre os homens, o jogo a dinheiro é a peiorcousa que há, e tem sido a cousa principal de grandes desgraças no seio das familias. O jogador de profissão é um homem perdido.Por mais illustre que elle seja, desde que esse vicio tome conta delle, inutilisa-o ou, 
pelo menos faz com que elle perca grande parte de sua importancia. E' o ponto fraco, é p lado podre do pecego que o vendedor de fructas procura impingir, embrulhando-o em papel de seda... O menino viciado no jogo perde pouco a pouco os sentimentos, chegando a maltratar e odiar a familia, si esta não lhe dá bastante liberdade para se entregar ao vicio. Relaxa o estudo. O seu pensamento é só abocanhar os nickeis dos companheiros de desgraça. Perde tudo, porque no jogo o prejuízo é certo ou $\log$ a principio ou no fim de algum tempo.Voltaremos ao assumpto e falaremos então no celebre jogo do bicho (O TICO-TICO, 11/07/1915, s/p).

Para evitar que os meninos se viciassem neste tipo de prática usava-se um discurso de caráter fatalista. Era preciso alertá-los, desde cedo, sobre os perigos aos quais eles estavam expostos. Narrativas de O Tico-Tico tratam destas temáticas a partir de conteúdos vinculados a extrema violência, assuntos que na atualidade não fariam parte de quaisquer publicações infantis. Uma boa lição aborda a temática do alcoolismo por meio da violência doméstica e da tentativa de homicídio $^{45}$ (Fig.24). Procurava-se salientar a mensagem de que ao alimentar os vícios, os homens deixavam de se preocupar com sua nação, sua família e seus estudos.

Nas páginas da revista, a sova era a principais formas de correção, com destaque para as histórias protagonizadas por meninos. Chiquinho, Benjamin e até o cachorro Jagunço eram alvo de corretivos. O Tico-Tico publicou um brinquedo de armar intitulado: Uma sóva perpétua, no qual os pequenos leitores poderiam castigar o menino peralta (Fig.25).

45 Esta não foi à única narrativa de cunho violento presente em $O$ Tico-Tico. $O$ crime de Joãosinho aborda uma tentativa de envenenamento orquestrada pelo menino título, de apenas 11 anos, contra a prima com quem havia brigado. Arrependido, ele pega um revólver tenta cometer suicídio. Neste momento, o menino descobre que sua prima, descobrira o plano, e fingiu passar mal para lhe dar uma lição. O TICO-TICO, 09/01/1918, s/p. 


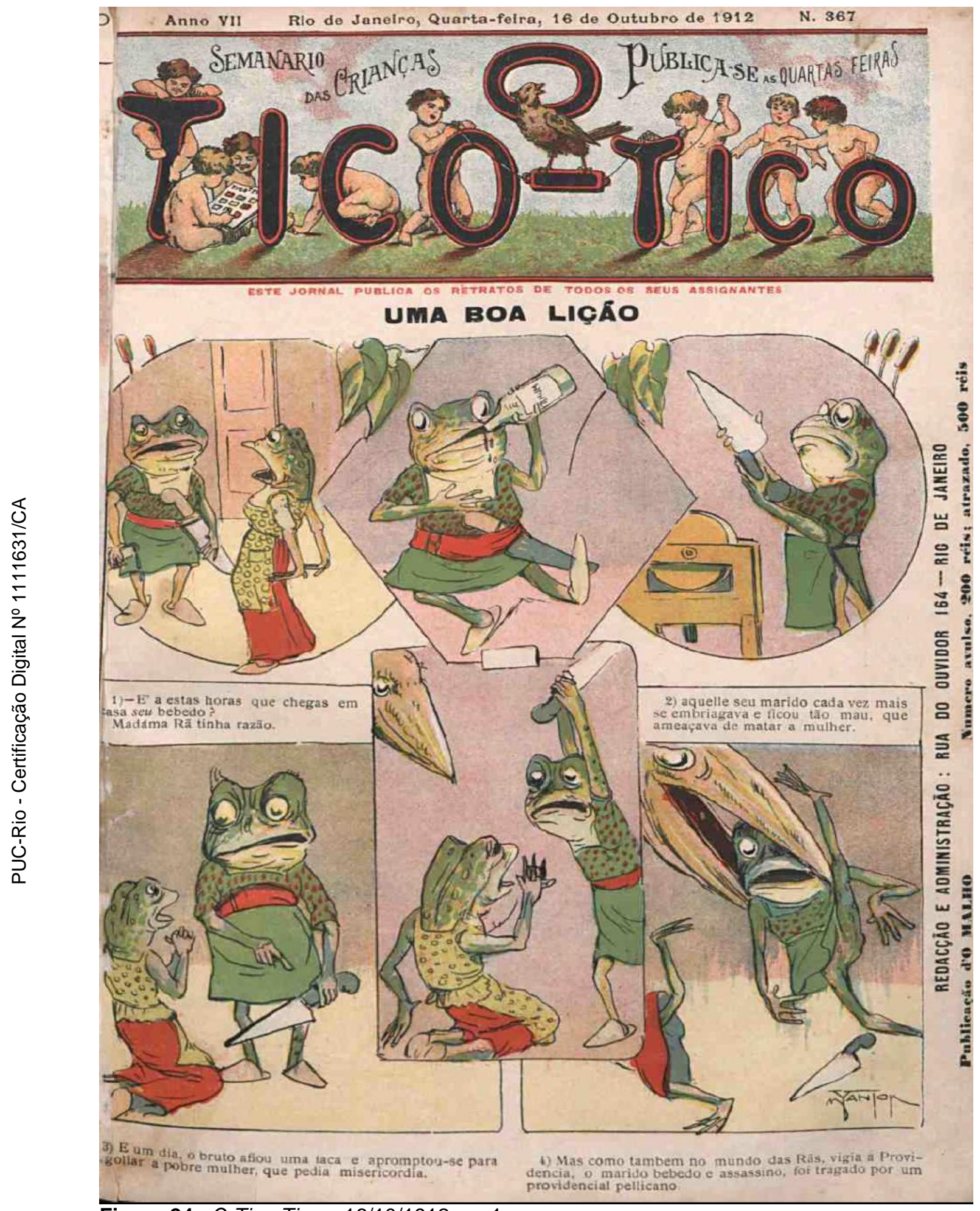

Figura 24- O Tico-Tico-16/10/1912-p.1 


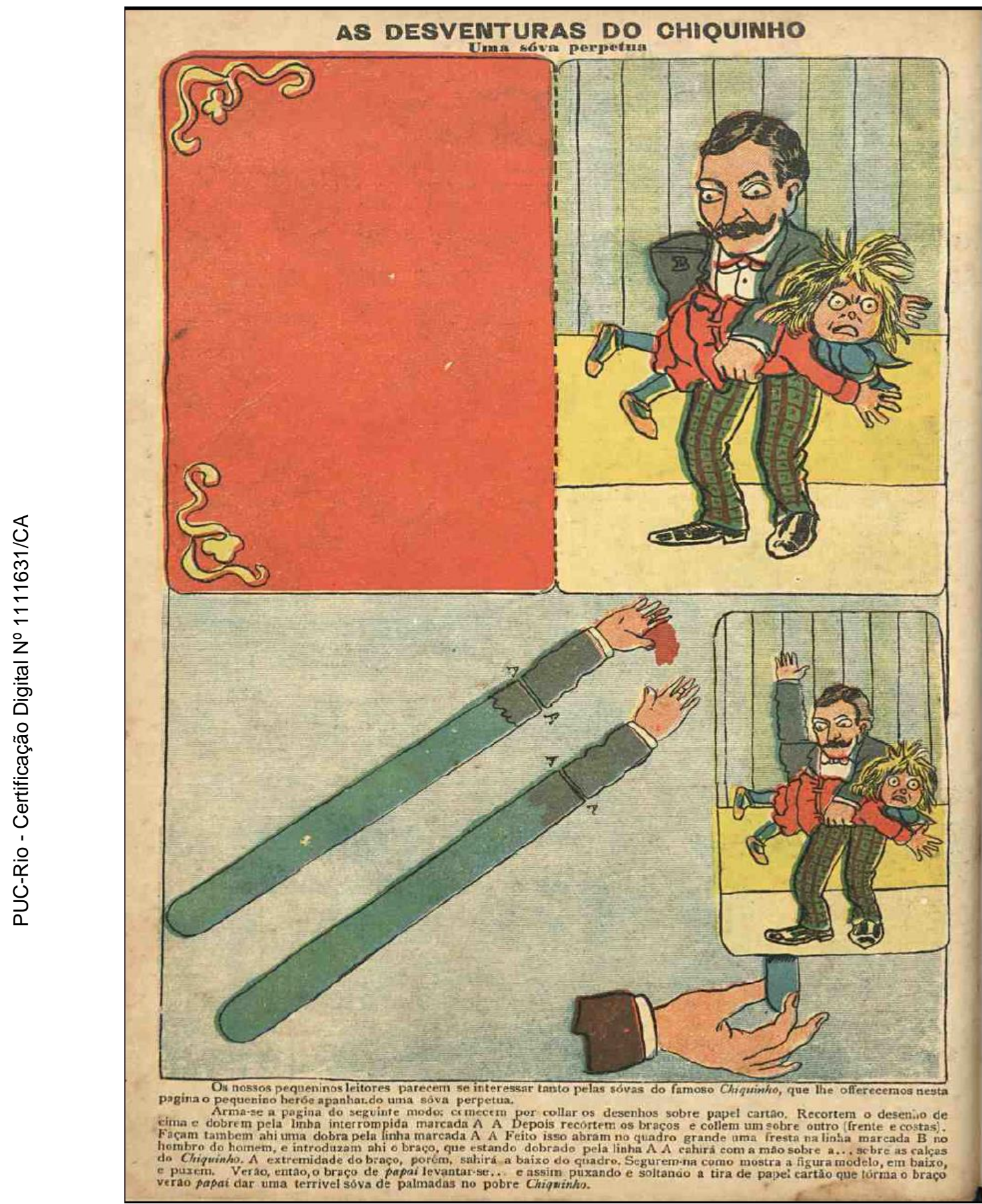

Figura 25- O Tico-Tico - 15/05/1907 - p.16 
No tocante às crianças pobres, as primeiras décadas do século $\mathrm{XX}$ foram marcadas por iniciativas de auxílio às famílias carentes. Foram implantadas creches, dispensários, cursos sobre a higiene infantil para as mães e campanhas de vigilância sanitária nas escolas. O Dr. Moncorvo Filho realizou ações voltadas à assistência infantil por meio da criação do Instituto de Protecção e Assistência a Infância (1901), do Departamento de Creança do Brasil (1918) e do I Congresso Brasileiro de Protecção à Infância (1922) (RIZZINI, 1997) (Fig.26).

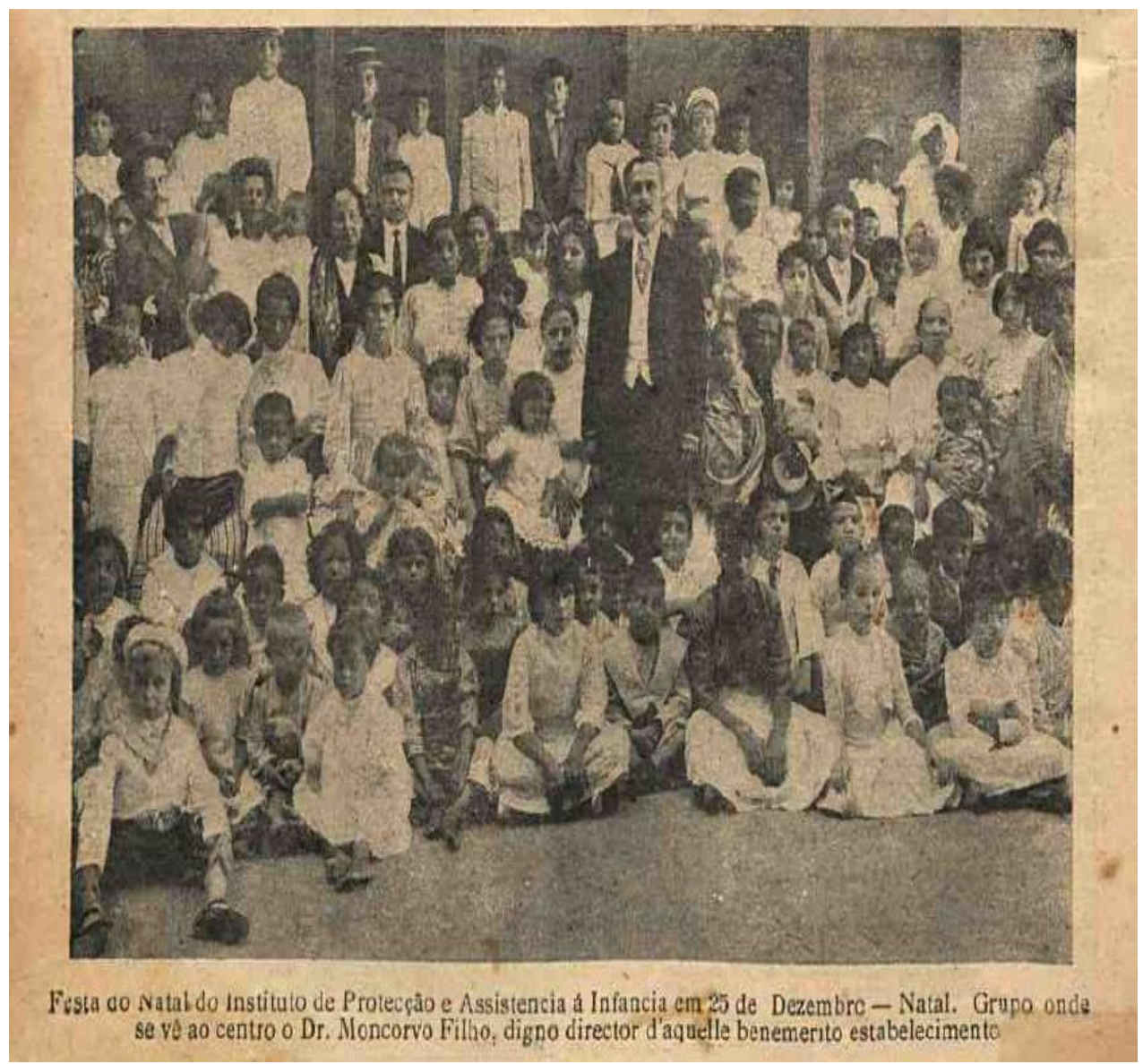

Figura 26 - O Tico-Tico-29/01/1912 - p.4

Nos exemplares de $O$ Tico-Tico as crianças são sempre aconselhadas a frequentar a escola e serem alfabetizadas. As narrativas demonstram que os meninos e as meninas que não se dedicassem aos estudos teriam um futuro sombrio. Não seriam cidadãos decentes e produtivos como se evidencia em Não estudou, virou um burro (Fig.27). Aos que estudassem com afinco, a vida traria recompensas. O sacrifício de Gaspar descreve como o pobre garoto Gaspar conseguiu ajuda para comprar os remédios de seu pai em virtude do bom 
desempenho escolar e o amor pelos livros (Fig.28). No caso das famílias menos abastadas, no momento em que as crianças assimilassem tais valores e comportamentos, elas poderiam vir a se transformarem em bons cidadãos e a agirem como agentes de mudança do seu próprio meio social.

Com o advento da República, havia a expectativa de que fossem criadas as bases de uma unidade nacional de ensino. A escola seria o local no qual as crianças teriam contato com os elementos formadores da identidade nacional. "Depositou-se confiança nas potencialidades da escola para espalhar as luzes e afastar as trevas da ignorância por meio do ensino, concebido como uma ação civilizadora e pelo qual se introduziria o povo no mundo do conhecimento (...)" (SÁ, 2010, p.223). O modelo exemplar de criança, em circulação nas páginas de O Tico-Tico, faz-se presente nas histórias complementares: Chiquinho estuda e admira, A grandeza do Brazil e Defesa da Pátria (Fig.29) (Fig.30) (Fig.31). Após ser recriminado pela mãe, o menino Chiquinho decide se tornar um bom estudante. O conhecimento lhe desperta um sentimento pátrio capaz de faze-lo defender sua nação, inclusive na ocorrência de uma guerra. A mãe o convence de que a maior contribuição de Chiquinho era estudar e se tornar um honrado cidadão republicano. 


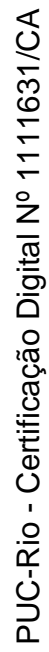

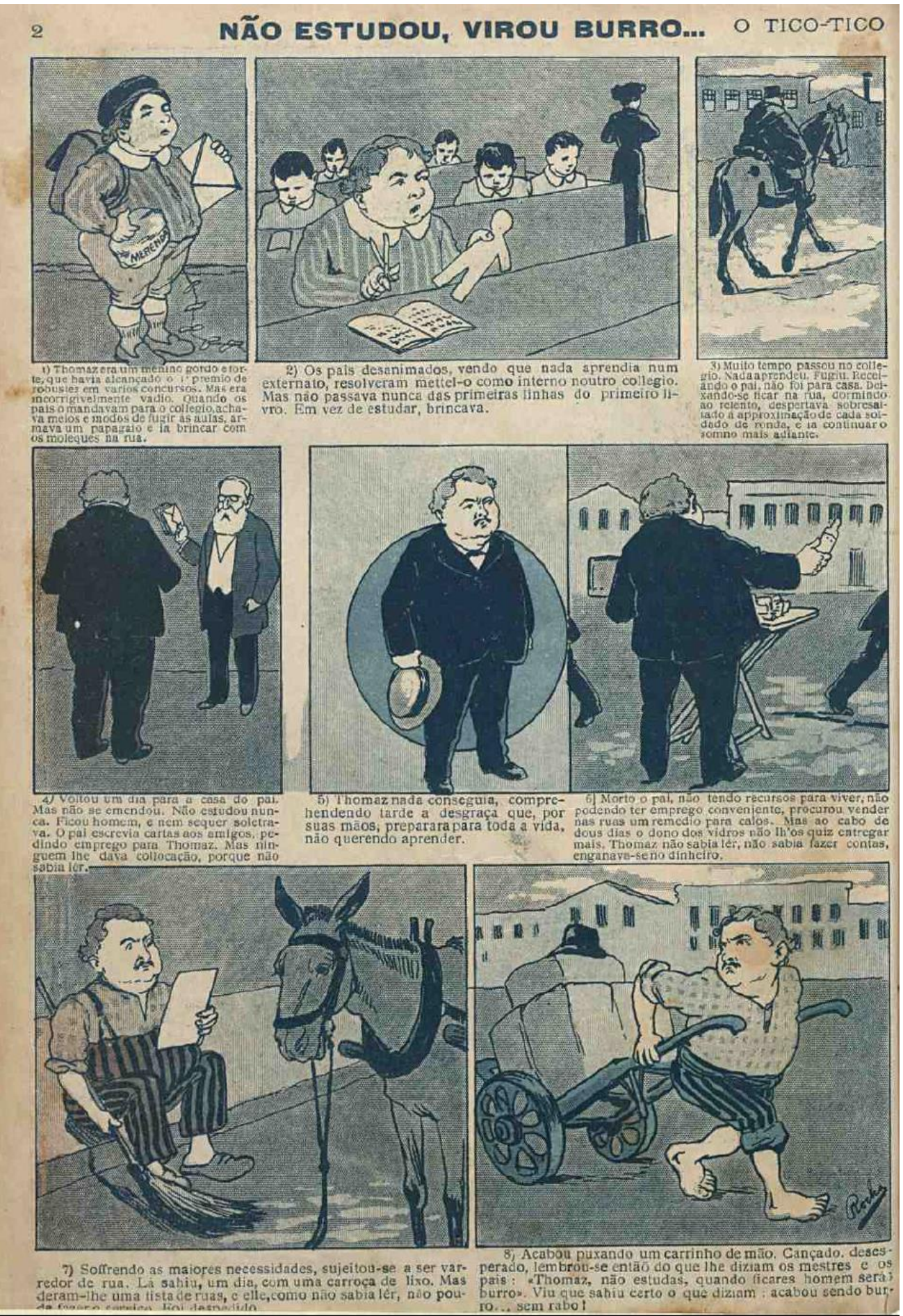

Figura 27 - O Tico-Tico-21/01/1914 - p.2 


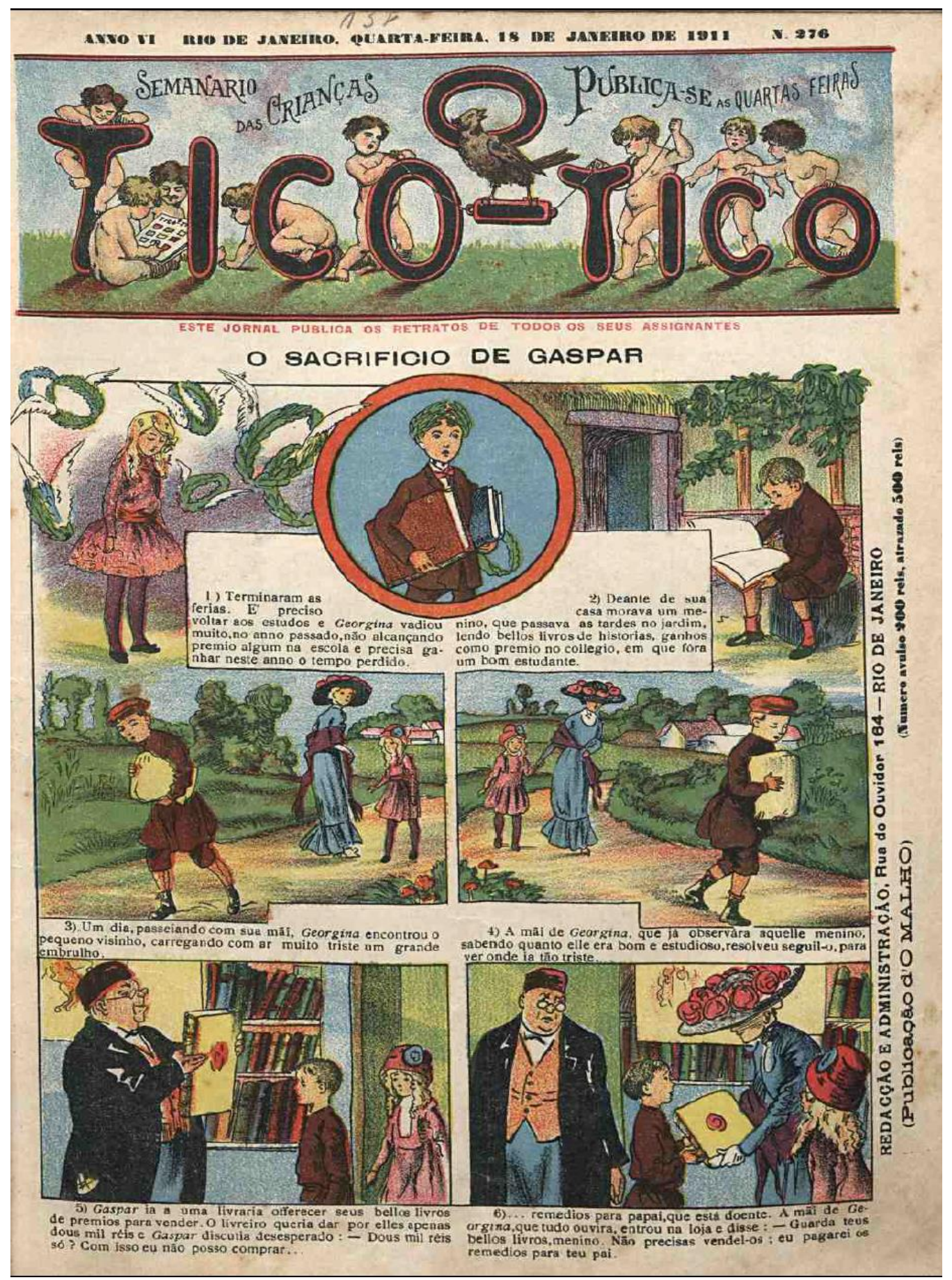

Figura 28 - O Tico-Tico - 18/01/1911-p.1 


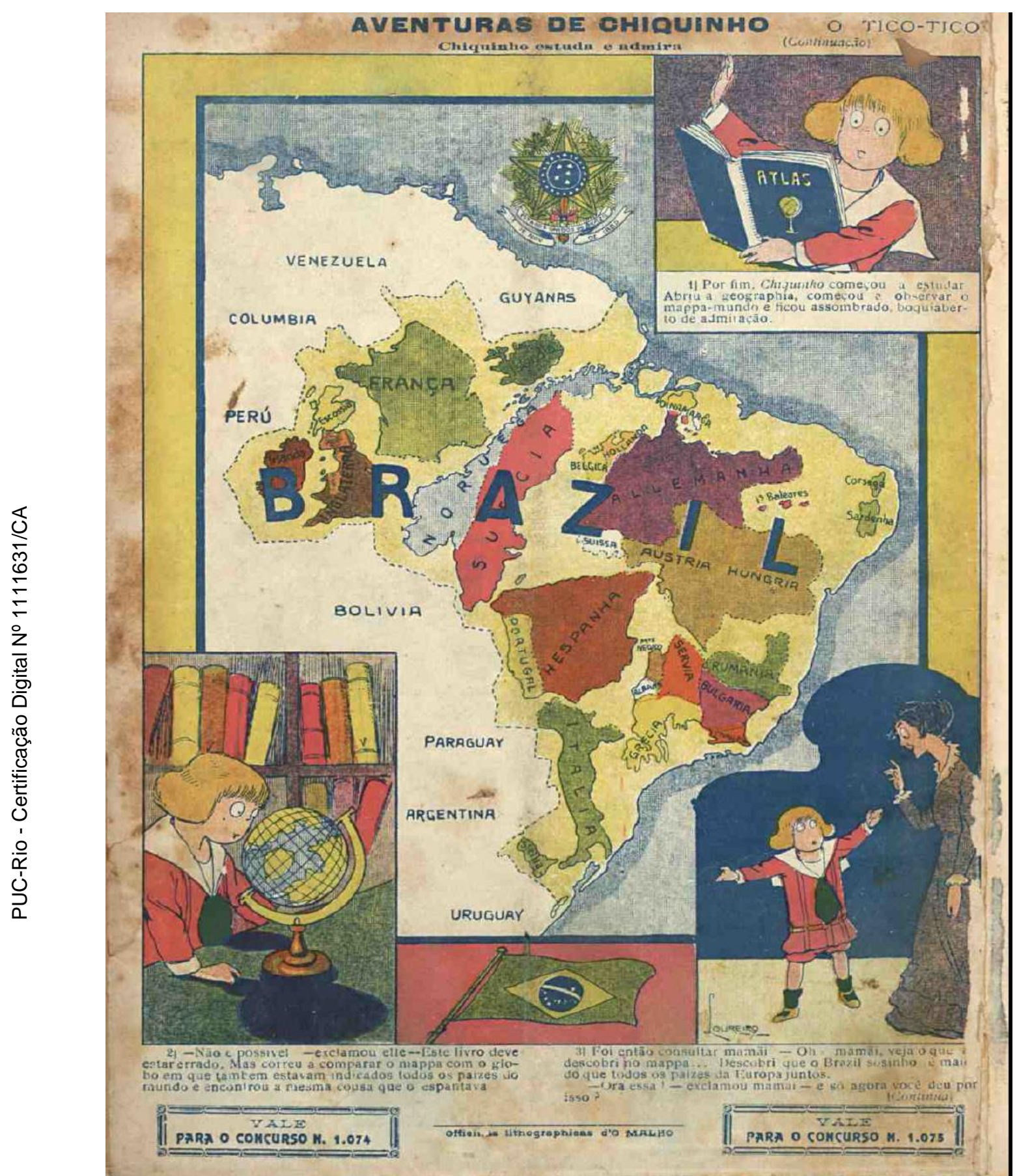

Figura 29 - O Tico-Tico-29/03/1916 - s/p 


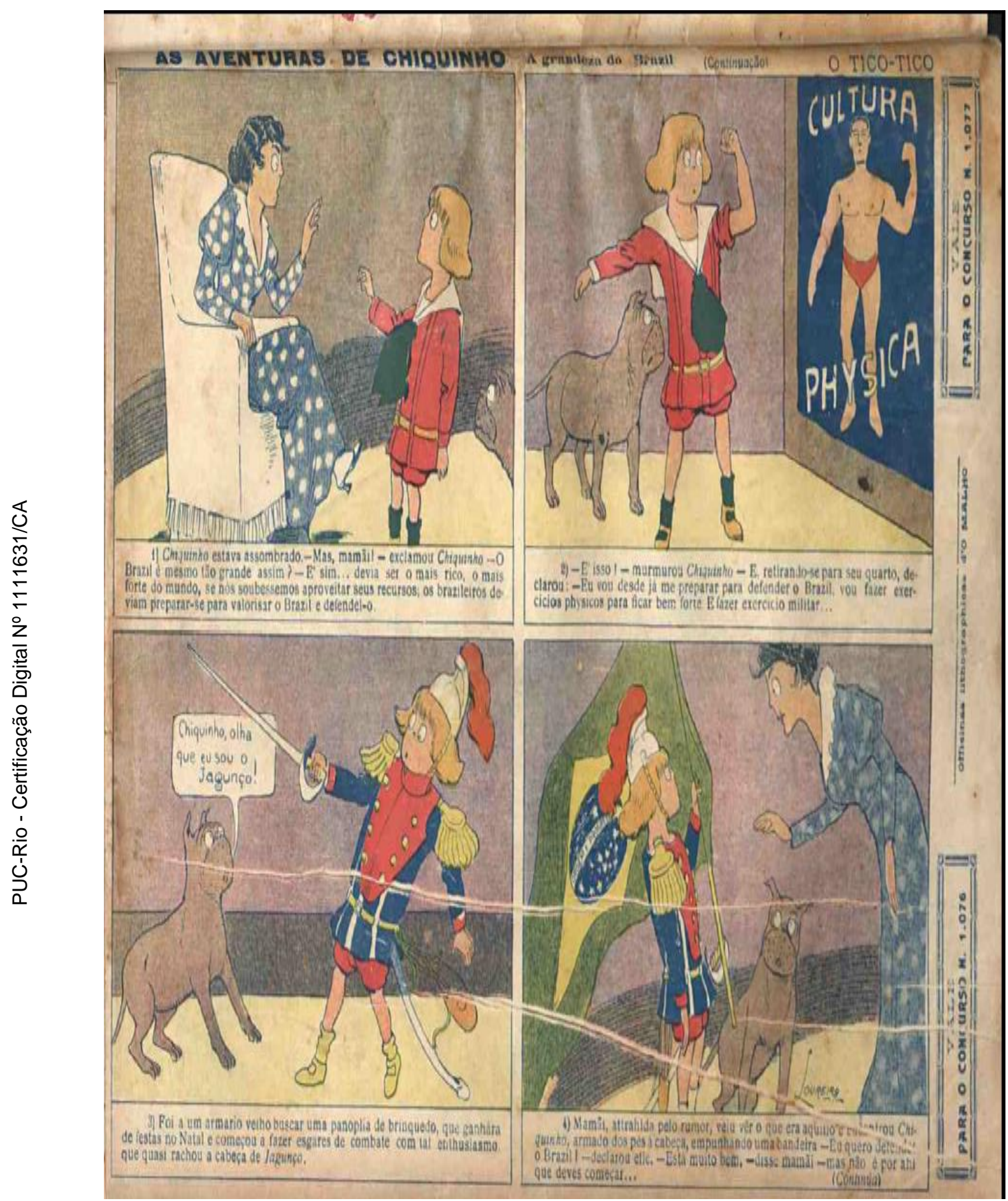

Figura 30 - O Tico-Tico - 05/04/1916 - s/p 


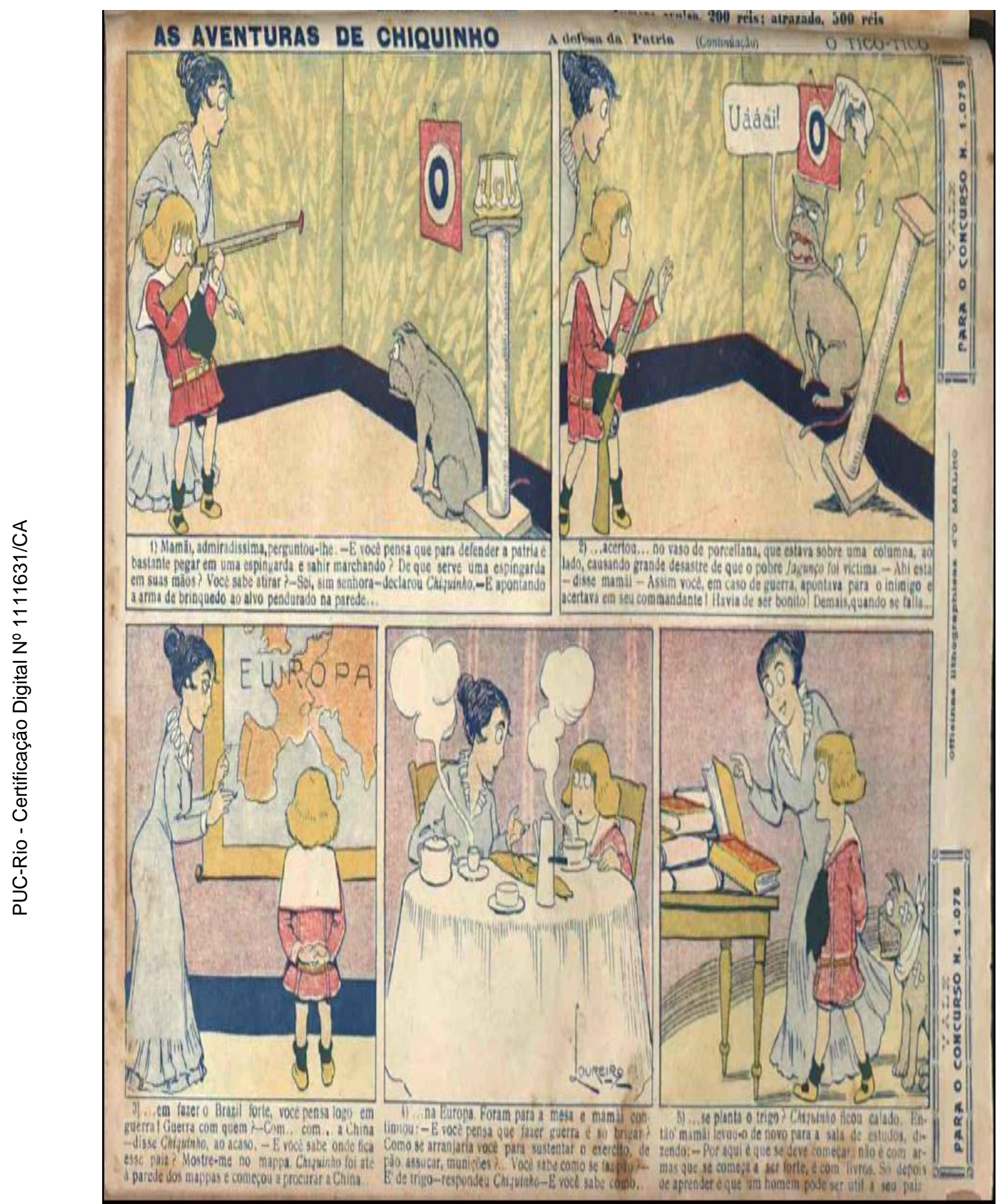

Figura 31 - O Tico-Tico - 12/04/1916 - s/p 


\subsection{As gentis leitoras de O Tico-Tico}

Em 16 de setembro de 1905 foi publicado em $O$ Malho um anúncio referente ao lançamento de $O$ Tico-Tico, no qual foram apresentava as regras de participação do primeiro concurso da revista intitulado $O$ que é que o menino quer ser? De acordo com as instruções, só poderiam mandar soluções crianças do sexo masculino com até 12 anos. Eles deveriam usar em suas redações o título $O$ que еи quero ser, e dissertar acerca dos seguintes aspectos: qual profissão gostariam de ter e apontar os motivos e as razões para a escolha de determinada profissão. Ao vencedor seria pago um prêmio de $100 \$ 000$ réis. As condições previam:

As respostas serão curtas, não podendo occupar mais que uma página de papel almasso: as que excederem uma pagina de papel almasso não serão acceitas. As respostas devem ser enviadas a nossoescriptorio até o $30 \mathrm{do}$ mez corrente, e devem trazer as verdadeiras assignaturas dos respectivos autores, a idade e o logar onde moram.É claro que nem os pais, professores ou quaesquer outras pessoas devem intervir nessas respostas, pois quem, por exemplo, preparasse ou emendasse a resposta dum menino não só desvirtuaria o intuito do concurso como praticaria um acto de falsidade que por si só, influiria pessimamente na moral do menino.Deixem os meninos responder inteiramente em conformidade com seu espírito e aspirações. A primeira virtude deste concurso estará nisso: desde logo o menino, dizer o que deseja ser, e pela maneira por que o disser, revelará suas tendencias, seu animo, seu valor. Desde logo o menino retratará o homem que guarde em si. E ao fim deste concurso, a que esperamos que concorram conforme as profissões mais desejadas, já nós poderemos calcular o que será o Brasil de amanhã, já poderemos prever si essa nova geração que ahi vem apontando terá a seiva e os ideais capazes de conduzirem esta grande patria ao futuro que sonhamos brilhante. Como vêem, trata-se de um concurso interessantíssimo (s/p).

Em uma leitura inicial, pode-se pensar que O Tico-Tico é uma revista voltada a formação apenas dos meninos. Acerca do concurso, a não participação feminina pode estar vinculada a perspectiva de que a mulher deveria apenas se preocupar com o casamento e a administração do lar. Assim, elas não poderiam enviar respostas sobre futuras profissões. Como afirma texto publicado na edição do $O$ Malho de 22 de setembro de 1905 sobre o referido concurso: "O pequenino bello sexo que não se magôe nem vá agora ficar maguado ou fazer pirraça. Para esse bello sexo, ainda em botão, abriremos muitos concursos depois” (p.13). 
Na edição inaugural de $O$ Tico-Tico foi publicado o Concurso n.2: AliBabá. Meninos e meninas tinham que recortar imagens de dez palhaços desenhadas em diferentes posições. Depois deveriam organizá-las e e formar a palavra Ali-Babá. O regulamento prevê: "Um premio de $10 \$$ será concedido ao menino ou menina que nos enviar até, o dia dez do mez próximo, a solução mais elegante" (O TICO-TICO, 11/10/1905, s/p).

Outro aspecto que ressalta a preocupação da revista também para com suas leitoras foi um artigo, em alusão aos seus 50 anos de circulação, publicado na própria $O$ Tico-Tico. $\mathrm{O}$ texto faz menção à importância do impresso na formação de diversas gerações de crianças brasileiras. No tocante à descrição dos objetivos alcançados, as meninas são citadas como parte integrante da revista:

\begin{abstract}
Nos cinquenta anos referidos, O Tico-Tico tudo fez, tudo empreendeu para amenizar a vida dos meninos e meninas de nossa terra. Promoveu certames grandiosos que foram oficializados pelos Govêrnos, lançou séries e séries educativas, lançou Albuns Patrióticos, publicou páginas de armar, lindos Presépios que foram disputadíssimos pelos leitores, promoveu festas, ofereceu ensejo de seus leitores irem a cinema, ofereceu histórias bonitas, criou uma Biblioteca Infantil que editou livros de escritores de renome, lançou um "Almanaque" - o querido" Almanaque d'O TICO-TICO" - que há quase cinquenta anos vem, também, interruptamente, alegrando o Natal de toda a garota do Brasil...e, de par com tudo isso, deu bons conselhos, divulgou os mais belos exemplos de aplicação ao estudo, de heroísmo, de patriotismo, de firmeza de caráter, de hombridade, de bondade, de piedade cristã, mostrando aos que liam e o lêem que o homem deve ser reto, bom justo, piedoso, integro, caritativo, religioso, para ser um verdadeiro HOMEM DE BEM (O TICO-TICO, 10/1955, p.19).
\end{abstract}

Pode-se inferir que a expressão Homem de Bem esteja inserida em uma perspectiva generalista e não de caráter excludente. Ao longo de suas edições, a revista publicou, de forma corriqueira, conteúdos destinados às meninas. "Coerentes com a missão da revista, buscavam, também em relação às matérias dirigidas às meninas, atender ao tripé 'recrear, informar e formar" (VERGUEIRO, Op.cit., p.177). As histórias costumam trazer meninas como protagonistas. Em Gulosa, mas boa companheira, a figura principal é Brazilina. A menina comilona teve uma indigestão por não dividir seus doces com as colegas de escola. A gula, não por acaso um dos sete pecados capitais, é prejudicial à saúde. Somente após o sofrimento ela compreendeu que seu comportamento mesquinho a afastava das amizades verdadeiras (Fig.32). 

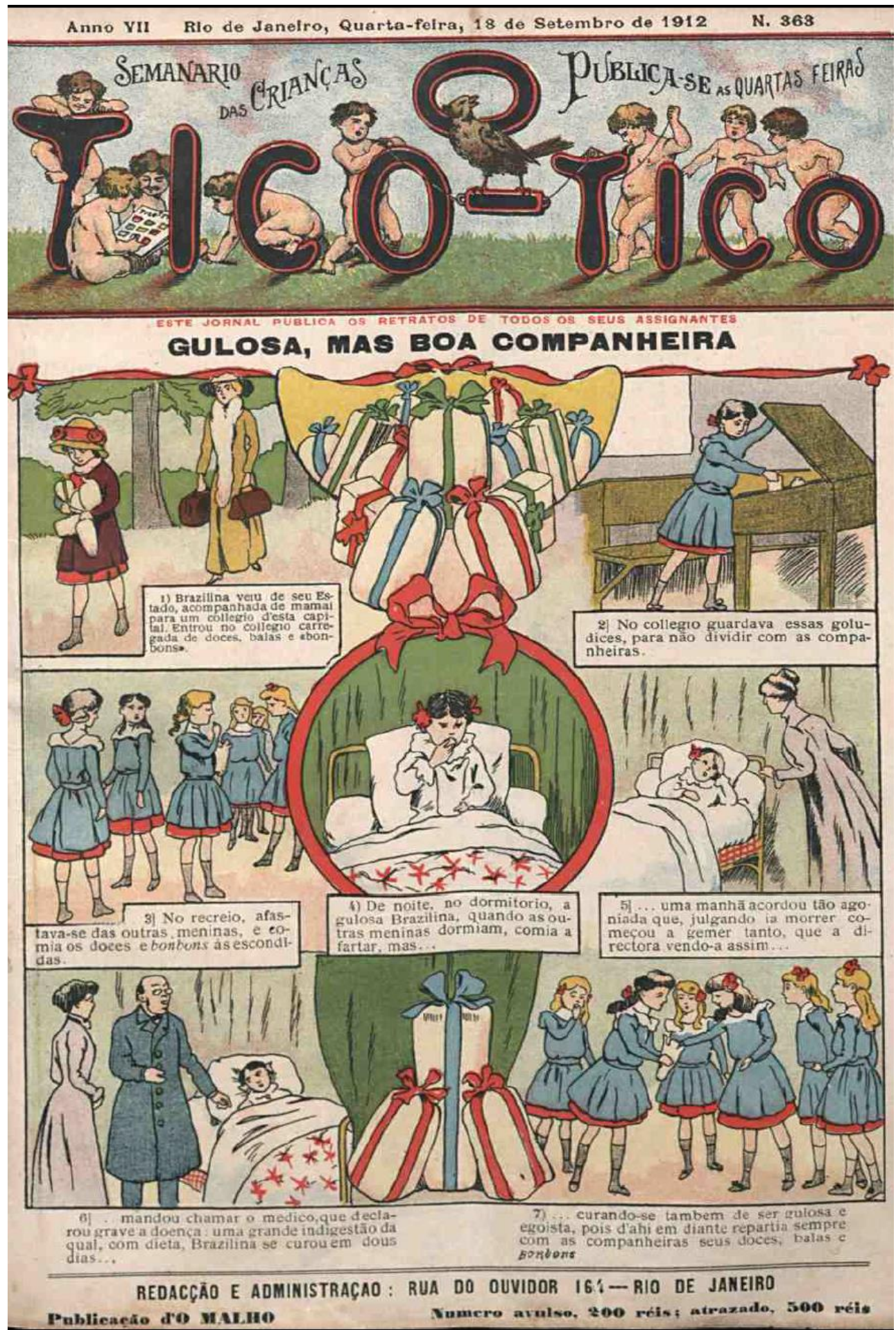

Figura 32 - O Tico-Tico- 18/09/1912-p.1 
Com o passar das décadas, a publicação ampliou os conteúdos dedicados ao público feminino. Criaram-se seções destinadas especialmente a elas: Secção para meninas, Secção para nossas leitoras, Figurinos para nossas leitoras, Para nossas leitoras e outros espaços. Mesmo nas seções direcionadas aos leitores em geral algumas edições privilegiam diversões consideradas próprias às meninas. Exemplares de Páginas de armar trazem bonecas de papel e roupinhas para serem montadas pelas leitoras (Fig.33).

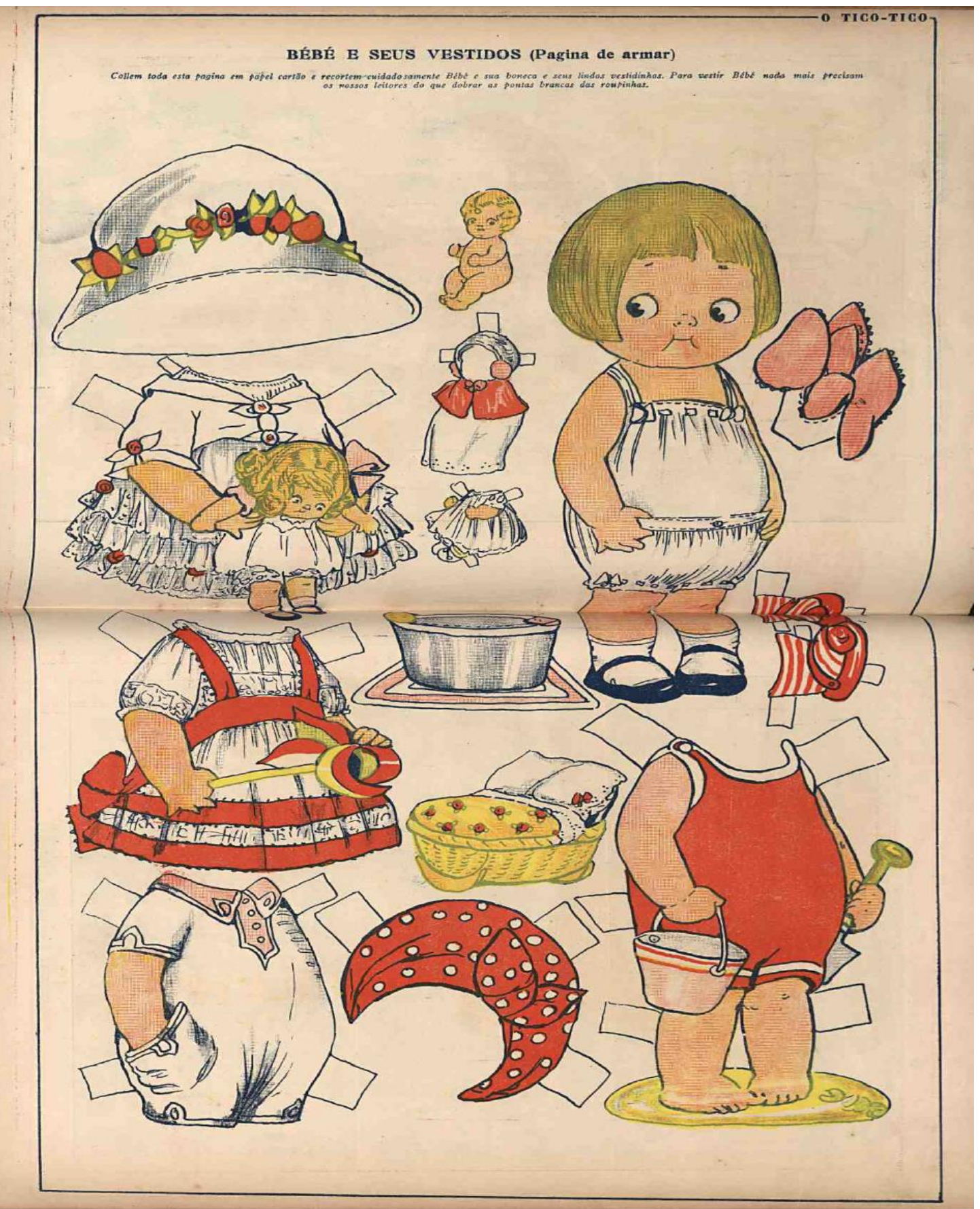

Figura 33- O Tico-Tico-05/11/1919-s/p. 
No tocante a relação de $O$ Tico-Tico e o sexo feminino, é preciso ressaltar a proximidade do impresso brasileiro e da revista La Semaine de Suzette. A publicação francesa, lançada pela editora Gautier-Languereau em 2 de fevereiro de 1905 , direcionava-se às meninas e às jovens, de 8 a 14 anos, pertencentes às famílias burguesas. Tinha-se o objetivo de promover a formação moral e religiosa de suas leitoras. A criação do impresso constituía-se em uma resposta à campanha em favor da Lei de Separação do Estado e a Igreja, promulgada posteriormente em 9 de dezembro de 1905. Diferencia-se de O Tico-Tico por ter mulheres na função de chefe da redação ${ }^{46}$. Os exemplares eram vendidos sempre às quintasfeiras. Os conteúdos abarcam poesias, jogos, concursos, narrativas ilustradas, peças de teatro, receitas de cozinha e moldes para costura. Entre as personagens mais conhecidas estão: a menina Suzette, a boneca Bleuette e a camponesa Bécassine. La Semaine de Suzette esteve em circulação até 1960. Nos 55 anos de funcionamento, Bécassine, a jovem que vivia na região da Bretanha, é a personagem de maior sucesso. ${ }^{47}$ Algumas de suas narrativas foram traduzidas e publicadas em $O$ Tico-Tico. No Brasil, as histórias receberam o título de Aventuras de uma criada, e Bécassine passou a se chamar Narcisa. Em algumas edições ela também foi nomeada Felismina (COUDERC, 2005; LUYTEN, Op.cit.; CAGNIN, Op.cit.; SANTOS, 2012) (Fig.34) (Fig.35).

\footnotetext{
${ }^{46}$ Destacaram-se neste cargo, as jornalistas Jacqueline Rivière e Madeleine-Henriette Giraud.

${ }^{47}$ Ashistórias de Bécassine eram desenhadas por Joseph-PorphyrePinchon (1871-1953). Posteriormente, esta função ficou sob a responsabilidade de Maurice Languereau (1867-1941). O sucesso da personagem foi tanto que resultou na venda publicações próprias como: L'Enfance de Bécassine (1913), Bécassine pendant la Grande Guerre (1914) e muitos outros títulos. Cf.: SANTOS, Armando Alexandre dos. Bécassine, a primeira heroína em HQ. In: VI Simpósio Nacional de História Cultural: Escritas da História - ver, sentir, narrar, 1., 2012, Teresina-PI. Anais... Teresina: Universidade Federal do Piauí-UFP, 2012.
} 


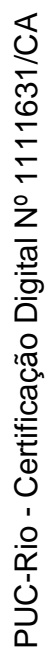

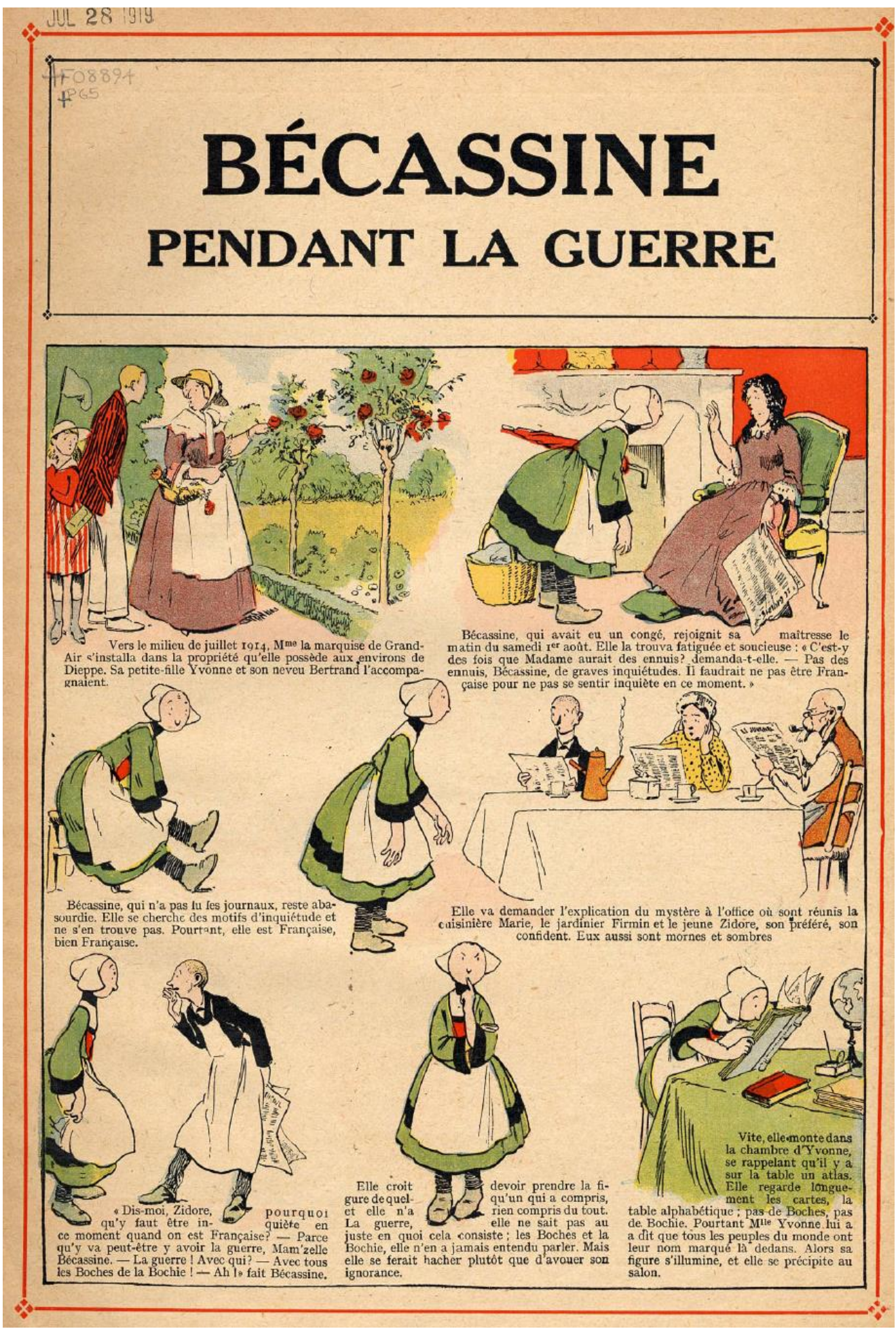

Figura 34 - Bécassine pendant la Guerre-28/07/1919 - s/p. 


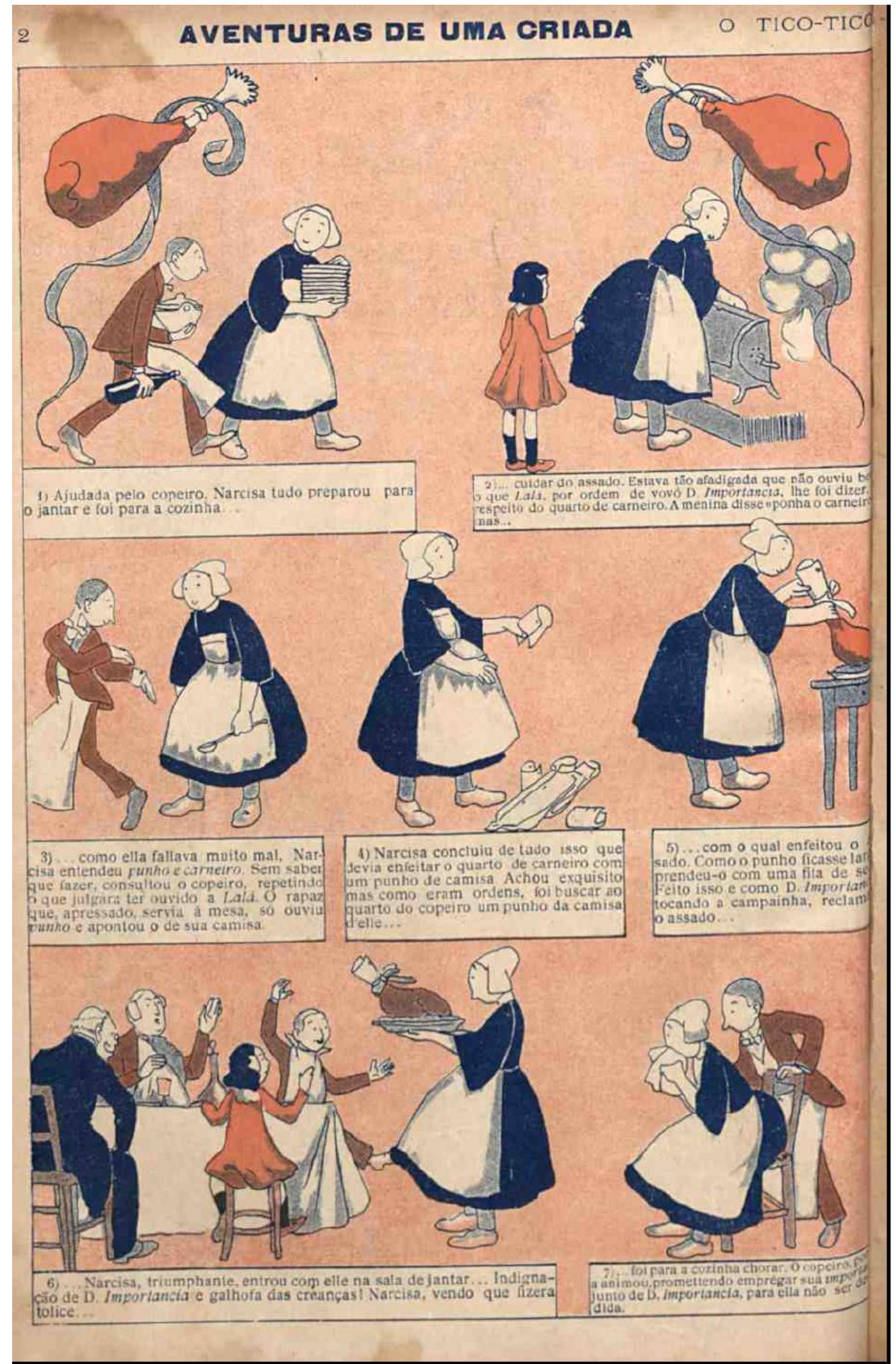

Figura 35- O Tico-Tico - 18/12/1912- p.2 
Para além das narrativas de Bécassíne, O Tico-Tico também reproduzia outros conteúdos de La Semaine de Suzette, como pode ser observado nos quadrinhos a seguir. $\mathrm{O}$ primeiro pertence à edição inaugural da revista francesa (Fig.36) e o segundo ao impresso brasileiro (Fig.37):

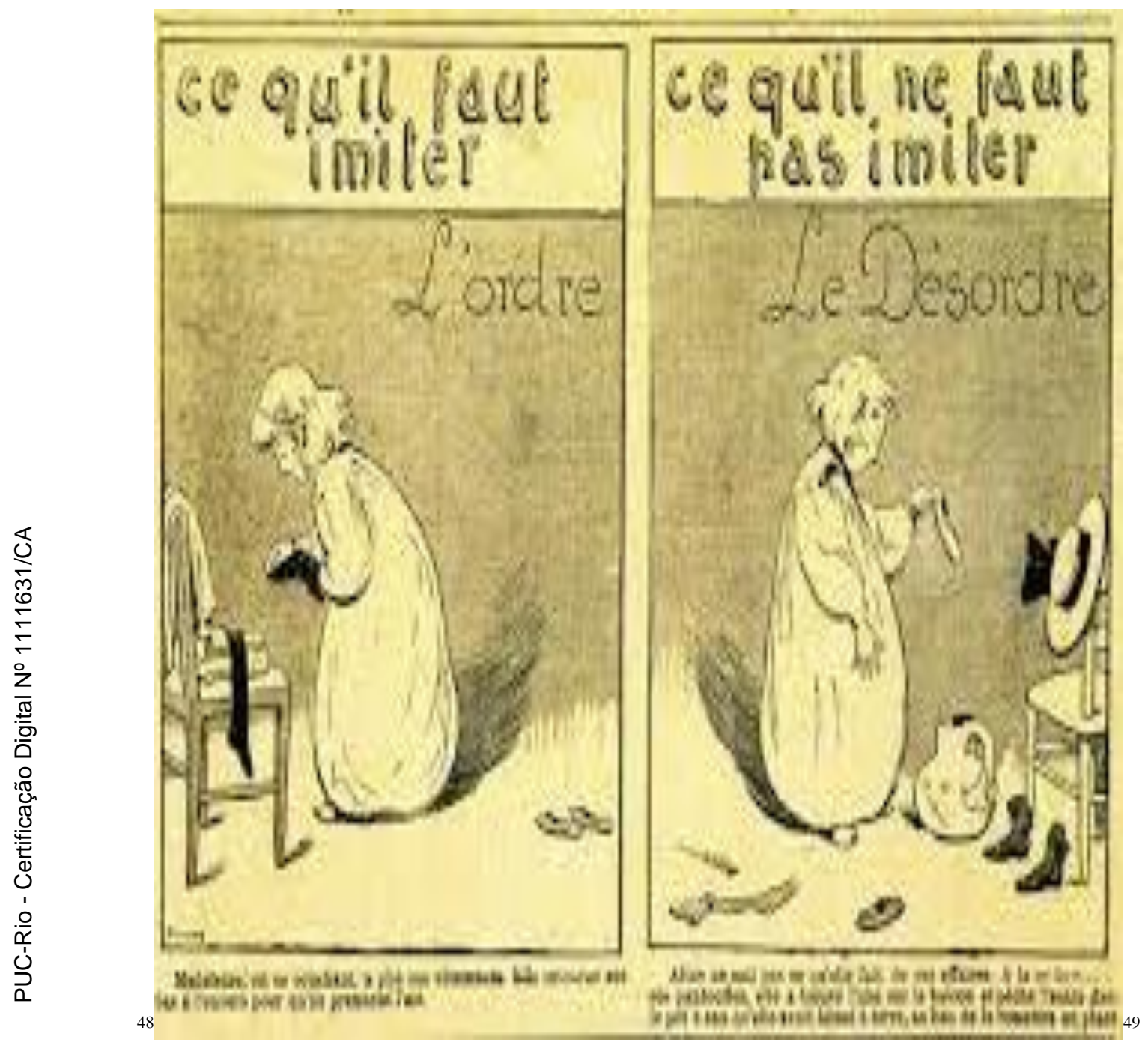

Figura 36 - La Semaine de Suzette - 02/02/1905 - s/p

\footnotetext{
${ }^{48}$ Legenda: Ce qu'il faut imiter L'ordre. Madeleine em se couchant a plié sés vêtements. Elle retourue sés bas à l'envers pour qu'ils prennent l'air.

${ }^{49}$ Legenda: Ce qu'il ne faut pas imiter L'ordre.Aline ne sait pas ce qu'elle fait de ses affaires. A la rechers ses pantouffes, elle a trouvé l'une sur le balcon et péche l'autre dans le pot à eau qu'elle avait laissé à terre, au lieu de le remettre en place.
} 


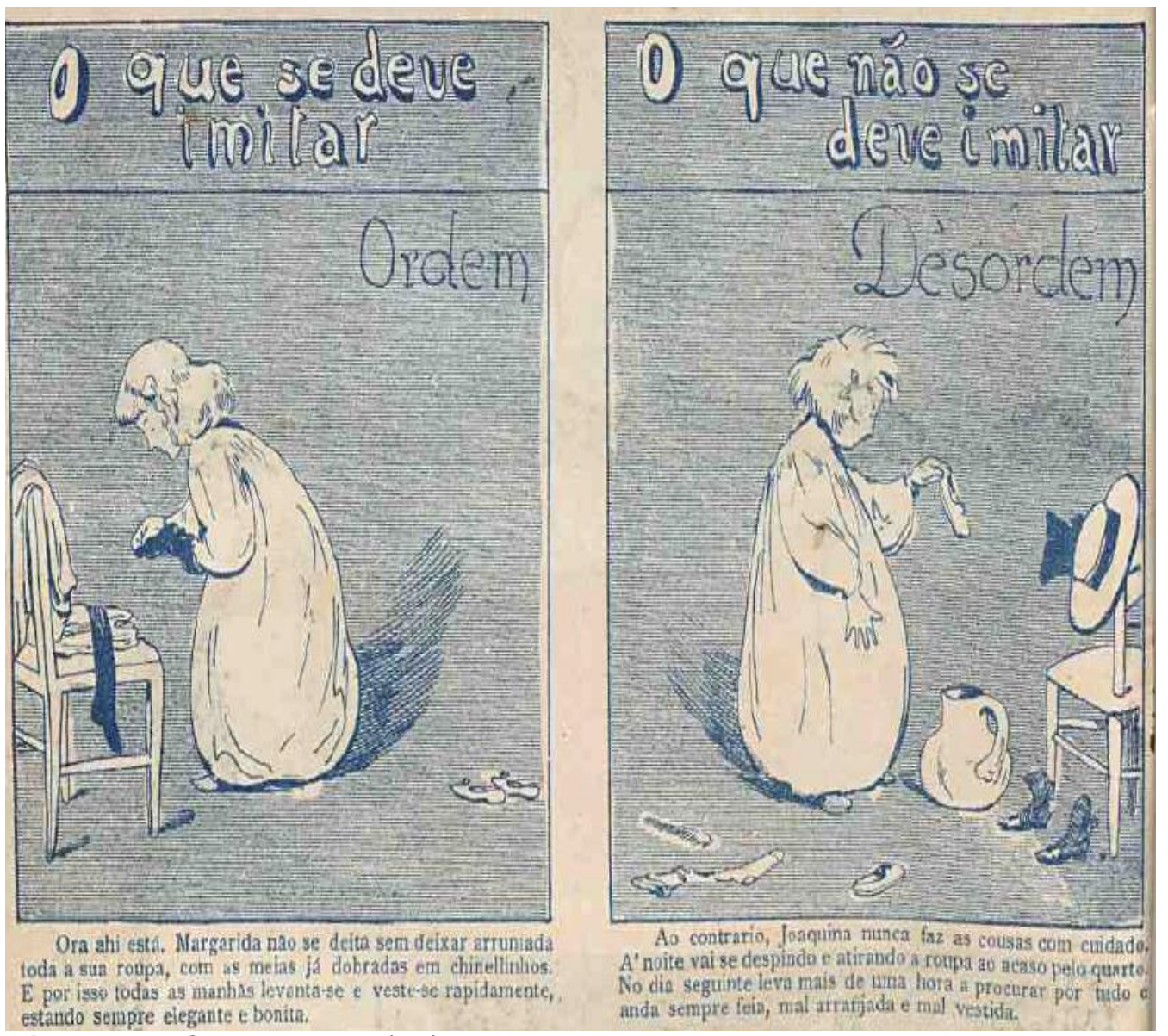

Figura 37 - O Tico-Tico -01/05/1907-p.2

Na versão publicada em $O$ Tico-Tico não houve qualquer alteração das imagens, embora os nomes das personagens tenham sido alterados: Madeleine passou a se chamar Margarida enquanto Aline virou Joaquina. Em L'ordre, ou Ordem, Margarida é apresentada como uma menina elegante e bonita, pois é cuidadosa e tem o hábito de organizar o quarto antes de dormir. Além de estar sempre arrumada e com os cabelos penteados. No tocante à Le Dèsordre, ou Dèsordem, Joaquina é descrita como feia e desleixada, pois não tem a preocupação com seus pertences e com a própria higiene pessoal.

Observa-se que tais narrativas eram publicadas no corpo do impresso e eram destinadas à todas as crianças. Era um conteúdo a ser lido pelos pequenos leitores e leitoras. Ambos os gêneros deveriam ter ciência da importância da ordem e da disciplina. Não por acaso, temas presentes no bojo das ações das elites intelectuais brasileiras entre os anos finais do século XIX e as primeiras décadas do século XX. 


\section{3. \\ O Tico-Tico e o Bello Sexo: uma questão de gênero}

A revista $O$ Tico-Tico de 28 de março de 1906, publicou o resultado do Concurso n.28 - Um passeio de baixo d'água. Na atividade semelhante a um quebra-cabeça, as crianças tinham que recortar as partes desenhadas e formar as imagens de um peixe e de um sapo. Os vencedores ganhariam prêmios de $10 \$ 000$. Em razão da facilidade, a publicação recebeu inúmeras cartas com a solução correta. Os ganhadores foram decididos por sorteio:

No sorteio entre os que mandaram solução exacta as meninas desta vez passaram a perna nos meninos. A sorte escolheu-as a ellas, mas por certo o pequeno sexo forte é sufficientemente amavel para não se zangar com isso" (p.16).

As expressões utilizadas para justificar a sorte das leitoras, suscitaram questões sobre as relações de gênero presentes $O$ Tico-Tico: Se os meninos eram o pequeno sexo forte, as meninas eram o pequeno sexo frágil? Quais eram os padrões sociais considerados femininos e masculinos? De que modo tais modelos sociais se traduziam no comportamento das personagens femininas e no conteúdo das seções informativas?

Segundo Priore (Op.cit.), as expressões sexo belo e sexo frágil foram forjadas pelo pensamento científico com o intuito de consolidar os parâmetros de inferioridade do corpo feminino. Posteriormente, estas adjetivações romperam as barreiras dos compêndios médicos e emergiram como categorias no mundo social:

Cristalizada pela forma de pensar de uma sociedade masculina, a evocação de imagens do corpo e da identidade feminina, na pluma de diferentes autores, refletia apenas subordinação: ele era menor, os ossos pequenos, as carnes moles e esponjosas, o caráter débil (p.177).

Para Chartier (1995), a suposta superioridade dos homens frente às mulheres foi construída pela por meio da legitimação social. O discurso médico atestava cientificamente a "diferença sexual (que é sujeição de umas e dominação de outros)" (p.43). Cita a categoria violência simbólica ${ }^{50}$, cunhada por Pierre Bourdieu, para a compreensão do processo de internalização das representações femininas como indivíduos menores.

${ }^{50}$ Cf.: BOURDIEU, P.. O poder simbólico. Rio de Janeiro: Bertrand Brasil, 2004. 
No capitulo Amando do livro Trabalho, Lar e Botequim, Sidney Chalhoub (2001) ressalta a influência do conhecimento científico na conformação dos papéis sexuais de homens e mulheres, definidos pela ótica burguesa das elites do Rio de Janeiro do início do século XX. Chalhoub cita o estudo de Jurandir Freire Costa (1979) sobre as teses defendidas na Faculdade de Medicina, Rio de Janeiro e Bahia, no século XIX. Costa pesquisou os discursos da diferença sexual centrados nas análises das características anatômicas. Os trabalhos acadêmicos visavam compreender como cada um dos sexos lidava com seus sentimentos. Em razão da fragilidade física, as mulheres foram descritas como delicadas e dóceis. Os homens foram caracterizados como indivíduos viris:

Criatura fraca por natureza, as principais virtudes femininas passam a ser a sensibilidade, a doçura, a passividade e a submissão. (...) O homem ao contrário, caracterizava-se pelo vigor físico e pela força moral. Dominado pela sua virilidade, o homem amava menos que a mulher e seu interesse estava mais voltado para o gozo puramente sensual. O homem era mais seco, racional, autoritário e duro (CHALHOUB, Op.cit., p.178).

As oscilações hormonais e o período menstrual também foram vistos como sinais da inferioridade do sexo feminino:

Esse discurso de que a mulher é frágil, possui instável humor por causa da menstruação, delicada, era uma forma de fazer com que a desigualdade entre homens e mulheres fosse mantida e muitas vezes agravada. Por isso, o trabalho fora do lar não lhe era considerado adequado (PERROT, 2005., p.177-178).

Estes discursos impuseram às mulheres, a prescrição do espaço privado do lar e a proteção do marido, como os remédios ideais para garantir o bem-estar feminino. Reforçavam a existência de relações dicotômicas e assimétricas entre os sexos. Representações que ganharam força na literatura e na imprensa. Como demonstra o trecho do artigo A missão da mulher escrita por Gina Lambroso Ferrero para a Revista Feminina, edição de abril de 1920:

As tradições e os exemplos, a educação, os ideaes moraes servem de estimulo para manter homens e mulheres em suas missões predestinadas; os homens é a celebridade que os contemporâneos e os posteros adjudicam a quem alcança a perfeição relativa - e, nas mulheres - o amor com que cobrem os ideaes mais bellos, e no carinho com que espalhem seu consollo moral e intellectual a todas as que não foram bafejadas pela sorte e aos seus filhos. (...) Involuntariamente, os homens das classes superiores que não fazem do accumulo da riquesa a sua finalidade, procuram aquellas carreiras que lhes pódem dar celebridade, ainda prestigio. Dobrada é, pois, a missão da 
mulher superior; ella será seu guia nessa conquista e seu premio e sua consoladora amiga durante as desilusões dos seus companheiros (s/p).

O conteúdo destaca os papéis sociais distintos, porém complementares de homens e mulheres. Aos maridos estava destinado o mundo do trabalho e a admiração pública. E às esposas? Ajudá-los a concretizarem seus desejos e vontades. Como? Dando-lhes o suporte emocional necessário para cumprirem suas jornadas. Se eles falhassem? Elas estariam prontas a apoiá-los. Se eles conseguissem? Elas saberiam que tinham cumprido o seu papel. Afinal, que atrás de um grande homem existe uma grande mulher.

Havia diferentes representações das mulheres em circulação na sociedade brasileira: as liberais, as tradicionais, as recatadas, as do lar e as da rua. Enfim, uma pluralidade de modos e jeitos de se exercer a condição feminina. No entanto, diante de uma sociedade conservadora, determinados modelos eram vistos como tipos ideais e outros como tipos desviantes.

Em Mulheres de estampas: o folhetim e a representação do feminino no Segundo Reinado, Oliveira (2001) define este gênero literário como a narrativa usada pelos escritores românticos para descrever os medos, as angustias e a luta da mulher para se constituir em um indivíduo, interna e socialmente, moderno. As personagens femininas são metáforas da sociedade que abandonava as características provincianas em prol de uma modernidade inspirada nos padrões europeus. Por este motivo, as heroínas estavam prontas a romper com os comportamentos pré-estabelecidos. O autor José Alencar não se furtou em escrever Lucíola (1862) e Senhora (1875) cujas protagonistas eram, respectivamente, uma prostituta e uma mulher que por vingança 'compra' o marido.

O folhetim contempla diversas representações femininas: as mulheres cultivadas caracterizadas como "mulheres de espírito", as mulheres naturais descritas como "seres frágeis e incapazes de dirigir suas vidas, tendo a necessidade imperativa de um provedor", as mulheres casa que "obedeciam aos seus maridos, davam lhes sexo obrigatório, comida de graça e filhos que lhes garantiam posteridade" e as mulheres livres ou da rua que "Assemelhavam-se aos homens, buscando prazer através do sexo, buscando livrar-se da maternidade como dever e não como escolha e prazer" (Ibidem, p.163-164). 
No livro A Formação das Almas, Carvalho (Op.cit.) exemplifica a relação de amor e ódio da imprensa com o regime republicano. Periódicos de grande circulação, como $O$ Malho, publicavam capas e caricaturas críticas aos rumos tortuosos da política nacional. A representação feminina da República inspirada em Marianne, símbolo da França republicana, era um dos alvos preferidos. A figura etérea vestida com uma longa túnica branca ganhou traços de uma mulher sem moral e escrúpulos ${ }^{51}$ (Fig.38):

(...) bem depressa os caricaturistas passaram a usar a figura feminina para ridicularizar a República. (...) A virgem ou mulher heróica dos republicanos era facilmente transformada em mulher da vida, em prostituta (p.87).

Os conteúdos publicados em O Tico-Tico tinham como referências, as representações calcadas na definição da mulher como alguém devotado à maternidade, ao casamento e ao lar. Outros modelos femininos também estavam presentes nas páginas da revista infantil, mas havia a preocupação de combatê-los via conselhos, histórias e discursos de cunho moralizador. Apostava-se no humor como forma de ridicularizar os anseios libertários femininos de personagens como Faustina.

\footnotetext{
${ }^{51}$ No artigo Alegorias femininas da República: a campanha republicana e os periódicos ilustrados no Rio de Janeiro, Aristeu Elisandro Machado Lopes se refere ao fato de José Murilo de Carvalho apontar que o mundo das artes foi mais resistente ao uso da figura feminina como alegoria do movimento republicano. Entre as razões apontadas, identificou-se que os pintores atuantes, no período posterior à Proclamação da República, tinham se formado nas escolas de arte do Império. Lopes afirma que o mesmo fenômeno não se repetiu nas publicações ilustradas. Desde a década de 1870, havia registros de representação femininas do novo regime político. LOPES, A.E.M.. Alegorias femininas da República: a campanha republicana e os periódicos ilustrados no Rio de Janeiro. In: KNAUSS, P.; et.al. (Org.). Revistas Ilustradas: modos de ler e ver no Segundo Reinado. Rio de Janeiro: MAUAD X; FAPERJ: 2011, p.141-155.
} 


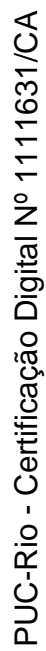

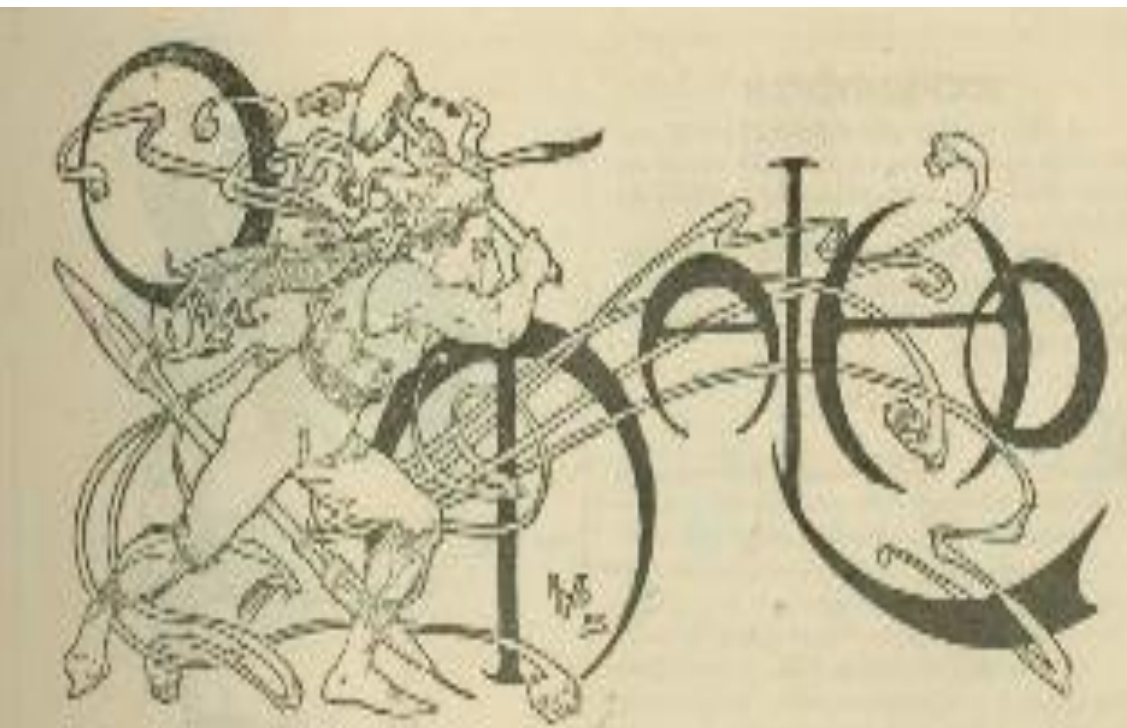

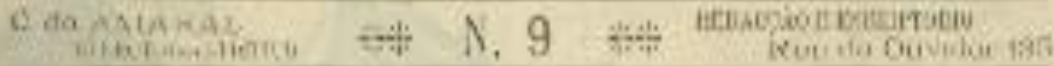

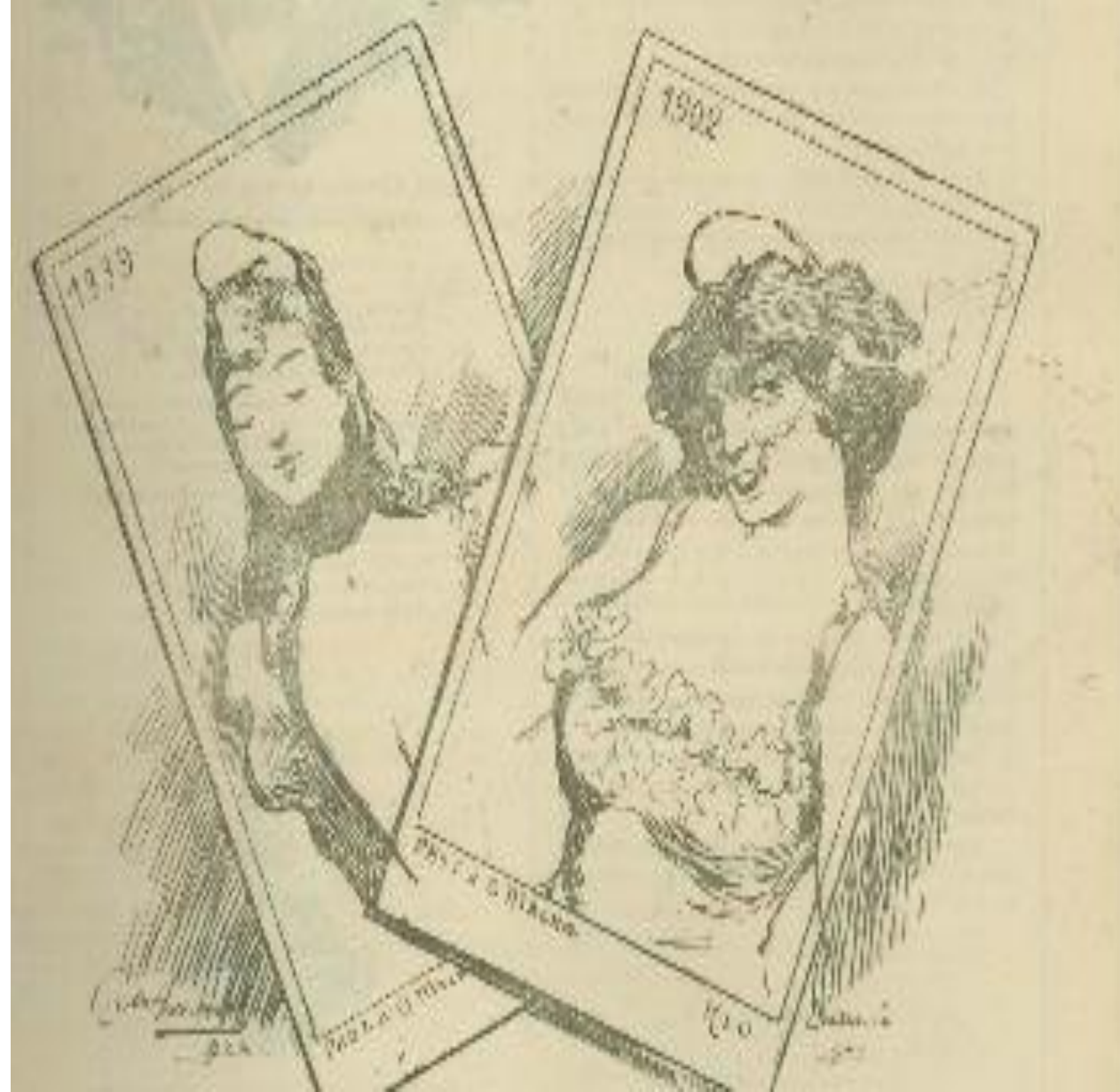

Figura 38 - O Malho - 15/11/1902 - s/p. Autor: C. do Amaral 


\subsection{Páginas em defesa da futura mãe e esposa}

No exemplar, de 3 de fevereiro de 1909, foi publicado o informativo Uma conferência infantil cujo conteúdo é o texto intitulado $A$ mulher perante a sociedade moderna. Uma transcrição do discurso proferido pelo menino Renato Nogueira, de 12 anos, em 24 de dezembro de 1908, durante a estadia na fazenda de seu pai, o Tenente Eduardo Nogueira, localizada na cidade de Cravinhos, interior de São Paulo.

\section{A MULHER PERANTE A SOCIEDADE MODERNA}

Minhas senhoras e meus senhores - Como quanto seja ainda muito cedo para tomar parte no movimento de progresso - que se manifesta por toda a parte, nestes tempos em que a humanidade caminha com passos de gigantes para alcançar o seu ideal, eu não posso ficar indifferente...Permitti que eu saia do meio destes pés de café para ter a ousadia de vos dirigir a palavra...O assumpto que escolhi para minha palestra: A mulher perante a sociedade moderna, é um assumpto que deveria ser tratado por uma intelligencia mais desenvolvida. [...] A mulher na actualidade esta destinada a fazer a felicidade, não só de um homem, como das nações!...A mulher mãi é o mais sagrado dos destinos... O' homem, quem és tu? de onde vens, para onde vais?

\section{A mulher esposa}

Qual de vós podeis negar que a esposa, a escolhida do vosso coração não é o manancial de gozos e de consolações?!!...Não podeis negar a influencia da mulher na sociedade moderna. Ella influencia sobre o bem, sobre a felicidade da familia e das nações. Ella é pela natureza, encarregada pela educação do homem, por isso que, recebendo-o n'um estado de innocencia e ignorância, ella ensina a balbuciar a primeira lettra d'esse grande alphabeto!!! O gráo de civilisação dos povos se marca pelo valor da mulher entre elles...[...] Mas ah! é preciso convir, império da mulher, ahi é que ella mais se distingue; o seu fim principal é dar cidadão ao mundo e mãis verdadeiras á humanidade.(...) (p.6).

O vocabulário rebuscado e a estrutura elaborada, estabeleceram questionamentos quanto a sua real autoria do texto. Um menino de apenas 12 anos poderia ter escrito aquele discurso? O garoto apenas leu o discurso feito por um adulto? A autoria foi creditada a uma criança apenas para que o texto pudesse sair em $O$ Tico-Tico? No entanto, não foram publicadas informações complementares sobre o evento ou o suposto autor.

Apreende-se a existência de um discurso vinculado à representação da mulher com alguém dotado da aptidão para ser mãe. Ela carrega sob os ombros a responsabilidade de criar cidadãos que possam contribuir para o engrandecimento 
da nação. A categoria mulher-mãe-esposa se torna o padrão feminino por excelência.

Segundo Camara (2013), este modelo fora amplamente difundido entre as décadas finais do século XIX e início do século XX. Estava vinculado à perspectiva da família como um dos eixos de sustentação da República. A escola era o espaço oficial da formação intelectual e cívica, mas é no seio familiar que meninas e meninos deveriam formar seu caráter. O lar era um dos fronts do de ação dos defensores de uma nação moderna e civilizada.

Como célula reprodutora, ela produz as crianças e proporcionalhes uma primeira forma de socialização. Garantia da espécie, ela zela por sua pureza e saúde. Cadinho da consciência nacional, ela transmite valores simbólicos e a memória fundadora. A "boa família" é o fundamento do Estado e, principalmente para os republicanos (PERROT, Op.cit., p.91).

Para D’ Incao (2009), a ascensão burguesa à condição de classe dirigente, instituiu um processo de reorganização "das vivências familiares e domésticas, do tempo e das atividades femininas; e por que não, a sensibilidade e a forma de pensar o amor" (p.223). O crescimento e a modernização das cidades, com destaque para o Rio de Janeiro, estabeleceram novos padrões de comportamento. “(...) toda a sorte de expressões locais e de relações sociais que não fossem consideradas civilizadas eram combatidas pela imprensa e proibidas por lei" (Ibidem.,p.226). As moradias também se modificaram e por consequência, relações familiares. As casas passaram a ser isoladas e não mais pertencentes a lotes comunitários. O convívio entre os vizinhos se tornou mais distante. Cada vez mais, as famílias passam a contar apenas com seus próprios membros. $\mathrm{O}$ processo de interiorização do lar, acarretou na necessidade de dividir os espaços de atuação entre cada um de seus componentes. Coube à mulher, a tarefa de cuidar do lar $\mathrm{e}$ dos filhos, e ao homem o papel de provedor e a inserção no mundo do trabalho.

A valorização da família nuclear resultou na instituição da categoria da "família feliz" (CAMPOS,2009, p.9). Este modelo exigia que mães e pais, preenchessem os requisitos idealizados de "esposas afetivas, sadias, belas, instruídas e castas, companheiras perfeitas para um marido também idealizado, laborioso, esforçado, portador de hábitos regrados, enfim” (Ibidem., p.90). Em consonância a tal pensamento, Maluf e Mott (2006) afirmam: “A arquitetura do lar feliz aprisionou homens e mulheres dentro de uma moldura estritamente normativa"(p.382). 
A aprovação do Código Civil, Decreto n ${ }^{\circ} .3017$ - $1^{\text {o }}$ de janeiro de 1916, reforçou a condição da mulher como dona de casa e mãe. Ele instituiu, sob bases jurídicas, os direitos e os deveres de homens e mulheres. No exercício da função marital, o esposo era considerado o chefe da família. Cabia ao homem ser o representante legal dos bens familiares e, dependendo do regime de casamento, dos bens particulares da esposa. A escolha do domicílio também era prerrogativa masculina. O marido tinha o poder de autorizar ou proibir que a esposa trabalhasse e dormisse fora do lar, quando o emprego exigisse tal condição.

\section{E os direitos e deveres da mulher?}

Art. 240. A mulher assume, com o casamento, os apelidos do marido e a condição de sua companheira, consorte e colaboradora dos encargos da família, cumprindo-lhe velar pela direção material e moral desta.

(...)

Art. 247. Presume-se a mulher autorizada pelo marido:

I.Para a compra, ainda a crédito, das coisas necessárias à economia doméstica.

II. Para obter, por empréstimo, as quantias que a aquisição dessas coisas possa exigir.

III. Para contrair as obrigações concernentes à indústria, ou profissão que exercer com autorização do marido, ou suprimento do juiz.

A promulgação do Código Civil de 1916, constituiu-se como um meio formal de garantir à ordem familiar e definir, em bases legais, quais os papéis sociais destinados aos homens e às mulheres. Ratificava uma construção de gênero baseada na existência de relações de poder assimétricas entre os sexos. Mott e Maluf (Op.cit.) apontam esta iniciativa também era uma forma de se defender das mudanças no comportamento feminino que tanto assustavam os conservadores. Segundo Priore (Op.cit.), os conservadores difundiram discursos de culpabilização das mulheres trabalhadoras:

A preocupação era convencer a mulher de que o amor materno era inato, puro e sagrado, e que apenas por meio da maternidade e da educação dos filhos ela realizava sua "vocação natural". Sanear a sociedade por intermédio das mulheres era a meta (p.136).

Em $O$ segundo sexo, Simone de Beauvoir (2009) descreve que “(...) a passividade essencialmente a mulher "feminina"” é construída desde a infância (p.375). Afirma não haver influência biológica neste processo, apenas a ação de pais e educadores que educavam meninos e as meninas de forma distinta. Aos garotos é permitido ousar e experimentar. "A imensa sorte do menino está em que 
sua maneira de existir para outrem encorája-o a pôr-se para si. Ele faz o aprendizado de sua existência para o mundo" (Loc.cit.). Para Beauvoir, eles têm liberdade para subir em árvores e rivalizar com seus colegas, em práticas esportivas, jogos violentos e brigas. Considera-se comum aos meninos, sentirem certo desprezo pelas meninas, pois se veem como sujeitos mais fortes e viris do que elas. Além de não lhes ser permitido, compartilharem socialmente, dos mesmos interesses. Podem testar seus limites para encontrar seu lugar no mundo. As garotas são educadas para agradar aos outros, situação que impede sua autonomia. A elas são impostas práticas e princípios do universo feminino:

Dão à menina por amigas, outras meninas, entregam-na a professoras, ela vive entre matronas no tempo do gineceu, escolhem para elas livros e jogos que a iniciem em seu destino, insuflam-lhe tesouros da sabedoria feminina, propõe-lhe virtudes femininas, ensinam-lhe a cozinhar, a costurar, a cuidar da casa ao mesmo tempo da toalete, da arte de seduzir, do pudor; vestem-na com roupas incômodas e preciosas das quais precisa cuidar, penteiam-lhe de maneira complicada, impõe-lhe regras de comportamento (Ibidem.,p.377).

O sexo feminino deve aprender a ser meninas. Correr, brigar ou andar despenteada era visto como uma ameaça à feminilidade, uma das principais virtudes da mulher. $O$ Tico-Tico tinha o costume de publicar narrativas que salientavam o papel da mãe, como a detentora de dons naturais para cuidar dos filhos. A mãe postiça (Fig.39) é uma história na qual se faz referência aos papéis do ser mulher e do ser homem. A esposa precisa sair e pede ao marido que cuide do filho do casal. Quando o bebê começa a chorar, o pai não sabe o que fazer para acalmar o menino. Como solução, o homem fantasia um manequim com as roupas da mulher. Desta forma, a falsa mãe ninaria a criança. Demonstra-se que a figura paterna não tinha as aptidões naturais e necessárias para cuidar dos filhos.

A história em quadrinhos $O$ inimigo das mulheres trata da mesma temática, porém com personagens infantis (Fig.40). São feitos questionamentos sobre o valor social da mulher. A personagem feminina não tem nome próprio. Durante a leitura, destacam-se as ofensas deferidas por Lulu contra a irmã. Outro aspecto é o fato do menino se vangloriar da superioridade do homem frente à mulher. Lulu apenas toma consciência do valor da mulher quando se machuca e precisa de cuidados e de atenção. A irmã prontamente lhe faz curativo.

Como observa Vergueiro (Op.cit.): 
A preocupação com a formação das meninas em $O$ Tico-Tico em coerência sob a égide da visão dominante da época sobre o papel da mulher na sociedade brasileira, ou seja, a de baluarte do ambiente familiar, responsável pela educação das crianças e pelas tarefas domésticas (p.177).

No impresso infantil, a figura materna tem a função de aconselhar e corrigir os comportamentos inapropriados dos filhos. Cabe a ela fazer as crianças refletirem sobre seus atos e assim internalizarem as boas ações e cultivar os bons sentimentos. A mais generosa apresenta uma mãe de ilibado comportamento (Fig.41). Questiona a filha sobre o fato dela se gabar por ter doado uma pequena quantidade de dinheiro a uma pobre mulher. No decorrer da história, a garota aprende a diferença entre soberba e os verdadeiros atos de caridade e generosidade. Situação semelhante ocorre em O Livro e a bola. Nesta sequência, a mãe ensina à filha sobre a importância de ajudar ao próximo (Fig.42). Em Flagrante, a preguiçosa Lina conta uma mentira para evitar arrumar o próprio quarto. Após descobrir a mentira, a mãe lhe proíbe de usar um valioso presente dado por sua madrinha ${ }^{52}$ (Fig.43). Na história Mamãi já não gosta mais de mim, Lili entende as repreendas de sua mãe como sinais de desamor. Após uma longa conversa, a filha compreende que tais censuras tinham o propósito de evitar os maus comportamentos (Fig.44). O papel das mães é o de demonstrar aos filhos a importância da honestidade e da dedicação aos estudos. Elas devem ser exemplos de ilibada conduta.

\footnotetext{
${ }^{52} \mathrm{Na}$ ausência materna, as histórias de $O$ Tico-Tico traziam as tias, as avós e as irmãs mais velhas como as responsáveis por fazer as crianças trilharem o bom caminho. Em As trez caixinhas, a avó faz um desafio às netas com o intuito de descobrir qual delas era a mais digna de receber seu anel valioso. O Tico-Tico - 16/09/1916 - p.1
} 


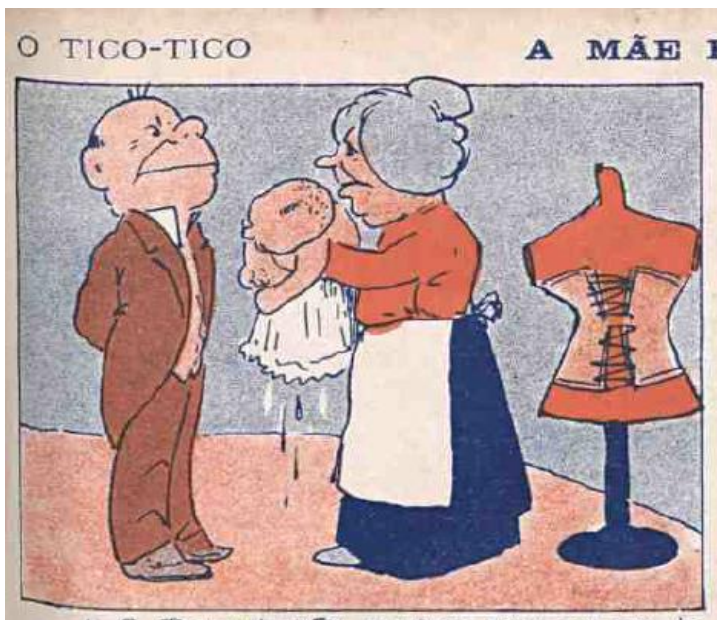

1) O Bermudes nāo prestava para ser pae de familia Sua mulher tendo que sahur en:regou-the Dequerrucho, para que 0.6

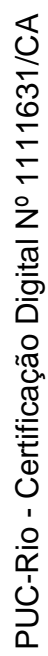

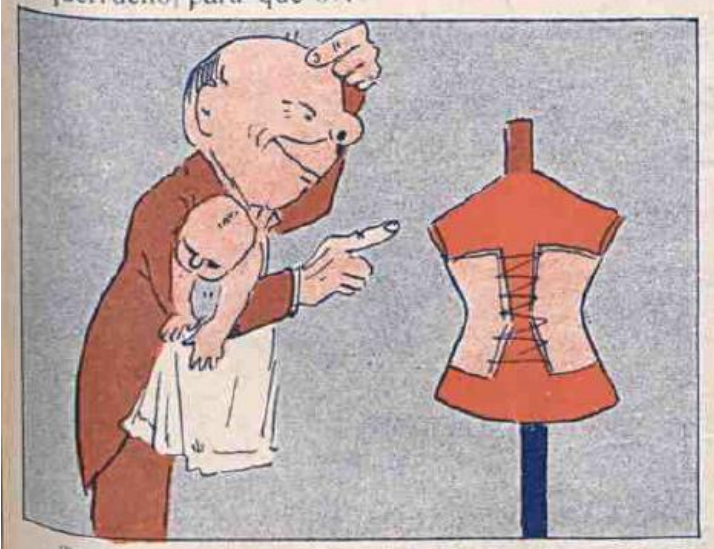
3) berrava tanto, que Bermudes, vendo uma manequim
4a milher, que era modista, conseguiu ter uma ideia para ver livre das manhas do pequeao.

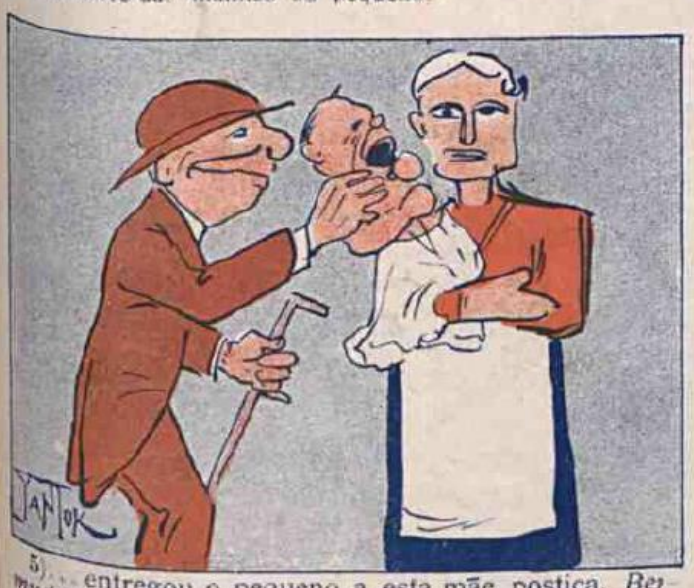

mud entregou o pequeno a esta māe postiça. Ber te toi sahindo de barriga para dar um passeio allivio

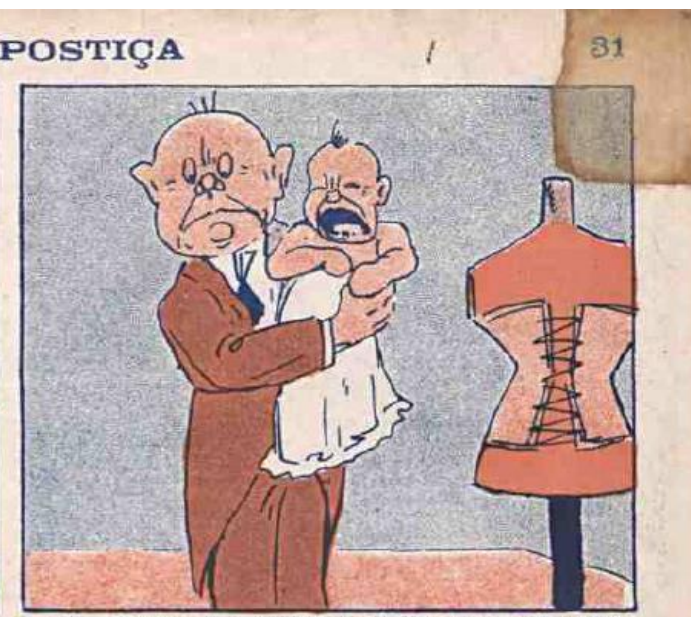

2) Bermudes curdasse d'elle. de sorte a nāo deixal-o chorar durante a sua ausencia. Mas. qual 20 pequeno era dos diabos e...

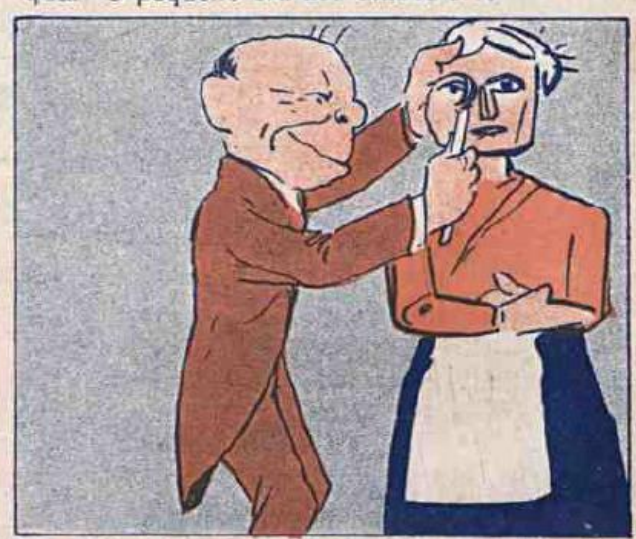

4) Vestiu a manequim com a roupa da muIher, pintou uma cara mais ou menos carran cuda e. sem mais nada.

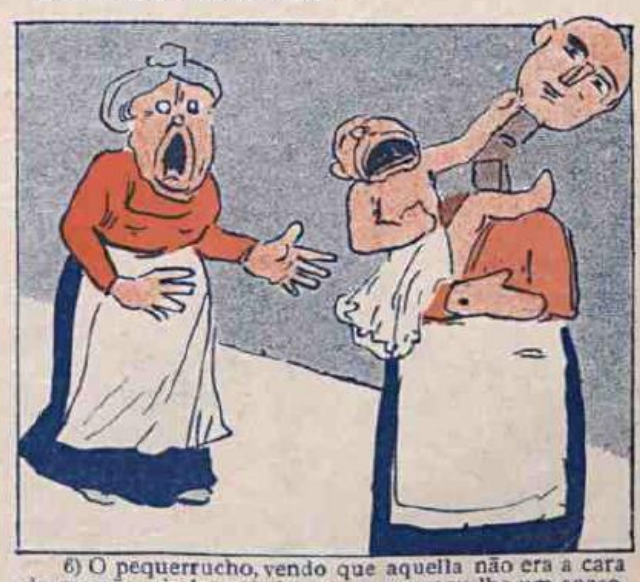

6) $O$ pequerrucho, vendo que aquella nāo cra a cara da mamae, ainda mais berrou e arrumou-lhe um socco, da verdadeira máe quando, de regresso, viu aquillo!

Figura 39- O Tico-Tico - 14/05/1913-p.31 


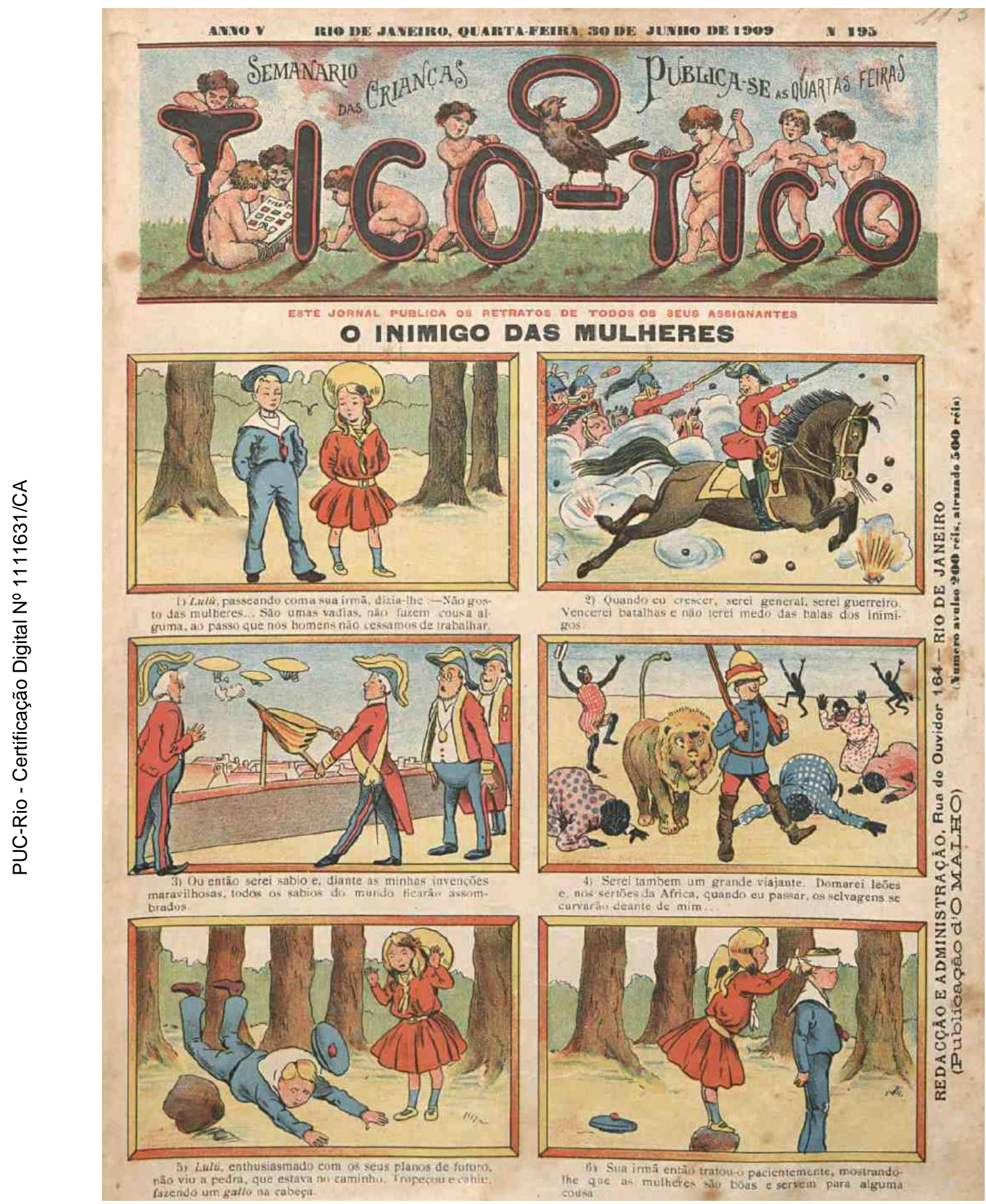

Figura 40 - O Tico-Tico -30/06/1909 - p.1 


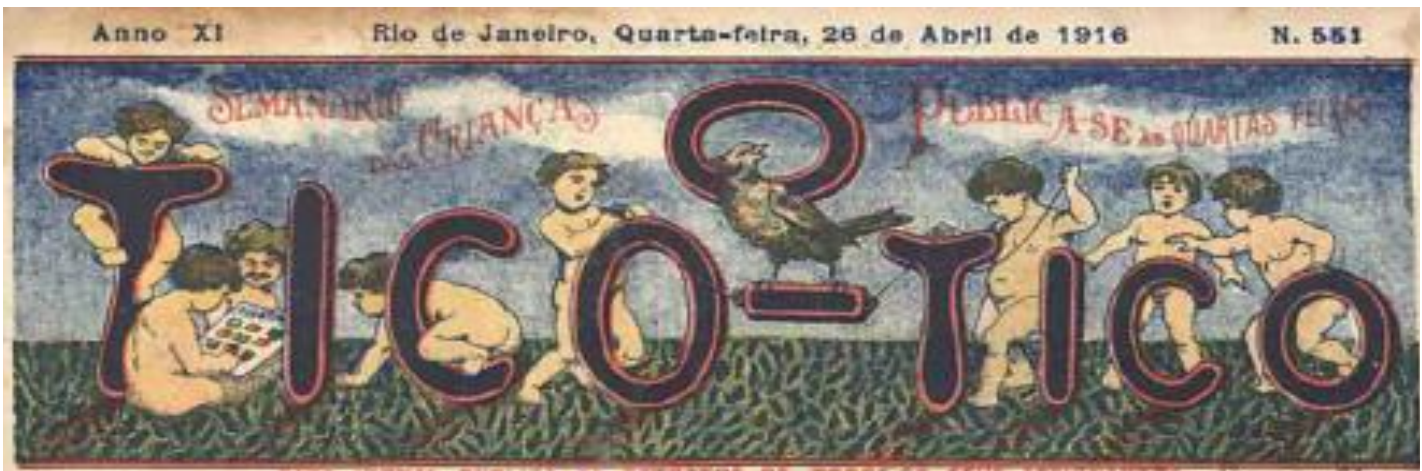

A mAIS GENEROSA

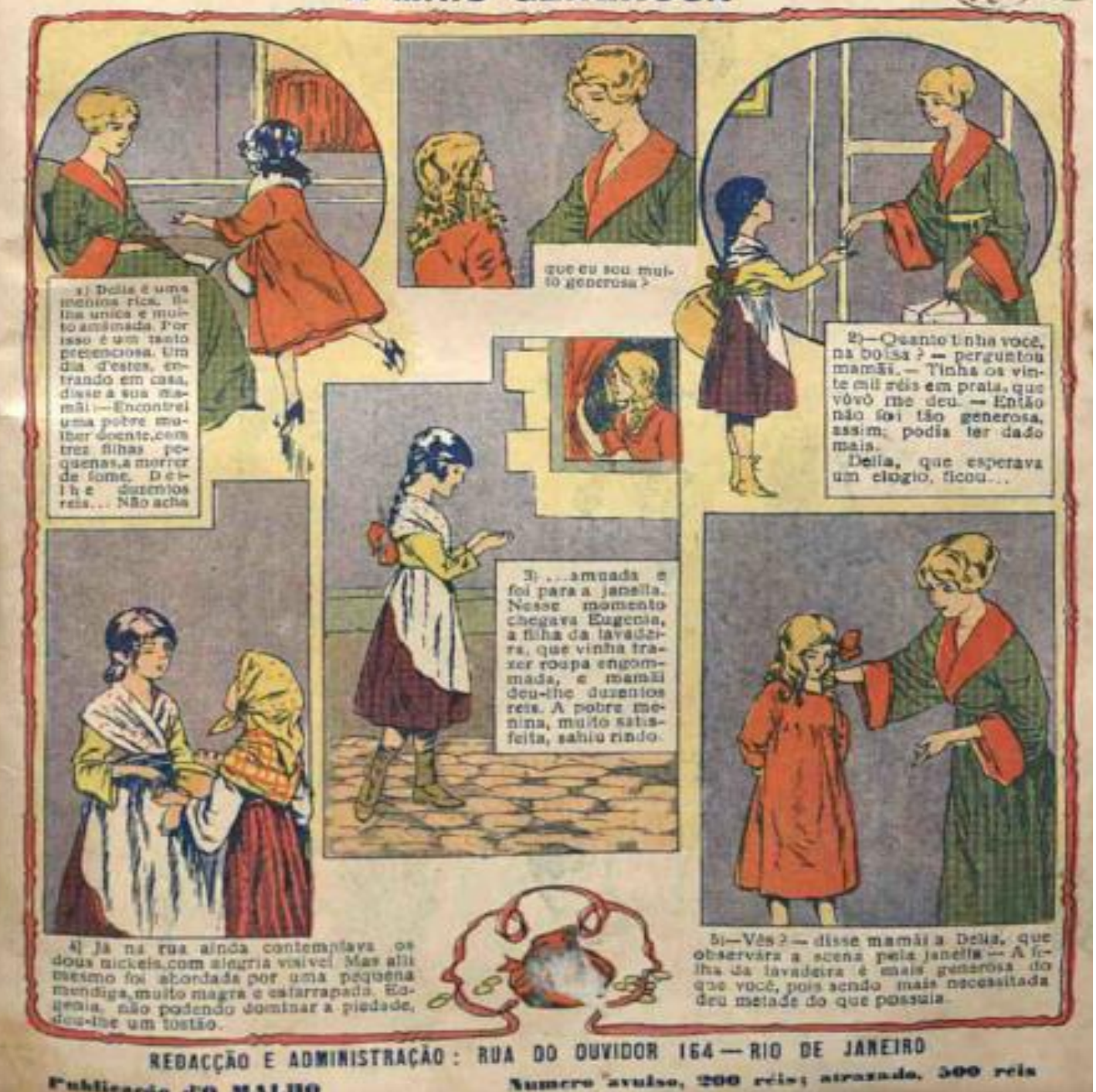

Figura 41 - O Tico-Tico - 26/04/1916 - p.1 


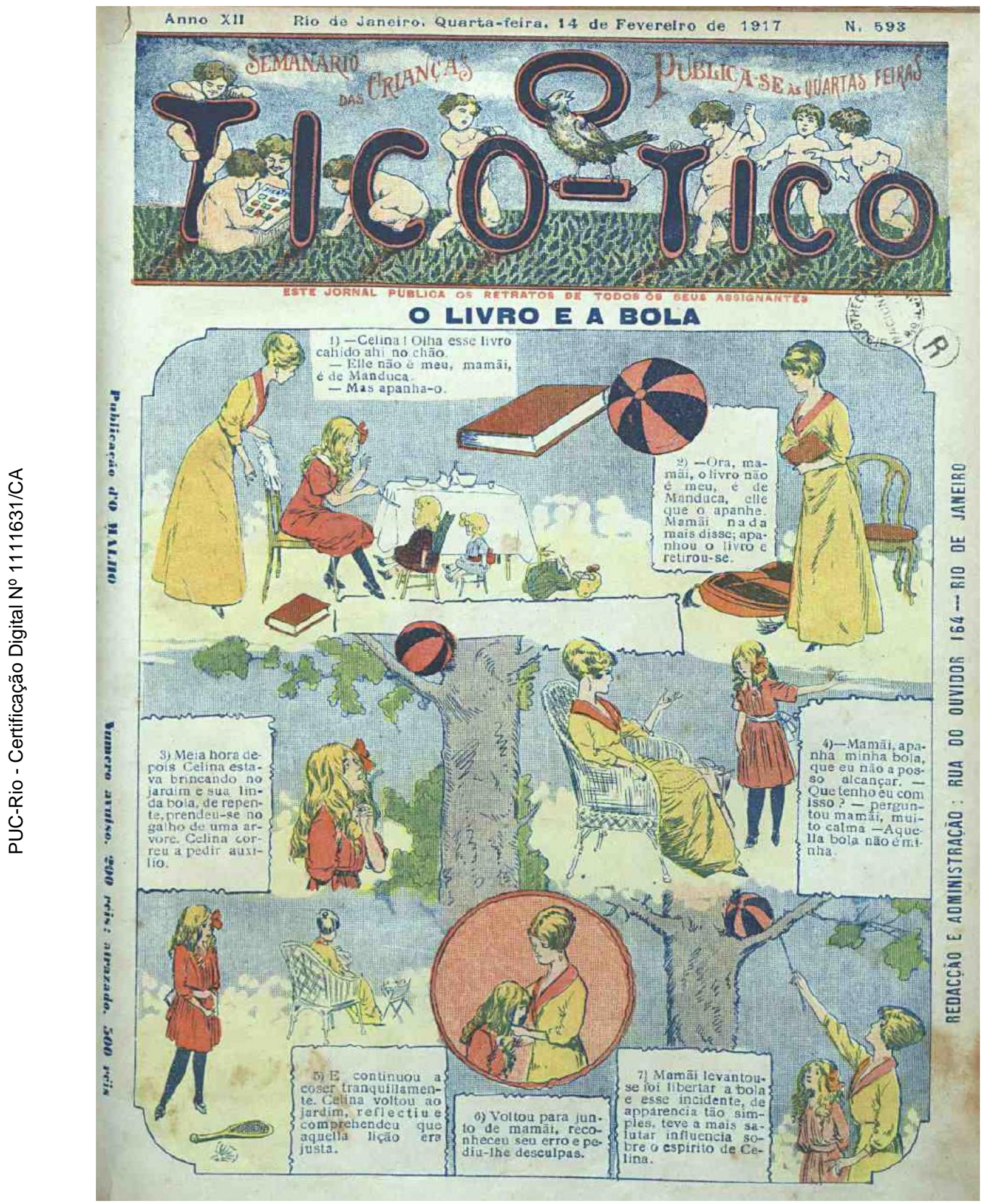

Figura 42 - O Tico-Tico - 14/02/1917 - p. 1 


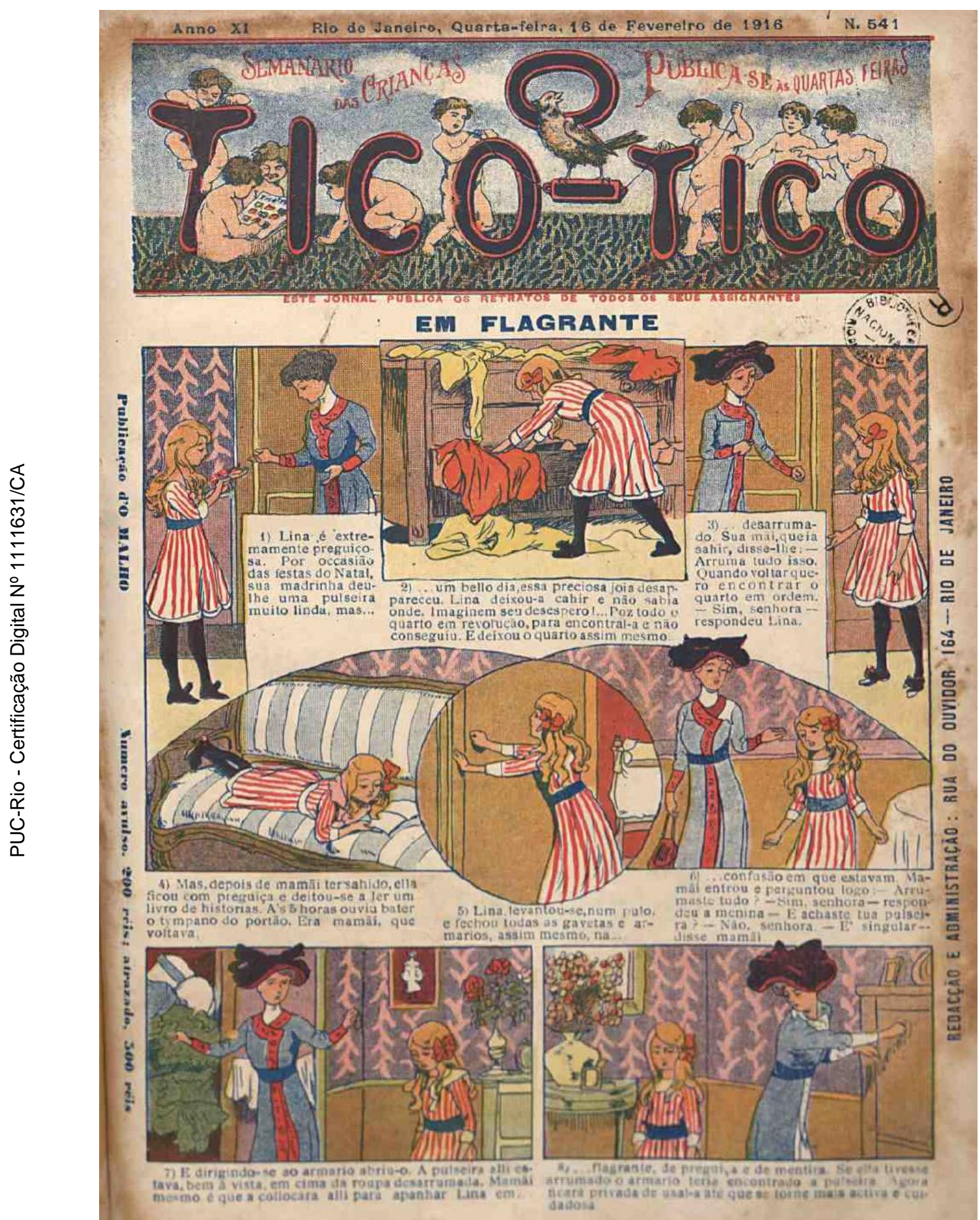

Figura 43 - O Tico-Tico - 16/02/1916 - p.1 


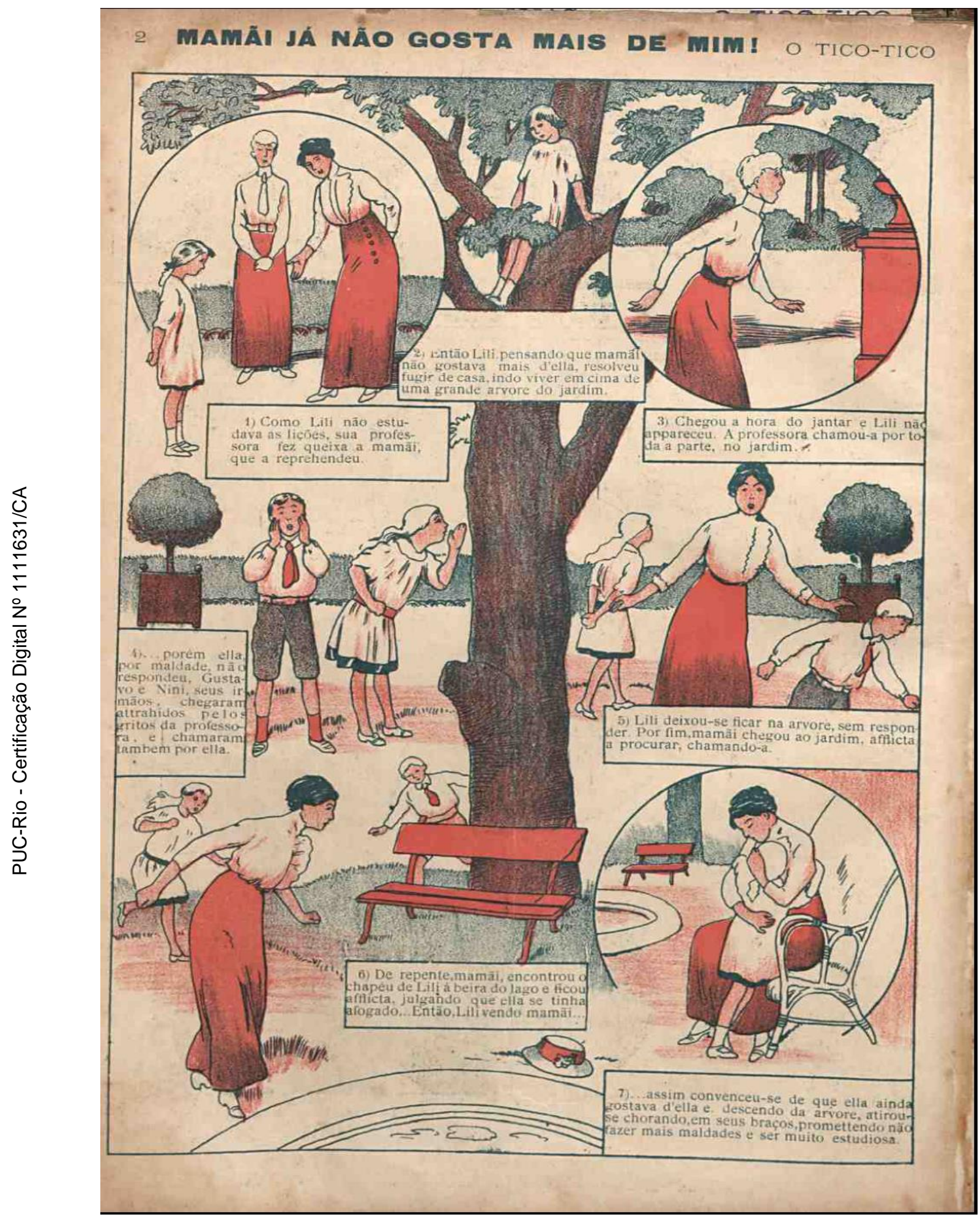

Figura 44 - O Tico-Tico-14/08/1912 - p.2 
Este modelo de comportamento feminino também era difundido pelo positivismo. O ideário positivista preconiza que a principal função do sexo feminino é prover o cuidado familiar. Segundo Comte (1978), esta tarefa foi designada às mulheres, em virtude das mesmas constituírem o sexo afetivo, caracterizado por indivíduos que representam a humanidade e seguem os desígnios do coração. Por não participarem do mundo da política e do trabalho, deixam de ser contaminadas pelo egoísmo reinante da sociedade industrial. Por esta razão, as mães têm a função de despertar nos homens os sentimentos de veneração, apego e bondade. Se o papel feminino é o de formar moralmente as crianças, qual papel do sexo masculino? Prover o sustento da mulher para que ela não se afaste de sua missão.

\begin{abstract}
A arte jamais poderá representar a Humanidade de modo condigno senão sob a forma feminina. Mas a providência moral de nossa Deusa não se exerce só pela ação coletiva do vosso sexo sob o meu. Esse ofício resulta sobretudo da influência pessoal de cadê digna mulher desenvolve sem cessar no seio da família. Do santuário doméstico dimana de contínuo esse santo impulso, único que nos pode preservar da corrupção moral a que sempre nos dispõe a existência prática ou teórica. Sem tais raízes privadas, a ação coletiva da mulher sobre o homem não comportaria, por outro lado, nenhuma eficácia permanente (p.172).
\end{abstract}

Neste sentido, Veríssimo (Op.cit.) aponta a importância da mulher na educação do caráter e das vontades de meninos e meninas. A educação do caráter tem a função de incentivar atos de bondade, piedade e altruísmo. A educação das vontades visa transformar os pequenos em indivíduos úteis. Os pais não poderiam atender a todos os desejos de seus filhos. Os progenitores devem desafiar as crianças a transformar suas vontades em ações de ajuda ao próximo. A conformação do caráter e das vontades é uma atividade do cotidiano feminino.

Os argumentos religiosos e higienistas responsabilizavam a mulher pela manutenção da família saudável- no sentido - mais amplo do termo. A esses argumentos iriam se juntar também, os conhecimentos da psicologia, acentuando a privacidade familiar e o amor materno como indispensáveis ao desenvolvimento físico e emocional das crianças (p.454).

No tocante à educação e os bons modos, é preciso fazer menção ao fato de que o processo de formação moral também incluía os castigos físicos. Como ressalta Rosa (Op.cit.). 
A opressão a que era submetida a criança, no início do século, fazia com que ela fosse castigada pelo desrespeito aos adultos, pela teimosia, pela mentira, pela falta de asseio, pela falta de gulodice, pela desobediência, pelas brincadeiras de mau gosto e pelo arremedo grotesco de deformações e cacoetes (p.123).

O Tico-Tico traz histórias nas quais as mães, seja das classes mais baixas ou pertencentes as elites, costumavam bater em seus filhos. A personagem Mamãi do Chiquinho, símbolo da mulher burguesa, aplicava as chamadas sovas no menino, a cada desobediência (Fig.45).

\section{- CHIQUINIO}

(Explicaçẫo pessoal)

Para evitar reclamnçoes, perguntas e proteslos por náo apparecer neste numero o nosso amigo Chiq̨uinho, resolvemos averiguar as causas de sua ausencia.

Fomos a casa do nosso endinbrado amigo e ouvimos o seguinte dialogo ou antes trialogo:

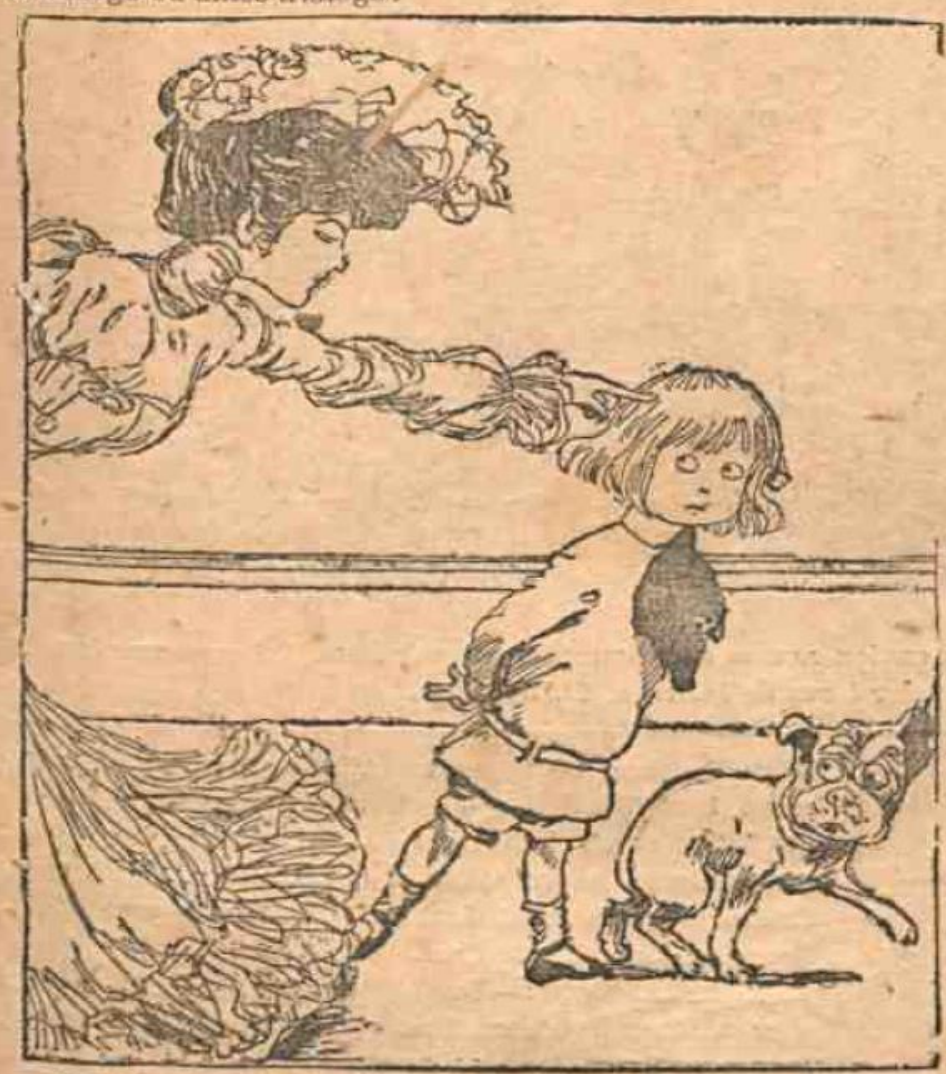

Chipuinho- Ora mamai, entan logo hoje eu nao saio..

Mamài - Náo. Vocé esta táo levado daje Dréca que até pode ser máo exemplo para os leitores d'O Tico-Tico.

Hojo fica passado vocé chegou a esborrachar a cara do copeiro. Hojo fica err casa por castigo...

e cu jagumo - Chil toca a fugir, mamai hoje esta mnito zangada e cu ná quéro apanhar algumas sobras...

Figura 45 - O Tico-Tico - 17/01/1906 - s/p 
O modelo feminino presente nas páginas de O Tico-Tico é consonante ao de La Semaine de Suzette. As representações e os discursos sobre o gênero feminino da revista francesa são semelhantes aos encontrados no impresso brasileiro. Segundo Couderc (Op.cit.), os conteúdos voltados à educação das meninas deveriam ressaltar a importância da família. Os papéis do homem e da mulher tinham de ser definidos e apresentados de forma específica. Com o propósito de facilitar o entendimento das leitoras sobre a importância das boas maneiras, dividia-se as personagens em dois grupos distintos: no primeiro estavam as meninas boas e honestas e no segundo se enquadravam aquelas consideradas fracas e capazes de cometer todo tipo de inconveniências. O TicoTico claramente também seguia tais padrões.

Ilustrações publicadas aleatoriamente na revista, embora semelhantes não se constituíam em uma seção, demonstram quais os sentimentos e os comportamentos tolerados ou não, em uma sociedade moderna e civilizada. Imagens femininas, em situações corriqueiras, demonstram o que se deve imitar ou o que não se deve imitar. Afinal, as mulheres eram responsáveis pela formação moral de seus filhos (Fig.46) (Fig.47).

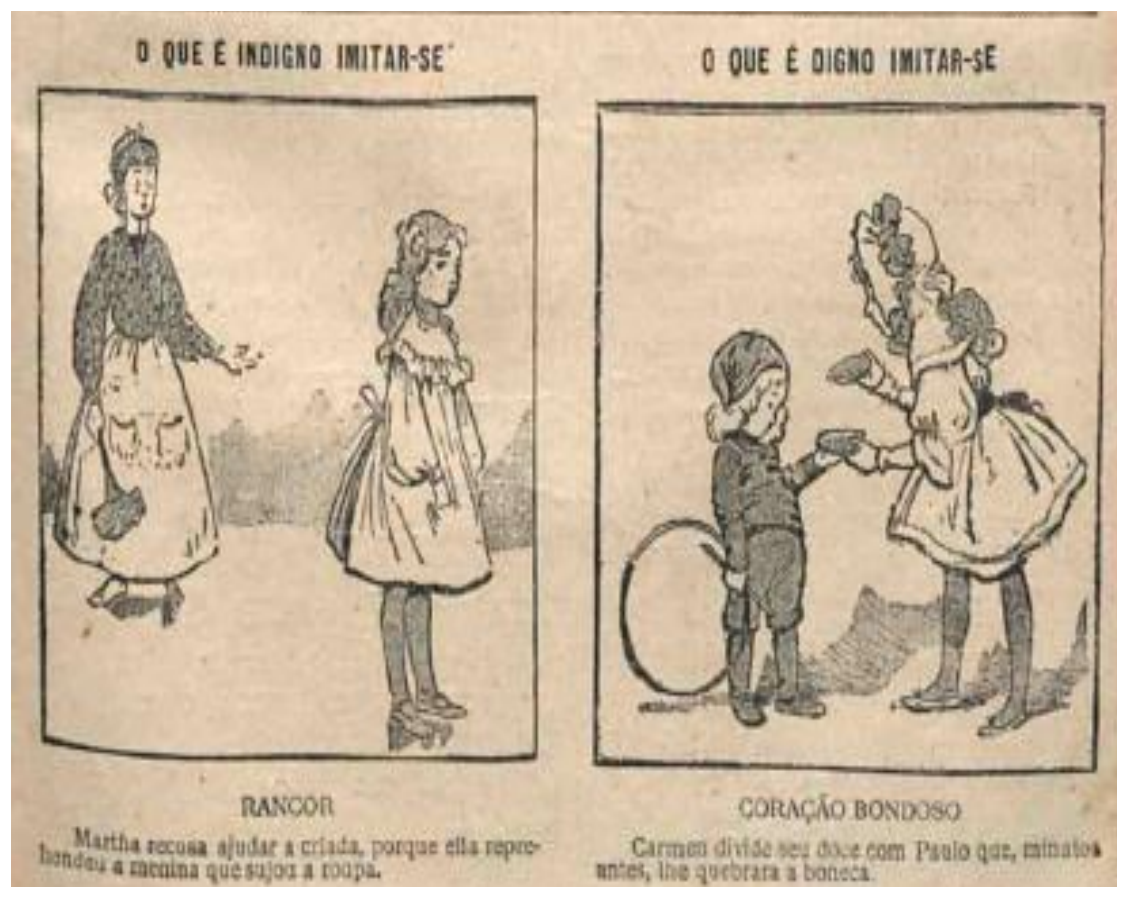

Figura 46 - O Tico-Tico - 27/11/1912 - s/p 


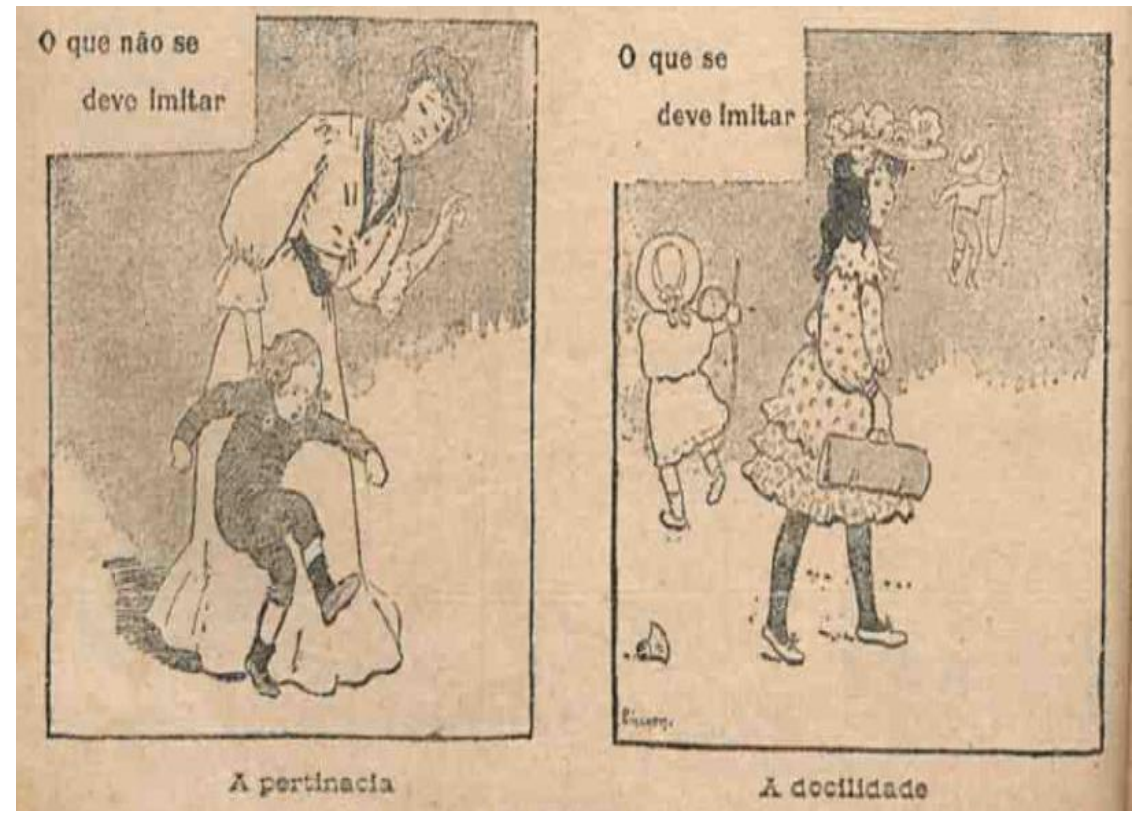

Figura 47 - O Tico-Tico - 11/12/1912 - p.20.

As imagens e as legendas apontam que o bom comportamento desperta a admiração e o respeito, ao contrário das más ações que provocam repúdio. Segundo Camara (Op.cit.), esta concepção de bem e mal, seguia o projeto republicano de regeneração social:

(...) os vícios e as virtudes configuraram-se como marcas definidoras das descendências e das proveniências sociais dos indivíduos, justificando ações intervencionistas no sentido de moldar uma nova identidade nacional ligada ao progresso e a civilização (p.125).

A promoção de tais modelos de conduta, remete à estrutura do pensamento cristão calcado em virtudes e pecados. Embora a Constituição de 1891 tenha instituído a laicidade do Estado brasileiro, a influência do Catolicismo ainda era proeminente nos lares brasileiros ${ }^{53}$. Como demonstra Priore (Op.cit.), estes

53 No decorrer dos anos 1920 e 1930, a disputa pela primazia na educação dos brasileiros foi marcada pela disputa entre os Intelectuais Católicos e os Escolanovistas. Os primeiros defendiam que a religião e a família eram tão importantes quanto o Estado no processo educacional. Entre seus principais defensores estavam Alceu Amoroso Lima e Padre Leonel Franca. O segundo grupo era formado por partidários da Escola Nova. Propunham um ensino de caráter laico e o monopólio do Estado na educação. Os educadores Anísio Teixeira, Lourenço Filho, Fernando de Azevedo eram seus principais nomes. $\mathrm{O}$ aprofundamento das disputas ocorreu durante os debates sobre a obrigatoriedade do ensino religioso nas escolas; situação que acarretou na publicação, em 1932, do Manifesto dos Pioneiros na Educação Nova. MAGALDI, Ana Maria Bandeira de Mello.. A quem cabe educar? Notas sobre as relações entre a esfera pública e a privada nos debates educacionais dos anos de 1920 -1930. Revista Brasileira de História da Educação, Campinas, v. 5, 2003, p. 213-231. 
princípios religiosos também se faziam presentes na composição da família e na defesa da mulher-mãe-esposa:

Pobre ou rica, a mulher possuía, porém um papel: fazer o trabalho de base para todo o edifício familiar - educar os filhos - segundo os modelos cristãos, ensinar-lhes as primeiras letras e obedecer e ajudar o marido. Ser enfim a "santa mãezinha". Se não o fizesse seria confundida com o "diabo cosmético". Afinal, sermões difundiam que a mulher podia ser perigosa, mentirosa $\mathrm{e}$ falsa como uma serpente. Pois ela não havia conversado com uma no paraíso? O modelo ideal era Nossa Senhora. Modelo de pudor, severidade e castidade (p.13).

As páginas do impresso infantil eram preenchidas por narrativas que frisavam um determinado padrão feminino de pureza. Distinguiam-se de forma clara, as virtudes que necessitavam ser cultivadas e vícios que deveriam ser reprimidos.

(...) a formação sadia das meninas correspondeu, além do cultivo de virtudes como abnegação, sacrifício, honestidade, humildade, bondade, generosidade e caridade, a idealização da mulher submissa confinada às tarefas domésticas. (ROSA, Op.cit., p.149).

Era preciso educar a alma pura das meninas e defendê-las dos pecados e das tentações. Os sentimentos mesquinhos não reprimidos na infância poderiam resultar em um adulto irresponsável e não ciente de seu papel para com a nação e a coletividade. Couderec (Op.cit.) descreve como possíveis pecados capitais da infância: o egoísmo, a desobediência, o orgulho, a raiva, ciúme e a mentira. Em $O$ Tico-Tico é ressaltado o combate a outro mau comportamento: a curiosidade. $\mathrm{Na}$ sua edição inaugural foi publicada $A$ mulher que enganou o Diabo (Fig.48). Por ter conseguido fazer com que o diabo voltasse para a garrafa, aberta mesmo com os alertas do marido, a protagonista demonstra alívio por ter evitado apanhar do cônjuge. A história possui um título sugestivo, pois a bisbilhotice feminina é vista como algo negativo desde a Grécia Antiga, associada na mitologia à figura de Pandora.

No tocante a violência sofrida pela mulher, Chalhoub (Op.cit.) identifica que o modelo de dominação do homem também se reproduziu no âmbito judicial. $\mathrm{Na}$ análise dos processos criminais e notificações de crimes passionais, ocorridos na cidade do Rio de Janeiro no início da Primeira República, o autor cita o estudo 
de Mariza Corrêa (1983) sobre o mesmo tipo de crime acontecidos, de 1952 a 1972, na cidade de Campinas. Nos dois contextos temporais, demonstra-se que

(...) o que esta em questão em cada julgamento é a defesa de um sistema de normas visto como universal e absoluto. Os julgamentos, então, objetivam reafirmar as normas dominantes, sendo que as pessoas envolvidas serão julgadas nem tanto pelo ato criminoso em si, mas pela adequação de seu comportamento às regras de conduta moral consideradas legítimas. Sendo assim, o modelo ideal de mulher que aparece nos autos é o de mãe, ser dócil e submisso cujo principal índice de moralidade é sua fidelidade e dedicação ao marido (p.179-180).

Assim como os conteúdos, os títulos das histórias deixam claro, quais comportamentos tinham de ser reprimidos. As leitoras de $O$ Tico-Tico não podiam ser curiosas, mentirosas, vaidosas ao extremo, preguiçosas, invejosas, descuidadas entre outras desqualificações. Como se observa em $O$ gozo de nada fazer (Fig.49) e Luizinha é vadia (Fig.50).

Neste período, a honra do homem não dependia apenas dos seus atos de honestidade, mas também das ações de sua esposa. Por tal razão, as meninas tinham aprender como se portar. Em Os tres segredos da avozinha, a neta recebe conselhos da avó sobre como se portar na escola e na vida. As recomendações são para que ela fosse sempre pontual, cuidasse bem da casa e falasse apenas o necessário e quando perguntada (Fig.51). Uma mulher bela, piedosa e que cuidasse bem do lar e dos filhos era vista com uma escolha perfeita (Ibidem.). Apesar do lar ser considerado seu espaço de ação por natureza, as esposas não ficavam alijadas do no meio social. As portas das casas das famílias de elite se abriam para receber os amigos e convidados do esposo. Caso a residência fosse elogiada pelo cuidado e refinamento da decoração, o marido tinha feito a escolha correta. 


\section{A MULHER ENGANOU O DIADO}

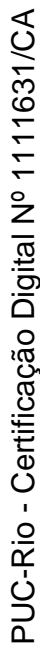
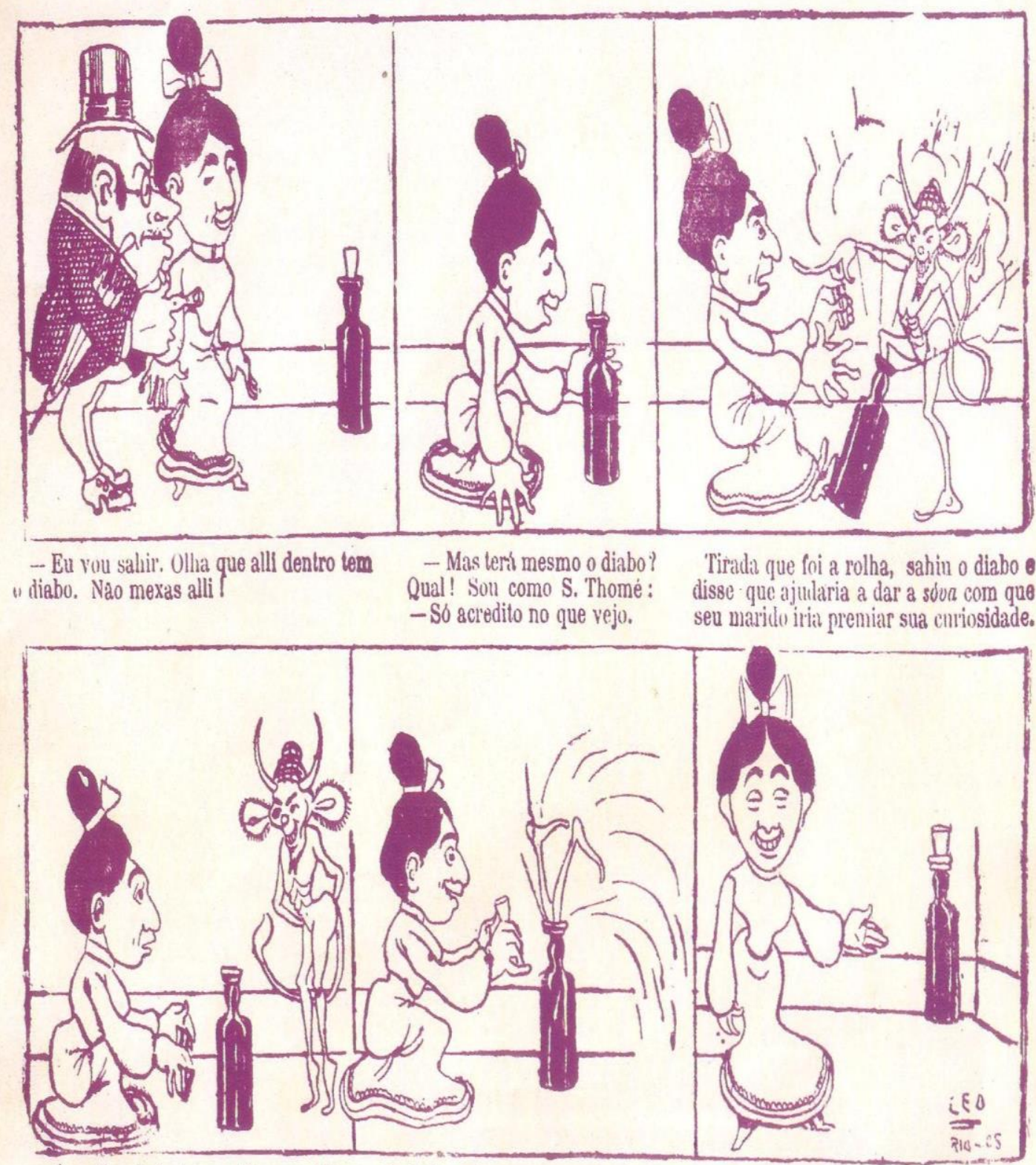

A mulherriulla leve ontao uma idéa 0 diabo entao entrou para provar.

Botou-a lá no cénto e tú muito de

disce: - 'Tu uàn estavas ahi dentro! A mulliersinha arrolhou a garrafä.

- Pislivil simn, respondeu o diabn.

- Qutal! l." mmilira! 'lu ès um ler enganado o diabu e de se ver livre mande minlinisu! da surra, que da certo levaria si elle tivesuc firmilo sollth.

- Biskava. jai disse.

- So acreiliburei si cnhares para 011 Vor?

Figura 48 - O Tico-Tico - 11/10/1905 - p.2 


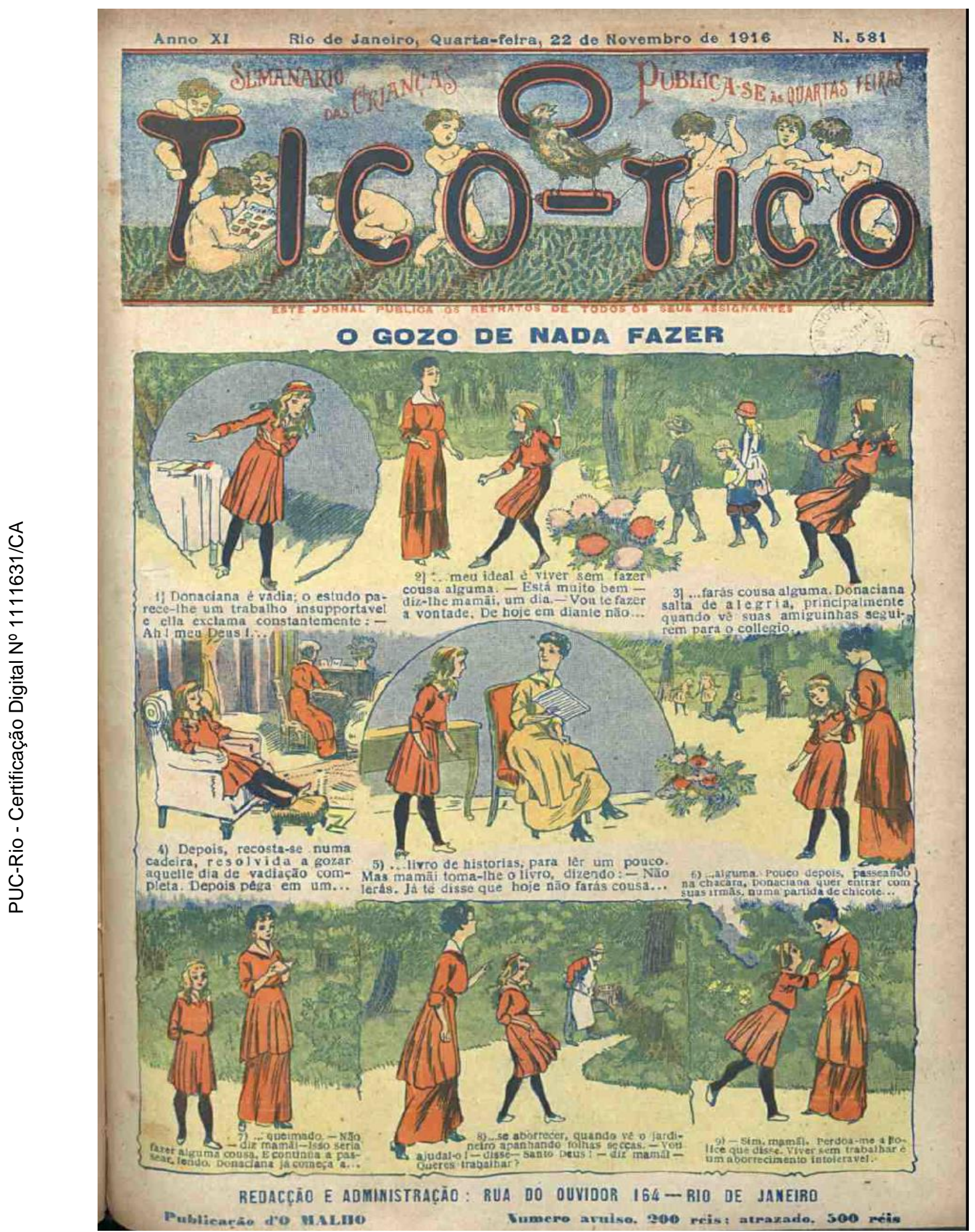

Figura 49 - O Tico-Tico-22/11/1916 -p.1 


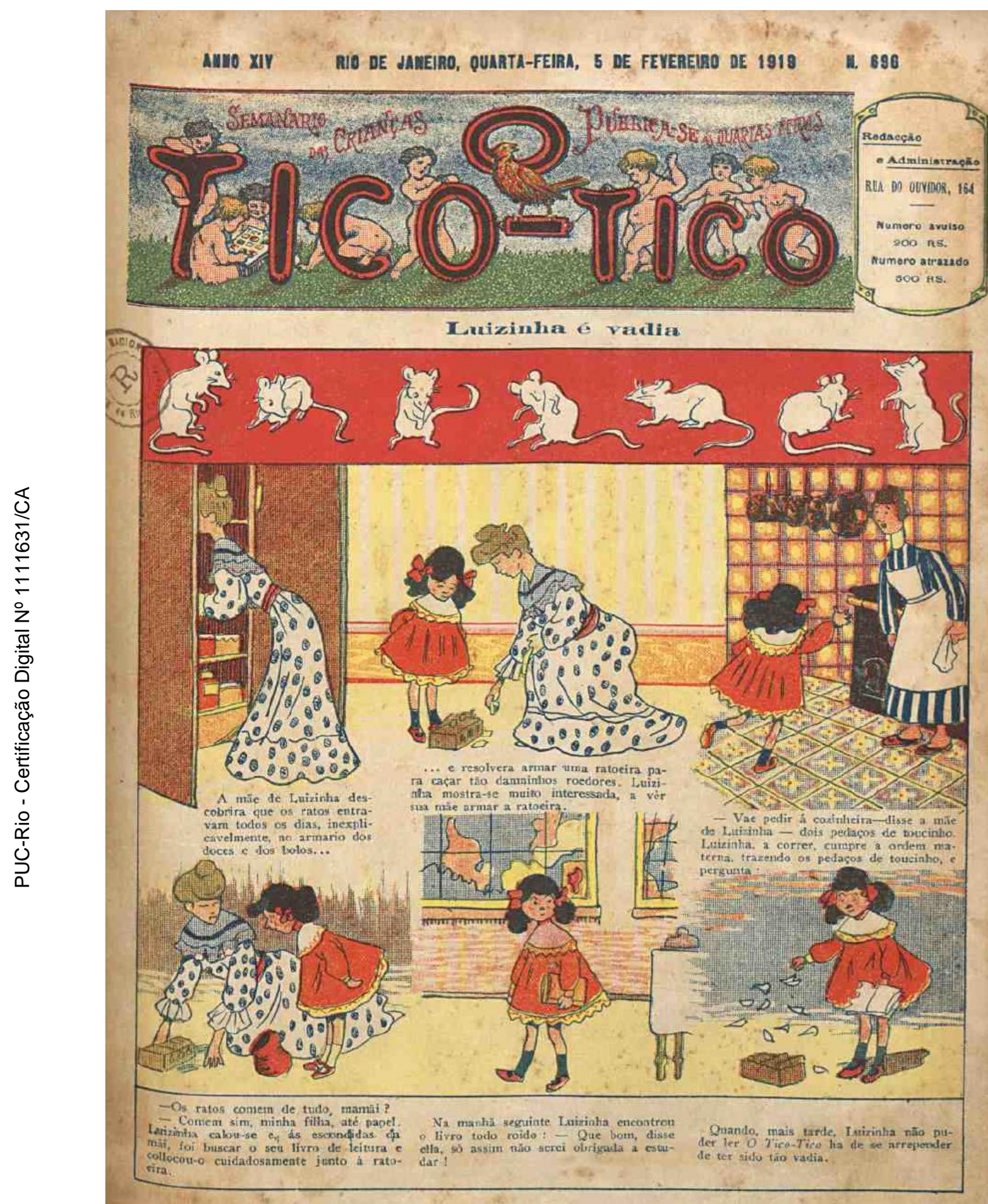

Figura 50 - O Tico-Tico - 05/02/1919 - p.1 


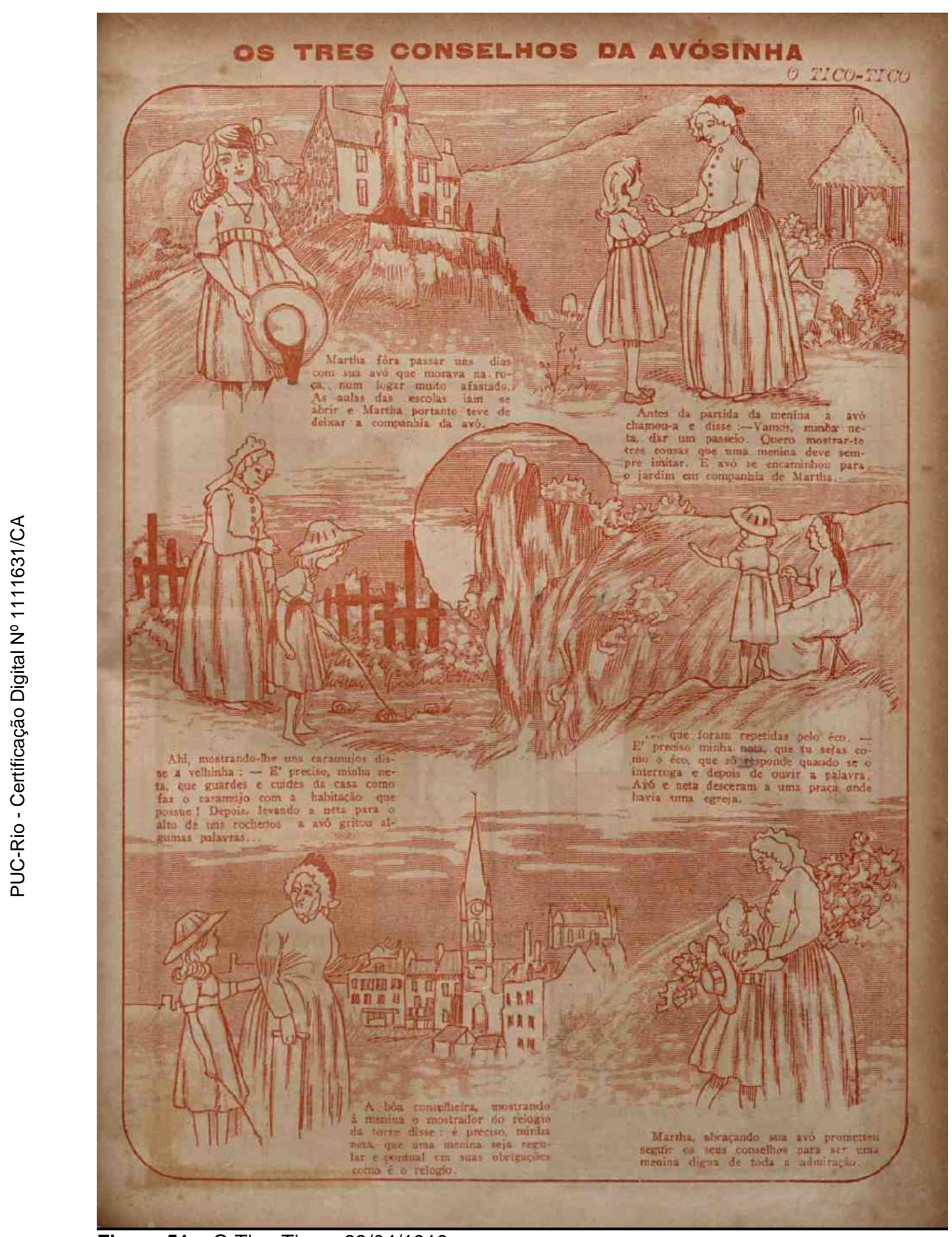

Figura 51 - O Tico-Tico - 23/04/1919 


\subsection{A educação feminina: ler, escrever e cuidar}

\section{Leitura}

Põe mais cuidado na escolha dos livros da tua leitura do que na dos manjares da mesa. O que comes é fiscalisado pelos sentidos: os olhos vêem, palpam as mãos, fareja o olfacto, prova o paladar e é preciso que o mal seja muito subtil para que desça ao estomago depois do exame de tantos e tão atilados peritos. A boa alimentação fortalece o corpo, tempera o sangue, mantem a saude, sem a qual não há espírito esclarecido. E' na saude que a intelligencia medra com mais serviço. Corpo doente é como terra apaúlada ou resequida de sóes: para tirar-se della um fructo é necessario esforço e o que se obtem com facilidade no bom terreno, só a força do labor consegue-se carrascal. Quem se alimenta sem zelo, ou, por não escolher o que come, ou por não regular as horas das refeições, não aproveita o que ingere: enfarta-se, mas não se nutre. Os alimentos do espírito não são examinados pelos sentidos: passam dos olhos ao cérebro e nelle ficam em depósito. Se levam substância apreciavel espalham a seiva pela intelligencia e, sendo boa, fornece instrucção sadia, sendo nociva deprava a alma. O livro, minha filha, é sempre um degrau: sobe se é bom; desce se é mau. Por elle o espírito ascende á claridade ou abysma-se na treva. Não basta andar com os olhos no livro, é preciso parar nas pausas, demorar nas idéas, absorval-as, não com a memória, que tudo apanha, mas com o raciocínio, que escolhe (NETO, 1928, p.133-134).

O texto de Coelho Neto, publicado em Alma: Educação feminina, aconselha as meninas sobre o valor da leitura e do estudo, destacando a importância de aprenderem a diferenciar as boas das más leituras. As boas leituras contribuem para o desenvolvimento intelectual e pessoal. As más leituras devem ser evitadas, pois em nada ajudam à formação dos indivíduos. A narrativa enfatiza um tema que ganhava espaço em debates sobre a sociedade brasileira: a educação das meninas e das jovens.

Defendia-se a perspectiva do ensino feminino como forma de adequação ao discurso modernizador republicano. Ao mesmo tempo, propunha-se que os princípios de uma formação cristã-católica não deveriam ser abandonados. Desta forma, elas poderiam ter acesso à ensinamentos propícios e voltados a aflorar no sexo feminino os bons sentimentos que marcam sua própria natureza:

Elas deveriam ser diligentes, honestas, ordeiras, asseadas; a ela caberia controlar seus homens e formar os novos trabalhadores e trabalhadoras do país; àquelas que seriam as mães dos líderes também se atribuía a tarefa de orientação dos filhos e filhas, a manutenção de um lar afastado dos distúrbios de perturbações do mundo exterior (...)Para muitos, a educação feminina, não poderia ser concebida sem uma sólida formação cristã. (...) Ainda que a República formalizasse a separação da Igreja 
Católica do Estado, permaneceria como a dominante moral religiosa que apontava para as mulheres a dicotomia entre Eva e Maria. A escolha entre esses dois modelos representava, na verdade, uma não-escolha, pois se esperava que as meninas e jovens construíssem suas vidas pela imagem de pureza da Virgem. Através do símbolo mariano se apelava tanto para a sagrada missão da maternidade quanto para a manutenção da pureza feminina. Esse ideal feminino implicava o recato e o pudor, a busca constante de uma perfeição moral, a aceitação de sacrifícios, a ação educadora dos filhos e filhas (LOURO, 2009, p.447).

$\mathrm{Na}$ análise do conteúdo educativo de A Mãi de Familia: Jornal ScientificoLitterario- Educação da infancia - Hygiene da Familia - Modas para crianças, Karoline Carula (2013) observa que o impresso defendia que as mulheres tinham de ser educadas em bases científicas. Assim, elas poderiam exercer a maternidade de forma amorosa, mais também baseada em conhecimentos científicos. As mães estariam aptas a garantir a saúde, o desenvolvimento físico e a formação moral de seus filhos. "Jornais, e revistas, tanto direcionadas às mulheres, quanto os voltados a um público amplo, dedicaram-se a tal causa civilizatória e modernizadora" (p.87). Não por acaso, o impresso A Mãi de Família foi criado por um médico ${ }^{54}$. Instituía-se a categoria "maternidade científica" (PRIORE, Op.cit., p.133). Tinha-se a preocupação de torná-las cientes dos valores burgueses e de seu papel como educadora e protetora das futuras gerações republicanas.

As mães deveriam estar imbuídas da noção de que a criação dos filhos não poderia ser sustentada apenas em instintos naturais. Era preciso que tais práticas fossem lapidadas por ensinamentos higienistas. Priore (Ibidem) cita o exemplo do médico pernambucano Carolino da Silva Campos. Na segunda metade do século XIX, ele introduziu o debate sobre a necessidade das mães darem banhos em seus filhos (p.131). A Mãi de Família era direcionado às mulheres pertencentes às elites da cidade do Rio de Janeiro.

Os redatores e colaboradores do periódico defendiam que a educação feminina deveria ser pautada no aprendizado de conteúdos científicos, literários e das belas artes. A escolha não foi aleatória, também demonstrava que os conhecimentos direcionados à instrução do sexo feminino se diferenciava dos conteúdos destinados ao ensino masculino. Afinal, homens e mulheres não eram considerados indivíduos iguais em sua compleição física, mental e emocional. A

\footnotetext{
${ }^{54} \mathrm{O}$ fundador e redator principal da publicação era o médico Antonio de Paula Costa.
} 
educação feminina não era vista como fim, mas como meio de prover a felicidade dos outros. As mulheres educadas seriam melhores mães, esposas mais atraentes e eficientes administradoras do lar (CARULA, Op.cit.).

Magaldi $(2004 ; 2007)$ cita os manuais femininos escritos na virada do século XIX para o século XX, como um dos principais meios de formação de meninas e jovens mulheres de famílias abastadas da cidade do Rio de Janeiro e que não frequentavam o ensino regular:

(...) a própria popularidade dos manuais pode ser compreendida como resposta à demanda formulada por mulheres daquela sociedade, que se encontravam em busca de referências sobre papéis a desempenhar e comportamentos a incorporar (...) (MAGALDI, Op.cit., p.88-89).

As análises são centradas em três obras de autoria da intelectual Julia Lopes de Almeida: Livro das noivas (1896), Livro das donas e donzelas (1906) e Maternidade (1924). O primeiro tem como público-alvo as moças casadouras enquanto o segundo é voltado às mulheres casadas. $\mathrm{O}$ último aborda temas para além daqueles considerados tradicionalmente femininos: reflexões sobre o pós Primeira Guerra Mundial e o pacifismo. Embora possuam estratégias e linguagens distintas, estes manuais são classificados como um conjunto de saberes destinados ao sexo feminino.

Destaca-se os conteúdos de Livro das noivas e Livro das donas e donzelas sobre à vida doméstica. Em virtude das mudanças ocorridas na sociedade brasileira, tornava-se salutar ensinar às meninas como se tornarem boas mães e esposas. Era preciso normatizar os comportamentos e valores femininos. Segundo Magaldi (Ibidem), a linguagem presente em Livro das noivas é marcada pelo tom imperativo, pois era fundamental fazer as leitoras internalizarem os saberes indispensáveis ao exercício do papel social de esposa e mãe. No item Bons Alvitres aos Recem Casados, Julia Lopes de Almeida aconselha os casais sobre como devem se portar maridos e esposas para um casamento de sucesso (1929), p.29):

Aos maridos:

Gaste menos do que ganhar.

Faça um orçamento.

Guarde um registro de despesas.

Tenha uma conta no banco.

Faça um seguro de vida.

Segure sua casa e seus bens. 
Seja dono de sua casa.

Pague suas contas pontualmente. Reparta com os outros.

Evite o desperdicio sobre qualquer modalidade.

Torne effectiva a responsabilidade do casamento seja qual for a occasião.

(...)

Os maridos devem proporcionar ás suas esposas muitos divertimentos. Laval-as ao cinema, passeios de automovel, á pé, natação, tennis, ou qualquer outra coisa que lhes agradar...

Às esposas:

As esposas devem consinhar bem, se quizerem conservar seus maridos.

Os maridos devem confiar nas esposas e estas devem se interessar pelos negocios dos maridos.

As esposas devem ser sempre elegantes. Se o marido gostar da ultima moda, a mulher deve procurar acompanhal-o.

Ao casal:

Se tiver algum arrufo, beijem-se e façam as pazes antes de dormir. Nunca deixem esses ressentimentos ultrapassarem a noite.

O texto se configura como um receituário no qual homens e mulheres devem se encaixar em determinados padrões. Ele como o provedor da família e ela se esforçado para fazê-lo feliz. Destaque para o fato das as esposas terem a rua como espaço de circulação e lugar de divertimento, mesmo que restrita a companhia do marido. Quaisquer mudanças ou desvios poderiam resultar na infelicidade do casal.

Em A Educação Nacional, José Veríssimo (Op.cit.) dedica um capítulo às reflexões sobre a Educação da mulher brazileira. Desde as primeiras linhas, o educador afirma que, para uma nação ser desenvolvida, é imperativo reconhecer a importância do ensino feminino:

Si de verás pensamos em educar a sociedade, a educação da mulher impões-se com o rigor do postulado geométrico. (...). Ora como em toda a significação do termo, o primeiro e principal educar do indivíduo, desde o seu nascimento, é quiça ainda em antes, até de sua morte, é a mulher, segue-se logicamente, necessariamente, que a educação da sociedade deve começar pela educação da mulher (p.139).

Por meio da educação, as mulheres tomariam consciência da importância de seu papel social para com sua própria família e o país: 
A mulher brazileira como de outra qualquer sociedade de mesma civilização, tem de ser mãi, esposa, amiga, companheira do homem, sua aliada na lucta da vida, criadora e primeira mestra dos filhos, confidente e conselheira natural de seu marido, guia da sua prole, dona e reguladora da economia de sua casa, com todos os mais deveres correlativos a cada uma destas funções. (...) requerer-se-iam na mãi de família mais capacidades do que têm de commum ainda os mais capazes chefes de Estado (p.152-153).

Observa-se que todas as funções citadas reforçam às referências que vinculam socialmente o sexo feminino ao universo do lar:
A descrição harmoniosa do "pequeno Estado" discriminava as funções de cada um, atribuindo ao marido e à mulher papéis complementares, mas, em nenhum momento igualdade de direitos. Acentuava-se o respeito mútuo, que pode ser traduzido como a expressa obediência de cada sexo aos limites do domínio do outro (MALUF; MOTT, Op.cit., p.374-375).

José Veríssimo (Op.cit.) critica como veemência o modelo educacional feminino por não privilegiar a formação cívica, principalmente pelas mães terem a responsabilidade de socializar e educar as crianças antes de matriculá-las na escola. Para o autor, o governo não investia o suficiente na ampliação do número de estabelecimentos de ensino secundário destinados às mulheres. As Escolas Normais, embora desempenhassem um papel relevante, ainda não se caracterizavam pela excelência acadêmica.

De sorte que a ultima das cousas que a uma menina brazileira ouve no momento em que se lhe forma o espírito é o que se refere a sua patria, e si por acaso a sua curiosidade infantil recorre á sua mãi, que teve a mesma educação, ou não teve nenhuma, o que é por ventura melhor, para uma informação, ainda que muito geral, ella não a saberá satisfazer (p.156).

Acusa a sociedade brasileira de vivenciar um processo de "desnacionalização da mulher brasileira" (Loc.cit.). Por não terem acesso à educação de qualidade, o sexo feminino se instruiria via conversas nos salões de beleza e leituras fúteis provenientes da França. Identifica que as brasileiras tinham maior conhecimento e proximidade com a cultura francesa frente suas próprias referências nacionais.

Segundo Vasconcelos (2009), a partir da segunda metade do século XIX, foram intensificados os debates na imprensa, com destaque para os impressos escritos por mulheres, sobre qual modelo ideal de educação feminina. Importantes setores da intelectualidade defendiam um modelo centrado na lapidação das 
habilidades e dos talentos manuais das meninas. Aprenderiam a bordar, a costurar e a usar seus dotes para manter o lar na mais perfeita ordem. Para além destas tarefas, era considerado de bom tom, que as filhas das classes mais abastadas, aprendessem francês e a tocar piano. A primeira era língua da civilidade e o segundo era a forma mais sofisticada de entretenimento.

Veríssimo (Op.cit) defende a educação feminina integral e de caráter livresco como a dos homens. No entanto, os conteúdos não poderiam ser iguais. Para sanar as lacunas do ensino feminino, propunha-se a implementação da educação estética cujo objetivo era alegrar a vida e o lar. As mulheres teriam aulas de desenho, de modelagem em gesso e de pintura. Tais disciplinas substituiriam os trabalhos manuais (cozer e bordar) considerados, pelo educador, como desperdício intelectual. Embora reconheça o papel de primeira educadora da mulher, salienta que o homem é superior ao sexo feminino. A instrução não deveria as transformar meninas em sábias, mas sim as fazer compreender, desde a infância, a responsabilidade de “(...) dar o tom á casa, ela é a alma da família (...)” (p.156).

No impresso A Mãi de Familia e na obra A Educação Nacional, a educação feminina tem um caráter utilitário. As mulheres provenientes das classes médias e altas, deveriam ser educadas para empreender seu conhecimento em em prol do lar. Em outro trecho da Conferência Infantil A mulher esposa é corroborada esta a visão acerca da instrução feminina:

Percorrei o mundo, e onde achardes povos no auge da civilisação, perguntai que logar occupam as mulheres no meio d'esse povo? E se houver um povo na terra que vos responda: a nossa rainha é uma mulher. Que Idea fareis desse povo?...Oh! como é bello! a mulher ahi é, em primeiro logar, a rainha do lar, é professora, é médico, é advogado; é instruída, cultiva a sciencias e as bellas artes; goza de respeito e eguaes direitos, suas funções na sociedade são respeitadas...Mas ah!é preciso convir, o lar é o império da mulher, ahi é que ella mais se distingue ; o seu fim principal é dar cidadão ao mundo e mãis verdadeiras a humanidade. [...] Convencido d'esta verdade remato a minha palestra com meu axioma: o mestre instrue. A mulher educa (O TICO-TICO, Op.cit.,s/p).

O conteúdo do discurso faz referência a uma suposta igualdade de direitos entre homens e mulheres, porém a Proclamação da República não conferiu ao a elas os mesmos direitos políticos devotados ao sexo masculino. Posteriormente, o 
sufrágio feminino se caracterizaria como uma das principais demandas das feministas.

Segundo Camara (Op.cit.) e Rodrigues (2008), entre os anos finais do século XIX e as primeiras décadas do século XX, foram inauguradas no Rio de Janeiro, então Distrito Federal, instituições de ensino profissionalizante destinadas ao atendimento de meninas de pobres. As alunas teriam a oportunidade de se desenvolvem nos âmbitos físico, moral, intelectual, profissional e no aprendizado das prendas domésticas. No cerne do discurso republicano da regeneração social, elas estariam livres das influências das classes perigosas. Era preciso instituir iniciativas e meios para desviá-las deste caminho. A pobreza era vista como um fator de desordem, a porta de entrada para o crime e a promiscuidade.

\begin{abstract}
A criação de um instituto voltado para atender às meninas provenientes das camadas populares tinha como objetivo ensinar o trabalho doméstico necessário, procurando supri-las das noções básicas sobre os deveres da mulher, da dona de casa e da mãe, bem como afastá-las dos vícios e da vida desregrada tão presentes na capital do país (CAMARA, Op.cit., p.239).
\end{abstract}

Educadas em espaços organizados a partir da disciplina rígida e da valorização do trabalho, as alunas das escolas profissionais femininas recebiam uma educação escolar que tinha por objetivo, também afastá-las da circulação desnecessária pela cidade e do consumo excessivo, prepará-las para realizarem o trabalho remunerado ou não e torná-las aptas a fazer escolhas econômicas (RODRIGUES, Op.cit.,p.73).

Em 1898, foi inaugurada a primeira instituição do gênero: o Instituto Profissional para o Sexo Feminino. Estabelecimento de caráter assistencialista, dedicava-se à formação de órfãs e filhas de funcionários públicos municipais. No ano de 1901, passou a funcionar no bairro do Engenho Velho, hoje Tijuca. Após dois anos, transformou-se no internato Instituto Profissional Orsina da Fonseca, homenagem à primeira esposa do Presidente Hermes da Fonseca ${ }^{55}$ (1910-1914) (CAMARA, Op.cit.). Em 1910, foram inauguradas na capital da República mais duas instituições: a Escola Profissional Bento Ribeiro e a Escola Profissional Feminina Rivadávia Correa.

55 Posteriormente, o Presidente Hermes da Fonseca se casou, em 1913, com Nair de Teffé (18861981) considerada a primeira caricaturista brasileira. Cf.: RODRIGUES, A. E. M.. Nair de Teffé, vidas cruzadas. Rio de Janeiro: FGV,2002. 
A estrutura curricular destes institutos estava alicerçada nos parâmetros da educação doméstica, definida por Louro (Op.cit.) como “(...) uma série de ensinamentos referentes à administração do lar" (p.458). É ressaltado que a mesma não se caracterizava como mera transposição, para o universo da escola, das tarefas domésticas. Esta modalidade educacional, segundo seus partidários, era pautada por conhecimentos científicos pois tinha “(...)uma roupagem escolar e didática" (Loc.cit.). Camara (Op.cit.) descreve, como exemplo, o currículo da escola profissional feminina Paulo de Frontin, externato criado em 1918, a partir da divisão do Instituto Orsina da Fonseca que permaneceu como internato:

As escolas femininas passaram a se organizar com as seguintes seções: Costura (corte e feitio de roupas brancas grosseiras e de roupas para operários); Corte e feitio de roupas brancas finas e vestidos e roupas para senhoras e crianças; Bordados e Rendas; Flores e Chapéus, Lavagem e Engomados; Cozinha; Arranjos e Serviços Caseiros; Avicultura e Apicultura; Leite (fabricação de leite e manteiga); Luvas e Gravatas (p.248-249).

O rol de disciplinas oferecidas às meninas, seja no âmbito da educação profissional ou na educação regular, diferia das estudadas pelos meninos. As aulas de trabalhos manuais deveriam proporcionar o aprimoramento de um dom inerente ao sexo feminino. Desta forma, “(...) tinha o objetivo de prepará-las para a execução manual de uma grande variedade de produtos, compreendia como habilidade artística e competência intelectual (RODRIGUES, Op.cit., p.73).

Para Louro (Op.cit.), a escola padecia de um caráter ambíguo. Retirava-se do lar a primazia da formação feminina, no entanto os conteúdos ensinados visavam reforçar os laços entre a mulher e o universo doméstico.

As narrativas de $O$ Tico-Tico salientam a relevância das meninas receberem orientações quanto aos saberes domésticos, assim evitariam cometer erros no futuro. Sem a formação correta, os bons sentimentos femininos não se traduziam em ações positivas e úteis. Em Zelo Demasiado, Lolota é descrita como uma boa garota sempre pronta a ajudar nos trabalhos domésticos. Embora um poço de bondade, a menina não tinha os conhecimentos necessários para assumir o papel de administradora do lar (Fig. 52).

A leitura e escrita deviam ser parte do cotidiano das meninas. O analfabetismo não era uma opção. As narrativas de $O$ Tico-Tico sobre o tema costumam trazer um tom dramático. A menina ignorante descreve as agruras da garota Claudina que, por ser desleixada nos estudos, não consegue brincar com os 
amigos porque todas as atividades envolviam saber ler, escrever e contar (Fig.53). $\mathrm{Na}$ história $O$ Bilboquet, a garota Yovonne aprende que ninguém é suficientemente inteligente que não precise se dedicar aos estudos (Fig.54). Em $A$ cura dupla, a menina Luizinha quase matou a própria a mãe por ser má aluna e aos 11 anos continuar analfabeta. Deu-lhe o remédio errado porque não conseguia ler os rótulos dos medicamentos (Fig.55). O não saber ler e escrever impedia ao sexo feminino de exercer de forma plena o seu papel para com a nação. A educação feminina tinha a função de formar e conformar, a partir do ambiente privado do lar, os hábitos e os comportamentos das futuras gerações republicanas.

As leitoras de $O$ Tico-Tico tinham que ser como Mimi, a protagonistas de Uma encantadora menina:

Mimi é uma menina muito sensata, muito estudiosa e muito trabalhadora, tem a sua boneca, uma boneca quasi do seu tamanho, que ganhou no dia de seu anniversario natalicio, como premio de sua appliacação nos estudos e do modo como ajuda a mamãi nos arranjos da casa e em cuidar dos irmãos mais novos (...) (O TICO-TICO, 09/10/1912,p.13).

Para Souza (1998) "A imperiosa finalidade moralizadora, cívica e civilizadora estendeu-se à educação feminina" (p.46). A autora faz referência à Reforma educacional realizada em São Paulo, Decreto Lei $n^{\circ} 88$ - de 8 de setembro de 1892, que obrigou os grupos escolares a oferecerem o mesmo número de classes para meninos e meninas. Não poderia haver diferenciação quanto aos programas de ensino, a metodologia, o material didático, à higiene escolar entre outros aspectos. No entanto, a coeducação não era permitida, "apenas em casos extraordinários quanto uma escola não tivesse número suficiente de alunos de um sexo ou outro" (Loc.cit.).

A importância da educação em $O$ Tico-Tico também se refletia na publicação de notinhas informativas sobre as datas dos exames finais, das celebrações de término do ano letivo das escolas públicas femininas. A revista também dedicava espaços às fotografias de professoras e suas alunas. A seção As nossas escolas, de 19 de junho de 1907, traz a foto das "Alumnas do Colégio de D. Mariana da distincta professora publica" da cidade de Barra do Piraí, no estado do Rio de Janeiro (s/p.) (Fig.56). 


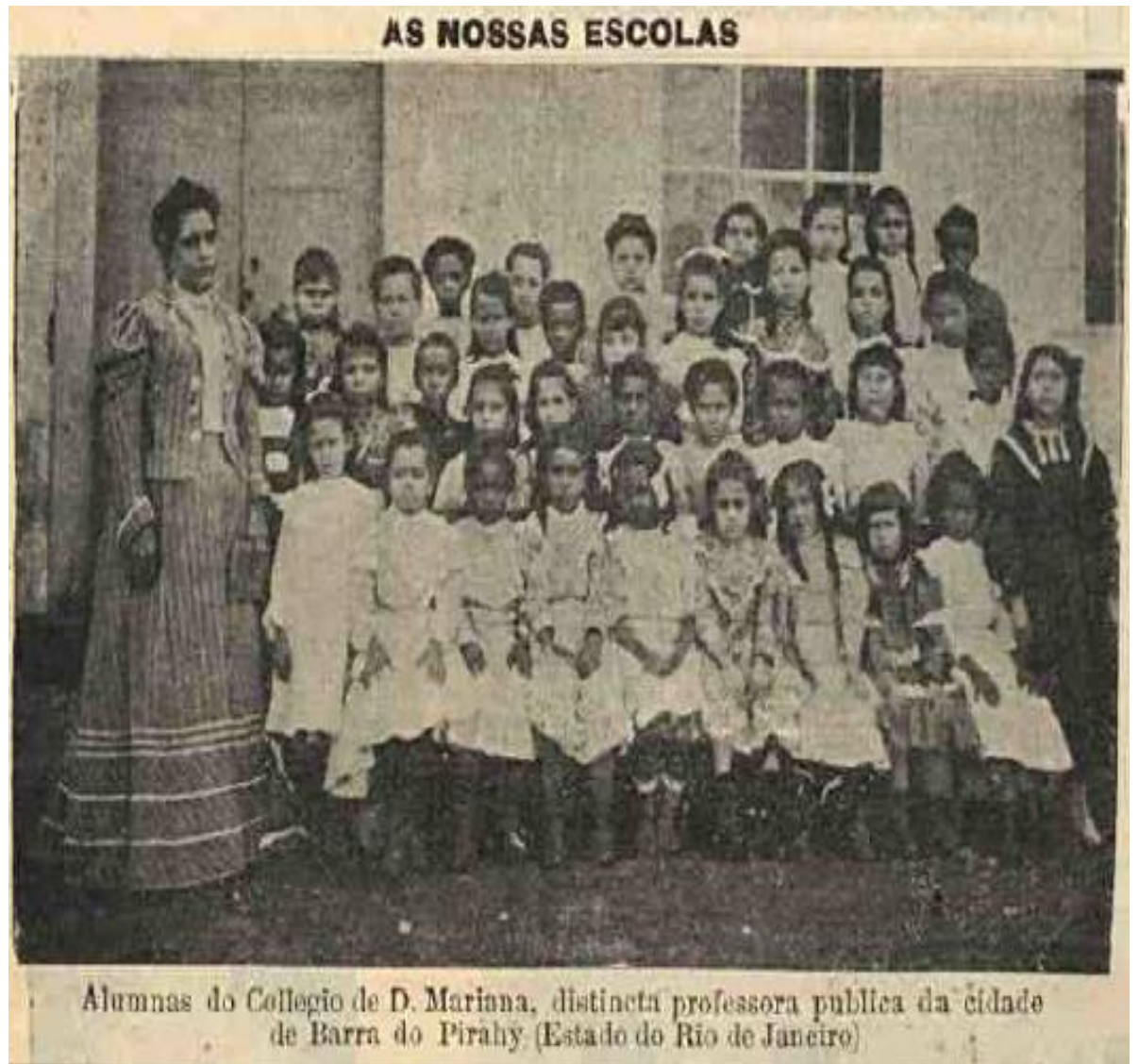

Figura 56 - O Tico-Tico - 19/06/1907 - s/p

$\mathrm{Na}$ imagem, a professora e as alunas estão como uma expressão séria. D. Mariana usa roupas fechadas e os cabelos presos por um coque. As estudantes, brancas e negras, trajavam vestido, em sua maioria brancos, e algumas estão com os cabelos enfeitados com laços de fita. Segundo Louro (Op.cit.) a representação da mestra com “(...) roupas escuras, abotoadas e de mangas cumpridas, rosto fechado, cabelo em coque, costas retas, pés unidos, mãos postas ao lado do corpo ou sobre os joelhos (...)" faz menção a figura da professora solteirona, aquela que abdica de sua vida particular para se dedicar às crianças (p.466). Neste caso, a legenda ratifica tal visão ao informar que aquele espaço escolar pertencia à educadora. Remete-se ao modelo das Escolas Isolada ${ }^{56}$.

\footnotetext{
${ }^{56} \mathrm{~A}$ Escola Isolada é um modelo educacional, aplicado às escolas públicas ou particulares, típico do período monárquico. No entanto, ainda permanece emdestaque no decorrer das primeiras décadas republicanas. As instituições eram classificadas e hierarquizadas, não por séries e conteúdos, mas por sua localização: urbana e rural. Funcionava, em sua maioria, nas casas ou nos prédios alugados pelo professorado. Caracterizava-se como a educação no espaço do lar. Era um misto de sala de aula e residência do professor e de sua família. O professor era o responsável por controlar todo o processo educativo e o tempo escolar. As turmas eram formadas por alunos de diversas idades e em momentos de aprendizagem diferentes. SCHUELER, Alessandra, "Grandeza da Pátria e Riqueza do Estado": Expansão da escola primária no Estado do Rio de Janeiro (18931930), Revista de Educação Publica (UFMT), v.19, n.41, 2010, p.535 - 550.
} 


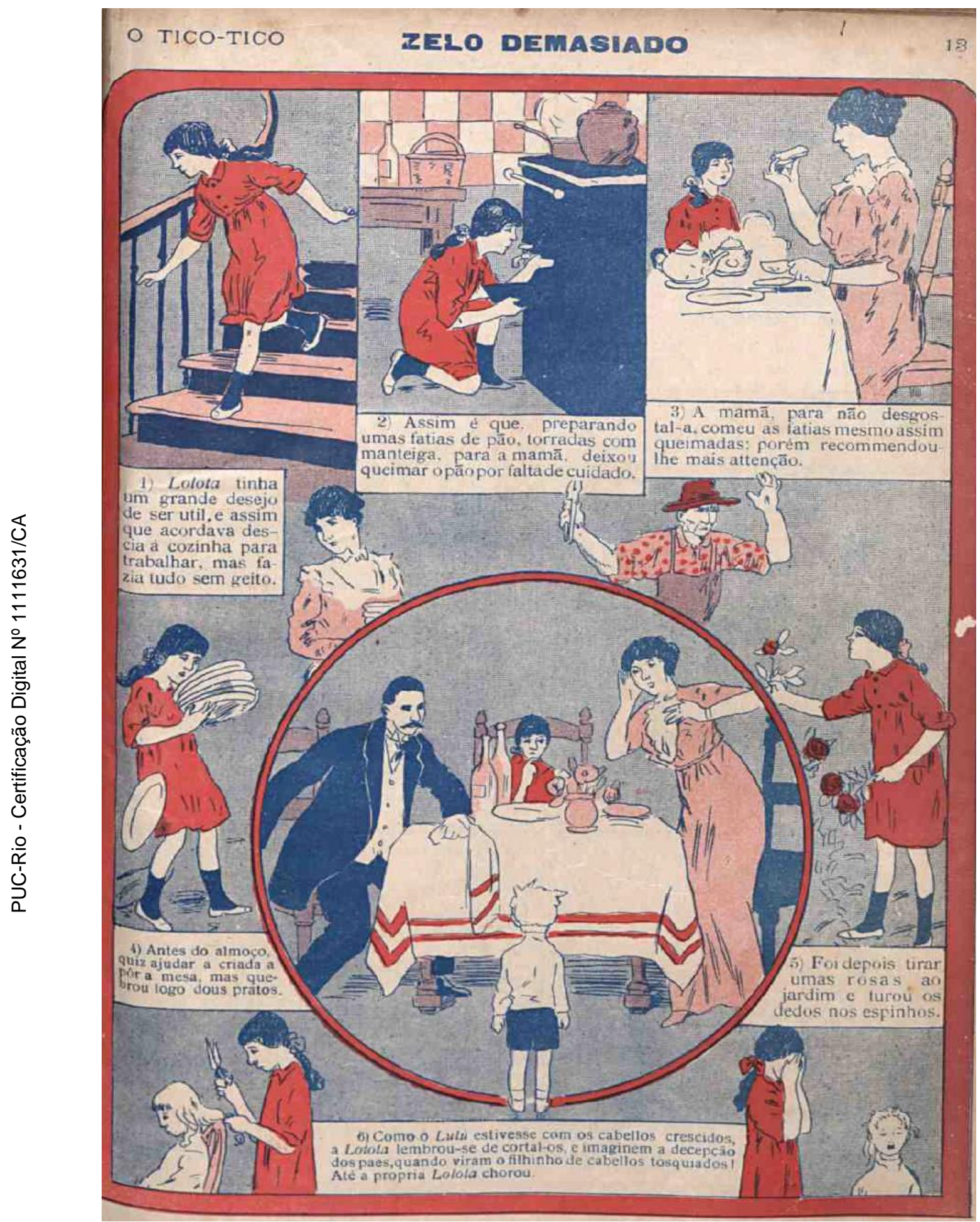

Figura 52- O Tico-Tico-30/04/1913-p.13 


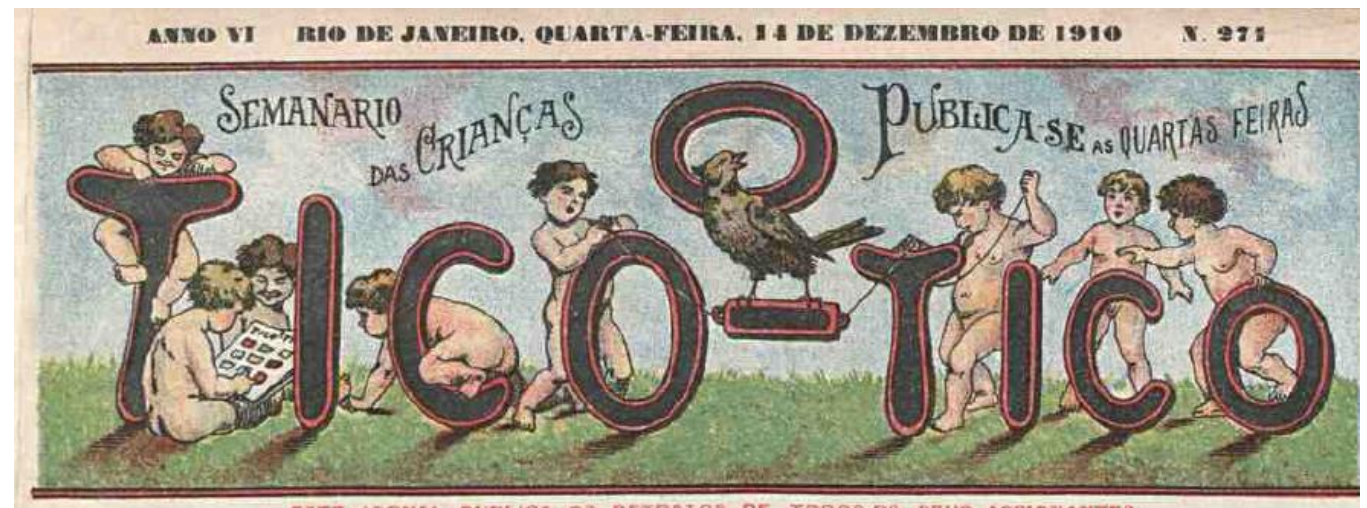

A MENINA IGNORANTE

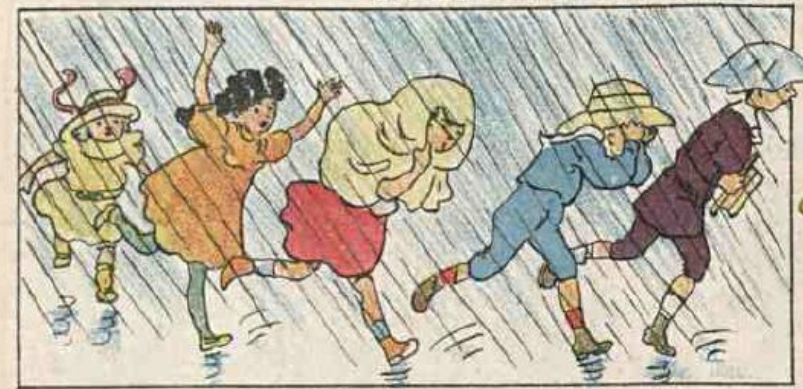

1-Estavam ciaco ereanças brincando alegremente no jardim quando de repenie começol a chover. Correram todus para casa. Pavadas do jardim, as cteanças...

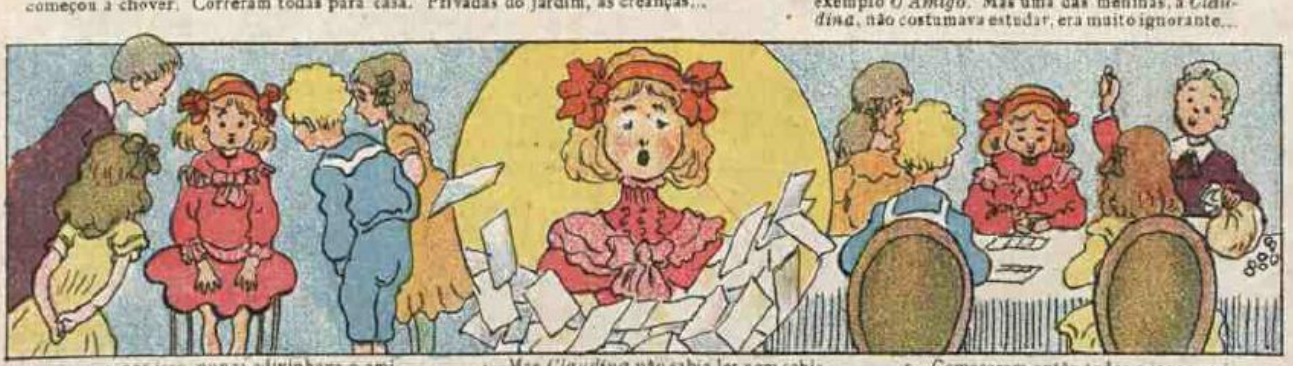

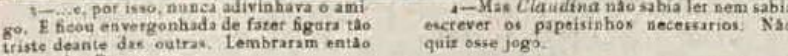

pora. Mas Claudinat ento todos a jogar a vis.

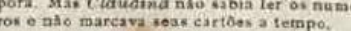

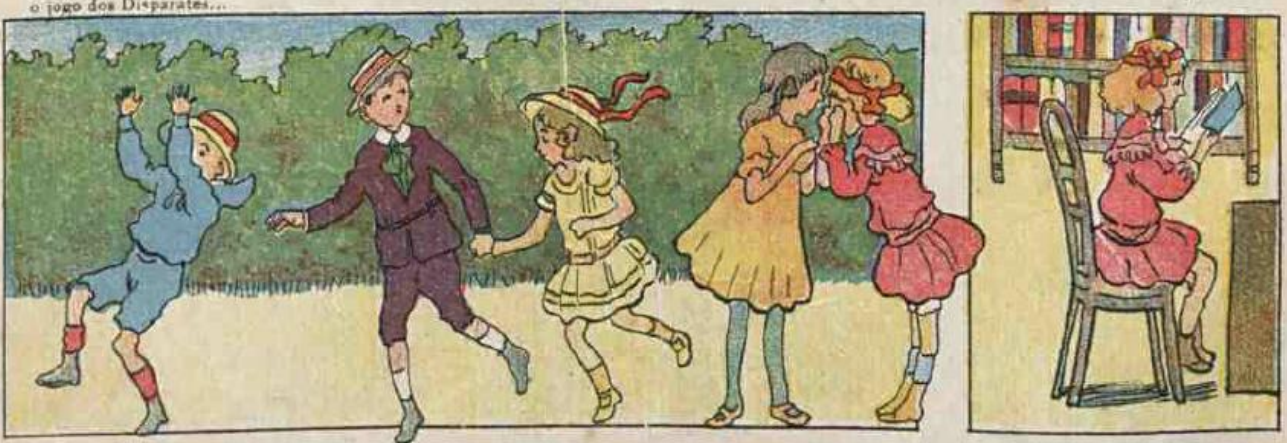

to-Desathu a chorar. Felizmente ja is chuva tibla passado e puscram voltar todox ao jurdim.

7- Ella coraprehenden que ternoc-ne estudion e em pouco tecupo sabia tanto cono saj cow.

REDACCAO E ADMINISTRACA AO. Rua do Ouvidor 164-RIO DE JA NEIRO (Publicapăo diO MATHO)

(Numero arulso 900 réls, atracade 500 réls) 


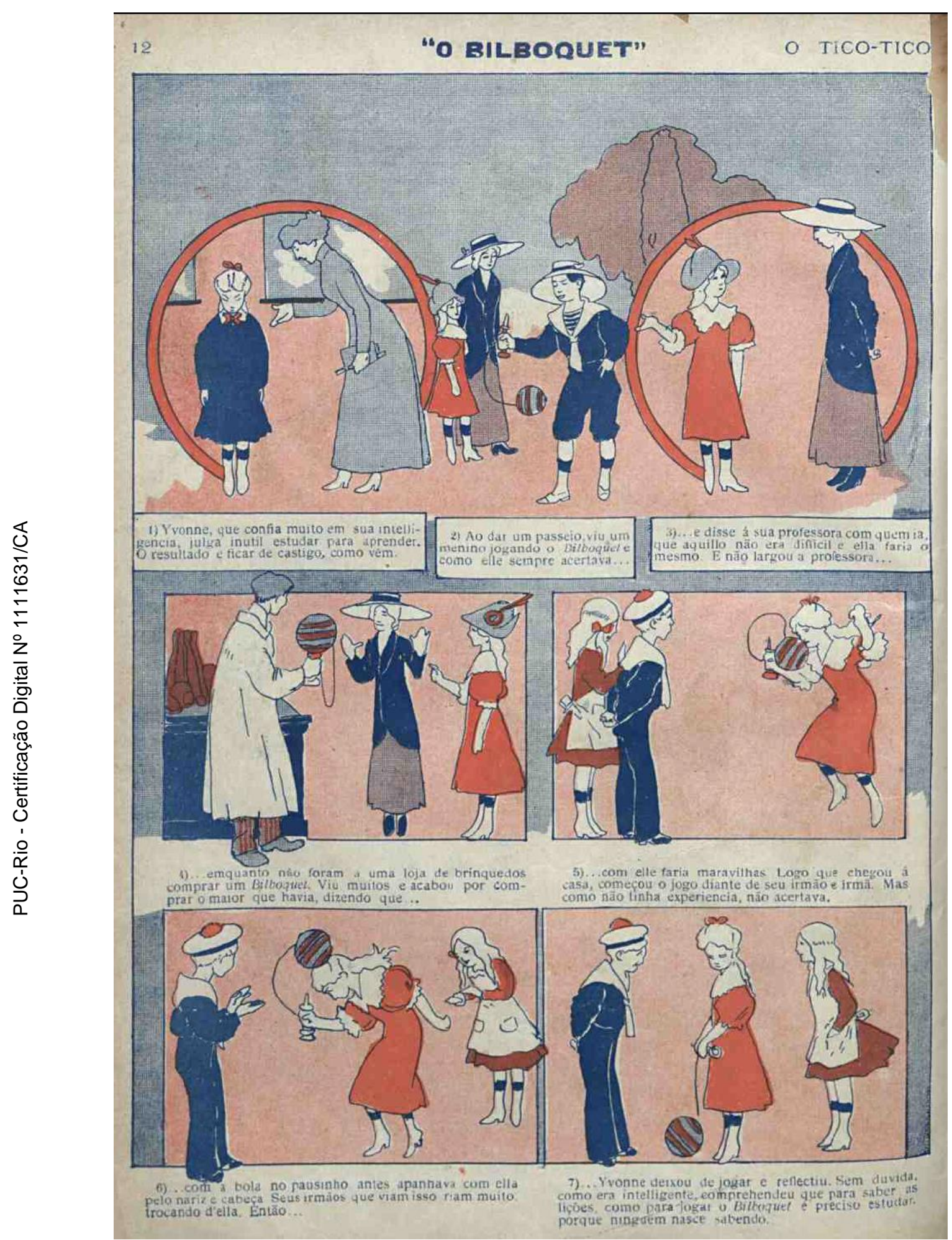

Figura 54 - O Tico-Tico - 29/01/1913 - p.12 


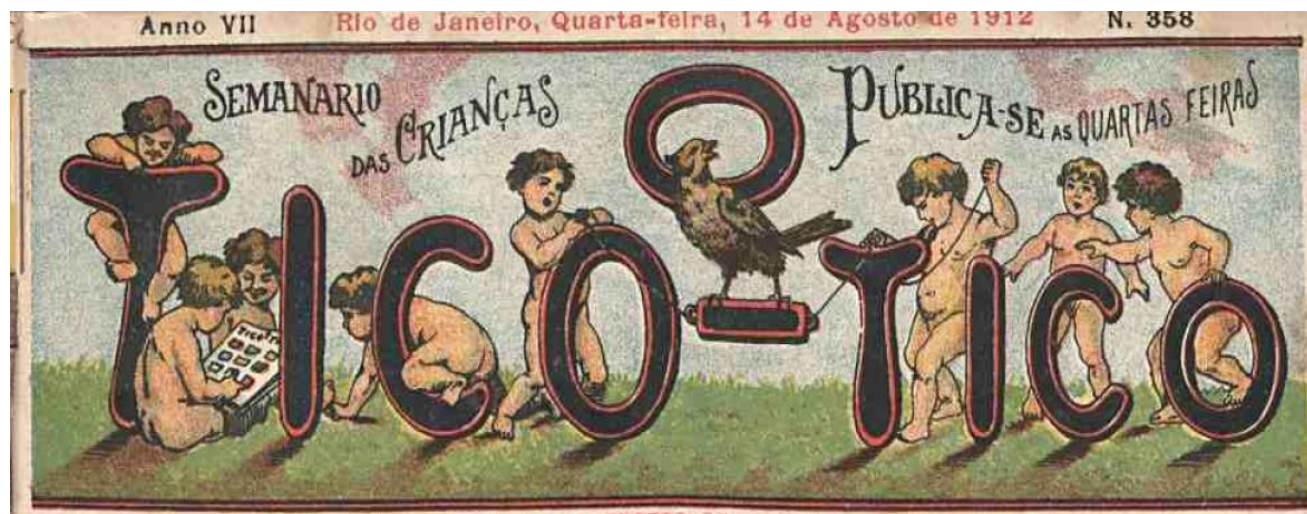

ESTE JORNAL PUBLIOA OS RETRATOS DE TODOS OS SEUS ASEIQNANTES

A CURA DUPLA

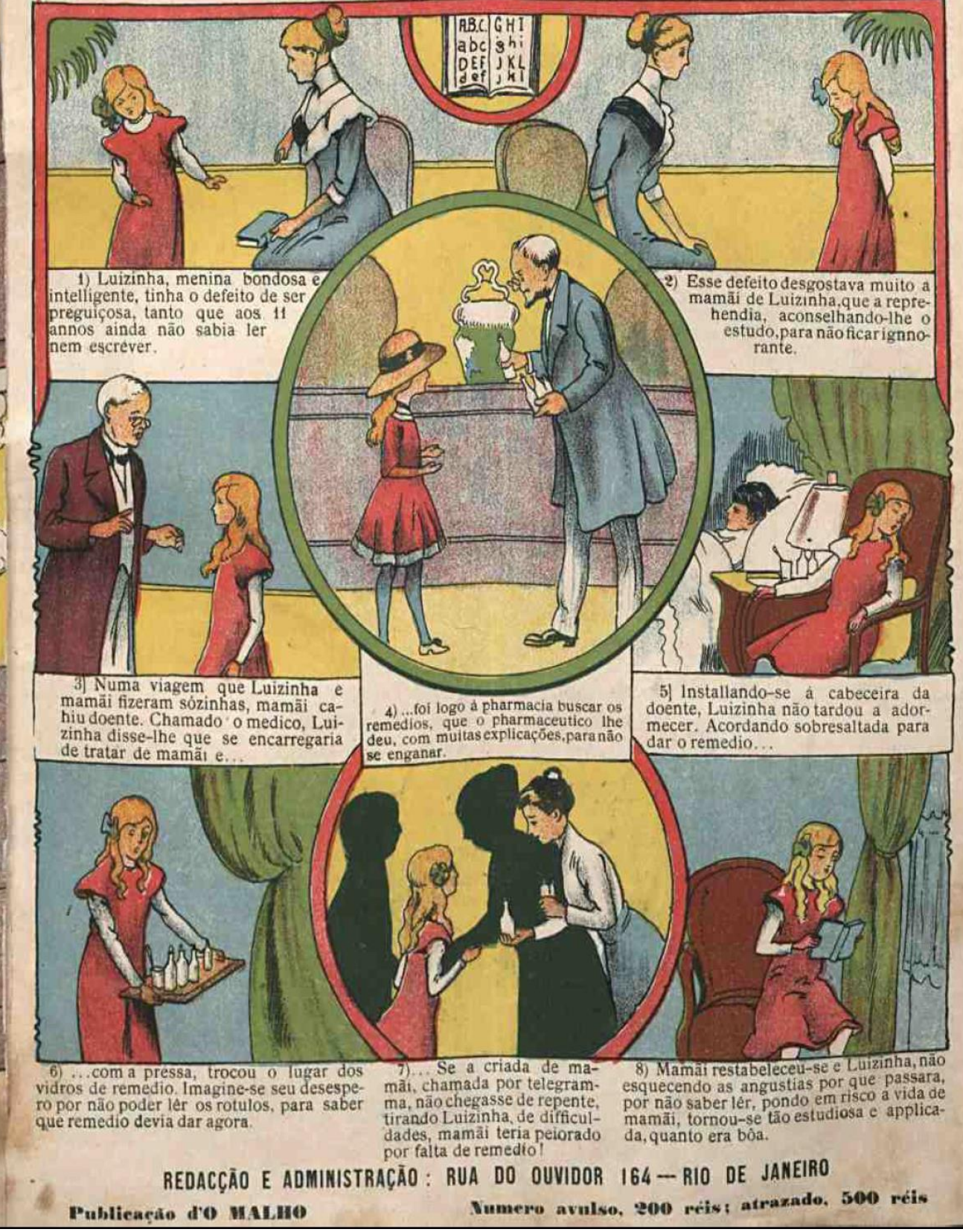

Figura 55 - O Tico-Tico - 12/08/1912 - p. 1 


\section{3 - O trabalho feminino: mais lar e menos rua}

Quer sejamos doutores, professoras, artistas ou literatas, estas profissões não nos eximem de intervir na vida collectiva, partecipando das suas angustias e dos seus prazeres. Humildes ou potentes, profissionaes ou mães, está em nós o dever de manter alta a vida em nosso redor, dar alegria e evitar a dor. Dar alegria e evitar a dor divisa instictiva e inconsciente de todas as mães, problema affanoso das preoccupações de todas as mulheres. Dar alegria e evitar a dor - missão simples e enorme, que comprehende toda a gamma da moral humana, desde a caricia até ao trabalho exhauslivo, desde o sacrifício de si mesmo, ás audacias mais maravilhosas; desde admirações mais humildes até ao enthusiasmo e á fé mais ardentes.

Este é mais um trecho do artigo A missão da mulher de Gina Lambroso

Ferrero. A autora ressalta que o fato de exercerem uma profissão, não as exime da missão natural de proteger os entes queridos das agruras e do sofrimento.

Scott (1991) descreve que as mulheres sempre trabalharam e exerceram as mais diferentes funções, desde costureiras até polidoras de metais. No entanto, no decorrer do século XIX, a categoria mulher trabalhadora passou a ser alvo de debates:

A mulher trabalhadora foi um produto da revolução industrial (...) A visibilidade da mulher trabalhadora resultou da sua percepção como um problema, um problema de criação recente e que exigia solução urgente. Esse problema implicava o próprio sentido de feminilidade e a sua compatibilidade com o trabalho assalariado; foi posto e debatido em termos morais e categoriais. (...) deve a mulher trabalhar por um salário? Qual o impacto do trabalho assalariado no corpo feminino e na sua capacidade de desempenhar as funções maternais e familiares? Que gênero de trabalho é adequado a mulher? (p.443).

No cerne da questão estava a mudança do local de trabalho feminino. As atividades anteriormente realizadas pelas mulheres estavam vinculadas, prioritariamente, ao espaço do lar. Supunha-se que conseguiam combinar perfeitamente a maternidade e suas ocupações produtivas. No entanto, com a Revolução Industrial, as mulheres teriam que se dividir entre a casa e a fábrica, situação que prejudicaria a criação dos filhos e a administração do lar:

O resultado segundo se dizia, era que as mulheres só poderiam trabalhar durante curtos períodos das suas vidas, abandonando o emprego remunerado depois de casarem ou terem filhos, voltando ao trabalho mais tarde só caso de os maridos não serem capazes de sustentar a família. Daí advinha ficarem confinadas a certos empregos não especializados, reflexo da prioridade das suas obrigações domésticas e maternais sobre 
qualquer identificação profissional ao longo prazo (Ibidem, p.444).

Ganhou espaço, o discurso de que os indivíduos do sexo masculino não interrompiam sua carreira, ao contrário das mulheres que engravidavam e precisavam se dedicar à família. Na prática, tal argumento não se sustentava, pois os homens ficavam doentes e passavam por períodos de desemprego. Scott (Ibidem) ressalta que “(...) o sexo era oferecido como a única razão para a diferença entre homens e mulheres no mercado de trabalho" (p.445).

Para Perrot (Op.cit.), o século XIX se caracterizou pela acentuação da divisão do mundo do trabalho entre homens e mulheres. A eles foram destinados os afazeres nas fábricas e a elas os cuidados com lar e a família. O sexo masculino seria remunerado por seus serviços, a mulher não. Constituía-se a perspectiva de que o trabalho feminino era uma missão.

A realidade demonstrava que grande parte das mulheres precisava trabalhar. Neste sentido, instituiu-se a seguinte questão: $O$ que é um trabalho de mulher? Em uma sociedade marcada pelo discurso da fragilidade feminina, os trabalhos destinados a elas se caracterizavam por

Qualificações reais fantasiadas como "qualidades" naturais e submissas a um atributo supremo, a feminilidade: tais são os ingredientes da "profissão da mulher", construção e produto da relação entre os sexos (Ibidem, p.253).

A identificação da mulher com certo tipo de empregos e como mão-de-obra barata foi formalizada e institucionalizada de várias maneiras durante o século XIX, de tal modo que se tornou axiomática, uma questão de senso comum. (SCOTT, Op.cit. p.454).

As personagens femininas de $O$ Tico-Tico em sua maioria eram donas de casas, em uma perspectiva de sintonia com o modelo feminino defendido por setores mais conservadores das elites burguesas (VERGUEIRO, Op.cit.). Ao longo de suas edições, o trabalho feminino foi abordado de forma lúdica, mais também com certo tom de desprezo. Um exemplo foi a letra da cançonet $a A$ Copeirinha, escrita pelo poeta Eustorgio Wanderley, e publicada no exemplar de 26 de abril de 1916: 
I

Copeirinha elegante e delicada

Eis aqui,

Com modos de servir muito sympathicos, Nas casas em que estou como empregada,

Nunca ouvi

Senão os elogios mais enphaticos;

Patrôas e patrões, principalmente,

Sem cessar,

Não deixam de elogios me fazer;

E eu bem contente

Assim de casa em casa sem parar,

A todos vou servindo com prazer.

Sou copeirinha, ai! ai!...

E arrumadeira, olé!

D'esta maneira, ai!ai!...

Ninguém me passa o pé.

Sou copeirinha, ai! ai!...

E arrumadeira, olé!

D’esta maneira, ai!ai!...

Não sei quem é...

II

Quando meu ordenado é pequenino,

Vou tratar

De uns cobres conseguir com certas lábias,

E o methodo, que emprego aqui ensino

A quem achar

Que deve ouvir minhas lições tão sabias:

Nas compras vou fazendo economia...

Para mim,

E o que custa um tostão digo ser mais,

No fim do dia

Eu tenho minha féria feita assim,

De grão em grão enchendo meu cabaz

Sou copeirinha, ai! ai!...etc

III

Com a crise medonha em que vivemos

A soffrer

Eu tenho prejuízos enormissimos,

Pois tudo caro, assim como sabemos

E' de crer

Que os nickeis que eu empalmo são pouquíssimos...

Por isso, agora eu ando precisada

De encontrar

Patrões, que sejam muito liberaes,

Pois é massada

A gente numa casa se empregar

$\mathrm{E}$, fora do ordenado...nada mais

(Gesto de dinheiro) $(\mathrm{s} / \mathrm{p})$

Para entoar a canção de forma mais engraçada, a leitora é aconselhada a usar um avental branco, uma pequena touca na cabeça e carregar uma cesta para dar a impressão de que estava retornando das compras. O conteúdo frisa que a 
empregada tem de servir bem os seus patrões, mas seu trabalho como outras tantas mulheres, não é bem remunerado. Observa-se o fato dela ter pedido sorte para encontrar patrões liberais, em meio a grupos das elites que perpetuavam visões conservadoras acerca dos afazeres femininos. As trabalhadoras eram motivo de galhofa. Assim, as meninas aprendiam desde cedo que trabalhar fora não era o melhor para elas. Na revista $O$ Tico-Tico, o trabalho feminino fora do lar era visto com complacência apenas quando estivesse relacionado ao próprio sustento e da família. As profissões deveriam se restringir a empregos que estivessem vinculadas à própria natureza da mulher. Como salienta Campos (Op.cit.) as funções consideradas apropriadas ao sexo feminino eram

(...) extensão pública dos papéis sociais historicamente delegados às mulheres, pois requeriam qualidades supostamente constitutivas do sexo frágil, como paciência, docilidade, sensibilidade e disposição intrínseca à submissão (p.83).

Em Correspondência do Dr. SabeTudo, de 2 de setembro de 1914 e 19 de

maio de 1915, Dr. SabeTtudo aconselha suas leitoras a seguirem o magistério ao invés de optar pela carreira de farmacêutica ou musicista:

Qualquer uma das duas é bôa carreira para uma moça que deseja ser independente; mas se não conta com pessoa de sua absoluta confiança, que lhe reserve um logar de pharmaceutica, deve preferir o magisterio, pois com elle irá lidar com creanças o que fica bem a uma moça e não te arrisca a ter que trabalhar em qualquer laboratorio entre desconhecidos (p.19).

A carreira musical é talvez mais brilhante; a do magistério, mais modesta e trabalhosa, é porém mais segura. E não impede que cultive sua vocação musical. Ao contrario, isso será para minha bôa amiguinha mais uma vantagem (p.17).

A restrição a determinados tipos de emprego foi narrada em Os sonhos da Lili de 6 de junho de 1906. A menina que desejava ser uma princesa ou uma rainha quase foi nomeada General. No entanto, ela acordou e a realidade se fez presente (Fig.57). No início do século XX, não havia a possibilidade das mulheres pertencerem às Forças Armadas. Este contexto apenas se modificou em $1980 \mathrm{com}$ a criação do Corpo Auxiliar Feminino da Reserva da Marinha, Decreto Lei n. 6807 - 7 de julho de 1980. Embora já tivesse ocorrido exceções. Em 1823, Maria Quitéria $^{57}$ se vestiu de soldado para combater as tropas portuguesas na província da Bahia que não reconheciam a Independência do Brasil.

${ }^{57}$ Maria Quitéria nasceu em Salvador no ano de 1792. Recebeu a condecoração Ordem do Cruzeiro do Imperador D.Pedro I por ter . Embora reconhecida por sua atuação nos combates pela consolidação da Independência do país, não pôde seguir carreira militar. Sua condição de 


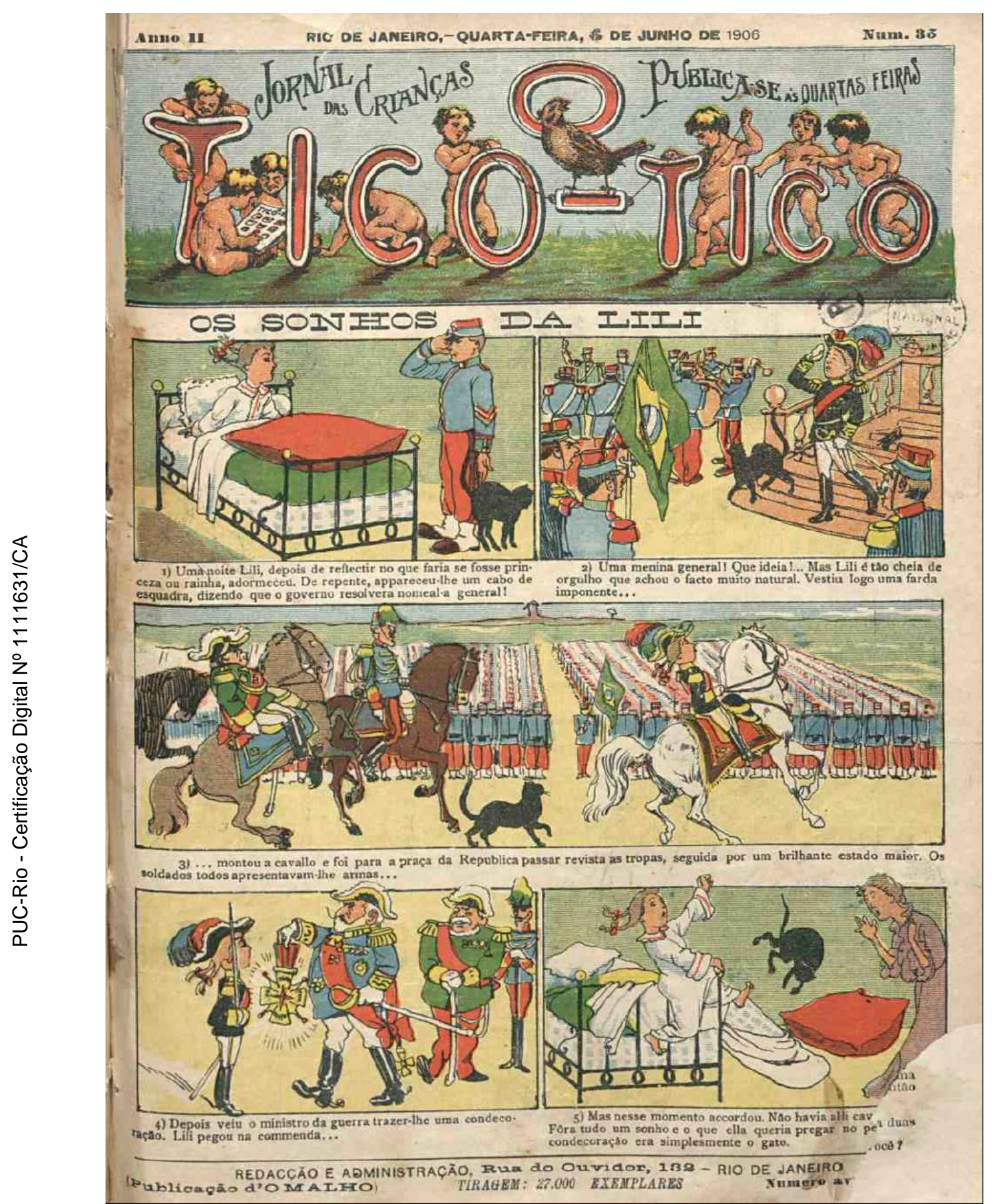

Figura 57-O Tico-Tico-06/06/1906 - p.1

excepcionalidade foi realçada por sido permitido que vestisse um saiote por cima do uniforme de soldado durante os combates. Nas referências iconográficas sobre a personagem histórica, ela é retratada com a referida vestimenta. Maria Quitéria faleceu aos 61 anos, em 1853 na cidade de Salvador. No ano de 1996 foi nomeada Patrona do Quadro Complementar dos Oficiais do Exército brasileiro. VAINFAS, Ronaldo. (Org.). Dicionário do Brasil imperial. Rio de Janeiro: Objetiva, 2008. p.523-525. 
Os trabalhos costumeiros destinados às mulheres que trabalhavam fora eram o magistério primário, a enfermagem e o emprego doméstico. Em 23 de setembro de 1914, Dr. SabeTudo aconselhou: “ (...) mas não acho das melhores a profissão de advogada para uma moça" (p.9).

No impresso infantil, esta última função era realizada por órfãs e mulheres pobres. De forma majoritária, as mulheres pardas e negras costumavam ser retratadas no impresso a partir deste segmento social. Reflexo de uma sociedade marcada pelo preconceito racial. Na história $O$ talento de Juquinha-A terrível vingança, o menino Juquinha, primo de Chiquinho, pintou um grande painel no qual descrevia sua família e os agregados que faziam parte de seu convivo. No desenho os patrões são brancos, os serviçais são negros (Fig.58). Segundo Rago (2009), documentos oficiais e estatísticas sobre o mundo do trabalho, nas primeiras décadas do século $\mathrm{XX}$, indicam que, um número considerável de mulheres negras, exercia funções de empregada doméstica, de cozinheira, de lavadeira, de vendedora e até prostituta. Em razão do preconceito, elas eram descritas como mulheres de pouca educação, rudes e de pouco traquejo social. Além de receberem salários mais baixos.

Acerca da figura da professora do ensino primário, Louro (Op.cit.) destaca que os relatórios provinciais sobre a Instrução Pública, a partir da segunda metade do século XIX, apresentam dados sobre a ampliação da quantidade de mulheres matriculadas e formadas nas Escolas Normais. Constatava-se o início da feminização do magistério, processo ocorrido em meio às ações de modernização e urbanização das principais cidades brasileiras ${ }^{58}$.

O impresso O Sexo Feminino - Semanário dedicado aos interesses da mulher - fundado por D. Francisca Senhorinha da Mota Diniz, em 7de setembro de 1873 - defendia o acesso da mulher à instrução como meio de garantir a sua inserção no magistério e no espaço público. FILHO, Luciano Mendes de Faria; et.al.A história da feminização do magistério no Brasil: balanços e perspectivas de pesquisa. In: PEIXOTO, Ana Maria Cassanta; PASSOS, Mario. (Org.). A escola e seus atores - educação e profissão docente. Belo Horizonte: Autêntica, 2005.p.53-87. 
Estava-se imerso ao discurso vitorioso de que o sexo feminino possuía as aptidões naturais para cuidar e educar as crianças. Instituiu-se a representação do magistério como extensão da maternidade e trabalho apropriado às mulheres. $\mathrm{O}$ turno de trabalho reduzido não as impediria de cuidar do lar. Ressalta-se que a carga horária menor era uma das justificativas para baixos salários. Este contexto também envolveu a construção de determinadas representações do ser professora: a feia, a solteirona, a severa, a cuidadosa, a boazinha ou a "mãe espiritual" (LOURO, Op.cit., p.463). Na revista $O$ Tico-Tico, as professoras são retratadas de diversas formas: algumas são bondosas, outras são bravas e muitas eram alvos de brincadeiras e travessuras por parte de seus alunos. Na narrativa Meninos malcriados, os alunos chegam a amarrar a professora durante uma visita ao Passeio Público (Fig.59). Nota-se a presença do estereótipo da professora de óculos e com os cabelos presos em um coque. Tem-se este exemplo em Sciencia de Solange (Fig.60).

Por outro lado, em virtude de sua natureza materna, elas têm a responsabilidade, de ensinar o conteúdo, mais também de reprimir os maus comportamentos e sentimentos. Na história A mentira do silencio, a professora demonstra às meninas Joaninha e Laura sobre o quanto é importante sempre falar a verdade, pois ocultar uma mentira pode prejudicar pessoas inocentes (Fig.61). Em A lição de desenho, professora demonstra ser justa e reconhece o esforço de uma aluna ridicularizada pelas colegas por não conseguir fazer belos desenhos (Fig.62). 


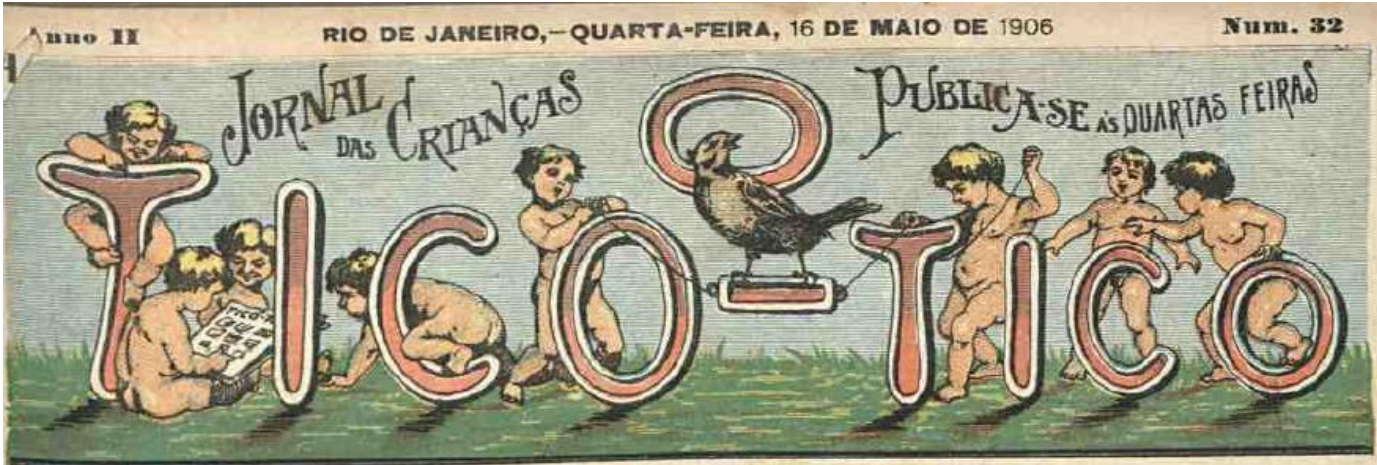

D TALETTO DO DUQUENHA TEREIVEL VINGANQA

Os leitoros recordam-se ainda da ultima pilleria do Juquinha :

O nosso heróe depois de ter pregado aquella peca do caf́s gelado, apsanhou uma sova tromenda. tmagnitico painel que alli esti.

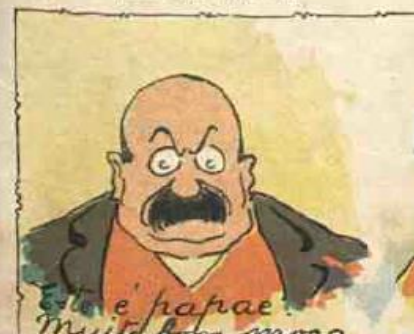

Qula

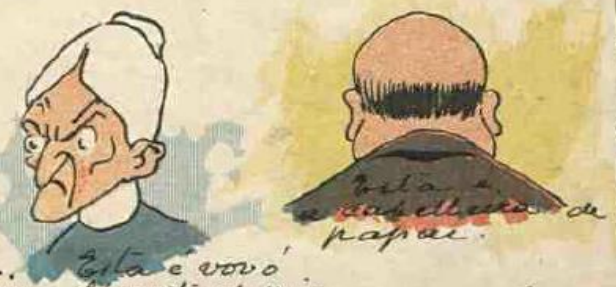

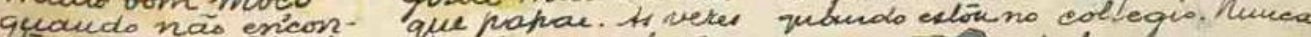
riva 3 a mad minhas ore D lhas com for ca.
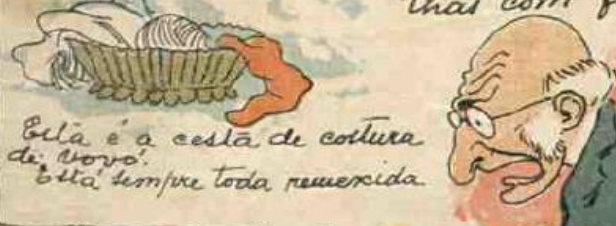

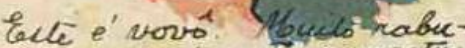

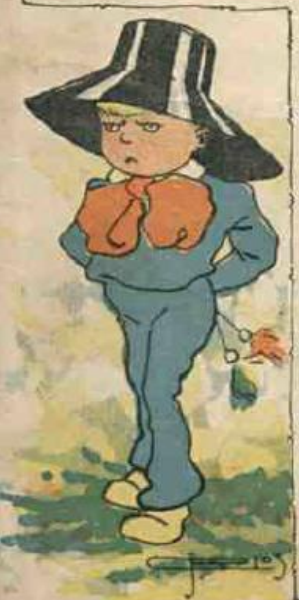

euto quaudo mas emcontra gend beugala, 0 leque on o frenal ofrual nuxa he So

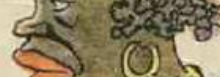

\section{Evà a द्र}

Esca. Es a Marra. Leva Codo dia gritando: it hasi- Vire farendo quexas. nha ora io Juquicha que fá for tolminha patróa to gallinheito. Yalluha tudo tá sôto. o menino ea atá a bexer toluces $c$ a

Lista é buigala que dicer nomes firos

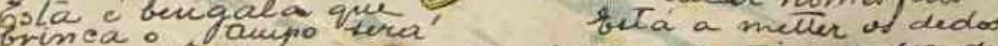
com vôvo. côco.

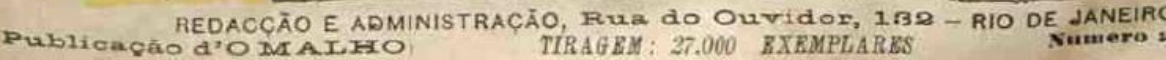

Figura 58- O Tico-Tico-16/05/1906-p.1 


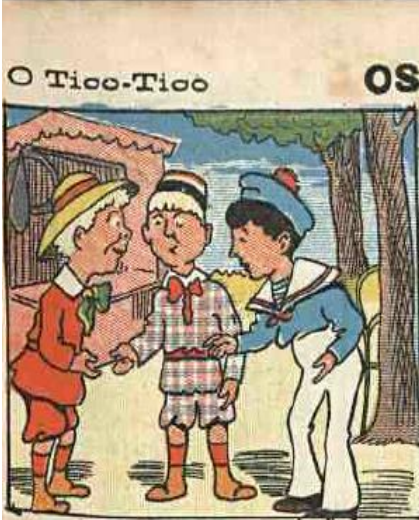

1) Tullio, Juca e Neco foram passeiar no Passeio Publico com sua professora.
OS MENINOS MALCREADOS

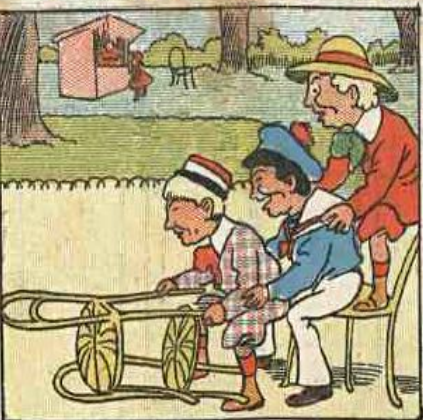

2) Mas afastaram-se d'ella e começaram a inventar brinquedos perigosos,

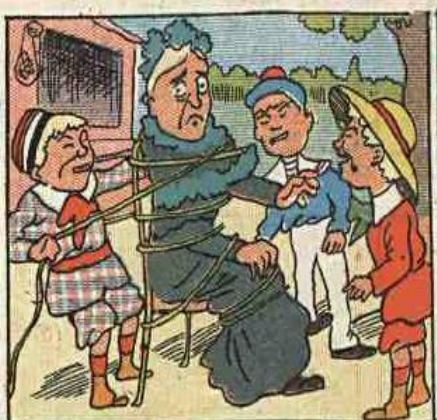

5) ...elles arranjaram umacorda etraiçoeideira.

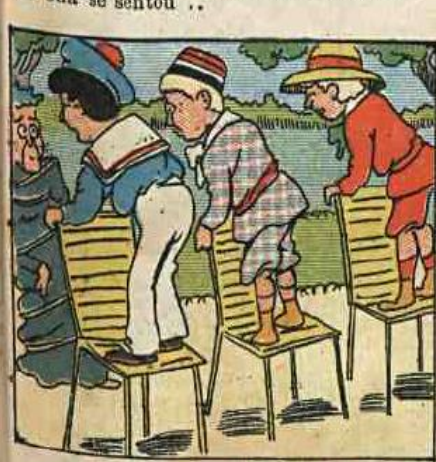

7) ...e, trepando sobre ellas, puzeram se a sir đa aituaçáno da professora...

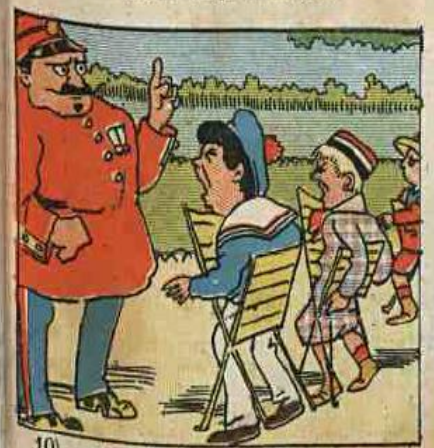

10) ...prendendo os meninos malcresBuard que começaram a gritar. Veiu um

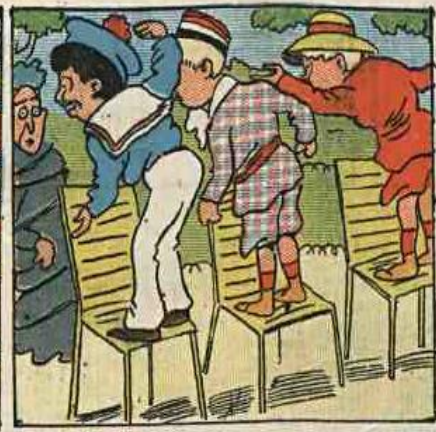

8) .. pulando de contentes, Mas as cadeiras eram de molas..

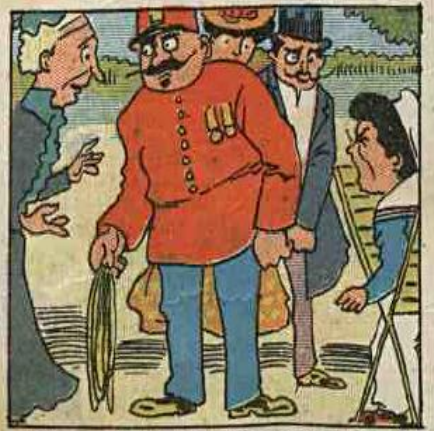

14) que Tullio, Juca e Neco haviam feilo.

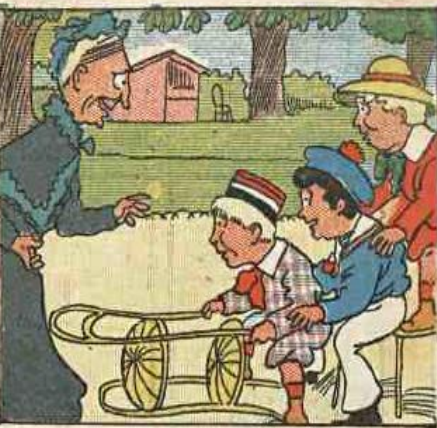

3) A professora vin e ralhou com elles. Mas Tullio, Juca e Neco são mal educados.

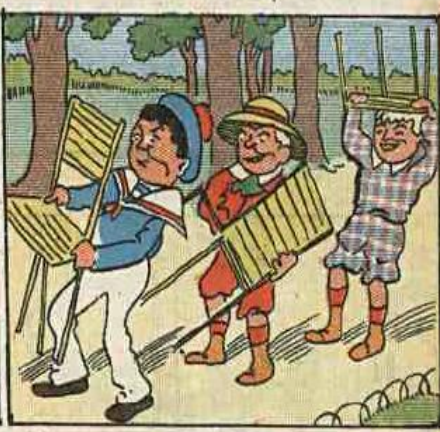

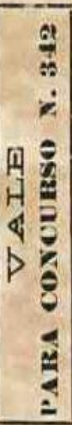

6) Suito satisfeitos com sua maldade oram buscar outras cadeiras...

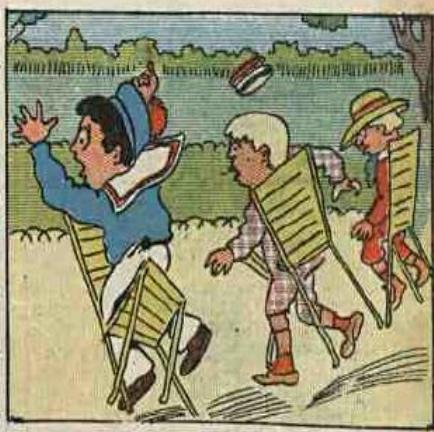

9) $\ldots .$. c com os pulos que os meninos da

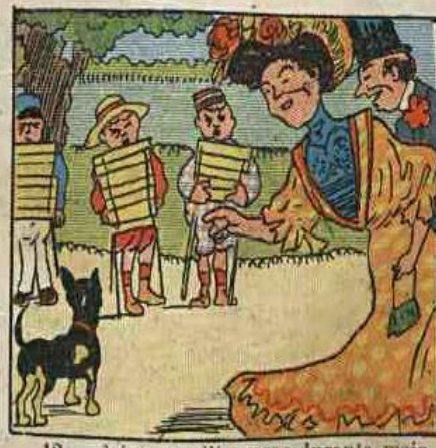

12 .. deixon.os alli presos lurante meia hora. provocando o riso de todas as pessons que passavam.

Figura 59-O Tico-Tico - 31/03/1909-s/p. 


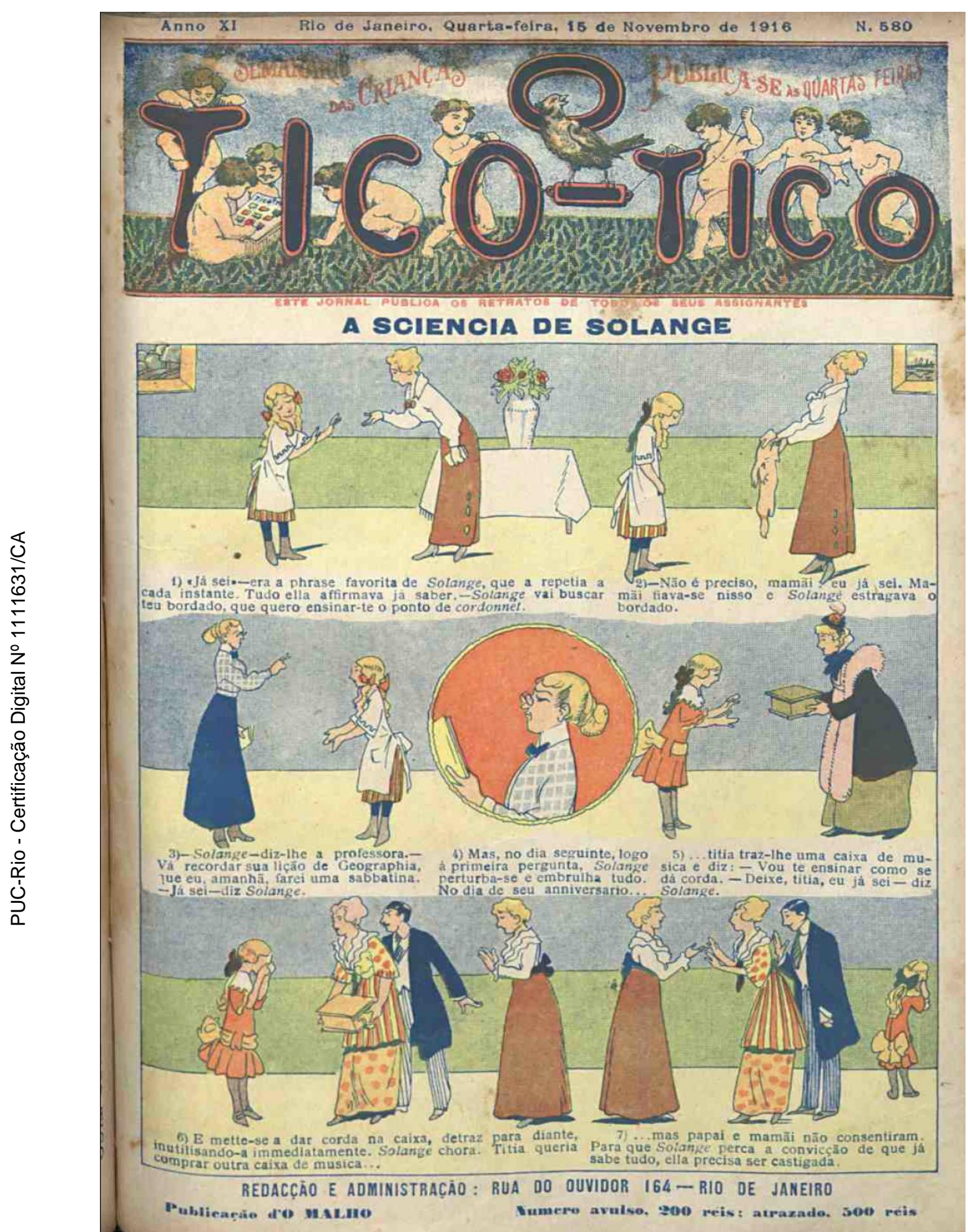

Figura 60 - O Tico-Tico - 15/11/1916 - p. 1 


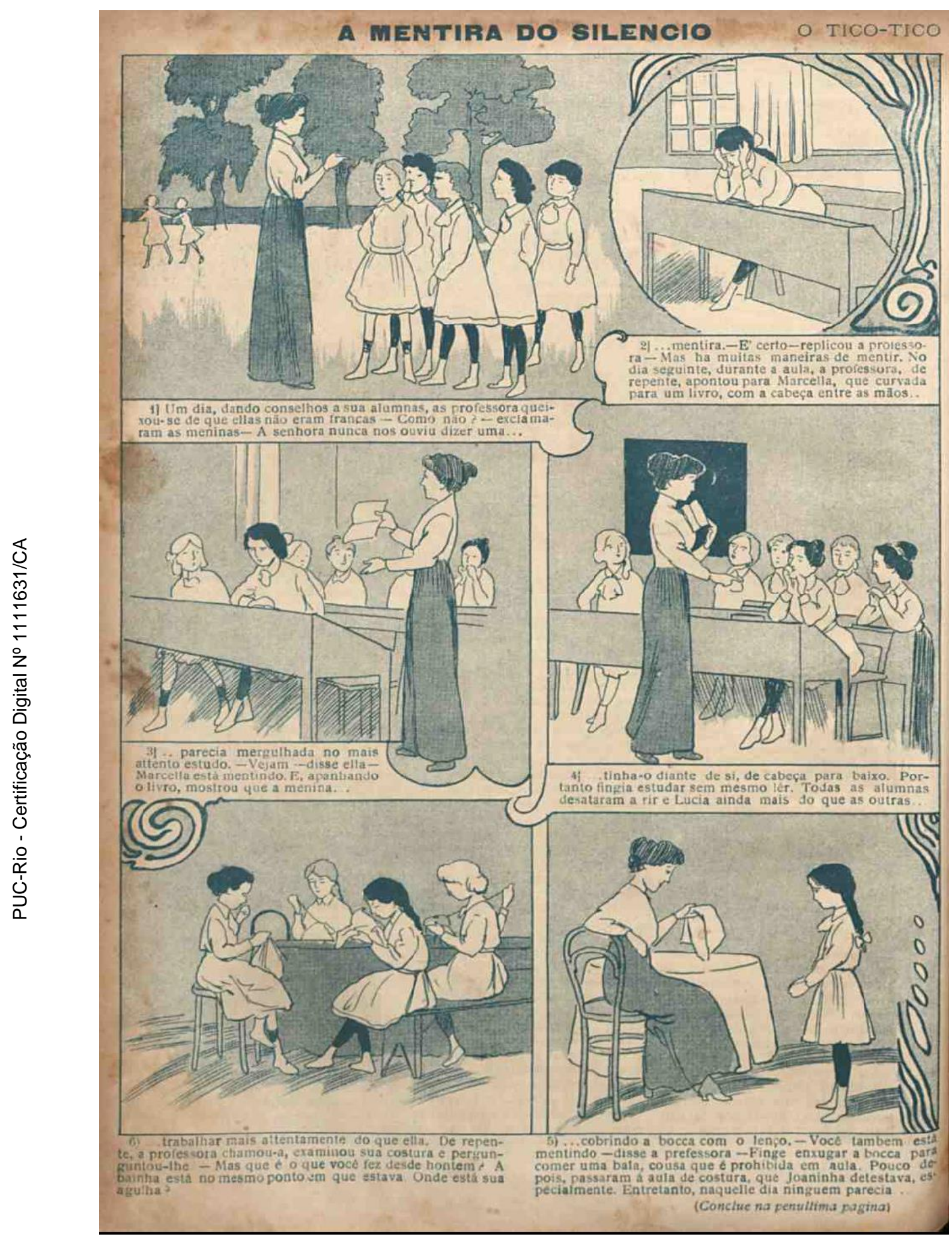

Figura 61 - O Tico-Tico - 16/02/1916 - p.2 


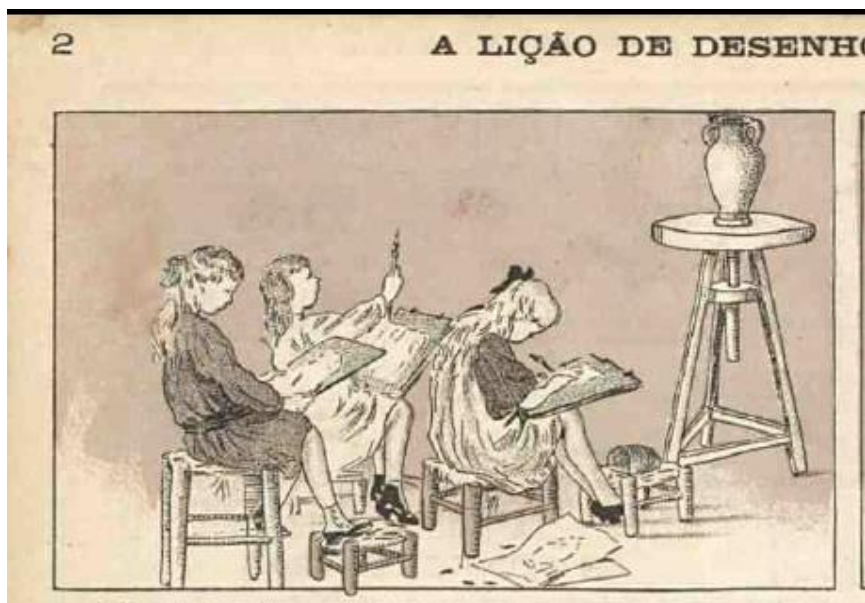

1) Numa aula đe desenho, Maria está fatugadissima e ainda não conseguiu co. varias folhas de pope.
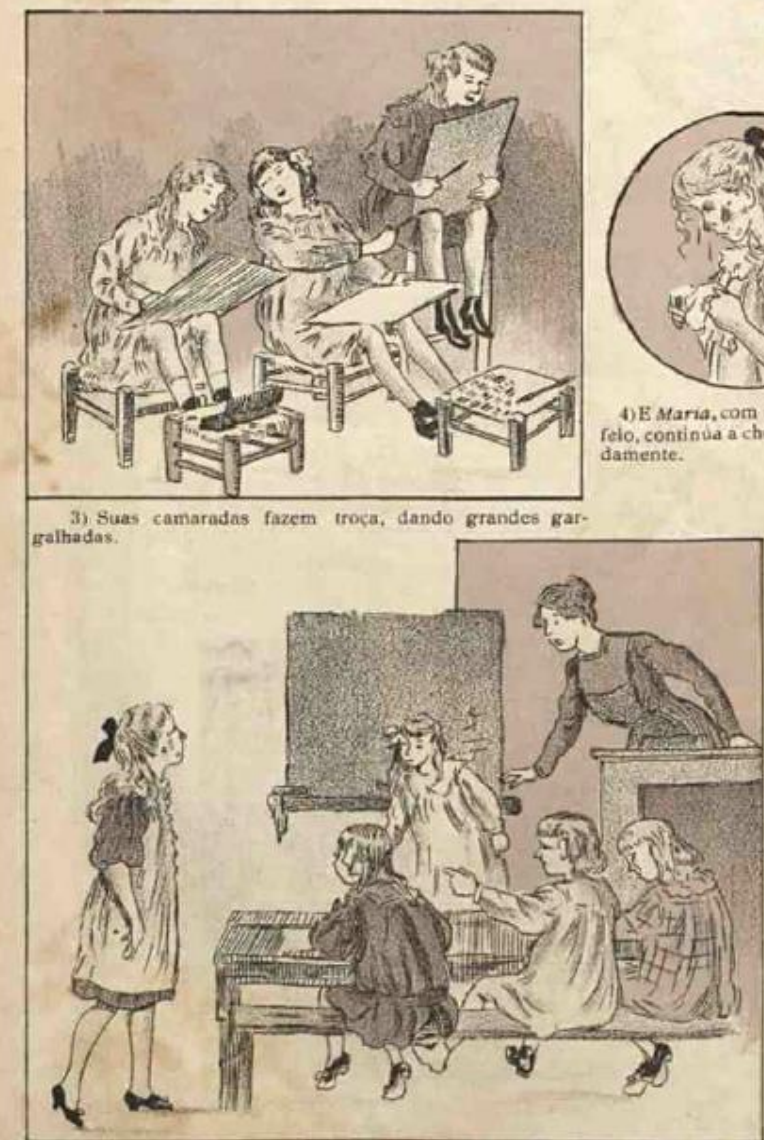

6) A menina sahe e vai ter ạ classe dos menores. Novas gargalhadas; Mari fica mufio irite

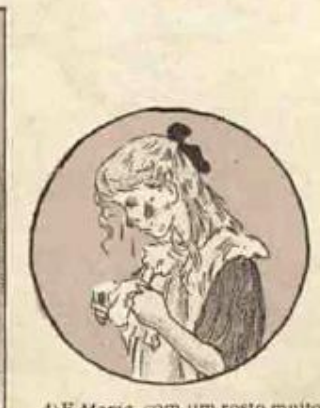

4) B Maria, com um rosto muits celo, continua achorar desesper: relo, contin
damente.

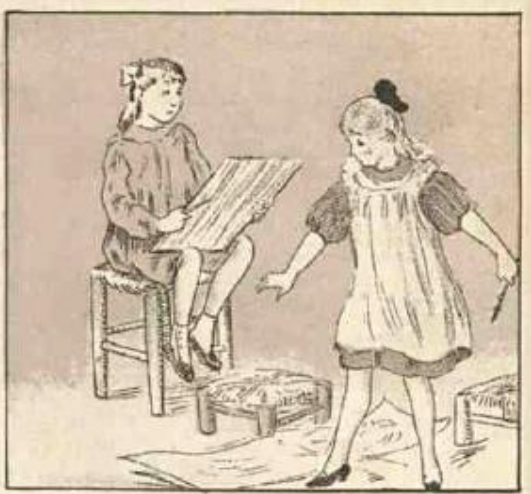

9 Descapecadis atira ao chas a pasta

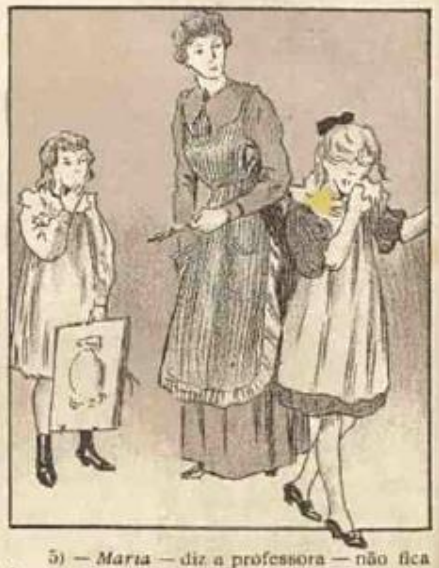
hem a urma moça chorar d'esta mancira.

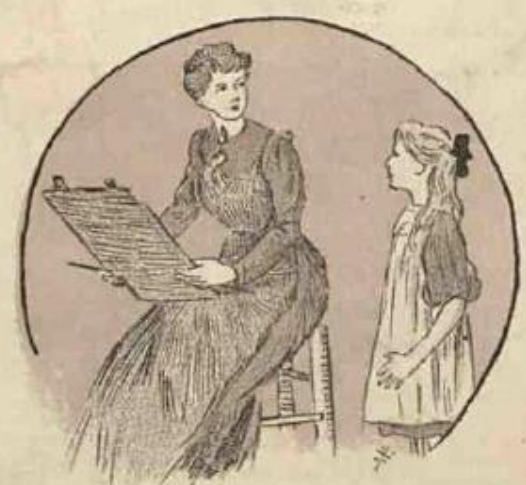

7) Mas, ao voltar aovameate da sua aula, teve uma surpreza agradavel. A professora dera-libe grau 8 no

Figura 62 - O Tico-Tico- 12/10/1910-p.2 
No que tange a perspectiva de $O$ Tico-Tico sobre o emprego feminino, chama a atenção os anúncios da médica Ursulina Lopes Torres identificada como especialista em infância. Diante das poucas informações encontradas sobre mesma, sabe-se que ela era paulista da cidade de Sorocaba. Em 1901 se formou em Farmácia no Rio Grande do Sul e posteriormente se graduou em Medicina no Rio de Janeiro e trabalhou com o médico Fernandes Figueira (MOTT et al., 2008) $)^{59}$ (Fig.63).

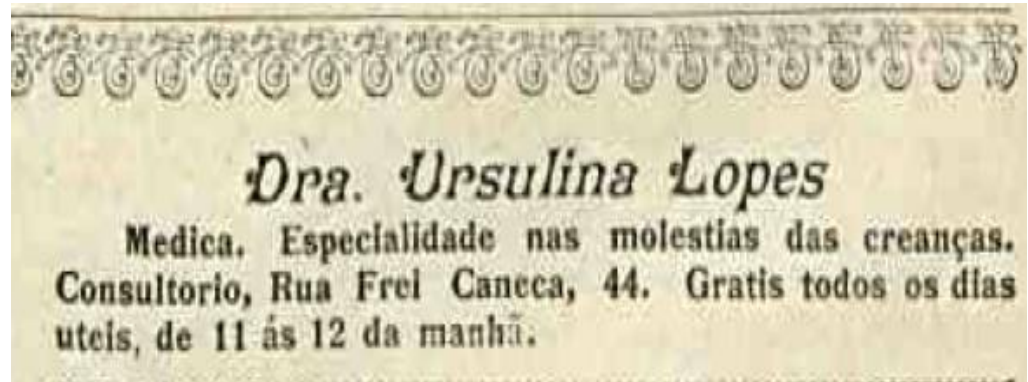

Figura 63 - O Tico-Tico-27/10/1909 - p.16

Para além dos trabalhos considerados femininos, como o magistério e a enfermagem, era comum que as mulheres republicanas de baixa condição social trabalhassem em longas jornadas nas fábricas que começam a se instalar pelo país. De acordo com Scott (2012), o padrão social burguês não se adequava a todas as camadas da sociedade. Nem todos viviam junto às cidades mais urbanizadas como o Rio de Janeiro; e nem em suas nas aéreas mais ricas. A família branca e burguesa não correspondia à realidade das estruturas familiares formadas por pessoas de diferentes etnias. Além disso, uma vasta parcela das mulheres tinha que trabalhar para garantir o próprio sustento e/ou o de sua família. Nas primeiras décadas do século $\mathrm{XX}$, dependendo do tipo de função exercida, a carga horária podia passar de 10 horas diárias:

A rotina de trabalho nas fábricas era muito pesada, variando de 10 a 14 horas por diárias, e estava sob a supervisão de contramestres e outros patrões. Em geral, na divisão do trabalho, as mulheres ficavam com as tarefas menos

\footnotetext{
${ }^{59}$ Na edição do jornal Correio da Manhã, de 20 de novembro de 1914, foi publicado um anúncio sobre a volta da médica ao Brasil, após uma temporada de estudos de dois anos na Europa. "A DRA. URSULINA LOPES, de volta de uma viagem á Europa, onde permaneceu dois annos, freqüentando sempre os maiores hospitaes de Londres ,Berlim e Paris, fazendo cursos especiaes de gynecologia, obstetricia, pediatria, electrotherapia, massagem manual e vibratória, gymnastica medica, cystocopia e catheterismos dos ureteres, anesthesia, tratamento moderno pelo ar quente, ar comprimido, ar rarefeito, participa ás suas dignas amigas e clientes que se acha novamente á sua disposição, á rua Miguel de Frias, sobrado (p.9). DRA URSULINA LOPES. Correio da Manhã, Rio de Janeiro, p.9,20 nov.1914.
} 
especializadas e mal remuneradas; os cargos de direção e de concepção, como os de mestre, contramestre e assistente, cabiam aos homens. Sem uma legislação trabalhista que pudesse proteger o trabalho feminino, as reclamações das operárias contra as péssimas condições de trabalho, contra a falta de higiene nas fábricas, contra o controle disciplinar e contra o assédio sexual (...) (RAGO, Op.cit.p.583-584).

Sobre o trabalho feminino, outra questão pertinente é a defasagem salarial existente entre os $\operatorname{sexos}^{60}$. De acordo com Scott (Op.cit.), a diferença está calcada no discurso de que, ao longo da mesma jornada de trabalho, os homens produziam mais mercadorias. Outra justificativa era a de que a diferença física entre homens e mulheres, condicionava-as a trabalhar na fabricação de objetos de menor valor.

A assimetria do calculo do salário era chocante: os salários dos homens incluíam os custos de subsistência e reprodução, enquanto os salários das mulheres necessitavam de suplementos familiares, mesmo para sua subsistência individual. Além do mais, os salários dos homens deveriam proporcionar o suporte económico que mantinha uma família e que possibilitava que os filhos fossem alimentados e se tornassem adultos trabalhadores. Os homens eram, por outras palavras, responsáveis pela reprodução (p.456).

Deve-se observar que mesmo com o crescimento dos movimentos operários e das discussões sobre os direitos do trabalhador, alguns dos primeiros benefícios trabalhistas voltados às mulheres, foram instituídos apenas em 1932, quando o Departamento Nacional do Trabalho decretou que a jornada de trabalho das mulheres, no ramo do comércio e da indústria, não poderia exceder oito horas por dia. Como também proibiu o emprego noturno feminino e propôs a equiparação salarial entre homens e mulheres (CARVALHO, Op.cit.). Com a aprovação da Consolidação das leis do trabalho (CLT) em 1943, alguns destes ganhos foram confirmados e novos direitos foram concedidos. ${ }^{61}$

$\mathrm{Na}$ prática, a vida de uma mulher trabalhadora se constituía em uma jornada plural, pois ela também tinha a obrigação, perante a sociedade, de manter

\footnotetext{
${ }^{60}$ De acordo com dados da Diretoria Geral de Estatística de 1907, a média da diária paga pela indústria, calculada em um período de 290 dias trabalhados, era de $6 \$ 000$ para o homem, de $3 \$ 000$ para a mulher e de $2 \$ 000$ para a criança. DIRECTORIA GERAL DE ESTATISTICA. Boletim Commemorativo da Exposição Nacional de 1908. Rio de Janeiro: Typhographia da Estatistica, 1908.p. XXVII.

${ }^{61}$ O Decreto Lei n. ${ }^{\circ} 5.452$, de $1^{\circ}$ de maio de 1943 , referente à Consolidação das leis do trabalho (CLT) possui um capítulos sobre a regularização do trabalho feminino: Da segurança do trabalho da mulher. A CLT manteve a jornada de trabalho em oito horas diárias e a proibição do trabalho noturno, mas permita exceções, por exemplo, para as enfermeiras. Proibia as mulheres tivessem seu contrato de trabalho rescindido em caso de casamento ou gravidez. BRASIL. Decreto $\mathrm{n}^{\circ} .5452$, de 1 de maio de 1943.
} 
a estrutura do seu lar e de sua família. No entanto, Chalhoub (Op.cit.), aponta que pelo fato dela trabalhar e ajudar nas despesas do lar, esta mulher poderia ter alguma chance de vivenciar uma relação mais equilibrada com seu cônjuge. Além disso, existiam situações nas quais a trabalhadora desistia de uma relação amorosa para viver sozinha e a manter seu sustento a partir do próprio salário.

A possibilidade do sexo feminino alçar outros caminhos, para além daqueles defendidos por setores das elites da sociedade brasileira, costumava ser combatida em inúmeras frentes. Priore (Op.cit.) cita a preocupação do poder público com as operárias brasileiras. Para convencer a trabalhadora a abandonar o emprego e retornar ao lar, foram distribuídos cartilhas e boletins sobre a importância da mulher se dedicar integralmente aos cuidados dos filhos. Foram criados os Concursos de Robustez no qual as mães que provassem, ter amamentado o filho até o sexto mês de vida, eram premiadas. Utilizou-se o discurso a favor da amamentação como forma de legitimar o papel da mulher como mãe, esposa e administradora do lar.

Na prática, cabia à mãe burguesa educar os futuros líderes da nação e às mulheres menos abastadas creditou-se a função de formar os trabalhadores que ajudariam no crescimento da economia nacional.

\subsection{A formação tradicional versus a mulher em transformação}

Na seção Correspondência do Dr. SabeTudo de 6 de novembro de 1918, foi publicada a resposta à pergunta de uma leitora sobre o processo que impedia o crescimento dos animais. Ela foi informada de que o tema não seria abordado o porque o procedimento poderia causar sofrimento aos bichos. Em compensação, a menina foi comtemplada por um estudo grafológico de sua letra. $\mathrm{O}$ resultado foi a seguinte: 
Quanto a estudo graphologico comparece á minha presença uma linda menina cheia de modéstia e franqueza de temperamento frio e positivo, com uma perfeita ligação de ideias, que a tornam uma grande força para a vida pratica. Sem ternura, sem bondade, sem arrebatamento, sem idealismo, póde realisar perfeitamente o modelo da mulher-homem, isto é, do feminismo invasor das occupações habitualmente desempenhadas por indivíduos do sexo forte. E não será grande perspicácia prognosticar-lhe um grande futuro em qualquer carreira scientifica ou comercial ( $\mathrm{s} / \mathrm{p})$

A resposta demonstra o descontentamento de Dr.SabeTudo com a análise da personalidade da menina, supostamente constituída por características pouco femininas, por exemplo, o tino para a vida prática. Neste contexto, destaca-se o uso da categoria mulher-homem. Afinal, o que é uma mulher-homem? Uma mulher com características físicas parecidas com as de um homem? Uma mulher que gostaria de seguir uma carreira não afeita ao sexo feminino? Uma mulher com personalidade masculina?

No dicionário, a expressão mais próxima de mulher-homem é uma das definições de mulher-macho: "Mulher que apresenta qualidades viris de coragem, valor, capacidade de comando e decisão" (DICIONÁRIO AURÉLIO, 1997, p.1169). No tocante ao conteúdo da seção de Dr. SabeTudo, também é possível pensar que a categoria mulher-homem foi usada como sinônimo de feminista.

O feminismo era um tema em voga na imprensa e alvo de controvérsias. Segundo Käppeli (1991) não se pode classificá-lo como homogêneo, por isso a necessidade o compreender como plural, ou seja, os feminismos. No contexto europeu, identifica-se duas correntes principais: a igualitária e a dualista. "A corrente igualitária burguesa considera o legislador como motor central da mudança" e "a representação dualista (...) coloca no centro a faculdade maternal da mulher - qualidade definida não apenas fisicamente, mas também psíquica e socialmente" (p.542.). 
O movimento feminista desembarcou em terras brasileiras no século XIX e ganhou força nas décadas iniciais do século XX. A educadora Nísia Floresta, considerada uma das precursoras do feminismo no Brasil, protestava por maior acesso à educação de qualidade ${ }^{62}$. Na imprensa feminina foram publicados textos sobre as demandas como o direito ao voto. ${ }^{63}$ Em 1922, Bertha Lutz ${ }^{64}$ criou no Rio de Janeiro a Federação Brasileira para o Progresso Feminino.

Campos (Op.cit.) aponta que o ser feminista era vinculado a diversos perfis femininos: uma atleta, uma fã de Greta Garbo ou até uma senhora que fizesse assinaturas de revistas femininas publicadas nas cidades do Rio de Janeiro e São Paulo. "As feministas podiam ser ainda sufragistas católicas, espíritas ou rotarianas até mesmo leitoras de romances açucarados" (p.116).

Almeida (2007) partilha da perspectiva de que, inicialmente, as feministas não propunham rupturas profundas nas relações de gênero. Defendiam acesso à educação de qualidade, mas ainda consideravam o matrimônio como o destino ideal para o sexo feminino. As mulheres poderiam trabalhar ou estudar, desde que tal ocupação não atrapalhasse a rotina de mãe e esposa devotada. O discurso sobre a educação feminina recebeu apoio de outros setores da sociedade: "O movimento feminista revelou um raro sentido de argúcia e sensatez buscando a cooptação e o consentimento das elites intelectuais masculinas" (p.53).

As feministas eram vistas com reservas e desconfianças, pois como advertem Maluf e Mott (Op.cit.), setores conservadores temiam que as demandas do movimento pudessem mudar as bases estruturais da família e, por

${ }^{62}$ Nísia Floresta Brasileira Augusta (1810-1885) foi o nome adotado por Dionísia Gonçalves Pinto. Contrária as convenções do casamento, exerceu o magistério e fundou, em 1838, no Rio de Janeiro, o Colégio Augusto; instituição de ensino feminino. Morou na França e publicou diversos artigos e livros sobre a situação das mulheres brasileiras. VAINFAS, Ronaldo. (Org.). Dicionário do Brasil imperial. Rio de Janeiro: Objetiva, 2008. p.552-553.

${ }^{63} \mathrm{O}$ voto feminino foi instituído pelo código eleitoral de 1932 , e reafirmado na Constituição de 1934. De acordo com a legislação, qualquer indivíduo com mais de 18 anos e alfabetizado estaria apto a votar. BRASIL. Constituição (1934). Constituição da República dos Estados Unidos do Brasil. Promulgada em 16 de julho de 1934.

64 Bertha Lutz (1894-1976) foi uma das principais defensoras dos direitos das mulheres no Brasil. Filha do médico Adolfo Lutz, conheceu de perto o movimento feminista europeu durante o período em que concluiu os estudos escolares na Inglaterra e a graduação em Ciências naturais pela Universidade de Sorbonne, em Paris. Em 1919 foi aprovada em concurso público para o cargo de bióloga do Museu Nacional. Naquela época foi apenas a segunda mulher brasileira a conseguir tal feito. Posteriormente se formou em Direito. Na década de 1930, foi eleita suplente de deputado federal. Durante décadas foi atuou como pesquisadora do Museu Nacional. SOIHET, Rachel..A conquista do espaço público. In: PINSKY, Carla Bassanezi; PEDRO, Joana Maria..(Orgs.). Nova história das mulheres no Brasil. São Paulo: Contexto, 2013.p.218-237. 
consequência, o papel do homem na sociedade. Como demonstra a caricatura publicada na revista Careta (Fig.64) :

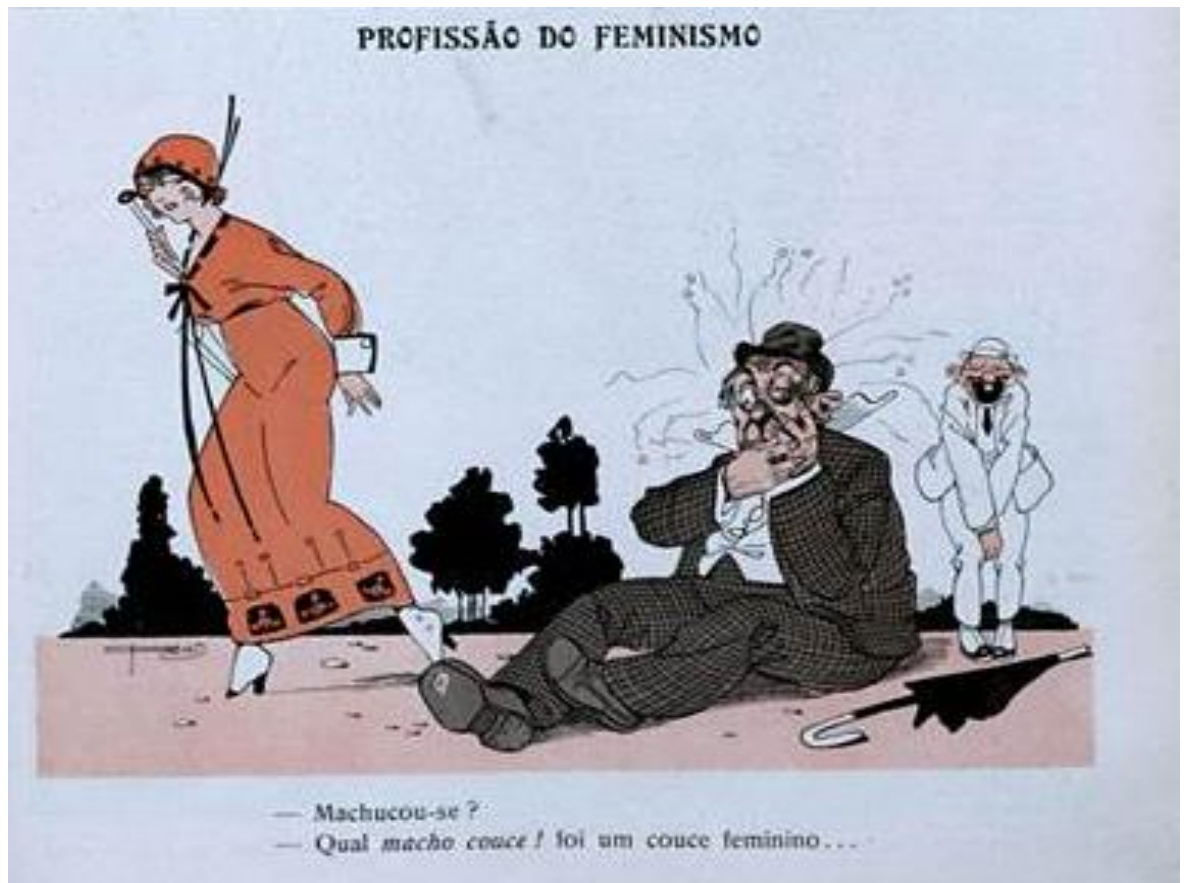

Figura 64- Careta - 31/01/1914-s/p.

Aqueles que se consideravam os porta-vozes da modernidade, tinham uma visão restritiva sobre as transformações no papel social da mulher. Não cogitavam a possibilidade, das feministas defenderem uma sociedade justa e igualitária, pois as classificavam como portadoras de comportamentos nefastos. Acusavam-nas de querer substituir os homens e exercer funções consideradas exclusivamente masculinas. Por tal razão, as críticas feitas às meninas que tinham aptidão para carreiras ligadas às áreas científicas. O sexo forte não podia ser desafiado pelo sexo frágil:

Autoridades, políticos em geral, juristas negam-se a considerar positivamente as pretensões de autonomia feminina. Respaldam-se na ciência da época, sinônimo, naquele momento, de verdade absoluta. Apelando para tais convicções e para prejuízos acarretados à família, já que este era visto como seu espaço prioritário, buscam limitar as mulheres nas suas ações, desejos e emoções naturalizando determinação histórica e socialmente estabelecida (SOIHET, 2000, p.99-100).

Na edição do jornal $O$ Paiz, de 23 de maio de 1896, foi publicado na seção Carta Parisiense, um artigo sobre o Congresso Internacional das Mulheres realizado em Paris. O texto, de conteúdo ambíguo, inicia-se com um balanço 
sobre o sucesso do evento. Em seguida, o autor não identificado, aconselha os governantes brasileiros a prestarem atenção nas demandas de igualdade: sexo, e direitos políticos, econômicos e culturais. Inclusive, concorda com tais pleitos femininos. Ao mesmo tempo, debocha da luta pela aprovação do divórcio, da participação das mulheres em júri profissional e da regulamentação da prostituição:

Somos feministas, mas pelo minimum sensato das reformas acima humana. Se o homem cumpre o serviço militar a mulher cumpre outro serviço ainda maior, o da maternidade. $\mathrm{O}$ soldado mata, e a mulher cria a humanidade. Nem o homem é superior á mulher e nem a mulher é superior ao homem: os dois seres completam-se na integridade humana. Mas quando os feministas reclamam para a mulher o direito de poder ser ministro, ou deputado, o prefeito de policia ou juiz de tribunal, então afastamo-nos desses propagandistas, rindo do comico que ha em todas estas reclamações que compromettem mesmo tudo quanto há de justo no feminismo racional (p.2).

O conteúdo do texto aponta para a existência de um feminismo irracional, no qual as mulheres ousavam pleitear lugares até então reconhecidos, socialmente, como espaços masculinos. As mulheres não teriam autoridade para prender alguém ou julgar casos complicados. O motivo? O sexo feminino é fraco, assim como o excesso de sentimentos as impediriam de tomar decisões difíceis. Não obedecia à natureza das mulheres, nem ao determinismo sexual sob o qual estavam subjugadas.

A Revista da Semana também publicou artigos sobre o movimento feminista e as suas consequências para os lares brasileiros. $O$ que aconteceria com maridos e filhos? As mulheres sairiam para trabalhar enquanto os homens cuidariam do lar e das crianças? Os textos tratam a emancipação feminina por meio de uma visão maniqueísta. Apontava-se a existência de dois feminismos: o bom e o mau. O bom feminismo concedia à mulher igualdade e uma maior liberdade, mas sua natureza, voltada ao cuidado do lar, é mantida. O mau feminismo instiga à mulher a querer ocupar o lugar do homem. Na edição, de 20 de fevereiro de 1910, a resposta a uma pergunta feita por uma leitora sobre o feminismo versava sobre a existência esta dualidade:

Dividamos o feminismo em bom e máo. O bom feminismo protege a mulher como ser fraco, reconhece o direito que tem de aproveitar os progressos da civilisação para poder desenvolver suas virtudes, intelligencia e aptidões. Para este desenvolvimento, o bom feminismo emprega em todas as suas 
forças, mas elle nunca pretendeu nem pretenderá fazer uma mudança radical na condição da mulher, cousa aliás impossível, sonho absurdo, perigoso, ridículo, porque se baseia unicamente nas regras da moral e do bom senso. O máo feminismo não se firma nestas regras. Pouco importa que o ideal que elle exalta seja uma simples chimera que o seu pretendido projecto de relevantamento e de felicidade se ache antemão condemnado a um insucesso. Estas tentativas, completamente vãs, só servem de pretexto, mascaram seus fins, perturbam os cerebros, destruindo a ordem familiar e social. Duas cousas estão ao abrigo das fluctuações humanas: a natureza e o dever. (...) (ACRISIO, s/p).

Novamente, tem-se a ridicularização das demandas feministas. Podiam ser concedidos certos direitos ou benesses às mulheres, desde que as relações de gênero não se alterassem. A justificativa era a de que quaisquer mudanças bruscas nos comportamentos, poderiam desestruturar as relações familiares e por consequência à própria República. Circulava nas páginas de jornais e revistas, o discurso do mudar para não mudar. Alegava-se que o envolvimento das mulheres no mundo da política poderia macular os nobres sentimentos que as tornavam aptas a cuidar do outro. As reivindicações feministas deveriam ser classificadas, como moda passageira.

A narrativa A menina travessa e o menino tranqüilo traz à tona o receio sobre mudanças nas relações de gênero. A figura materna, a todo o momento, repreende a filha pelo fato da mesma gostar de brincadeiras tradicionalmente vinculadas ao universo masculino: imitar soldado e correr pelo quintal assustando as galinhas. Em determinado momento, a mãe reclama que garota tem um comportamento masculinizado enquanto o irmão é muito quieto. A menina se machuca gravemente. É punida por não agir delicadamente (Fig.65). A missiva está na necessidade e manter as construções do ser mulher e do ser homem normatizadas. 


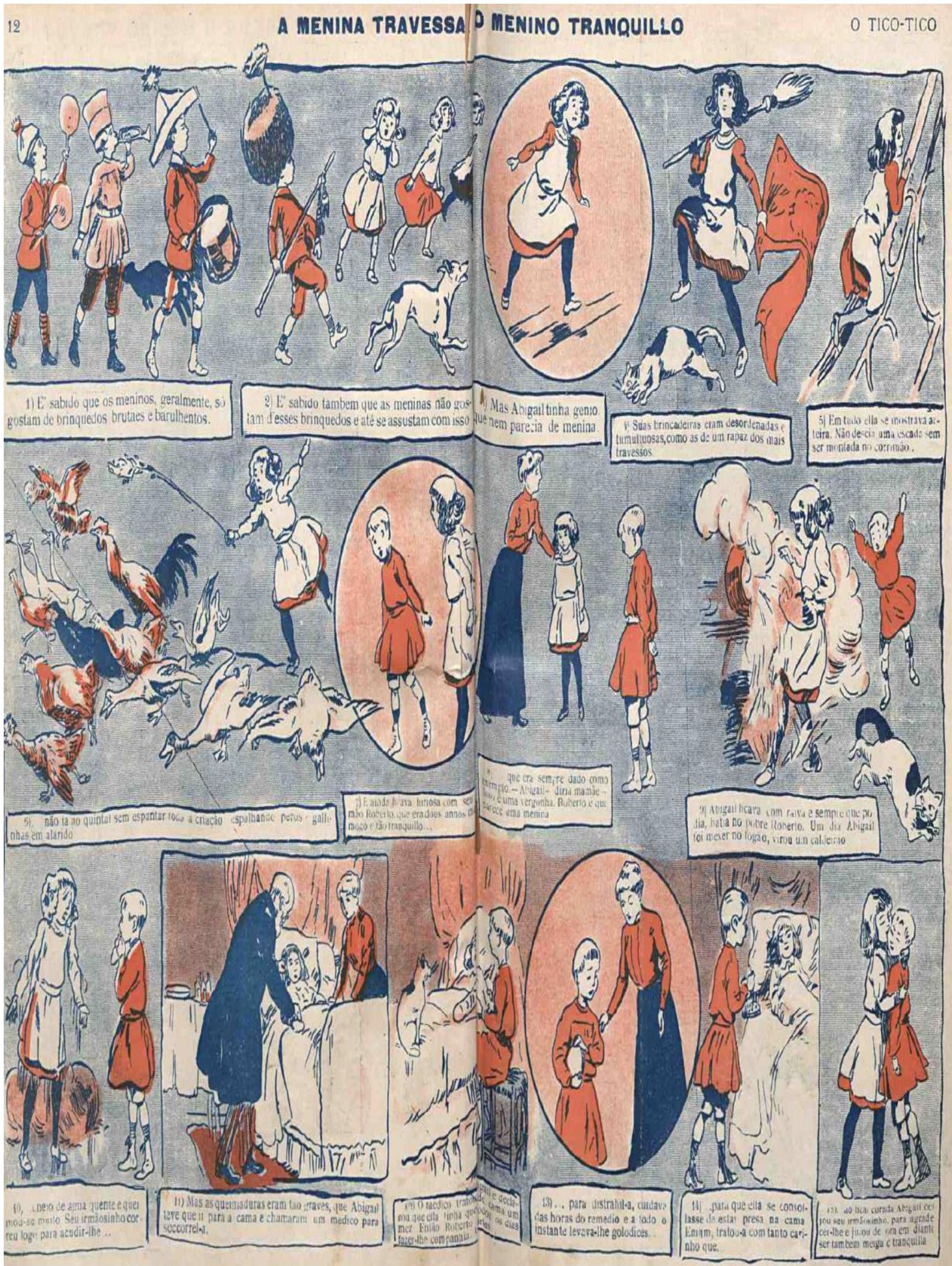

Figura 65 - O Tico-Tico - 08/04/1914 - p.12. 
Um novo modelo feminino, exigiria mudanças na construção do gênero masculino. A cada degrau de independência e direitos conquistados por elas, significaria aos homens rever seu papel de autoridade familiar máxima e provedor.

Em O Tico-Tico os anseios feministas eram tratados através do chiste e da brincadeira. Como observa Soihet (Op.cit.), este tipo de posicionamento estava presente em impressos, peças de teatro, literatura e em tantas outras manifestações culturais do período. Criou-se os estereótipos de que eram as feministas eram "masculinizadas, feias, despeitadas e, mesmo amorais (...)" (p.100). Duas cançonetas, sobre tais aspirações femininas, foram publicadas no impresso infantil: A Feminista de 15 de novembro de 1911, e A Suffragista de 21 de maio de 1913, ambas de Eustorgio Wanderley.

\section{A Feminista}

Do feminismo sou partidária; Quero a egualdade mais verdadeira; A mulher deve ser voluntaria, Egual ao homem, desta maneira; Formando juntas do seu partido, Deve ter voto nas eleições, Embora vote contra o marido Pela conquista das posições. II

Se eu fosse eleita p'ra deputada Então veriam p'ra quanto eu presto, Pois não havia de ficar calada

Nem um só dia, sem um protesto, Protestaria contra o abuso

Destes senhores, nossos eguaes;

Contra os costumes e contra o uso

De achal-os sempre nossos rivaes. III

E se eu chegasse a ser presidente Desta republica...Ah! Que alegria...

Tudo mudava, pois certamente, Um outro gallo é que cantaria Se duvidarem do que lhes digo, Custa bem pouco experimentar Para o futuro votem commigo

Ou no meu nome queiram votar. (p.8)
A Suffragista

I

Da grande ideia salvadora

Sou a maior propagandista,

E fui aqui a iniciadora

D'esta campanha suffragista.

Seguindo o exemplo da Inglaterra Eu vou agora trabalhar,

Para a mulher da minha terra

Ter o direito de votar II

Se nós pagamos os impostos Tendo deveres opressores, Nossos direitos eram postos, Na mais altura dos senhores. Queremos votar e ser votadas

Para a mais alta posição:

Ser senadora ou deputada,

Ou presidentas da nação.

III

Se conseguir, em breve data, Esse ideal que tenho em vista,

Eu me apresento candidata

Pelo partido...Sufraggista

Peço perdão se fui cacete

Porém não deixe de me votar

Para me verem no Catete Este paiz endireitar. (p.7) 
As leitoras são aconselhadas a usarem roupas masculinas quando fossem cantar estas músicas. Em A Feminista, deveriam usar chapéu, casaca, colarinho, gravata e bengala. No caso de A Suffragista, também é preciso segurar entre os dedos um charuto apagado. Afirmava-se que, a participação no campo político, não era coisa de mulher. As praticas do mau feminismo eram criticadas e rechaçadas. Uma das formas encontradas foi a ridicularização de tais personagens. As leitoras achariam graça das situações, mas não iriam querer passar por tais momentos vergonhosos.

\subsubsection{O exemplo de Faustina}

É publicada na edição de 8 de março de 1911, história sobre a cerimônia de batismo da esposa de Zé Macaco (Fig.66). Embora a personagem se fizesse presente em narrativas anteriores, ela não tinha nome próprio. Costumava ser chamada apenas de Senhora Zé Macaco ou Mme. Zé Macaco. A justificativa para a celebração de tal sacramento, era a necessidade do esposo encontrar um novo nome para à mulher, “ em virtude de ter-se extraviado o primitivo nome de sua symphatica esposa (...)" (p.14). Na presença do padre, do padrinho Chiquinho e da madrinha Jagunço (o cachorro veste trajes femininos), ela recebe a alcunha de Faustina. 


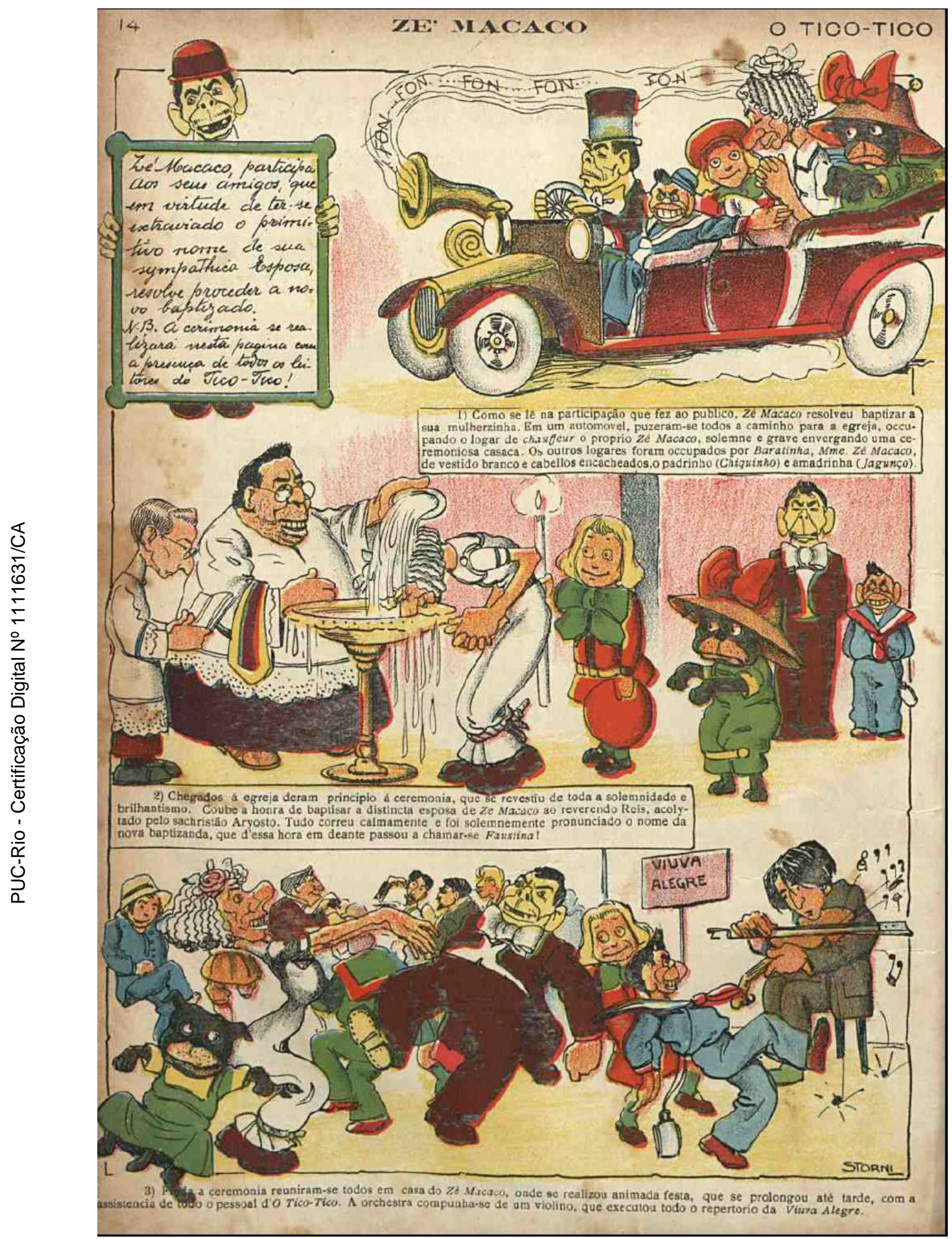

Figura 66 - O Tico-Tico - 08/03/1911-p.14 
Inicialmente, o conteúdo desta narrativa, pode suscitar que a personagem partilhava do mesmo perfil, de outras figuras femininas presentes em O Tico-Tico. Seria mais uma esposa dedicada e submissa ao marido? Afinal, ela apenas se tornou alguém após Zé Macaco ter lhe conferido um nome, uma identidade. No entanto, a trajetória de Faustina se configura na máxima de que a primeira impressão é a que não fica. No texto Um Passarinho, o escritor Carlos Drummond de Andrade, ao escrever sobre as memórias que tinha de O Tico-Tico, descreveu a personagem como "a sufragista Faustina" (1956, p.54). Neste contexto se questiona: Quem é Faustina?

O ilustrador Alfredo Storni começou a publicar histórias com a participação de Faustina em 1910, quando Zé Macaco, criado em 1908, passou a ter uma família: a esposa Faustina, o filho Baratinha, o agregado Chocolate e o cachorro Serrote.

As informações presentem nas narrativas apontam que Faustina pode ser uma carioca de ascendência inglesa. Nas edições de 26 de agosto e 2 de setembro de 1914 , a família Zé Macaco recebe a notícia sobre a eclosão da Primeira Guerra Mundial. Revoltada, Faustina decide se alistar no exercito inglês (Fig.67) (Fig.68). Embora tal tentativa tenha falhado, pois ela optou por ir andando à Inglaterra, seu comportamento demonstra uma atitude desafiadora ao modelo feminino tradicional. O marido não demonstrou vontade de participar do conflito. Outro indício sobre suas relações de parentesco foi a visita que recebeu do " irmão legitimo", o inglês Mr.Bráo. (O TICO-TICO, 04/06/1913, s/p).

Não foi encontrada uma história específica sobre como Faustina e Zé Macaco se conheceram. Apenas informações desencontradas presentes nas seções de $O$ Tico-Tico. Durante um período no qual as narrativas de Zé Macaco pararam de ser publicadas, os leitores escreviam questionando o seu paradeiro. A Gaiola d' $O$ Tico-Tico informou que ele estava na Europa acompanhado da esposa: "Zé Macaco, com a fortuna que lhe deu a mulher, embarcou para a Europa, onde está construindo uma grande Jeringonça aérea com a qual pretende fazer uma viagem à Lua" (O TICO-TICO, 27/04/1910, p.9.). Depois, afirmou que "Zé Macaco passa actualmente vida regalada em Londres, onde esta fruindo a fortuna que a loteria lhe deu; agradece as lembranças" (O TICO-TICO, 13/07/1910, p.19). Por fim, comunicou: "Zé Macaco esta tendo muito successo em Londres com um aeroplano, que inventou. Dentro em breve elle virá a esta Capital" (O TICO- 
TICO, 14/09/1910, p.6). Na edição de 21 de dezembro de 1910, anunciou-se o retorno de Zé Macaco e família ao Brasil.

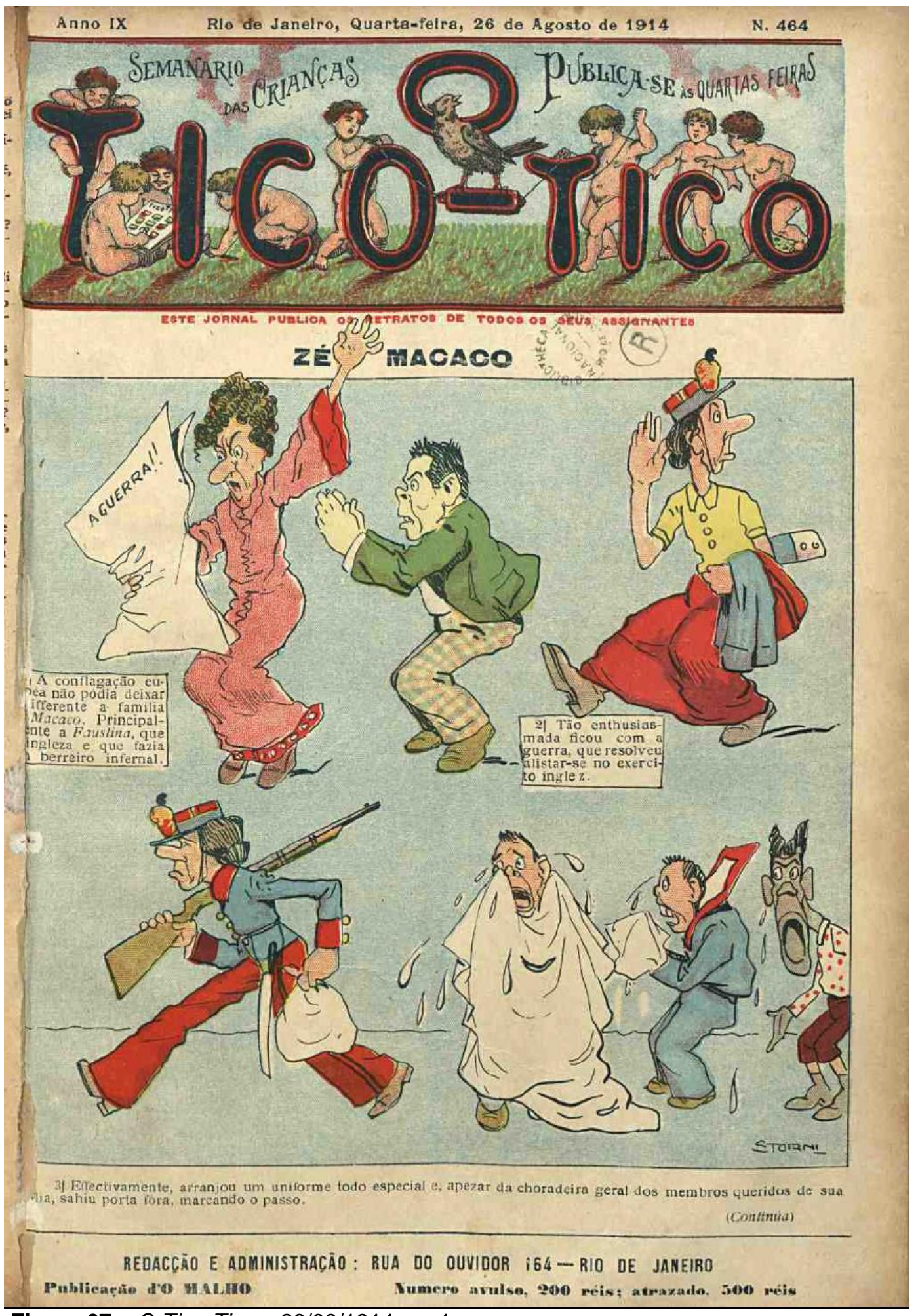

Figura 67 - O Tico-Tico - 26/08/1914 - p.1 


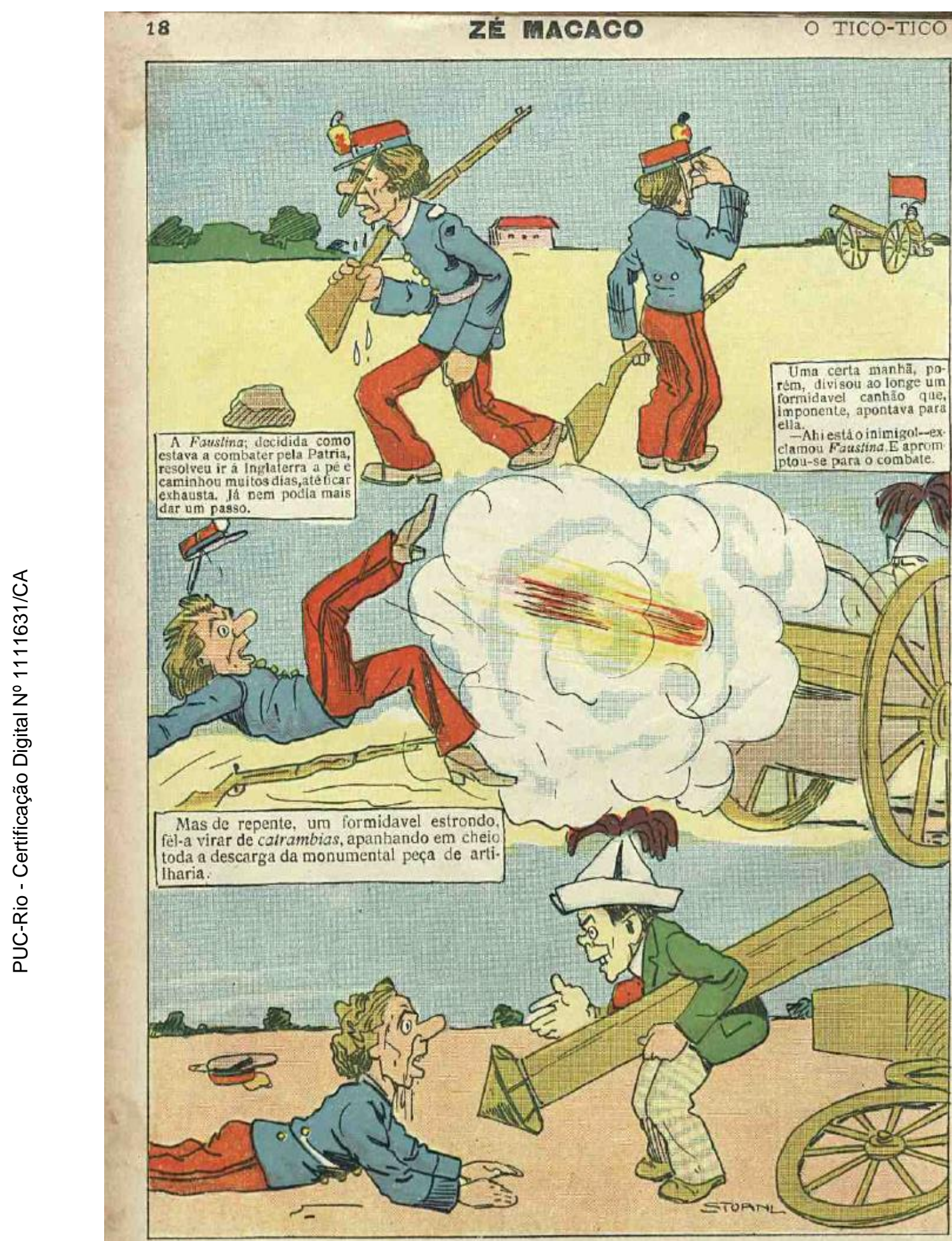

Quando voltou a si, achou-se em trente de Zé Macaco.

Seu maridinho. sempre engenhoso, havia planejado essa brincadeira, afim de obrigal-a a voltar para o lar, deixando de commetter tolices, cuidando de seus filhos e de seu marido.

A descarga fora dada com polvorá sècca, dentro de uma chaminé.

Figura 68-O Tico-Tico-02/09/1914-p.18 
Faustina é dona de casa e mãe amorosa. O marido é um inventor cuja criação mais conhecida é o aeroburro, um burro alado. Quando obtinha sucesso com alguma de suas invenções, a família desfrutava, mesmo que por uma história, de uma vida confortável. Por exemplo, morar em um Palacete no bairro de Botafogo (O TICO-TICO, 07/07/1912, p.14). Normalmente, as personagens não passavam por apuros causados pela falta de dinheiro. Em tempos de crise, Faustina não se furtou em usar vestidos feitos com papel de seda (O TICOTICO,25/11/1914, p.1; O TICO-TICO, 02/12/1914,p.16). Por razões financeiras, chegam a trabalhar como dançarinos em um teatro de variedades, tornam-se atrações exóticas de um circo norte-americano e advinham o futuro como cartomantes. (O TICO-TICO, 29/11/1911, p.14; O TICO-TICO, 06/12/1911, p.14; O TICO-TICO, 20/12/1911, p. 24; O TICO-TICO, 17/01/1912, p.24; O TICOTICO, 24/01/1912, p.14; O TICO-TICO, 06/03/1912, p.14; O TICO-TICO, 19/03/1915, p.24).

Faustina é loura, alta e magra. Características físicas exaltadas em uma sociedade que se inspira nos padrões de beleza em voga na Europa (FREYRE, 2009). No entanto, a personagem é nariguda e desdentada. Não se adequava ao perfil da mulher de traços e gestos delicados. Sofre por não ser bela. Na ânsia em se enquadrar neste perfil, torna-se refém de dolorosos tratamentos estéticos. Faz uso de maquinários que remetem a aparelhos de tortura, como a máquina para diminuir o tamanho do nariz (O TICO-TICO, 14/01/1914, p.14) (Fig.69). Nenhuma de suas iniciativas funcionou adequadamente. As tentativas apenas salientavam sua inadequação. Para cuidar do corpo, as mulheres passaram a fazer exercícios físicos, considerados sucesso na Europa, como o tênis. A esposa de Zé Macaco pratica boxe (O TICO-TICO, 22/10/1913, p.14) (Fig.70). Impressos ilustrados, como a Revista da Semana, vinculam as lutas de boxe femininas ao movimento feminista $(29 / 04 / 1911$, p.9). 


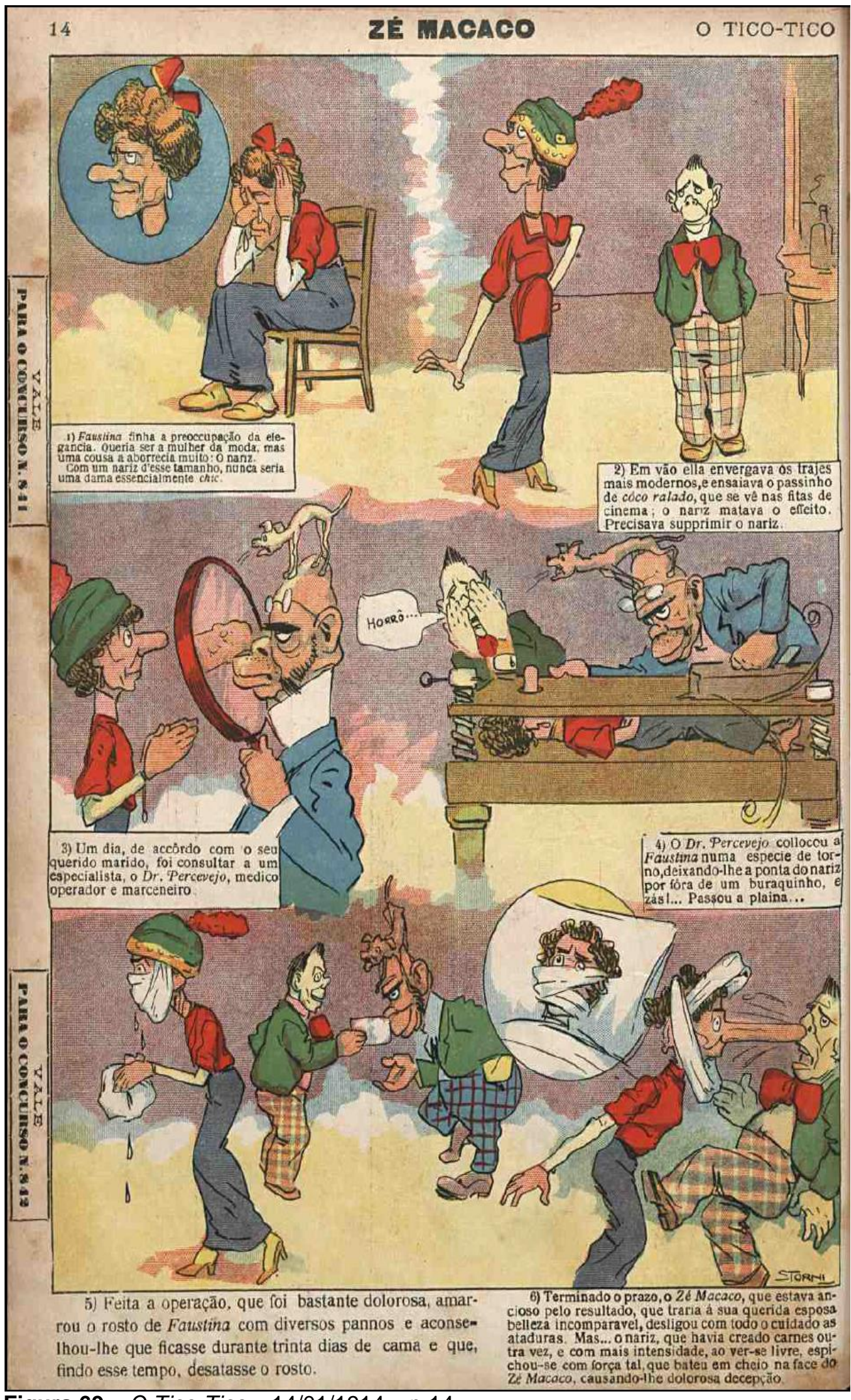

Figura 69 - O Tico-Tico - 14/01/1914 - p.14 


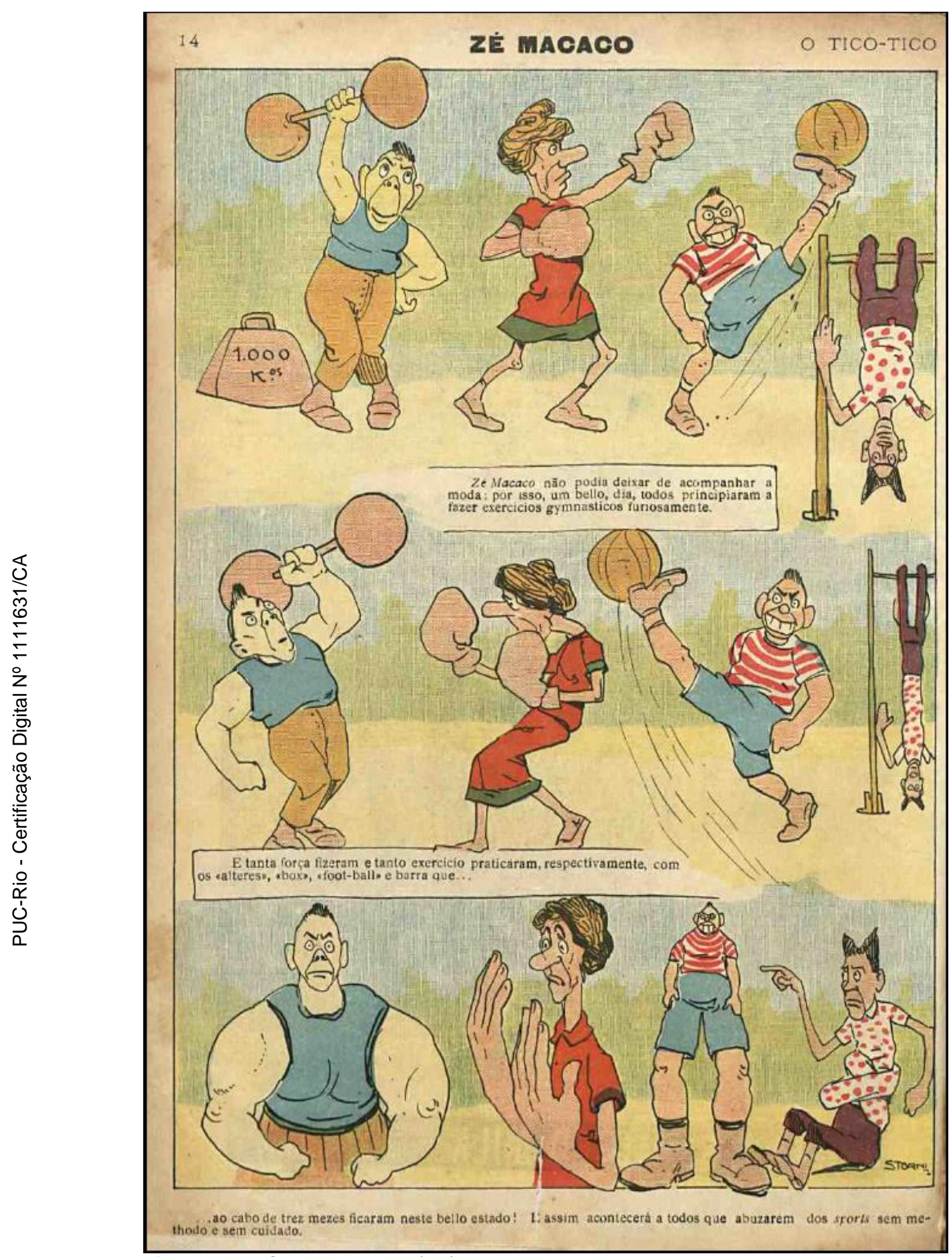

Figura 70 - O Tico-Tico - 22/07/1914 - p.14 
Faustina é fascinada por moda. Por tal razão, toma medidas extremas como assassinar um burro para usar suas orelhas em um chapéu (O TICO-TICO, 18/02/1914, p.14). Este adorno era o mais desejado pelas mulheres elegantes da Belle Époque. O uso do chapéu envolvia uma gama de códigos sociais. O modelo escolhido dependia da idade, da vestimenta, do horário, do evento, da posição social e do estado civil (SEVECENKO, Op.cit.). A seção Instanaeos publicada na na revista Careta de 10 de junho de 1911, aborda os motivos pelos quais as mulheres tinham o chapéu em tão alta conta:

As senhoras elegantes costumam sahir á rua de chapéo, mesmo quando não chove, porque o chapéo é o ornamento muito elegante para as graciosas cabeças femininas, digam lá o que disserem os que no theatros e cinematograthos se queixam quando a sorte os colloca posteriormente a uma senhora devidamente chapeauteé de que nada mais podem ver do que fitas e plumas, flores e passaros da maravilhosa cobertura de uma galante cabeça. Os que taes queixas fazem não absolutamente gentes smart. Se o fossem jamais diriam ( $/ \mathrm{p}$ ).

Para atender aos desejos da esposa, Zé Macaco constrói uma máquina de fazer chapéus. Para decepção de Faustina, ao invés do elegante adorno, a invenção produziu panelas (O TICO-TICO, 03/11/1915, p.1). Uma forma de demonstrar que o lugar da mulher por excelência é o lar. $\mathrm{O}$ fato da personagem gostar de usar chapéus também está vinculado a vontade de flanar pelas ruas do Rio de Janeiro.

As iniciativas de personagem em seguir as tendências da moda, costumavam terminar em confusão. Para que seu vestido tivesse o formato balonê, amarrava a barra da saia e do vestido com uma corda. Por tal razão, tinha um modo de andar esquisito (O TICO-TICO, 18/01/1911, p.14). Quando um costureiro erroneamente transforma sua saia em uma minissaia, teve que usar um um par de calças do esposo por baixo da peça estragada. Embora envergonhada, a criação fez sucesso com as transeuntes (O TICO-TICO, 07/03/1917). Brigou com um homem, pois ele ousou ridicularizar sua moderna saia com bolso na parte trás (O TICO-TICO, 22/01/1913, s/p.). Os seus elaborados chapéus são sempre destruídos (O TICO-TICO, 09/07/1913, p.11.).

A busca de Faustina para ser uma mulher moderna, é o aspecto mais desperta atenção no conjunto das narrativas analisadas. Identifica-se uma vontade de ser mãe, esposa e algo mais. É no cenário das ruas largas e da atmosfera afrancesada do Rio de Janeiro, que a personagem quer ver e ser vista. Reflexo das 
mudanças vivenciadas pelo sexo feminino, na passagem do século XIX para o século XIX. Período no qual as mulheres pertencentes às classes mais passaram a cobrar maior acesso à educação e ao mercado de trabalho:

\begin{abstract}
Ao lado das mulheres pobres, desde sempre inseridas no mercado de trabalho, passaram a busca-lo também aquelas dos segmentos médios e mesmo mais elevados da sociedade. Para isso, colaborou, entre outros motivos, o fato de os produtos consumidos pelas famílias com a industrialização, passarem a ser adquiridos no mercado, dando lugar à crescente necessidade de contribuição financeira por parte também das mulheres. Em decorrência, em amplos setores médios sobrevieram reivindicações de aumento das possibilidades de capacitação profissional e da supressão de barreiras impostas ao trabalho feminino remunerado. A essas causas também aderiram mulheres da alta burguesia, igualmente desejosas de realização profissional e autossuficiência econômica. Acesso pleno à educação, direito de voto e de elegibilidade foram, então, considerados instrumentos essenciais ao alcance desses objetivos (SOIHET, 2013, p. 218).
\end{abstract}

Faustina é ridicularizada por querer fazer parte deste novo mundo. Ela frequenta cafés, teatros e cinemas, porém não tem o traquejo social ir a estes lugares. Como é narrado o desastroso passeio das personagens pela Avenida Central. Os dois "uniformizados e em passo de urubu malandro se dirigiram para a grande artéria" (O TICO-TICO, 22/03/1911, s/p; O TICO-TICO, 29/03/1911, p.11). A esposa de Zé Macaco, ao invés de comer de forma comedida como uma dama, empanturrou-se de tanto sorvete que acabou congelada. O marido tentou de tudo para rever o processo, mas só obteve sucesso quando cozinhou a mulher em uma fogueira (Fig.71) (Fig.72). Foram expulsos do cinema e levados pela polícia, por terem se comportado de forma inapropriada. Gargalharam tão alto que alguns espectadores abandonaram a sessão (O TICO-TICO, 03/05/1911, p. 14; O TICOTICO, 10/05/1911, p.14) (Fig.73) (Fig74).

O modo de agir das personagens era proposital. Segundo Rosa (Op.cit.), a família Zé Macaco compunha “(...) o protótipo de uma família carioca urbana, hipoteticamente grã-fina, vivendo, em aventuras excêntricas, as alegrias e agruras do cotidiano" (p.195). Em entrevista a Revista da Semana, de 31 de março de 1945, o ilustrador Alfredo Storni diz que o objetivo das histórias era ensinar às crianças sobre maus comportamentos: 
E como obra nacionalizante, penso que as aventuras dêsse pessoal têm alcançado o fim que eu visava. Além disso, pretendo incutir nos espíritos infantis, através do grotesco e do ridículo, a verdadeira concepção de modéstia, da serenidade e de todas essas virtudes, que cada dia se tornam mais esquecidas dos homens. Zé Macaco é do tipo vaidoso, do "granfino" que compra um automóvel sem saber onde irá buscar dinheiro para o carvão. E Faustina lhe segue nas águas. Mas no fim das histórias a sua mania de granfinismo é sempre castigada, e êles acabam caindo em ridículo (p.25).

Este posicionamento crítico é sintetizado, na ida do casal ao teatro para assistir uma peça autobiográfica. Com vergonha do conteúdo apresentado deixam o espetáculo. Uma senhora representando a imoralidade, observa a cena. (O TICO - TICO, 06/11/1913, p.1) (Fig.75).

A conduta de Faustina é alvo de escárnio e recriminação. Sarcasticamente é chamada de elegante e bela. A mulher bondosa e virtuosa, tem seus ímpetos modernizadores combatidos com goles da aguardente Paraty. Forma encontrada por seu esposo para acabar com um audacioso passeio de motocicleta (O TICOTICO, 19/02/1913, p.1) (Fig.76). A imagem de uma mãe de família tomando bebida alcoólica no gargalo podia ser engraçado, mas na prática deveria ser repudiado.

As histórias de Zé Macaco e Faustina eram chamadas por seu autor de "desopilantes" (O TICO-TICO, 30/12/1914, p.16). A identificação do humor como ferramenta crítica, faz-se presente na imprensa brasileira desde o século XIX, por exemplo, nas ilustrações e nas caricaturas. Segundo Lustosa (2008), os recursos humorísticos são empregados como afirmação de uma posição social e política. Velloso (Op.cit.) define o humor como elemento essencial, do discurso crítico acerca da modernidade, difundido por parte da intelectualidade carioca. 


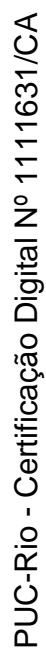

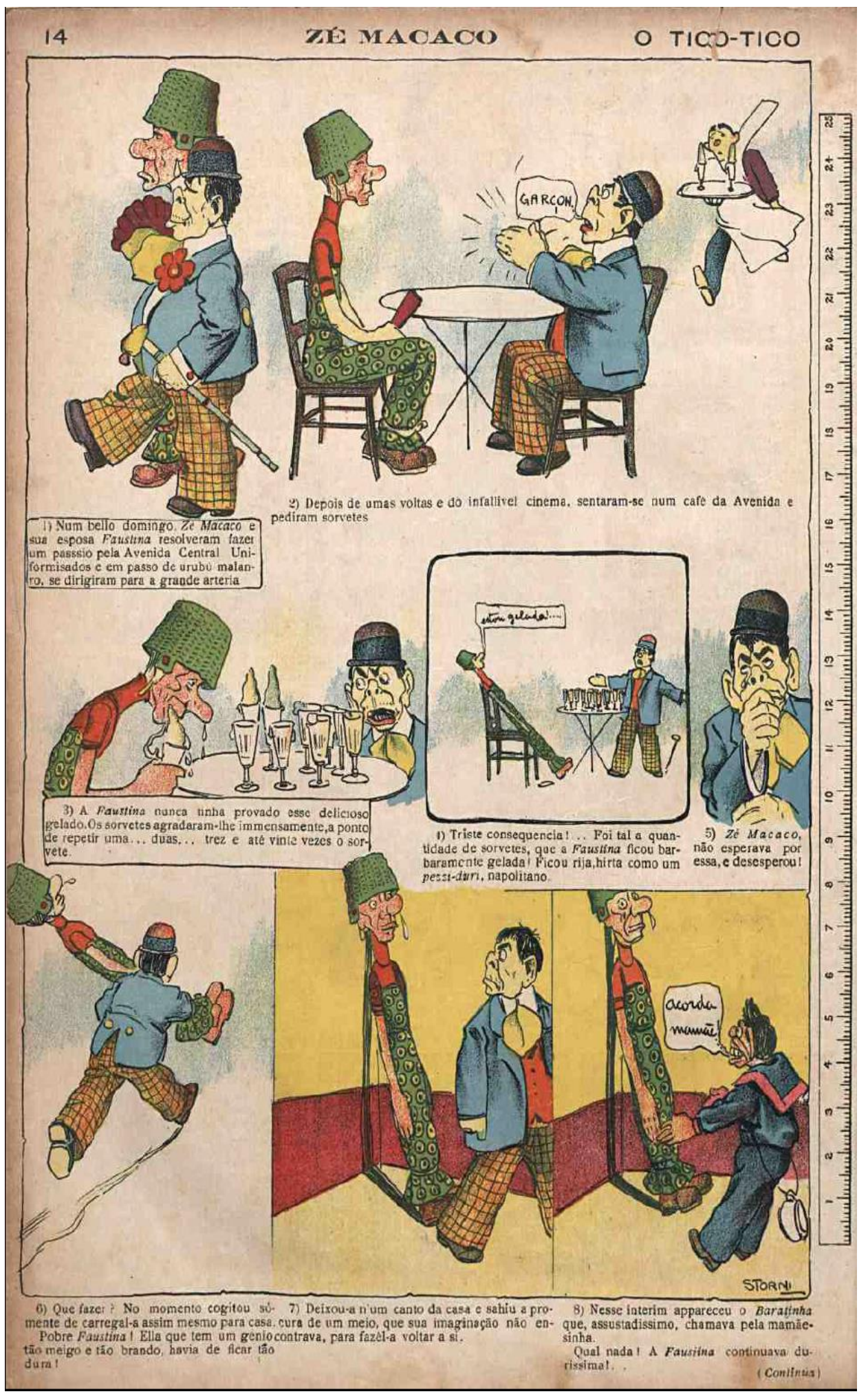

Figura 71 - O Tico-Tico - 22/03/1911-p.14 


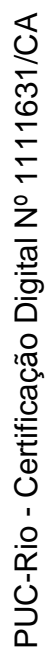

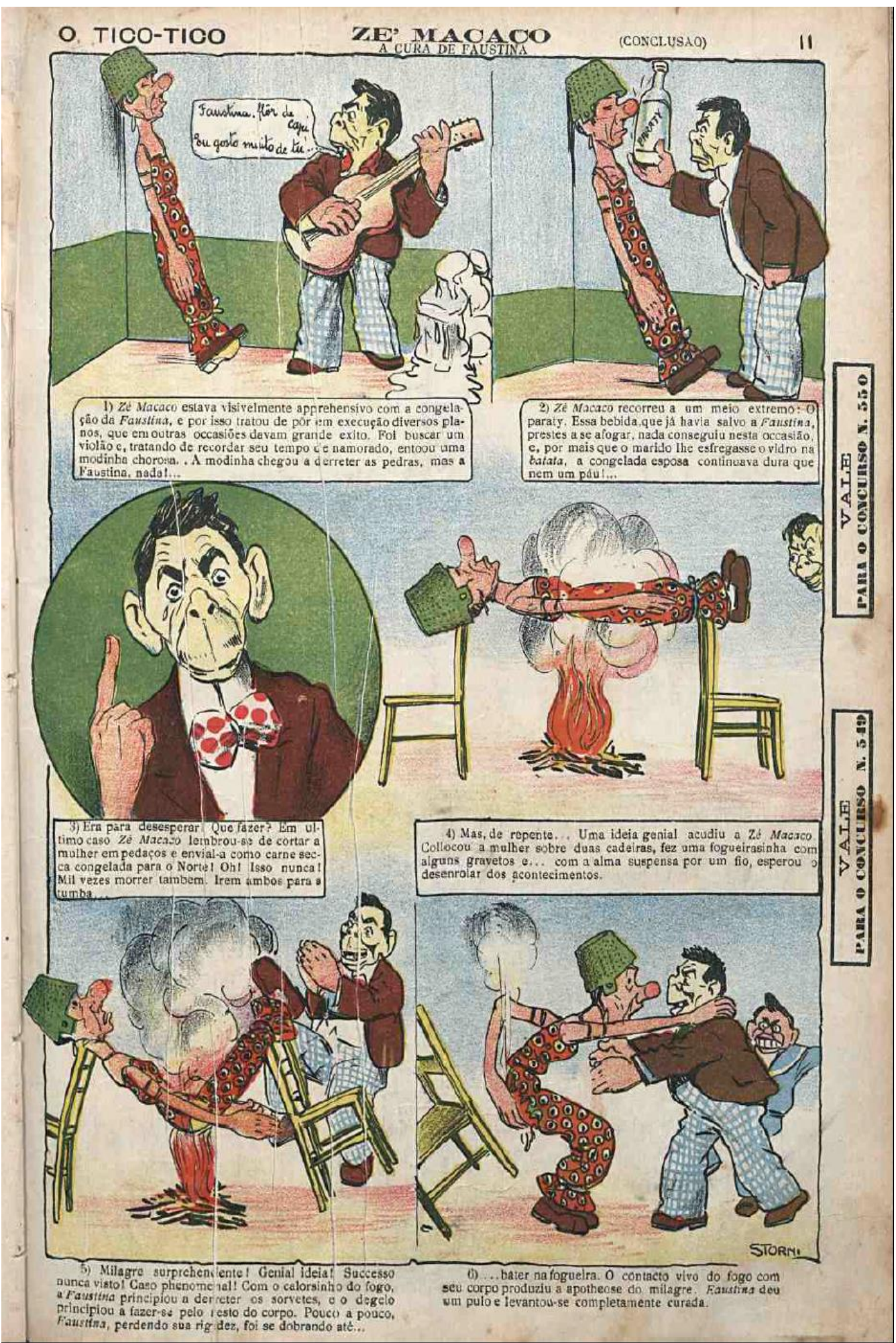

Figura 72- O Tico-Tico-29/03/1911 - p.11 


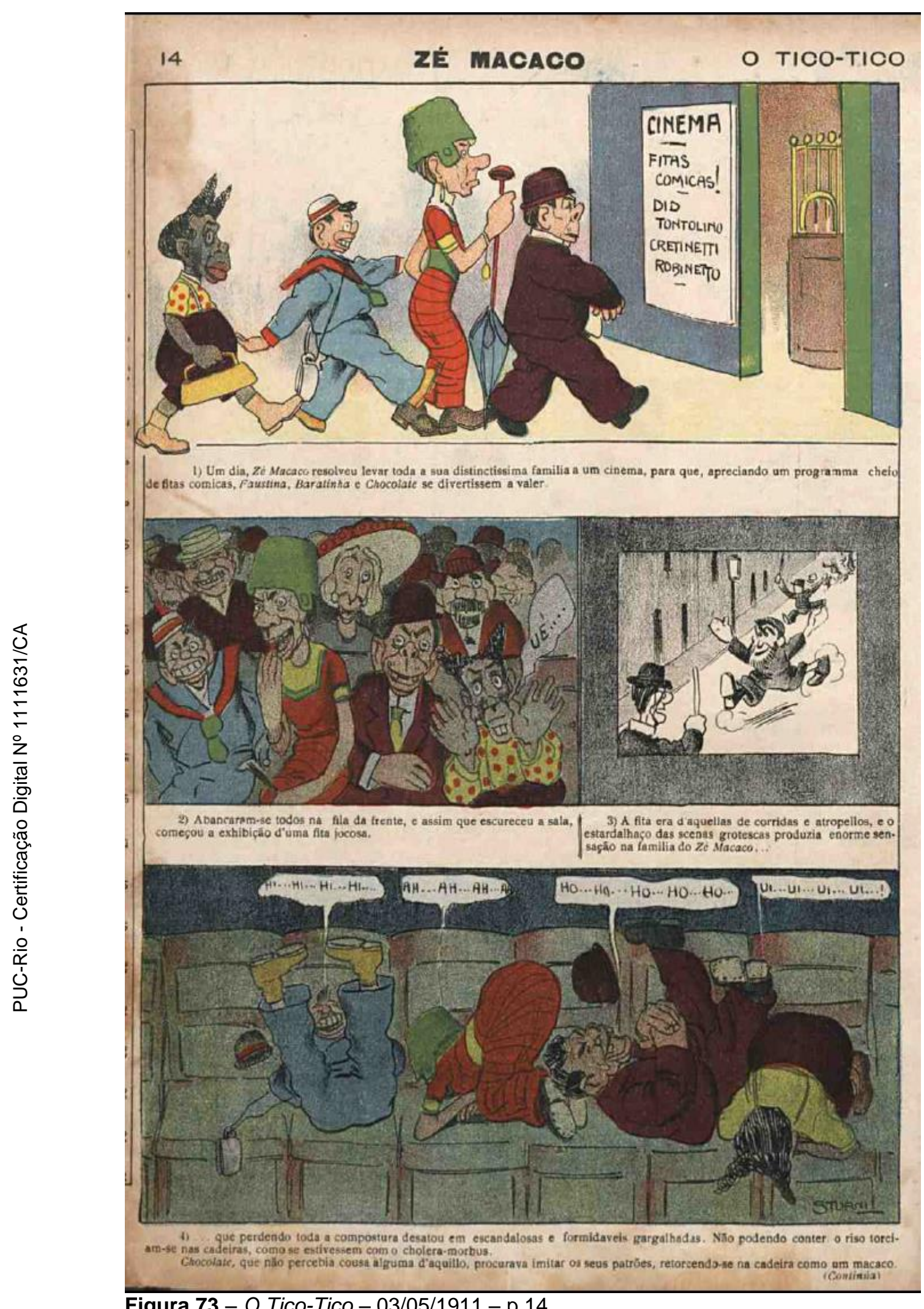

Figura 73 - O Tico-Tico - 03/05/1911-p.14 


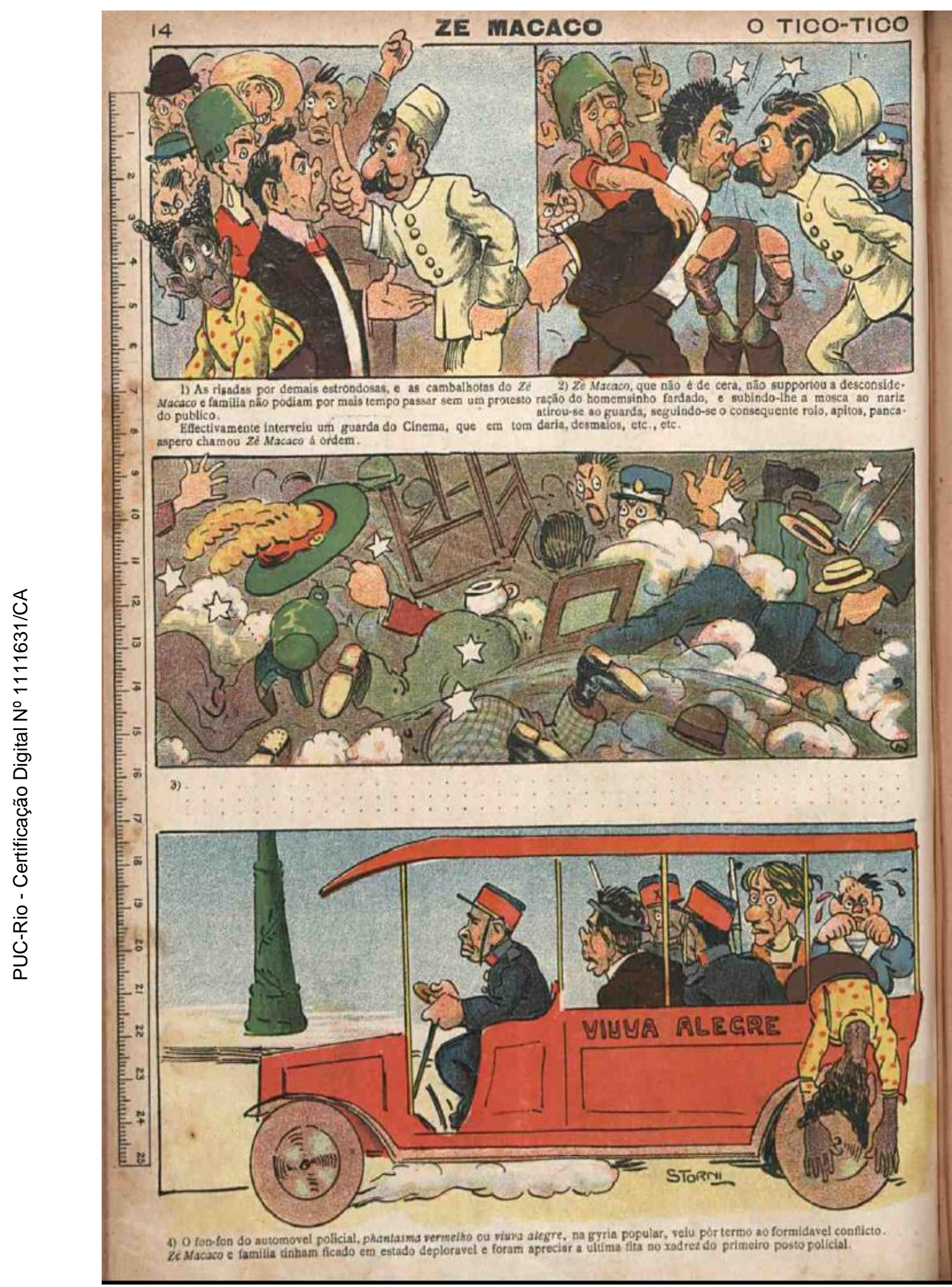

Figura 74 - O Tico-Tico - 10/05/1911-p.14 


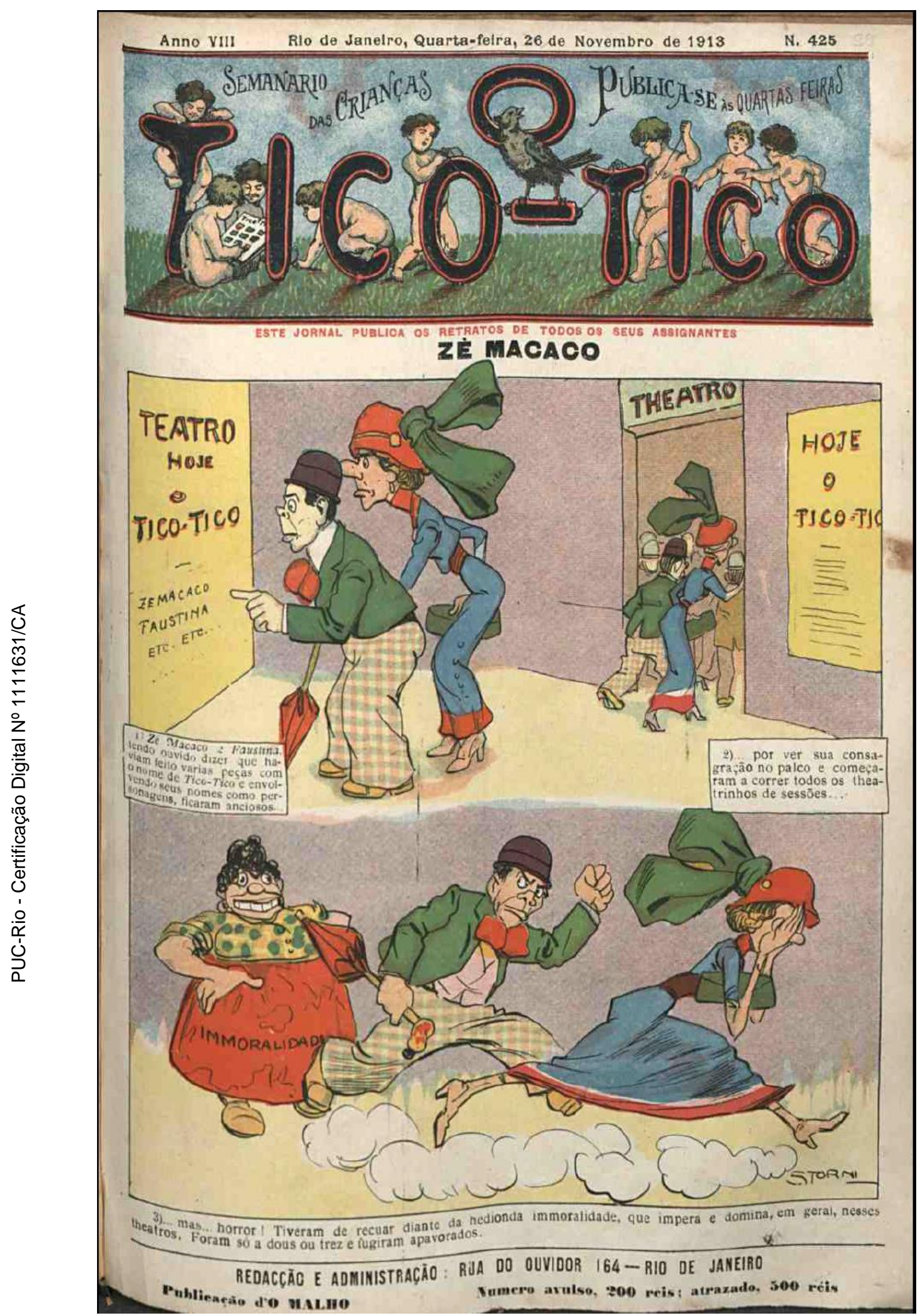

Figura 75-O Tico - Tico - 6/11/1913 - p.1 


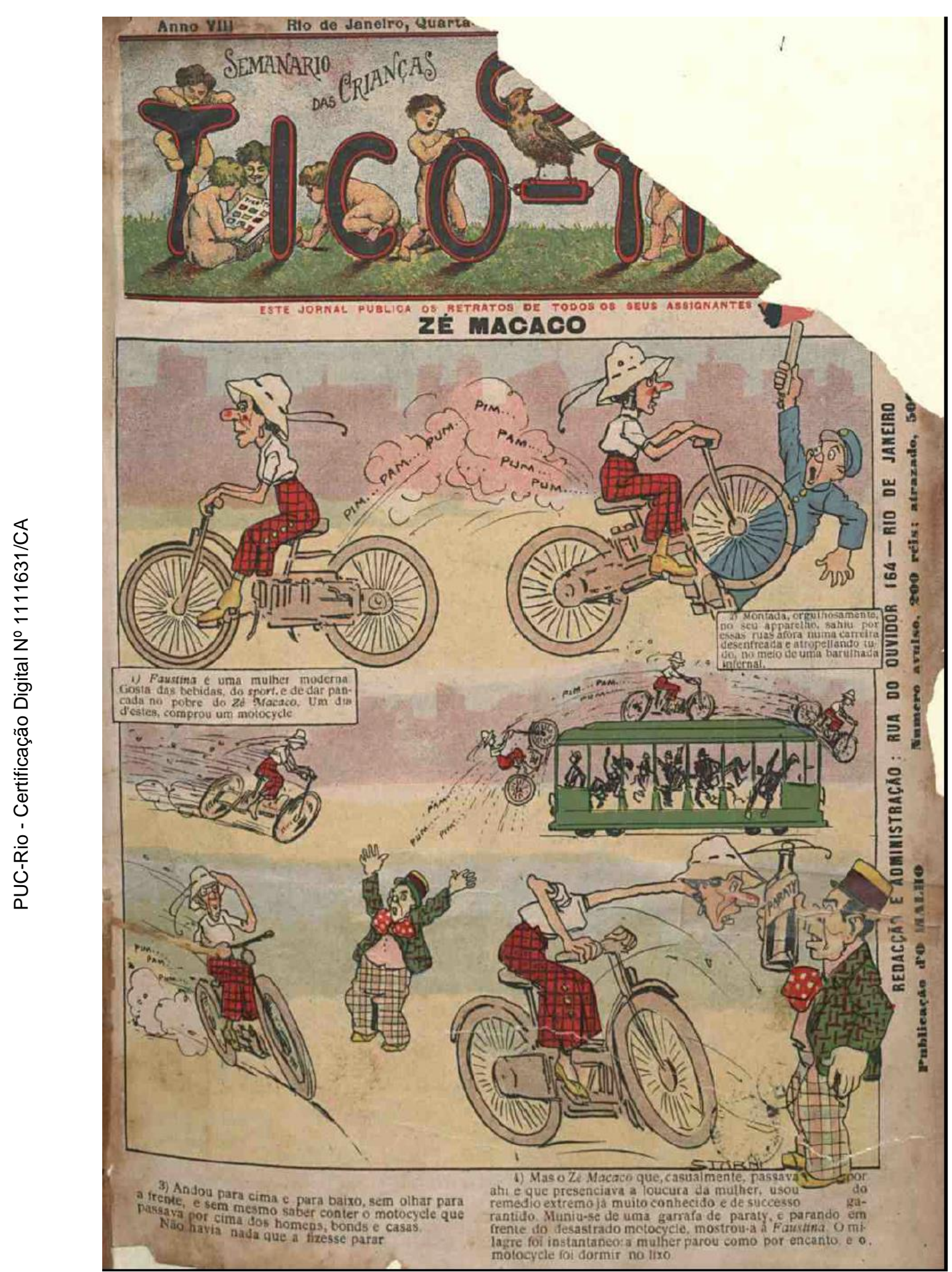

Figura 76 - O Tico-Tico - 19/02/1913-p.1 
Narrativas demonstram que Faustina, mesmo uma boa esposa, revolta-se contra a autoridade marital do esposo. Depois de bater em Zé Macaco, sai às ruas conclamando as mulheres a apoiar sua causa. “- Viva a liberdade! Nós queremos a mancha-paixão da mulher! E tanto Faustina berrou pelas ruas, tanto reboliço fez a fallar em Mancha-Paixão em vez de emancipação" (O TICO-TICO, 07/06/1911, p.11; O TICO-TICO, 14/06/1911, p.14). Teriam comparecido à menifestação 600.000 mulheres. Apenas uma faltou por causa do reumatismo. De acordo com o Censo de 1920, a cidade do Rio de Janeiro tinha uma população de 1.157 .873 habitantes (IBGE, 1920). No entanto, o entusiasmo das participantes diminuiu com o passar das horas. Faustina ficou sozinha até reencontrar o choroso marido (Fig.77) (Fig.78).

A iniciativa da personagem é vista com um capricho. Uma mulher que não consegue dizer corretamente a palavra emancipação, poderia liderar um movimento feminista? O que elas entendem como emancipação feminina? $\mathrm{Na}$ história, a liberação feminina termina quando chega a hora de preparar o jantar.

Outra ação de Faustina, a causar rebuliço na cidade foi a malfadada tentativa de usar uma a jupe-cullote (saia calça). Como não tinha recursos para comprar uma peça, resolve usar um par de calças de Zé Macaco. O fato de uma mulher usar roupa masculina na, causou uma série de violentos protestos. “ Mas a bella Faustina que julgava sua elegancia capaz unicamente de produzi aplausos na multidão, via, com grande susto, que o povo a seguia grosseiramente, com pilherias, chufas e prorompia afinal em formidavel vaia" (O TICO-TICO, 12/04/1912, p.14; O TICO-TICO,19/04/1912, p.14). A personagem precisou ser salva pelo marido e seu aeroburro (Fig.79)(Fig.80). 


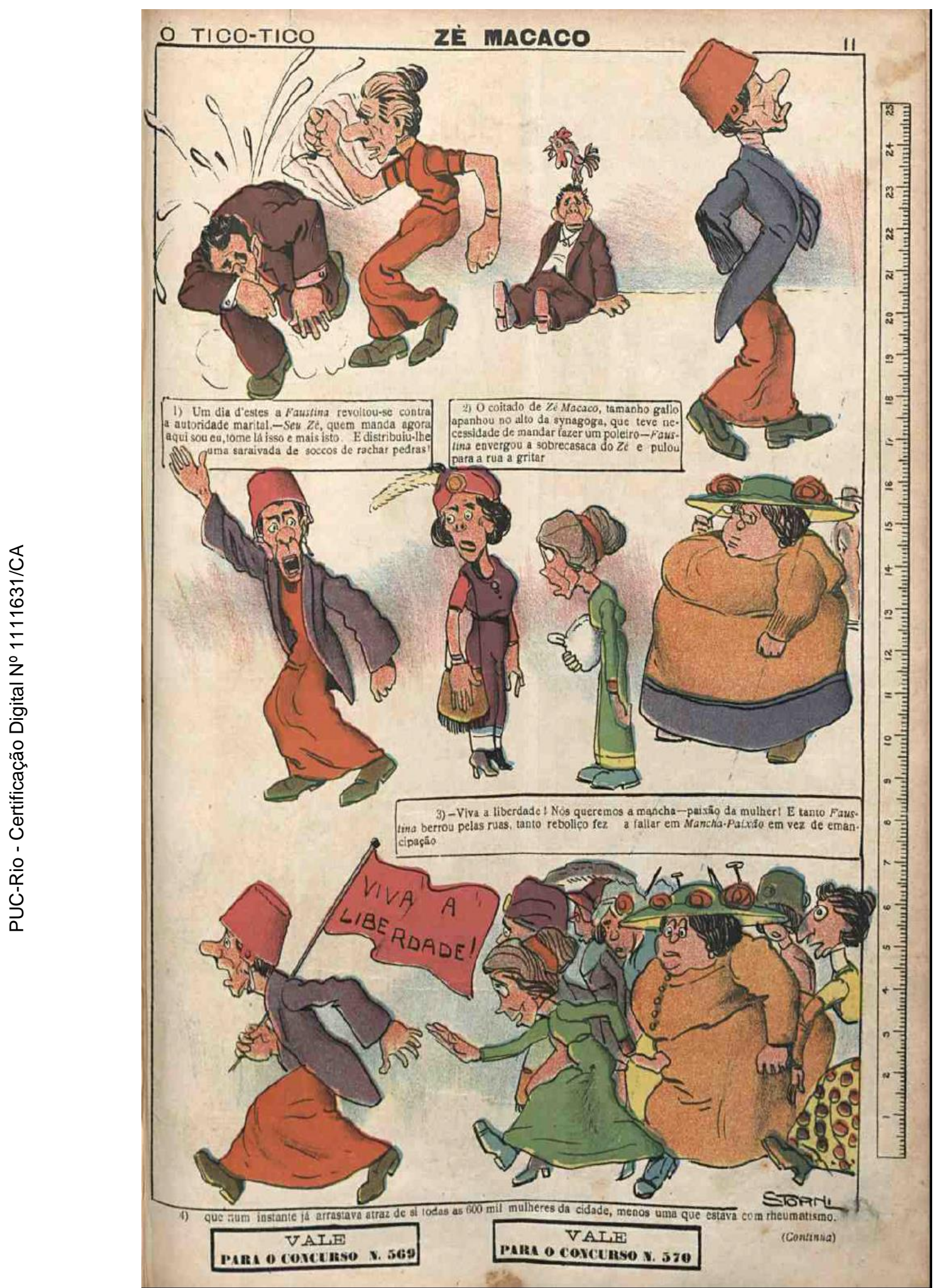

Figura 77 - O Tico-Tico-07/06/1911 - p.11 


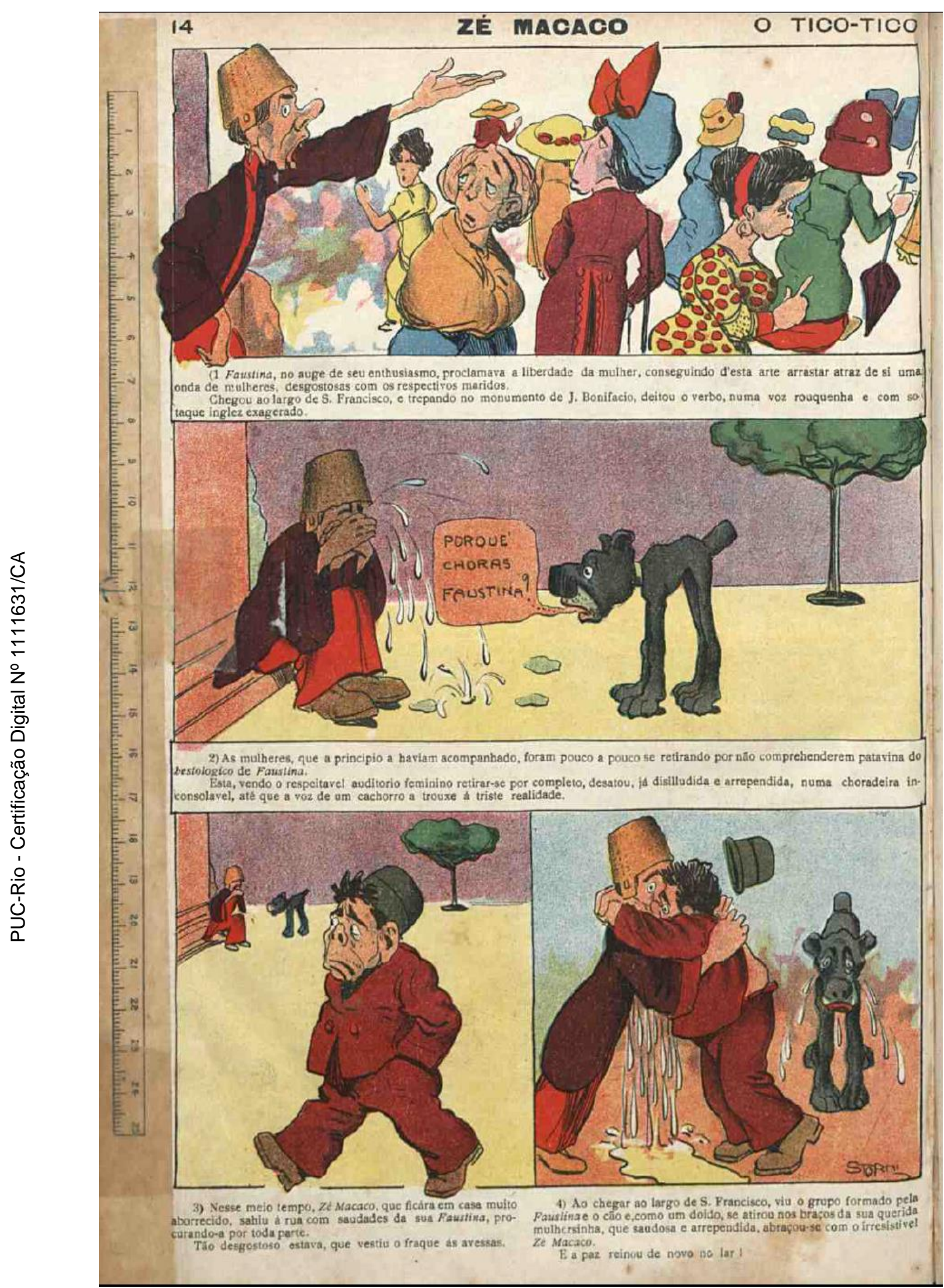

Figura 78 - O Tico-Tico - 14/06/1911-p.14 


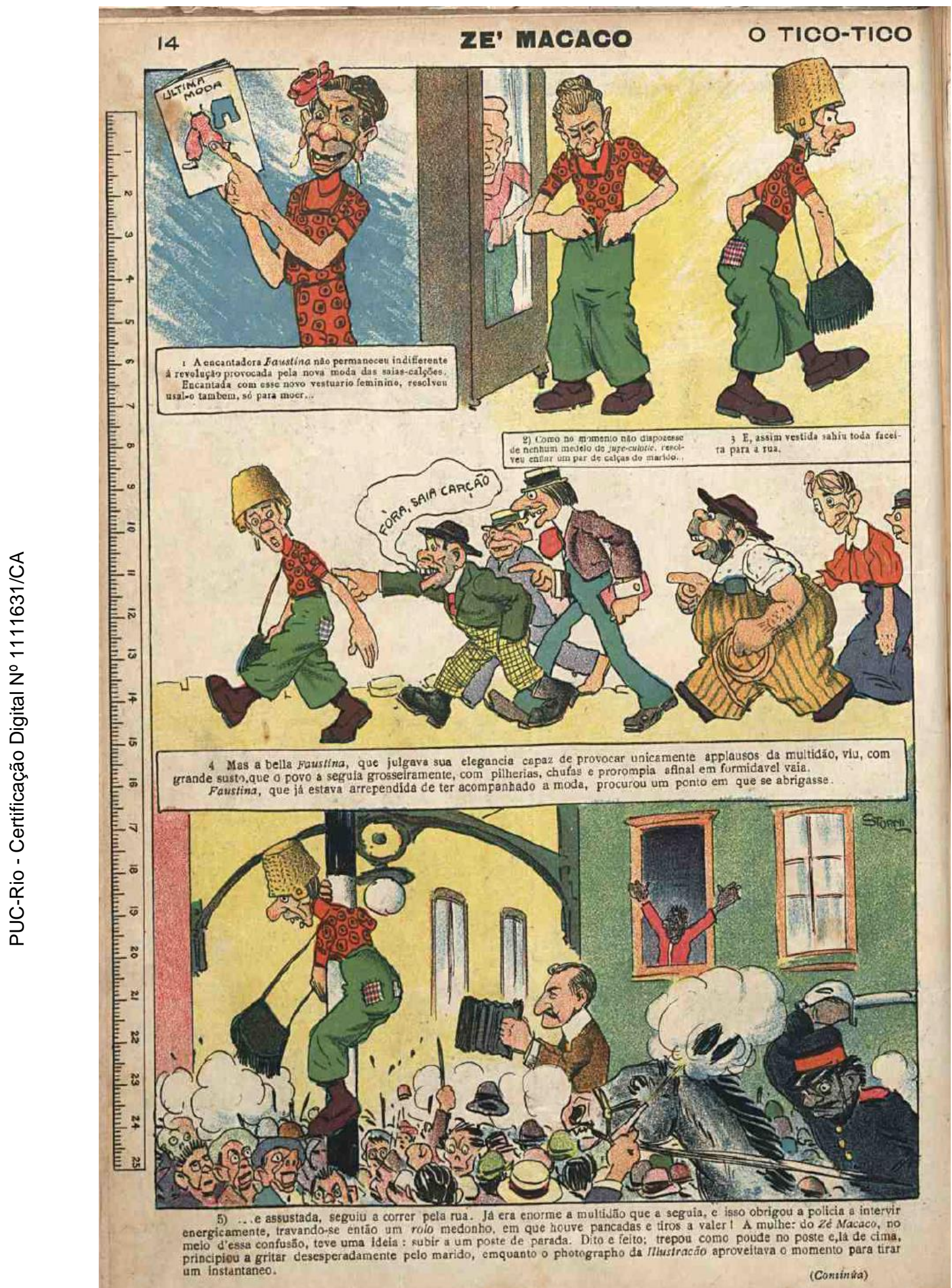

Figura 79-O Tico-Tico - 12/04/1912 - p.14 


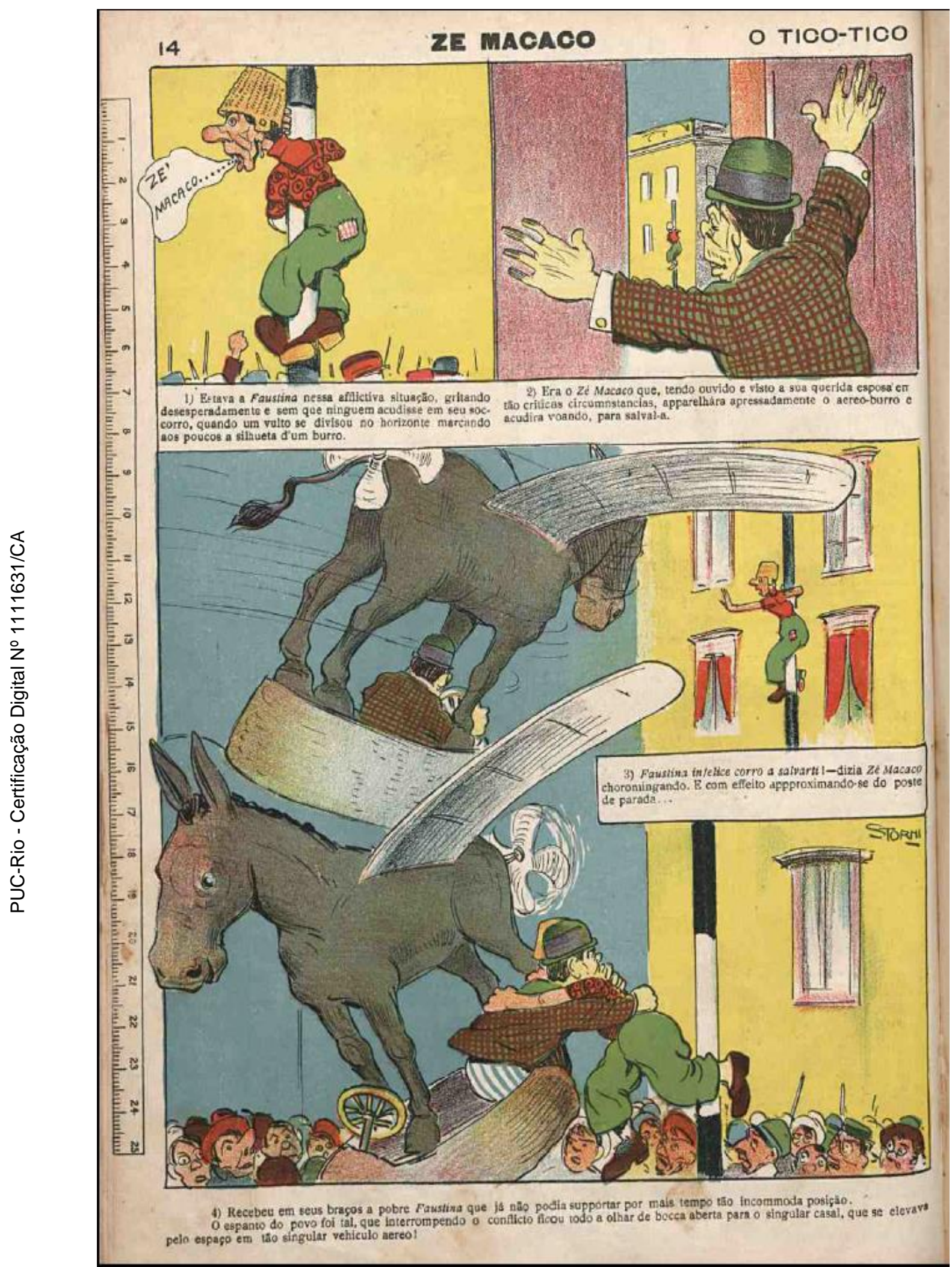

Figura 80 - O Tico-Tico - 19/04/1912 - p.14 
Os rompantes de Faustina, voluntários ou involuntários, também se constituem em elementos de debate sobre as relações de gênero. Os leitores deveriam perceber o quanto era estranho um homem que chora e se desespera por não ter a presença da esposa em casa. Como também, aprender que mulheres como Faustina são engraçadas apenas nos quadrinhos:

$\mathrm{Na}$ verdade, havia na sociedade brasileira, em geral, e entre autoridades e políticos em particular, forte oposição às reivindicações das mulheres. Respaldando tal oposição, a ciência da época considerava as mulheres, por suas supostas fragilidade e menor inteligência inadequadas para as atividades públicas, afirmando que o lar era o local apropriado à sua inserção social e o cuidado com a família, sua ocupação prioritária (SOIHET, Op.cit., p.219).

A escolha por desenhar uma personagem desviante e pertencente às classes menos abastadas está vinculada ao estereótipo de que "A dona de casa popular não tem muitas papas na língua. Muitas vezes é uma rebelde, tanto na vida privada quanto na vida pública" (PERROT, Op.cit., p.113). Para defender o padrão da mulher dedicada ao lar, não se faria troça das representações femininas defendidas pela publicação.

Faustina pode ser ridicularizada, justamente porque não se encaixa em tal modelo. É presa com a acusação de ser um homem travestido de mulher. "Prendeu a Faustina com a conviç̧ão plena de que ella era um homem, que assim andava disfarçado para illudir a humanidade" (O TICO-TICO, 12/06/1912, p.14; O TICO-TICO, 19/06/1912, p.14). A personagem é obrigada a deixar a delegacia, usando trajes masculinos. Ao chegar em casa, não é reconhecida pelo marido. Somente após uma surra, ele percebe que aquele homem era sua esposa (Fig.81) (Fig. 82). 


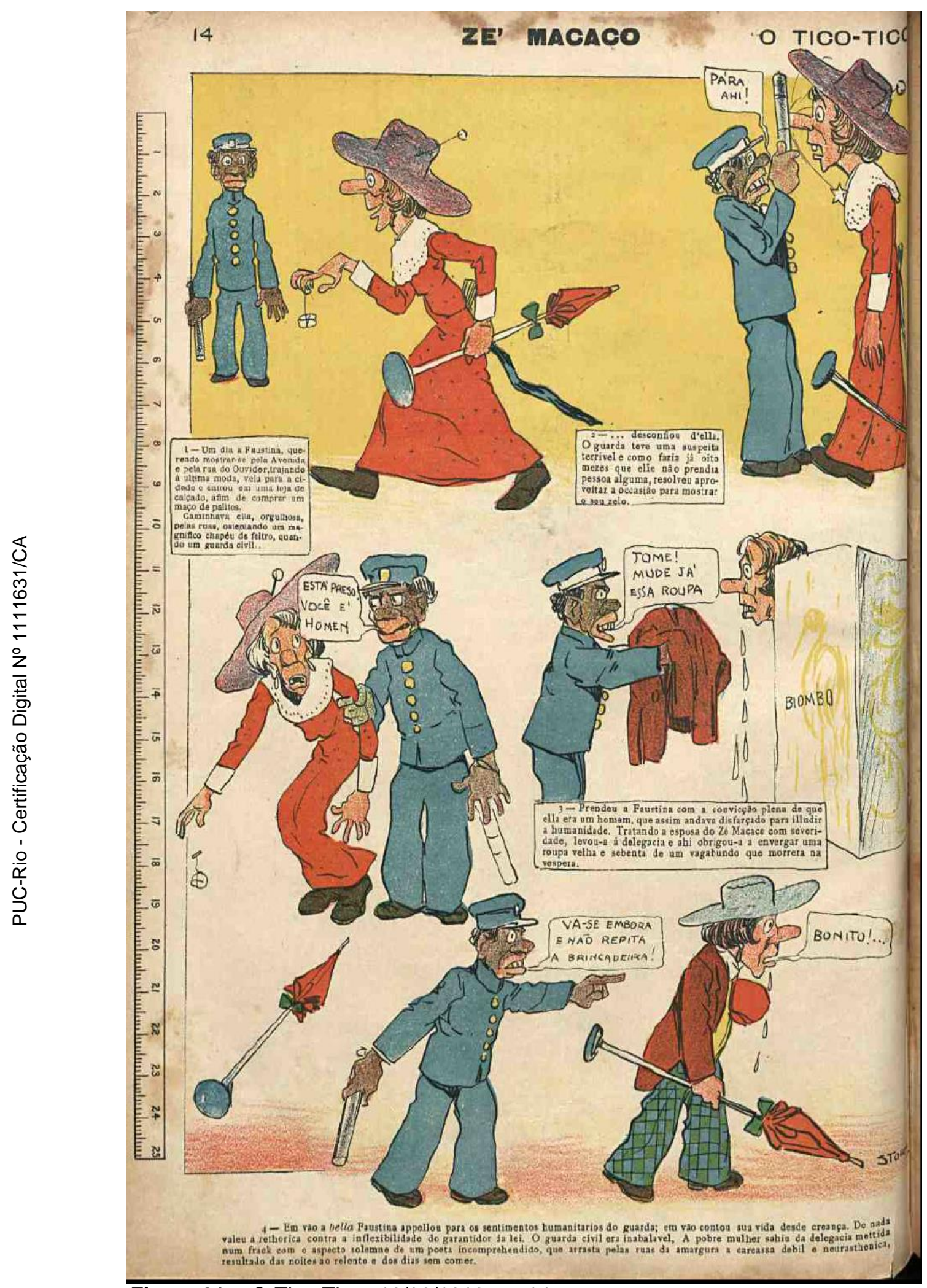

Figura 81 - O Tico-Tico - 12/06/1912 - p.14. 


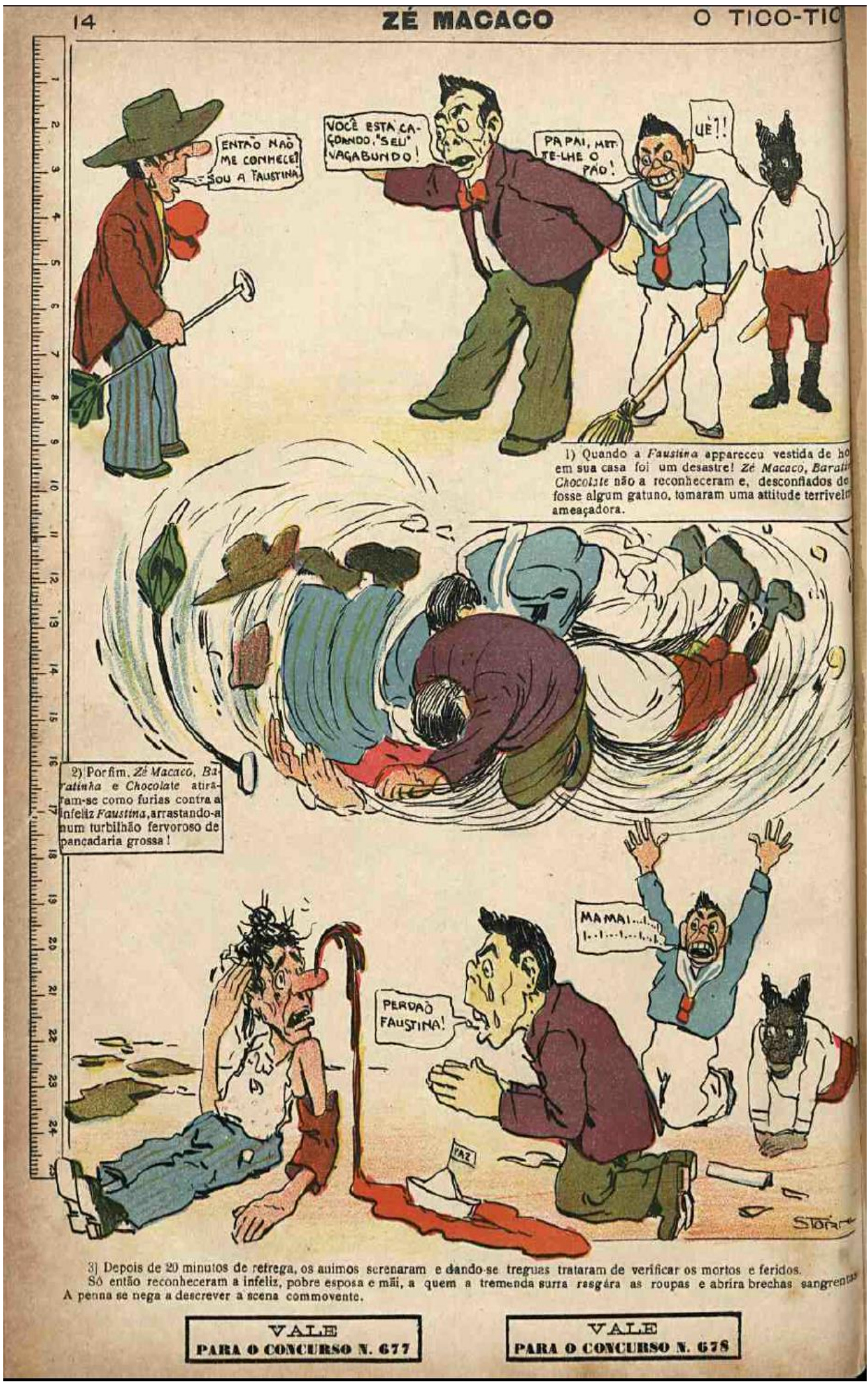

Figura 82- O Tico-Tico - 19/06/1912 - p.14. 
Novamente, ressalta-se a temática da construção social do gênero feminino. A esposa de Zé Macaco remetia ao estereótipo da feminista ou de qualquer mulher que lutasse por mudanças na sociedade brasileira. Quando sai para passear, Faustina se esquece do marido (Fig.83). Havia a necessidade de reforçar os padrões de comportamentos femininos tradicionais.

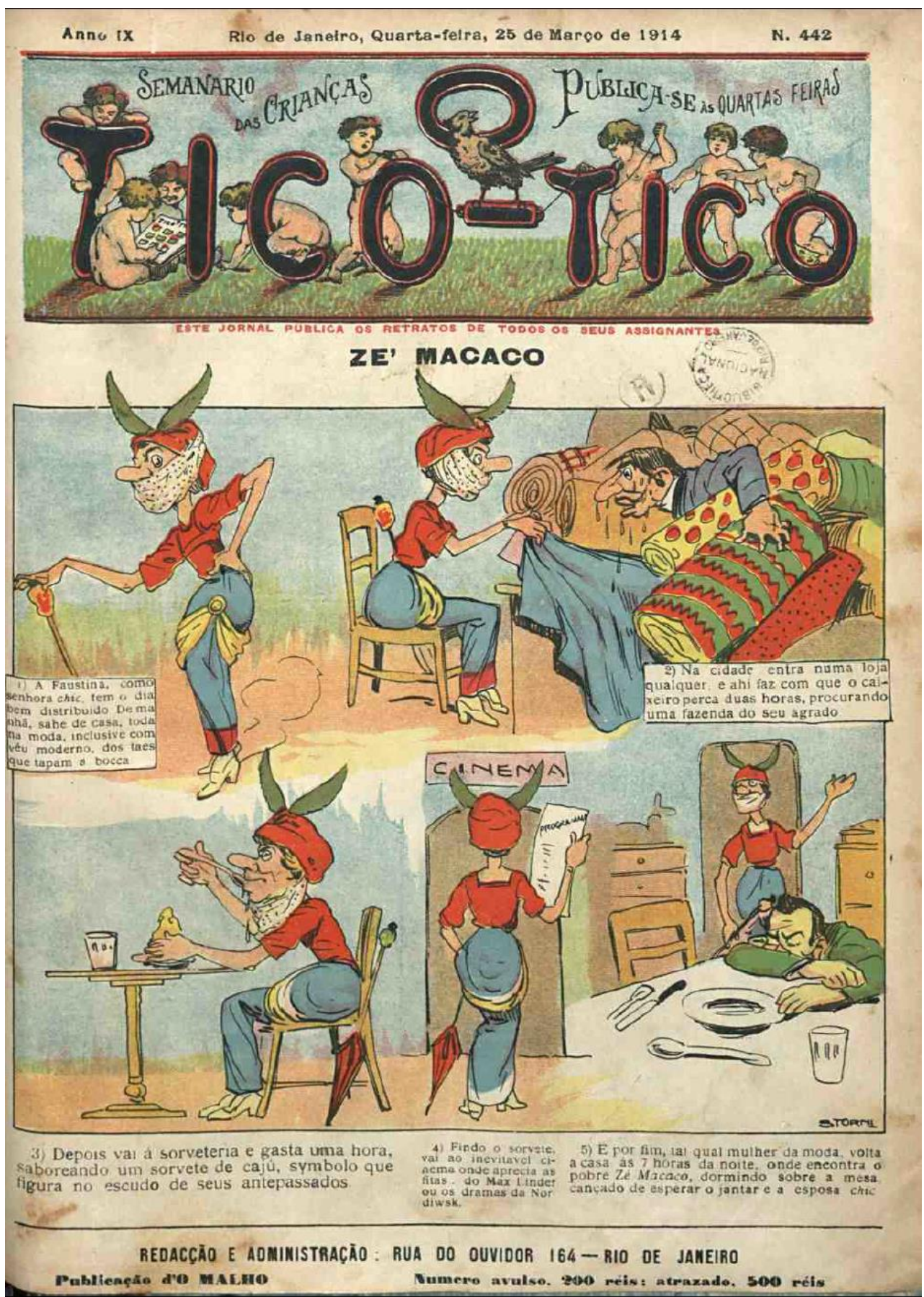

Figura 83 - O Tico-Tico - 25/03/1914-p.1 
Embora a personagem passasse por situações constrangedoras, ao longo dos mais de 50 anos de $O$ Tico-Tico, nenhuma figura feminina foi tão famosa quanto Faustina. No artigo Louvação ao "Tico-Tico", Dinah Silveira de Queiroz faz referência a esta popularidade:

Compreendi a fôrça dessa revistinha, que passara à glória nacional, através de suas histórias e suas figuras, por isso no cinqüentenário, eu me detive a examinar a biografia de Storni, criador de Zé Macaco e Faustina. Agradeci a esse proporcionador de desrecalques, as personagens que ele havia animado (1956, p.57-58).

Faustina Foi protagonista de concursos promovidos pela revista, estrelou anúncios publicitários e foi retratada em inúmeros desenhos e poemas enviados para a redação da publicação (Fig.84) (Fig.85)

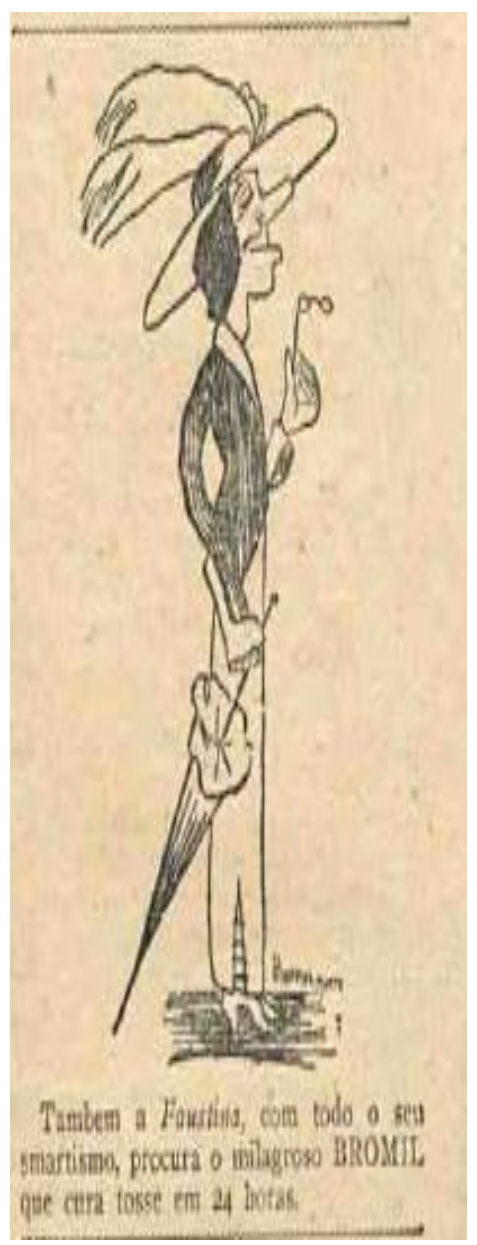

Figura 84 - O Tico-Tico 03/09/1913 - p.6

\section{CARTAS DE UM TABAREO}

Pelo assiduo teitor Walfrides B. Irindade.

cAo pessod d O Tico Tico.

Venho pru meio d'esta

Fuze uma descripsăo

Tà gravada na minh alma

No fundo do cornę̧īo.

Ze Macaco 0 amigo vétio

Meu maió camarátío,

Pra todo nossos leito

Queristo do coraçấo.

Raustina, sua muid

E uma farça e tratante

Eoganando cumpade véio

$\mathrm{A}$ andar sempre iniegante.

Baratinha, scu finho

- Daque la muié ingrat.

E. o menino mais leio

E de todgs o mais perarta.

Chocolate, seu criado

Nio ba zente que o mate

Muleque nasceu do chóco

Tem rairya do cho que late.

So Chiquinbo eo Jagunço

Os amizo das travissura

Nio ha semana que nảo leve

Umas meia duzia de surta.

A fora sinha Lili

Qui secumportou um pouquinho

Blla so faz travessura

A' mando do sồ Chiquinho.

Caximboring home das lettra

E otro camaradăo

So trata de seus estudo

$\mathrm{E}$ mais da sua invençăo.

Figura 85 - O Tico-Tico

04/03/1914-p8 


\section{Páginas dedicadas às meninas e às mulheres}

A leitura dos exemplares de $O$ Tico-Tico permite identificar a presença de conteúdos considerados eminentemente femininos. Qual seriam tais assuntos? Beleza, cosméticos, elegância, moda, maternidade, saúde, trabalhos manuais e prendas domésticas.

Algumas destas temáticas são facilmente demarcadas, pois a revista possui seções criadas somente para suas leitoras: Secção para meninas, Moda para nossas leitoras, Figurinos para nossas leitoras e Para nossas leitoras. Apenas a Secção para meninas traz a indicação de ser direcionada à formação de um público específico. As outras seções por suas características imagéticas e textuais, caracterizavam-se por também serem direcionadas ao consumo das mães, irmãs, senhoritas e senhoras.

No tocante ao recorte temporal estudado, observa-se que as páginas de publicidade presente em $O$ Tico-Tico também podem ser classificadas como espaços dedicados ao sexo feminino. Embora existam anúncios protagonizados por meninos, homens e Chiquinho, os discursos são destinados às mães.

Este contexto, suscitou uma série de questões: Por que criar conteúdos específicos para o sexo feminino? Haveria uma diferenciação entre os conteúdos que toda a criança deveria saber e aqueles que apenas o gênero feminino deveria conhecer? Por que tais temáticas eram consideradas femininas? Por que esse tipo de informação era considerado importante para as leitoras do impresso infantil?

Em $O$ Tico-Tico, as seções femininas são entendidas como uma demanda das próprias leitoras. A Gaiola d' O Tico-Tico, de 13 de novembro de 1907, publicou resposta sobre o pedido de cinco meninas para a criação de espaços dedicados ao sexo feminino:
A sua ideia é muito razoável, mas não a tinhamos comprehendido bem na primeira carta. Imaginávamos que desejavam uma secção para meninas com trabalhos, etc. Mas como explicaram agora, ainda é mais interessante. Estamos dispostos a satisfazel-as, mas esperem um pouco. E' preciso imaginar e preparar os desenhos....Em todo caso fiquem já sabendo que brevemente publicaremos a historia Mariquinha dorminhoca (p.12).

No decorrer da pesquisa não foi encontrado o exemplar no qual a narrativa Mariquinha dorminhoca foi publicada. No entanto, demonstra-se que os 
colaboradores e os redatores de $O$ Tico-Tico estavam atentos aos desejos das leitoras. Novamente, refuta-se a ideia de que o impresso apenas se preocupava com sexo masculino.

No impresso infantil, o processo de seleção e escolha dos temas abordados nestes espaços era um reflexo da imprensa feminina e dos manuais destinados às moças e às mulheres, em circulação dede as décadas finais do século XIX.

Buitoni (1990):

Imprensa feminina é um conceito definitivamente sexuado: o sexo de seu público faz parte de sua natureza. (...) A começar do nome, a maioria das publicações, programas de TV femininos indicam claramente para quem se dirigem (p.7)

Costa (2012) :

(...) inaugurava a prática, presente até os dias atuais, de deixar claro no título dos periódicos que se tratava de leitura para as mulheres (tanto que revistas de sucesso adotaram nomes femininos: Claudia, Ana Maria, Carícia, enquanto poucas revistas masculinas adotaram nomes de homens, como George, de Jonh Kennedy Jr., a Getulio ou a recente Samuel (p.389390).

Luca (2013):

Essa imprensa particulariza-se por dirigir-se para o público feminino, ainda que nem sempre tenha sido produzida por mulheres. Trata-se de um tipo de produção jornalística que não é movida pela necessidade de registrar o fato novidadeiro do dia anterior, matéria-prima por excelência do jornalismo. Pelo contrário, a imprensa feminina orbita em torno de temas perenes, não submetidos à premência do tempo curto do acontecimento. Moda, beleza, casa culinária ou cuidado com os filhos comportam uma abordagem circular, ligada à natureza circular, ligada å natureza e às estações do ano: afinal, receitas, recomendações, conselhos indicados para o inverno e o verão podem ser retomados em anos subsequentes, desde que revertidos de ar de atualidade e apresentados como a última palavra no assunto (p.448).

Neste contexto, além dos "recônditos do lar" (MALUF; MOTT, Op.cit.), tinha-se também os recônditos da imprensa.

Buitoni (2009) aponta que a imprensa feminina pode ser inicialmente percebida como algo menor ou marcada pela passividade, porém "é mais ideologizada que a imprensa dedicada ao público em geral. Sob a aparência de neutralidade, a imprensa feminina veicula conteúdos muito fortes” (p.21). Em jogo, a disputa pela legitimação de determinadas representações femininas. De um lado, a conservadora na qual as mulheres devem ser as rainhas do lar. De outro, a 
concepção de que o sexo feminino deveria se dedicar às atividades intelectuais mais do que às prendas domésticas. Como salienta Chartier (2004), as sociedades são marcadas pela disputa de representações:

As lutas de representações têm tanta importância como lutas econômicas para compreender os mecanismos pelos quais um grupo se impõe ou tenta impor sua concepção de mundo social, os valores que são seus, e o seu domínio (p.17).

O fato de $O$ Tico-Tico ter classificado determinados temas como adequados ao gosto feminino, evidencia que o impresso tinha o objetivo de validar um conjunto de regras e comportamentos a serem internalizados por suas leitoras.

A imprensa feminina ganhou espaço na França e na Inglaterra, no final do século XVII (COSTA, Op.cit.). No Brasil, as primeiras publicações do gênero entraram em circulação a partir da primeira metade do século XIX. Para Oliveira (Op.cit.), as mulheres “(...) tornaram-se sujeitos fundamentais na construção da literatura e da imprensa nacional. Elas eram consumidoras vorazes" (p.166). O editor Paula Brito lançou A mulher do Simplício ou A Fluminense exaltada (1832), considerada a primeira revista feminina do país (Ibidem, p.167). Costa (Op.cit.) condiciona este pioneirismo, ao impresso O Espelho Diamantino (1827). Segundo Sodré (Op.cit.), a maior parte deste publico leitor era composto por

(...) moças casadouras e pelos estudantes, e o tema literário por excelência deveria ser, por isso mesmo, o casamento, misturado um pouco com o velho motivo do amor, a imprensa e a literatura, casadas estreitamente a atender a essa solicitação premente (p.198).

A percepção da mulher como consumidora de produções literárias e jornalísticas ocorreu em virtude da liberação feminina da "clausura colonial" e o fato de terem começado a frequentar as boutiques francesas da Rua do Ouvidor (Loc.cit.). Neste cenário, ampliaram-se os títulos disponíveis às leitoras: $A$ Familia, A Mãi de Familia, A Bella Fluminense, Bello Sexo Bom Tom, Brazil Elegante, Correio das Damas, Correio das Modas, Jornal das Moças Solteiras, O Bello Sexo, O Espelho das Brazileiras, Recreio do Bello Sexo e mais tantos outros. Costa (Op.cit.) e Guimarães (2011) observam que em seus primórdios, os impressos femininos eram redigidos em sua maioria por homens. Com o avançar das décadas, os jornais escritos por mulheres também se tornaram conhecidos: $O$ Quinze de Novembro do Sexo Feminino, O Sexo Feminino, Jornal das Familias entre tantos outros periódicos. 
Alerta-se que um jornal ou uma revista recebem a alcunha de feminino não por serem redigidos por mulheres. "O grande elemento definidor ainda é o sexo de suas consumidoras" (BUITONI, Op.cit., p.8).

Santaella (2008) identifica que desde o início do século XX, a imprensa feminina vem se constituindo como um dos eixos de construção das identidades das mulheres. Por meio dos textos, das seções de aconselhamentos e das imagens, circulam determinados padrões do ser mulher:

E ela que vem proporcionando versões da feminilidade, padrões de moda, auto-estima, autonomia e autenticidade. Foi ela que favoreceu a expansão social dos produtos de beleza, contribuindo para fazer da aparência uma dimensão essencial da identidade feminina (p.105).

Ferreira (2005) aponta que as matérias jornalísticas são elementos importantes para a constituição do sujeito feminino. Nos anos finais do século XIX, as enunciações sobre o ser mulher ganharam a chancela de verdade:

Na confluência de diferentes formações discursivas - liberal, republicana, abolicionista, positivista, médico-higienista, dentre outras - era construída discursivamente a imagem da mulheresposa-mãe burguesa cuja educação era necessária para que pudesse ser responsável pela higiene e moralização do lar e pela regeneração dos costumes (...) (p.63).

Objetivava-se a normatização dos corpos e dos comportamentos. Priore (Op.cit.) aponta que a maternidade se constituiu como um tema, amplamente utilizado na imprensa e na publicidade, como estratégia de conformação de determinadas representações femininas.

No artigo Caras amigas, raras leitoras? A formação da mulher leitora no Brasil (1914/1936), Heller (2005) analisa os as edições da seção Jardim Fechado, espaço no qual as leitoras da Revista Feminina, em circulação de 1914 a 1936, trocavam correspondências. Publicada, de 1918 a 1927, a seção foi criada a partir da sugestão de seu público. Podiam ser enviados poemas e poesias, participar das enquetes e fazer comentários sobre os conteúdos da revista. Destacam-se as correspondências relacionadas à leitura. As mães tinham à preocupação de solicitar indicações de bons livros para as filhas. Algumas leitoras publicavam textos de própria autoria. No entanto, como as cartas podiam ser assinadas com pseudônimos não se pode confirmar a autoria de tais conteúdos. Para Heller, este cenário configura o "início da desconstrução da informação de que apenas $20 \%$ das mulheres até 1920 eram alfabetizadas em nosso país e, portanto, leitoras em 
potencial” (p.11). Havia um público ávido pela leitura, mas também preocupado com os conteúdos publicados nos impressos direcionados às mulheres adultas e às meninas.

Neste sentido, o capítulo visa analisar as representações femininas em circulação nas seções destinadas às leitoras de O Tico-Tico.

\subsection{Secção para meninas: uma formação para o lar}

Em 15 de maio de 1907, foi publicada a primeira seção destinada às leitoras de $O$ Tico-Tico. Denominada Distracções para meninas, seu conteúdo é referente as prendas do lar (Fig.84). Ressalta-se o uso da palavra Distracções, sinônimo de passatempo, para intitular uma seção feminina. As atividades destinadas às meninas eram consideradas algo menor? O texto alerta para o fato, das leitoras perderem muito tempo tentando fazer lindos adornos com rendas. Para facilitar a tarefa, a revista decidiu ensiná-las como usar tesoura e papel para criar bonitos enfeites. No decorrer a pesquisa esta foi a única edição localizada de Distracções para meninas.

Neste mesmo ano, em 31 de julho também foi veiculada a edição inaugural de Secção para meninas, espaço destinado a trabalhos manuais (Fig.85). Ainda não era uma coluna fixa. Passou a ser publicada com regularidade de 1909 a 1919. Após este período, suas edições foram se tornando escassas até 1921, quando foi substituída pelas seções Prendas Femininas e Secção de meninas.

Secção para meninas é inspirada em Nous habillons Bleuette ${ }^{65}$ de La Semaine de Suzette. Na revista francesa, as leitoras aprendiam como cuidar da boneca Bleuette ${ }^{66}$. No impresso brasileiro os conteúdos foram transpostos para o ambiente doméstico. As coincidências também se fazem presentes na formatação das seções. (Fig.86) (Fig.87) (Fig.88) (Fig.89) (Fig.90) (Fig.91)

\footnotetext{
${ }^{65}$ A tradução pode ser entendida como: Nós vestimos Bleuette.

${ }^{66} \mathrm{O}$ número inaugural de La Semaine de Suzette traz a história $O$ nascimento de Bleuette. A personagem ainda faz sucesso. Existem diversos sites dedicados à boneca, como também foi realizada uma exposição em sua homenagem, no Museu das Bonecas em Paris. COUDERC, Marie-Anne. La Semaine de Suzette: histoire de filles. Paris: CNRS Editions: 2005.
} 


\section{O Tico-Tico}

yenero mato conseguiam ners siquer etguer-se fo solo. Fintus Dumont foio primeiro homem que obteve esse liumplio.

O seu aeroplano erguet se o voon.

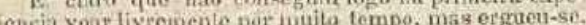

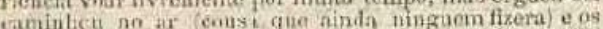
wivenotnveis reionisislis do nundo ipplaudiram, onthutirsuatos, as sir victortir.

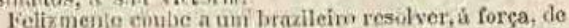
sutudo a dediencio, esse problema cm que tantos desoniм.แаตา.

DISTRACÇÓES PARA MENINAS

Muita moca por ahi perde tampo o esforecos para corlar uma simples toallinilat de papel o nío conserue Modelo A

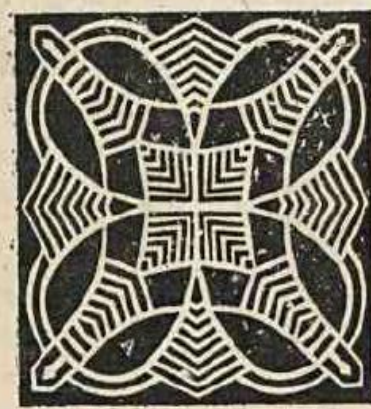

linhas rectis isas lindas cosmo qualquer cai va verlate dis nao efacil, lates lopes que scaprende quenthe cos, podendo até fazer novas combinacōes.. os modelos que aqui prblicarnus sito bomitos e faccis de re produzlr. Basta tima rolha de papel, yma Com um pouco de liabilidade está a ronda prompla. Eis a liçáo: Toma-se uma folha do papel lina, mas

Corta-se um quadride We 1 h a 15 centimetros c tobra-se om diagonal como mosira a fifura 1. Depois dobri. re mais una vez (tizura 2 e mais outra (ligura 3 .

Fica cutao tim triansulo estí natcado com um A na figura. Nesse triangulo trisenm-se linhas como meater a figura corn tam-sens pirtes es ras. Depolse soidesdo hrar e eeth promptic a tosilitia de rende.

Para recortar as figutas curvas a mellior bon camivelo;

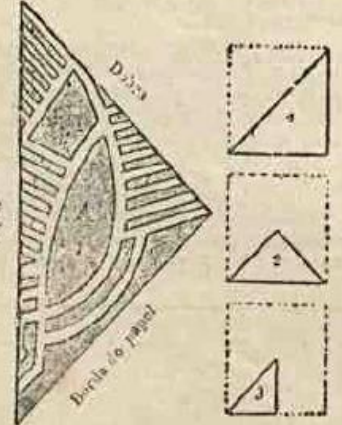
Figuras mostranio como so ciobra o Moclelo $\mathbf{B}$

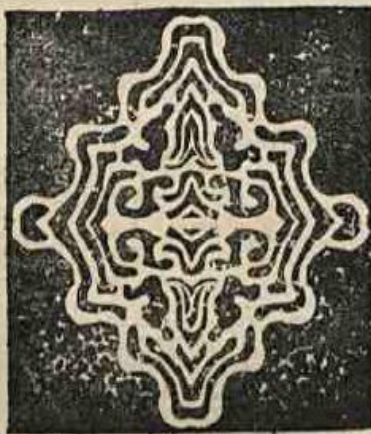

se polem fazer bem com 08 cortes rectos que comegam nas ze poutem fazer bem com os cortes
dobras ou nas bordas do papel.
E' preciso ter muito cuidado prits que a papel seja dobrado, fteando com as pontas beu certas, qute ex paris s renda ficar symelrita $c$ absolutamente regular

Depois de tado cortado e preciso abtit o payel com delleadeza pari níc risgur.

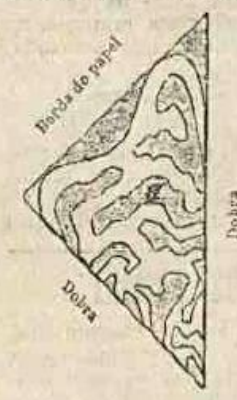
Moctolo C Dober

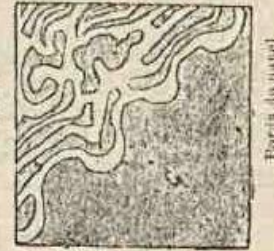

Borda do papd

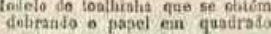

MENÇOOES HONROSAS

Vuito interessanto is o trabalho que nos enviou a nossi bóa aniguínha Maria Villela, como solugâo para o rosso concurso 125. Representa o emblema da grande paça amiga exceutado com muito gosto, tendo no alto, om lettras douradas, as palayris que cons -Nio menos valiosa a solueico quo par

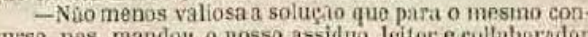
Wr um guadto leitor e cultaberados

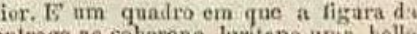
nossa Republien ontrega ao soborano luzitano uma bella coròa de louros. A scena é illuminada por um grande sol de... papel prateado em cujo centro so tem tas nalavras: 0 . Carlos 1, Rei de Portugats, solugio esacta dis problema. De grande efreito.

\section{OS PREMIOS D O TICO-TICO}

6) Tica-T*co, pagou durante a ultima semana os sc-

f Cezario Silya, residento em Pirassunumga, S. Parlo, cuncurso no 136,105 .

A Helena Lwes B, da silva, residente $\mathrm{cm}$ hecire. or interinedio do Igostinlio Bezerra, concurso n. 115, 158

Carlos Rochis tambem rosidone em Rocife, cone curso n. 113,158 .

\section{- anniversario do juguinha}

0 nosso torrivel e travesso Juquinlia agradece pomoradissimo os cumptimentos e felicitncôes que reclies for occssizo do seu anmiversano natalifer.

Buviaram-lhe ver'sos c cartoes postaes os fentis Icilores:

Antonio Drammond Fillo, Gloria Alves Teixeira. Maria A. de C. Serra, Oetavinlín Motta Fillsa, Joào Bor ges Bacearat, Rita Candiola, Syltwo A. Terseira e Gladys ledrado (Onro Preto)

Glady e seus irmãos Lulü e Fioriano enviatan maí ama saudaço on inglez o os suguntes verzos:

"Ao am iguinte querid

Juquinhit, o bravo peli

Nesse dia tico feliz.

A leitora Anfoniclta Clotilde (B turité, Cearrh, mandou us seguintes versos:

Comesplendor festival

1 Iojo risonlio fulgura

$O$ dá do tem nataif.

Oht licróe da travessura.

Por isso venho brindar

Tuas Jouras prinavera

Que desciumbrantes climeras.

Do sol ao tromulo raio

Colli mimosa florinha

Que pelo 5 de Mriti

Vou offertax-te, Juquinha!

BORO BORACICA - cura O CADCTO

Figura 86 - O Tico-Tico - 15/05/1907 - s/p. 


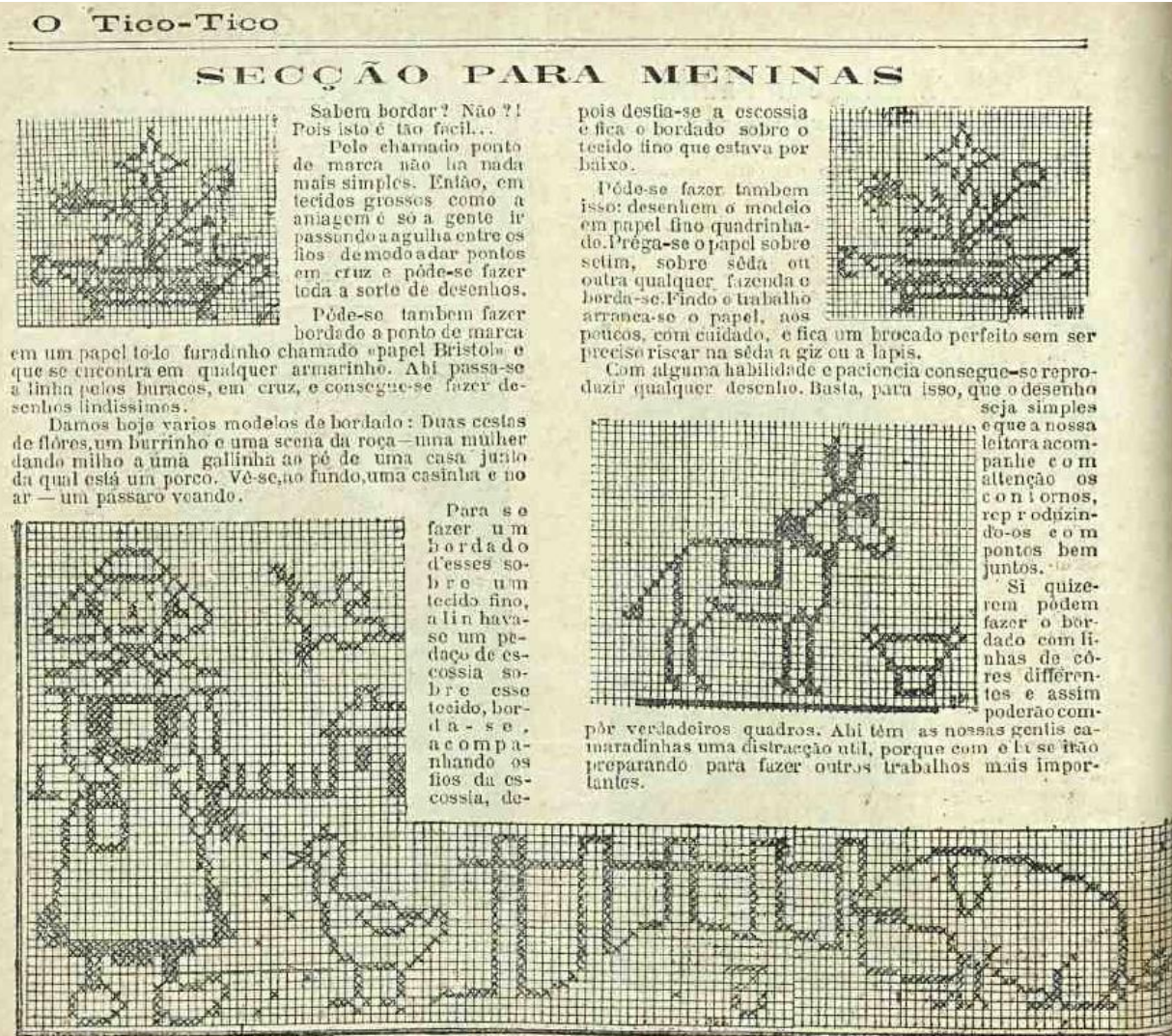

Figura 87- O Tico-Tico - 31/07/1907 - s/p.

7

O TICO-TIOC

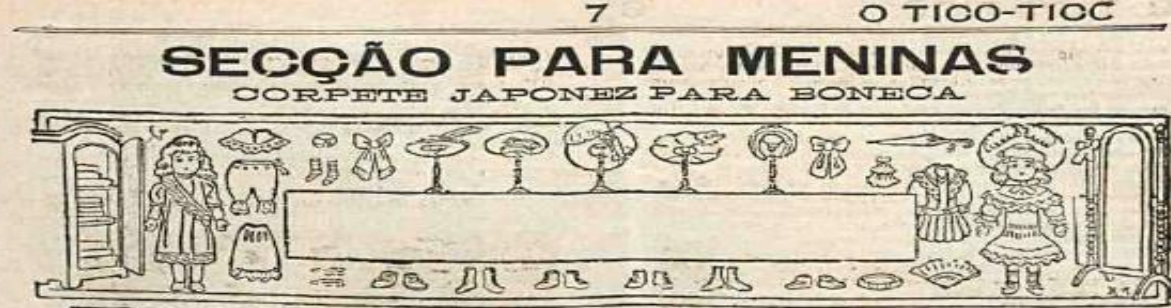

Figura 88 - O Tico-Tico - 25/01/1911- p.7

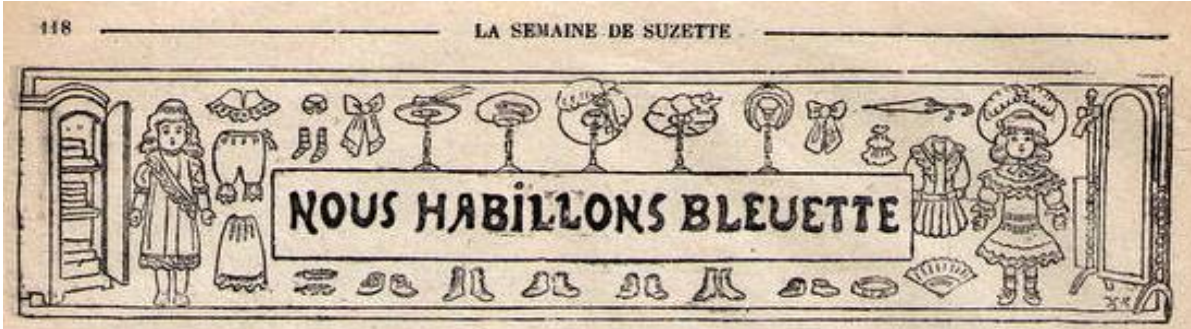

Figura 89 - La Semaine de Suzette - [s.d], p.118 


\section{SECCূÃO PARA MENINAS}

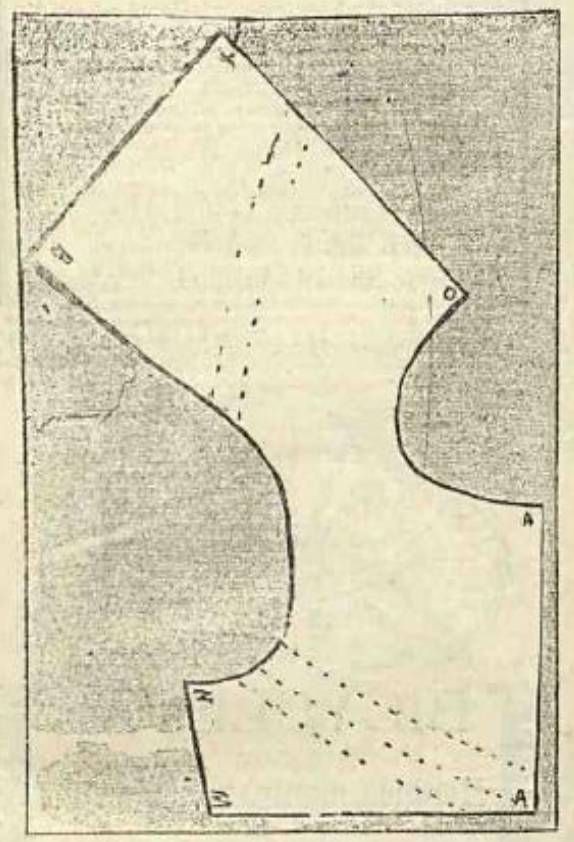

Corpo do vestiag

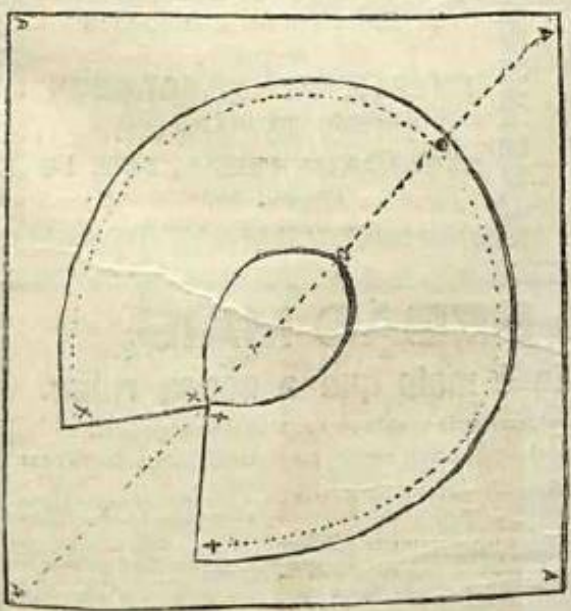

Paia

Este modelo não et de confeccto difficil. E' un vestide americano, formado por utra pesa latcira e guadrada, terminando por uma pala
Para o corpo do vestido, deyem tomar um pedago de boneca o padróno ace lare com, is de alto. Se for para desenho, so mostra metade te como

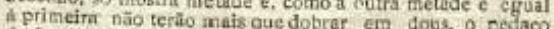
de fazenda, de maneira a ter, $0 \mathrm{~m} 10$ de largura, mas pecmpo m, Is de altura. Bem justa com o flo da fozenda, colloquem

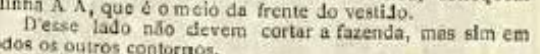
A Ilaha A O \& a pala: OX, o melo de traz, por onde parie de traz: a linha B R deve ser cosida contudo pele cava do braso, a linha gue race de $\mathrm{L}$ a $\mathrm{N}$ e coldestinad a manigas: finalmente a inha rects, que rai de $M$ a $A, b$ berra pela parte da lreate do vestido.

Vamos ver agora como se faz a pala.

Esta nío tem costura olguma e e formada por um qusDobremo quadrado eta fliti, seguindo a linha ponte-
ada.

Depois de passar o mo brem em dous, pela, doponteada 0 O. A fazenda que vém no centro da palo. ceve ser retirada pera del. xar passal o pescoco. As logar por onde se focha pala. por onde so focha a

Fiste vestico abotoa-se pela parte de traz como ac fora uma blura. O ruehe que: tossc na parte da freate a ea jucra e que cortado ean dous nos, wio ce mais As mangas sio de babados, franzidos na cava e Cortern cada manga uma tira de $0 \mathrm{~m}, \mathbb{2} \mathrm{dc}$ comprida e $0 \mathrm{~m}, 05$ de large. contando com as costieras e

Este trabalho,posto que pareca citriicil, th facilitimo. ofo tem a guc o vestido cee embellors contrias. 0 por meio de fechiss c lasos

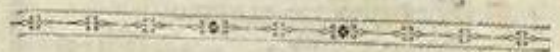

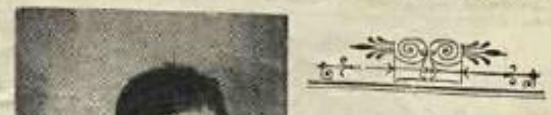

Eimitiono Erines Neira, Allho do Sr. Joäo Baptista Neiva, morador na Penha (Capital)

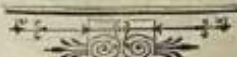

Figura 90 - O Tico-Tico - 15/11/1911 - p.17 
tas

Li sxa

\section{NOUS HABILLONS BLEUETTE \\ ROBE D'ÉTE}

Ce poll prit moditle n'ret pas tris dillicile \& faire. C'est

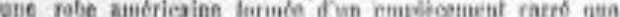

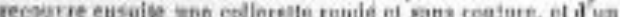

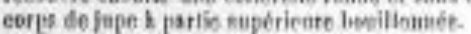

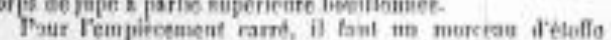

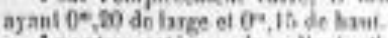

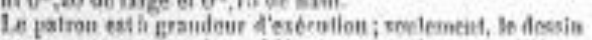

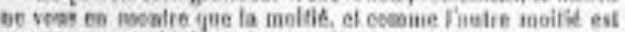
exaciessent semblable a in poemibe, vous n'antez nu'a plitr

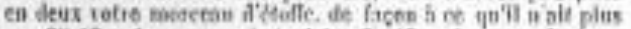

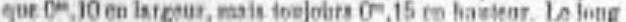

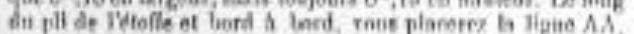

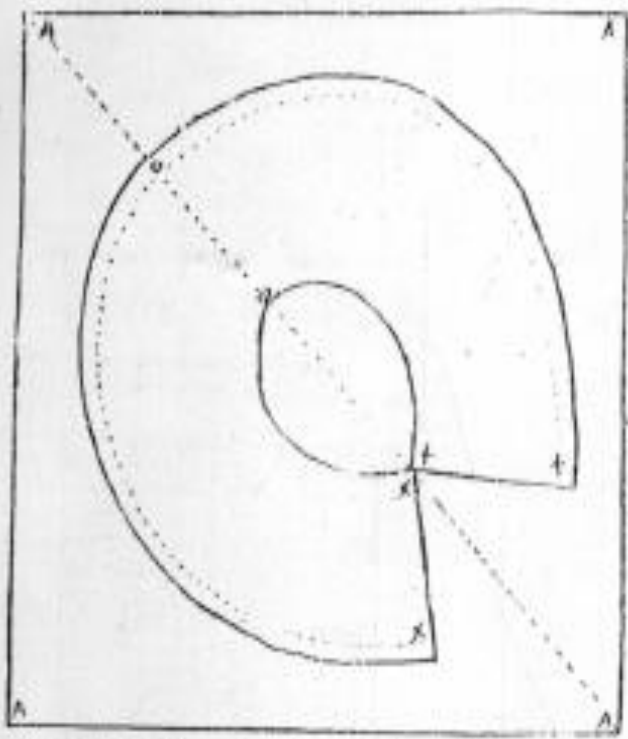

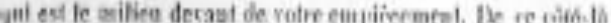

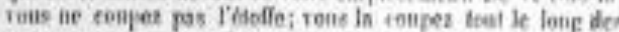

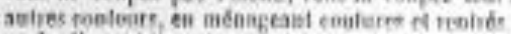

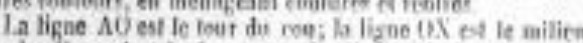

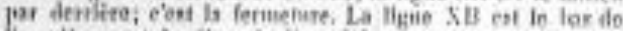

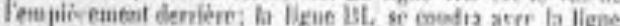

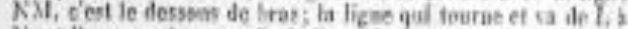

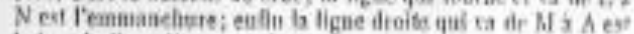

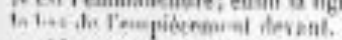

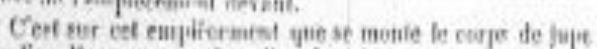

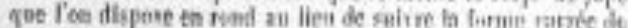

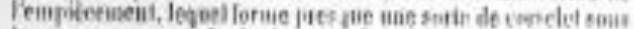

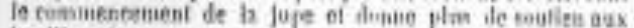
lowillowines.

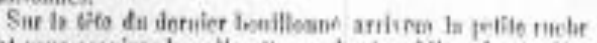

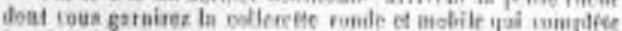

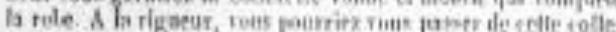

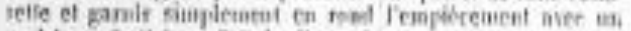

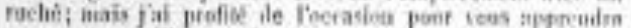

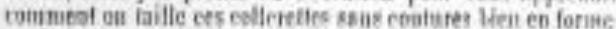

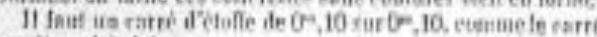
hisciti $\cos A, A A$.

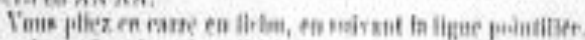

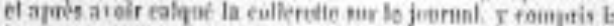

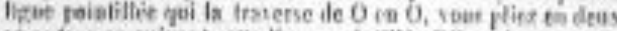

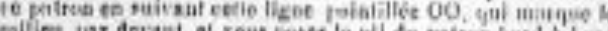

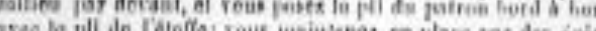

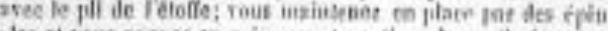

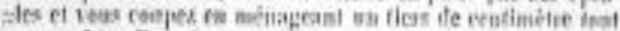

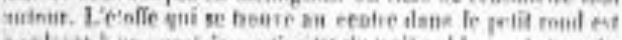

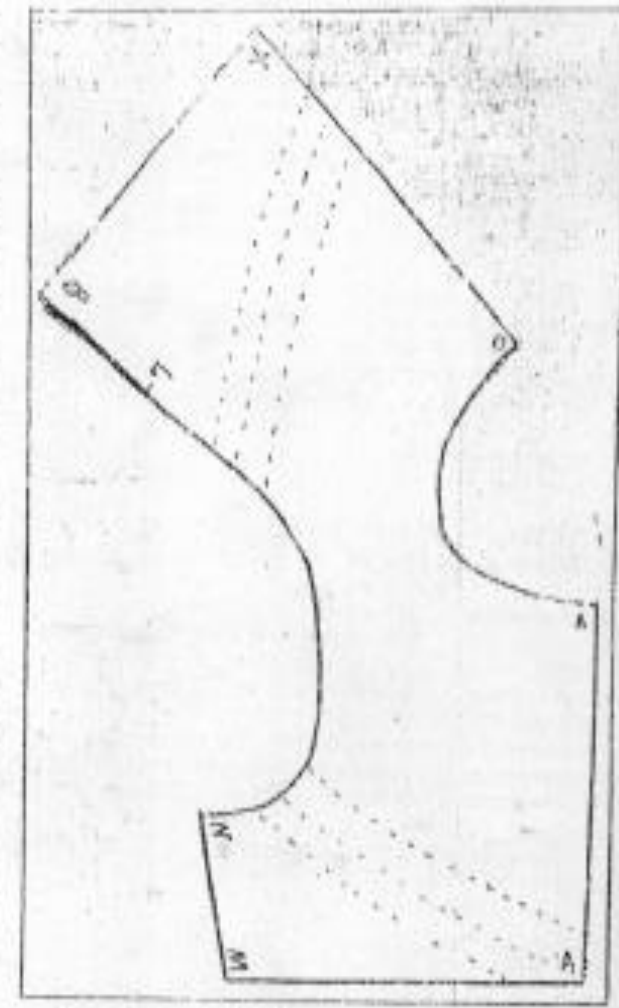

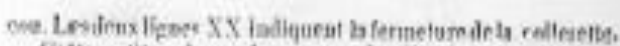

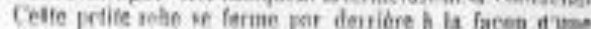

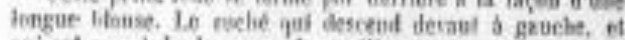

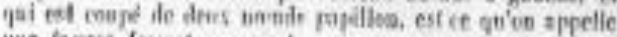
liue bave formetare: $c$ est uti sthenent.

I'osit le eorps de juje,

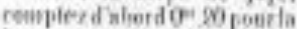
hatient, ense pour hat he cetur.

Vous cesaincited par ke

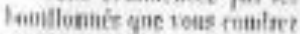

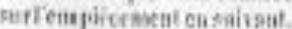

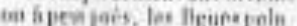
liliert aptes yuni, viens at. redices to los en lasout loatle.

la mateclic est un indant

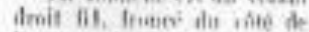
femmatolieie of eamis ait

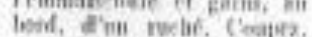

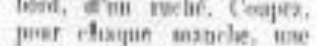

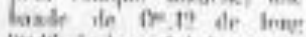

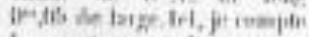
lis rentares of bo seithi

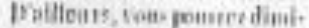

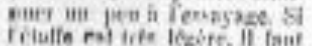

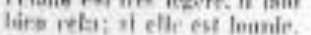
ipisec, it latiofa an pen mahs.

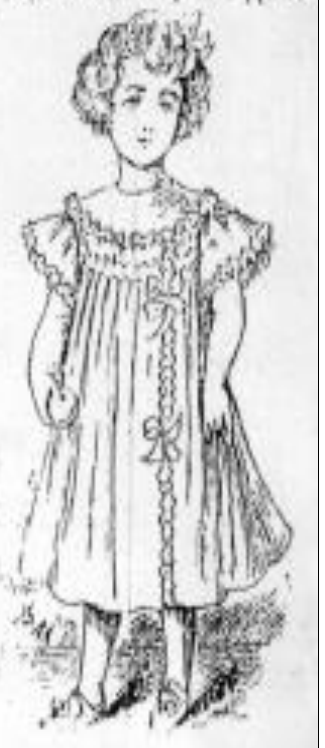

Figura 91 - La Semaine de Suzette - 11/05/1905 - s/p 
A Secção para meninas pode ser considerada um manual infantil de formação da futura dona de casa. Seus exemplares ensinam: como bordar golas, fazer pontos de crochê, costurar roupas para bonecas, criar enfeites de mesa e elaborar de presentes sem gastar muito dinheiro. Quando crescesse, a leitora que houvesse seguido os conselhos contidos em cada um de seus exemplares, estaria pronta para administrar um lar. Seguindo a perspectiva de que:

As matérias informativas voltadas para mulheres destacavam as atividades domésticas. Enquanto, para os meninos essas matérias em sua maioria enfocavam a construção de aviões de brinquedos e objetos diversos, muitas vezes envolvendo conhecimentos rudimentares nas artes da marcenaria ou serralheria, as dedicadas às mulheres - como as que compuseram a Seção para Meninas, publicada entre 1911 e 1919 -, centravam-se em trabalhos de costura, bordados e cerzidos, maneiras de arrumar a mesma de jantar e até mesmo a forma correta de dobrar um guardanapo (VERGUEIRO, Op.cit.,p.178).

Seguia-se o pressuposto de que as meninas tinham uma aptidão natural para este tipo de atividade:

As meninas, exactamente porque são em geral mais delicadas, mais elegantes e mesmo mais habilidosas do que os meninos, em tudo quanto diz respeito a trabalhos manuaes ou de agulha, têm o dever de manter certa elegancia e chic em todos os objectos com que lidam. Assim como a roupa de uma menina é mais leve e mais enfeitada do que a de um menino, assim tambem as meninas devem ter o mesmo capricho em todos os objectos do seu uso, dando-lhe sempre aspecto gentil. Isso tem, além de tudo a vantagem de lhes dar occasiçao empregarem sua actividade mostrando de quanto é capaz sua habilidade e bom gosto. E' por isso que temos ensinado aqui a fazer varias cousas de utilidade pratica, que serão de certo de certo mais lindas e preciosas confeccionadas por suas mãosinhas do que compradas feitas. Cada um desses objectos, comprado em uma loja será igual a muitas dezenas de outros que sahem das fabricas, feito por nossas leitoras será talvez mais fragil porém de certo mais gracioso e terá cunho mais pessoal, uma originalidade de bom aspecto. (SECÇÃO PARA MENINAS, 27/12/1911, p.7). 
As leitoras eram chamadas de minhas leitorazinhas, gentis leitoras, talentosas leitoras, habilidosas leitoras entre outras tantas adjetivações. Uma forma de estabelecer uma relação de proximidade com o público:

Dentre as marcas distintivas desse gênero está a linguagem que se particulariza pelo tom coloquial, de alguém próximo e que aconselha, ampara, aplaca angústias, resolve dúvidas, sugere, fazendo as avezes de uma amiga e companheira à qual se pode recorrer (LUCA, Op.cit., p.448).

Como forma de reforçar tal relação de confiança, a seção ganhou uma espécie de interlocutora: a personagem Tia Thereza. Descrita como "a bondosa senhora que entretem nossas gentis leitoras com a sua Secção para meninas", refere-se às meninas como minhas sobrinhas (O TICO-TICO, 05/02/1919, s/p.). $\mathrm{Na}$ seção Gaiola d'O Tico-Tico são feitas referências aos seus quitutes e as receitas $^{67}$. O primeiro registro de Tia Thereza na Secção para meninas foi na edição, de 8 de janeiro de 1919, quando ensinou às sobrinhas a fazer um belo porta-joias (Fig.92). A participação da personagem se restringiu ao ano de 1919.

\footnotetext{
${ }^{67}$ Nas edições de $O$ Tico-Tico n. 696 (05/02/1919) e n. 698 (19/02/1919) foi publicada a seção $O s$ doces da Tia Thereza.
} 


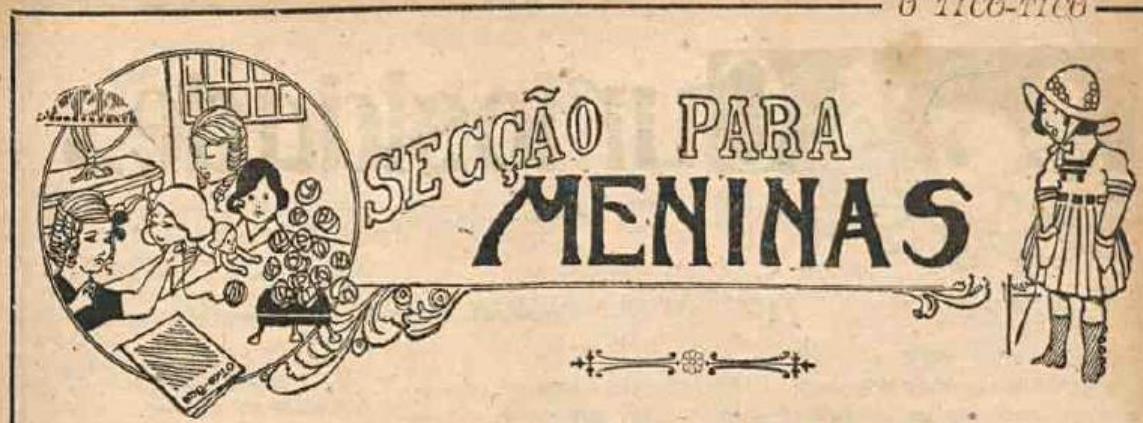

A caixa de joias o o quadro oval

Caras e prendadas leitoras desta seeção tên-nos criviado cartas pedirdo um modelo para crixa de joins e para um quadro, ou melhor uma moldura para retrato. Satisfazendo a esses podidos táo fąceis quio agradaveis para nós, apresentantos ás gentis hitoras os modelos acima referidos.

A figura I é uma linda caixa de joias de fórma hexagonal. Em relor de un lixagoun, cortado em fazenda amarello-ouro ou dourada, desenhem as nossas gentis leitoras, a certa distancia da beira da ceixa, una especie de fita ou cadeia feita com lentcjoulas dotradas. De espaço a espaço dos meandros da car deia iaşam, a rgtroz, grupos de tres hastezinlias" terminadas por tentejonlas vordes ou rubras, conforme o gosto.

O centro é occupado por uma graciosa gravura sobre seda, de dois centimetros e meio, ems redor $\mathrm{da}$ qual scintilla uma aurcola de lentejottas,

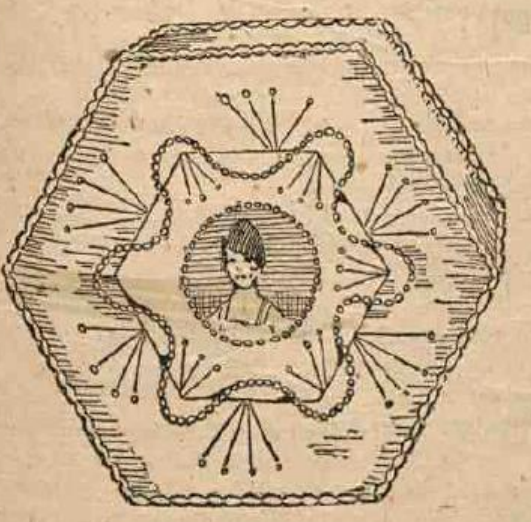

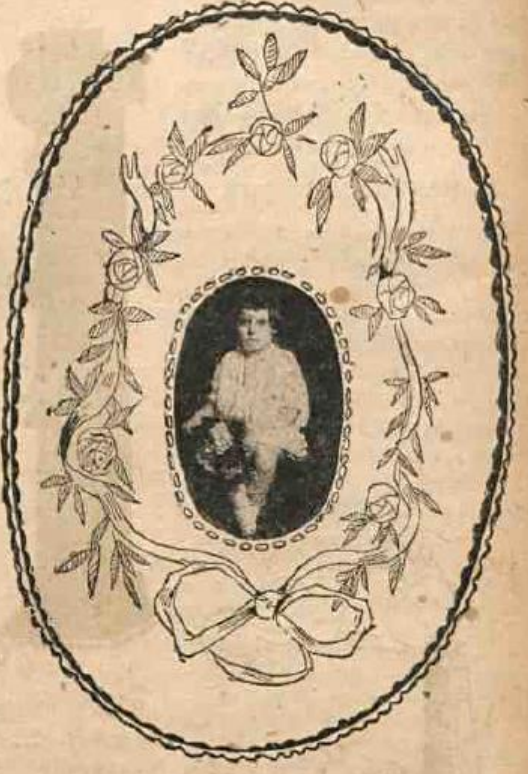

Fig. $2-0$ quadro oral

A figura 2 ó um quadro oval, estylo genuinamente a Luiz XV, com a fita e guirlandas graciosamente dispostas.

A fita é bordada com seda azul velho, de tres tons difierntes, que se combinam mtrito bem com as fitas cor de rosa empregadas para as flores da guirlanda.

As follas säo igualmente em rocócb, mas en tons verdes e as hastes em pohto de laste.

Fig. $\mathrm{I}-A$ caika de joias

TIA THEREZA

Figura 92 - O Tico-Tico - 08/01/1919 - s/p. 
O fato de $O$ Tico-Tico publicar uma seção voltada às prendas domésticas, vincula-se a perspectiva de que a imprensa feminina prima pelo caráter utilitário:

O prático, o funcional- eis uma das grandes buscas da imprensa dirigida a mulher. Almanaques e enciclopédias de artes práticas já traziam informações que facilitavam a vida cotidiana. Se a mulher cuidava da casa, e casa significava todo um saber prático, era natural que os periódicos femininos dedicassem muito espaço a conselhos, receitas, procedimentos. A possibilidade de utilização concreta de seu conteúdo sempre foi um motivo de venda. Além disso, estimulava o hábito de colecionar. A imprensa feminina tinha utilidade - e assim muitos pais deixaram que suas filhas assinassem jornais que não eram apenas literários, traziam conselhos úteis sobre economia doméstica (BUITONI, Op.cit., p.73-74).

A mulher devotada à família também deveria ter noções e conhecimentos sobre a decoração do lar. A partir do século XIX, a casa foi consagrada não apenas ao espaço de convivência da família, mais também como um o "espaço de aparência (aparência burguesa) “ (MALTA, 2014, p.10). Enquanto os quartos permaneceram como locais de privacidade, os salões se abriram aos convidados.

Em Fundo, detalhe e satisfação visual: decoração doméstica em A Estação, Malta (2011) aborda a temática do olhar decorativo por meio da análise dos exemplares, do impresso quinzenal feminino, A Estação: Jornal Ilustrado para a Família ${ }^{68}$. Versão do periódico francês La Saison, tinha o conteúdo dividido nas seguintes seções: moda, literatura, moldes para costura e decoração. $\mathrm{O}$ aspecto decorativo se fazia presente nas composições dos cenários das imagens de moda ${ }^{69}$. "Subentendia-se que toda a dama elegante deveria estar inserida em um interior tão refinado quanto as roupas" (p.94). As ilustrações deveriam servir de referência às donas de casa. Publicava-se a seção Variedade com o propósito de ensinar as normas de decoração.

A circulação dos "manuais de composição decorativa" e dos "manuais domésticos" coincidiu com os discursos que propunham a modernizacão da

\footnotetext{
${ }^{68}$ No momento de seu lançamento, o impresso tinha subtítulo: Jornal das modas parisienses, dedicado às senhoras brasileiras

${ }^{69}$ Os temas ligados à decoração poderiam ser apreciados a partir de três perspectivas: fundo, detalhe e satisfação visual. A decoração como fundo era o cenário no qual as damas mostravam seus vestidos. Poderia ser no toillete ou na sala de visita. Na decoração em detalhe, os objetos estavam inseridos nas páginas junto às sugestões de trabalhos manuais e vestuário. As senhoras eram encorajadas a bordar almofadas, fazer a forração de cadeiras e a costurar cortinas. No contexto da satisfação visual, o aspecto decorativo estava presente na ornamentação das páginas, nos desenhos de cenas domésticas e nas situações familiares que ilustravam as seções dedicadas à literatura. MALTA, M.. Fundo, detalhe e satisfação visual: decoração doméstica em A Estação. In: KNAUSS, P.; ; OLIVEIRA, C de.; VELLOSO, M.P.(Org.).Revistas Ilustradas: modos de ler e ver no Segundo Reinado. Rio de Janeiro: MAUAD X; FAPERJ, 2011.p.94-102.
} 
sociedade brasileira. (Id., Op.cit.,p.14). No tocante à família ter se tornado um dos esteios da nação, tornava-se imperativo que o lar estivesse à altura desta missão. "No geral esses livros tratavam de aconselhar as donas de casa a organizarem seus lares e a convencerem-nas da responsabilidade do papel de mãe e esposa na formação do caráter e da saúde da nação (...)" (Loc.cit) ${ }^{70}$.

Embora o educador José Veríssimo (Op.cit.) considerasse os trabalhos manuais uma inutilidade, eles permaneceram no currículo escolar e eram compreendidos como recursos importantes na formação da futuras mães e esposas (LOURO, Op.cit.). Como demonstra Schueler (2010), a reforma do ensino primário do estado do Rio de Janeiro, já no período republicano, manteve as distinções disciplinares por sexo. O Decreto Lei $n^{\circ} .37$, de 23 de dezembro de 1897, regulamentado posteriormente pelo Decreto n. 588 de 25 de janeiro de 1900, instituiu a seguinte estrutura curricular:

Currículo dos meninos: português, instrução moral e cívica, aritmética, metrologia, geografia, corografia do Brasil e noções de história pátria, lições de coisas, noções concretas de ciências físicas e naturais, caligrafia em desenho, música e ginástica;

Currículo das meninas: trabalhos de agulha, corte de roupa branca, noções de economia doméstica.

A diferenciação do ensino pelo gênero e a perspectiva de que a formação dos meninos era mais intelectualizada do que a instrução oferecida às meninas, fazia-se presente nas edições da Secção para meninas:

\section{UM COMPASSO DE PAPEL}

Já no outro dia, em um numero passado, ensinamos a arranjar com papel cartão apparelhos capazes de substituir um esquadro, uma regra, etc. Muitas vezes para fazer trabalhos de agulha ou brinquedos d'esses que temos ensinado a fazer, têm-se a necessidade de esquadros, réguas, compassos... Ora, raramente uma menina possue d'esses objectos, por isso é forçada a pedilos emprestados e, sem querer quebral-os. O melhor é não pedir (07/04/1909, p.19).

\footnotetext{
${ }^{70}$ Estes manuais também salientavam a importância do lar como um lugar de aconchego e descanso do marido. Caso a esposa o mantivesse organizado, o esposo não teria motivos para frequentar outros lugares para se distrair. MALTA, Marize. O olhar decorativo: ambientes domésticos em fins do século XIX no Rio de Janeiro. d. Rio de Janeiro: MAUAD X; FAPERJ, 2014.
} 


\section{COMO SE DECALCA UM DESENHO}

As meninas lutam geralmente com grande difficuldade para fazer certos trabalhos porque não dispõem dos instrumentos necessários. Os meninos têm instrumentos de desenho, apparelhos especiaes, tudo lhes é fornecido para facilitar os seus estudos, que em geral são mais serios e importantes, do que os das meninas. Mas o que acontece é que as nossas amiguinhas, não dispondo dos recursos necessarios, ficam muitas vezes privadas de rabiscar certos trabalhos delicados, que dependem,principalmente, de paciencia, cuidado e zelo, qualidades mais faceis de encontrar nas meninas, do que nos meninos (05/05/1909, p.16).

As leitoras não possuíam um compasso, objeto que não fazia parte de sua rotina escolar porque elas não tinham aulas de geometria. Um um sinal de diferenciação na formação educacional.

As meninas não tinham compasso, mas deveriam ter um avental. "Toda a menina que se preza deve possuir um avental, pois seria censurável trabalhar nos arranjos de casa com o vestido com que vai sahir, sem abrigal-o contra a poeira e nodoas" (p.5). Este conselho ou advertência, intitulado Como fazer um avental, foi publicado na Secção para meninas, de 19 de abril de 1911. O avental é descrito como um item indispensável às pequenas leitoras que pretendem aprender sobre o mundo dos trabalhos manuais e das prendas domésticas.

Os discursos presentes em Secção para meninas classificam o ócio, como algo a ser combatido. As meninas são aconselhadas a ajudar às mães nos afazeres domésticos e encontrar seu espaço de atuação na casa. A moral burguesa defende que a mulher seja um indivíduo útil (CAMPOS, Op.cit):

\section{O "POUSA-PRATOS"}

Carinhosas sobrinhas:

Estamos em época de férias collegiaes, mas isso sem duvida não quer dizer que as minhas queridas leitoras desprezem em absoluto os trabalhos. Não; até para mostrar á mamãi e ao papai a habilidade que possuem, devem reservar algum tempo das horas de férias na confecção de trabalhos. E quantos trabalhos não poderão fazer minhas as caras sobrinhas? Desde a pequenina flor de papel de seda, do paninho de crochet original, até o vestido da moda para a boneca ou mesmo para os irmãosinhos pequenos. Aproveitar o tempo, empregando-o na confecção de um trabalho ou de uma acção util, é a melhor prova que poderão dar as minhas caras sobrinhas de que serão amanhã, as irmãs ou esposas cuidadosas, completas $(19 / 02 / 1919$, p.19). 
Na edição de 29 de dezembro de 1909, a temática da formação utilitária feminina é citada em Como as meninas se podem tornar úteis numa casa:

A's vezes, as meninas tem perdido dias inteiros, em diversões sem importância, para passar o tempo e, no entanto, existem em casa certos serviços leves, nos quaes poderiam empregar esse tempo com maior vantagem, acostumando-se a serem donas de casa. Quando não houver um irmão pequenino para cuidar e cobrir de carinhos, ou uma boneca para vestir, as meninas poderão divertir-se dobrando a roupa, limpando os torneados dos moveis, emfim, fazendo esses pequenos serviços que muito ajudam, despertando ao mesmo tempo a vontade de trabalhar, pois uma moça, por mais rica que seja, será muito inferior á pobresinha da rua que saiba corer o seu vestido, cuidar de suas roupas e dos arranjos da casa. A ociosidade é mãi de todos os vicios, diz o dictado, e as meninas devem evital-a quanto puderem. Foi devido a ociosidade que a «mãi miséria» entrou na casa d'aquelles filhos de um camponez, o qual ao vêr chegado o seu ultimo momento, chamou para junto de si, os que ia abandonar para sempre e recommendou-Ihcs que trabalhassem. Tendo expirado seu pai, esqueceram-se da sua advertencia, e, pouco depois, lá ia tudo pela água abaixo: casa creação, horta, emfim, uma calamidade. Os inglezes têm um dictado muito certo: «O tempo ê dinheiro» e aquelles que o perdem acabam cahindo na miséria. O único remédio para sanar essas desgraças é o trabalho e quem não se acostumar desde pequeno a trabalhar, nunca mais se entregará a elle com prazer. A's meninas cabem o crochet, a marca, os bordados, emfim, todos os paramentos do seu vestuário, que muitas vezes deixam de possuir, por não poderem comprar. E, no entanto, com grande facilidade os poderiam fazer. Antigamente não se procurava ver se uma moça era feia ou bonita, mas sim, se era prendada, se era uma boa dona de casa. E as meninas podem vêr em quadros e photographias que, muitas vezes, uma camponeza rude, sem ter uma idéa do que fosse uma avenida, um automóvel, sabia vestir-se e confeccionar os seus vestuários, sabia cuidar dos principaes serviços de uma casa, que, quasi sempre em nossos dias, e com os nossos empregados, deixam muito a desejar. Trabalhem, pois, e verão como se tornarão queridas de suas mamais $\mathrm{c}$ de todos aquelles que as conhecerem (p.6). 
Em tom de aconselhamento, o texto reforça o estereótipo da função social da mulher de casar e cuidar do lar. As meninas são incitadas a utilizar seu tempo livre para treinarem ser donas de casa, ao invés de aprimorarem os estudos ou brincarem ao ar livre. Deixar-se tomar pela ociosidade poderia resultar em um futuro marcado solteirice ou um mau casamento. Ser prendada era um prérequisito importante para um homem escolher sua futura esposa.

Para além de aprender a postar uma bela mesa ou a bordar um pano de mesa, a Secção para meninas também indica que o brincar de boneca, não significa apenas diversão, mais também em uma espécie de treinamento para ser mãe. Segundo Beauvoir (Op.cit.), por meio destas brincadeiras a menina aprende que o papel social da mulher está associado à maternidade:

\begin{abstract}
A menina constata que o cuidado das crianças cabe à mãe, é o que lhe ensinam; os relatos ouvidos, livros lidos, toda sua pequena experiência o confirma; encorajam-na a encantar-se com essas riquezas futuras, dão-lhe bonecas para que desde logo um aspecto tangível. Sua "vocação" é imperiosamente ditada a ela (p.378).
\end{abstract}

A boneca triste narra o sentimento de abandono de um brinquedo, em virtude da indiferença de sua dona. Como qualquer criança, elas também possuem sentimentos (Fig.93). Deveriam ser bem alimentada, vestidas e acalentadas. Histórias como Uma boneca que se revolta trazem situações nas quais as meninas são punidas e alvo de ações vingativas, por parte de bonecas maltratadas. (Fig.94) (Fig.95). Cuidar bem de uma boneca já era visto como um sinal de preparação para uma futura maternidade. 


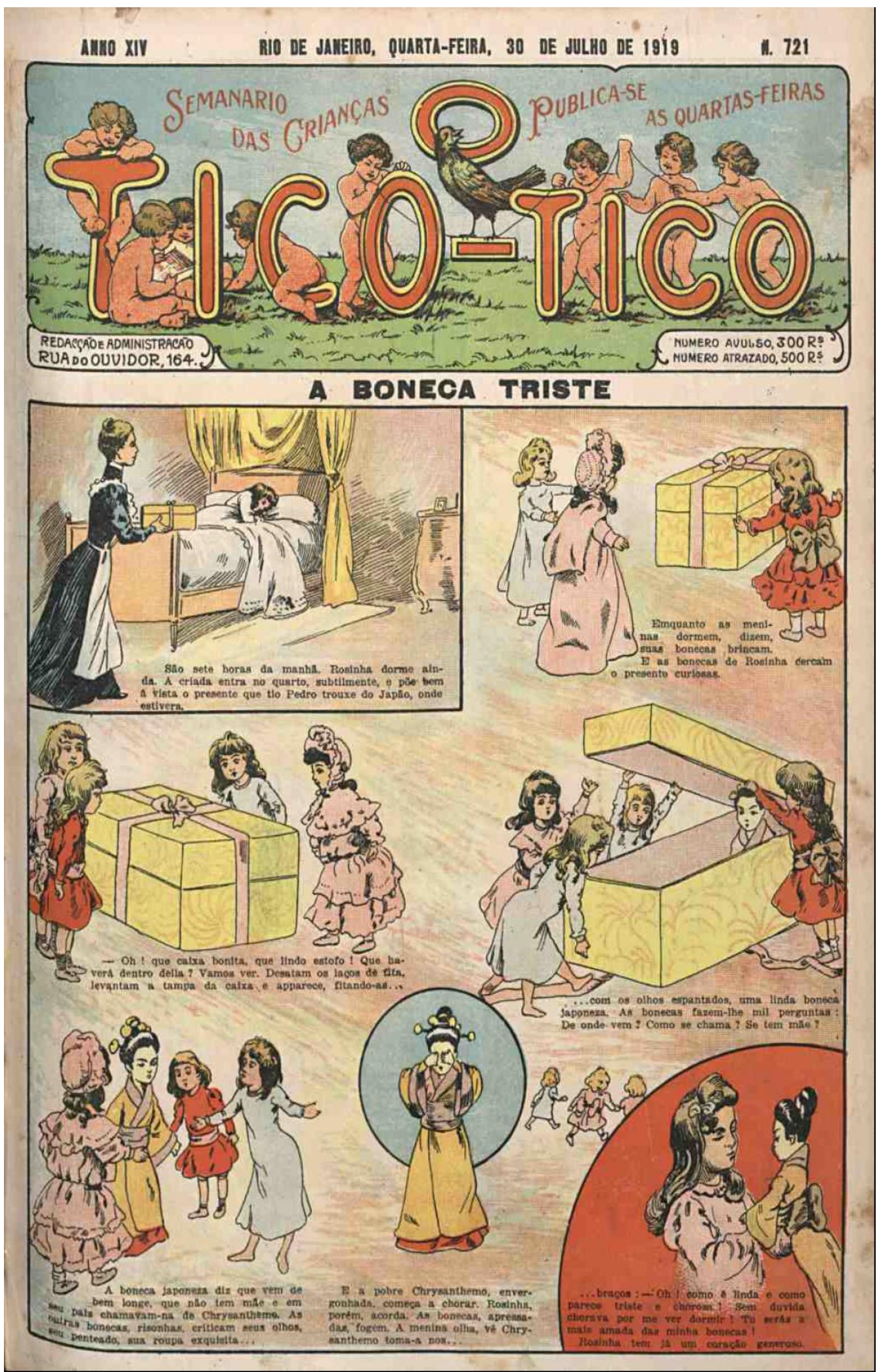

Figura 93- O Tico-Tico-30/07/1919-p.1 


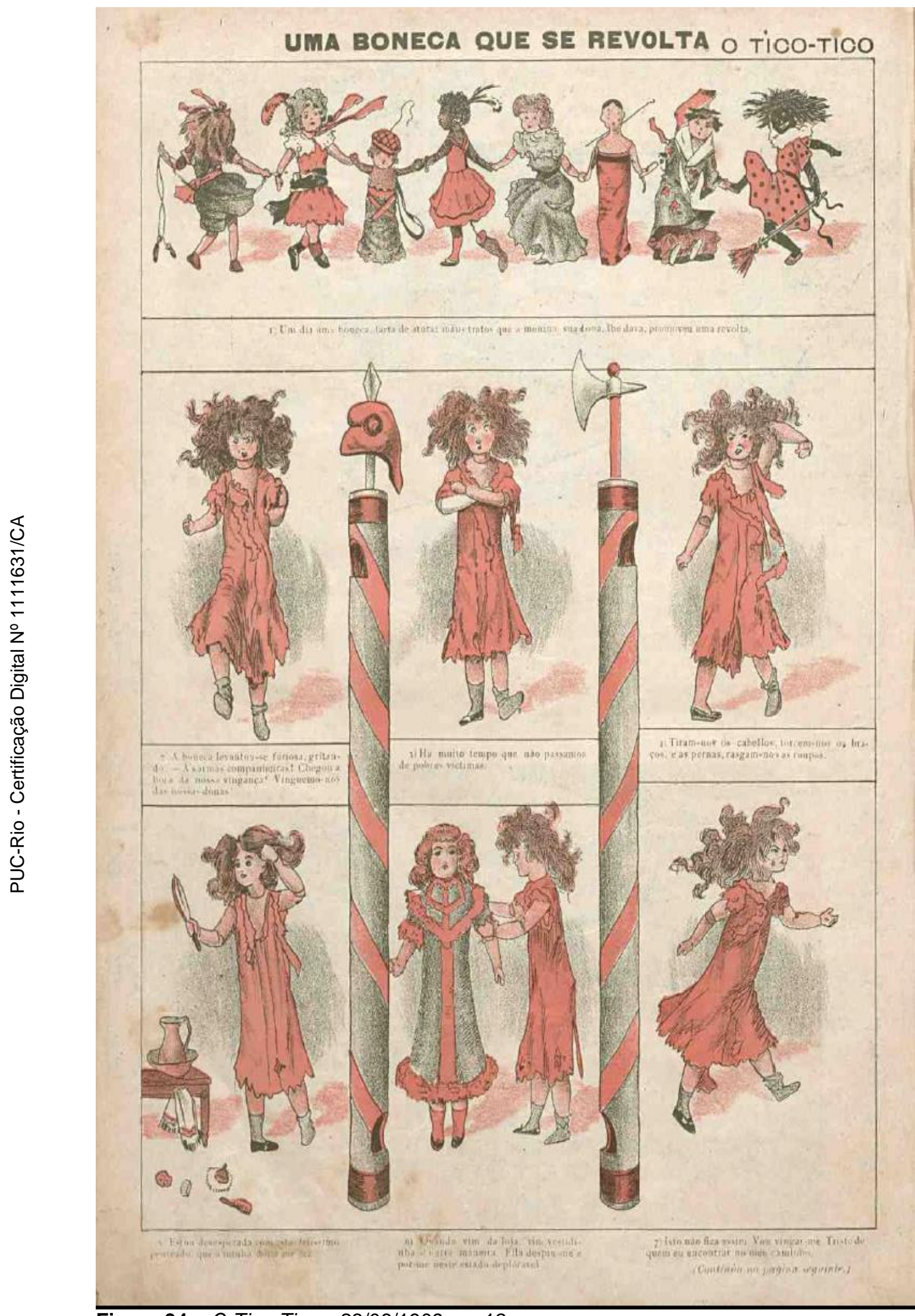

Figura 94 - O Tico-Tico-23/06/1909-p.12 


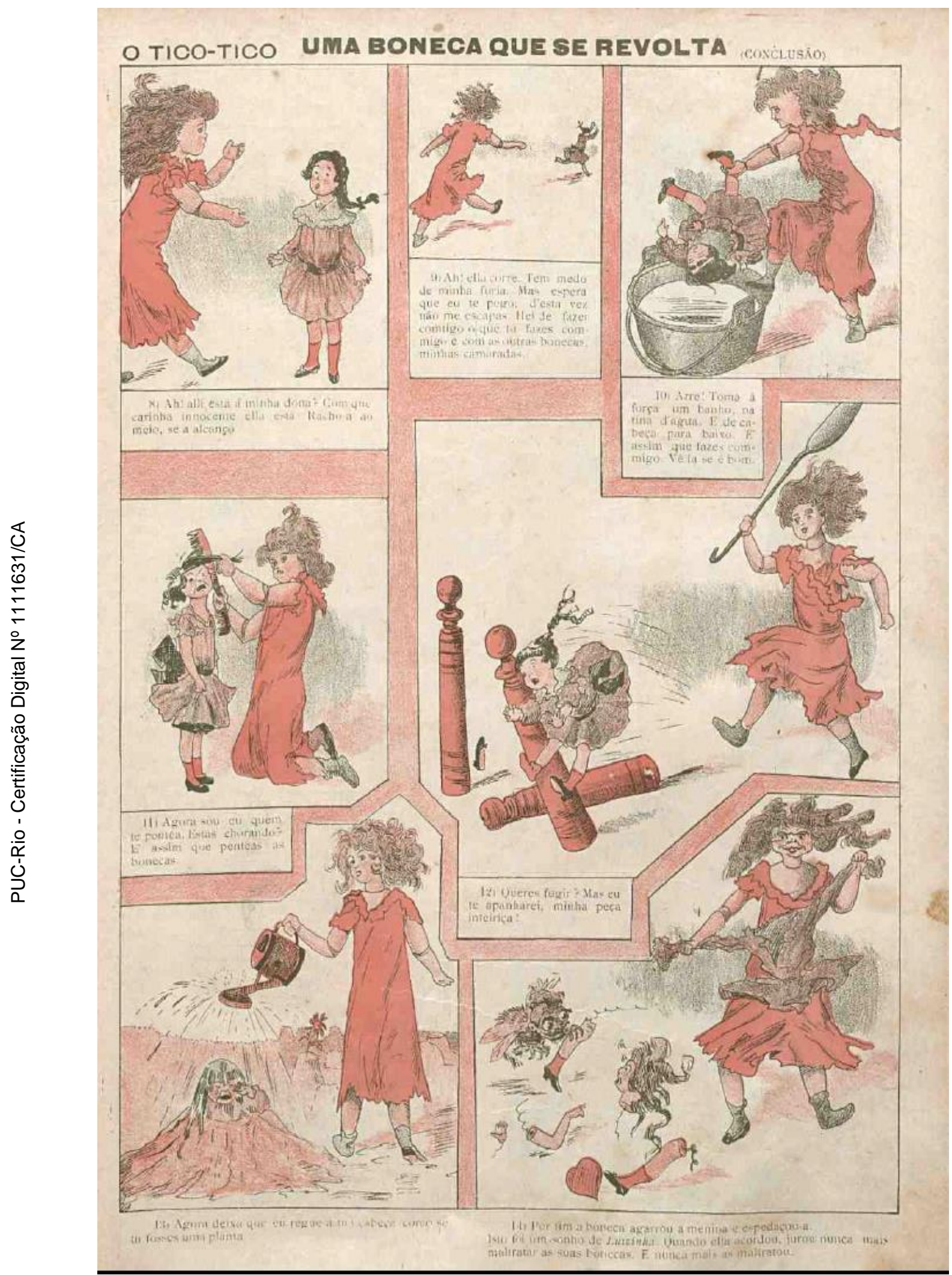

Figura 95 - O Tico-Tico - 23/06/1909-p.13 
O discurso da utilidade feminina era um modo de superar a representação da mulher patriarcal, descrita de forma caricata, como alguém ocioso que passava os dias em casa sem fazer nada. Considerava-se “(...) ultrapassada, aquela que havia nascido e crescido sob a égide da Monarquia, do analfabetismo, da escravidão, do latifúndio, particularidades que os jornalistas esforçavam-se por desqualificar" (CAMPOS, Op.cit., p.121). Queria-se decretar o fim da mulher, descrita nos relatos de viajantes estrangeiros que chegaram ao país:

A senhora de engenho quase nunca aparecia aos estranhos, é verdade; era entrar homem estranho em casa e ouvia-se logo o ruge-ruge de saias de mulher fugindo, o barulho de moças de chinelo sem meia se escondendo pelos quartos ou subindo as escadas. O que se dava tanto nos sobrados das cidades como nos engenhos (FREYRE, 2003, p.4).

Era preciso difundir a representação da mulher "útil e moralizadora" que poderia "ajudar a reformar o mundo social que se corrompia" (CAMPOS, Op.cit.,p.121). Em Pequeninas Costureiras, o pai criou um concurso para saber qual de suas filhas conseguiria fazer a melhor vestimenta em 15 dias. A vencedora foi a a pequena Yolanda que encontrou um destino útil à sua criação, pois tricotou uma peça para a filha da criada que estava doente (Fig. 96).

Desde a infância era preciso encontrar estratégias para que o sexo feminino identificasse a mulher moderna como um indivíduo produtivo e prendado. Como também, considerasse que trocar os chinelos e os camisolões por elegantes vestidos cinturados seria a combinação perfeita. 


\section{AS PEQUENINAS COSTUREIRAS}

O TICO-TIOO

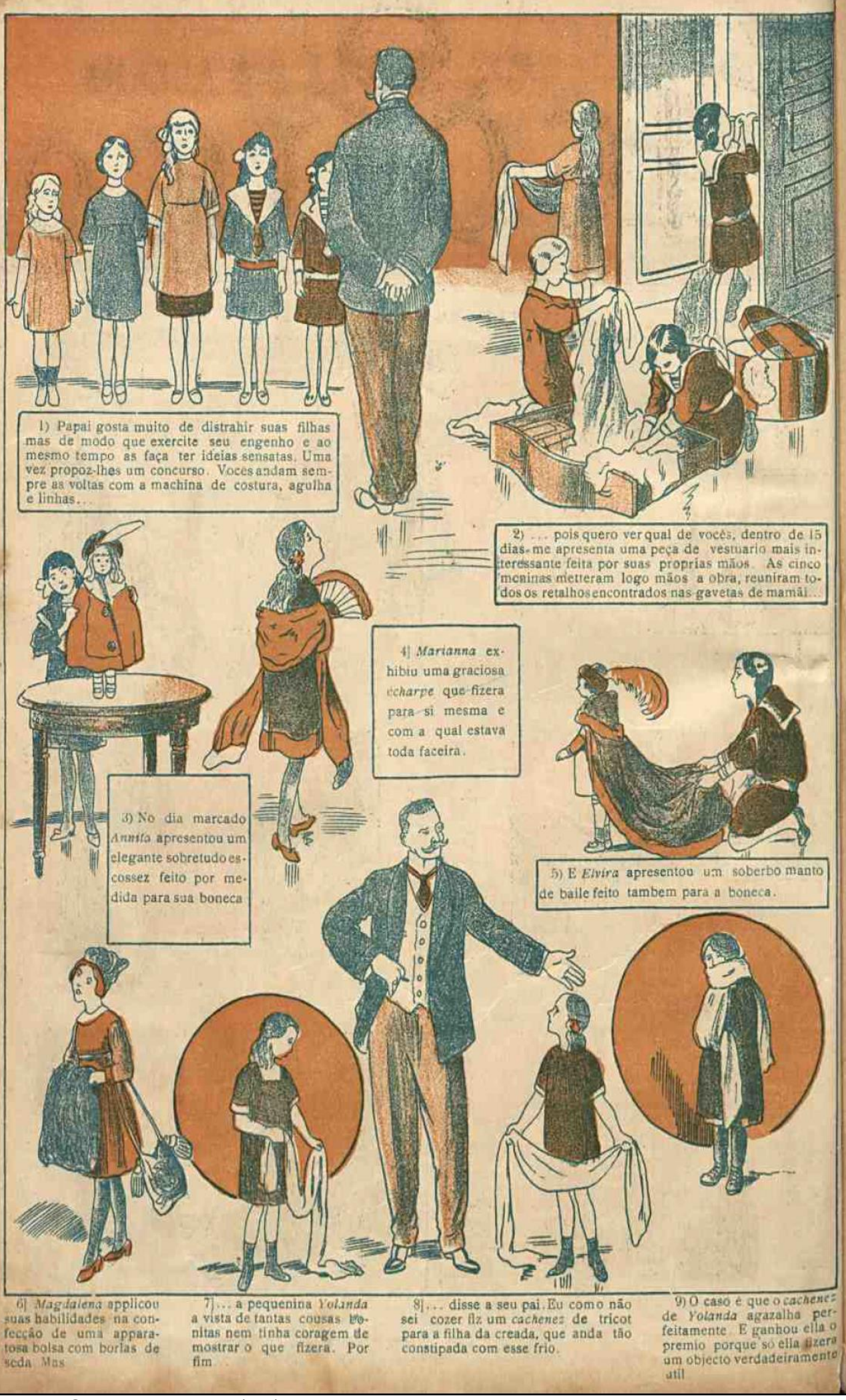

Figura 96 - O Tico-Tico - 19/06/1912-p.2 


\subsection{Leitoras na moda: meninas e mulheres elegantes}

E eu pergunto: Com que roupa? Com q roupa que eu vou? A questão famosa no refrão da música de Noel Rosa pode traduzir um dos temas de maior presença nas publicações femininas: a moda.

Para Freyre (2009) a moda significa

(...) uso, hábito ou estilo geralmente aceito, variável no tempo e resultante de um determinado gosto, ideia, capricho, ou influências do meio. Uso passageiro que regula a forma de vestir, calçar, pentear etc. Arte e técnica de vestuário. Maneira, feição. Vontade, fantasia, capricho. Ária, cantiga, modinha. Canção típica do folclore. Fenômeno social ou cultural, mais ou menos coercitivo, que consiste na periódica de estilo, e cuja vitalidade provém da necessidade de conquistar ou manter, por algum tempo, determinada posição social (p.28).

Hunt (2009) identifica que a escolha do vestuário não é algo aleatório. Em momentos da trajetória histórica, vestir-se foi considerado um um ato político. Após a Revolução Francesa (1789), os jornais de moda passaram a publicar indicações sobre quais os trajes femininos eram considerados adequados ao período da Constituição:

De acordo com o Journal de la Mode et du Goût [ Jornal da Moda e do Gosto], a 'grande dama' de 1790 veste 'cores listradas estilo nação' e a 'mulher patriota' usa tecido de cor azul-rei com chapéu de feltro negro, fita do chapéu e roseta tricolores (p.21).

Segundo Souza (1987), a moda é um elemento de integração e, ao mesmo tempo, de distinção social. Com destaque para as últimas décadas do século XIX, tornou-se comum os impressos femininos brasileiros dedicarem páginas à reprodução de modelos publicados nas revistas francesas. Os discursos proferidos pelas elites republicanas, incluíam um novo modo de se portar e de se vestir. Para fazer parte desse espetáculo era preciso saber escolher o figurino correto:

Com efeito, a moda é um dos instrumentos mais poderosos de integração e desempenha uma função niveladora importante, ao permitir que o indivíduo se confunda com o grupo e desapareça num todo maior que lhe de apoio e segurança. E com as modas vigentes são sempre as da classe dominante, os grupos mais próximos estão a cada momento, identificando-se aos imediatamente superiores através da imitação das vestimentas (p. 130). 
Priore (Op.cit.) ressalta o caráter simbólico e diferenciador da moda. Representa um código de aproximação ou de afastamento entre determinados grupos que compõem uma mesma sociedade:

\begin{abstract}
Ato de diferenciação, vestir-se era, em essência, um ato de significação. Manifestava, em termos simbólicos ou por convenção, ao mesmo tempo ou separadamente, uma essência, uma tradição, um apanágio, uma herança, uma casta, uma linguagem, uma proveniência social e geográfica, um papel econômico. Em resumo, a roupa tornava visíveis as hierarquias, segundo um código garantido e perenizado pela sociedade. $\mathrm{Na}$ elaboração da aparência, as classes dominantes procuravam, desde sempre, distanciar-se das classes populares. Não só pelo uso de tecidos e materiais prestigiosos, mas pela falta de conforto que levaria a um comportamento menos hierático (p.205-206).
\end{abstract}

As roupas podem ser consideradas uma espécie de protocolo de identificação. Junto à penteados bem feitos, a escolha da maquiagem e o uso determinados acessórios, constroem a linguagem da moda.

A imprensa feminina tinha a missão de ser a porta-voz do modelo ideal de vestimenta das mulheres brasileiras. Ao publicarem os últimos lançamentos da moda parisiense, esperava-se que os trajes fossem reproduzidos pelas modistas nacionais. Observa- se que o uso de roupas semelhantes, não significava ser vista como uma igual. Detalhes como o tipo de tecido e os bordados aplicados funcionavam como elementos de distinção.

Estar bem vestida também relacionava ao fato da mulher, principalmente as mais ricas, começarem a frequentar com mais constância os espaços fora do lar. As reformas urbanas ocorridas na cidade do Rio de Janeiro criaram novos espaços e logradouros que também passaram a ser ocupados pelo sexo feminino:

(...) o complexo processo de apropriação dos espaços públicos empreendido pelas mulheres nesse período. Tal assimilação caracterizou-se como um movimento essencialmente contraditório, porque ao mesmo tempo em que os personagens femininos ocuparam inexoravelmente lugares antes inexistentes ou restritos aos homens, amiudaram-se os discursos oriundos de variados campos de saber propugnando justamente a restrição desse sexo ao império do lar (CAMPOS, Op.ci., p.82).

Observa-se que estas mudanças coincidiram com a ampliação das colunas sociais nos jornais e nas revistas. Além de reportar os eventos frequentados pelas elites, também descreviam os trajes usados pelas senhoras e as senhoritas elegantes. Publicada no periódico Gazeta de Notícias, a coluna Binóculo escrita 
por Conde de Affonso Celso, analisa detalhadamente os tecidos, as rendas e os cortes usados pelas damas da sociedade carioca:

Vimos hontem: Mme. Nioméa Segom, trajando lindo, encantador, elegantíssimo vestido em fazenda de riscas azul e preta composto de saia pregueada dos lados, num folho que parte das costuras do avental, e de um casaco meio justo, com golla de seda, acima do folho a saia tem um largo bordado feito com sotache, o casaco é bordado dos lados no genero da saia (...) $(18 / 01 / 1910, \mathrm{p} .3)$.

Em O Tico-Tico a temática da moda estava presente em múltiplas seções.

Como pode ser observado na tabela a seguir:

Tabela 3

\begin{tabular}{|c|c|}
\hline Seções & Número de Edições \\
\hline A moda & 1 \\
\hline A moda infantil & 11 \\
\hline A moda para nossas leitoras & 1 \\
\hline A moda para nossos pequenos leitores & 1 \\
\hline As nossas modas & 1 \\
\hline Figurino para creanças & 1 \\
\hline Figurino para meninas & 1 \\
\hline Figurinos infantis & 1 \\
\hline Figurinos para nossas leitoras & 6 \\
\hline Figurinos para nossos leitores & 2 \\
\hline Moda infantil & 5 \\
\hline Modas do Tico-Tico & 1 \\
\hline Modas infantis & 6 \\
\hline Modas para crianças e senhoritas & 1 \\
\hline Modas para leitores de O Tico-Tico & 1 \\
\hline Modas para nossas leitoras & 13 \\
\hline Modelo da semana & 10 \\
\hline Modelos para nossas leitoras & 1 \\
\hline Para nossas leitoras & 33 \\
\hline Secção para nossas leitoras & 2 \\
\hline Vestidos para meninas e senhoritas & 1 \\
\hline
\end{tabular}

Fonte: ACERVO REVISTA O TICO-TICO

Para além da pluralidade de seções, a faixa etária a quem se destinavam também era ampla. Foram identificadas edições voltadas às crianças de 1 a quatro anos (FIGURINOS PARA NOSSOS LEITORES, 15/12/1915, s/p), meninas e 
senhoritas dos 6 aos 15 anos de idade (FIGURINOS PARA NOSSAS LEITORAS, 01/12/1915, s/p.) e mulheres adultas. O fato de estes espaços priorizarem o vestuário infantil e feminino reforça-se a perspectiva de que - mães, irmãs ou outra responsável pelos pequenos e pequenas - eram consumidoras deste tipo de conteúdo (Fig.97) (Fig.98)(Fig.99) (Fig.100) (Fig.101) ( Fig.102).

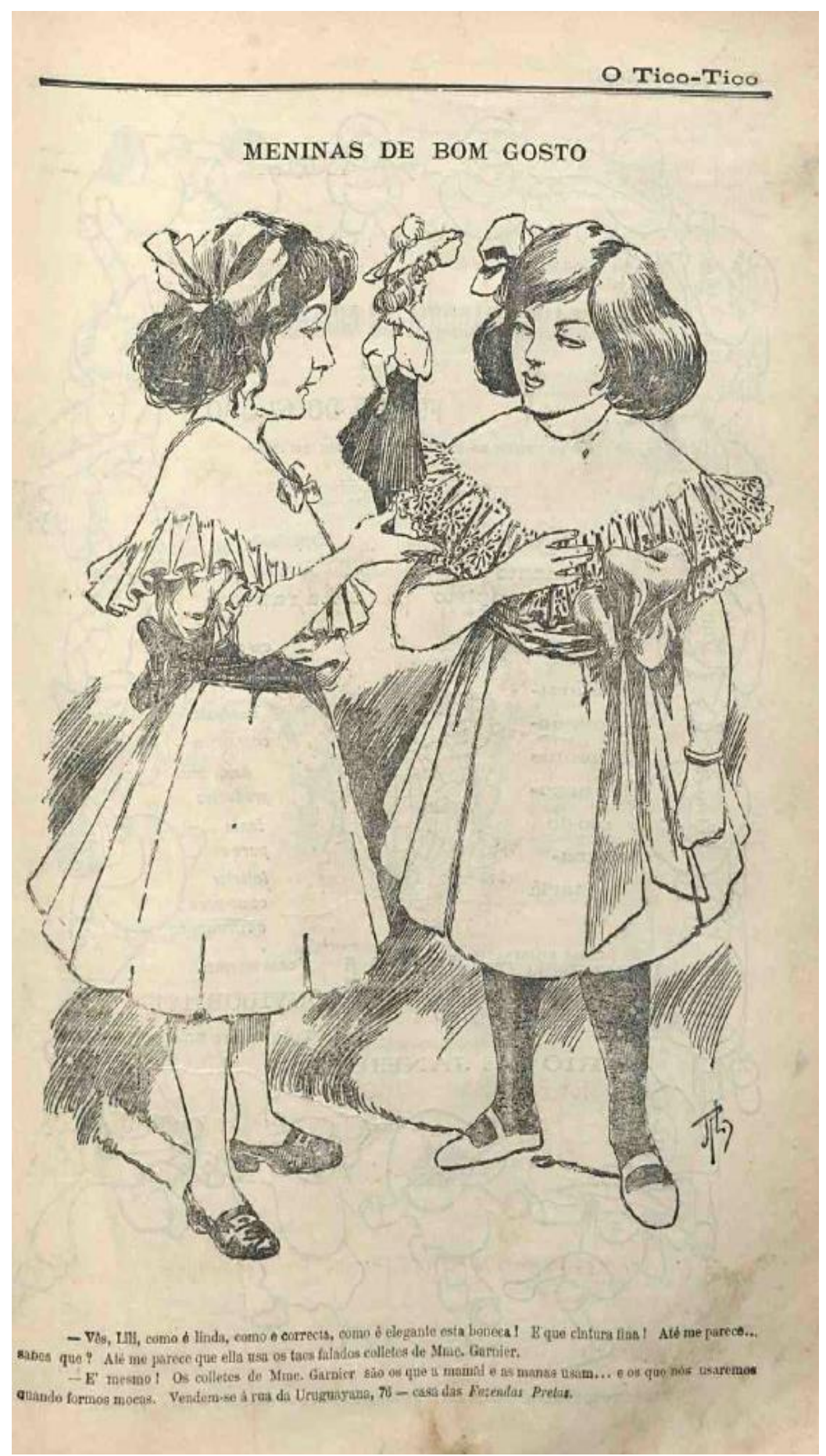

Figura 97 - O Tico-Tico-07/02/1906 - s/p 


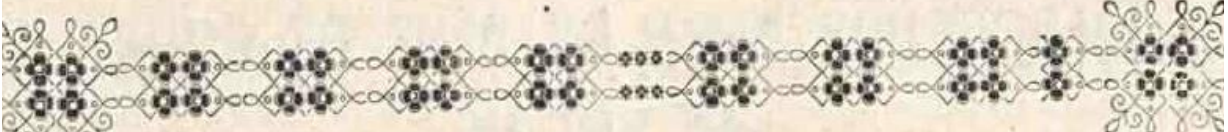

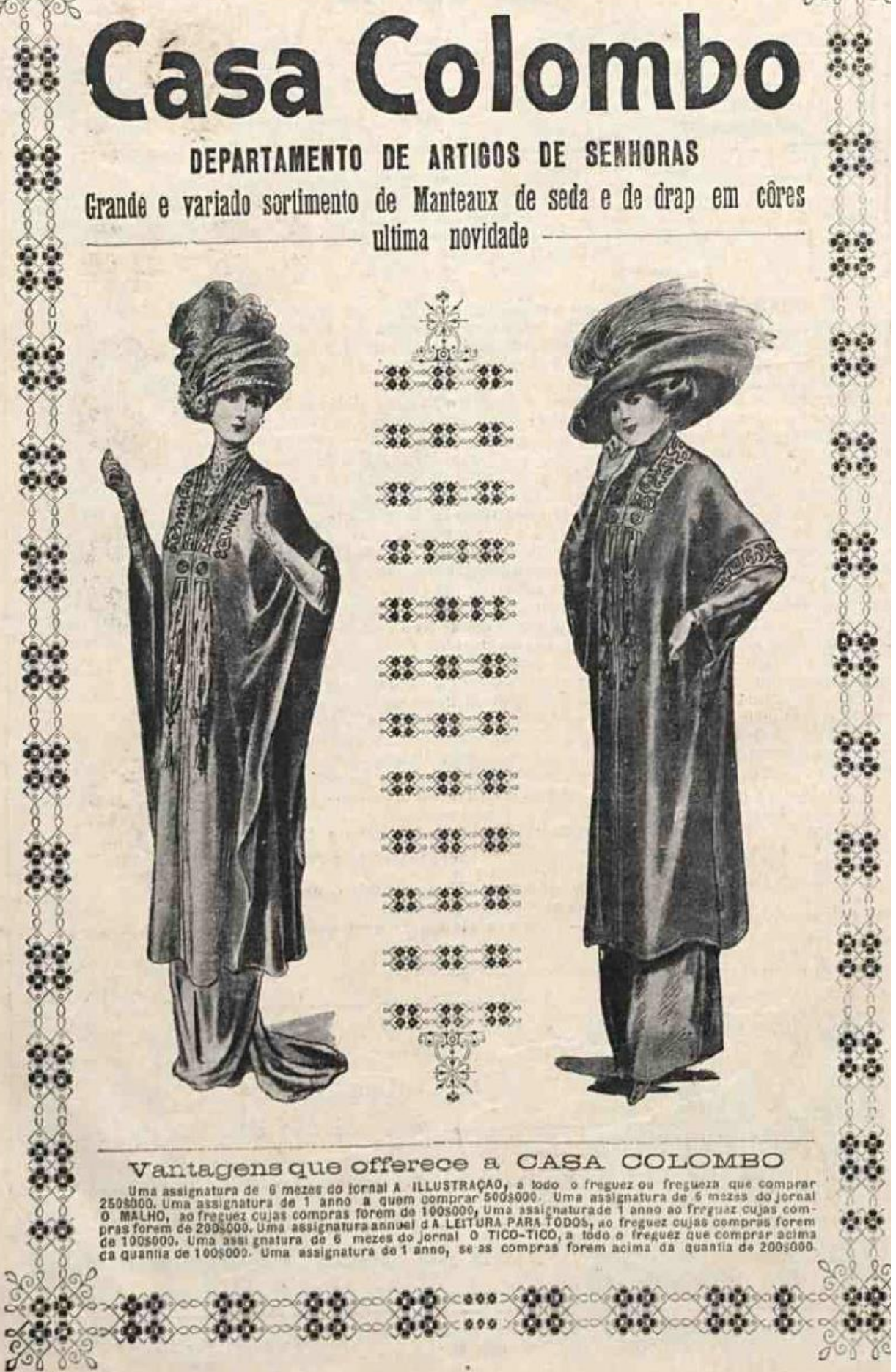

Figura 98 - O Tico-Tico - 07/06/1911-p.8 


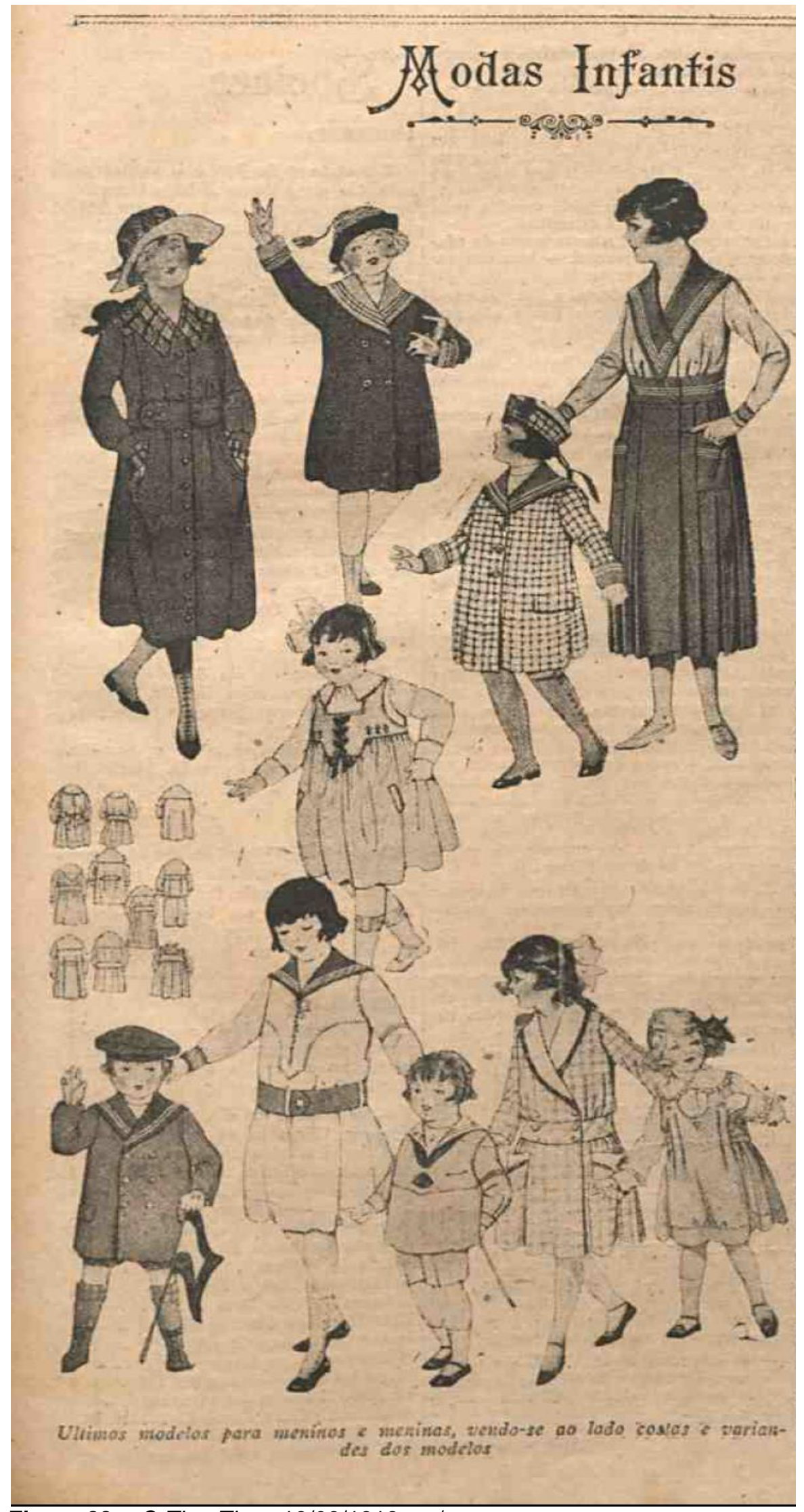

Figura $99-O$ Tico-Tico - 19/06/1918-s/p 


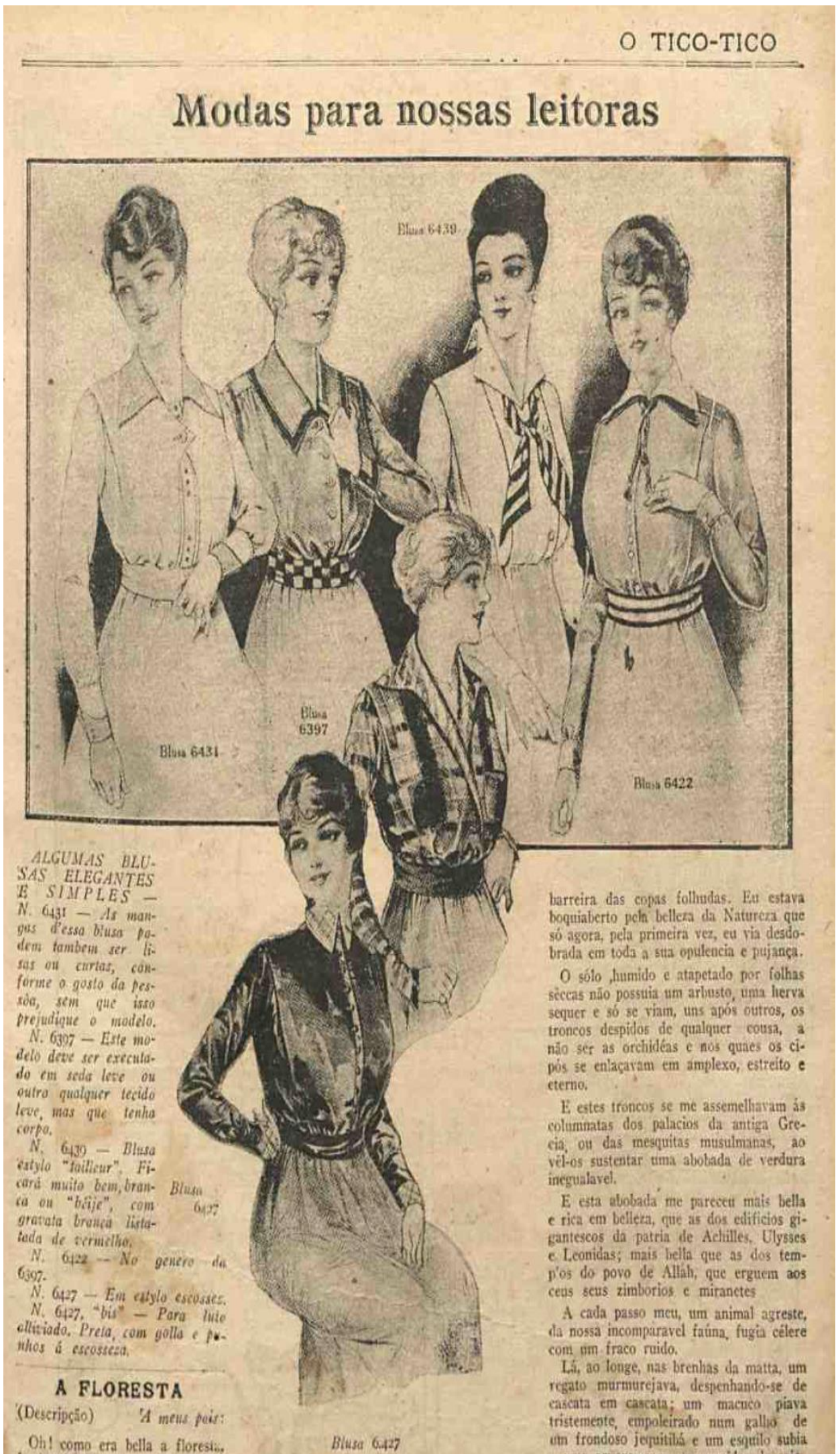

Figura 100 - O Tico-Tico - 26/01/1916 - s/p 


\section{PARA NOSSAS LEITORAS VESTIDOS PARA VERÃO}

I - Saia de gatardina branca; arregacada nas costas e com dobms nos lados; abotôs na frente com botóes de mindreperola.

2 - Vestido de voile branco: a saia tem uma tiri larga bordada, tanto $\mathrm{ma}$ frente como nas costas; o corpinho tambem bordado $\mathrm{e}$ com

renda; cinturiso de voile.

(1)




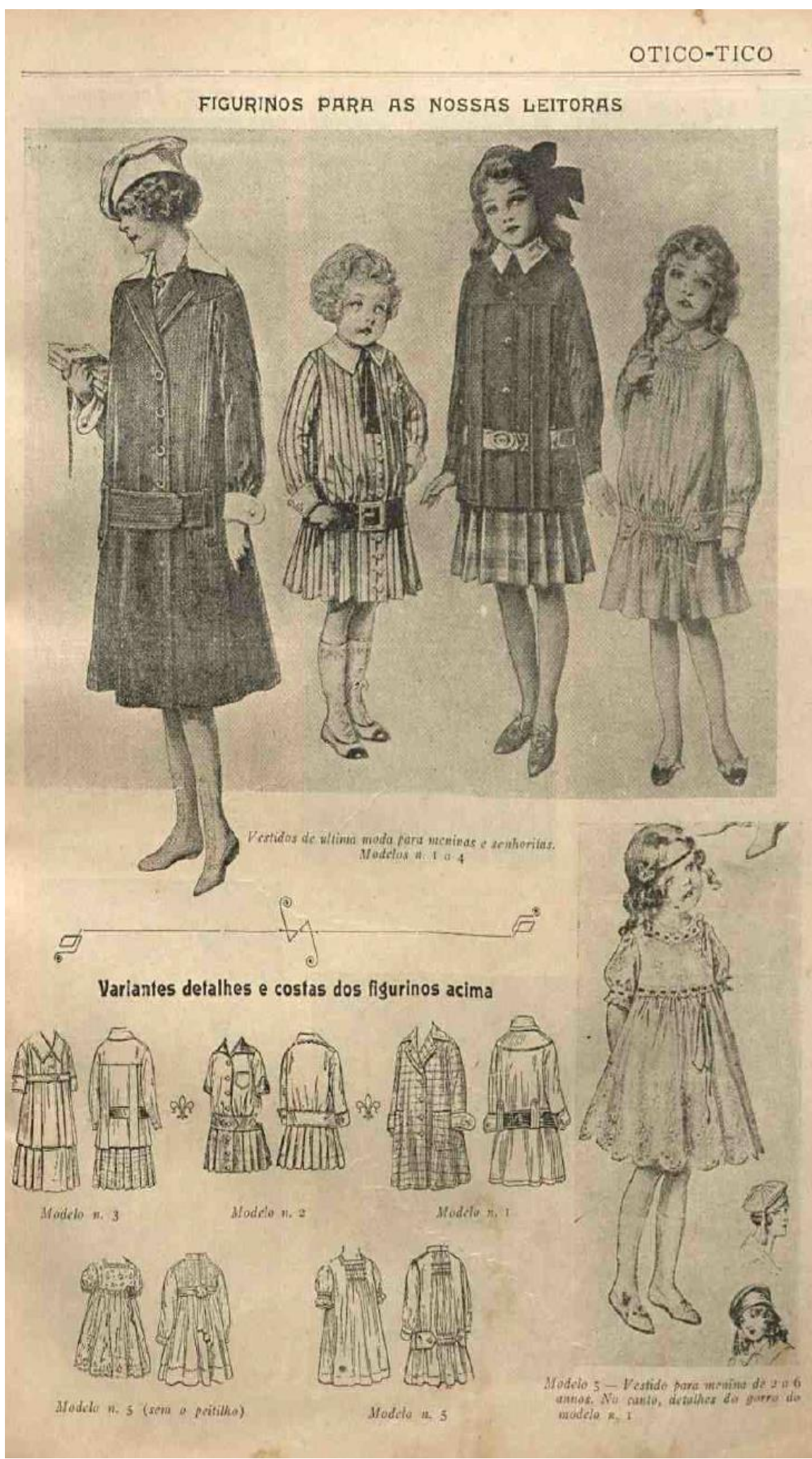

Figura 102 - O Tico-Tico - 27/10/1915 - s/p. 
O primeiro espaço em $O$ Tico-Tico dedicado a vestimenta de suas leitoras foi Seção de nossas leitoras: figurinos modernos (Fig.103). De acordo com o texto inaugural, de 9 de junho de 1915, o lançamento foi um pedido do público feminino:

Para satisfazer os constantes pedidos de nossas leitoras, daremos de hoje em deante, nesta secção, figurinos e licções de costura a nossas gentis leitoras. Além d'isso, daremos indicação sobre as cores, figurinos, tecidos, sapatos e demais artigos de vestuário mais em moda. Esperamos que nossas amiguinhas continuem a nos escrever, indicando os pontos sobre os quaes mais precisam de esclarecimento. E teremos muito prazer em satisfazer os seus pedidos (p.7).

As seções não se limitam a apresentar os últimos lançamentos da moda, elas se constituem como um manual iconográfico do comportamento feminino. Por meio das imagens em circulação, as leitoras tinham a noção sobre os prérequisitos necessários para se incluir no padrão exigido pela sociedade. Para as meninas, um aprendizado a ser adquirido desde a infância. No tocante às jovens e as mães, reforçar que o modo como uma mulher se veste pode simbolizar a possibilidade de um bom casamento ou um sinal de prosperidade do marido:

Mesmo porque, em sociedades chamadas burguesas, o modo de as mulheres casadas se apresentarem em público constitui um dos meios dos maridos se afirmarem prósperos - aqui vai algum marxismo - ou socioeconomicamente bem situados. Sendo assim, é preciso que os vestidos de esposas ou de filhas variem, de menos a mais exuberantemente caros, e adornados com expressão de aumento de prosperidade ou de ascensões socioeconômicas ou políticas ou na ocupação de cargos ilustres dos mesmos maridos ou pais (FREYRE, Op.cit., p.53).

Estes espaços não apresentam apenas conteúdos imagéticos, também trazem descrições sobre cada roupa. Tinha-se a preocupação dar ensinamentos acerca do traje correto para cada ocasião:

As modas, não há duvidas, representam cada vez mais uma preoccupação social. Não sómente para as senhoras, mas para as senhoritas ninõs, a moda actualmente é motivo de cogitações. (MODAS INFANTIS, 03/04/1918, p.15).

Os records da "verdadeira" elegancia são propriedade, a harmonia e a simplicidade. Um vestido ou chapéu com ornatos inultimente complicados não podem ser bonitos; podem conter detalhes lindos, mas em conjunto são desagradáveis. Esse é o primeiro ponto que se refere á simplicidade e ensina que os enfeites e guarnições devem se justificar pelo caracter do vestido ou utilidade... O segundo, que se refere á propriedade, é o de compreender que um vestido, um chapéu ou uns sapatos, 
que ficam muito bem em certas occasiões, são disparates em outras occasiões.Por exemplo, por bello que seja um vestido de sêda,ornado com setim e vidrilhos, e um chapéu de plumas opulentas denunciam máo gosto se uma moça usa d'elles para sahir pela manhã, fazendo compras, ou se fôr com elles a um "pic-nic". Isso é um disparate tamanho como ir a uma recepção, á noite, com um vestido tailleur e um chapéu canotier. Cada cousa deve ser usada em logar e hora apropriados. Quanto a harmonia á harmonia, ella consiste em pôr todos os attributos do vestuario em accôrdo um com outro. Por exemplo, um vestido de linho não se pode combinar com uma blusa de cetim, ornada com rendas de sêda. Em compensação, uma saia de setim não se pode ornar com bordados de linho. Um vestido tailleur não admite chapéu de apparato, nem sapatos de entrada baixa. E há muitos outros pontos em que a elegancia sem manifesta pelo bom senso. Nada mais impróprio do que usar joias pela manhã, com um vestido de linho ou drap; nada menos elegante do que uma moça solteira usar joias opulentas. Essas cousas não são novidades da moda, são princípios fixos, que se devem observar sempre. De novidades, fallaremos no próximo numero. (PARA NOSSAS LEITORAS, 22/03/1916, $\mathrm{s} / \mathrm{p}$.

Os textos afirmam que saber a forma correta de vestir, não era mera frivolidade pois significava uma forma de demarcar o pertencimento a um determinado grupo social. Em uma cidade como o Rio de Janeiro, na qual as classes mais abastadas viviam a efervescência da Belle Époque, poderia significar a oportunidade de se aproximar dos padrões ditados pelas elites. Segundo Cecchin e Cunha (2007), tal período foi marcado pela publicação de manuais de etiqueta voltados à normatização das práticas sociais:

Vários eram os pressupostos ditados neste tipo de texto com vistas ao refinamento das aparências no âmbito das sociabilidades aburguesadas: regras sobre como comportar-se em festas, eventos da sociedade, artes de bem viver; conselhos indispensáveis à aquisição de êxito nas investidas ao bom comportamento no grupo social (p.4). 


\section{SECȨĀO DE NOSSAS LEITORAS}

FIGURINOS MODERNOS

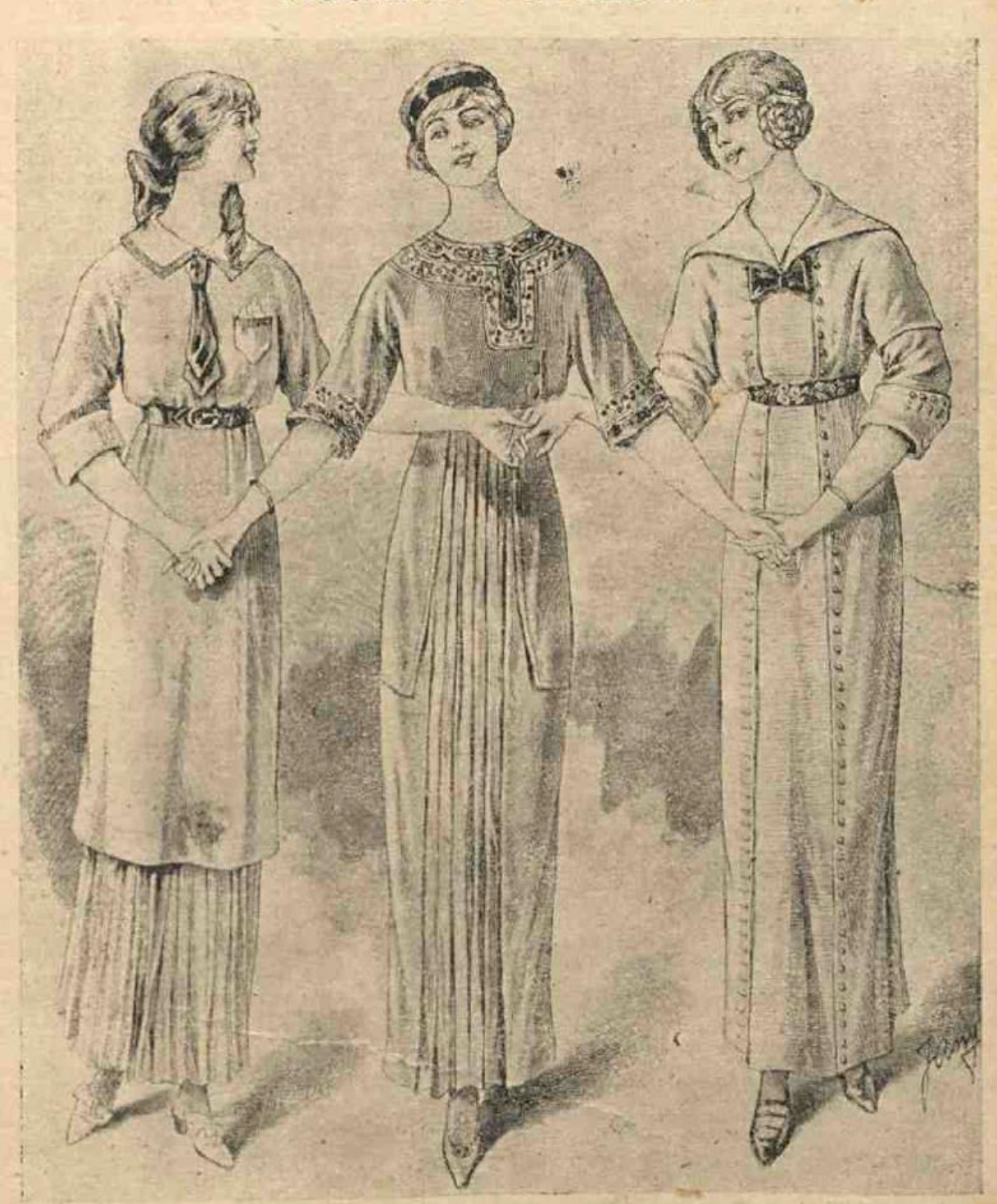

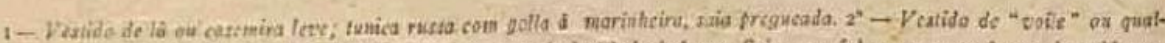

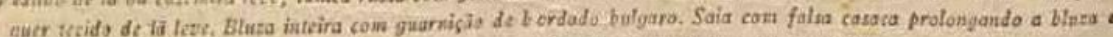

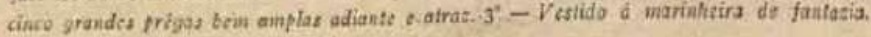

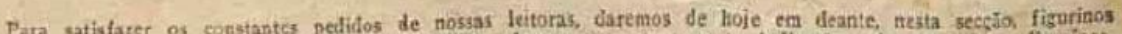

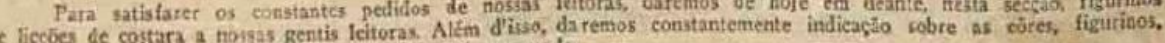
ccodos, sapatos e demais artizos de vestario mais $\mathrm{cm}$ moda.

Epermos que nossas amiguinhas continzem a nos escrever, indicando os pontos sobre os quaes mais previsam de

Figura 103 - O Tico-Tico - 09/06/1915 - p.7 
Os manuais tinham o sexo feminino como principais consumidoras. As páginas recheadas de lições de boas maneiras e posturas corretas, traziam "descrições do bom-tom, relações em sociedade, costumes, educação religiosa, as boas maneiras e a etiqueta" (CECCHIN; CUNHA, Op.cit., p.6). Inicialmente, este tipo de literatura era destinado ao espaço privado do lar, mas progressivamente ganhou o espaço da rua, em virtude do uso de seus exemplares nas instituições escolares femininas.

No contexto de $O$ Tico-Tico, torna-se imperativo citar o manual $A$ Civilidade Pueril de Erasmo de Rotterdã. Publicado em 1530, foi descrito por Elias (Op.cit.) como uma obra pertencente ao processo de transição, entre a sociedade medieval e a consolidação do Estado Absolutista. A estrutura social foi alterada e como consequência, os modos e comportamentos também se modificaram. Para Revel (Op.cit.) a publicação tinha como caráter diferenciador, o fato de ser direcionada ao público infantil:

Pois, símbolo da simplicidade e da inocência evangélicas, a criança que ainda não foi pervertida pela vida social está aberta a todos os aprendizados e ao mesmo tempo encarna uma espécie de transparência elementar: não sabe esconder nada do que ela é (p.174).

O manual é uma compilação das noções de boas maneiras e dos maus comportamentos no decorrer de um determinado período histórico. Por meio de sua leitura, é possível compreender quais condutas deveriam ser seguidas e quais deveriam ser rechaçadas, seja no espaço privado ou nas relações sociais para além do lar:

De fato, em algumas dezenas de páginas esse manual reúne com vaga ordem observações e conselhos para uso das crianças, abordando as principais circunstâncias da vida em sociedade. Assim, trata da postura, dos comportamentos sociáveis (na igreja, à mesa, por ocasião de um encontro, nas brincadeiras) e, por fim, do deitar-se (Ibidem.,p.172).

A conformação de novos hábitos e costumes está inserida em uma dimensão pedagógica.

Nas seções de moda de $O$ Tico-Tico, as figuras femininas vestem elegantes blusas e vestidos, além de ostentarem chiques penteados. As imagens, fossem de meninas ou de mulheres, tinham como padrão de beleza: a pele branca e o corpo esguio. Ostenta-se expressões faciais serenas, um sorriso contido e olhar cândido. 
Os braços, as mãos e as pernas sempre postados em gestos delicados. Como afirma Revel (Op.cit.)

A leitura psicológica do olhar constitui para nós um lugarcomum elementar. Porém, todos os movimentos, todas as posturas corporais, a própria roupa podem ser objeto de uma leitura semelhante. Os gestos são signos e podem organizar-se numa linguagem; expõem-se à interpretação e permitem um reconhecimento moral, psicológico e social da pessoa. Não há intimidade que não revelem (p.173).

Para além do bem vestir, estes espaços ressaltavam uma característica imprescindível ao sexo feminino: a elegância. Ser elegante também passou a ser visto com uma forma de distinção. Institui-se a "distinção estética da elegância" (SOUZA, Op.cit.,p.134).

Como demonstram Revel (Op.cit.) e Elias (Op.cit.), os manuais de civilidade abordam o controle das pulsões, dos gestos e dos sentimentos com o propósito de estabelecer um modelo de cidadão padrão. Em O Tico-Tico, a delicadeza e a feminilidade são características estimuladas. Reflexo de um modelo na qual as mulheres são belas e frágeis como uma peça de porcelana. Nas palavras de Higonnet (1991): “A feminilidade é em parte uma questão de aparências" (p.298).

As imagens e os conteúdos presentes nestes espaços, também se constituem em fontes para se identificar as mudanças no vestuário das brasileiras. Priore (Op.cit.) aponta que as primeiras décadas republicanas foram marcadas pela famosa cinturinha de pilão ou ampulheta, fruto do uso de corpetes e de espartilhos. Peças obrigatórias para as madames que frequentavam as boutiques mais chiques da cidade, e queriam manter suas formas corporais inspiradas nos padrões europeus. "Não há descrição de heroína de romance nem fotografia da aristocracia do café em que as mulheres não apareçam com o enrijecimento dorsal, típico do uso do espartilho" (p.215).

O espartilho ou colete foi criado na Inglaterra do século XVI. Para manter a sustentação dos seios, tinha a armação feita com barbatana de baleia. Depois, utilizou-se lâmina de aço. Após a Revolução Francesa, as mulheres abandonaram o uso do espartilho, considerado um dos trajes símbolo do Antigo Regime. No decorrer do século XIX, ele voltou à moda e se tornou um dos símbolos de elegância e status da mulher burguesa (SOUZA, Op.cit.). O Tico-Tico publicou anúncios sobre espartilhos ou coletes. As peças publicitárias ressaltam a 
capacidade de modelar as formas femininas e auxiliar na postura e na elegância. (Fig.104).

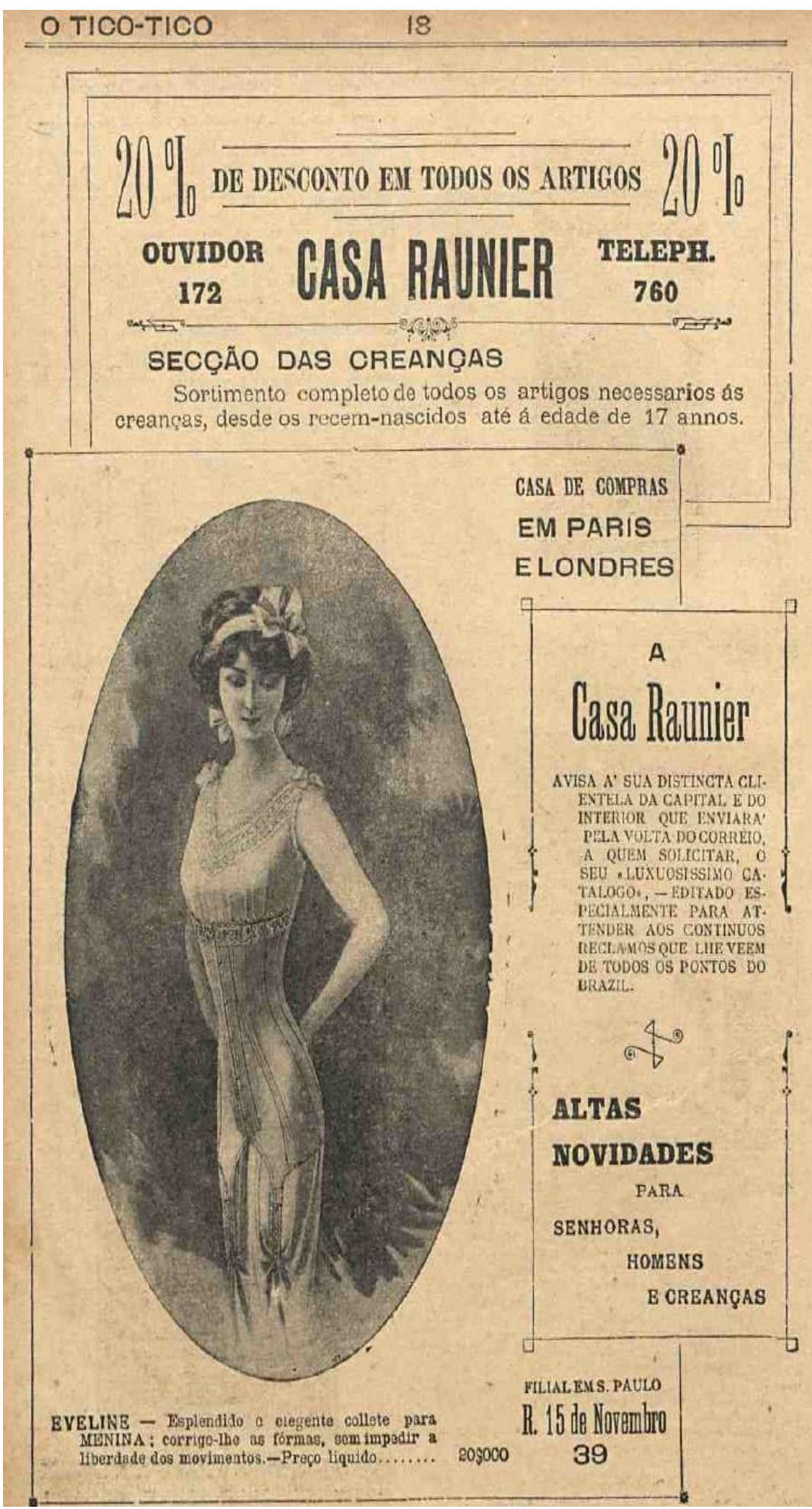

Figura 104 - O Tico-Tico - 16/08/1911- p.18 
Os espartilhos eram vistos ao mesmo tempo, como um sinal de elegância e como possível causa de malefícios ao corpo feminino ${ }^{71}$. Eram acusados de espremer os órgãos e dificultar a respiração. Inclusive foram apelidados como " $\mathrm{O}$ dissimulado instrumento de tortura" (PRIORE, Op.cit. p.216). O advento de modelos mais modernos, com varetas flexíveis de aço, não cessou os questionamentos $^{72}$. Os debates sobre o corpo ganharam cada vez mais espaço, inclusive nas páginas de $O$ Tico-Tico.

\subsection{0 corpo feminino: meninas e mulheres esbeltas}

Em 2 de agosto de 1916, a seção Para nossas leitoras debateu o tema do ganho de peso. Intitulado Para não se engordar demasiadamente, o texto aconselha as leitoras a seguir o exemplo das norte-americanas que praticavam exercícios físicos para cuidar do corpo:

As senhoras americanas têm horror á obesidade e procuram por todos os meios a seu alcance, sobretudo se apreciam o sport, fazer guerra...á gordura. Procuram, nos pontos em que podem patinar, essa distracção fatigante, convencidas de que esse exercicio além de muito saudavel...conserva a regularidade das linhas, impedindo em absoluto que appareça a gordura tão detestada. Nos Estados Unidos, em todos os hoteis, por cima dos prédios, existem terraços destinados a diversões de todo o genero, sendo de notar que a distracção, mais commum, este anno tem sido o exercicio de "saltar na corda", brinquedo esse usado em todos os collegios e que constitue o martyrio dos pais por causa do calçado que se estraga. Este exercicio, feito com certa calma, é tão gracioso quanto qualquer outro, tanto que as meninas, mesmo já de certa edade, buscam os jardins de sua residencia para saltar na corda. (s/p).

A temática do artigo não foi escolhida de forma aleatória. O início do século XX foi marcado pelo discurso de que a boa aparência não estava ligada apenas ao uso de roupas elegantes, mais também a um corpo saudável. A juventude, a saúde e a beleza se tornaram lemas da sociedade moderna e civilizada (SEVCENKO, Op.cit.). Sant'Anna (2011) salienta que “ o asseio foi visto como sinônimo de boa educação e uma maneira de obter distinção social"

${ }^{71}$ A revista $O$ Tico-Tico publicou dois extensos textos sobre o uso correto do espartilho. Na edição de 16 de maio de 1916, a seção Para nossas leitoras publicou $O$ espartilho. No exemplar de Lições do Vovô, de 13 de setembro de 1916, dedicou sua coluna a ensinar às leitoras o modo correto de escolher um colete.

${ }^{72}$ Em 1905, o estilista francês Paul Poiret revolucionou a moda, ao desenhar vestidos nos quais o uso do espartilho era desnecessário. KNIBIEHLER, Yvonne. Corpos e corações. In: DUBY, Georges.; PERROT, Michelle. História das mulheres no Ocidente: o século XIX. v.3. Porto- Por: Edições Afrontamento/ São Paulo: EBRADIL, 1991. p.357. 
(p.292). A preocupação com o físico também passa a estar na moda. Prost (2009) observa que o passar das décadas estabeleceu mudanças, principalmente, no vestuário feminino. Novos modelos de roupas exigiam uma nova conformação corporal:

(...) os corpetes e as cinturas recuam, cedendo espaço a calcinhas e sutiãs. As roupas se encurtam e as meias valorizam as pernas. Os tecidos mais macios revelam discretamente as linhas do corpo. A aparência física passa a depender mais do próprio corpo, e portanto é preciso cuidar dele (p.83).

Os rostos pálidos cederam lugar às bochechas rosadas. Havia a necessidade de construir uma imagem feminina ligada a hábitos saudáveis. O discurso higienista ganha legitimação junto às elites, inclusive como justificativa para a realização das reformas urbanas no Rio de Janeiro.

O cronista Luiz Edmundo (Op.cit.) descreve que os líderes do movimento republicano vivenciaram um período no qual manter um corpo saudável, não era um hábito costumeiro:

Até o fim do século que passou nós vivíamos, a bem dizer, indiferentes aos prazeres e às alegrias salutares do esporte. A geração que vai proclamar a República, exceção feita dos homens que se guiam a carreira das armas, era uma geração de fracos e enfezados, de lânguidos e de raquíticos, sempre enrolada em grossos cache-nez de lã, a galocha no pé e um guarda-chuva de cabo de volta de baixo do braço, mal aparecia no céu uma nuvem cinzenta. Mens sana in corpore sano não passava de uma frase inexpressiva e vaga do velho Juvenal. Não se cuidava de cultura física (p.519).

$\mathrm{O}$ autor estabelece comparações entre as gerações dos jovens de 1880 e 1901. Na primeira "Não se pratica a ginástica do corpo. A do sentimento basta" (p.521). A segunda já se fazia imersa ao discurso regenerador da sociedade brasileira.

As revistas passam a publicar reportagens sobre como despertar nas leitoras o gosto pela alimentação saudável e pelos exercícios diários. A mulher quando, disposta e em plena forma física, contribui para a harmonia doméstica e familiar. Priore (Op.cit.) demonstra que a "elegância feminina começou a rimar com a saúde" (p.213).

Em $O$ Tico-Tico, os cuidados com o corpo da mulher também se fizeram presentes. A saúde de Julinha narra as agruras de uma menina muito fraquinha 
cuja vida se transformou após ter começado a praticar ginástica sueca (Fig.105) (Fig.105) (Fig.106).

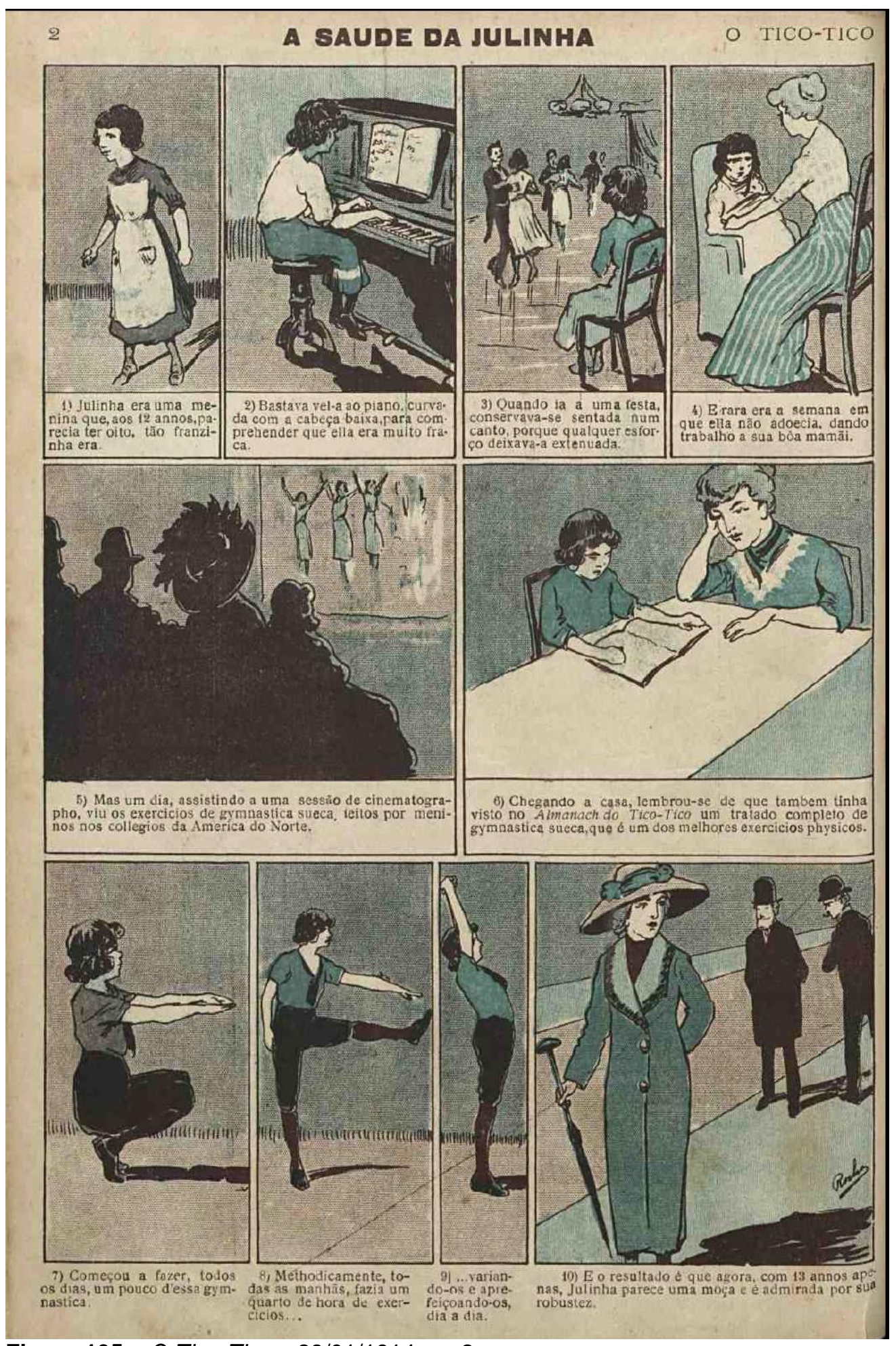

Figura 105 - O Tico-Tico - 28/01/1914-p.2 


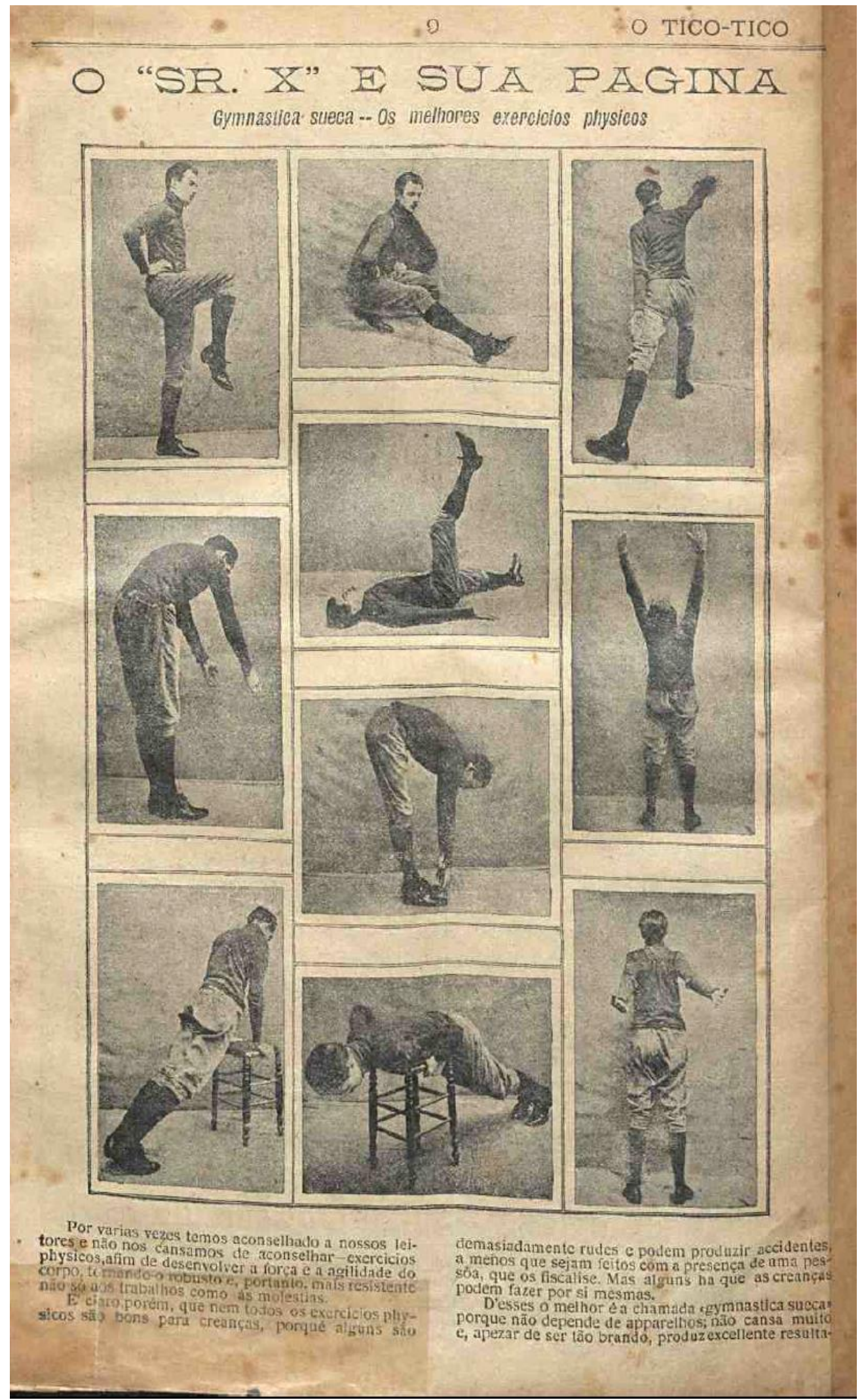

Figura 106-O Tico-Tico-17/07/1912-p.9 


\section{\begin{tabular}{ll}
0 TICO-TICO $\quad 10$ \\
\hline
\end{tabular}}

61-em pouco lempo asgrienta o volume dos musculos, cenrijg-ose di-lines elasticidade.

Vanios explicar os cercicios representados em nossas gtaruras e que sio os essenciaes para uma completa educaço pluysica.

A'esqueda.

1- Caericio cos musculos, das pernas \& quadris. Collocer-se de pé bem cajallibrado, com as móos ni cinture, crover alternativamente unn eoutro joetho ale collocal.os na mesma cintura.

2-Collocar-se ben perfillado e baixar o tronec com os brasos esticados:

3-Apoir as mâos a um banco,e mantendo os pes Juntos, dexar calitio corpo tanto quanto for possicel e ergacl-a de novo, couservando sempre os bracos e acorpo csicados.

Ao centro.

1- Bsticar uma perna para deante c colbara a outa até sentur-so sobre o calcanlare, mantendo as mäos ha cintura. Feer isso allernativamentc, ora con uma pema ore cont a outita.

2-Détar-se no chảo ben estendico de costas e erguer 0 mais que pader uma perna,mantendo a outhi pema os braços estendidos. Fazer on com uma cma, ora con a outra,

3- Manter as pernas ceflicadas, os ples juatos e currarese até locar conn os dedos nas pontas dos pes.

1-Curvarsese para deante, com as pes juntos. apoitado as máos a un banco, e baikar o cotpo atc loar com o peito no baccoe erguel-o de novo o más possivel.

A'direita.

IrCollocasese de pé com o calcanhar do pe direito encostado fa curva do pe esquerdo, flomando un angulo recto com os pes depois adeantar o pédireifo escutremando com elle pelo chão e assim a astaloo 0 masis posisivel.

2-Curvar o corpo para laa o mais possivel.

3-Inclinar o corpo para deante o mais possiecl, mantendo-o discito.

Nota importante-Todos bsses mencicios devert

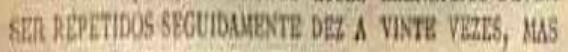

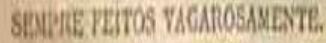

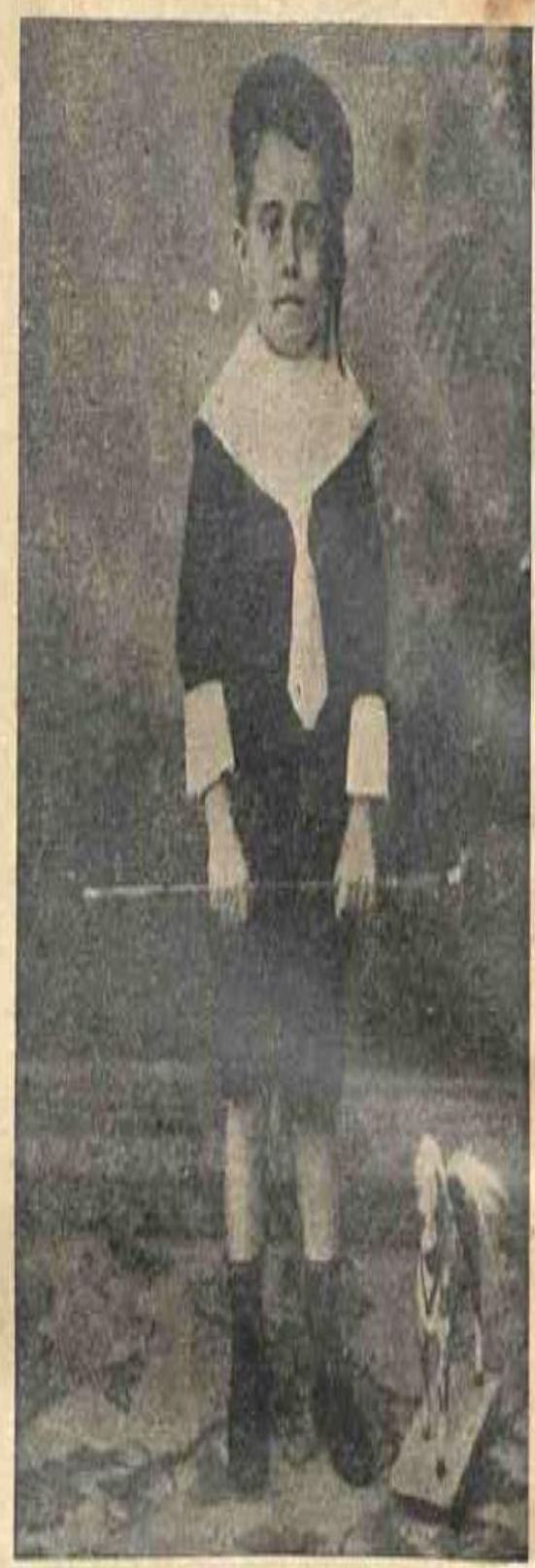

Armino Dutre da Silva, 5 antos, fillho do S: Joino Dotra da Silva. Egrande admindor di arta Phillatelica, e amizo de Chinguinho

Figura 107-O Tico-Tico-17/07/1912 - p.10 
Método desenvolvido no século XIX pelo poeta Pehr Henrick Ling, promovia os exercícios físicos como meio de formação de indivíduos fortes, saudáveis e úteis à nação. Entre os aparelhos utilizados estavam: a barra móvel (usada em exercícios de suspensão e equilíbrio), os plintos $^{73}$ e o banco sueco ${ }^{74}$. Para a formação das crianças, utilizava-se a modalidade ginástica pedagógica ${ }^{75}$. Destinada a meninos e meninas, tinha tinha o objetivo de melhorar a postura, evitar os vícios e as doenças (SOARES, 2004)

No início do século XX, a ginástica sueca começou a ser praticada no Brasil. A fama de tornar as crianças robustas fez com que este tipo de exercício fosse utilizado no ambiente escolar. O princípio da regeneração social encontrava consonância junto aos discursos propalados por intelectuais pertencentes aos grupos dirigentes da República, como Rui Barbosa (Ibidem). A fotografia a seguir mostra as alunas do Instituto Geral do Povo durante uma aula de ginástica sueca na Quinta da Boa Vista, no Rio de Janeiro (Fig.108).

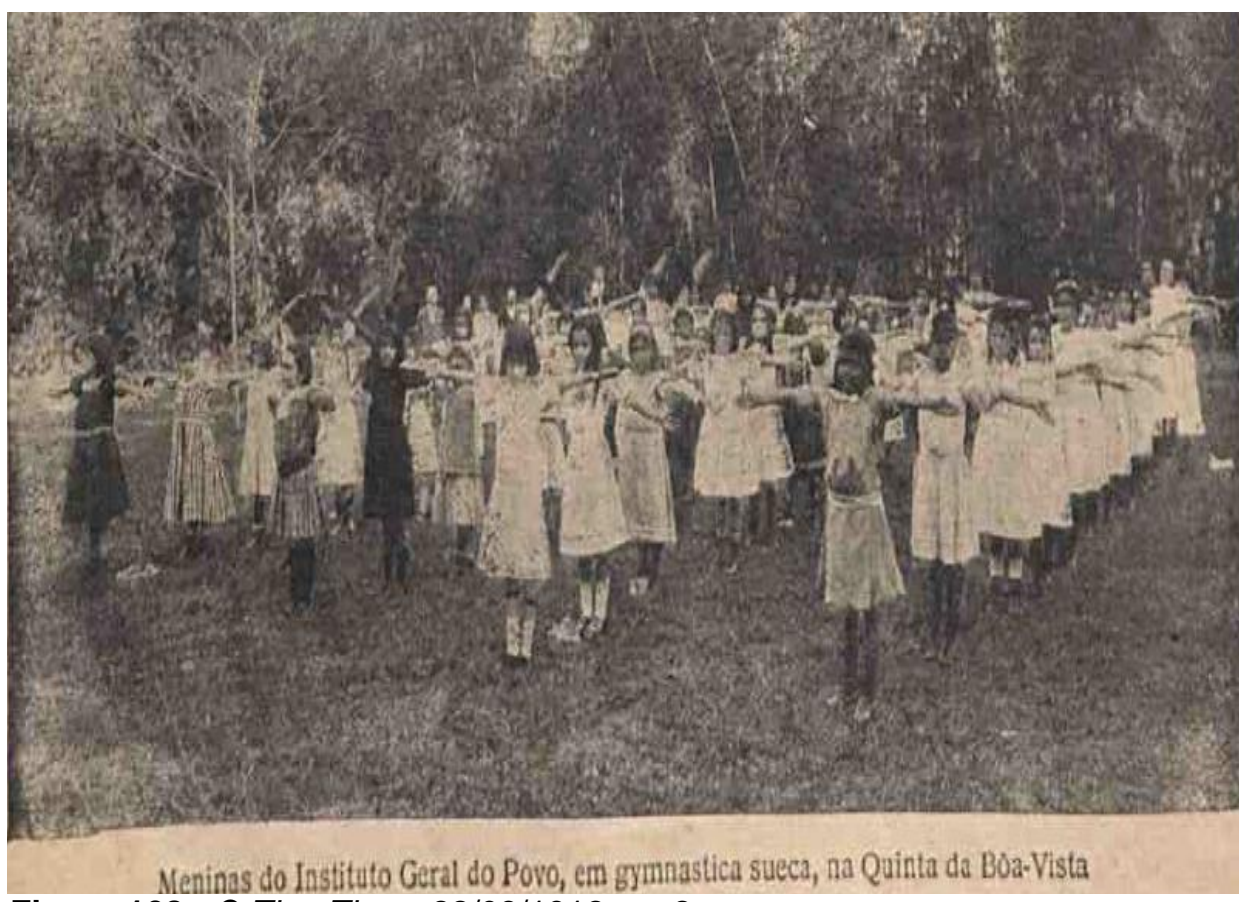

Figura 108-O Tico-Tico - 22/08/1912 - p.2

\footnotetext{
${ }^{73} \mathrm{O}$ banco sueco é feito de madeira e remete a estrutura utilizada pelos atletas da ginástica artística na prova da trave de equilíbrio.

${ }^{74}$ Peça em madeira utilizada para saltos. Na ginástica artística é destinada às competições salto sobre o cavalo.

${ }^{75}$ As três outras modalidades da ginástica sueca são: a ginástica militar, a ginástica médica e ortopédica e a ginástica estética. A primeira é voltada a preparação de soldados, a segunda visa auxiliar na cura de doenças e enfermidades e a terceira faz uso da dança para obter um corpo belo e gracioso. SOARES, Carmem. Educação Física: raízes européias e Brasil. 4.ed. Campinas-SP: Autores Associados, 2004. p.57-60.
} 
As meninas podiam realizar estas atividades físicas porque não afetavam sua feminilidade. O sexo feminino deveria: "evitar movimentos muito acentuados para trás; não realizar movimentos que possam congestionar a bacia e abster-se do trabalho físico durante a menstruação" (SOARES, Op.cit., p.59). A disciplina educação física tinha uma metodologia distinta para meninas e meninos. As garotas realizavam os chamados exercícios calistênicos voltados ao fortalecimento dos quadris $^{76}$. Eram desaconselhadas a fazerem esportes considerados masculinizantes que envolvessem saltos, golpes, lutas e qualquer tipo de contato físico. A ginástica sueca permitia às meninas manter a forma, mas sem comprometer os comportamentos femininos.

A mulher também podia se exercitar em casa. Em 18 de dezembro de 1918, O Tico-Tico publicou o artigo A conservação da figura. O conteúdo faz referência aos Simples exercícios de prática doméstica desenvolvidos pelo professor norte-americano Edwin Checkley da Escola de Cultura Física da Filadélfia. Ele propunha que as mulheres dedicassem, alguns minutos na parte da manhã e antes de dormir, à prática de atividades para manter a "symetria, graça e atitude" ( $\mathrm{s} / \mathrm{p})$. Para além dos benefícios físicos, também acarretava melhora no temperamento feminino (Fig.109) (Fig.110).

\footnotetext{
${ }^{76}$ Os exercícios físicos destinados aos meninos tinham como referência os pelotões miliares. Os alunos aprenderiam, desde a infância, sobre a necessidade de estarem prontos a defender o país. No ano de 1916, houve a sugestão de ser criar batalhões escolares no estado do Mato Grosso. Os participantes usariam uniformes, espingardas de madeira e tambores. SÁ, Elizabeth Figueiredo de. A Construção da Identidade Nacionalista da Criança Mato-Grossense. In: VIDAL, Diana G.; SCHWARTZ, Cleonara. (Org.). História das culturas escolares no Brasil. Vitória: EdUFES, 2010, p.223-246.
} 
18 de Dezembro

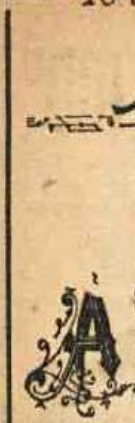

f conservação đa figura

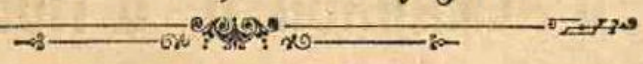

duo, a mulher principalmente,

que conseguiu melhorar ou aper-

feicoar as fómas geraes do set

corpo, nẩ pode abandonar a

sta obra, stippondo-a definitiva

e completa.

E' muito importante para ella adquirir symetria, graça e attitude, e para isso é egualmente importante, que ella consagre uma parte do sen tempo e das suas energias a exercicios, que tenham por objecto a manuten-

SIMPLES EXERCICIOS DE PRATICA DOMESTICA

çăo do typo e a perfeição da fór

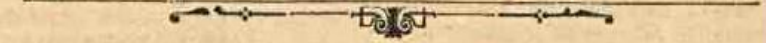

ma, já adquiridos. Ella deve saber

nāo só o modo de se tomar perfeita,

mas tambem o de conscriar a sua $f$

gura.

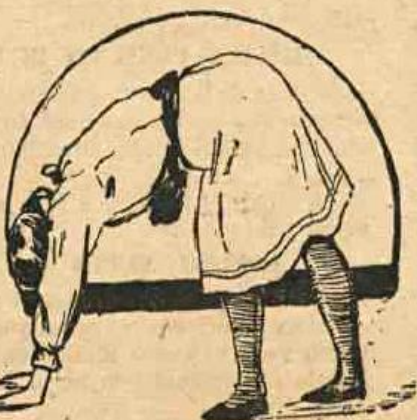

Fig. 2

perna que avanga. Procure-se, $\mathrm{em}$ seguida, endireitar novamente as pernas, sem mudar a posição dos pés. Ao principio a execuçáo desta parta do exercicio serí difficil ; mas, insistindo na stua pratica, chegar-se- 4 a conseguil-3 com facilidade.

Para ustender scientificamente os membros e para estimuiar : circulaçâo, esteja-se de pé, direita com os calcanhares unidos $\mathrm{z}$ as mãos erguidas á maior altura acima da cabeça. Cruzem-se os pol kgares, e unam-se os braços aos lados da cabeça. Consarvenr-se os braços tảo altos quanto scja pos' sivel, por um minuto os mais, ois

torem praticados com regularidade, até que os bracos e os hombros comeas juntas e os musculos conservario teem a sdormecer ou a tremer. EinA fexibilidade, $\mathrm{c}$ ao corpo será man- lảo incline-se o corpo para an frente, O primeiro exercicio aconselhado do-o pelos quadris, e mantendo a caEm conformicade com isto, o pro- pelo professur Checkley item por fim bega e os braços nas mesmas posifessor Edwin Checkley, da Escola de manter os unusculos da cintura, dos şócs relatisas cn que estavam anCultura Pliysica, de Philadelphia, bragos, e os dos membros inferiores tes.

imaginou uma excellente série de em boas condiçōes, e conservar o con- Nessa curratura do corpo, haja toexercicios simples para serem prati- torno perfeito da cintura e dos qua- do o cuidado en que a espinha dorexercicios simples para serem prati- Jris.
cados diariamente pelas senhoras, dris se mantenha dircita, isto é, náo se que tenham consegutido tormar a sua Ajoelhe-se, e curve-se o corpo para entortanto para um lado ou outro, e figura geral täo perfeita quanto possi- a frente até as máos assentarem so que, is medida que o corpo se vá invel. No entender do douto professor, chảo; em seguida, puxem-se estas para

vel. No cntender do douto prosessor, o corpo até quasi tocarem nos joeos exercicios por elle recommendados hos. Levante-se entāo o corpo sobre demandam, apenas, uns cinco minu- hos. Levante-se entáo o corpo sobre co, e de cinco a dez minutos, todas as der. Tenha-se cuidado em que os calço. e de cornhares assentem no châo todo o noites, proximo da hora de dertar. Se corpo. Mantenha-se esta posiçäo o

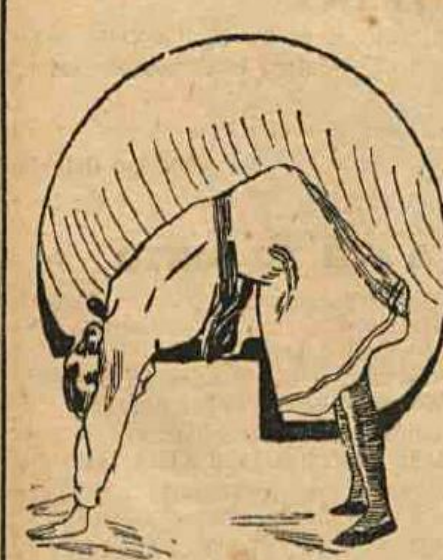
tempo necessario para contar de un a dez, e depois vagarosamenfe desça-se o corpo até se ficar sobre as mãos $\mathrm{e}$ os jocthos outra vez. Repita-se este exerci. cio umas cinco vezes todas as manhẩs.

O seguinte exercicio para a conservação da figura é muito semelhante ao que neste mo. mento acxibamos de descrever. Ajoethe-se como se explicou no primeiro exercicio, clevantese a corpo até se ficar firmada nas mâios c nos pés, com a eabesa para baixo, entre os bracos, Avance-se, depois, um dos pés, numa extensáo de duas vezes o comprimento delle, pouco mais ou menos. Para conseguir isso Fig. I

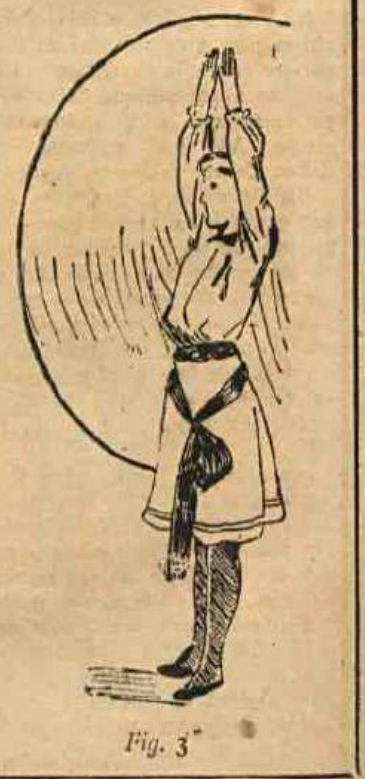

Figura 109- O Tico-Tico - 18/12/1918 - s/p 


\section{$01100-11 C 0$}

clinando mais e mais, toda a acçăo se vem dobrar, e as coșas deven ser zes de pratica de um systema regular centralize na junta dos quadris só- mantidas tâo direitas quanto possi- de exercicios gymmasticos, pode desvel, a a cabeca conservada tio aper- apparecer o desanimado das attituNesta ultima parie do exercicip, tada entre os braços como estava, des, a compleiçáo tornar-sc mais viva deve-se successivamente ir dobrau quando se tinha o corpo vertical na e alegre, melhor a respiraçăp, mais do o corpo até as pontas dos dedos primeira posicio. tocarem o chão, ou até se approxi- As senhoras, que tenham aperfei- por conseguinte a amplidăo do busto, marem do chảo tanto quanto se pos- As senhoras, que tenham aperfei- em stmma, toda a figura pode ser sa conseguir. Os joellios naio se de- coado a sua figura, e queiram fa- sensivelmente melhorada. (seguiräo manter as vantagens adquiridas, durante muitos annos de sua vida.

O đr. Chicekley crê que além do mellhoramento de figura conseguido por uma trenagem physica, ha outra razão pela qual as senhoras se deven enilregar regularmente a excrcicivs musctlares, fázendo d'elles uma parte obrigada do set programuna diario. :2' que os bons exercicios physicos tèn sempre effeito particular, immedialo e benefico, na ccmpleiçío de uma mu. ther. Diz ter observado muitas mudanças maravilhosas no temperamentp, na disposiçio e na forma de ser te bastantes mullieres, sob a ação de exercicios physicos methodicos e relativamente ligciros.

Affirma que, dentro de poucos me

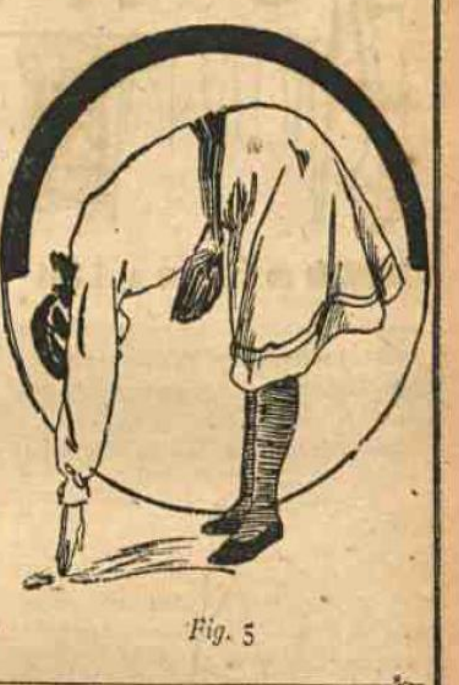

Figura 110 - O Tico-Tico-18/12/1918 - s/p

Os anos iniciais do século XX foram marcados pela emergência de uma "verdadeira febre esportiva" (SEVCENKO, Op.cit., p.568). O escritor Machado de Assis chegou a utilizar a expressão civilização esportiva ${ }^{77}$, para identificar um discurso baseado na "ética do ativismo, a idéia de que é na ação e portanto no engajamento corporal que se concentra a mais plena realização do destino humano" (Ibidem.,p.569). Nas páginas de O Tico-Tico é identificada a defesa das atividades físicas. Na seção Sports d'O Tico-Tico são divulgados os resultados de competições e torneios infantis. Também foi publicado o Manual de Athletismo com ensinamentos sobre o modo correto de se praticar a natação e a corrida de obstáculos (Fig.111).

${ }^{77}$ Crônica publicada no periódico A Semana publicada em 29 de março de 1896. 


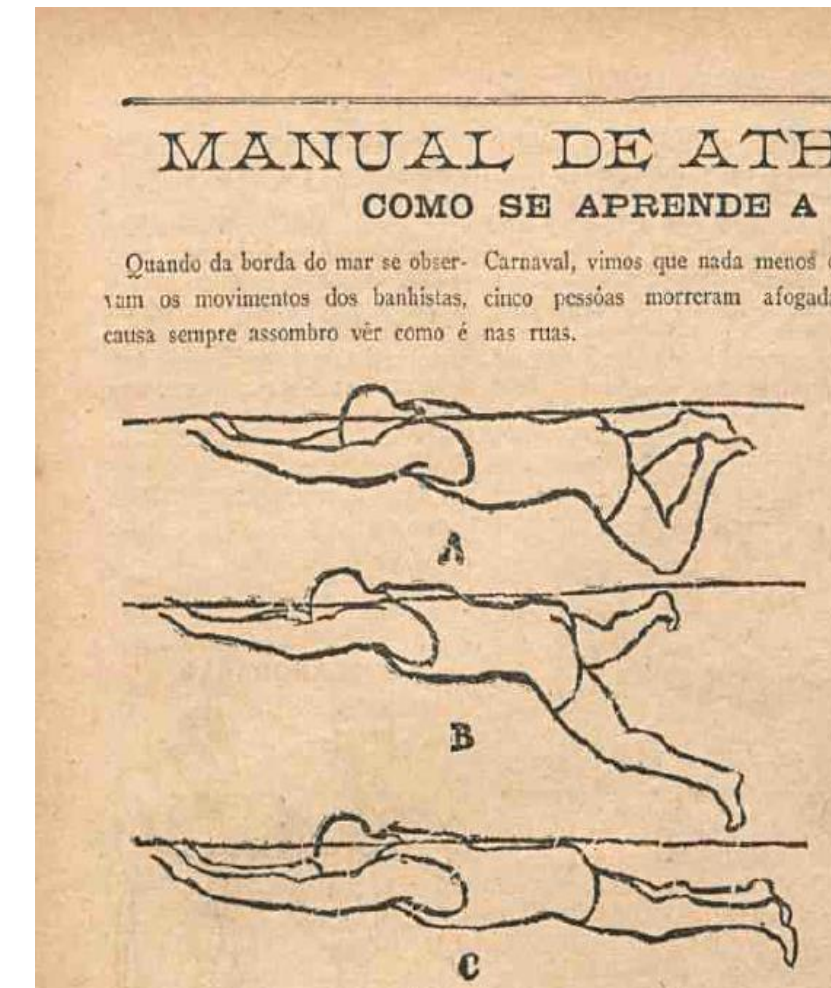

Figura 1 - Mavinentos das pernas, na natação

O TICO-TICO

ETISMIO NADAR lam os movimentos dos banhistas, cinco pessóas morreram afogadas que os passagciros, são lançados á agua, antes que tenham tempo sequer de pensar em apparethos de salทaçลี่อ.

De resto, porque náo aprender a nadar, se isso é tão facil ?

E' claro que os principiantes não se deven metter nisso, sem a vigilancia de um nadador perito e experimentado, mas desde que se tenha essa garantia ,0 exercicio de mataçio, por si mesno, não é de aprendizagem longa ,nem dififici.

Um homem de constituiçäo normal, collocado, na agua deve fluctuar e movendo-se, deve caminhar na agua.

Sendo assim, sendo que o homen por sin propria constituiçio physica, devia fluetuar na agua, naturalmente, como todos os animaes, como explicar que na aprendizagem uma creatura humana, ao cahir ma agua, vá logo ao fundo ?

grance a proporção das pessỏas que nẫo sabem nadar.

Dirño os teimosos. Ha o recurso dos silva-vidas.

Isso é tanto mais lamentavel quan-. Mas quen se poderá munir d'esses

Isso se explica muito simplesmento além do prazer que esse sport pro- apparelhos, em caso de intundação, e te: Uma creatura humana submerporciona e das vantagens que o saber que quasi sempre é inesperada? E ge-se apenas porque o medo a leva a nadar póde trazer, nẫo só para ga- mesmo num naufragio, muitas vezes tomar attitudes inconvenientes, que rantia da vida do proprio nadador en caro de accidente, como para sal. 7at a existencia de um semelhante, cahido nos mares, rios e lagos; alén d'essas vantagens muito apreciaveis, convén naio esquecer que não ha exercicio physico mais completo e que mais proveito traga ao deservolvinento do corpo humano.

Demais, é uma inferioridade sertsivel o ser incapaz de se manter e mover na agtia.

Não ha pessòa, por mais tranguilla e cascira que seja, que năo se possa um dia vèr diante da necessidade de enfrentar uma massa d'agua.

Sem fallar na hypothese de viagens $\mathrm{c}$ natfragios, o perigo de inumdaçōes é sempre possivel c ainda lia bem pouco tempo, por oceasiazo da tempestade, que desabou sobre o Rio de Jantiro na terça-feira de
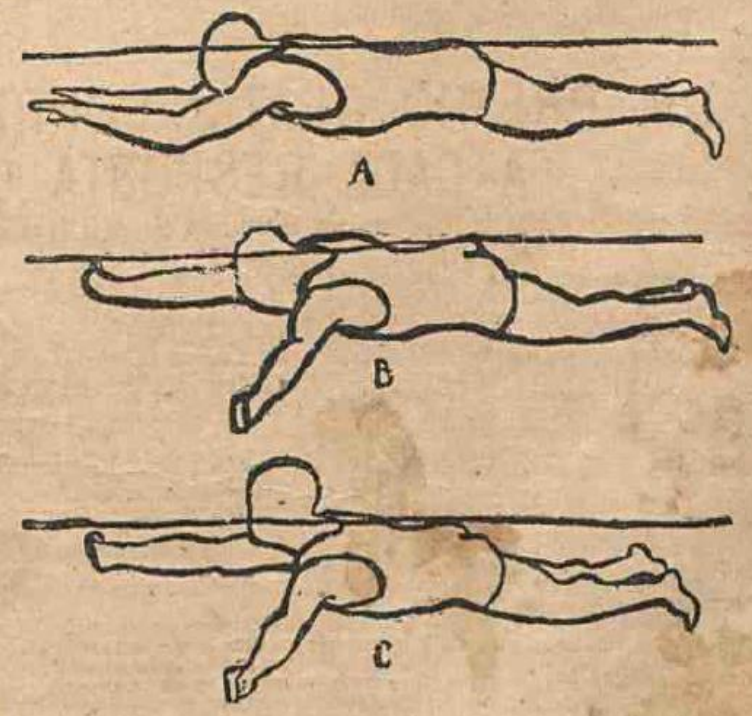

Figura 2 - Movinentos dos bracos

Figura 111 - O Tico-Tico - 29/03/1916 - s/p. 
A participação feminina nos esportes começou a crescer. Este tipo de atividade ganhou espaço com a chegada dos imigrantes europeus e a convivência destes com as elites brasileiras. As mulheres passaram a nadar, a pedalar e a frequentar quadras de tênis. Priore ressalta (Op.cit.) que nem todos viam com bons olhos a inserção feminina nas práticas esportivas:

Não faltou quem achasse imoral, uma degenerescência e até mesmo pecado. Perseguia-se tudo que pudesse macular o papel de mãe dedicada exclusivamente ao lar. Era como se as mulheres se aproximassem de exercícios próprios da natureza masculina. Algumas vozes toda via levantaram-se contra a satanização da mulher esportiva. Médicos e higienistas faziam a ligação entre a histeria e melancolia - as grandes vilãs do final do século - e a falta de exercícios físicos. Confinadas em cada, diziam, as mulheres só podiam fenecer, estiolar, murchar (p.214-215).

A partir da segunda metade do século XIX, identifica-se uma aproximação das mulheres brasileiras e o universo dos esportes. Destaque para as competições de turfe que se configuraram em eventos sociais de destaque. Embora se tenha registro de uma prova realizada em 1875, com a participação de joquetas, as mulheres costumavam ir a tais eventos apenas para acompanhar os pais e os maridos. Tornou-se comum aos frequentadores e à imprensa, admirarem os vestidos e os chapéus usados por senhoritas e senhores nestas competições. Uma tradição que atravessou o século XX (MELO,2007).

O banho de mar e as competições de remo também foram alçadas a parte do lazer feminino. Inicialmente, havia restrições sobre a presença do sexo feminino nas praias. As mulheres respeitosas se banhavam apenas no início da manhã e sem a companhia masculina. Caso contrário, poderiam ficar mal faladas:

Às sete da manhã a praiazinha vai-se fazendo vazia de famílias, pois senhora de qualidade não aparece nunca para banhar-se depois dessa hora, que é a hora das cocottes e da rapaziada bulhenta que nada, que rema, grita, prega partidas e quer divertir-se (COSTA, Op.cit., p.525)

Além do horário específico, elas usavam roupas enormes que não lhes marcavam as formas do corpo:

Do mesmo tecido, um blusão com gola larguíssima, à marinheira, obrigada a laço, um laço amplo que serve de enfeite e, ao mesmo tempo, de tapume a uma possível manifestação de qualquer linha capaz de sugerir o feitio vago de um seio. As calças vão até tocar o tornozelo quando não caem num babado largo, cobrindo o peito do pé. Toda a roupa é sempre azulmarinho e encadarçada de branco. Sapatos de lona e corda, 
amarrado no pé e na perna, à romana. Na cabeça, vastas toucas de oleado, com franzido à Maria Antonieta, ou exagerados chapelões de aba larga, tornando disformes as cabeças, por uma época em que os cabelos são uma longa, escura e pesada massa (COSTA, Op.cit., p.523).

Mostrar partes do corpo feminino ainda era visto como algo que maculava a respeitabilidade das mulheres.

Posteriormente, as barreiras entre homens e mulheres foram derrubadas e ambos puderam frequentar a praia no mesmo horário. $\mathrm{O}$ banho de mar, para além do discurso médico sobre as propriedades medicinais da água salgada, foi um incentivo à prática da natação. Nas décadas seguintes, surgiram as primeiras nadadoras de sucesso como Maria Lenk (MELO, op.cit.). Em 8 de fevereiro de 1920, a piscina do Fluminense recebeu a primeira competição de natação feminina com três provas, cada uma em estilo de nado diferente (PRIORE, Op.cit.,p.226). Na edição de $O$ Tico-Tico, de 12 de janeiro de 1916, fez referência a fundação de um clube para nadadoras:

\section{SWIMMING}

Grupo dos Amphybios:

Por iniciativa de Mlle. Carmen Lydia, acaba de se fundar uma agremiação para a pratica do mais salutar dos sports: a natação. A nossa sociedade merece o mais franco acolhimento dos nossos sportmen, e dado o interesse despertado pela natação, nitidamente entre nós, aos Grupos dos Amphybios, está reservado estrondoso sucesso. Do Grupo dos Amphybios, fazem parte diversas gentis senhoritas que se dedicam á natação no Cattete. A festa inaugural do Grupo dos Grupo dos Amphybios, realizou-se domingo, na ponte do Cattete, com muita concurrencia e animação, sendo feitos os convites pela senhorita Carmen Lydia. (s/p).

Observa-se que nas competições de remo, as mulheres tiveram um papel mais ativo, inclusive na organização de torneios. A maioria das participantes eram filhas de estrangeiros e pertencentes às elites. Além disso, o remo fazia parte do currículo escolar de escolas privadas junto com o cricket, o hipismo, o tiro ao alvo e o atletismo (MELO, Op.cit.). 
Não se deve pensar as atletas mulheres eram vistas com naturalidade. A Revista da Semana de 19 de fevereiro de 1916, publicou uma reportagem sobre a fundadora do Grupo dos Amphybios. Desperta atenção, as criticas ao traje banho da nadadora:

Carmen Sylvia, a pequena bailarina que nos salões elegantes do Rio já ehxibiu os seus talentos choreographicos, é tambem uma nadadora. No templo de Terspychere como nos aquáticos dominios de Neptuno, a jovem Carmen Sylvia, bailarina e sereia, tornou-se uma pequenina notabilidade. Commandando, como uma Amphitrite, o "Grupo dos Amphibios", a senhorinha Carmen Sylvia escolheu a ponte presidencial do Flamengo para os seus ensaios aquaticos ... e as suas attitudes plasticas, trajando, como Kallermann, o classico maillot preto. Surgem porém reclamações contra o maillot da senhorinha Carmen Sylvia. A "Revista da Semana" habilita os seus leitores, com esta pagina flagrante, a votar pró ou contra o maillot (p.25).

O estranhamento e a curiosidade sobre as práticas esportivas femininas, pode ser exemplificado com uma competição de luta realizada no Rio de Janeiro. De 10 de maio a 2 de junho de 1910, realizou-se no Theatro São Pedro "O grande campeonato feminino de lucta romana - $\mathrm{O}$ maior acontecimento da época pela primeira vez nas Américas" (O PAIZ, 10/05/1910, p.12). O torneiro foi considerado um sucesso e teve grande presença de torcedoras. Ao mesmo tempo em causavam admiração, a atletas despertavam comentários por terem corpos mais fortes e usarem roupas curtas e coladas ao corpo. Este aspecto pode ser observado na legenda da foto publicada na Revista da Semana, em 1 de maio de 1910, sobre as esportistas russas: 


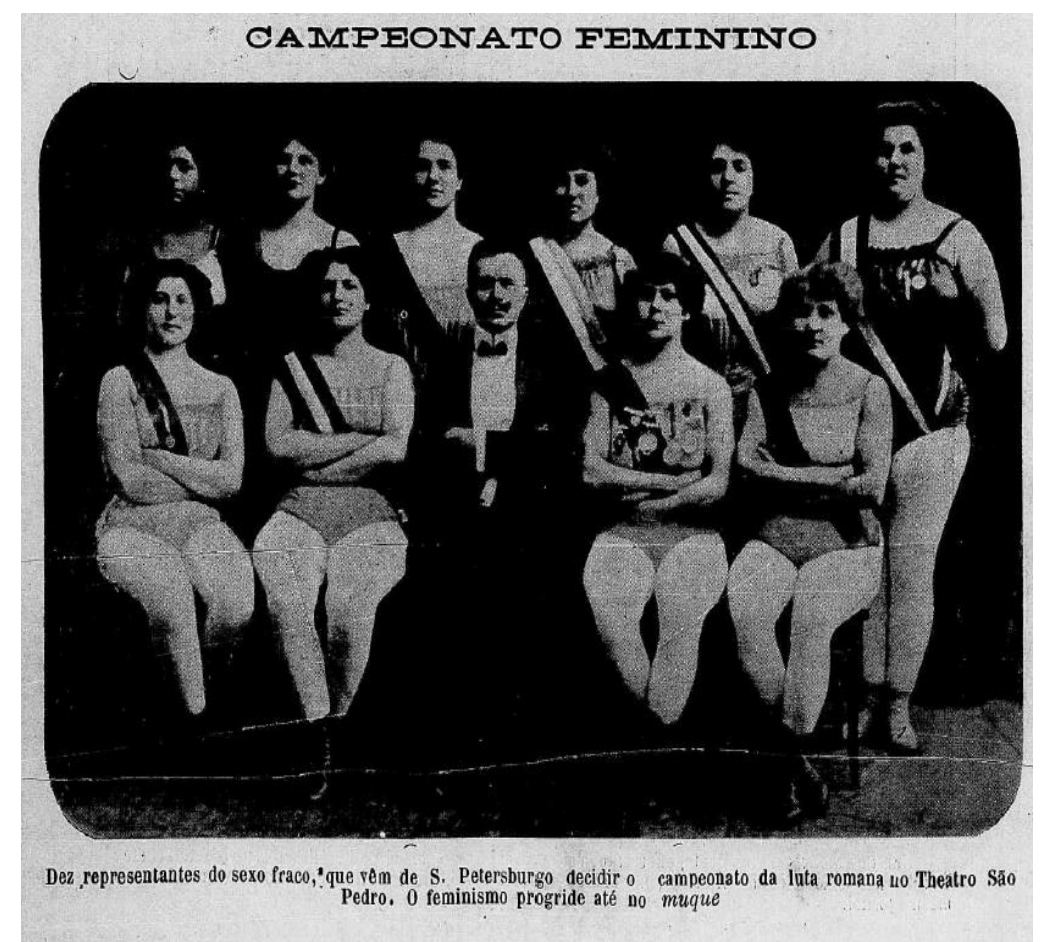

Figura 112 - Revista da Semana - 01/05/1910 - s/p

A foto de mulheres de maiô, em uma cidade na qual as senhoras respeitadas iam às praias com roupas fechadas. A legenda reforça o caráter de estranhamento: "Dez representantes do sexo fraco que vêm de S. Petersburgo decidir o campeonato de luta romana no Theatro São Pedro. O feminismo progride até no muque" ( $\mathrm{s} / \mathrm{p})$.

Identifica-se o o grupo como sexo fraco, ao mesmo tempo em que relacionam a força das atletas a supostas ligações ao movimento feminista. Em $O$ Tico-Tico, as práticas esportivas eram aconselhadas, desde que direcionadas a tornar o sexo feminino mais belo. Junto ao discurso da "esbeltez" (CAMPOS, Op.cit., p.148), havia a perspectiva de que um corpo saudável também estava ligado a aquisição de novos hábitos de higiene.

A narrativa $O$ pouco asseio de Mimi, de 11 de dezembro de 1912, ressalta a mensagem de que a falta de asseio pode prejudicar as relações sociais. A menina Mimi sempre sujava as roupas e não gostava de tomar banho. A consequência de seus atos foi não ter podido sair para passear de automóvel. Seus irmãos, sempre limpos, puderam se divertir (Fig.113) 


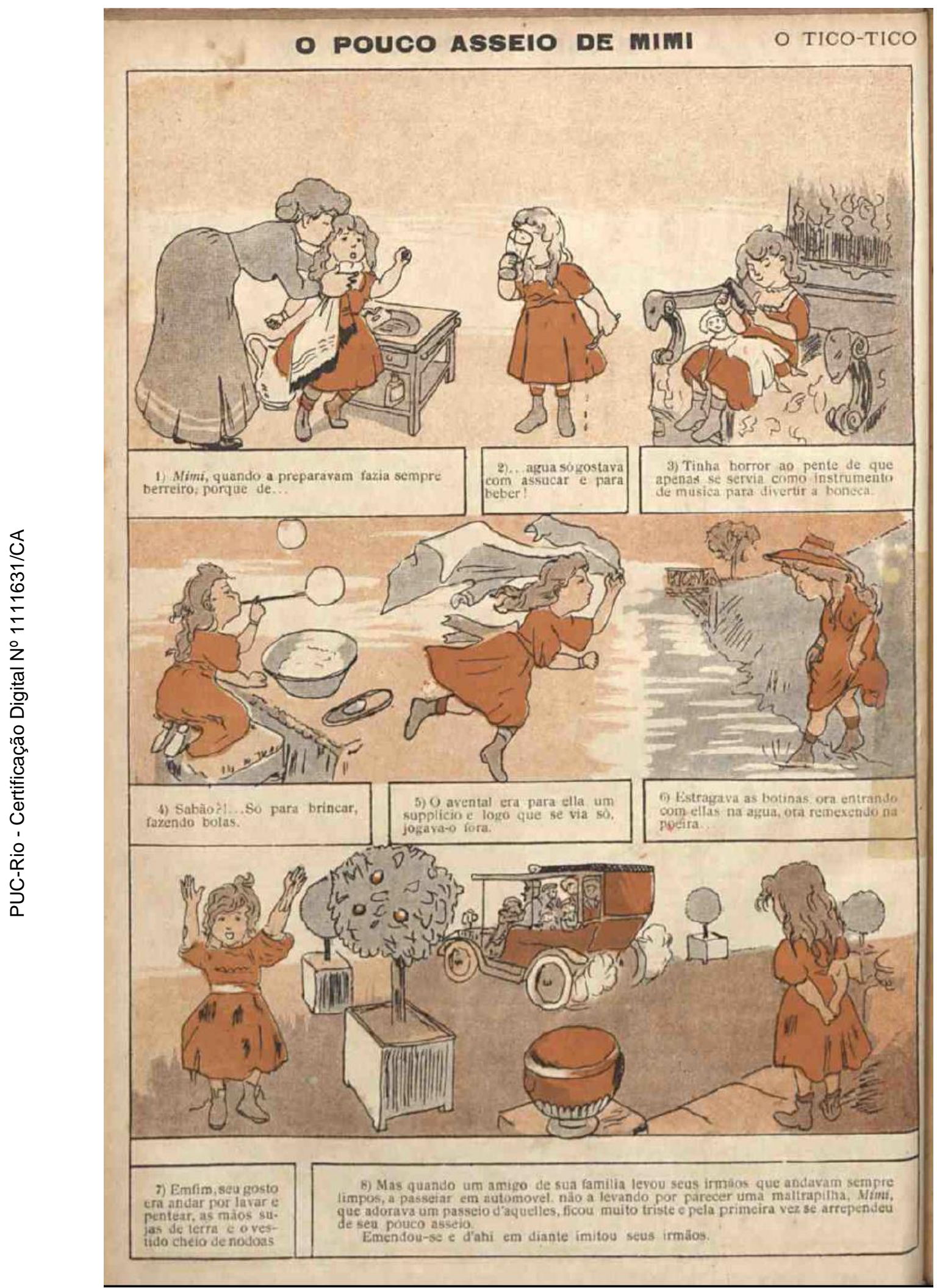

Figura $113-O$ Tico-Tico $-11 / 12 / 1912-s / p$. 
A seção $A$ arte de formar brasileiros, publicada entre maio e outubro de 1906, tinha o propósito de auxiliar na formação dos futuros líderes do país. Por meio dos conselhos de Tio José, personagem criado por Angelo Agostini, os meninos aprenderiam lições sobre como ser bons cidadãos e trabalhadores. “A leitura dos textos publicados em 'A arte de formar brasileiros' demonstra enorme cumplicidade entre a configuração de um tipo de nacionalismo preocupado com a formação de um novo homem e valores(...)" (HANSEN, Op.cit., p.33). Embora direcionada ao sexo masculino, a seção trazia personagens femininas.

Na edição, de 26 de setembro de 1906, na qual se debatia a questão do asseio, as meninas se fizeram presentes. Aborda-se à necessidade das crianças cuidarem da higiene pessoal: "Meus caros amiguinhos: Tenho lhes falado muito das qualidades moraes e intellectuais que um menino ou uma menina devem ter para que sejam mais tarde pessoas de valor e de merito" (s/p). Em seguida, descreve-se que os cuidados com o corpo são tão importantes quanto à dedicação aos estudos:

Não basta que se tenham qualidade de espírito, não basta ser intelligente e instruido para ser um homem digno ou moça apreciável; é necessario ter tambem vantagens physicas: em primeiro lugar ser robusto, sáo e agil, ter maneiras distinctas e asseio. (Loc.cit.).

As representações da falta de asseio trazem imagens de meninas que relutam em seguir as regras de higiene. $\mathrm{Na}$ primeira figura, uma garota nitidamente descontente por ter que pentear os cabelos. "As meninas que não cuidam de seus cabellos e choram quando alguem as vai pentear, por mais bonitas que sejam sempre parecem feias" (Loc.cit). A segunda imagem apresenta uma menina sendo repreendida por estar com o vestido sujo. "Esta menina não tem zelo pela roupa. Vestiu um vestido novo, estava toda faceira, mas já se sujou de tinta, zangando seu pai e agora não pode ir passear com seus irmãos" (Loc.cit.) O fato da seção de meninos apresentar questões de higiene pelo víeis feminino, poderia ser uma forma dos pequenos leitores reconhecerem, desde a infância, os predicados que o sexo feminino deveria cultivar afim de ser tornarem bons partidos no futuro. 
Segundo Sant'Anna (Op.cit), as práticas de asseio eram identificadas como uma espécie de virtude. Estar com aparência e as roupas limpas, significava ter um atestado de ilibada conduta. As mulheres demonstravam sua preocupação com a limpeza ao manterem a casa sempre arrumada e as vestes lavadas:

As roupas brancas, lavadas e penduradas nos varais dos quintais, assim como as panelas areadas - com areia misturada à água - e expostas para secar sobre o peitoril das janelas, também possuíam tal função, assemelhando-se a troféus obtidos pela labuta diária (p.293).

A aquisição destes novos hábitos de higiene precisava ser em ensinada aos cidadãos. Para além dos artigos e reportagens, a publicidade se constituiu em um dos principais meios utilizados para tal finalidade. Inicialmente, os anúncios publicitários não estavam presentes nas páginas de $O$ Tico-Tico, mas por razões financeiras este panorama foi rapidamente modificado. No comunicado $O s$ Annuncios d'O Tico-Tico - Páginas A' Parte, publicado em 17 de janeiro de 1906, foram apresentadas as razões pelas quais, impresso revista teria oito folhas de anúncios, e com isso passaria de 16 para 24 páginas totais:

Para attender a varias solicitações $O$ Tico-Tico apparece hoje com mais oito páginas, que são de annuncios, mas de annuncios que, em grande parte, por sua natureza podem ainda cumprir a nossa missão de divertir e estimular e ser útil ás crianças. $O$ Tico-Tico surgiu sem publicar annuncios, sendo uma de suas principais novidades, pois que no Brasil, e não só no Brasil como em toda a parte, os jornaes todos inserem annuncios. Vejam os mesmos jornaes de crianças de Pariz e verão que não ha um só que deixe de acolher a materia paga. Mas O Tico-Tico, jornal destinado ás crianças do Brasil, resolveu não publicar annuncios; e agora, como os pedidos para que o fizessem fossem muitos, para attender a esses pedidos e ao mesmo tempo não se afastar de seu programa, $O$ Tico-Tico deliberou conciliar as duas cousas, publicando annuncios, sim, mas prejudicar seus queridos pequenos leitores. Os annuncios d'O Tico-Tico são publicados em paginas a maior, como se pode ver neste numero. São paginas á parte e em muitas dellas se encontram annuncios que, pelo seu feitio interessante, podem ser ainda leitura agradável e própria para crianças. Entre esses annuncios há por exemplo, novos concursos que lhes dão direito a premios, etc. Portanto, é preciso que fique bem acentuado que, com as nossas paginas de annuncios nada perdem os leitores d $O$ Tico-Tico e antes ganham. São mais oito páginas que lhes damos (p.5). 
Observa-se que, a indústria farmacêutica e alimentícia, eram os principais anunciantes de $O$ Tico-Tico. Em virtude de seus conteúdos, os leitores poderiam ter acesso aos produtos de higiene e medicamentos mais modernos. "As ações publicitárias focalizavam prioritariamente as mulheres, destacando-as como consumidoras, através dela influenciavam a mudança de hábitos de toda a família" (MATOS, 2010, p.1). No impresso infantil, tais mensagens como principal destinatário: a mãe.

A marca de sabonete Reuter publicou o anúncio Como amou o banho, no qual descreve a forma correta de se banhar um menino com aversão à água $(\mathrm{O}$ TICO-TICO, 15/10/1919, s/p.):

Este pequerrucho era selvajamente refractario á água. Quando ouvia qualquer ruído numa banheira, punha-se a gritar como um condemnado. Nem bonbons, nem festas, conseguiam domar esta aversão. Seus paes haviam decidido não banhal-o, porque, cada banho mais ligeiro que fosse, originava no nenê uma enfermidade. Uma nova ama secca achou o remedio, de sorte que o pequenote agora chapinha na banheira até mesmo vestido. $\mathrm{O}$ remedio foi o sabonete Reuter. Em casa contam isso como um milagre. Um dia viu-o sobre a mesa e quiz comel-o.A ama secca pegou nelle e foi com elle para o quarto de banho. O menino a seguiu.

-Dou-te-o se me deixas despir-te. O "bijou" não oppoz resistência.

- Bom: agora deixe-me untar a cabeça com elle.

- Sem agua?

- Não: com água.

- Porém a agua vae-me molhar.

- Depois te enxugo.

- E em seguida m’o dáz?

- Sim.

O pequerrucho poz docilmente a cabeça debaixo da torneira.

- Fecha os olhos.

- Assim?

-Sim.

- E me dáz a cousa côr de rosa?

- Sim

- Que rico cheiro!

- Mette-te na agua.

- Eu não sei nadar.

- Não faz mal, eu seguro-te.

- E dás-me a cousa rosada?

Sim...

Para abreviar: metteu o menino na banheira. A servente lavouo, muito bem lavado, e logo o envolveu em seus vestidinhos recem-passados a ferro, apresentando-o em seguida a seus paes jubilosos com um sabonete de Reuter em cada mão. 
Este tipo de publicidade tem o caráter profilático, pois além de apresentar os produtos às mães, também as ensina como utilizá-lo corretamente. Quando as crianças se mostram bem cuidadas e sadias, tem-se um indicativo de que a figura materna cumpriu seu dever com louvor. A perspectiva higienista entende o corpo como uma vitrine da nação (MATOS, Op.cit.).

A partir do século XIX, a presença do médico de confiança da família passa a ser uma constante nas classes mais abastadas. Situação que também se repetiu no Brasil: “Os pacientes e seus familiares ouvem seu diagnóstico, compreendem seus conselhos, sabem escutar suas instruções, têm todos os meios para respeitar a higiene que ele prescreve" (CORBIN, 2009, p.554).

O universo escolar também foi afetado pelo discurso sanitarista. Nas décadas iniciais século XX, foram criados pelotões de saúde. Tinham o propósito de estabelecer "a vigilância sobre o estado de limpeza do corpo, da roupa e dos modos dos seus colegas" (NUNES, 2011, p.385). Os alunos membros tinham que verificar se os outros estudantes tinham cumprido as seguintes regras de higiene (Loc.cit.):

1 - Lavei as mãos e o rosto ao acordar.

2 - Tomei banho com água e sabão.

3 - Penteei os cabelos e limpei as unhas.

4- Escovei os dentes.

5- Fiz ginástica ao ar livre.

6- Fiz uma evacuação intestinal, lavando depois as mãos com água e sabão.

7 - Brinquei mais de meia hora ao ar livre.

8 - Tomei um copo de leite.

9 - Bebi mais de três copos de água.

10 - Fiz respirações profundas ao ar livre.

11- Estive sempre direito, quer de pé, quer sentado. Só li e escrevi em boa posição.

12 - Só bebi água no meu copo e só limpei os olhos e o nariz com o meu lenço.

13 - Dormi a noite passada oito horas pelo menos, em quarto ventilado.

14- Comi frutas e ervas bem lavadas. Lavei as mãos antes de comer e mastiguei devagar tudo o que comi.

15- Andei sempre calçado e com roupa limpa.

16- Não beijei nem me deixei beijar.

17- Não cuspi nem escarrei no chão. Ao espirrar ou tossir usei o meu lenço.

18 - Não coloquei na boca, no nariz e nos ouvidos nem o lápis nem nada que estivesse sujo ou pudesse machucarme.

19 - Não tomei álcool. Não fumei.

20 - Não menti, nem brincando. 
As páginas de $O$ Tico-Tico são forradas de anúncios de fortificantes, vermífugos, depurativos sanguíneos, complementos alimentares e remédios que prometiam a cura para as mais variadas doenças.

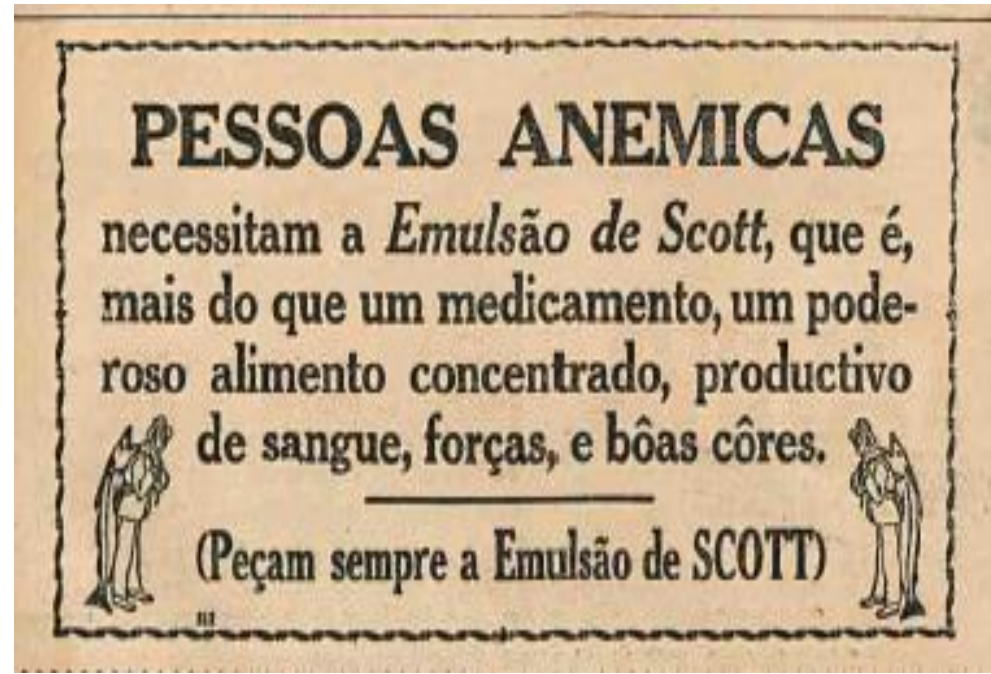

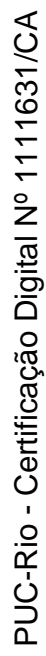

Figura 114-O Tico-Tico - 10/03/1920 - s/p

\section{CODTRA A FRARUEZA, DERUOSIDADE $\epsilon$} DYSPEPSIA, TOMAR PHOSPHORO E FERRO

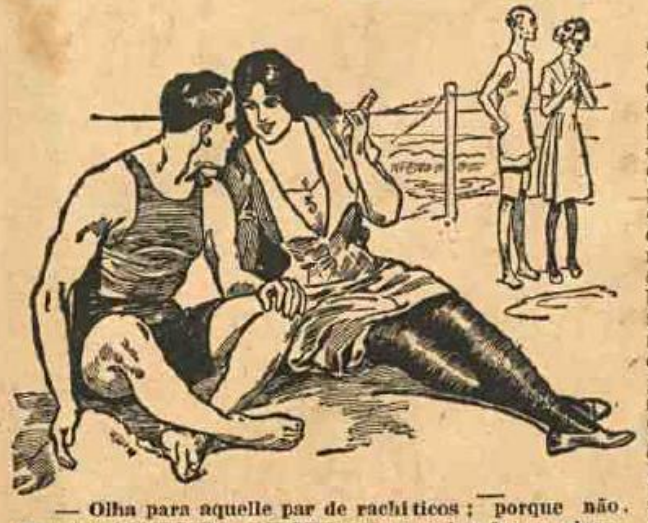

A grande maioria das pessoas fracas, nervosas a dyspepticas, desejosas de augmentarem suas forcas e energras, incorre infelizmente no grande erro de mecicase com orimeiro remedio que varn annuriclado, sob o nome de fortificante, ete, sem verificar estado de saude. Se elles soubessem que a sua fia queza e debifidade sáo devidas, nio a ralta de drogas, mas a defficiencia de seus orgãos digestivos e do assimilapio em extrahirem dos alimentos todo o ferro e phosphoro de que tanto precisa seu orga nismo, de certo que reconheceriam scu erro, e sc explicariam porque os medicamentos lomados naio thes fizeram bem algum. O que taes pessoas precimam con mo, tomando por a gum tempo com as releicóes phuto ferruginoso-organico) cue é o tonico' (phosintivo a niti-drspeptico mis eftieaz conheciniCom o auxilio do COMPUSTO RBBOTT seu sin gue tirará dos alimentos todo o ferro e phosphoro que seu organismo precisa, fazendo-o fanliar forças, energias e vitatidade com rapidez assom- Oiha para aquelle par de rachi ticos : porque não. brosa. Muitas pessoas duplicam e até triplieath

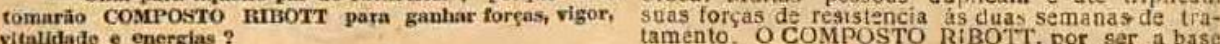
vitalidade e energias ? de ferro organico, na sua forma mais assimilavel conhecida, produz milhōes de globulos vermelhos no sangue, tortiffea, dá yida e vigor, calma os nervos, e e um poderoso vigorante para homens, malheres e creancas. Se V. Sente-se raco, cervoso e abitudo. se seu estomago na digere bem os allon a poreza do sangue incommoda com recommendara 0 coMposTo RIBOTT vende-se em todas as drogarias e pharmacias acreditadas. Mart daremos amostra gratis as pessoas interessadas que solicitem nrecos e remettam 400 rés para pagar o porfe etc. Unico depositario no Brazil: B. Nieva, Cuika postal, 979 . Rio de Jineito.

Figura 115 - O Tico-Tico - 09/10/1918 -p.2 


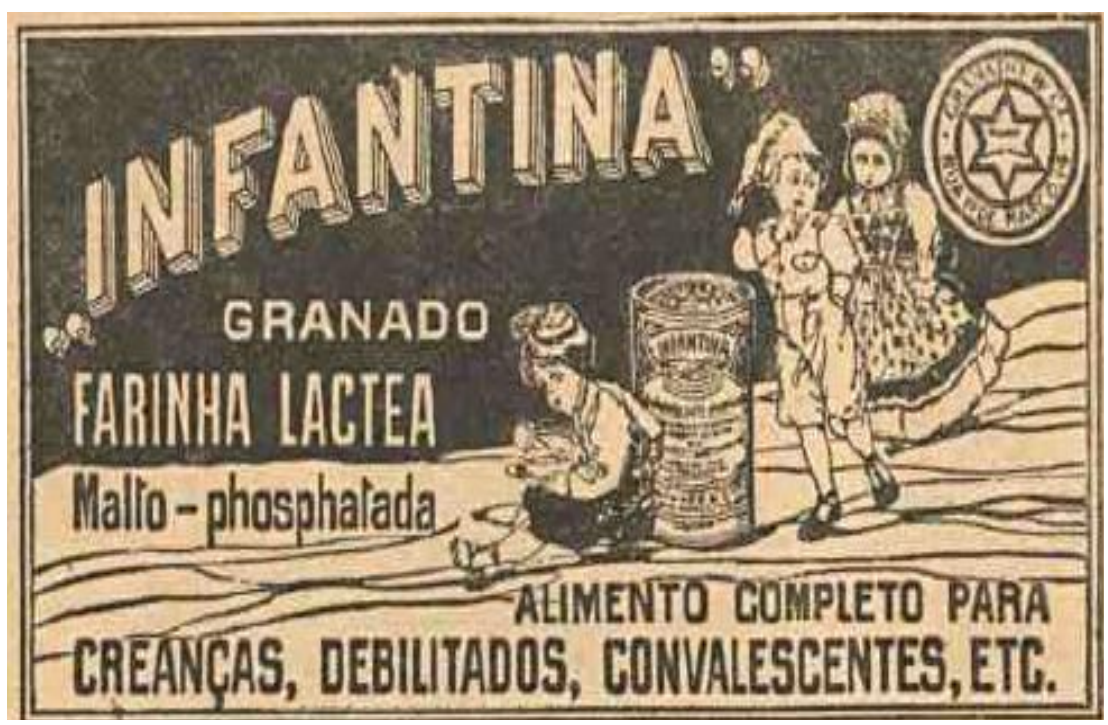

Figura 116-O Tico-Tico-11/07/1918 - s/p

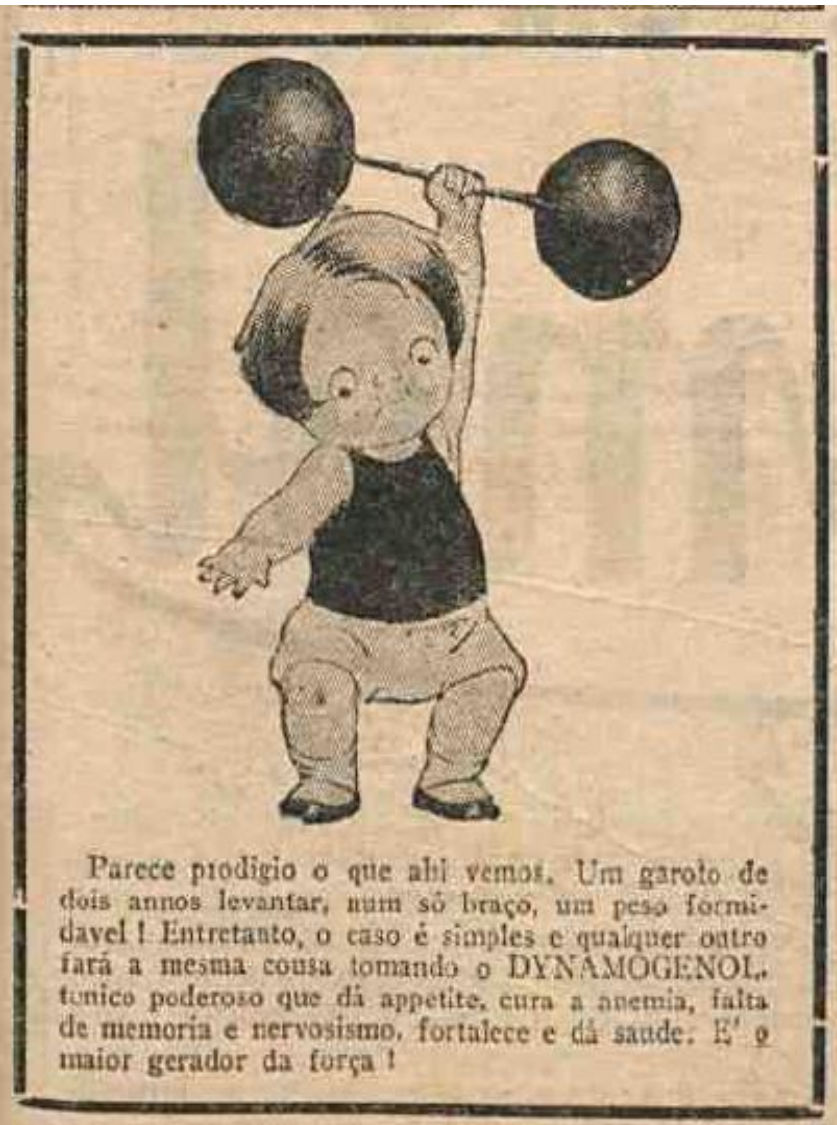

Figura 117- O Tico-Tico - 15/01/1919- s/p 


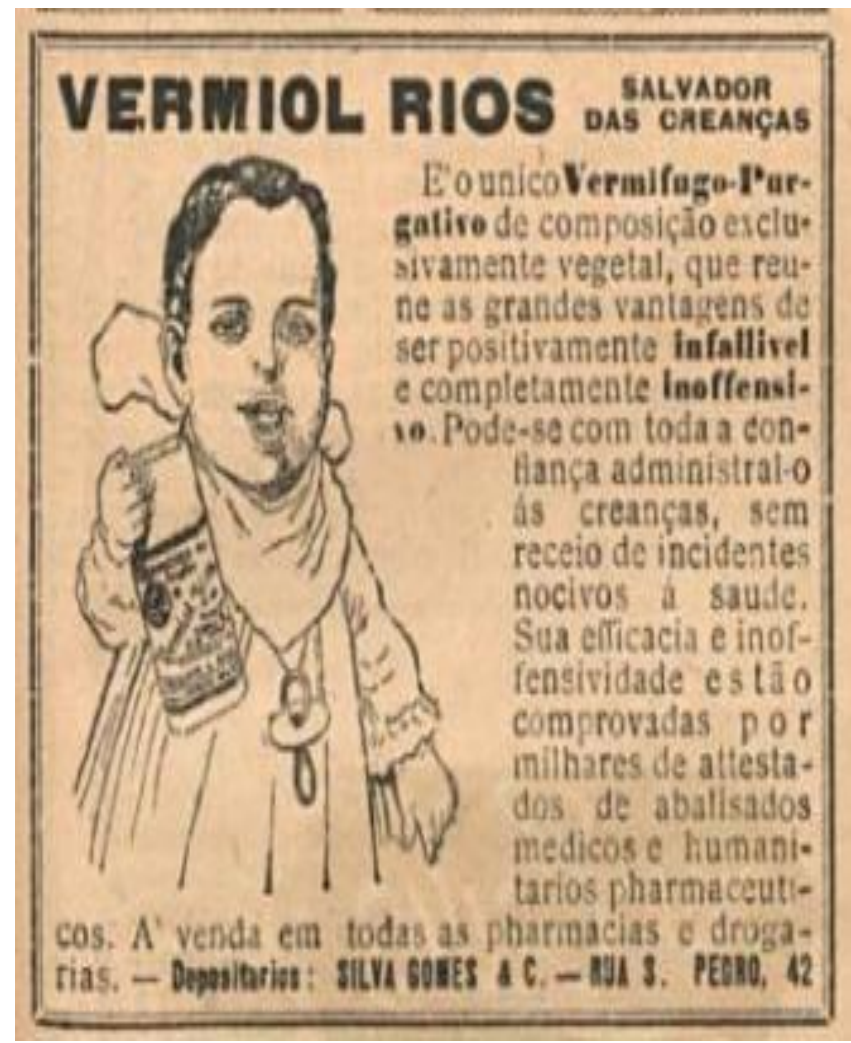

Figura 118 - O Tico-Tico - 21/11/1917- s/p

Este tipo de publicidade apresentava às mães quais os medicamentos poderiam curar as moléstias e as fraquezas infantis. A anemia e a magreza extrema passaram a ser vistas como sinônimo de feiura. Neste sentido, a propaganda

(...) projetava influenciar e aumentar o consumo, mas também transformava hábitos, educava e informava, através do seu caráter repetitivo permitia maior facilidade de memorizar a mensagem. Enquanto produto cultural reproduzia expectativas e práticas que circulavam socialmente, não inventava sentidos, mas recriava e reforçava, além de vender estilos de vida, sensações, emoções, visões de mundo, desejos, dentro de certa margem de autonomia dos receptores (MATOS, Op.cit.,p.1).

Segundo Cott (1991) a publicidade, no início do século XX, foi usada como meio de circulação dos anseios prescritos às mulheres modernas. Apontam o modo correto de se vestir, de pentear-se, de comportar-se e de promover a felicidade familiar. "Através das compras ligava-se a dona de casa à nova economia doméstica e a mãe a educação científica dos filhos” (p.108). Com o avanço das técnicas gráficas e o advento da fotografia, os anúncios passaram a englobar não apenas um determinado produto, mais também certas construções imagéticas do sexo feminino. Para Joly (2006) tais mensagens são formuladas com o propósito de serem compreendidas por um grande número de pessoas. Por 
tal razão, demonstram claramente seus elementos e os conteúdos a serem transmitidos.

Inicialmente, os publicitários exerceram o papel de educadores e prestadores de serviços. Era preciso que as consumidoras compreendessem a necessidade de se adequarem as mudanças na sociedade. Depois, desempenharam a função de despertar desejos e necessidades. Instituir uma relação de intimidade com o público, em meio ao crescimento industrial e a produção de mercadorias em massa:

Os publicitários e especialistas em técnicas de promoção se referiam sempre ao consumidor como 'ela'. Inúmeras publicações dos anos 20 citavam a estatística de que $80 \%$ das compras de consumidores eram efectuadas por mulheres (COTT, Op.cit.,p.109).

Este tipo de anúncio, salienta o fato do público feminino adulto também fazer parte da base de leitores de O Tico-Tico.

\subsection{A perfeição feminina: a boa mãe e bela mulher}

A seção Para nossas leitoras de 11 de outubro de 1916, publicou uma série de conselhos sobre a importância dos cuidados com a pele:

\section{O COLLO E O ROSTO}

$\mathrm{O}$ collo e o rosto precisam dos maiores cuidados, pois que a frecura da pelle constitue um dos maiores encantos da mulher. Belleza do collo depende unicamente do livre exercício dos orgãos e da voz. Se estes se acham fatigados, o pescoço incha e os músculos engrossam e deformam o collo. O gritar ou fallar em voz mais alta do que o tom que a natureza lhe nos concedeu tambem desfigura a beleza natural do collo, porque obriga os canaes vocaes a dilaterem-se, e essa dilatação reproduz-se exteriormente. A garganta não se deve trazer comprimida com artefactos, porquanto esses apertos prejudicam a belleza do rosto, convulcionando-o, avermelhando-o, tornando-o defeituoso e enchendo o pescoço com rugas. Para que as intempéries não ataquem a pelle, roubando-lhe seus encantos, defendei a garganta e o collo com um pouco de pó de arroz. Ao deitar, é conveniente para a frescura e a belleza de pelle, passar sobre o rosto e o collo uma esponja embebida em chá verde, muito forte, ou agua de Colonia (s/p).

Em 8 de dezembro de 1920, foi publicado o anúncio de uma marca de alimentos Nestlé. O conteúdo, voltado às mães, trata da amamentação e cuidados com os filhos: 


\begin{abstract}
PROTECÇÃO A INFANCIA
UMA GENEROSA OFFERTA ÁS MÃES BRASILEIRAS

A Companhia Nestlé por intermédio do seu amável Chefe de Publicidade Sr. Jorge Farriá, teve a nímia gentileza de offerecer-nos dois utillissimos livrinhos de hygiene infantil, destinados á distribuição gratuita entre as senhoras brasileiras. Num paiz como o nosso, onde a infancia e os problemas que lhe dizem, pouca ou nenhuma attenção merecem dos poderes públicos, uma iniciativa como esta prestará, incontestavelmente, um valioso serviço á nossa população sobretudo ás jovens mamãs inexperientes em assumptos de hygiene das creanças. Sabidamente, a falta de instrucção, a ignorancia, por parte do povo, das regras mais comesinhas de hygiene infantil, constituem uma das causas principaes da grande mortandade de creancinhas, entre 1 e 2 annos de idade. Para esses, para os pobre e desprotegidos da fortuna, é que a preciosa dádiva da Nestlé será um verdadeiro presente do Céo; sem nenhuma despesa, nalgum dias apenas, uma Mãe carinhosa aprenderá o sufficiente para salvaguardar seus filhos dos inúmeros perigos de uma alimentação deffeituosa. Além disso, qualquer dos dois volumes traz farta mésse de conselhos, regras e preceitos applicaveis a todas as phases do crescimento do bébé (s/p).
\end{abstract}

Os textos fazem referências a duas representações constantemente vinculadas ao sexo feminino: a boa mãe e a bela mulher.

\title{
4.4.1 - A boa mãe
}

E`s mãe! - Quanta sublimidade existe neste monossyllabo! Mãe, sanctuario aberto ao pequenino ser que desponta na manhã da vida; abençoado nome que ao pronuncial-o nos sentimos cheios de vida, de fé e cheios de coragem para a luta que devemos empreender! Não ha palavra, não ha verso que defina esse bemdito e sublime none - Mãe! Eis a razão porque deves te sentir summamente feliz neste momento em que já sabes o que é maternidade. Mas, minha boa amiga, ser mãe não é apenas ter a certeza de possuir uma filha ou um filho, e sim ter a convicção de saber educal-a no dia de amanhã (p.19).

Este texto foi publicado, em 18 de janeiro de 1917, na seção Cartas ás mães de família, do impresso Jornal das Moças. O conteúdo é parte da resposta de MLLe. Maria de Lourdes endereçada à leitora Antonietta, uma mãe de primeira viagem. Ao longo do texto é ressaltada a beleza da maternidade e o quanto a mesma pode tornar completa a vida de mulher. No entanto, o cuidado com o desenvolvimento dos filhos se constitui em uma missão que deve ser cumprida com responsabilidade. 
As mensagens imagéticas e textuais, contêm uma linguagem imperativa na qual é salientada a missão feminina de cuidar dos filhos. As crianças necessitam de uma formação moral, mais também da garantia do seu pleno desenvolvimento físico. Neste contexto, a maternidade se torna temática recorrente nos anúncios publicitários. Estampam-se imagens de mulheres realizadas e felizes cuidando da alimentação e da higiene dos filhos. Centra-se no discurso da mãe devotada.

Os conteúdos seguem os padrões os manuais femininos, como os escritos por Julia Lopes de Almeida, nos quais à maternidade é considerada um instinto natural feminino que necessita ser estimulado e lapidado (MAGALDI, Op.cit.). Afirma-se que a totalidade das mães não sabe cuidar dos rebentos corretamente. Ensiná-las, afastaria o perigo da má criação e de consequências nefastas para o desenvolvimento das crianças.

Todas as senhoras devem (...) ler com escrupuloso cuidado, antes do nascimento do seu primeiro filho, algum livro concernente à boa higiene das amas e à amamentação das crianças - importante saber que tipos de alimentos devem comer, que cuidados devem tomar (...), de modo a atingirem a boa criação dos filhos (ALMEIDA,1905 apud Ibidem, p.94).

Os anúncios publicados em $O$ Tico-Tico ressaltam as dimensões informativa e educacional. As mães são apresentadas a novos produtos e cuidados higiênicos. Quando não fazem uso de tais aparatos, elas são consideradas culpadas por eventos como a mortalidade infantil. A ignorância materna tinha de ser combatida. O discurso publicitário do leite em pó Glaxo Maternizado, desenvolvido pelo grupo inglês The Harrison Institute, reforça esta mensagem:

\section{DEUS NO CÉU E GLAXO NA TERRA}

Deus é o protector das crianças e da infancia e o GLAXO LEITE MATERNIZADO, produto inglez, é a alimentação natural e a mais apropriada para a subsistencia das creanças. Para que nenhuma creança soffra, por ignorar sua mãe que existe este substituto exacto do leite materno, o "THE HARRISON INSTITUTE", organisado para combater a grande mortandade infantil, remete livre de porte a todas as mães de familia, mediante o recebimento do coupon abaixo, devidamente informado, um livro tratando dos cuidados das creanças, intitulado "O REI DA CASA" (O TICO-TICO, 22/04/1914, p.4)

O conteúdo deixa claro que, o complemento substitutivo ao leite materno, tem o papel de proteger meninas e meninos dos sofrimentos impingidos, por uma mãe leiga. Por ter a função social de cuidar do futuro da nação, quaisquer desvios 
eram identificados como falhas de uma mulher desnaturada. Neste sentido, ocorre uma criminalização da mãe quando esta não consegue amamentar os filhos. Para evitar que tais situações ocorressem, o fortificante Emulsão Scott se apresentava como um auxiliador e não como um substituto da figura materna:

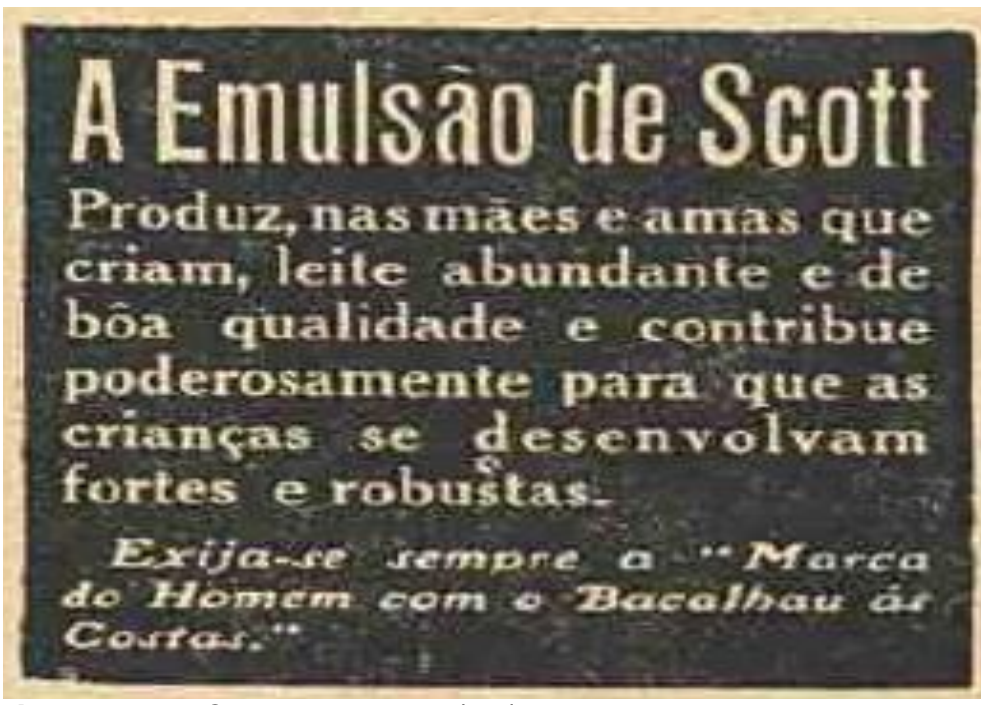

Figura 118- O Tico-Tico-14/06/1911-p.16

Este período foi marcado por debates sobre o aleitamento materno. Segundo Priore (Op.cit.), de um lado estavam as indústrias voltadas à produção do leite artificial, leite condensado e o leite pasteurizado. De outro se encontravam os médicos e os intelectuais que classificavam o leite materno como uma forma de proteção à criança.

As edições do periódico A Mãi de Familia trazem argumentos favoráveis ao aleitamento materno, mais do isso, salientam. "Entregar o filho para ser amamentado por outra mulher era apontado como um erro gravíssimo" (CARULA, 2012, p.198). Os textos proclamam a amamentação como a única forma da mulher exercer de forma plena à maternidade. As mães que não cumprissem com tal papel eram consideradas egoístas e displicentes:

Se a mulher alimentara o filho com o seu próprio sangue durante nove meses, nada mais correto que, após o nascimento, continuasse a fazê-lo por meio do leite. Para sustentar seu argumento, Carlos Costa citou os animais na natureza, que alimentavam seus filhotes sem que ninguém precisasse lhes dizer o que fazer (Ibidem., p.199).

Identifica-se como formas de aleitamento: o artificial, o misto feminino e o mercenário. A amamentação artificial só deveria ser aceita em caso de 
enfermidade materna. Neste caso, o leite de vaca deveria ser o preferido. O misto feminino era admitido quando a mãe não produzisse leite em quantidade suficiente. Recorria-se à ajuda de uma ama de leite. O modelo mercenário estava vinculado à prática de receber pagamento para amamentar os filhos de outras mães. A publicação combatia a figura das amas de leite, principalmente quando negras (escrava ou liberta). O discurso calcado em um ideário racista, alegava que comportamentos inapropriados poderiam ser transmitidos através da amamentação (Ibidem.).

As mães são constantemente chamadas à responsabilidade de evitar que os filhos sofram na vida adulta, as consequências dos maus hábitos adquiridos durante à infância. Os anúncios do líquido Odol, destinado à limpeza dentária, clama que elas cumpram o papel de garantir às crianças, um crescimento saudável:

\begin{abstract}
A'smãis que não quizerem nada descuidar afim de preservar as suas creanças das doenças contagiosas, nós damos o seguinte conselho: Sabe- se que o nariz é a via principal pela qual penetram os microorganismos de todo a sorte de doenças contagiosas e, em particular, affecções de garganta, diphtrite, tuberculose, etc. Está também provado que a bocca mesma offerece um terreno muito favorável para o desenvolvimento de toda a sorte de micróbios pathogenicos Ora, a medida preventiva contra as infecções consiste em prevenir o desenvolvimento, dos germens que poderiam ter tido accesso na bocca. Pode-se obter este resultado, d'uma maneira mui simples e mui agradável, lavando-se a bocca regularmente com o dentifricio antíseptico Odol. Os adultos se enxagoam a bocca com o Odol, ás creanças limpa-se a bocca com um panno molhado n'uma mistura de água e de Odol; devem-se fazer estas operações de limpar particularmente,de manhã e de tarde,se for possivel, depois de jantar. Não pretendemos dar aqui um remédio universal contra todas as doenças infecciosas, mas nós buscamos fazer conhecer um meio excellente de prevenção, cuja utilidade incontestável ninguém deve desconhecer, e especialmente os pais. O Odol vende-se em frascos especiaes, cujo contendo é sufficiente para o emprego de alguns mezes. Acha-se á venda em todas as boas pharmacias, drogarias, perfumarias. etc (O TICO-TICO, 07/07/1912, s/p).
\end{abstract}

\title{
UMA GRAVE RESPONSABILIDADE
}

pesa sobre as mães que não tratam da bocca e dos dentes dos seus filhos desde a sua tenra idade. Os peiores males, precisamente aquelles que victimam muitas existencias, são causados pelos micróbios que se desenvolvem na cavidade da bocca. Entretando é muito facil de paralysar a acção desses 
seres perniciosos, em usando quotidianamente o dentifrício liquido ODOL (O TICO-TICO, 30/03/1921, s/p.).

Denominado As mães, a propaganda do preparado Vinol de combate à fraqueza, ressalta que as mulheres devem oferecer o composto aos filhos. O conteúdo apela à descrição de crianças doentes para sensibilizar as mães sobre a importância de adquirir o complemento alimentar:

Quando virdes os vossos filhos fracos e rachiticos, em
consequencia do crescimento demasiado, excesso de estudo,
falta de exercicio, ou anemias; ou, quando, após enfermidades
que debilitam os seus pequeninos corpos, os virdes continuar
fracos e tristez, mezes e mezes consecutivos, como si jamais
recuperassem a saude perdida, da-lhas VINOL, nosso delicioso
preparado de fígados frescos de bacalhão, sem oleo, combinado
com Peptonato de Ferro Medicinal, e vereis logo como ficam
fortes, tomam boas cores, e os vossos corações de mães se
alegrarão com essa transformação - VINOL não contém oleo,
não repugnando, portanto ao estomago mais delicado, e é alem
disso, de sabor delicioso. - Com seu uso tornam-se; as crianças
robustas e sadias e é um dever das mães experimentar este
preparado, na sciencia de que devolveremos o dinheiro si não
der os resultados que annunciamos (O TICO-TICO, 20/01/
1909, p.8).

É importante salientar novamente o emprego do verbo dever. A imagem de filhos bem nutridos se configura perante a sociedade, em um símbolo de aprovação da mulher como mãe. Os anúncios não fazem referência à possíveis causas dos males infantis, apenas reforçam o maniqueísmo entre a boa mãe e a mãe displicente. Neste contexto, todos os tipos de produto lhes eram oferecidos. Por exemplo, o Collar Indiano do Dr. Rouvillot e a Matricaria. Supostamente aprovados por médicos e cientistas, prometiam amenizar os males da primeira dentição. Com a chancela da ciência, as Mães Carinhosas e A's Mães de Familia poderiam evitar o sofrimento dos pequeninos. 


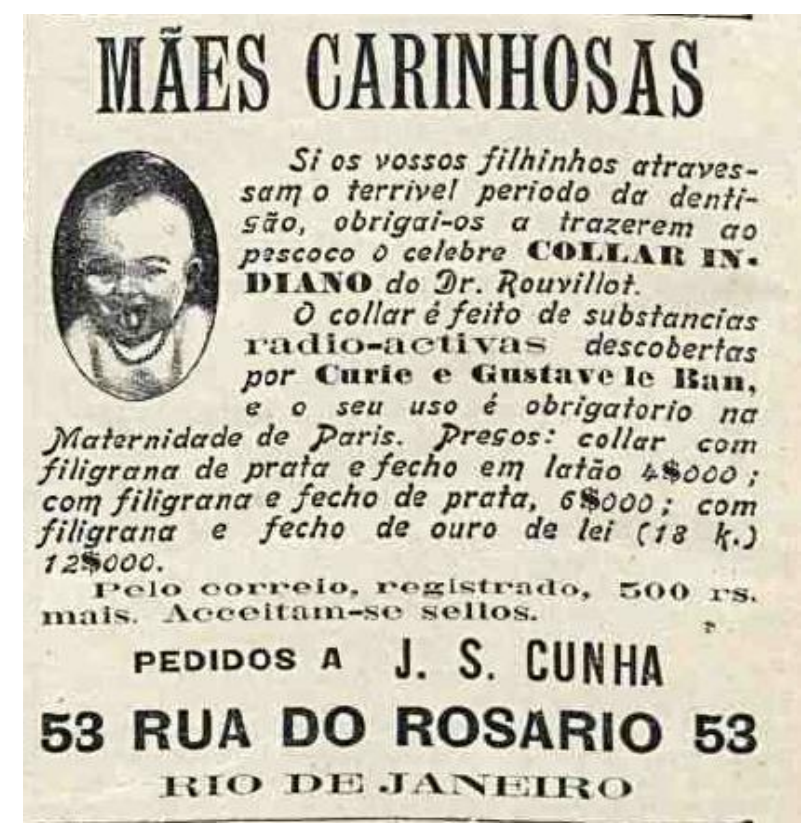

Figura 119 - O Tico-Tico - 01/05/1907 - s/p

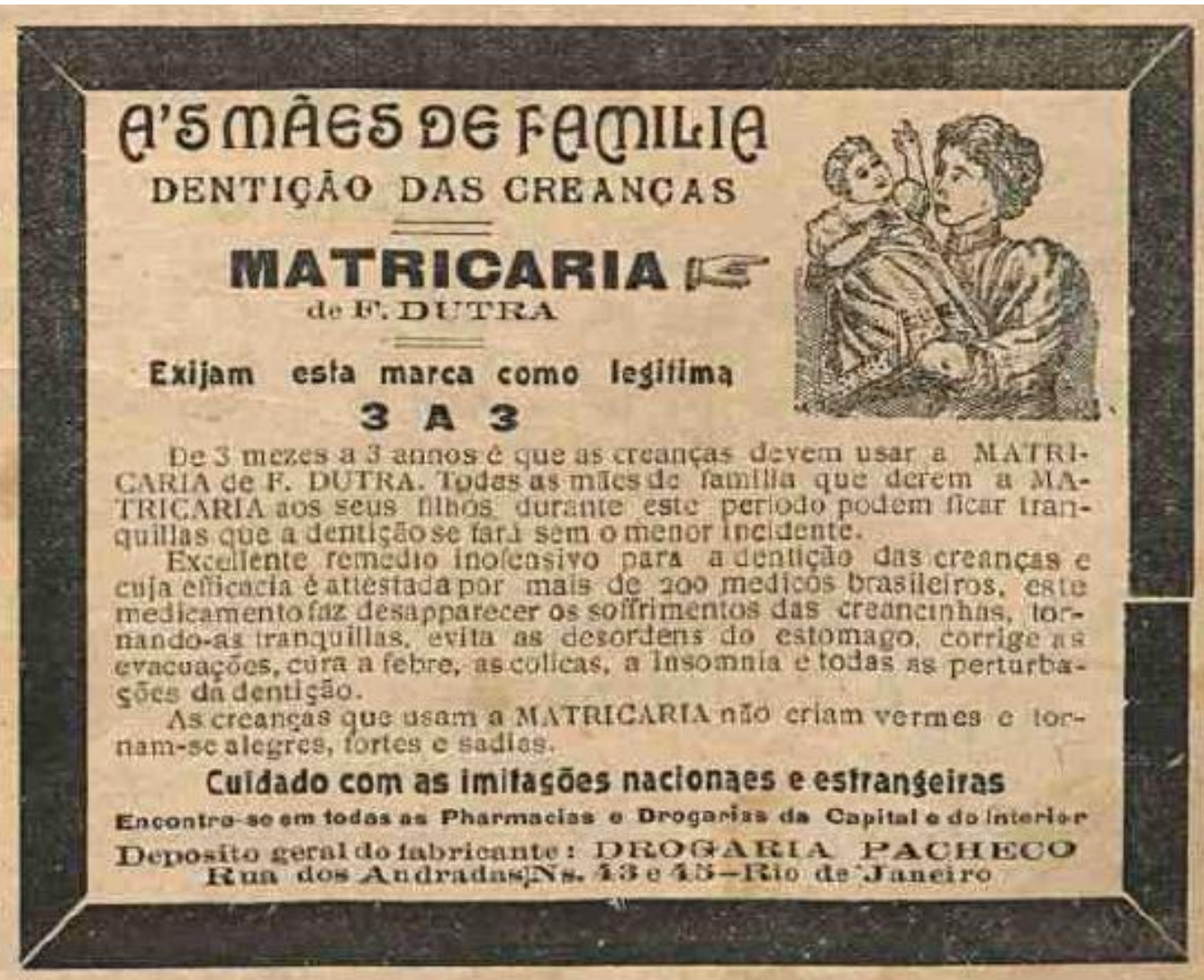

Figura 120 - O Tico-Tico-23/08/1916 -s/p. 
Para que as mães pudessem cumprir plenamente sua missão, os anúncios presentes em $O$ Tico-Tico também visavam auxiliar o fortalecimento do físico feminino. Uma mulher cansada não conseguiria cuidar dos filhos e administrar a casa, situação que poderia acarretar na desarmonia familiar. Em outro anúncio, a Emulsão Scott se propõe a incentivar a robustez materna:

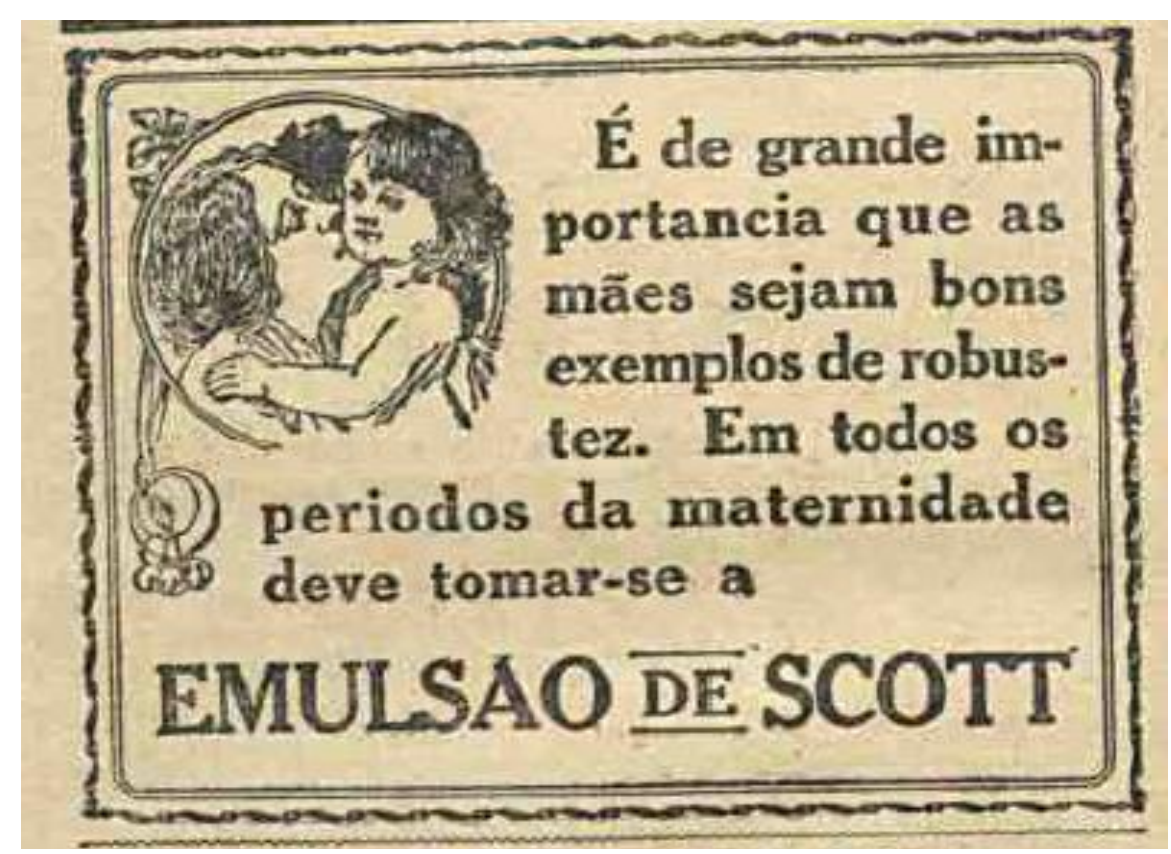

Figura 121-O Tico-Tico - 30/10/1912 - s/p

O anúncio do Xarope das Crianças, responsável por curar- tosses, bronquites e catarros da infância - traz a imagem de uma mulher e uma menina, supõe-se mãe e filha. Ambas vestem roupas elegantes e estão bem penteadas, indicação de pertencimento às elites. A mãe traz uma expressão serena ao dar o xarope para sua filha. Pode-se identificar tal feição como a certeza de que o medicamento faria bem a menina. 


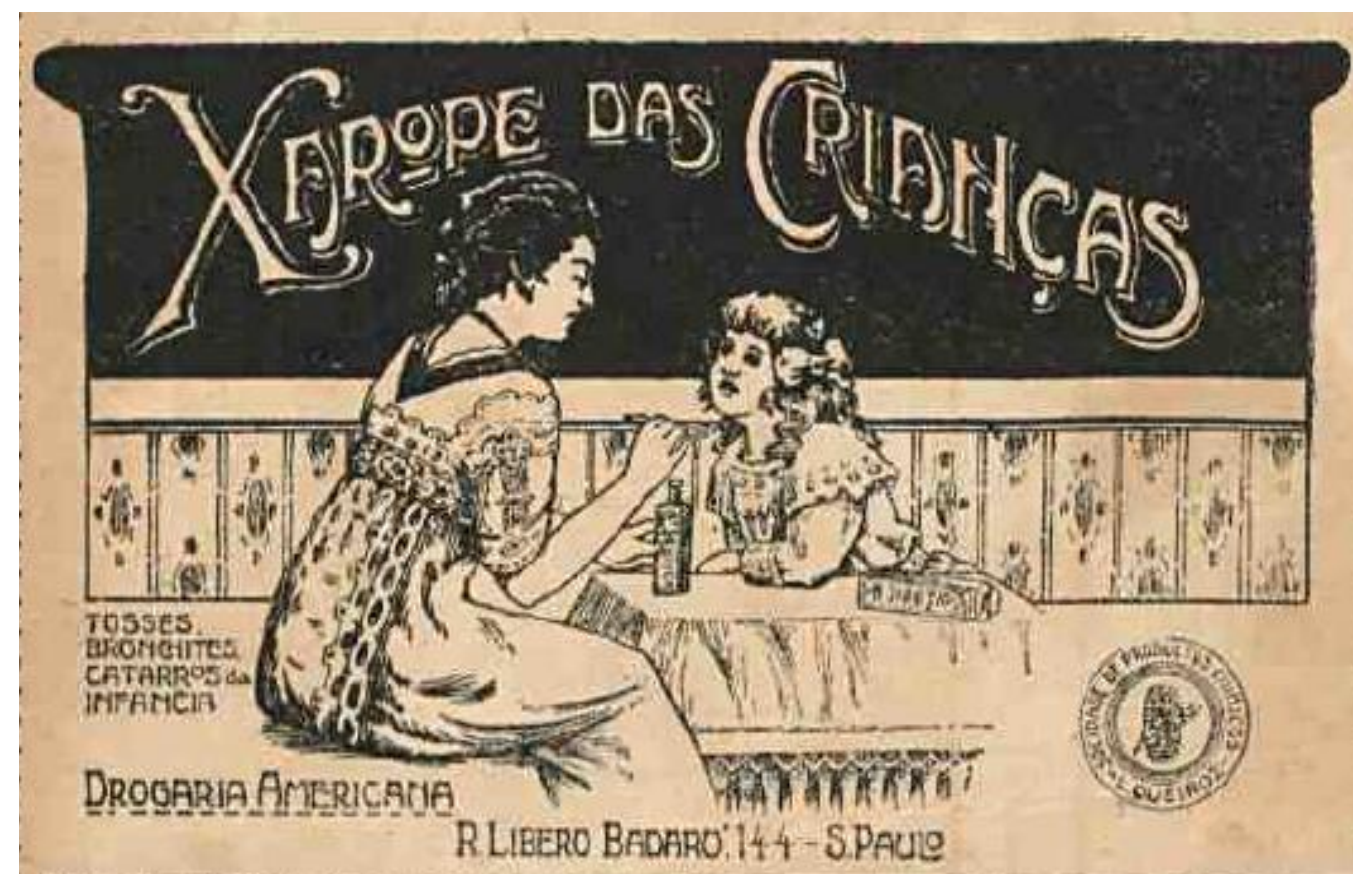

Figura 122- O Tico-Tico - 10/03/1920 - s/p

A publicidade de Bromil voltado ao combate da coqueluche, apresenta a

figura de uma mulher com uma criança pequena nos braços. O pequeno parece chorar por querer o remédio destinado à irmã. Novamente, tem-se a representação da maternidade calcada em um semblante calmo e resignado.

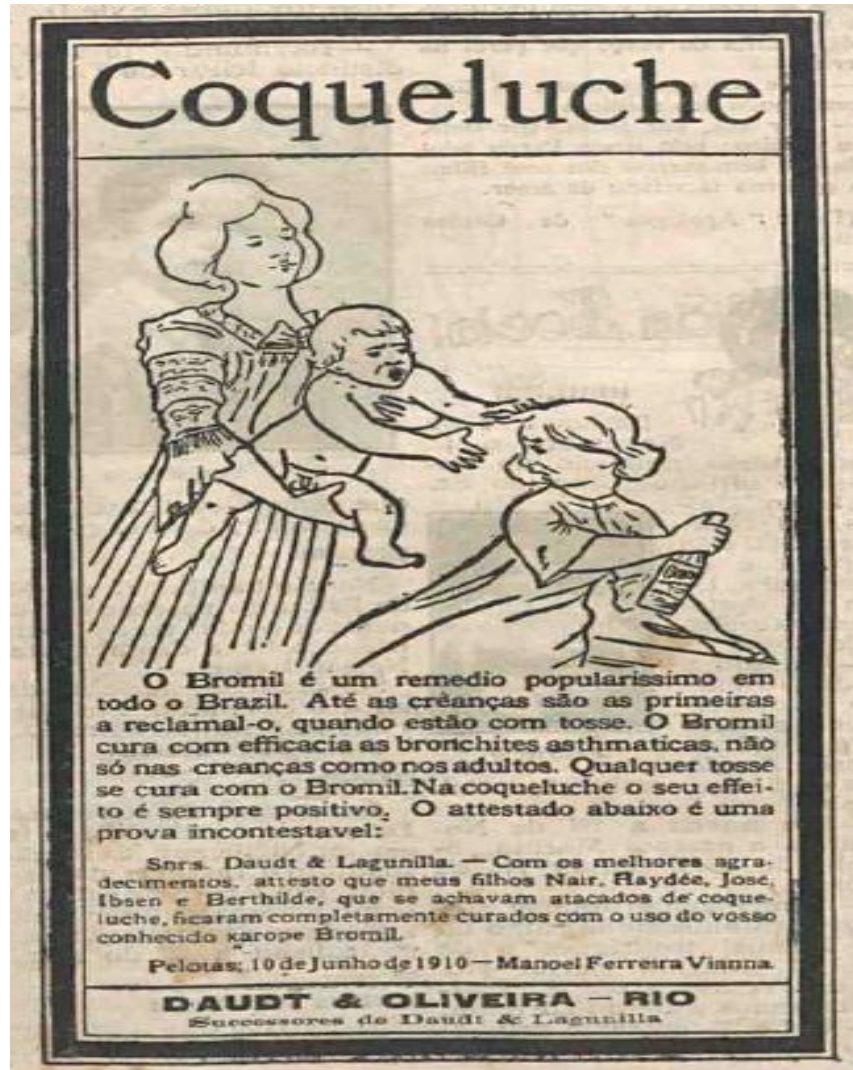

Figura 123 - O Tico-Tico - 06/12/1916 - s/p 
Os anúncios publicitários de $O$ Tico-Tico propagam uma representação feminina de uma cuidadora, sempre pronta a ajudar o próximo. No entanto, as morais republicanas e burguesas também evidenciavam a necessidade da mulher ser além de dedicada, mas também bela.

\subsubsection{A bela mulher}

Na edição, de 1 de maio de 1915, do Jornal das Moças foi publicado o seguinte verso:

As mulheres se dividem em duas categorias: as bonitas e as feias. As bonitas são as mulheres amadas; as feias aquellas que não são amadas (p.18).

Japiassú e Marcondes (2006) definem a beleza:

Caráter do que é belo, podendo aplicar-se as coisas, as pessoas ou as obras de arte. O filósofo considera que o belo é aquilo que desperta nos homens um sentimento particular chamado "emoção estética", e acredita que tal sentimento seja inteiramente desinteressado, muito embora seja parcialmente determinado pelos hábitos e os conhecimentos: até mesmo as emoções estéticas que sentimos diante de certos espetáculos da natureza dependem, pelo menos em parte, dos valores culturais do momento (p.28).

\section{Segundo Priore (Op.cit.)}

(...) ser feia, nas primeiras décadas do início do século XX, tinha seus pontos negativos. Todas as mulheres sabiam que a fotografia, o cinema e a imprensa divulgavam padrões que deveriam ser seguidos (...) A chamada "boa aparência" impunha-se; os bons casamentos, sobretudo, dependiam dela (p.221-222).

O aparato colocado a serviço da beleza corporal, feito de receitas de fabrico doméstico, de produtos farmacêuticos ou de artifícios de maquiagem, parecia prometer à mulher a possibilidade de, em não sendo bela, tornar-se assim. Haja salvação! A propalada coquetterie, desdobrada em cursos de maquiagem, cuidados de pele e cabelo, massagens e tratamentos dos mais variados, cursos para aprender a caminhar a gesticular, constituía um investimento - as feias teriam chance (Loc.cit.).

As citações demonstram como beleza foi alçada a uma categoria tão importante quanto o caráter. A bela mulher é naturalmente alvo de admiração e elogios. Possuem as características certas para cumprir sua missão: casar e ter filhos. A mulher considerada fora do padrão, deve se esforçar e se encaixar no 
modelo dominante: pele branca, traços finos, cabelos bem cuidados, corpo esbelto e jovem. Torna-se alarmante o discurso que vincula o ser feia, com a ausência de amor. A beleza é vista não como algo subjetivo, ela engloba um conjunto de regras a ser respeitado e seguido. Não por caso, período de transição, entre os séculos XIX e XX, foi marcado pela ampliação da publicidade de cosméticos com o propósito de "tornar a mulher bonita e saudável" (SOARES; BARROS, Op.cit., p.110). O fortalecimento indústria da beleza a transforma em um juízo de valor.

A Revista Feminina tinha uma relação diferenciada com a Empreza Feminina Brasileira. Lançava seu catálogo de produtos, com destaque para os cosméticos, nas páginas do impresso. Mantinha-se, uma espécie de classificados no qual eram publicados anúncios de cabelereiros, produtos médicos e livros. Entre 1920 e 1921, a seção A arte da beleza apresentou às leitoras informações sobre a beleza da mulher moderna e enquetes sobre como obter um corpo ideal (Ibidem). Os discursos destinados às mulheres são construídos a partir das categorias: moda e refinamento e "esbeltez" (CAMPOS, Op.cit.)

Em O Tico-Tico, os anúncios voltados à beleza feminina, seguiam as mesmas diretrizes das publicações destinadas às mocinhas, às moças e às senhoras. A Secção para meninas, de 26 de janeiro de 1910, traz o texto Uma lição de elegancia de trez penadas sobre a menina Amelia que, durante viagem à fazenda de seu tio, deixou de cuidar do próprio asseio. Passou a não lavar e pentear os cabelos, até que foi repreendia pela pequena Paulina por estar suja e feia (p.7).

Os conteúdos publicitários abordam a importância de cuidar dos cabelos, afinal eles se constituem na moldura do rosto. O preparado capilar Arlus cuja ação era cessar a queda de cabelo, tinha como slogan: "A mulher mais bella? Não poderá ser completa, se não possuir lindos e bastos cabelos" (O TICO-TICO, 1910, p.17). O anúncio de Pixavon, um sabão liquido de alcatrão, salienta a necessidade das brasileiras aprenderem o modo correto de fazer a higiene capilar como as inglesas:

Admiramos as cabelleiras magnificentes dos inglezes, especialmente na alta classe do sexo feminino, e julgamos de ordinario que essa prodigiosa fartura de cabellos seja d'elles uma particularidade especial. Este modo de pensar é totalmente falso. As senhoras inglezas devem seus cabellos admiraveis principalmente á hygiene da pelle mantida com o maior cuidado no couro cabelludo. Na Inglaterra é costume muito usado o qual 
vem mantido succecivamente desde época remota, lavar com regularidade os cabellos e o couro cabeludo. Neste sentido podemos tomar francamente os ingleses como exemplo nosso. Elles servem-se para esse fim de um meio muito em voga na Inglaterra, que consiste em lavar os cabellos com um sabão suave de alcatrão, assim como o é Pixavon, o qual, em tão pouco tempo, difundiu-se por toda a parte. Pixavon é um sabão liquido e suave de alcatrão para lavar a cabeça, ao qual tirou-se chimicamente o cheiro penetrante. O Pixavon destroe facilmente a caspa e impurezas que se depositam sobre o couro cabeludo e produz uma espuma magnifica que sai facilmente dos cabelos, enxagoando-os ligeiramente. Tem um cheiro muito agradavel e, devido ao alcatrão que contém, combate vantajosamente a queda parasitaria dos cabellos. Depois de algum tempo de uso do Pixavon comerçar-se-á a sentir o bem estar que provoca. Por isto, pode-se consideral-o como o proparado ideal para o tratamento dos cabellos. Vende-se nas drogarias, pharmacias e perfumarias. Um frasco dá para vários mezes (O TICO-TICO, 22/11/1911, p.8).

Para além dos cuidados com a higiene dos cabelos, o impresso publica anúncios de produtos que prometem deixar os cabelos mais bonitos. Surgem questões sobre alisamento capilar, como a respondida na seção Correspondências do Dr. SabeTudo:

Remedio que ponha lisos os cabellos, que são naturalmente crespos, não ha, e nem pode haver, porque isso de ser crespo depende da constituição do cabello. O cabelo liso tem o fio redondo, o cabello crespo tem o fio achatado e por isso se enrola facilmente $(14 / 02 / 1917, \mathrm{~s} / \mathrm{p})$.

No entanto, as páginas de $O$ Tico-Tico trazem diversas possibilidades para as leitoras mudarem o visual dos cabelos. São anúncios de tinturas, alisantes e até apliques capilares.

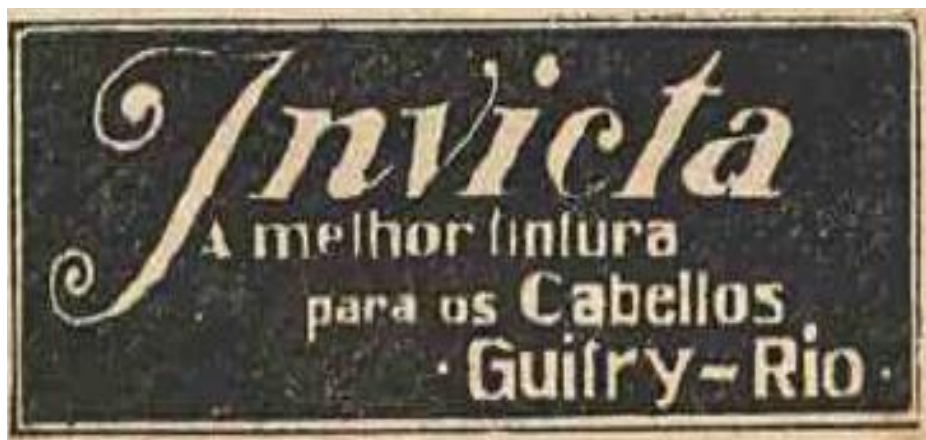

Figura 124 - O Tico-Tico-09/01/1918 - s/p. 


\section{ALYSIL}

Producto Indicado para alisar os cabetlos crespos (enearapintados?. Torna-os lisos e lastrosos.

Este producto e util tambem na casDa solta. Scus resultados sao garantidos.

$$
\text { Deposilo : Pharmecia Figueirado }
$$

RUA DA CARIOCA, $33-$ RIO

Preoo : Vidro 2\$000-Pelo correlo 35sooo

\section{PEDTEADOS DA MODA}

Executados com os posti. cos Maurice, os mais periei. tos, em cabello ondeado natural. Salōes especiates para senhoritas e creanças. Especialidade em tintura llenne.

\section{Salão Academico 165 Rua do Ouvidor 165 (sobrado) \\ Attendy a chemediv, polo telephent : Norte 1.30s}

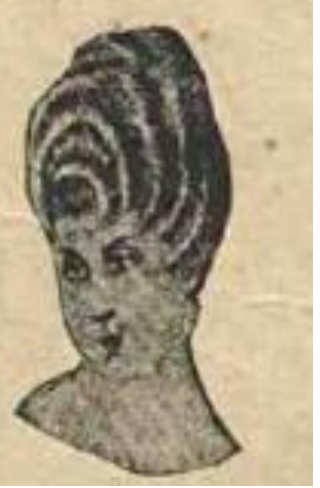

Figura 126 - O Tico-Tico - 04/07/1917 - s/p.

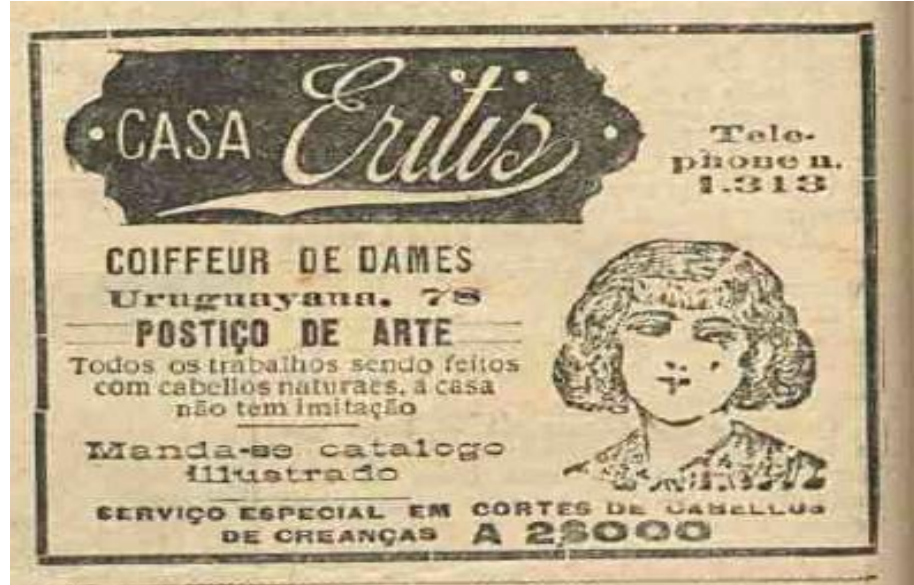

Figura 127 - O Tico-Tico - 09/01/1918 - s/p.

A presença de um produto para alisamento é vinculada ao padrão de beleza modelo europeu: cabelos lisos ou ondulados. Representação dos tipos capilares considerados socialmente bonitos. Também se podia optar pelo uso de apliques como mostram os anúncios do Salão Acadêmico e da Casa Eritis. 
Freyre (Op.cit.) aponta o fascínio das meninas brasileiras pelas bonecas de porcelana francesa, como uma das explicações para este padrão de beleza ter se tornado referência, a partir do século XIX:

O culto das bonecas loiras e de olhos azuis entre as meninas de gente mais senhoril ou rica do Império deve ter concorrido para contaminar algumas delas de certo arianismo; para desenvolver no seu espírito a idealização das crianças que nascessem loiras e crescessem parecidas às bonecas francesas; e também tornar a francesa o tipo ideal de mulher bela e elegante aos olhos das moças em que depressa se transformavam nos trópicos aquelas meninas (p.297).

As memórias da infância de mulheres provenientes das classes abastadas, demonstram o quanto algumas rejeitavam quaisquer referências à figura dos negros e glorificavam apenas as características vinculadas à beleza europeia:

Da. Isabel Henriqueta de Souza e Oliveira, nascida na Bahia em 1853 , confessa que quando moça 'desejava ser francesa' e 'conhecer as modas [francesas] de perto'; e também confessa ter sempre achado que deveria 'manter a distância social' de branco para negro, sendo o negro ' raça inferior' (Ibidem, p.297).

Nas histórias de $O$ Tico-Tico, utiliza-se a denominação cabelos crespos para descrever os cachos das personagens femininas. Os cabelos das meninas e mulheres negras são denominados crespos encarapinhados.

Beleza e juventude passam a ser vistas como uma combinação perfeita. Os fios brancos característicos da maturidade são identificados, principalmente no caso feminino, como algo depreciativo. Envelhecer significa não ser mais considerada atraente:

(...)os representantes do sexo masculino mantinham preservada sua importância social, muito diferentemente das mulheres que, reduzidas ao papel de 'encantadoras' e 'belas', simplesmente estavam destinadas à solidão quando viúvas ou solteironas, à piedade, assim que o binômio juventude/beleza tivesse seu ocaso (CAMPOS, Op.cit., p.162).

Enquanto ele envelhece de maneira contínua, a mulher é bruscamente despojada de sua feminilidade; perde, jovem ainda, o encanto erótico e a fecundidade de que tirava, aos olhos da sociedade e a seus próprios olhos, a justificação de sua existência e suas possibilidades de felicidade: cabe-lhe viver, privada de todo o futuro, cerca de metade de sua vida adulta (...) (BEAUVOIR, Op.cit., p.757). 
O estatuto da velhice se modifica. Ao invés de ser entendida como um período de acúmulo de experiência e sabedoria passa a ser classificada como uma época de decrepitude. Cobrir os fios brancos poderia criar a ilusão de um prolongamento da juventude. Nos anúncios presentes em $O$ Tico-Tico, cabelos bem cuidados e pintados não eram as únicas formas da mulher manter uma aparência jovial. É preciso manter o viço e o frescor da pele, por isso as leitoras são apresentadas a diversos tipos de loções e emulsões:

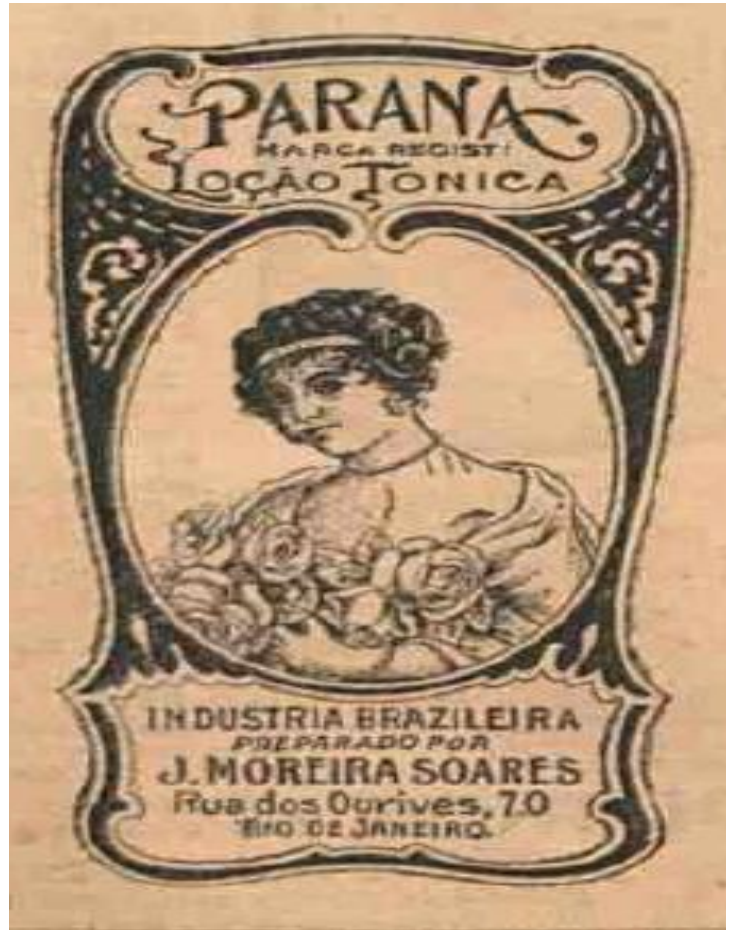

Figura 128 - O Tico-Tico-21/08/1918 - s/p.

O anúncio da loção tônica Parana tem como figura central, uma jovem com o pescoço e o colo à mostra. O fato de ela estar de perfil permite que se observe a ausência de marcas e rugas.

Para além dos cabelos sedosos e da pele bem cuidada, o sorriso também ganha status de beleza e juventude:

Os anúncios difundiam padrões de beleza femininos, interrelacionavam beleza e higiene e disseminando os cuidados que as mulheres deveriam ter para com os seus dentes, buscando manter,um sorriso bonito, jovial, simpático, sedutor, com dentes brancos, brilhante e frescor no hálito (MATOS, Op.cit, p.8).

O sorriso enigmático de Monalisa cede lugar a um sorriso menos contido. Por tal razão, o anúncio do dentista Dr.Sa' Rego apresenta a possibilidade de se fazer implantes de dentes artificiais. 


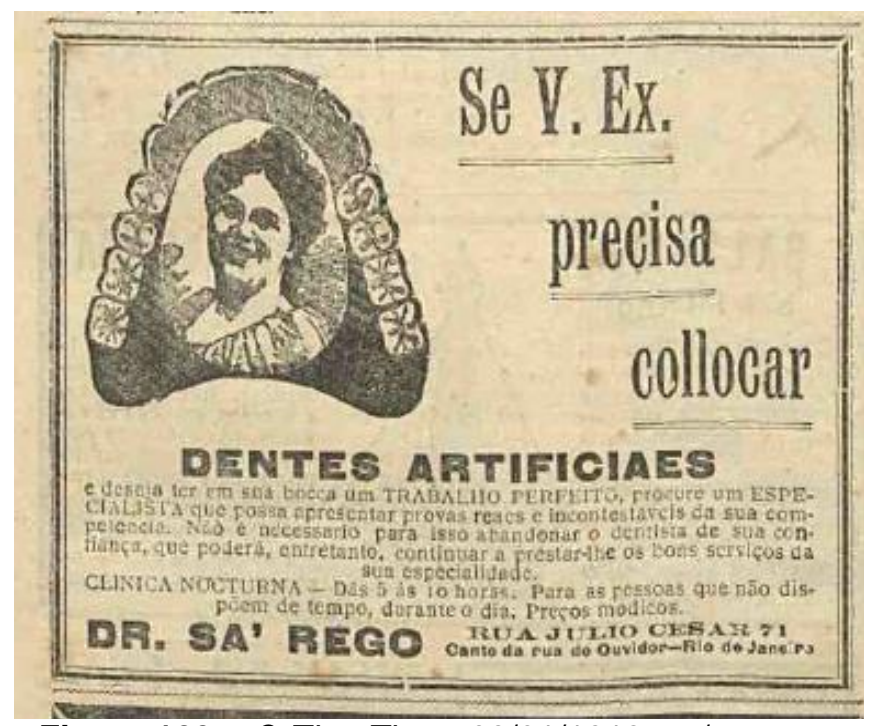

Figura $129-$ O Tico-Tico $-09 / 01 / 1918-\mathrm{s} / \mathrm{p}$.

A imagem de uma arcada dentária com uma mulher sorrindo, demonstra que o cuidado com os dentes se transformou em sinônimo de graciosidade. A mulher desdentada não pode sorrir, sem virar algo de escarnio. O uso de dentes artificias poderia garantir sua adequação a estética do belo sorriso. Como ocorreu na prática da higienização capilar, os anúncios salientam a importância de se aprender a cuidar dos dentes.

A propaganda do dentifrício Odol apresenta a figura de duas irmãs e seus belos sorrisos. Elas transparecem a felicidade por terem dentes bem cuidados. A legenda aponta para o fato de que muitas crianças não gostam e sabem fazer a limpeza bucal. É ressaltado o caráter inovador de Odol pelo gosto suave, agradável e refrescante. O diferencial é não queimar a boca de meninos e meninas como outros produtos dentários. 


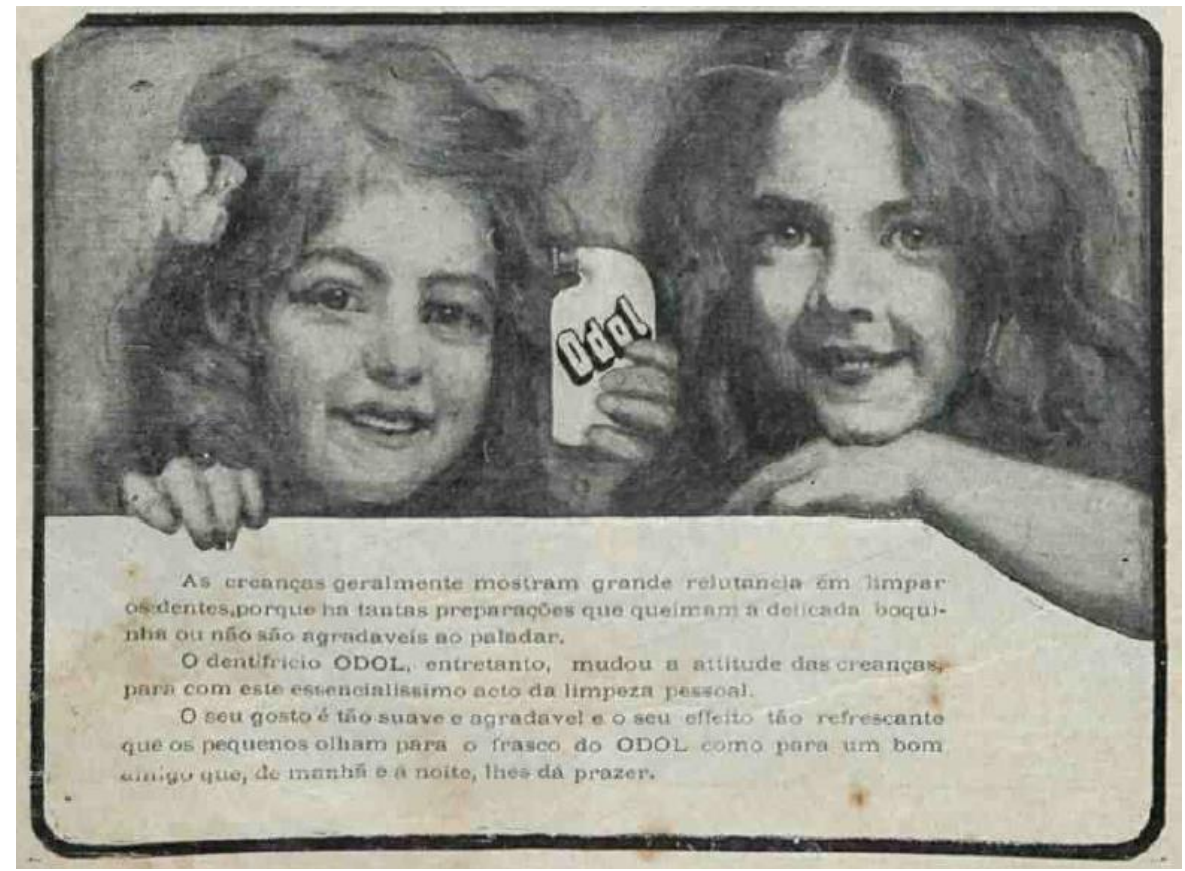

Figura 130- O Tico-Tico-10/03/1909-s/p

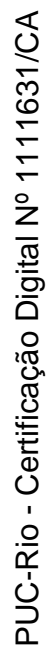

Em outro anúncio do mesmo dentifrício produto, duas mulheres representam os benefícios do produto.

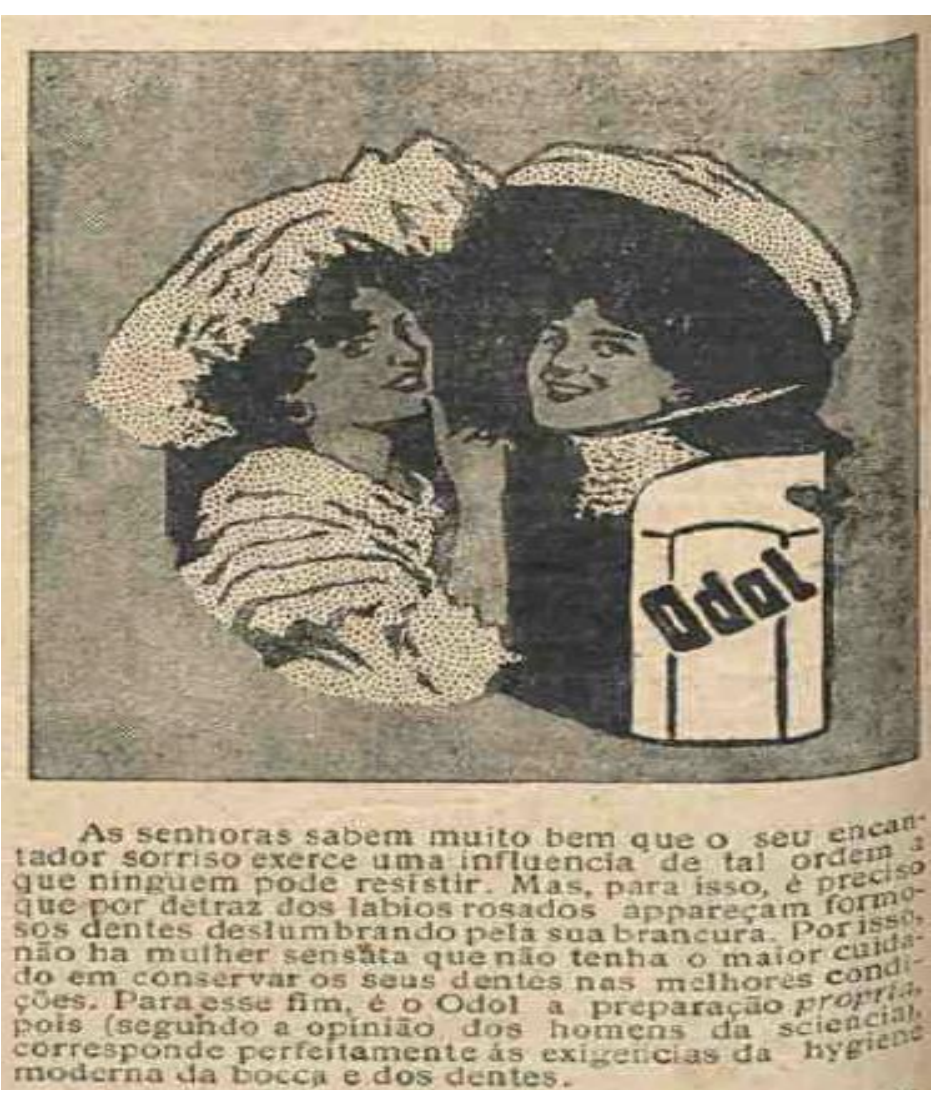

Figura 131-O Tico-Tico - 10/03/1909 - s/p 
Junto à imagem, o seguinte texto:

As senhoras sabem muito bem que o seu encantador sorriso exerce uma influencia de tal ordem que ninguém pode resistir. Mas, para isso, é preciso que por detraz dos lábios rosados appareçam formosos dentes deslumbrando pela sua brancura. Por isso, não ha mulher sensata que não tenha o maior cuidado em conservar os seus dentes nas melhores condições. Para esse fim, é o Odol a preparação propria, pois (segundo a opinião dos homens da sciencia) corresponde perfeitamente às exigências da higyene moderna da bocca e dos dentes (O TICO-TICO, 10/03/1909, s/p).

O conteúdo reforça que um belo sorriso tem a capacidade de influenciar os outros e se constitui em uma forma de poder e sedução. No impresso infantil, as propagandas instituem a “(...) construção de novos padrões estéticos, e de síntese entre saúde e beleza, doença e feiúra, é visível a agitação que os novos comportamentos despertavam nos personagens de então" (CAMPOS, Op.cit., p.150).

Uma jovem com roupas estilo marinheiro e um par de botas até os joelhos, demonstra estar com ótima saúde. Admira-se no espelho, com uma expressão de satisfação (Fig. 131). Uma mulher de vestido longo com babados e cabelos elegantemente presos sorri (Fig.132). Ambas não parecem sofrer de nenhum dos males combatidos pelo xarope Grindelia: tosse, bronquite, catarro, coqueluche, rouquidão, asma, resfriado e constipação. Os anúncios fazem menção a dicotomia entre o bonito e o feio. Facilita-se a identificação dos benefícios prometidos por cosméticos ou medicamentos. No tocante à Grindelia, a imagem da mulher saudável se constitui em uma representação de futuro. Uma consumidora, caso sofra de alguma destas moléstias, pode vislumbrar sua própria transformação após o uso do remédio. 


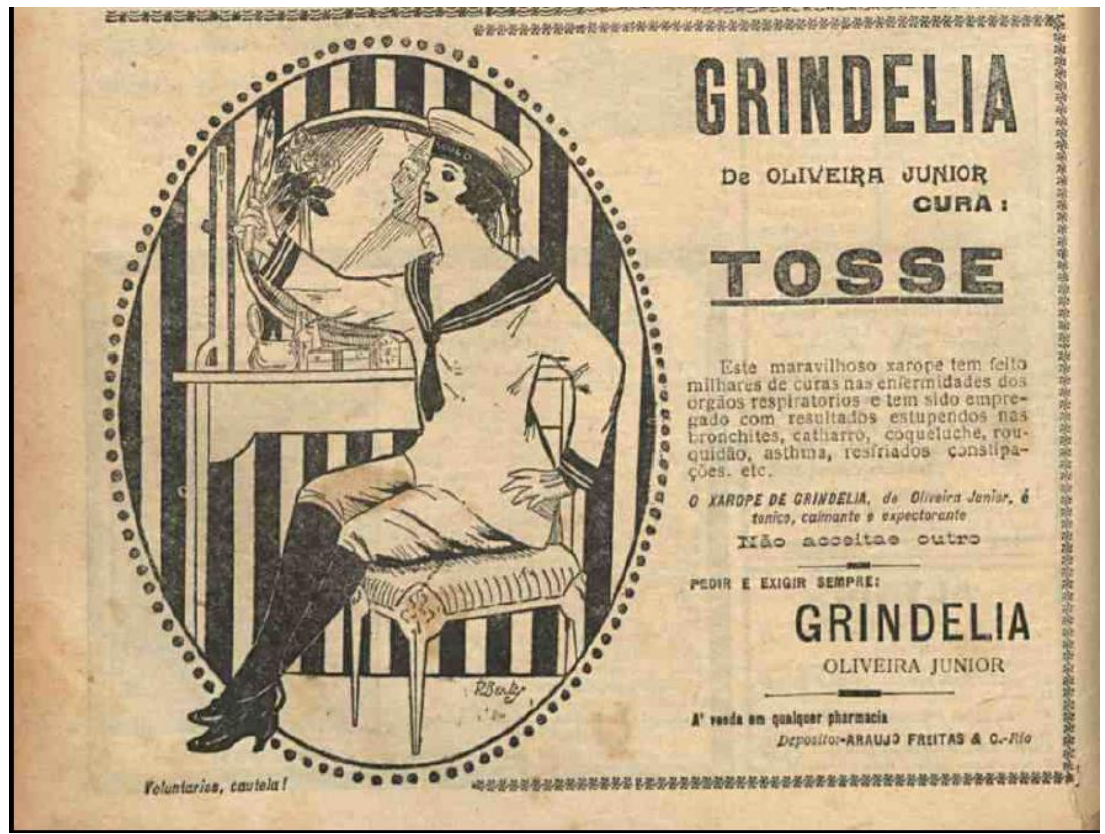

Figura 132- O Tico-Tico-24/10/1917 - s/p

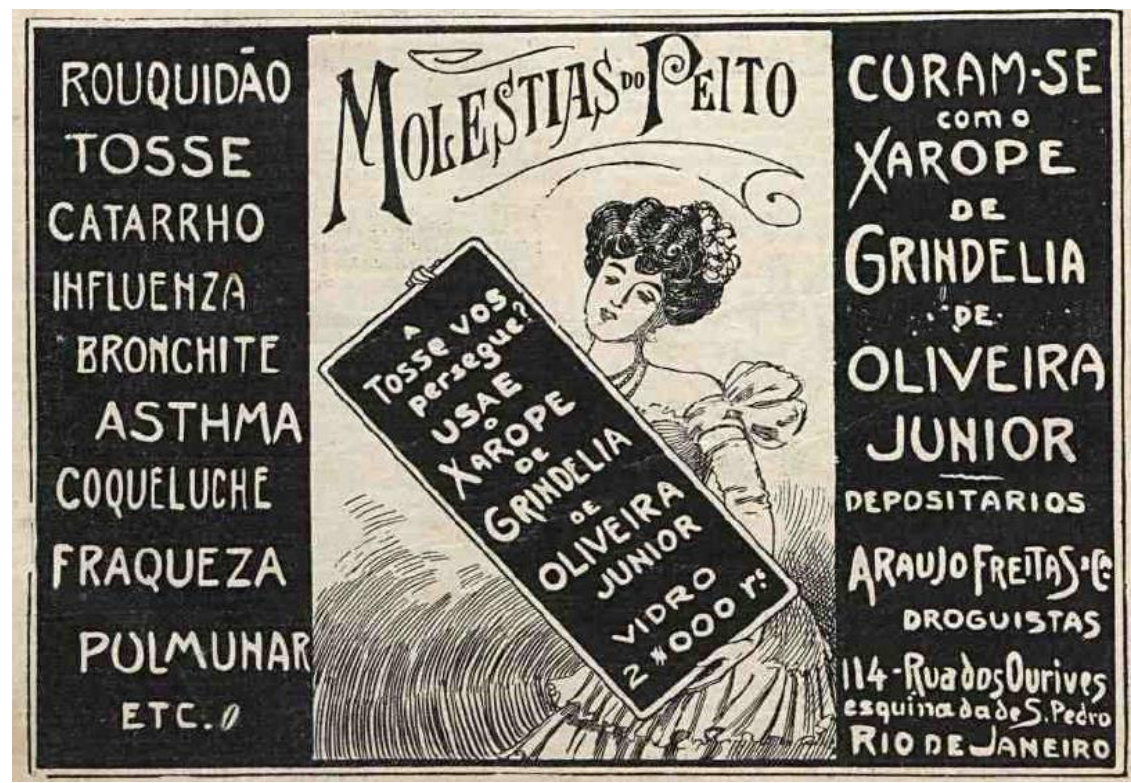

Figura 133 - O Tico-Tico - 23/06/1909 - s/p.

Não por acaso, o medicamento tem um nome feminino. É a mãe ou outra responsável que possui o papel de garantir o bem estar da família. "A indústria cultural ensina às mulheres que cuidar do binômio saúde-beleza é o caminho para a felicidade individual" (PRIORE, Op.cit., p.240). O anúncio da loja de departamentos Royal Store sintetiza o ideário mulher perfeita presente nas páginas de publicidade de $O$ Tico-Tico. 


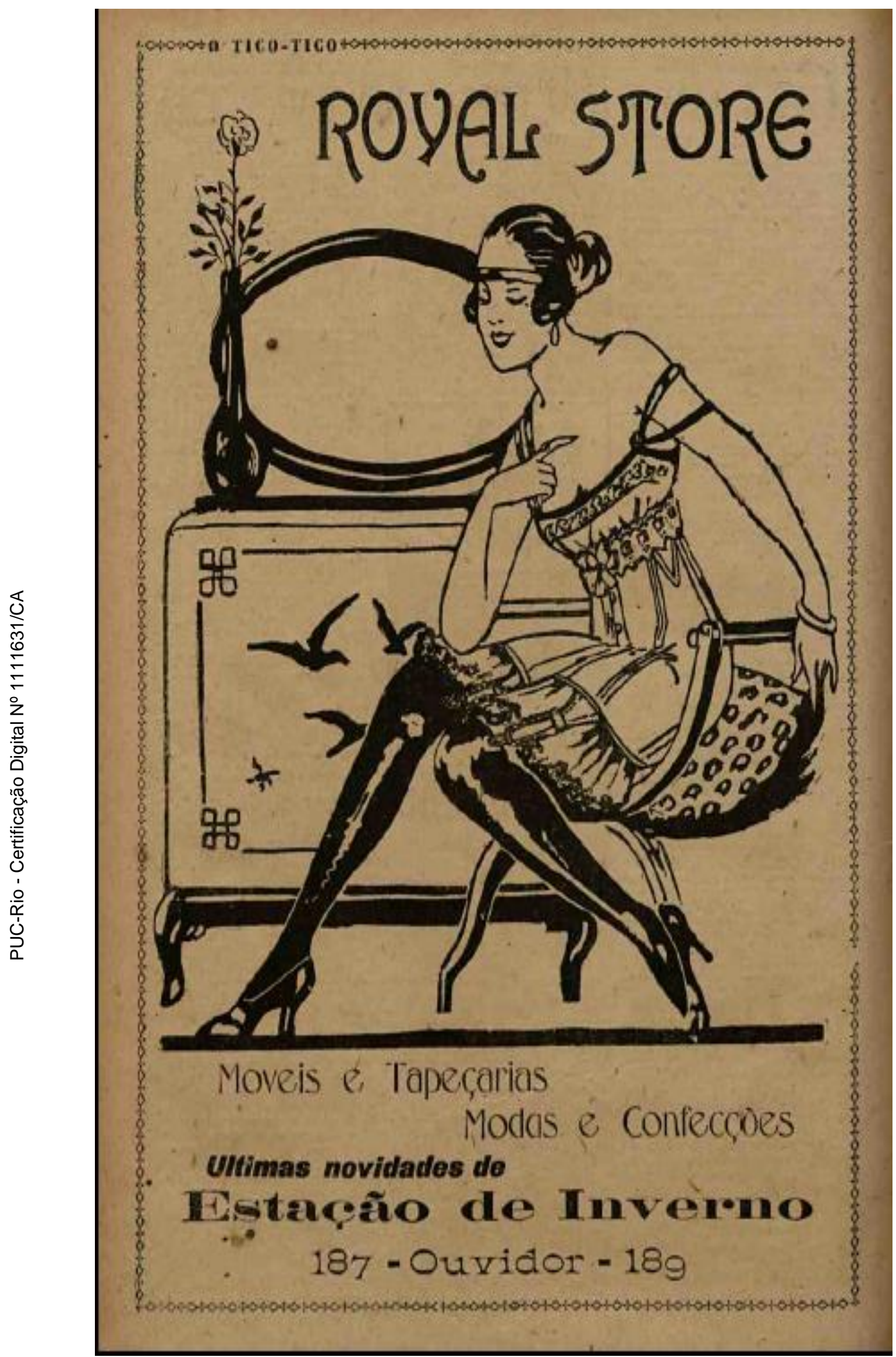

Figura $134-O$ Tico-Tico - 25/05/1921 - s/p 
A imagem apresenta um quarto que aparenta ter sido cuidadosamente decorado. Contexto que demonstra o cuidado com o lar. Um aspecto ressaltado é o é o fato da publicidade mostrar o sexo feminino em um momento de privacidade. Como figura central, uma mulher de gestos delicados e elegantes. A bela jovem, ostenta roupas de gosto refinado. As meias, os sapatos de salto, a pulseira e o penteado apontam que ela está se preparando para sair. Talvez para conhecer as novidades da Parc Royal. Supondo-se que ao ter contato com tal mensagem publicitária, as leitoras pudessem compreender como deveria ser uma boa esposa e uma bela mulher. 


\section{5.}

\section{Considerações Finais}

Hansen (Op.cit.) e Gouvêa (Op.cit.) identificam a literatura infantil como um gênero marcado pelo viés ideológico. No decorrer da pesquisa sobre os exemplares de O Tico-Tico, em circulação de 1905 a 1921, constatou-se que se tratava de uma revista que tinha o propósito de difundir determinadas representações legitimadas da criança brasileira. Caracterizando-a como fonte na qual se tem

(...) acesso às representações sobre a criança e aos modelos de comportamento infantil num determinado período e contexto histórico, mas também às representações sobre os modelos de ação social e conhecimento do mundo ali legitimados (Ibidem, p.29).

O Tico-Tico é composta histórias em quadrinhos, personagens e seções que, por meio da diversão e da ludicidade, tinham o propósito de auxiliar na conformação de comportamentos e papéis sociais consonantes a um projeto de sociedade, calcado no desejo reformador das elites brasileiras. O país das mazelas e do atraso, tornar-se-ia moderno e civilizado. Para além de sua implantação, havia a necessidade de garantir a sua continuidade. Identificadas como o futuro da nação, caberia à infância nacional estar apta a cumprir tal missão.

Entre as instâncias a serem normatizadas, pode-se claramente apontar às relações de gênero. De forma contrária a perspectiva de que $O$ Tico-Tico centrava suas atenções apenas na formação dos meninos, a revista também se dedicava a formar as meninas brasileiras. As elites tinham a preocupação de reforçar o modelo social no qual eles tinham de ser preparados para o mundo trabalho. Assim como, elas aprenderiam sobre prendas domésticas e os cuidados com o lar. Reflexo de um meio social, marcado por fortes traços conservadores e machistas, que vinculava o sexo feminino às representações de fragilidade e de submissão. A preocupação com as leitoras, centrava-se no fato de que as mesmas seriam as mães de famílias futuras que criariam os futuros líderes da nação.

As edições de $O$ Tico-Tico priorizavam a instrução das pequenas e dos leitores. Pode-se questionar a construção do gênero feminino veiculado em seus exemplares, mas não a existência de silêncios sobre o ser mulher. A revista pautava seus conteúdos, pela dicotomia entre o sexo forte e o bello sexo. 
Defendia-se um modelo baseado na submissão das meninas frente aos meninos. Elas deveriam ser belas, bondosas, prendadas e bem comportadas. Não por acaso, foram criados espaços específicos para que as leitoras pudessem ler sobre as últimas tendências da moda e como fazer belos bordados. O domínio destes assuntos era entendido como um importante trunfo para a conquista de um bom partido e se fazer um ótimo casamento.

Os anúncios publicitários presentes no impresso infantil reforçavam tais representações ao difundir o discurso de que a beleza se constituía em um objeto de valor. As mulheres podiam cuidar do corpo e praticar esportes, desde que não maculassem a feminilidade. No tocante à publicidade, ressalta-se que a conformação do gosto feminino tinha as mães como público privilegiado. Reforça-se que elas também atuavam como mediadores entre as crianças e conteúdos, quando muito pequenas ou ainda não alfabetizadas. Em O Tico-Tico são fartamente encontrados anúncios de cremes, tinturas e até dentaduras. Nada que pudesse fazer parte do universo infantil. Para além dos cuidados maternos, as senhoras e as senhoritas se enquadrassem no modo de vestir e nos gestuais burgueses da Belle Époque. Neste sentido, a figura materna se constituía em um exemplo a ser seguido por suas filhas. Lembre-se que o editorial de lançamento de $O$ Tico-Tico, garantia que as mães seriam as mais agradecidas pelo lançamento da revista.

Embora as personagens femininas tivessem a missão de reforçar os valores femininos e rechaçar brincadeiras e molecagens, o exemplo de Faustina se destaca. Desenhada para ser um símbolo do ridículo, tornou-se querida pelos leitores, de ambos os sexos. A personagem estereotipada, por ter ousado romper as barreiras do lar, consolidou-se como um dos principais símbolos da memória afetiva dos antigos leitores de $O$ Tico-Tico. No processo de pesquisa e feitura da tese, por coincidência ou não, Faustina também se constituiu no item que mais despertou atenção daqueles que leram o material.

No entanto, é preciso observar que a construção social do ser mulher presente no impresso infantil, ainda se fez presente, por décadas na imprensa feminina. De 1951 a 1958, a Sociedade Anonyma O Malho publicou a revista Cirandinha destinada, exclusivamente, às meninas de 8 e 14 anos de idade. A proposta editorial era o de continuar a difundir o ideário da boa mãe e esposa. 
No tocante a década de 1950, Bassanezi (Op.cit.) analisa os impressos Jornal das Moças, Querida, Vida Doméstica, Você e a seção Para mulher publicada em $O$ Cruzeiro para identificar os papéis femininos em circulação nas revistas e seções dedicadas a mulher no contexto dos anos 1950. Destaca-se o subitem Moça de família X Moça leviana. As moças de família ou boas moças eram recatadas, virgens, cheias de moral e respeitavam os pais. Características imprescindíveis para se conseguir um bom casamento. As moças levianas usavam roupas ousadas se permitiam ter contatos físicos mais próximos com homens antes do casamento. Eram consideradas más influências e recebiam apelidos pejorativos como maçaneta.

Não se deve pensar que a temática da formação feminina em $O$ Tico-Tico se esgota com esta pesquisa. A tese abrange apenas os primeiros 16 anos de existência de um impresso infantil que esteve em circulação por mais de 50 anos. Após o período analisado, foram publicadas histórias da menina Lamparina, desenhada por J. Carlos. A personagem Faustina teve sua trajetória descrita na revista até a década de 1950. Novas seções femininas ocuparam as páginas da revista. É estabelecida a possibilidade de se ampliar as reflexões sobre o gênero feminino e o impresso infantil. Desta forma, identificar mudanças e no modo como esta temática se fez presente em O Tico-Tico. 


\section{6.}

\section{Referências bibliográficas}

ACRISIO..Correspondencia. Revista da Semana, Rio de Janeiro, não paginada, 20.fev.1910.

AGOSTINI, Angelo.. Por causa de um cachorro. O Malho, Rio de Janeiro, não paginada, 22.out.1904.

..O Malho, Rio de Janeiro, não paginada, 15.out.1904.

Revista Illustrada, Rio de Janeiro, p.1, 05 fev. 1887.

ALMEIDA, Julia Lopes.. O livro das noivas de receitas e conselhos domésticos.

São Paulo: [s.e], 1929. Disponível em:

http://www.brasiliana.usp.br/bbd/handle/1918/06005600. Acesso em 20.nov.2014.

ALMEIDA, J. S.. Ler as letras: por que educar meninas e mulheres?. 1. ed. Campinas-SP: Autores Associados; São Bernardo -SP: Editora da Universidade Metodista de São Paulo, 2007.

ALVES, Francisco de Paula Rodrigues. Manifesto Inaugural de Francisco de Paula Rodrigues Alves. Rio de Janeiro: [s.n.],1902. p.1-15.

AMARAL, C. Caricatura Mlle. República, $O$ Malho, Rio de Janeiro, p.2, 15.nov.1902. Disponível em:

ANDERSON, Benedict. R.. Comunidades Imaginadas: reflexões sobre a origem e a difusão do nacionalismo. São Paulo: Companhia da Letras, 2008.

ARIÈS, Philippe.. História social da criança e da família. 2.ed.Rio de Janeiro:LTC,2006.

ARROYO, Leonardo.. Literatura infantil brasileira: ensaio de preliminares para a sai história e as fontes. São Paulo: Melhoramentos, 1968.

ASSIS, Machado. Esaú e Jacó. São Paulo: Globo, 1997. 
AZEVEDO, Ezequiel de. O Tico-Tico: cem anos de uma revista. São Paulo: Via Lettera, 2005.

BARBOSA, Marialva C.. Imprensa e encenações de Modernidade no início da República. Vivencia Rio Grande do Norte, v. 38, p. 129-142, 2011.

BASTOS, Anália Franco. As mães e educadores. Álbum das meninas: revista literária dedicada às jovens brasileiras, São Paulo, n.1,p.1-3,30.abr.1898.In: ARQUIVO PÚBLICO DO ESTADO DE SÃO PAULO.Disponível em: http://www.arquivoestado.sp.gov.br/site/. Acesso em: 12.mar.2015.

BASTOS, M. H. C.. Cuore, de Edmundo de Amicis (1886). Um sucesso editorial.. In: XXVII CONGRESSO BRASILEIRO DE CIÊNCIAS DA COMUNICAÇÃO: COMUNICAÇÃO, ACONTECIMENTO E MEMÓRIA. 1.,2004, Porto Alegre. Anais... Porto Alegre: [s.n], 2004, p. 1-16. Disponível em: http://www.intercom.org.br/papers/nacionais/2004/resumos/R0767-1.pdf. Acesso em: 22.mar.2015.

BEAUVOIR, Simone de. O segundo sexo.2.ed.Rio de Janeiro: Nova Fronteira,2009.

BOMFIM, Manoel. Lições de pedagogia: theoria e pratica da educação. 2. ed. Rio de Janeiro: Francisco Alves, 1920.

BOSI, Alfredo. Cultura. In: CARVALHO, J. M.. et.al. (Coord.). A construção nacional: 1830-1889. Rio de Janeiro: Objetiva, 2012. p.225-279.

BRASIL. Decreto Lei n.6807, de 7 de julho de 1980.Disponivel em: http://www.planalto.gov.br/ccivil_03/leis/1980-1988/L6807.htm. Acesso em: 23.fev.2014.

.Decreto Lei $\mathrm{n}^{\mathrm{o}} 5.452$, de $1^{\circ}$ de maio de 1943. Dispõe sobre legislação trabalhista brasileira. Disponível em: http://www2.camara.leg.br/legin/fed/declei/1940-1949/decreto-lei-5452-1-maio1943-415500-norma-pe.html. Acesso em: 11 ago. 2012. 
Constituição (1934). Constituição da República dos

Estados Unidos do Brasil. Promulgada em 16 de julho de 1934. Disponível em: http://www2.camara.leg.br/legin/fed/consti/1930-1939/constituicao-1934-16julho-1934-365196-publicacaooriginal-1-pl.html. Acesso em: 20.nov.2014.

IBGE. Censo Demográfico, 1920.Disponível em: http://biblioteca.ibge.gov.br/visualizacao/livros/liv6478.pdf.Acesso em:26.ou.2014.

.Decreto $\mathrm{n}^{\circ}$. 3017, de $1^{\circ}$ de janeiro de 1916. Dispõe sobre a promulgação do novo Código Civil brasileiro. Disponível em: http://www.planalto.gov.br/ccivil_03/leis/13071.htm. Acesso em. 19.nov.2014.

O Decreto Lei $n^{\circ} 847$, de 11 de outubro de 1890. Dispõe sobre a promulgação do Código Penal de 1890. Disponível em: http://www2.camara.leg.br/legin/fed/decret/1824-1899/decreto-847-11-outubro1890-503086-publicacaooriginal-1-pe.html. Acesso em: 21 jan. 2015.

BRUNO, Pedro. A Pátria. 1919. il.color. Disponível:

http://www.museus.gov.br/wp-content/uploads/2013/11/Apatria_PedroBruno.jpg. Acesso: 10 abr. 2015.

BUITONI, Dulcília Schroeder. Mulheres de papel: a representação da mulher pela imprensa feminina brasileira. São Paulo: Summus, 2009.

.Imprensa feminina. 2.ed. São Paulo: Ática,1990.

BOURDIEU, P.. O poder simbólico. Rio de Janeiro: Bertrand Brasil, 2004.

BURKE, Peter..História e teoria social.São Paulo: UNESP, 2008.

CAGNIN, Antonio Luiz. Chiquinho, Buster Brown, a mais brasileira das personagens americanas. VERGUEIRO, Waldomiro; SANTOS, Roberto Elísio dos..O Tico-Tico: centenário da primeira revista em quadrinhos do Brasil. São Paulo: Opera Graphica Editora,2005.p.29-34.

CAMARA, Sônia. Reinventando a Escola: o ensino profissional feminino na Reforma Fernando de Azevedo.Rio de Janeiro:Quartet; FAPERJ, 2013. 
; COCKELL, Marcela.. O Intelectual Educador Manoel

Bomfim e a Interpretação do Brasil e da América Latina. Revista HISTEDBR Online, Campinas, v. 44, p. 293-307, 2011. Disponível em: http://www.histedbr.fe.unicamp.br/revista/edicoes/44/art19_44.pdf. Acesso em: 10.abr.2015.

. Sob a Guarda da República: a infância menorizada no

Rio de Janeiro da década de 1920. Rio de Janeiro: Quarter. 2010.

.Por uma cruzada regeneradora: a cidade do Rio de Janeiro como canteiro de ações tutelares e educativas da infância menorizada na década de 1920.In: VIDAL, Diana Gomes. (Org.). Educação e Reforma: o Rio de Janeiro nos anos 1920 e 1930. Belo Horizonte: Argumentum; São Paulo: CNPq: USP, Núcleo Interdisciplinar de Estudos e Pesquisas em História da Educação, 2008.p.145-172.

CAMBI, Franco. História da pedagogia. São Paulo: EDUSP, 1999.

CAMPOS, Raquel Discini..Mulheres e crianças na imprensa paulista (1920-1940). São Paulo: UNESP, 2009.

CARDOSO, Athos Eichler. Le Petit Journal Illustré de la Jeunesse: A verdadeira origem francesa d'O Tico-Tico.In: XXXI Congresso Brasileiro de Ciências da Comunicação,1.,2008, Natal. Anais...Natal: [s.n],2008,p.1-14 Disponível em: http://www.intercom.org.br/papers/nacionais/2008/resumos/R3-1506-1.pdf .Acesso:30.mar.2015.

CARMEN SYLVIA: NADADORA E BAILARINA. Revista da Semana, Rio de Janeiro, p.25, 19.fev.1916. Disponível em:

http://memoria.bn.br/docreader/DocReader.aspx?bib=025909_01\&pesq=Carmen \%20Sylvia. Acesso em: 22.fev.2015.

CARTA PARISIENSE. O Paiz, Rio de Janeiro, p.2, 23 maio.1896.Disponível em: http://memoria.bn.br/pdf/178691/per178691_1896_04251.pdf. Acesso em: 31.ago.2014.

CARULA, Karoline. A educação feminina em A Mãi de Familia. In: ;ENGEL, Magali Gouveia; CORRÊA, Maria Letícia. Os intelectuais e a nação: educação, saúde e construção de um Brasil moderno. Rio de Janeiro: Contra Capa, 2013.p.85-112. 
Perigosas amas de leite: aleitamento materno, ciência e escravidão em A Mãi de Familia. História, Ciências, Saúde-Manguinhos, Rio de Janeiro, v.19,p.197-214,2012. Disponível em: http://www.scielo.br/pdf/hcsm/v19s1/11.pdf . Acesso em: 23.out.2014.

CARVALHO, J.M.. Formação das Almas: O imaginário da República no Brasil. São Paulo: Companhia das Letras, 2009.

Os Bestializados: o Rio de Janeiro e a República que não foi. 3.ed. São Paulo: Companhia das Letras, 2009.

. Cidadania no Brasil - o longo caminho. 3.ed.Rio de Janeiro Civilização Brasileira, 2002.

CARVALHO, Marta Maria Chagas de. Pedagogia da escola nova e usos do impresso: itinerário de uma investigação. Educação, Santa Maria, v. 30, n.2, p. 87-105, 2005.

CELSO, Conde de Affonso. Por que me ufano do meu país. [S.1]: ebooksBrasil, 2002.Disponível em: http://www.ebooksbrasil.org/eLibris/ufano.html. Acesso: 23.jan.2014.

.Binóculo. Gazeta de Notícias, Rio de Janeiro,p.3,18.jan.1910.

CERTEAU, Michel de. A Invenção do cotidiano. Artes de fazer. Petrópolis: Vozes, 1994.

CHALHOUB, Sidney. Trabalho, Lar e Botequim: o cotidiano dos trabalhadores no Rio de Janeiro da belle époque. 2.ed. Campinas-SP:UNICAMP,2001.

Cidade febril: cortiços e epidemias na Corte imperial.

São Paulo: Companhia das Letras, 1996.

CHALMEL, Loic. Imagens de crianças e crianças nas imagens: representações da infância na iconografia pedagógica nos séculos XVII e XVIII. Educ. Soc., Campinas, v. 25, n. 86, p. 57-74, abril. 2004. 
CHARTIER, Roger..A história ou a leitura do tempo. 2.ed.Belo Horizonte: Autêntica, 2010.

. Textos, Impressão, Leituras. In: HUNT, Lynn. (Org.).

A Nova História Cultural. 2.ed.São Paulo: Martins Fontes,2006.p.211-238.

.A construção estética da realidade - vagabundos e pícaros na idade moderna. Tempo, Niterói, n.17,p.33-51,2004.

. A ordem dos livros: leitores, autores e biblitecas na Europa entre os séculos XIV e XVIII. 2.ed. Brasília: UNB,1998.

. Diferenças entre os sexos e dominação simblica.

Cadernos Pagu, Campinas-SP, v.4, p.37-47, 1995.

O mundo como representação. Estudos Avançados, São

Paulo, v.5.n.11, p.173-191, 1991.

.A história cultural entre praticas e representações.

Rio de Janeiro: Bertrand Brasil; Lisboa: DIFEL, 1990.

COMTE, Auguste. In: Coleção Os Pensadores. São Paulo: Abril Cultural Victor Civita, 1978.

CÔRREA, Mariza. Raimundo Nina Rodrigues e a "garantia da ordem".Revista USP, São Paulo, n,68,p.130-139,dez/fev.2005-2006.

COSTA, Carlos. A Revista no Brasil do século XIX: a história da formação das publicações, do leitor e da identidade do brasileiro. São Paulo: Alameda, 2012.

COSTA, Emília Viotti. Da Monarquia a República: momentos decisivos.6.ed. São Paulo: UNESP.

COSTA, Luís Edmundo de M. P. da..O Rio de Janeiro do meu tempo. Brasília: Edições do Senado Federal, 2003. 
COTT, Nancy F.. A mulher moderna: o estilo americano dos anos vinte. In: DUBY, Georges; PERROT, Michelle. História das mulheres no Ocidente: o século XX.v.5. São Paulo: EBRADIL;Porto:Afrontamentos,1991.p.95-113.

COUDERC, Marie-Anne. La Semaine de Suzette: histoires de filles. Paris: CNRS Editions, 2005.

CUIDADO COM O FEMINISMO. Revista da Semana, Rio de Janeiro, não paginada, 29.abr.1911. Disponível em: http://memoria.bn.br/pdf/025909/per025909_1911_00572.pdf. Acesso em: 10.mar.2015.

DARNTON, Robert. $O$ beijo de Lamourette: mídia, cultura e revolução. São Paulo: Companhia das Letras, 2010.

DICIONÁRIO AURÉLIO. São Paulo: Editora Nova Fronteira, 1997.

D’ INCAO, Maria Ângela. Mulher e família burguesa. In: PRIORE, M.L. M..(Org); BASSANEZI, Carla. (Coord. de texto). História das mulheres no Brasil. 9.ed .São Paulo: Contexto:2009.p.223-240.

DIOGO, Marcia Cezar. O Moderno em Revista na cidade do Rio de Janeiro. CHALHOUB, Sidney; NEVES, Margarida de Souza; PEREIRA, Leonardo Affonso de Miranda. (Org.). História em Cousas Miúdas. Campinas- SP: Editora da Unicamp, 2005. p.459-489.

DIRECTORIA GERAL DE ESTATISTICA. Boletim Commemorativo da Exposição Nacional de 1908. Rio de Janeiro: Typographia de Estatistica,1908. O Tico-tico, Rio de Janeiro, não paginada, 05.fev.1919.

DOCES DA TIA THEREZA. O Tico-tico, Rio de Janeiro, não paginada, 19.fev.1919.

DRA URSULINA LOPES. Correio da Manhã, Rio de Janeiro,p.9,20 nov.1914.

EL FAR, Alessandra. Páginas de Sensação: literatura popular e pornográfica no Rio de Janeiro (1870-1924). São Paulo: Companhia das Letras, 2004. 
ELIAS, Norbert. O processo civilizador: uma história dos costumes. v.1.Rio de Janeiro: J. Zahar, 1994.

EM FLAGRANTE, O Tico-Tico, Rio de Janeiro, p.1, 16.fev.1916

ESTADOS UNIDOS DO BRASIL. REVISTA ILLUSTRADA, Rio de Janeiro,p.2, 07 dez.1889.

FERREIRA, Lucia M. A. Uma memória da normatização da conduta feminina na imprensa. In: ;RIBEIRO, Ana Paula G.. (Org.). Memória e produção de sentidos na mídia. Rio de Janeiro: MAUAD,2005.

FERRERO, Gina Lambroso. A missão da mulher. Revista Feminina,São Paulo, abril de 1920. s/p.

FILHO, L. M. F. Da feminização do magistério no Brasil: balanços e perspectivas de pesquisa. In: PEIXOTO, Ana Maria Cassanta; PASSOS, Mario. (Org.). A escola e seus atores - educação e profissão docente. Belo Horizonte: Autêntica, 2005.p.53-87.

FREYRE, Gilberto..Modos de homem \& Modas de mulher.2.ed.rev.São Paulo:Global,2009.

.Ordem e Progresso.6.ed.rev.São Paulo: Global.2004. Sobrados e Mucambos: decadência do patriarcado rural e o desenvolvimento do urbano. 14.ed. São Paulo: Global Editora,2003. . O “Tico-Tico". In: SOCIEDADE ANONYMA O MALHO. Cinqüentenário de "O Tico-Tico": da sua fundação até os nossos dias - noticiário e homenagens diversas à tradicional publicação. Rio de Janeiro: SOCIEDADE ANONYMA O MALHO, 1956.p.51-53.

GOMES, Ângela Maria de Castro.. A República, a História e o IHGB. Belo Horizonte: Argumentum, 2009.

GONDRA, José Gonçalves; SCHUELER, Alessandra.. Educação, poder $e$ sociedade no império brasileiro. São Paulo: Cortez, 2008. 
GONTIJO, Rebeca. Manoel Bomfim. Recife: Fundação Joaquim Nabuco; Recife: Editora Massangana, 2010.

- Manoel Bomfim: "pensador da história" na Primeira República. Rev. Bras. Hist., São Paulo, v. 23, n. 45, p. 129-154, julho 2003.

GOUVÊA, M.C.S.. A literatura como fonte para a história da infância: possibilidades e limites. In: LOPES, Alberto; FARIA FILHO, L. M.;FERNANDES, R..(Org.). Para a compreensão histórica da infância. Belo Horizonte: Autêntica, 2007.

A Construção do Infantil na literatura brasileira. Teias,

Rio de Janeiro, v. 2, p. 41-50, 2000.

GRANDE CAMPEONATO FEMININO DE LUCTA ROMANA. O Paiz, Rio de Janeiro, p.12, 10.mai.1910. Disponível em: http://memoria.bn.br/pdf/178691/per178691_1910_09348.pdf. Acesso em: 18.jan.2015.

GUIMARÃES, Roberta.. Mulheres precursoras na educação: histórias de professoras e professores primários na capital do Império: Rio de Janeiro: Letra Capital, 2011.

HALLEWELL, Laurence..O livro no Brasil: a sua história. São Paulo: EDUSP,2005.

HANSEN, P. S..Sobre o conceito de país novo e a formação de brasileiros nas primeiras décadas da República. Iberoamericana, Madrid, v. 45, p. 7-22, 2012. Disponível em: http://www.iai.spkberlin.de/fileadmin/dokumentenbibliothek/Iberoamericana/45-

2012/45_Santos.pdf. Acesso: 22. abr.2103.

O didático e outros usos da literatura infantil no início do século XX. Interpretar os livros destinados às crianças para além dos textos. In: IX CONGRESSO LUSO-BRASILEIRO DE HISTÓRIA DA EDUCAÇÃO, 1., 2012, Lisboa.Anais...IX Congresso Luso-Brasileiro de História da Educação. Lisboa, 2012.p.719-728. Disponível em: http://colubhe2012.ie.ulisboa.pt/wpcontent/uploads/COLUBHE-2012-pp.-1-32201.pdf. Acesso: 30.jun.2013.

.Intelectuais e a escrita para crianças: algumas considerações sobre uma atividade anti-intelectualizada. In: IX CONGRESSO 
LUSO-BRASILEIRO DE HISTÓRIA DA EDUCAÇÃO, 1., 2012, Lisboa.Anais...IX Congresso Luso-Brasileiro de História da Educação. Lisboa, 2012.p.967-973. Disponível em: http://colubhe2012.ie.ulisboa.pt/wpcontent/uploads/COLUBHE-2012-pp.-1-32201.pdf. Acesso: 30.jun.2013.

.Autores, editores, leitores: o que os livros cívicos para crianças da Primeira República dizem sobre eles?. História (São Paulo. Online), São Paulo, v. 30, p. 51-80, 2011. Disponível em: http://www.scielo.br/pdf/his/v30n2/a04v30n2.pdf .Acesso em: 24. jun.2013.

Infância como Projeto. Nacionalismo, sensibilidades e etapas da vida em Olavo Bilac.. In: XXVI SIMPÓSIO NACIONAL DE HISTÓRIA, 1.,2011, São Paulo. Anais... São Paulo: XXVI Simpósio Nacional de História. São Paulo, 2011.p.1-13.Disponível em:http://www.snh2011.anpuh.org/resources/anais/14/1300631786_ARQUIVO_I nfanciacomoprojeto.pdf. Acesso em: 25.nov.2012.

.América. Uma utopia republicana para crianças brasileiras..Estudos Históricos, Rio de Janeiro, v. 22, p. 504-521, 2009. Disponível em: http://www.scielo.br/scielo.php?pid=S010321862009000200010\&script=sci_abstr act\&tlng=pt. Acesso: 1.mar.2012.

Os primeiros livros infantis brasileiros. Análise da literatura cívico-pedagógica de ficção. Rio de Janeiro: PNAP/BN, 2009. Disponível em:http://www.bn.br/portal/index.jsp?nu_padrao_apresentacao=25\&nu_item_con teudo=1363\&nu_pagina=117. Acesso em: 10.jan.2014.

A arte de formar brasileiros: um programa de educação cívica nas páginas da revista O Tico-Tico.. In: MAGALDI, Ana Maria Bandeira de Mello; XAVIER, Libânia Nacif. (Org.). Impressos e História da Educação: usos e destinos.. Rio de Janeiro: 7 Letras, 2008,p. 45-58.

Brasil, um país novo: literatura cívico-pedagógica e a construção de um ideal de infância brasileira na Primeira República, 2007. 253 f. Tese (Doutorado em História) - Faculdade de Filosofia, Letras e Ciências Humanas, Universidade de São Paulo, São Paulo, 2007. 
HIGIONNET, Anne..Mulheres e imagens: aparências, lazer, subsistencia. In: In: DUBY, Georges; PERROT, Michelle. (Org.). História das mulheres no Ocidente: o século XIX.v.4. Porto: Edições Afrontamento.p. p. 297-324.

HELLER, B.. Caras amigas, raras leitoras? A formação da mulher leitora no Brasil (1914/ 1936). Revista da ANPOLL, v. 1, p. 11-30, 2005.Disponível em: http://revistadaanpoll.emnuvens.com.br/revista/article/view/438/447. Acesso em: 9.out.2014.

INSTANTANEOS NA AVENIDA. Careta. Rio de Janeiro, p.21, 24.dez.1910. . Careta, Rio de Janeiro, não paginada, 10.jun. 1911.

JAPIASSÚ, Hilton; MARCONDES..Dicionário básico de filosofia.4.ed.Rio de Janeiro: Zahar, 2006

JOGAR. O Tico-Tico, Rio de Janeiro, não paginada, 11.jul.1915.

JOLY, Martine. Introdução à análise da imagem. 10. ed. Campinas,SP: Papirus, 2006.

JORNAL DAS MOÇAS, Rio de Janeiro, 1.mai.1915. Disponível em: http://memoria.bn.br/pdf/111031/per111031_1915_00024.pdf. Acesso em: 21.dez.2014.

JÚNIOR, Gonçalo..A guerra dos gibis: a formação do mercado editorial brasileiro e a censura aos quadrinhos, 1933-64. São Paulo: Companhia das Letras, 2004.

KAPELI, Anne-Marie. Cenas femininas. In:DUBY, Georges; PERROT, Michelle. (Org.). História das mulheres no Ocidente: o século XIX.v.3. Porto: Edições Afrontamento. p.541-579.

KOSSOY, Boris.. Fotografia e História.São Paulo: Ateliê Editorial, 2001.

KNIBIEHLER, Yvonne.. Corpos e corações. In: DUBY, Georges; PERROT, Michelle. (Org.). História das mulheres no Ocidente: o século XIX.v.3. Porto: Edições Afrontamento.p.351-401. 
KUHLMANN JÚNIOR, Moysés.. O Pedagogium: sua criação e finalidades. In: MIGNOT, A. C. V.. Pedagogium: símbolo da modernidade educacional republicana. Rio de Janeiro: Quartet; FAPERJ, 2013.p.25-42.

LA SEMAINE DE SUZETTE, p.1, 13.mar.1909. Disponível em: http://www.bibliotheque.toulouse.fr/titres-pg04.html. Acesso em: 06.ago.2014.

LAJOLO, Marisa; ZILBERMAN, Regina..Literatura infantil brasileira: história e histórias. 7.ed. São Paulo: Ática, 2007.

LE GOFF, Jacques.. História e Memória. 5. ed. Campinas: Unicamp,2003.

LE PETIT JOURNAL ILLUSTRÉ DE LA JEUNESSE, 22/04/1906, p.1. Disponível em: http://www.topfferiana.fr/wp-content/uploads/2013/03/bakerrenversement176.jpg. Acesso em: 15.jan.2015.

LIMA, Herman de Castro.. História da Caricatura no Brasil. Rio de Janeiro: J. Olympio, 1963.

LINS, Vera; VELlOSO, Monica Pimenta; OLIVEIRA, Cláudia.. O Moderno em Revistas: Representações do Rio de Janeiro de 1890 a 1930. Rio de Janeiro: Garamond, 2010.

LOPES, Aristeu Elisandro Machado.. Alegorias femininas da República: a campanha republicana e os periódicos ilustrados no Rio de Janeiro. In: KNAUSS, Paulo; MALTA, Marize; VELlOSO, Monica Pimenta. (Org.). Revistas Ilustradas: modos de ler e ver no Segundo Reinado. Rio de Janeiro: MAUAD; FAPERJ, 2011.p.141-155.

LOURDES, Maria MLLE..CARTAS ÁS MÃES DE FAMÍLIA. Jornal das moças, Rio de Janeiro, p.19, 18.jan. 1917.Disponível em: http://memoria.bn.br/pdf/111031/per111031_1916_00083.pdf Acesso em: 15.fev.2015.

LOURO, Guacira Lopes.. Mulheres na sala de aula. In: PRIORE, M.D..(Org); BASSANEZI,Carla. (Coord. de texto). História das mulheres no Brasil. 9.ed.São Paulo: Contexto:2009. p.443-481.

LUCA,Tania Regina de.. Mulher em revista.In:Pinsky,Carla Bassanezi;Pedro, Joana Maria Pedro..(Orgs.). Nova história das mulheres no Brasil. São Paulo: Contexto, 2013.p.447-468. 
História de dos, nos e por meio dos periódicos. In:

PINSKY, Carla Bassanezi (Org.). Fontes Históricas. São Paulo: Contexto, 2008.p.111-153.

- A grande imprensa no Brasil da primeira metade do século $X X$. In: IX Congresso Internacional da Associação de Estudos Brasileiros (BRASA), 1.,2008, Nova Orleans. Anais... Nova Orleans: IX Congresso Internacional da Associação de Estudos Brasileiros. Disponível em: http://www.brasa.org/wordpress/Documents/BRASA_IX/Tania-Luca.pdf .Acesso em: 25.mar.2015.

LUIZ BARTHOLOMEU.. Ilustração Brasileira. Rio de Janeiro, p.35, 22 dez.1922.

LUYTEN, Sonia M. Bibe.. A geração de meninos traquinas. In: VERGUEIRO, Waldomiro; SANTOS, Roberto Elísio dos.. O Tico-Tico: centenário da primeira revista em quadrinhos do Brasil. São Paulo: Opera Graphica, 2005. p.41-49.

MACEDO. J.M.. Lições de História do Brazil. Rio de Janeiro: TYP Imparcial, 1861.

MAGALDI, Ana Maria Bandeira de Mello..;XAVIER, Libânia Nacif. Apresentação.In: .(Org.).

Impressos e história da educação: usos e destinos. Rio de Janeiro: 7Letras, 2008.p.9-14.

Lições de Casa: discursos pedagógicos destinados à família no Brasil. Rio de Janeiro: FAPERJ; Belo Horizonte: Argumentum, 2007.

.A infância em lições: um estudo sobre manuais femininos na sociedade do Rio de Janeiro. Revista Rio de Janeiro, Rio de Janeiro, n. 13-14, p. 85-102, 2004.

A quem cabe educar? Notas sobre as relações entre a esfera pública e a privada nos debates educacionais dos anos de 1920 -1930. Revista Brasileira de História da Educação, Campinas, v. 5, p. 213-231, 2003. 
MAGALHÃES, Bernardina Botelho de.. In: CASTRO, C.; LEMOS, R.(Org.). $O$

Diário de Bernardina: da Monarquia à República, pela filha de Benjamin Constant. Rio de Janeiro: Jorge Zahar,2009.

MAGNO, L.. História da Caricatura Brasileira: os precursores e a consolidação da caricatura no Brasil.v.1.Rio de Janeiro: Gala Edições de Arte,2012.

MALTA, Mariza.. O olhar decorativo: ambientes domésticos em fins do século XIX no Rio de Janeiro. 1. ed. Rio de Janeiro: Mauad X / Faperj, 2014.

Fundo, detalhe e satisfação visual: decoração doméstica

em A Estação. In: KNAUSS, Paulo; ;VELLOSO, Mônica

Pimenta.(Org.). Revistas Ilustradas: modos de ler e ver no Segundo Reinado: MAUAD/FAPERJ, 2011.p.91-104.

MALUF, Marina; MOTT, Maria Lúcia. Recônditos do mundo feminino. In: SEVCENKO, Nicolau. (Org.). História da Vida Privada no Brasil - República: da Belle Époque à Era do Rádio.v.3. São Paulo: Companhia das Letras, 2006.p. 367421.

MANDA QUEM PÓDE. O Tico-Tico, Rio de Janeiro, p,1, 11.10.1905.

MARTÍN-BARBERO, Jesús. Dos meios as mediações: comunicação, cultura e hegemonia. 2.ed. Rio de Janeiro: Editora UFRJ, 2003.

MARTINS, Ana Luiza. Revistas em revista: imprensa e práticas culturais em tempos de República, São Paulo (1890-1922).1.ed.São Paulo: EDUSP;FAPESP,2008.

MELO, V, A. Mulheres em movimento: a presença feminina nos primórdios do esporte na cidade do Rio de Janeiro (século XIX-primeira década do século XX). Revista Brasileira de História,São Paulo v. 27, p. 127-152, 2007.Disponivel em: http://www.scielo.br/pdf/rbh/v27n54/a08v2754.pdf. , Acesso em: 14.jan.2015.

MELlO, Maria Tereza Caves de. A Modernidade Republicana. Tempo. Rio de Janeiro, v. 13, p. 25-41, 2009. Disponível em: http://www.scielo.br/pdf/tem/v13n26/a02v1326.pdf. Acesso em: 23.dez.2014.

MERLO, Maria Cristina. O Tico-Tico: A brincadeira por meio da imaginação, conhecimento e entretenimento. In: VERGUEIRO, Waldomiro; SANTOS, Roberto Elísio dos.. O Tico-Tico: centenário da primeira revista em quadrinhos do Brasil. São Paulo: Opera Graphica,2005.p.81-87.

MONTELLO, Josué. No tempo d'O Tico-Tico. In: SOCIEDADE ANONYMA O MALHO. Cinqüentenário de "O Tico-Tico": da sua fundação até os nossos dias noticiário e homenagens diversas à tradicional publicação. Rio de Janeiro: SOCIEDADE ANONYMA O MALHO, 1956. p. 55-56. 
MORAES, Eneida de VIllas Boas Costa de. Um cinqüentenário. In: SOCIEDADE ANONYMA O MALHO. Cinqüentenário de "O Tico-Tico": da sua fundação até os nossos dias - noticiário e homenagens diversas à tradicional publicação. Rio de Janeiro: SOCIEDADE ANONYMA O MALHO, 1956.p.60-62.

MORETTI, Fernando. Cem anos de Buster Brown... No Brasil: Chiquinho. In: VERGUEIRO, Waldomiro; SANTOS, Roberto Elísio dos. (Org.). O Tico-Tico: centenário da primeira revista em quadrinhos do Brasil. São Paulo: Opera Graphica Editora, 2005.p.51-54.

MOTT, Maria Lucia et al. Médicos e médicas em São Paulo e os Livros de Registros do Serviço de Fiscalização do Exercício Profissional (18921932). Ciênc. saúde coletiva.v.13, n.3, p. 853-868. 2008. Disponível em: http://www.scielo.br/scielo.php?script=sci_arttext\&pid=S1413-

81232008000300008\&lng=pt\&nrm=iso\&tlng=pt . Acesso em: 15.dez.2014.

NASCIMENTO, Toninho et.al. Um Rio de Mar a Mar: do Valongo à Glória de São Sebastião. Rio de Janeiro: Escola de samba Portela, 2014.

NETO, Coelho. Alma: educação feminina. Rio de Janeiro: J. Ribeiro dos Santos, 1928.

NEVES, Margarida de Souza. Os cenários da República. O Brasil na virada do século XIX para o século XX. In: FERREIRA, Jorge; DELGADO, Lucilia de Almeida Neves. (Org.). O Brasil Republicano: o tempo do liberalismo excludente - da Proclamação da República à Revolução de 1930. v.1.3.ed. Rio de Janeiro: Civilização Brasileira, 2008.p.14-44.

NUNES, Clarice. (Des) encantos da modernidade pedagógica. In: LOPES, E.M.T.; FARIA FILHO, L. M; VEIGA, Cynthia Greive. (Org.). 500 anos de educação no Brasil. 5.ed. Belo Horizonte: Autêntica,2011.

OS 50 ANOS DE O “TICO-TICO": fala Vasco Lima. A Noite, Rio de Janeiro, p.1,11de outubro de 1955. Disponível em: http://bndigital.bn.br/hemerotecadigital/. Acesso em: 21.mar.2015.

O INIMIGO DAS MULHERES. O Tico-Tico, Rio de Janeiro, 30.jun.1909.

O OFİCIO MAIS DIVERTIDO: virar criança de novo. Correio da Manhã, p.3, 8 de dezembro de 1955. Disponível em: http://bndigital.bn.br/hemeroteca-digital/. Acesso em: 22. mar.2015.

O TICO-TICO, O Malho, Rio de Janeiro, não paginada, 23.set.1905.Disponível em: http://www.casaruibarbosa.gov.br/omalho/revista.asp?rev=158\&ano=1905. Acesso em: 16.fev.2014.

O TICO-TICO, O Malho, Rio de Janeiro, p.40,16.set.1905. Disponível em: http://www.casaruibarbosa.gov.br/omalho/revista.asp?rev=157\&ano=1905.

Acesso: 13.mai.2014. 
OLIVEIRA, Cláudia de. Mulheres de estampa: o folhetim e a representação do feminino no Segundo Reinado. In: KNAUSS, P.et.al. (Org). Revistas Ilustradas: modelos de ler e ver no Segundo Império. Rio de Janeiro: MAUAD X; FAPERJ, 2011.p.157 -172.

OLIVEIRA, Lúcia Lippi. As festas que a República manda guardar. Estudos Históricos. v.2.n.4, p.172-189, 1989.

OS HEROES D` O TICO-TICO. $O$ Malho, Rio de Janeiro, p.25, 26.mai.1906.Disponivel em: http://www.casaruibarbosa.gov.br/omalho/revista.asp?rev=193\&ano=1906\&pag= 24. Acesso em: 20.jan.2015.

PAGINA PARA CRIANÇA. O malho, Rio de Janeiro, não paginada, 02.set.1905. Disponível em: http://www.casaruibarbosa.gov.br/omalho/revista.asp?rev=155\&ano=1905 Acesso em: 26.dez.2014.

PEQUENINAS COSTUREIRAS. O Tico-Tico, Rio de Janeiro, p.2, 19.jun.1912.

PERROT, Michelle. Família triunfante. In: (Org.).

História da vida privada: da Revolução Industrial à Primeira Guerra. v.4.São Paulo:Companhia das Letras,2009.p.79-90.

.Funções da família. In: (Org.).

História da vida privada: da Revolução Industrial à Primeira Guerra. v.4.São Paulo:Companhia das Letras,2009.p.91-106.

.Figuras e papéis. In: (Org.).

História da vida privada: da Revolução Industrial à Primeira Guerra. v.4.São Paulo:Companhia das Letras,2009.p.107-168.

EDUSC, 2005.

As mulheres ou os silêncios da história. Bauru-SP:

Paulo, v.9,n.18,p.9-18,ago/set.89.

.Práticas da memória feminina. Rev.Bras.de Hist, São

PIMENTEL, Alberto Figueiredo. Histórias da Avozinha. Rio de Janeiro: [S.1.: s.n.], $1896 . \quad$ Disponível em: http://www.dominiopublico.gov.br/download/texto/bn000137.pdf Acesso em: 23.jan.2014.

PINSKY, Carla Bassanezi. Mulheres dos anos dourados. São Paulo: Contexto, 2014.

PRIORE,M.L.M..História das mulheres: As vozes do silêncio. In:FREITAS, Marcos C.. (Orgs.).Historiografia brasileira em perpectiva. São Paulo: Contexto,2014. 
.Histórias e conversas de mulher. São Paulo: Planeta,

2013.

PROFISSÃO FEMINISTA. Careta,.Rio de Janeiro, não paginada, 31.jan.1914.

PROST, Antoine.. Fronteiras e espaços do privado. In: ;VINCENT,Gérard (Org.). História da vida privada: da Primeira Guerra aos nossos dias. v.5. São Paulo: Companhia das Letras, 2009.p.13-136.

QUE SAUDADES do Rei Momo.. Revista da Semana, Rio de Janeiro, p.9-10, 11.fev.1950. Disponível em: http://bndigital.bn.br/hemeroteca-digital/. Acesso em: 21. mar.2015.

RAGO, Margareth. Trabalho feminino e sexualidade. In: PRIORE, M.L.M..(Org); BASSANEZI,Carla. (Coord. de texto). História das mulheres no Brasil. 9.ed.São Paulo: Contexto:2009.p.578-606.

RENATO DE CASTRO. Revista da Semana, Rio de Janeiro, p. 33, 9 maio. 1942.

REVEL, Jacques. Os usos da civilidade. In: ARIÈS, Philippe; CHARTIER, Roger.(Org.). História da vida privada: da Renascença ao Século das Luzes. v.3.São Paulo: Companhia das Letras, 1991.p.169-210.

RIO, João do..Os que começam...In: A alma encantadora das ruas. Rio de Janeiro: 2013.p.79-82.

RIZZINI, Irene. O século perdido: raízes históricas das políticas públicas para a infância no Brasil. Rio de Janeiro: Ed. Universitária Santa Úrsula: Amais,1997.

RODRIGUES, Roberta Ferreira. A escola em brincadeiras: intelectuais e nação na criação da revista O Tico-Tico In: CARULA, Karoline; ENGEL, Magali Gouveia; CORRÊA, Maria Letícia. Os intelectuais e a nação: educação, saúde e a construção de um Brasil moderno. Rio de Janeiro: Contra Capa, 2013.p.113-140.

RODRIGUES, Rosane Nunes. A escolarização dos saberes domésticos e as múltiplas representações do feminino. Rio de Janeiro - 1920 e 1930. In: VIDAL, Diana Gomes. (Org.). Educação e Reforma: o Rio de Janeiro nos anos 1920 e 1930. Belo Horizonte: Argumentum; São Paulo: CNPq: USP, Núcleo Interdisciplinar de Estudos e Pesquisas em História da Educação, 2008.p.59-76.

ROSA, Zita de Paula. O Tico-Tico: meio século de ação recreativa de pedagógica. Bragança Paulista: EDUSF, 2002.

SÁ, Elizabeth Figueiredo de. A Construção da Identidade Nacionalista da Criança Mato-Grossense. In: VIDAL, Diana G.; SCHWARTZ Cleonara. (Org.). História das culturas escolares no Brasil. Vitória: EDUFES, 2010.p.223-246. 
SANTAELLA, Lucia. Mulheres em tempo de modernidade líquida. Comunicação \& Cultura,Lisboa, n.6,p.105-113, 2008. Disponível em: http://cc.bond.com.pt/wpcontent/uploads/2010/07/06_05_Lucia_Santaella.pdf. Acesso em: 20.fev.2015.

SANT'ANNA, Denise Bernuzzi de..Higiene e higienismo entre o Império e a República. In:PRIORE,M.L.M..; AMANTINO, Marcia..(Orgs.).História do corpo no Brasil.São Paulo: Editora Unesp,2011.p.283-312.

SANTOS, Armando Alexandre dos. Bécassine, a primeira heroína em HQ. In: VI Simpósio Nacional de História Cultural: Escritas da História - ver, sentir, narrar, 1., 2012, Teresina-PI. Anais... Teresina: Universidade Federal do Piauí-UFP, 2012.

SANTOS, Roberto Elísio dos. Artistas e personagens de destaque da revista $\mathrm{O}$ Tico-Tico. In: In: VERGUEIRO, Waldomiro; O Tico-

Tico: centenário da primeira revista em quadrinhos do Brasil.São Paulo: Opera Graphica Editora, 2005.p.89-95.

SÃO PAULO. Decreto Lei $\mathrm{n}^{\circ}$ 88, de 15 de setembro de 1892. Reforma educacional dos grupos escolares paulista. Disponível em: http://www.al.sp.gov.br/repositorio/legislacao/decreto/1893/decreto-21827.11.1893.html. Acesso em: 10.abr.2015.

SCHUELER, A. F. M.. "Grandeza da Pátria e Riqueza do Estado": Expansão da escola primária no Estado do Rio de Janeiro (1893-1930), Revista de Educação Publica (UFMT), v.19, n.41, 2010, p.535-550.

SILVA, M. C.. Infância e Literatura. Rio de Janeiro: EDUERJ, 2010.

SIRINELLI, Jean-François. Os intelectuais. In: RÉMOND, René. Por uma História Política. 2.ed.Rio de Janeiro:FGV,2003.p.231-269.

SOCIEDADE ANONYMA O MALHO. Cinqüentenário de "O Tico-Tico": da sua fundação até os nossos dias - noticiário e homenagens diversas à tradicional publicação. Rio de Janeiro: 1956.

SCOTT, A.S.. O caleidoscópio dos arranjos familiares. In: PINSKY, Carla Bassanezi; PEDRO, Joana Maria. (Org.). Nova História das Mulheres no Brasil. 1.ed.São Paulo: Contexo, 2012, p. 15-42.

SCOTT, Joan W.. História das Mulheres. In: BURKE, Peter. A escrita da História: novas perspectivas. São Paulo: UNESP, 2012.p.65-98.

A mulher trabalhadora. In: DUBY, Georges; PERROT, Michelle. (Org.). História das mulheres no Ocidente: o século XIX.v.3. Porto: Edições Afrontamento. p.443-475.

SOIHET, Rachel..A comquista do espaço público. In:Pinsky,Carla Bassanezi;Pedro, Joana Maria Pedro..(Orgs.). Nova história das mulheres no Brasil. São Paulo: Contexto, 2013.p.218-237. 
.A pedagogia da conquista do espaço público pelas mulheres e a militância de Bertha Lutz. Revista Brasileira de Educação, Rio de Janeiro, v.15,p.97-117,2000.

. História das mulheres. In: CARDOSO, Ciro Flamarion;VAINFAS,Ronaldo. Domínios da história: ensaios de teoria e metodologia. Rio de Janeiro: Campus, 1997.p.225-311.

SEVCENKO, Nicolau. Literatura como missão: tensões sociais e criação cultural na Primeira República. 2.ed.São Paulo: Companhia das Letras,2003.

A capital irradiante: técnica, ritmos e ritos do Rio de

Janeiro. In: .(Org.). História da Vida Privada no Brasil República: da Belle Époque à Era do Rádio. v.3. São Paulo: Companhia das Letras, 2006.p. 513-619.

SOARES, Carmem. Educação Física: raízes européias e Brasil. 4.ed. CampinasSP: Autores Associados, 2004.

SOBRAL, José. O Tico-Tico de Além Mar. In: VERGUEIRO, Waldomiro; SANTOS, Roberto Elísio dos. O Tico-Tico: centenário da primeira revista em quadrinhos do Brasil. São Paulo: Opera Graphica Editora, 2005. p.69 -71.

SODRÉ, Nelson Werneck. História da imprensa no Brasil.4.ed. Rio de Janeiro: MAUAD, 1999.

SOUZA, Gilda de Mello e..O espírito das roupas: a moda no século dezenove.São Paulo:Companhia das Letras, 1987.

SOUZA, R. F.. A organização pedagógica da escola primária no Brasil: do modo individual, mútuo, simultâneo e misto à escola graduada (1827 1893). In: GONÇALVES NETO, W; MIGUEL, M. E. B; FERREIRA NETO, A.. (Org.). Práticas escolares e processos educativos: currículo, disciplinas e instituições escolares (séculos XIX e XX). Vitoria: EDUFES, 2011.p. 71-89.

Grupos Escolares. In: Espaço de Educação e Civilização: as origens dos J. S.(Org.). O Legado Educacional do Século XIX. Araraquara: UNESP, 1998, p. 11-47.

UMA BOA LIÇÃO. O Tico-Tico, Rio de Janeiro, p.1, 16.out,1912.

UMA BONECA QUE SE REVOLTA. O Tico-Tico, Rio de Janeiro, p.12-13, 23.jun.1909.

VAINFAS, Ronaldo. (Org.). Dicionário do Brasil imperial. Rio de Janeiro: Objetiva, 2008. 
VALDEMARIN, V. T.. Estudando as lições de coisas. 1. ed. Campinas: Autores Associados, 2004.

.Lições de Coisas: concepção científica e projeto modernizador para a sociedade. Cadernos do CEDES (UNICAMP), Campinas, v. 52, p. 74-87, 2000.

VELLOSO, Monica Pimenta. As distintas retóricas do moderno. In: LINS, Vera; ; OLIVEIRA, Cláudia. $O$ Moderno em Revistas: Representações do Rio de Janeiro de 1890 a 1930. Rio de Janeiro: Garamond, 2010.p.43-110.

VELLOSO. Monica Pimenta. A mulata, o papagaio e a francesa: o jogo dos estereótipos culturais. In:LUSTOSA, Lustosa. (Org.). Imprensa, humor e caricatura: a questão dos estereótipos culturais. 1ed.Belo Horizonte: UFMG, 2009, p. 365-390.

.Percepções do moderno: as revistas do Rio de Janeiro. In: NEVES, Lúcia Maria Bastos Pereira das; MOREL, Marco; FERREIRA, Tania Maria Bessone da C.(Org.). História e imprensa: representações culturais e práticas de poder. Rio de Janeiro: DP\&A, FAPERJ, 2006.p.312-331.

Rio de Janeiro: Fundação Getulio Vargas, 1996.

. Modernismo no Rio de Janeiro: tribunas e quixotes.

VENTURA, Roberto; SUSSEKIND, Flora. História e dependência: cultura e sociedade em Manoel Bomfim. 1. ed. São Paulo: Moderna, 1984.

VERGUEIRO, Waldomiro; SANTOS, Roberto Elísio dos. A postura educativa de O Tico-Tico: uma análise da primeira revista brasileira de histórias em quadrinhos. Comunicação \& Educação, v. 13, p.23-34, 2008.

A publicidade em O Tico-Tico. In:_SANTOS, Roberto Elísio dos.(Org.).Tico-Tico - 100 anos: Centenário da primeira revista em quadrinhos do Brasil. São Paulo: Opera Graphica Editora, 2005.p.131-140.

$\begin{array}{llllll} & \text { In: } & \text { O papel da mulher em } & \text { da } & \text { Tico-Tico } \\ \text { In } & & \text { São } & \text { Paulo:Opera } & \text { Graphica }\end{array}$

Editora,2005.p.175-179.

VERÍSSIMO, José. A Educação Nacional. Rio de Janeiro: Francisco Alves, 1906. Disponível em: https://archive.org/details/aeducaonacional00vergoog. Acesso em: 28.jan.1914.

VERGUEIRO, Waldomiro; SANTOS, Roberto Elísio dos..O Tico-Tico: centenário da primeira revista em quadrinhos do Brasil. São Paulo: Opera Graphica Editora,2005. 
VINCENT, Gérard. Segredos de família. In: PROST, Antoine;___. (Org.). História da vida privada: da Primeira Guerra a nossos dias. v.5. São Paulo: Companhia das Letras: 2009.p.223-281.

WANDERLEY, Eustorgio.. O "83" de Luiz Batholomeu. O Malho, Rio de Janeiro, p. 35-36, set.1952.

\section{Revistas Consultadas}

O TICO-TICO, 17/01/1906

O TICO-TICO, 25/04/1906

O TICO-TICO, 06/06/1906

O TICO-TICO, 31/01/1906

O TICO-TICO, 28/03/1906

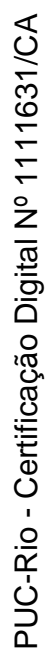

O TICO-TICO, 25/04/1906

O TICO-TICO, 16/05/1906

O TICO-TICO, 06/06/1906

O TICO-TICO, 04/07/1906

O TICO-TICO, 02/01/1907

O TICO-TICO, 02/02/1907

O TICO-TICO, 01/05/1907

O TICO-TICO, 15/05/1907

O TICO-TICO, 19/07/1907

O TICO-TICO, 13/11/1907

O TICO-TICO, 05/05/1909

O TICO-TICO, 20/01/1909

O TICO-TICO, 27/01/1909

O TICO-TICO, 03/02/1909 
O TICO-TICO, 10/02/1909

O TICO-TICO, 10/03/1909

O TICO-TICO, 31/03/1909

O TICO-TICO, 07/04/1909

O TICO-TICO, 05/05/1909

O TICO-TICO, 10/10/1909

O TICO-TICO, 27/10/1909

O TICO-TICO, 10/11/1909

O TICO-TICO, 29/12/1909

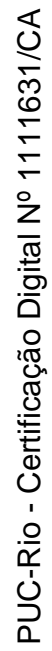

O TICO-TICO, 26/01/1910

O TICO-TICO, 27/04/1910

O TICO-TICO, 14/05/1910

O TICO-TICO, 13/07/1910

O TICO-TICO, 14/09/1910

O TICO-TICO, 12/10/1910

O TICO-TICO, 14/12/1910

O TICO-TICO, 21/12/1910

O TICO-TICO, 18/01/1911

O TICO-TICO, 25/01/1911

O TICO-TICO, 08/03/1911 
O TICO-TICO, 22/03/1911

O TICO-TICO, 29/03/1911

O TICO-TICO, 19/04/1911

O TICO-TICO, 03/05/1911

O TICO-TICO, 10/05/1911

O TICO-TICO, 07/06/1911

O TICO-TICO, 14/06/1911

O TICO-TICO, 15/11/1911

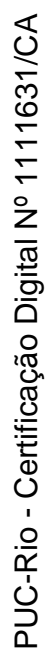

O TICO-TICO, 22/11/1911

O TICO-TICO, 29/11/1911

O TICO-TICO, 06/12/1911

O TICO-TICO, 20/12/1911

O TICO-TICO, 27/12/1911

O TICO-TICO, 17/01/1912

O TICO-TICO, 24/01/1912

O TICO-TICO, 29/01/1912

O TICO-TICO, 06/03/1912

O TICO-TICO, 27/03/1912

O TICO-TICO, 12/04/1912

O TICO-TICO, 19/04/1912 
O TICO-TICO, 12/06/1912

O TICO-TICO, 17/07/1912

O TICO-TICO, 12/08/1912

O TICO-TICO, 22/08/1912

O TICO-TICO, 18/09/1912

O TICO-TICO, 09/10/1912

O TICO-TICO, 30/10/1912

O TICO-TICO, 27/11/1912

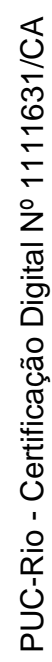

O TICO-TICO, 11/12/1912

O TICO-TICO, 20/12/1912

O TICO-TICO, 22/01/1913

O TICO-TICO, 29/01/1913

O TICO-TICO, 19/02/1913

O TICO-TICO, 30/04/1913

O TICO-TICO, 14/05/1913

O TICO-TICO, 21/05/1913

O TICO-TICO, 04/06/1913

O TICO-TICO, 09/07/1913

O TICO-TICO, 03/09/1913

O TICO-TICO, 22/10/1913 
O TICO-TICO, 06/11/1913

O TICO-TICO, 23/11/1913

O TICO-TICO, 31/12/1913

O TICO-TICO, 14/01/1914

O TICO-TICO, 28/01/1914

O TICO-TICO, 18/02/1914

O TICO-TICO, 04/03/1914

O TICO-TICO, 25/03/1914

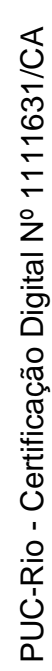

O TICO-TICO, 08/04/1914

O TICO-TICO, 18/04/1914

O TICO-TICO, 26/08/1914

O TICO-TICO, 02/09/1914

O TICO-TICO, 23/09/1914

O TICO-TICO, 22/10/1914

O TICO-TICO, 30/12/1914

O TICO-TICO, 19/03/1915

O TICO-TICO, 01/05/1915

O TICO-TICO, 19/05/1915

O TICO-TICO, 09/06/1915

O TICO-TICO, 03/11/1915 
O TICO-TICO, 31/11/1915

O TICO-TICO, 01/12/1915

O TICO-TICO, 15/12/1915

O TICO-TICO, 12/01/1916

O TICO-TICO, 22/03/1916

O TICO-TICO, 28/03/1916

O TICO-TICO, 05/04/1916

O TICO-TICO, 12/04/1916

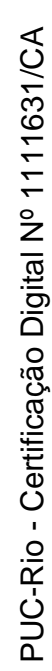

O TICO-TICO, 26/04/1916

O TICO-TICO, 02/08/1916

O TICO-TICO, 23/08/1916

O TICO-TICO, 13/09/1916

O TICO-TICO, 15/11/1016

O TICO-TICO, 22/11/1916

O TICO-TICO, 06/12/1916

O TICO-TICO, 13/12/1916

O TICO-TICO, 14/02/1917

O TICO-TICO, 28/02/1917

O TICO-TICO, 07/03/1917

O TICO-TICO, 24/10/1917 
O TICO-TICO, 21/11/1917

O TICO-TICO, 09/01/1918

O TICO-TICO, 03/04/1918

O TICO-TICO, 09/10/1918

O TICO-TICO, 06/11/1918

O TICO-TICO, 18/12/1918

O TICO-TICO, 08/01/1919

O TICO-TICO, 23/04/1919

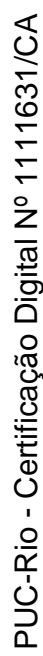

O TICO-TICO, 13/07/1919

O TICO-TICO, 30/07/1919

O TICO-TICO, 21/09/1919

O TICO-TICO, 10/03/1920

O TICO-TICO, 31/03/1920

O TICO-TICO, 25/05/1921

O TICO-TICO, 11/10/1933

O TICO-TICO, 12/10/1938

O TICO-TICO, 10/1949

O TICO-TICO, 10/1955 